\title{
HET SULTANAAT PALEMBANG
}

$1811-1825$ 


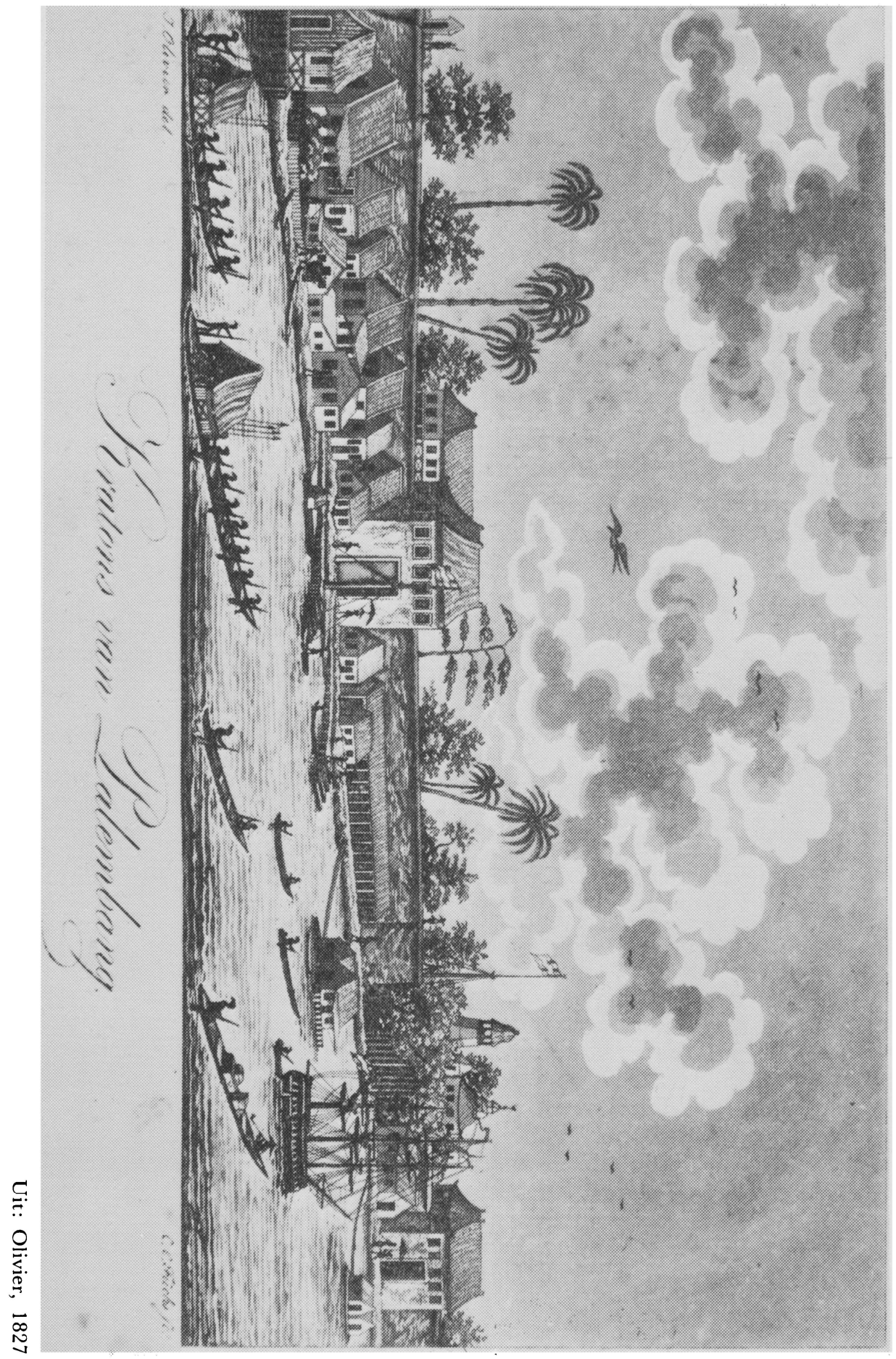




\section{E R H A N D E L I N G EN}

VAN HET KONINKLIJK INSTITUUT

VOOR TAAL-, LAND- EN VOLKENKUNDE

72

M. O. WOELDERS

\section{HET SULTANAAT PALEMBANG 1811-1825}

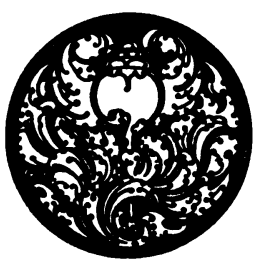

'S-GRAVENHAGE - MARTINUS NIJHOFF 1975

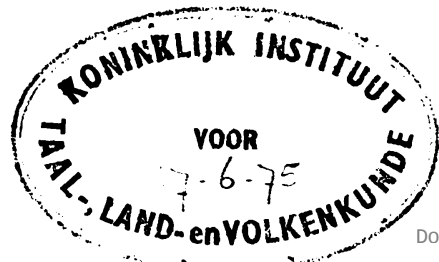


I.S.B.N. 90.247 .1762 .0

M.0. Woelders - 978-90-04-28703-7 Downloaded from Brill.com04/26/2023 04:49:19AM via free access 


\section{VOORWOORD}

Bij de voorbereiding van dit proefschrift heb ik mij ten doel gesteld een tekstuitgave te verzorgen van één of meer der slechts in handschrift overgeleverde Maleise geschriften die betrekking hebben op de geschiedenis van het eertijds als een zelfstandige staatkundige eenheid optredende Sultanaat Palembang, gelegen op het eiland Sumatra in de Indonesische archipel en thans deel uitmakende van de Propinsi Sumatera Selatan van de Republik Indonesia. Aan de hand van het na inventarisatie verkregen overzicht van het beschikbare materiaal, dat te omvangrijk bleek om in zijn geheel in één publikatie te worden opgenomen, heb ik daaruit datgene geselecteerd wat betrekking heeft op de geschiedenis van Palembang in de jaren 1811-1825, de laatste periode van de politieke onafhankelijkheid van het sultanaat en als zodanig door de Palembangse geschiedschrijvers met bijzondere belangstelling behandeld.

Met deze aldus beperkte tekstuitgave wordt beoogd een bijdrage te leveren enerzijds tot de ontsluiting van bronnenmateriaal voor historisch onderzoek en anderzijds tot de publikatie - ten behoeve van het filologisch onderzoek - van de voortbrengselen van de negentiende-eeuwse Maleise literatuur, deze laatste hier niet beperkt tot de bellettrie, zoals in beschouwingen op het gebied van de algemene literatuurwetenschap gebruikelijk is, maar - overeenkomstig het ten aanzien van de Maleise letteren heersende gebruik - in veel ruimere betekenis gebezigd ter aanduiding van het gehele assortiment van de schriftelijke overlevering. Hiermee, met deze tweeledige doelstelling, zijn de richtlijnen voor de overigens zeer eenvoudige opzet van dit boek gegeven. Over de praktische uitwerking daarvan kunnen we kort zijn.

Het historisch overzicht, waarmee het boek begint, dient om de belangstellende niet-deskundige lezer een globaal beeld te geven van het tijdvak van de Palembangse geschiedenis dat in de te publiceren Maleise teksten wordt beschreven. Dit overzicht is niet het resultaat van zelfstandig historisch onderzoek. Het pretendeert niet meer dan een chronologisch verhaal van de historische gebeurtenissen te zijn, geschreven aan de hand van voornamelijk secundaire bronnen. Daarom is ook afgezien van specifieke verwijzingen naar geraadpleegde literatuur. Men 
vindt deze opgenomen in de algemene bibliografie achter in het boek.

De behandeling van de Maleise historische teksten, die het eigenlijke onderwerp van studie uitmaken, voltrekt zich in vier fasen. In hoofdstuk II wordt het gevonden materiaal geïnventariseerd, beschreven en in een antal door formele en inhoudelijke kenmerken bepaalde categorieën ingedeeld. Langs deze weg komt de uiteindelijke selectie van het materiaal tot stand, dat dan in de hoofdstukken III, IV en V achtereenvolgens wordt gepubliceerd, in het Nederlands vertaald en aan een aantal criteria getoetst teneinde tot een voorlopige karakterisering van de onderscheiden teksten te geraken. De vertaler beseft dat met een Nederlandse vertaling slechts een zeer beperkte kring van belangstellenden wordt bereikt en dat hij door vertaling van de teksten of liever nog van zijn hele werk in het Engels zijn debiet aanmerkelijk had kunnen vergroten. Hij betreurt het dan ook dat hem daartoe de tijd en de gelegenheid hebben ontbroken.

In het kader van de tekstbehandeling passen verder nog de vermelding van de daarbij geconstateerde spellingseigenaardigheden, het kritisch apparaat bij de in twee niet geheel eensluidende handschriften overgeleverde rijmkroniek Syacir Perang Ménténg, de in hoofdstuk IV ingelaste samenvatting van een niet-gepubliceerde tekst ter vergelijking met de daarmee verwante wel-gepubliceerde tekst volgens het door mij als TR 1 aangeduide handschrift uit de collectie van het Koninklijk Instituut voor de Tropen te Amsterdam, de ten gerieve van de historici bijgevoegde opgave van de in de teksten voorkomende data volgens de moslimse jaartelling met vermelding van de corresponderende data volgens de christelijke jaartelling, en tenslotte de achter in het boek opgenomen registers, waarin ik gepoogd heb vast te leggen wat de gepubliceerde teksten aan lexicografische, genealogische en geografische gegevens hebben opgeleverd.

Het behoeft geen betoog dat deze tekstuitgave niet tot stand had kunnen komen zonder de medewerking van tal van functionarissen bij de instellingen waar het door mij bewerkte materiaal wordt bewaard. Ik heb deze medewerking, die de aan een behoorlijke dienstverlening te stellen eisen dikwijls verre te boven ging, bijzonder op prijs gesteld.

Met dankbaarheid denk ik terug aan de vlotte en deskundige hulp die ik heb ondervonden van de zijde van de bibliotheek van het Museum Pusat te Jakarta, de bibliotheek van het Koninklijk Instituut voor de Tropen te Amsterdam, het Algemeen Rijksarchief te 's-Gravenhage, het Koninklijk Instituut voor Taal-, Land- en Volkenkunde en de universiteitsbibliotheek te Leiden. Hierbij gaan mijn gedachten in het bijzonder 
uit naar degenen met wie ik mij door collegiale banden verbonden weet, maar de te Leiden geldende regels verbieden mij deze gedachten hier nader uit te werken.

Voor de bereidheid mijn werk op te nemen in de Verhandelingen van het Koninklijk Instituut voor Taal-, Land- en Volkenkunde betuig ik het bestuur van dit instituut gaarne mijn erkentelijkheid.

Tot slot een enkel woord ter toelichting op of zo men wil ter rechtvaardiging van de keuze van het onderwerp.

De Maleise teksten die betrekking hebben op de geschiedenis van Palembang zijn, behoudens de teksteditie van de Syacir Perang Ménténg door Atja, ${ }^{1}$ nog niet in druk verschenen. Ze zijn - afgezien van enkele gevallen van partieel en incidenteel gebruik voor andere doeleinden dan een tekstuitgave - zelfs nog in geen enkel opzicht onderzocht. Daar staat tegenover dat binnen het raam van de koloniale geschiedenis aan de Palembangse geschiedenis in de loop der tijden van westerse, met name van Nederlandse en Engelse zijde - zij het vaak uit min of meer chauvinistische motieven - juist bijzonder veel aandacht is geschonken. $\mathrm{Er}$ is daardoor sprake van een eenzijdige, uiteraard "Europa-centrische" visie op de geschiedenis van Palembang, welke een poging tot herstel van het verstoorde evenwicht door publikatie van produkten van Palembang's eigen historische overlevering op zichzelf reeds rechtvaardigt. Dit geldt in het bijzonder voor de periode 1811-1825, waarover aan beide zijden het meest is geschreven, zodat door de ontoegankelijkheid van de autochtone bronnen het verschil tussen de hoeveelheden beschikbare informatie van beide zijden hier op z'n grootst is.

$\mathrm{Er}$ is misschien nòg een reden, waarom het van nut kan zijn de stem van Palembang uit het verleden zelf aan het woord te laten. Palembang behoort tot de gebieden die door het "centrale", op Java gevestigde en zich in de eerste plaats op "Java en Madoera" concentrerende koloniale gezag als "buitengewesten" aangeduid en behandeld werden en waarvan dienovereenkomstig de geschiedenis, zoals bijvoorbeeld blijkt uit het werk van Colenbrander uit de jaren twintig," als "locale geschiedenis" werd beschouwd. Eerst tengevolge van de door Van Leur ingezette en vervolgens vooral na de tweede wereldoorlog door onderzoekers als Berg, Resink en Meilink-Roelofsz ieder op zijn of haar gebied nader uitgewerkte en aan de praktijk getoetste vernieuwing van de Indonesische geschiedbeschouwing ${ }^{3}$ is het wezenlijke belang van de

1 Atja, 1967.

2 Colenbrander, 1925-26.

3 Een samenvattend overzicht terzake vindt men bij Van der Kroef, 1958. 
geschiedschrijving van die gebieden buiten Java als autonome componenten van een vaak meer in naam souverein dan werkelijk alles beheersend Majapait, Nederlands-Indië of Indonesië in de eerste plaats ten opzichte van de Indonesische maar daarna ook voor de Zuidoostaziatische historiografie onderkend en erkend.. Deze erkenning heeft er mede toe geleid dat de vooroorlogse activiteiten op dit terrein ten aanzien van een aantal van deze gebieden zijn voortgezet en uitgebreid, zoals uit de in 1965 onder auspiciën van het Modern Indonesia Project van Cornell University verschenen inleiding tot de Indonesische geschiedschrijving ${ }^{5}$ kan blijken, met name uit de bijdragen over de Maleise historische bronnen en de geschiedschrijving van Zuid-Celebes. Het lijkt gewenst dat Palembang aan de hier bedoelde gebieden wordt toegevoegd.

Ongeacht van welke standpunt en langs welke weg het verleden wordt benaderd, uit welke gezichtshoek en in welk perspectief de geschiedschrijving van Indonesië ook wordt bezien - Europa-centrisch, Aziëcentrisch of, zoals Smail wil, universeel ${ }^{6}-$, als uitgangspunt zal steeds de eis blijven gelden dat de historisch relevante bronnen, van welke aard dan ook, zo volledig mogelijk voor onderzoek beschikbaar zijn. Eerst wanneer dat het geval is, zal een evenwichtige en dan toch wel liefst met Smail vanuit een universele culturele achtergrond op het totale beeld van de Indonesische geschiedenis gerichte beschouwing mogelijk zijn, ook al bestaat dat beeld ook dan nog uit vaak niet meer dan de top van de ijsberg van de historische werkelijkheid. Als in dit licht gezien het door mij als "archivaris van de kleine vorsing" ter nadere bestudering door de "artisten van de grote visie" aangedragen materiaal ${ }^{7}$ zou bijdragen tot een beter begrip van de Maleis-Palembangse historiografie en haar betekenis in het kader van de geschiedschrijving van geheel Indonesië, dan zou ik mijn moeite ruimschoots beloond achten.

4 Zie bijv. Resink, 1956, p. 445; Soedjatmoko, 1960, p. 22 en Mohammad Ali, 1965, passim.

5 Soedjatmoko, 1965.

- Smail, 1961.

7 De terminologie is ontleend aan Resink, 1953, p. 151. 


\section{INHOUD}

Frontispice: De kratons van Palembang

pag.

VOORWOORD . . . . . . . . . . . . . . . . . V

LIJST VAN AFKORTINGEN . . . . . . . . . . . . XI

HOOFDSTUK I: HISTORISGH OVERZICHT . . . . . 1

HOOFDSTUK II: DE HANDSCHRIFTEN . . . . . . . 28

Inventarisatie . . . . . . . . . . . . . . . . . 28

Beschrijving . . . . . . . . . . . . . . . . . 31

Rubricering en selectie . . . . . . . . . . . . . 62

Plaat: De rivieren van Palembang

Plaat: Plan van de batterijen en ligging der schepen

Plaat: Plattegrond van Palembang

HOOFDSTUK III: DE TEKSTEN . . . . . . . . . . 67

Tekst KI 4 (p. 26, r. 16 - p. 29) . . . . . . . . . . 69

Facsimile eerste pagina van UBL 7 . . . . . . . . . 72

Tekst UBL 7 . . . . . . . . . . . . . . . . . 73

Tekst TR 1 . . . . . . . . . . . . . . . . . 116

Facsimile eerste pagina van UBL 9 . . . . . . . . . 154

Tekst UBL 9 . . . . . . . . . . . . . . . . . . . . . . . 155

Facsimile eerste twee pagina's van MP 4a . . . . . . . 187

Facsimile eerste pagina van MP 4b . . . . . . . . . 188

Tekst MP 4b: Syacir Perang Ménténg . . . . . . . . 189

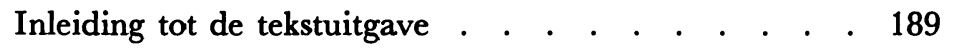

Syacir Perang Ménténg. . . . . . . . . . . . 194

Kritisch apparaat bij de tekstuitgave . . . . . . . . 223 
HOOFDSTUK IV: VERTALING VAN DE TEKSTEN . . 226

Vertaling KI 4 (p. 26, r. 16 - p. 29) . . . . . . . . . 226

Vertaling UBL 7 . . . . . . . . . . . . . . . 230

Vertaling TR 1 . . . . . . . . . . . . . . . . 279

Tekstvergelijking TR 1 - UBL 5/ MP 2 . . . . . . . . 321

Vertaling UBL 9 . . . . . . . . . . . . . . . . . . . . 347

Vertaling MP 4b: Syacir Perang Ménténg . . . . . . 385

HOOFDSTUK V: SLOTBESGHOUWINGEN . . . . . . 414

NOTEN . . . . . . . . . . . . . . . . 437

VERGELIJKINGSTABEL VOOR DATA VOLGENS DE

MOSLIMSE EN DE CHRISTELIJKE TIJDREKENING . . 454

WOORDENLIJST BIJ DE MALEISE TEKSTEN

GEPUBLICEERD IN HOOFDSTUK III . . . . . . . . 457

REGISTER BIJ DE MALEISE TEKSTEN

GEPUBLICEERD IN HOOFDSTUK III . . . . . . . . 473

BIBLIOGRAFIE . . . . . . . . . . . . . . . . . 490

SUMMARY . . . . . . . . . . . . . . . . . . . 510

Kaart . . . . . . . . . . . . . . . . . . . . 512 


\section{LIJST VAN AFKORTINGEN}

\begin{tabular}{|c|c|}
\hline $\begin{array}{l}\text { afl. } \\
\text { a.o. }\end{array}$ & $\begin{array}{l}\text { aflevering(en) } \\
\text { and others }\end{array}$ \\
\hline Aufl. & $\begin{array}{l}\text { and others } \\
\text { Auflage }\end{array}$ \\
\hline dn & $\begin{array}{l}\text { Aullage } \\
\text { banden }\end{array}$ \\
\hline ew. & bewerkt \\
\hline $\mathbf{K I}$ & $\begin{array}{l}\text { Bijdragen tot de taal-, land- en volkenkunde (van Neder- } \\
\text { landsch-Indië), uitgegeven door het Koninklijk Instituut voor } \\
\text { (de) Taal-, Land- en Volkenkunde (van Nederlandsch-Indië) } \\
\text { bijgewerkt(e) }\end{array}$ \\
\hline d. or. & $\begin{array}{l}\text { codex orientalis, term in gebruik bij de universiteitsbibliotheek } \\
\text { te Leiden ter aanduiding van elk der in één doorlopende } \\
\text { nummering opgenomen oosterse handschriften }\end{array}$ \\
\hline & deel \\
\hline & delen \\
\hline & druk \\
\hline & edited, edition, editor \\
\hline g. & Engels \\
\hline & erweitert(e) \\
\hline publ. & gepubliceerd \\
\hline & Hijrah, begin van de moslimse jaartelling \\
\hline & herzien $(e)$ \\
\hline & herausgegeben \\
\hline d. Gids & De Indische Gids, staat- en letterkundig maandschrift \\
\hline don. & Indonesisch \\
\hline trod. & introduction \\
\hline & Javaans \\
\hline IBRAS & Journal of the Malayan Branch of the Royal Asiatic Society \\
\hline AS & $\begin{array}{l}\text { Journal of the Royal Asiatic Society of Great Britain and } \\
\text { Ireland }\end{array}$ \\
\hline & jaargang \\
\hline BRAS & Journal of the Straits Branch of the Royal Asiatic Society \\
\hline & krama-woord, in Javaans vormelijk-beleefd taalgebruik \\
\hline l. Ts. & $\begin{array}{l}\text { Koloniaal Tijdschrift, uitgegeven door de Vereeniging van } \\
\text { Ambtenaren bij het Binnenlandsch Bestuur in Nederlandsch- } \\
\text { Indië }\end{array}$ \\
\hline & kampung \\
\hline & Maleis \\
\hline ded. KNAW & Mededelingen van de Koninklijke Nederlandse Akademie van \\
\hline & $\begin{array}{l}\text { Wetenschappen } \\
\text { medewerking }\end{array}$ \\
\hline & $\begin{array}{l}\text { manuscriptum orientale, term gebruikt ter aanduiding van } \\
\text { een oosters handschrift uit het bezit van het Koninklijk In- } \\
\text { stituut voor Taal-, Land- en Volkenkunde } \\
\text { ngoko-woord, in Javaans niet-vormelijk taalgebruik }\end{array}$ \\
\hline
\end{tabular}


no

nr

nrs

Not. B.G.

o.d.t.

p.

Pal.

Pang.

pl.

Port.

pp.

pr.

prep.

Pt

pts

r.

Ras, gloss.

Rd.

repr.

rev.

samengest.

str.

Suh.

TBG

TNI

transl.

Ts. Binn. Best.

Ubers.

uitg.

VBG

verb.

verm.

VKI

Vol.

Vols

voorw.

z.a.

z.o. numero

nummer

nummers

Notulen van de algemeene en bestuurs-vergaderingen van het Bataviaasch Genootschap van Kunsten en Wetenschappen onder de titel

pagina

Palembang, Palembangs(e)

Pangéran

plaat

Portugees

pagina's

printing

prepared

Part

parts

regel

Glossary and Index; in: Ras, 1968

Radén

reprint

revised

samengesteld

strofe

Suhunan

Tijdschrift voor Indische taal-, land- en volkenkunde, uitgegeven door het (Koninklijk) Bataviaasch Genootschap van Kunsten en Wetenschappen

Tijdschrift voor Neêrland's Indië; vanaf jrg. 10 (1848): Tijdschrift voor Nederlandsch Indië

translated, translation

Tijdschrift voor het Binnenlandsch Bestuur

Ubersetzung

uitgave, uitgegeven

Verhandelingen van het (Koninklijk) Bataviaasch Genootschap van Kunsten en Wetenschappen

verbeterd $(e)$, verbessert $(e)$

vermeerderd $(e)$

Verhandelingen van het Koninklijk Instituut voor (de) Taal-, Land- en Volkenkunde (van Nederlandsch-Indië)

Volume

Volumes

voorwoord

zie aldaar

zie ook 


\section{HISTORISCH OVERZICHT}

De geschiedenis van het Sultanaat Palembang gedurende het tijdvak 1811-1825 wordt bepaald door de Engels-Nederlandse strijd om de hegemonie in het Indonesië van die dagen en de koloniale politiek van het na de Franse overheersing herrezen Nederland, gericht op herstel en consolidatie van het gezag over de herkregen overzeese bezittingen. Het is deze politiek die na een moeizame militaire krachtmeting met de naar onafhankelijkheid strevende sultan van Palembang de dynastie ten val brengt en het lot van het sultanaat als zelfstandige politieke entiteit definitief bezegelt. Naast deze externe factoren zijn ook interne spanningen binnen de dynastie op de loop der gebeurtenissen van invloed geweest. Deze spanningen, met name de rivaliteit tussen "de oude sultan" Mahmud Badaruddin en diens jongere broer "de jonge sultan" Ahmad Najamuddin, die in deze periode beurtelings de troon bezetten, hebben hierbij echter nauwelijks een zelfstandige rol gespeeld, maar zijn veeleer door de Engels-Nederlandse machtsstrijd in de hand gewerkt en door de latere Nederlandse politiek van "verdeel en heers" tegelijk uitgebuit en gestimuleerd. Het was niet aan inwendig verval te wijten dat het sultanaat te gronde ging. Integendeel, de doelbewuste wijze waarop Sultan Mahmud Badaruddin de onafhankelijkheid van zijn gebied heeft verdedigd en de daarbij met name in 1819 behaalde opmerkelijke successen duiden op een sterk centraal gezag en getuigen van eendracht en vastberadenheid binnen de kring der heersende klasse. Dit verzet van Palembang tegen vreemde inmenging en overheersing was overigens geen nationale strijd voor de onafhankelijkheid, zoals wij die thans opvatten. Daarvoor was de bevolking te heterogeen van samenstelling, de maatschappij te zeer in standen verdeeld en het gewone volk te onmondig. Het was een mede door religieus fanatisme bepaalde strijd van de heersende klasse, die haar positie bedreigd zag door vreemdelingen met een inferieure, want aan het ware geloof vijandige leefwijze, maar niettemin met een irriterende superioriteit in technisch vernuft en materieel vermogen, wier aspiraties in toenemende mate met de belangen van het Palembangse hof in conflict kwamen en tenslotte tot de liquidatie van het traditionele gezag hebben geleid. 
Uitgaande van de bovengenoemde factoren, waardoor de geschiedenis van het sultanaat tussen 1811 en 1825 wordt bepaald, kan men dit tijdperk onderverdelen als volgt:

september 1811-mei 1812: een periode van onafhankelijkheid mei 1812-december 1816: een Engelse tijd

december 1816-juni 1819: een Nederlandse tijd juni 1819-juni $1821 \quad$ : een tweede periode van onafhankelijkheid juli 1821-oktober 1825 : de periode van ondergeschiktheid aan het Nederlandse koloniale gezag, gevolgd door de opheffing van het sultanaat en eindigende met de verbanning van de tegen het gezag opgestane laatste vertegenwoordiger van de dynastie.

De dynastieke geschiedenis geeft als gevolg van het ingrijpen der vreemde machthebbers een triest beeld van troonswisselingen te zien, die de volgende regeringsperioden opleveren:

$\begin{array}{lll}\text { april 1804-mei } 1812 & \text { : } & \text { Mahmud Badaruddin } \\ \text { mei 1812-juni } 1813 & \text { : } & \text { Ahmad Najamuddin } \\ \text { juli 1813-augustus 1813 }: & \text { Mahmud Badaruddin } \\ \text { augustus 1813-juni 1818 : } & \text { Ahmad Najamuddin } \\ \text { juli 1818-juni 1821 } & : & \text { Mahmud Badaruddin } \\ \text { juli 1821-augustus 1823 }: & \text { Ahmad Najamuddins oudste zoon Prabu } \\ & \text { Anom, als regerend vorst eveneens Ahmad } \\ & \text { Najamuddin genaamd. }\end{array}$

Ingevolge tractaat van 18 augustus 1823 komt Palembang onder rechtstreeks bestuur van het Nederlandse gouvernement en wordt de sultan gepensioneerd.

De centrale figuur in het drama dat dit stuk geschiedenis in de Indonesische historiografie oplevert, is ongetwijfeld Mahmud Badaruddin, volgens getuigenis van vriend en vijand een man van formaat, vorstelijkgroots in zijn deugden en ondeugden, die door zijn sterke persoonlijkheid zowel zijn concurrent Ahmad Najamuddin als de overige leden van het vorstenhuis volledig in de schaduw stelt. Zijn grote tegenspelers zijn Raffles - voornamelijk van achter de schermen - en Muntinghe, terwijl voorts een aantal uit de Engelse en Nederlandse koloniale geschiedenis bekende militairen, zoals Gillespie, Wolterbeek en De Kock, bij de voltrekking van het drama een belangrijke rol spelen.

$\mathrm{Nu}$ het verloop van de Palembangse geschiedenis tussen 1811 en 1825 
in enkele ruwe lijnen is geschetst en een aantal globale onderscheidingen binnen dit tijdvak zijn aangebracht, volge een chronologische weergave van de historische feiten, gebaseerd op de belangrijkste secundaire bronnen en publikaties.

Begin april 1804 overlijdt na een ruim zevenentwintigjarige regeringsperiode Sultan Muhammad Baha'uddin. Hij wordt opgevolgd door zijn oudste zoon Mahmud Badaruddin. Deze wordt door zijn tijdgenoten getypeerd als een oosters despoot met een onbetwist gezag, die zich volledig bewust is van zijn hoge vorstelijke waardigheid en de voor gewone stervelingen geldende normen daaraan ondergeschikt weet. In zijn onaantastbare positie kan hij zich alles, ook wreedheden en morele buitensporigheden veroorloven zonder zijn gezag afbreuk te doen. Hij is een intelligent en ontwikkeld man, een goed organisator, een geslepen diplomaat en een knap strateeg. Zijn veelzijdige belangstelling gold met name ook de letterkunde. Volgens Van Sevenhoven, in de jaren 18221823 als commissaris van het Nederlandse gouvernement te Palembang werkzaam, had hij "eene vrij uitgestrekte bibliotheek". ${ }^{1}$ In de notulen van het Bataviaasch Genootschap van Kunsten en Wetenschappen, deel XVIII (1880), pp. 75-76 lezen we dat in 1822 door dezelfde commissaris van Palembang aan de resident van Batavia zijn verzonden "55 (vijfenvijftig) zeer fraai geschreven, net ingebonden en wel geconditioneerde Maleische en Arabische manuscripten, waaronder zeer zeldzame, en achterhaald als toebehoord hebbende aan den Ex-Sultan van Palembang Machmoed Badr'Oeddin". Voorts heeft hij zich bekendheid verworven als auteur van de Syacir Sinyor Kista (of Kosta), van de Syacir Nuri en van een pantun "tot vertroosting des harten". ${ }^{2}$

In het economisch en bestuurlijk centrum van het Palembangse rijk bevindt zich aan de rechteroever van de Musi, dichtbij een zijriviertje, de Sungai Aur, en schuin tegenover het aan de linker Musi-oever gelegen kratoncomplex, als een vreemde enclave de Nederlandse nederzetting, ontstaan uit de daar reeds in 1662 gestichte vaste handelspost van de Oost-Indische Compagnie. De handelscontacten met de Compagnie, die reeds van 1619 dateerden, hadden in de loop der jaren een meer permanent karakter gekregen. Tussen de jaren 1641 en 1791 kwam een reeks van "plechtige overeenkomsten" tot stand betreffende de levering van peper en later - na de ontdekking omstreeks 1710 van de tinvoorkomens op het onder Palembang ressorterende eiland Banka - ook van tin. Het aldus gevestigde Compagniesmonopolie betekende voor Palembang de verplichting tot leverantie van de totale peper- en tinproduktie van het land aan de Compagnie tegen door haar vastgestelde, uiteraard 
niet-commerciële prijzen. Het spreekt vanzelf dat dit monopolie op ruime schaal werd ontdoken. Vooral in de laatste decennia van de achttiende eeuw, toen de positie van de Compagnie dermate was verzwakt, dat zij niet meer bij machte was de nakoming der monopoliebepalingen af te dwingen, nam de smokkel hand over hand toe. Tegen het eind van deze eeuw, wanneer de Republiek der Verenigde Nederlanden plaats moet maken voor de Bataafse Republiek en de OostIndische Compagnie wordt ontbonden, is de clandestiene uitvoer van peper en tin uit het Palembangse rijk tot een veelvoud van het aan de Hollanders geleverde contingent opgelopen en het prestige van de Nederlandse factorij te Palembang nagenoeg geheel verdwenen.

De ontwikkeling van de Britse koloniale macht daarentegen had zich in de tweede helft van de achttiende eeuw steeds verder in stijgende lijn bewogen. Terwijl in het absolutistische en feodale Frankrijk van Lodewijk XV en Lodewijk XVI sociaal-politieke toestanden heersten die een gezonde vooruitgang onmogelijk maakten en die tenslotte tot de revolutie van 1789 zouden leiden, maakte Engeland een enorme industriële en sociale ontwikkeling door. Het beheerste daardoor de zee en de wereldhandel. In de zevenjarige oorlog (1756-1763) had het Frankrijk als koloniale mogendheid uitgeschakeld. Het wist ondanks het verlies der Amerikaanse koloniën de suprematie ter zee te behouden en bevestigde deze in de oorlog van 1780-1784 nog eens tegenover Nederland. De Engelse posities in India werden verder uitgebreid en geconsolideerd, maar ook in de Maleis-Indonesische archipel nam de Britse invloed toe, door de bezetting van strategisch gelegen punten als Pulau Pinang en Malakka en voorts door verdere expansie op Sumatra, waar de Engelse Oost-Indische Compagnie reeds een eeuw lang vaste voet had door haar vestiging in Benkoelen.

In 1795, toen Prins Willem V naar Engeland uitweek en Nederland een vazalstaat van Frankrijk was geworden, namen de Engelsen met machtiging van de prins een deel der Nederlandse koloniën tegen een eventuele bezetting door Frankrijk "in bescherming". Dit betekende een verder prestigeverlies van de Nederlandse ten gunste van de Britse koloniale macht, ook al werden de Nederlandse bezittingen bij de vrede van Amiens in 1802 teruggegeven. Daarna ging het met de politieke zelfstandigheid van Nederland steeds verder bergafwaarts. Op de Bataafse Republiek volgde het Koninkrijk Holland onder Lodewijk Napoleon en in 1810 werd het land bij het Franse keizerrijk ingelijfd. Het Koninkrijk Holland bracht de Nederlandse koloniën in Indonesië op 1 januari 1808 
in de ijzeren greep van Maarschalk Daendels, die ruim drie jaar aan het bewind bleef. In april 1811, twee maanden nadat hem het officiële nieuws van de inlijving van Holland had bereikt, werd hij vervangen door Generaal Janssens. De Engelsen, die reeds tijdens het bewind van Daendels de Molukken hadden bezet, zetten de verovering van de nu Frans geworden koloniën voort, voerden in augustus 1811 een grootscheepse invasie uit op West-Java en dwongen Janssens nog geen maand later tot capitulatie.

Keren wij thans terug tot Palembang, waar Sultan Mahmud Badaruddin zich nog steeds geconfronteerd ziet met de op zichzelf ongevaarlijke maar voor zijn nationale trots toch wel hinderlijke aanwezigheid in de onmiddellijke nabijheid van zijn paleis van een Hollandse factorij met een - weliswaar klein - militair garnizoen, terwijl de berichten over het optreden van Daendels op Java ook voor Palembang weinig goeds van Hollandse zijde doen verwachten.

De Britse koloniale belangen hebben intussen een eminent voorvechter gevonden in de sedert 1805 als adjunct-secretaris van de Britse vestiging op Pulau Pinang werkzame Thomas Stamford Raffles, die een levendige en zeer veelzijdige belangstelling voor de Maleise en Indonesische wereld paart aan een sterk ontwikkeld nationaal bewustzijn en die een hartgrondige afkeer heeft van het Nederlandse koloniale bestuursstelsel. Zijn streven is rechtstreeks gericht op de vernietiging van het Nederlandse bewind. Nadat hij zijn ideeën omtrent de vereiste aanpak in Indonesië op schrift heeft gesteld en dit program, waarin de ten opzichte van Palembang te volgen politiek een voorname plaats inneemt, in Calcutta aan Gouverneur-Generaal Gilbert Elliot, Lord Minto, heeft voorgelegd, wordt Raffles in oktober 1810 benoemd tot "Agent to the GovernorGeneral with the Malay States". Deze benoeming biedt hem de volle gelegenheid zijn uitgebreide kennis van zaken en zijn diplomatieke talenten in dienst te stellen van de verwezenlijking van het door hem boven alles gestelde tweeledige doel: de vernietiging van het verfoeilijke Nederlandse bewind en de vestiging van het Britse gezag, dat naar zijn stellige overtuiging tevens de bevolking van de archipel tot zegen zou strekken. De waarschijnlijk door Raffles zelf ontworpen instructies, waarin zijn nieuwe taak is omschreven, verschaffen hem een ruime vrijheid van handelen. Raffles zal in overeenstemming met zijn persoonlijke opvattingen van die vrijheid een dankbaar gebruik maken, met name voor zover het Palembang betreft.

Op 10 december 1810, binnen een week na zijn aankomst te Malakka, 
waar hij zijn hoofdkwartier heeft gevestigd, opent Raffles een briefwisseling met de sultan van Palembang waarin hij deze tracht te overtuigen van de vijandige gezindheid der Nederlanders jegens Palembang en er bij hem op aandringt hen uit zijn land te verwijderen en een verdrag met de Engelsen, zijn werkelijke vrienden, aan te gaan. Mahmud Badaruddin beantwoordt Raffles' brieven met de grootste voorzichtigheid en tact; hij wil ten aanzien van het Engels-Nederlandse conflict voorlopig neutraal blijven. De correspondentie loopt tot eind mei 1811, wanneer de Engelse invasievloot voor de anval op Java reeds is uitgerust en bij Malakka samengetrokken. Raffles heeft de sultan tenslotte laten weten dat hij als onafhankelijk vorst zal worden beschouwd, mits hij de Hollanders zal hebben verdreven vóórdat Java door de kracht der Britse wapenen zal zijn veroverd; met de val van Java zouden immers alle Nederlandse vestigingen in de archipel automatisch onder Britse heerschappij komen. Bij zijn laatste brief stuurt Raffles tachtig geweren en tien manden ammunitie en zegt hij de sultan verdere militaire hulp tegen de Hollanders toe.

Mahmud Badaruddin aanvaardt deze geschenken op hoofse wijze, maar volhardt overigens in zijn afwachtende houding, terwijl hij zich door zijn informanten op de hoogte laat houden van de ontwikkeling van de strijd op Java, welke begin augustus is begonnen. Eerst nadat hem is gemeld dat Janssens bij Meester Cornelis beslissend is verslagen en Batavia in Engelse handen is (26 augustus), gaat hij tot actie over. De Hollanders in Palembang kunnen niet meer op steun van het centraal gezag rekenen en de Engelsen, die hem bij monde van Raffles trouwens hun fiat hebben gegeven om tegen de Hollandse factorij te Palembang op te treden, hebben voorlopig hun handen vol op Java. In deze positie van lachende derde weet de sultan de Nederlandse loge op listige wijze te overrompelen (14 september 1811). De uit vierentwintig Hollanders en drieënzestig Javanen bestaande bezetting wordt ontwapend, in prauwen de Musi afgevoerd en aan de monding, bij Sungsang, vermoord. Slechts de klerk Willem van de Weeteringe Buijs, zoon van een Palembangse moeder, en enkele vrouwen uit de nederzetting weten de dans te ontspringen. ${ }^{3}$

Door de Hollanders te vermoorden in plaats van hen te dwingen Palembang te verlaten had de sultan tevens het risico geëlimineerd, dat zijn tegenover de Engelsen vol te houden bewering, als zou hij zijn land reeds vóór de val van Java van het Nederlandse juk hebben bevrijd, later van Nederlandse zijde zou worden tegengesproken. Behalve de bezetting moest ook de loge zelf het ontgelden. Alle gebouwen werden 
met de grond gelijkgemaakt en om de indruk te vestigen dat de plaats reeds geruime tijd geleden was verlaten, werd het gehele terrein met bomen en struiken beplant en verder aan de tropisch-snelle plantengroei prijsgegeven.

Begin november 1811 zendt Raffles in zijn hoedanigheid van Luitenant-Generaal van Java en Onderhorigheden, nog onkundig van het gebeurde in Palembang, een gezantschap van drie man, Richard Phillips, Alexander Hare en Willem Wardenaar, naar de sultan om de Hollandse factorij over te nemen en vooral om voor Engeland het tinmonopolie en de afstand van Banka te bedingen. Deze eisen worden door Mahmud Badaruddin met een beroep op Raffles' brieven van de hand gewezen. Hij is nu baas in eigen huis en wenst dat te blijven. De liquidatie van de Nederlanders had toch niet gediend om de Engelsen als hun rechtsopvolgers binnen te halen! Over de ware toedracht met betrekking tot de Hollandse loge komt het gezantschap niets te weten. Het keert 6 december onverrichterzake in Batavia terug.

Eerst een maand later verneemt Raffles via Malakka het nieuws van de Palembangse moord. Was een gewelddadig optreden jegens de sultan door diens houding tegenover Phillips c.s. reeds noodzakelijk geworden, de moord op de Hollanders verleende daaraan nu een morele rechtvaardiging bovendien.

Een militaire expeditie onder commando van Major-General Robert Rollo Gillespie, 20 maart 1812 van Batavia vertrokken, arriveert een maand later voor de monding van de Musi. Mahmud Badaruddin ontvangt de Britse troepen niet onvoorbereid. Onmiddellijk na de actie tegen de Hollandse loge was hij begonnen met de aanleg van uitgebreide vestingwerken op strategische punten langs de rivier en op de daarin gelegen eilanden. Ook drijvende batterijen, bewapende vaartuigen en vlotten met brandbaar materiaal om als "branders" op de vijandelijke schepen te worden afgezonden zijn in het verdedigingsstelsel opgenomen, terwijl de eigenlijke vesting Palembang, waarbinnen de kraton is gelegen, met tweehonderd tweeënveertig vuurmonden de vijand opwacht.

Niettemin wordt Palembang binnen een week door de Britse troepen bezet. De voornaamste versterkingen, die op het eiland Borang, waren de Engelsen door de tweeslachtige houding van de met de verdediging ervan belaste broer van de sultan, de Pangéran Adipati Ahmad Najamuddin, op 24 april zonder slag of stoot in handen gevallen. Dit verpletterende nieuws had de sultan doen besluiten de kraton te verlaten en zich met medeneming van de schatkist alsmede van de voor de 
uitoefening der regering niet minder belangrijke rijkssieraden of -insigniën, de traditionele tekenen van de vorstelijke waardigheid, in het binnenland terug te trekken om later de strijd tegen de vreemdelingen zo nodig te kunnen hervatten. Gillespie reageert onmiddellijk op het bericht van Badaruddins vlucht door met een kleine voorhoede naar Palembang te roeien. Hij weet reeds in de nacht van 25 op 26 april de aan ordeloosheid prijsgegeven stad te bezetten en voor verdere brandstichtig en plundering te behoeden.

Op 26 april 1812 wordt de Engelse vlag op de vesting Palembang officieel gehesen en de volgende dag opent Gillespie besprekingen met Ahmad Najamuddin, die hem een geschikt troonopvolger voor Palembang lijkt. Met groot ceremonieel wordt de veertiende mei Mahmud Badaruddin van de troon vervallen verklaard en zijn broer Ahmad Najamuddin tot sultan verheven. Zijn rechten en verplichtingen worden nader geregeld in een op 17 mei 1812 gesloten verdrag, waarbij de nieuwe sultan tevens Banka en Billiton aan de Engelsen afstaat.

Gillespie verlaat vervolgens met de hoofdmacht van de expeditie Palembang, waar een bezetting van honderd man achterblijft. De twintigste mei in Muntok aangekomen neemt hij Banka, waaraan bij deze gelegenheid de naam "Duke of York Island" wordt gegeven, formeel voor de Britse koning en de Engelse Oost-Indische Compagnie in bezit. Captain R. Meares, die als "Malay interpreter to the Commander of the Forces" de expeditie heeft meegemaakt, wordt tot resident van Palembang en Banka benoemd en krijgt een gedeelte van de troepen ter beschikking, waarna Gillespie met de rest van de strijdmacht naar Java terugkeert.

$\mathrm{Na}$ ter plaatse orde op zaken gesteld te hebben, begeeft Meares zich in de tweede helft van augustus met een deel van de bezettingstroepen naar Palembang om de voortvluchtige ex-sultan op te sporen en tot overgave te dwingen. Deze had zich bij het stroomopwaarts aan de Musi gelegen Buaya Langu verschanst. Daar komt het tot een treffen, waarbij Meares gewond raakt. Hij keert naar Palembang terug en wordt vervolgens naar Muntok vervoerd, waar hij op 16 september, twee weken na aankomst, aan zijn verwondingen overlijdt. Badaruddin vaart nu verder de Musi op en vestigt zich bij de samenvloeiing met de Rawasrivier, in Muara Rawas. Hij weet zich daar als "de oude sultan" een grote aanhang te verwerven. Zijn jongere broer daarentegen, die regeert bij de gratie van de Engelsen, een weinig krachtige figuur is en bovendien gehandicapt wordt door geldgebrek en het gemis van de door 
Badaruddin meegenomen regalia van de dynastie, heeft zelfs ter hoofdplaats weinig gezag.

Het is derhalve begrijpelijk dat Major William Robison, die Meares als resident was opgevolgd en die Raffles, met wie hij in zijn ambtelijke carrière reeds enige malen in conflict was gekomen, als de hoofdschuldige aan de moord op de Hollanders beschouwt, niet ongevoelig blijft voor de avances van de oude sultan om - desnoods tegen betaling van een aanzienlijke som gelds - in zijn waardigheid te worden hersteld. Op grond van een juist inzicht in de krachtsverhoudingen maar in strijd met zijn instructies ziet Robison af van militaire actie tegen het zwaar versterkte hoofdkwartier van Badaruddin in Muara Rawas.

In mei 1813 stuurt hij een Brits officier, bijgestaan door een Nederlands officier in Britse dienst als tolk, naar Muara Rawas om de situatie ter plaatse op te nemen en de oude sultan te bewegen als ambteloos burger naar Palembang terug te keren. Wanneer deze zijn aanspraken op de troon onverkort blijkt te handhaven, vertrekt Robison de negentiende juni zelf met een militair escorte naar Muara Rawas, waar hij door Badaruddin vriendschappelijk wordt ontvangen. Als resultaat van de ter plaatse gevoerde onderhandelingen komt op 29 juni een verdrag tot stand, waarbij Badaruddin als sultan van Palembang wordt erkend (op voorwaarde dat Najamuddin daarmee instemt!), maar tevens de afstand van Banka en Billiton aan de Engelse Oost-Indische Compagnie bekrachtigt. Hij verbindt zich voorts tot opzending naar Batavia van zijn oudste zoon wegens diens aandeel in de moord op de Hollandse factorij, tot betaling van 400.000 Spaanse dollars ter dekking van de onkosten der expeditie onder Gillespie en tot de wederopbouw van het voormalige Hollandse fort, welke laatste verplichting eventueel kan worden afgekocht door betaling van 20.000 Spaanse dollars en beschikbaarstelling van werkkrachten voor de bouw. Robison reist naar Palembang vooruit om de jonge sultan van het met zijn broer gesloten tractaat in kennis te stellen. Najamuddin, die nu zijn grote concurrent naar de hoofdstad onderweg is minder dan ooit op steun van zijn volk kan rekenen, moet zich wel laten welgevallen, dat hij wordt onttroond en de zogenaamde oude kraton weer als verblijf krijgt toegewezen. Badaruddin zelf komt 13 juli in Palembang aan en betrekt de grote kraton. Het gesol met de sultanswaardigheid en het vernederende stuivertje verwisselen tussen de beide broers is weer begonnen.

De vreugde is slechts van korte duur, want het eigenmachtig optreden van Robison, die in Batavia van de nieuwe ontwikkelingen persoonlijk 
verslag heeft uitgebracht, wordt door Raffles afgekeurd, het tractaat nietig verklaard en Robison niet alleen ontslagen, maar zelfs wegens zijn financiële manipulaties in staat van beschuldiging gesteld. Reeds een maand later verschijnen voor Palembang de schepen van een inderhaast door Raffles uitgeruste expeditie met een commissie onder Major W. Colebrooke aan boord, die de opdracht heeft de toestand van vóór het tractaat met Robison te herstellen. De desbetreffende proclamatie van Raffles d.d. 4 augustus 1813 wordt de dag na aankomst der commissie tijdens een plechtige bijeenkomst in de ontvangzaal van de kraton voorgelezen. De oude sultan moet wederom plaats maken voor zijn jongere broer, die op 21 augustus een nieuw verdrag met de Engelsen tekent. Badaruddin weigert de krachtens het Islamitisch erfrecht hem persoonlijk toebehorende regalia aan zijn broer af te staan en moet door de Britse bezettingsmacht onder bedreiging van geweld tot afgifte daarvan worden gedwongen. De bedragen die hij Robison indertijd voor zijn herstel op de troon heeft betaald, worden hem door de Engelsen gerestitueerd, met rente, zoals de Palembangse kroniekschrijver uitdrukkelijk vaststelt. De oude sultan ziet intussen kans door zijn persoonlijk overwicht en met behulp van de uitgebreide financiële middelen waarover hij nog steeds beschikt, zijn aanzien te versterken en een krachtige oppositie te vormen tegen het gezag van Najamuddin, dat uitsluitend steunt op de kracht der Britse wapens. Zo blijft de toestand in het in zichzelf verdeelde Palembang onder de volgende Britse resident Major M. H. Court gespannen en onzeker, zonder dat het evenwel tot een uitbarsting komt.

Terwijl de sultan van Palembang zich moet tevredenstellen met de opbrengsten van de in belang afnemende pepercultuur, concentreert de belangstelling aan Engelse zijde zich in de komende jaren op de veel lucratievere exploitatie van de tinmijnen op Banka. De smokkel wordt krachtig bestreden en het toezicht op de produktie gereorganiseerd. Via de Britse factorij in Kanton worden Chinezen voor het werk in de mijnen aangeworven. Door al deze maatregelen wordt de opbrengst in de jaren 1814-1816 meer dan verdrievoudigd.

Intussen is in Europa de ster van Napoleon gedaald en het machtsoverwicht naar geallieerde zijde verschoven. Napoleon is na het échec in Rusland bij Leipzig beslissend verslagen en wordt tenslotte gedwongen afstand te doen van de troon. Nederland heeft zich van de Franse overheersing bevrijd en zich als zelfstandige staat hersteld onder de uit Engeland teruggekeerde Prins van Oranje, die op 2 december 1813 als 
Koning Willem I de souvereiniteit aanvaardt. Tot het herstel van de Nederlandse staat behoorde ook de teruggave van de koloniën, die Engeland indertijd met machtiging van de Prins tegen de Fransen in bescherming had genomen. Reeds spoedig na de "eerste" vrede van Parijs neemt Engeland het initiatief om deze kwestie te regelen.

Zo komt op 13 augustus 1814, nog vóór het begin van het Wener Congres, de Conventie van Londen tot stand, waarbij Zijne Britse Majesteit zich verbindt om aan de Souvereine Vorst der Verenigde Nederlanden de koloniën terug te geven die Holland bezat op 1 januari 1803 (dus na de vrede van Amiens, waarbij Ceylon aan Engeland was afgestaan), met uitzondering van de Kaapkolonie en de etablissementen van Demerary, Essequebo en Berbice in de West, terwijl Banka zal worden geruild tegen de Hollandse vestiging in Cochin aan de kust van Malabar. Deze laatste bepaling hield geen rekening met de afhankelijke positie van Banka ten opzichte van Palembang, tengevolge waarvan het stilzwijgend onder de terug te geven koloniën was begrepen. Het kon derhalve bezwaarlijk als ruilobject gelden, al was het dan ook sinds 1812 door de sultan van Palembang aan de Engelsen afgestaan. Dit gaf later moeilijkheden bij de overdracht van Billiton, dat in het tractaat niet met name werd genoemd, maar eveneens door de sultan van Palembang aan de Engelsen was afgestaan. Ook op enkele andere punten waren de bepalingen van het in grote haast opgestelde tractaat niet behoorlijk tot in hun directe consequenties doordacht. Met name de in de artikelen 3 en 5 vervatte voorschriften nopens de tenuitvoerlegging der conventie, waarbij werd bepaald, dat de koloniën zouden worden teruggegeven: a) binnen zes maanden na de ratificatie van het tractaat, welke uiterlijk drie weken na de ondertekening ervan zal moeten plaatsvinden en b) in de staat waarin ze zich bevinden ten tijde van de ondertekening der conventie, geven gelet op de toenmalige communicatiemiddelen en de gebrekkige kennis in Europa omtrent de toestand der koloniën weinig blijk van realiteitszin.

Mede door Napoleons verrassende come-back in het voorjaar van 1815 , tengevolge waarvan het vertrek van de tot overname der koloniën gemachtigde commissarissen-generaal, Van der Capellen, Elout en Buyskes, moest worden uitgesteld, heeft het twee jaar geduurd voordat aan de bepalingen der conventie een begin van uitvoering kon worden gegeven. Commissarissen-generaal, op 29 oktober 1815 van Texel vertrokken, bereikten Batavia begin mei 1816. John Fendall, die Raffles op 12 maart 1816 als luitenant-generaal van Java en onderhorigheden 
was opgevolgd, stelt de bestuursoverdracht uit in afwachting van instructies van het opperbestuur in Bengalen. Wanneer deze zijn ontvangen, wordt de conventie van 1814 in de Java Government Gazette van 13 juli 1816 afgekondigd. De officiële overdracht van het bestuur te Batavia vindt tenslotte op 19 augustus plaats.

Tot resident van Palembang en Banka wordt door commissarissengeneraal benoemd K. Heynis, die op 10 december 1816 te Muntok het bestuur van resident Court overneemt en een week later in Palembang arriveert. Muntok blijft voorlopig, evenals tijdens de Britse periode het geval was geweest, de hoofdzetel van het bestuur. Van een wezenlijke bestuursvoering van Nederlandse zijde is voorlopig geen sprake, vooral niet in het gebied van Palembang zelf, waar de controverse tussen de in naam regerende sultan en zijn oudere broer de politieke toestand blijft beheersen en de gezagsloosheid hand over hand toeneemt. De bevolking van de binnenlanddistricten, die door de sultan als apanagegebieden onder zijn familieleden zijn verdeeld, wordt door de apanagehouders op feodale wijze uitgebuit. Er wordt geroofd en geplunderd, zelfs tot over de grenzen met Benkoelen en de Lampongs. De klachten, die zowel door de betrokken bevolking als door de Britse resident van Benkoelen bij de vertegenwoordiger van het koloniale gezag in Palembang worden ingediend, blijven zonder resultaat. Het onmachtige Nederlandse bestuur, zo het al tot inmenging in de binnenlandse politiek bereid mocht zijn, is daartoe zeker niet in staat. Resident Heynes laat zich bovendien meer aan zijn persoonlijke belangen dan aan het welzijn van Palembang gelegen liggen. Hij maakt zich op ruime schaal aan knoeierijen schuldig en wordt na een onderzoek naar zijn praktijken door een commissie uit de Raad van Financiën, bestaande uit R. Coop à Groen en J. du Puy, ontslagen. Het bestuur wordt vervolgens met ingang van 29 juni 1817 door deze commissie waargenomen. Du Puy keert 16 december om gezondheidsredenen naar Batavia terug, waarna Coop de zaken alleen blijft behartigen in afwachting van de komst van Mr. Herman Warner Muntinghe, die reeds bij besluit van CommissarissenGeneraal dd. 27 oktober 1817 van zijn functie als president van de Raad van Financiën ontheven en tot commissaris van Palembang en Banka was benoemd.

Muntinghe had sedert 1804 achtereenvolgens onder Wiese en Daendels verscheidene hoge ambten bij het opperbestuur in Batavia bekleed en was na de val van Java door Raffles, die een grote waardering voor hem had, tot lid van het hoogste regeringscollege, de Raad van Indië, be- 
noemd. In 1813 trok hij zich echter uit de gouvernementsdienst terug. $\mathrm{Na}$ het herstel van het Nederlandse gezag treedt hij weer op in het publieke leven, eerst als president van de Raad van Justitie, daarna als president van de Raad van Financiën. Ingevolge regeringsbesluit van 12 januari 1819 wordt hij, nog te Palembang als commissaris in functie, tot lid van de Raad van Indië benoemd. Het is in deze hoedanigheid, waaraan de titel van Edelheer of Edeleer is verbonden, dat Muntinghe in de Maleise literatuur is blijven voortleven als "Idelir Ménténg".

Door een samenloop van omstandigheden duurt het vele maanden eer Muntinghe zijn nieuwe bestemming kan volgen. Eerst op 20 april 1818 arriveert hij te Muntok, waar hij het bestuur van Coop à Groen overneemt. Onder Muntinghe komt het zwaartepunt van de bestuursvoering duidelijk in Palembang te liggen, al blijft Muntok officieel zetel van het gewestelijk bestuur. Met het dagelijks beleid van zaken in Muntok wordt M. A. P. Smissaert belast, die, evenals Muntinghe bij besluit van 27 oktober 1817 benoemd, reeds in januari 1818 als "inspecteur-generaal der tinmijnen" naar Banka was gezonden.

Begin juli 1818 steekt Muntinghe, wiens geheime instructie onder meer de opdracht inhield een eind te maken aan de onenigheid tussen de regerende en de oude sultan teneinde op een hechte basis het Nederlandse gezag over het rijk te vestigen, van Banka naar Palembang over om er de nieuwe politiek met kracht ten uitvoer te leggen. Deze politiek had de vooropgezette bedoeling de door de Engelsen ten troon verheven sultan te degraderen ten gunste van zijn oudere broer, maar tevens het Palembangse rijk geleidelijk aan het sultansgezag te onttrekken. $\mathrm{Na}$ met beide partijen te hebben onderhandeld weet Muntinghe eerst Badaruddin en daarna ook Najamuddin tot aanvaarding der Nederlandse voorwaarden te dwingen. Met de ondertekening van de contracten van 20 respectievelijk 24 juni 1818 tekenen de beide broers in feite hun politieke doodvonnis. Badaruddin krijgt de sultanstitel en mag tegen betaling van een schadevergoeding aan zijn broer weer eens in de grote kraton, het statussymbool, gaan wonen, terwijl Najamuddin zich in de oude kraton moet terugtrekken. Beiden krijgen enig gebied toegewezen om daaruit de nodige inkomsten te verwerven. Maar daar staat dan het harde feit tegenover, dat het overgrote deel van het land aan het Nederlandse gouvernement wordt afgestaan.

Intussen was Raffles na een verblijf in Engeland de tweeëntwintigste maart 1818 als resident van Benkoelen met de persoonlijke titel van luitenant-gouverneur in de koloniale politiek teruggekeerd. Van meetaf 
had hij zich op het standpunt gesteld, dat hem met deze benoeming impliciet de behartiging der Britse belangen in geheel Sumatra en onderhorigheden was toevertrouwd, ofschoon zijn instructie een dergelijke interpretatie allerminst toeliet. Vanuit deze persoonlijke visie verzette Raffles zich met woord en daad tegen het herstel van het Nederlandse gezag, niet alleen in de Lampongs en in Minangkabau, maar ook in West-Borneo en op Riau, om tenslotte - begin februari 1819 - zijn diplomatieke activiteiten bekroond te zien met de stichting van het later zo belangrijke Britse steunpunt Singapore.

Ten aanzien van Palembang huldigde hij de opvatting, dat dit gebied krachtens het indertijd door Sultan Najamuddin met de Engelsen gesloten verdrag onder Britse bescherming stond. Reeds vóór Muntinghe's komst te Palembang was er een gezantschap uit Benkoelen ter plaatse verschenen en toen de Nederlandse bezetting van Palembang een feit was geworden, liet Raffles een officieel protest bij commissarissengeneraal horen.

Najamuddin had zich van zijn kant, zodra hem uit de eerste onderhandelingen met Muntinghe duidelijk was geworden dat zijn positie ernstig gevaar liep, gehaast Engelse hulp in te roepen. Raffles beantwoordt dit verzoek door op 22 juni een voornamelijk uit sepoys 4 bestaande troepenmacht van een paar honderd man onder commando van Captain Francis Salmond over land van Benkoelen naar Palembang te zenden. Salmond bereikt de hoofdstad met een kleine voorhoede reeds op 4 juli en sluit met Najamuddin een vriendschapsverdrag, waarna deze op de oude kraton de Engelse vlag laat hijsen. Dan grijpt Muntinghe in en laat de groep ontwapenen en via Muntok naar Batavia opzenden, vanwaar men later netjes naar Benkoelen zal worden teruggebracht.

Najamuddin, die zich bij het Nederlandse bestuur nu geheel onmogelijk heeft gemaakt, trekt zich in een gedeelte van de grote kraton terug, waar hij vervolgens door Muntinghe met hulp van Badaruddin onder bewaking wordt gesteld. De hem bij contract van 24 juni 1818 toegewezen districten worden hem ontnomen en aan Badaruddin in beheer gegeven.

Zodra de groep-Salmond Palembang heeft verlaten, rust Muntinghe - wederom met volledige medewerking van Badaruddin - een militaire expeditie uit om de Engelse hoofdmacht, die onder luitenant Haslam in Muara Beliti is achtergebleven, op te sporen en tot de aftocht te dwingen. De expeditie, met Muntinghe zelf aan het hoofd, vertrekt 13 juli en bereikt binnen twee weken Muara Beliti, dat inmiddels door de Engelsen, die er met de plaatselijke bevolking in conflict waren 
geraakt, blijkt te zijn ontruimd. $\mathrm{Na}$ zich ervan overtuigd te hebben dat Haslam c.s. inderdaad naar Benkoelen zijn teruggetrokken, keert Muntinghe naar Palembang terug, waar hij 16 augustus aankomt. Er hebben zich daar tijdens zijn afwezigheid geen bijzonderheden voorgedaan.

Muntinghe acht nu de tijd gekomen voor de organisatie van het binnenlands bestuur op westerse grondslag en doet bij plakkaat van 1 september 1818 afkondiging van de beginselen en richtlijnen van het nieuw te voeren beleid in de verwachting, dat de bevolking van Palembang de zegeningen van het vreemde gezag zal weten te prefereren boven het wanbeheer en de willekeur van haar eigen hoofden, een in de koloniale politiek vaker vertoonde misvatting, welke ook hier een illusie zal blijken te zijn. Muntinghe's optimisme is te minder gerechtvaardigd, daar aan zijn plannen tot stichting en handhaving van de pax neerlandica zowel ter plaatse als op Banka de nodige machtsbasis ontbreekt, terwijl op hulp uit Java gedurende de westmoesson niet te rekenen is. Tot het inzicht, dat voor de uitvoering van deze plannen, ja zelfs ter handhaving van eigen positie, een aanzienlijke versterking van het militaire apparaat absoluut noodzakelijk is, komt Muntinghe eerst enige tijd later, wanneer de loop der gebeurtenissen hem heeft geleerd, dat hij niet alleen de vasthoudendheid van Raffles maar vooral ook de invloed van de door hemzelf weer in het zadel geholpen oude sultan heeft onderschat.

Raffles, zojuist van een Engelse propagandatocht door de Padangse bovenlanden in Fort Marlborough teruggekeerd, had op het vernemen van het échec van de Salmond-missie een nieuwe expeditie van 400 man voor Palembang uitgerust, waarvan de leiding werd toevertrouwd aan resident Hayes, onder Raffles belast met het bestuur over het Benkoelense deel van de Rejang en voor de gelegenheid benoemd tot commissaris van het stroomgebied van Musi, Klingi en Beliti. Deze had de opdracht eerst het tot het Palembangse grondgebied behorende deel van de Rejang tot aansluiting bij Benkoelen over the halen en vervolgens verder oostwaarts te trekken tot Muara Beliti, waar de bevolking op overeenkomstige wijze moest worden bewerkt.

Reeds medio september dringen de eerste geruchten over de tweede Engelse inval tot Palembang door. Deze doen Muntinghe besluiten Najamuddin, nog steeds onder arrest, uit Palembang te verwijderen en hem met zijn naaste familieleden en vertrouwelingen naar Batavia te deporteren. Door het ontbreken van vervoersgelegenheid kan dit besluit niet onmiddellijk worden uitgevoerd. Eerst op 30 november vertrekt het 
uit drieënzestig personen bestaande gezelschap aan boord van een korvet, die uit Malakka militaire versterkingen voor Palembang heeft aangebracht. Het schip komt 18 december in Batavia aan. $\mathrm{Na}$ een kort oponthoud aldaar worden de ballingen naar hun uiteindelijke verblijfplaats in de Preanger overgebracht.

Behalve met dit politieke ingrijpen had Muntinghe ook met militaire maatregelen op het nieuws van de Engelse inval gereageerd. Hij detacheert een klerk van het bestuurskantoor in Muara Beliti, die er de door Hayes vooruitgezonden brieven in handen krijgt, waaruit het reisdoel der Engelsen Muntinghe tijdig bekend wordt, stuurt er vervolgens een groep van dertig militairen heen (ongeveer de helft van de te Palembang gelegerde bezetting!) en stelt verder alles in het werk om uit Banka versterkingen te laten overkomen, waarbij hij echter op ernstige weerstand van militaire zijde stuit. Wanneer Hayes eindelijk op 26 november, ten gevolge van de onderweg van bevolkingszijde ondervonden tegenwerking veel later dan verwacht werd, voor Muara Beliti verschijnt, verlaten de Nederlanders onmiddellijk hun post en vluchten in allerijl terug naar Palembang.

In deze hachelijke situatie besluit Muntinghe zelf naar Muara Beliti te gaan. Hij stelt zijn vertrek uit tot de dag, waarop Najamuddin en de zijnen naar Batavia worden afgevoerd. Zo begint Muntinghe op 30 november 1818 zijn tweede tocht naar het binnenland, de bestuurszaken te Palembang aan de commies J. J. V. Valckenaer en de handhaving van orde en rust aan een garnizoen overlatend, waaraan een belangrijk deel voor de expeditie is onttrokken. Hij zal bijna een half jaar wegblijven, lang genoeg om Sultan Badaruddin de gelegenheid te geven het verzet tegen het vreemde gezag tot ver buiten de hoofdplaats te organiseren en tevens lang genoeg om Muntinghe zelf het verschil te leren kennen tussen werkelijke aanhankelijkheid van de bevolking aan het vreemde gezag en de betuigingen daarvan, waartoe die bevolking zich verplicht ziet zolang dat gezag zich kan doen gelden.

De reis verloopt voorspoedig. Na twee weken wordt Muara Rawas bereikt en op 24 december is men Muara Beliti zo dicht genaderd, dat nauwkeurige inlichtingen over de situatie aldaar kunnen worden verkregen. Hayes blijkt inmiddels te zijn overleden en luitenant Haslam, die ook de eerste Engelse expeditie had meegemaakt, heeft het commando overgenomen. Het was de Engelsen ook na hun aankomst te Muara Beliti allerminst voor de wind gegaan. De bevolking was weggetrokken en de troepen leden aan ondervoeding. $\mathrm{Na}$ een inleidende 
briefwisseling tussen Muntinghe en Haslam komen partijen tot onderhandelingen, die op 31 december 1818 worden afgesloten met een overeenkomst, waarbij Muara Beliti aan de Nederlanders wordt overgegeven en de Engelsen zich verplichten het Palembangse grondgebied te ontruimen.

Muntinghe heeft versterkingen uit Palembang opgeroepen en wanneer deze ter plaatse zijn aangekomen, besluit hij tot een soort goodwilltournee tot aan de grens met Benkoelen, waarmee hij behalve vlagvertoon ook controle op de naleving door de Engelsen van de overeenkomst van 31 december beoogt. Het is 19 maart 1819, eer men van Muara Beliti opbreekt. Na twee dagreizen in zuidwestelijke richting stuit men op gewapende tegenstand van de bevolking, vooral van uit het grensgebied der Padangse bovenlanden naar het Palembangse uitgezwermde Minangkabauers. $\mathrm{Na}$ een fel vuurgevecht trekt de expeditie verder westwaarts, maar ook daar moet men strijd leveren. De steeds vijandiger houding der bevolking dwingt Muntinghe ten slotte zijn plan om tot de Rejang door te dringen op te geven. Hij trekt zich op Muara Beliti terug en aanvaardt op 13 mei de terugreis naar Palembang.

Intussen zijn ook de bewoners van het Rawas-district in opstand gekomen. Onder hen bevinden zich eveneens grote groepen rondzwervende Maleiers uit Minangkabau, die Sultan Badaruddin gedurende zijn verblijf aldaar in de jaren 1812-1813 zo krachtig hadden gesteund. $\mathrm{Zij}$ blokkeren de Musi en plunderen de voor de expeditie bestemde zendingen vivres en ammunitie uit Palembang. Bij Muara Rawas, dat 17 mei wordt bereikt, komt het tot een felle strijd, waarbij volgens Muntinghe's verslag aan vijandelijke zijde veertig à vijftig doden vallen. De expeditie zakt daarna verder de Musi af en is op 20 mei eindelijk in Palembang terug.

Nog dezelfde dag vaardigt Muntinghe, die op grond van tijdens zijn tocht verkregen aanwijzingen de sultan verantwoordelijk acht voor het verzet in het binnenland, een formeel besluit uit, dat hij onderweg wel geconcipieerd zal hebben. Daarin worden de concrete gevallen van Badaruddins intriges tegen het Nederlandse gezag opgesomd en wordt hem opgedragen de opstandelingen onverwijld van tegenorders te voorzien, hun aanvoerders te doen arresteren en deze aan het gouvernement uit te leveren. Bovendien wordt van de sultan geëist, dat hij zijn oudste zoon en enige andere vertrouwelingen op transport stelt naar Java om onder toezicht van de Nederlands-Indische regering te worden gesteld. Het is begrijpelijk dat vooral deze laatste eis bij de sultan nog meer 
kwaad bloed zet. Hij reageert voorlopig noch in positieve noch in negatieve zin en weet de zaak drie weken te traineren. Intussen arriveert op 4 juni - een Nederlandse troepenmacht van ruim tweehonderd man uit Java, waardoor de sterkte van het plaatselijk garnizoen bijna wordt verdubbeld. Bij gebrek aan accommodatie op het terrein van de Nederlandse bestuursvestiging aan de rechteroever van de Musi worden de troepen voorlopig in de oude kraton ondergebracht. Op 10 juni verklaart de sultan zich bereid de eisen van Muntinghe in te willigen, met uitzondering evenwel van de eis tot opzending naar Batavia van de kroonprins. Twee dagen later laat de sultan weer weten, dat hij de "gijzelaars" 's avonds zal uitleveren, waarop Muntinghe belooft de nieuw aangekomen troepen naar een provisorisch kampement aan de overkant te zullen overbrengen.

Terwijl 's middags de voorbereidingen voor deze verhuizing in volle gang zijn, doen de Palembangers vanuit de grote kraton een hevige aanval op de Hollandse troepen en opent het geschut van de kraton het vuur op de op stroom liggende korvetten "Eendragt" en "Ajax". Hiermee begint de openlijke strijd, die in de Syacir Perang Ménténg op dichterlijke wijze wordt weergegeven en die in drie dagen tijd ten gunste van de Palembangers zal zijn beslist.

Het scheepsgeschut blijkt niet in staat in de ruim twee meter dikke vestingmuren een bres te schieten, pogingen om de hoofdpoort te forceren mislukken eveneens. De troepen kunnen zich in de oude kraton niet handhaven en zien zich gedwongen alsnog de rivier over te steken om zich bij het garnizoen aan de overkant te voegen. De schepen krijgen al spoedig gebrek aan ammunitie en moeten stroomafwaarts van de kraton een veiliger positie kiezen. De volgende dag, 13 juni, doet Muntinghe pogingen met de sultan onderhandelingen aan te knopen, waarbij hij voorstelt de vijandelijkheden te beëindigen in afwachting van een beslissing van de gouverneur-generaal inzake Muntinghe's besluit van 20 mei. De korte onderbreking van de strijd gedurende het diplomatieke verkeer tussen partijen werkt overigens vooral in het voordeel van de sultan, die de tijd benut om zijn volk binnen de vesting te concentreren en de geschutopstellingen op de muren zodanig te herzien en uit te breiden, dat ook de factorij aan de overkant binnen het bereik der kanonnen komt te liggen.

In de vroege ochtend van de vijftiende juni wordt de strijd hervat. De sultan werpt opnieuw branders in de strijd tegen de schepen en houdt het bestuurscomplex vanuit de kraton onder vuur. Wanneer zijn officieren hem melden dat vrijwel het laatste kruit verschoten is, ziet 
Muntinghe zich gedwongen tot de aftocht. Zodra de inscheping der troepen ondanks de aanhoudende vijandelijke aanvallen op de factorij is voltooid, lichten de schepen het anker en zakken langzaam de rivier af. Vier dagen later wordt de monding bereikt en zet men koers naar Muntok. Na order te hebben gegeven de verbinding van Palembang met de zee af te snijden door de riviermond met de korvetten te blokkeren, aanvaardt Muntinghe de reis naar Batavia om er persoonlijk het roemloos einde van het Nederlandse gezag te Palembang te gaan melden.

Wanneer hij de zestiende juli in Batavia aankomt, bevindt GouverneurGeneraal Van der Capellen zich op een tournee door Java. Muntinghe reist hem achterna en haalt hem bij Cheribon in, waarna beiden naar Semarang doorreizen voor een ontmoeting met de marinecommandant, Schout-bij-nacht Constantijn Johan Wolterbeek, en de legercommandant, Generaal-Majoor Hendrik Merkus baron de Kock. Op 30 juli wordt ter plaatse over de situatie te Palembang vergaderd en tot een militaire expeditie onder opperbevel van de marinecommandant zelf besloten. Daarbij wordt bepaald dat de expeditie uiterlijk omstreeks medio augustus (nog vóór het aanbreken van de westmoesson dus) zal moeten vertrekken en dat Muntinghe de tocht zal meemaken. Deze laatste brengt de volgende dag schriftelijk advies uit, waarbij hij een beschrijving geeft van het oorlogspotentieel en de verdedigingswerken van Palembang en tevens aanbevelingen doet voor een succesvolle bestrijding van de vijand. Enige dagen later geeft hij bovendien op omstandige wijze zijn inzichten ten beste met betrekking tot de bezetting van de sultanstroon, waarbij hij concludeert dat Badaruddin moet worden afgezet en adviseert als troonopvolger te benoemen de derde zoon van "de jonge sultan", Pangéran Jayaningrat, die zijn vader het jaar daarvóór in ballingschap naar Java was gevolgd. Bij besluit van de gouverneurgeneraal d.d. 4 augustus 1819 wordt dienovereenkomstig Badaruddin van de troon vervallen verklaard en Jayaningrat als zijn opvolger aangewezen. Hij zal als zodanig met de expeditie naar Palembang meereizen.

$\mathrm{Na}$ een veel te korte tijd van voorbereiding vertrekt op 22 augustus 1819 de expeditievloot van Batavia: twee oorlogsschepen, twee kanonneerboten, vier bewapende transportschepen en een aantal kleinere vaartuigen van Indonesische makelij. De sterkte der landingstroepen bedraagt ruim negenhonderd man. Tegen het eind van de maand is de vloot ter rede van Muntok. Hier zullen nog vier oorlogsschepen, waaronder een fregat, en een aantal voor een deel nog van elders te 
requireren Indonesische vaartuigen aan de expeditie worden toegevoegd, terwijl de landmacht zal worden uitgebreid tot ruim veertienhonderd man. Dit alles vergt tijd, terwijl bovendien het treffen van nadere voorzieningen in de uitrusting, die op vele punten gebreken vertoont, de manschappen nog geruime tijd in beslag neemt. Ondertussen verleent een detachement van tweehonderd man landingstroepen er - overigens zonder veel succes - assistentie bij de bestrijding van de sedert Muntinghe's aftocht uit Palembang in verscheidene streken van het eiland, vooral rond Banka-Kota, uitgebroken onlusten, waar de op Banka gelegerde legereenheden volkomen machteloos tegenover staan. In de tweede helft van september kan de oversteek naar de monding van de Palembangrivier beginnen en op 9 oktober is het laatste schip van de vloot over de bij Sungsang in de riviermond gelegen bank, die op de meeste plaatsen door grote schepen slechts bij springtij kan worden gepasseerd en dan nog alleen nadat eerst een deel van de lading is gelost.

Sultan Badaruddin had vier maanden de tijd gehad om het verdedigingsstelsel van Palembang uit te breiden en te versterken. Hij had voldoende inzicht in en ervaring met de koloniale politiek der Nederlanders om te begrijpen dat ze het er na Muntinghe's nederlaag niet bij zouden laten zitten. Dat bleek trouwens direct al uit de blokkade van de Sungsang. De ligging van Palembang, ver landinwaarts aan een rivier die aan weerszijden door ondoordringbaar moerasbos was omzoomd en zo de enige toegangsweg van zee vormde, bood de stad op zichzelf reeds een natuurlijke bescherming tegen een zich met moeite tegen de stroom opwerkende vijand. Gebruikmakend van de gegeven natuurlijke situatie was de sultan erin geslaagd Palembang tot een vrijwel ongenaakbare en onneembare vesting te maken door zowel op het benedenstrooms van de stad in de rivier gelegen eiland Kembara als op de oever van Musi en Plaju ertegenover zeer solide en zwaarbewapende vestingwerken aan te leggen, door de doorvaart tussen eiland en vastewal met in de rivierbodem ingeheide palen af te sluiten en bovendien daarachter op een kunstmatig aangelegd eilandje en op verankerde vlotten verscheidene batterijen op te stellen. Het is voor deze verdedigingslinie van Kembara tot Plaju met een vuurkracht van circa vijftig kanonnen, dat de expeditiemacht na vergeefse pogingen van Wolterbeek en Muntinghe om de sultan langs diplomatieke weg tot overgave te bewegen op 21 oktober in een beslissende slag wordt verslagen en onder zware verliezen tot de aftocht wordt gedwongen. Wanneer de vloot bij het eiland Salahnama op een veilige afstand van de Palembangse batterijen is gekomen, probeert Wolterbeek alsnog met diplomatieke middelen iets 
te bereiken door wederom een zinloze correspondentie met de sultan aan te gaan, waarop deze even minzaam en superieur reageert als op de Nederlandse toenaderingspogingen van vóór de slag bij Kembara. Na aldus ook op het diplomatieke vlak volledig te hebben gefaald, trekt Wolterbeek verder naar de monding terug.

Muntinghe reist naar Banka vooruit en komt op 8 november in Muntok aan. De toestand blijkt er gespannen. Het vuur van de opstand was na het vertrek van de expeditievloot naar Palembang opnieuw opgelaaid en naar de zuidelijke districten van het eiland overgeslagen. Smissaert, die zelf naar Pangkal Pinang was gegaan om de situatie op te nemen, wordt de veertiende november op de terugweg overvallen en vermoord. Er zijn aanwijzingen dat het verzet tegen het Nederlandse gezag van Palembang uit wordt aangewakkerd. Wanneer de mare van de Nederlandse nederlaag voor Palembang op Banka doordringt, breidt de opstand zich ook tot de overige districten uit. Ingevolge besluit van de gouverneur-generaal d.d. 18 november 1819 keert Muntinghe, na het civiele bestuur te hebben overgedragen aan de luitenant-kolonel W. J. Keer, de vijfentwintigste december naar Batavia terug. Zijn rol in de Palembangse geschiedenis is uitgespeeld. Ook Wolterbeek verdwijnt van het toneel. Hij vertrekt 18 februari 1820 naar Riau en Lingga, waar het ook onrustig is geworden, en gaat na er de orde te hebben hersteld medio april naar Java terug. Onder leiding van Overste Keer, die na het vertrek van Wolterbeek naar Riau-Lingga ook als militair commandant van Banka was opgetreden, wordt de strijd tegen de opstandelingen met wisselend succes voortgezet, een strijd die de Nederlandse strijdkrachten op Banka nog een jaar lang handen vol werk zal geven.

Zo was Badaruddin er niet alleen in geslaagd de onafhankelijkheid van het Sultanaat Palembang tegenover het koloniale gezag te handhaven, maar had hij tevens zijn eigen positie versterkt.

Over het hierna volgend tijdvak van november 1819 tot mei 1821 , waarin elk Nederlands contact met Palembang ontbreekt, is ons uit westerse bron niets bekend, terwijl de Indonesische geschiedschrijving in deze periode van rust, zonder militaire of politieke gebeurtenissen van belang, al heel weinig de moeite van het vermelden waard vindt.

$\mathrm{Na}$ de overwinningsfeesten, die een week duren, wordt het werk ter versterking van de defensie hervat. Zolang men bedacht moet zijn op een Nederlandse revanche, blijft opvoering van de militaire weerbaarheid Palembang's primaire taak. Hiertegen kan de Nederlandse blok- 
kade, die op last van Wolterbeek gehandhaafd blijft maar natuurlijk herhaaldelijk wordt doorbroken, weinig uitrichten. Aan bepaalde artikelen ontstaat wel gebrek, maar over het algemeen is de economie van het land, dat zelf over voldoende hulpbronnen beschikt, flexibel genoeg om zich aan te passen.

In Batavia heeft men ondertussen ook niet stilgezeten. Reeds spoedig na het bekend worden van Wolterbeeks nederlaag besluit de regering een nieuwe expeditie tegen Palembang uit te rusten. Men neemt er ditmaal de tijd voor en zet er alle andere zaken voorlopig voor opzij: de handhaving van het Nederlandse gezag, ook elders in de archipel, was met het welslagen van de onderneming gemoeid. Voor dit doel is men bereid zich de uiterste militaire krachtsinspanning te getroosten. Niet alleen wordt het grootste deel van de in de archipel beschikbare militaire macht voor de actie tegen Palembang samengetrokken, ook uit het moederland laat de Indische regering, vastbesloten geen enkel risico meer te nemen, schepen overkomen. Speciale aandacht wordt verder besteed aan díe voorzieningen, aan het ontbreken waarvan naar het oordeel der militaire deskundigen het échec van de Wolterbeekexpeditie voornamelijk te wijten is geweest: scheepsgeschut van zeer zwaar kaliber, berekend op de palissaden van de vestingwerken en de muren van de kraton, kiellichters, ook wel kiezentrekkers genoemd, om het paalwerk in de rivier op te ruimen en een groot aantal goedmanoeuvreerbare landingsboten. Wanneer de militaire voorbereidingen zijn voltooid, wordt, evenals in 1819 vóór het vertrek van de Wolterbeekexpeditie was geschied, voorzien in de aanwijzing van een regerend sultan voor Palembang. Na overleg met de ex-sultan Ahmad Najamuddin wordt zijn oudste zoon, Pangéran Prabu Anom, die met zijn vader uit de Preanger naar Buitenzorg is opgeroepen, in een op 28 april 1821 aldaar gehouden vergadering als sultan aangewezen. Vader en zoon tekenen er een overeenkomst, waarbij mede wordt bepaald dat eerstgenoemde zich geheel buiten de regeringszaken zal houden.

Pangéran Prabu Anom krijgt naam en titel van zijn vader en zal straks dus als Sultan Ahmad Najamuddin optreden, terwijl zijn vader susuhunan of suhunan als titel en Husin Dia'uddin als naam aanneemt. Beiden zullen met hun gevolg de expeditie naar Palembang vergezellen. Voorts wordt bij besluit van de gouverneur-generaal d.d. 6 mei 1821 de luitenant-kolonel Keer aangewezen om na het herstel van het gezag voorlopig de functie van resident van Palembang waar te nemen.

Onder opperbevel van de commandant van de landmacht, Generaal- 
Majoor De Kock, vertrekt de expeditie na een inspectie door de gouverneur-generaal op 9 mei van Batavia, ondanks het feit dat kort tevoren op Java cholera is uitgebroken en deze epidemie zich ook reeds onder de troepen heeft verbreid; zij zal de expeditie meer dan honderd man kosten.

Het is inderdaad een zeer groots-opgezette onderneming geworden: een vloot van zevenenveertig grotere en kleinere oorlogsschepen, zestien transportschepen en vele tientallen prauwen, met een bewapening van vierhonderd veertien stukken scheepsgeschut en achttien veldstukken en met een bemanning van 2580 man zeemacht en 1679 landmacht.

$\mathrm{Na}$ een voorspoedige reis is de vloot 13 mei op de rede van Muntok en twee weken later over de bank bij Sungsang. De Kock stuurt lieden uit het gevolg van de suhunan naar Palembang vooruit met een tot de bevolking gerichte proclamatie, waarin het doel van zijn komst wordt bekendgemaakt. Het diplomatieke verkeer blijft overigens van bescheiden omvang ditmaal. Op 10 juni kan men zonder veel moeite de westelijke doorvaart langs Salahnama passeren, die in tegenstelling tot de oostelijke niet met palen blijkt te zijn afgesloten. In het zicht maar buiten het bereik van de batterijen van Kembara en Plaju gaat de vloot ten anker. Hier wordt een gecombineerde aanval van land- en zeemacht voorbereid. Nadat het terrein is verkend en een pad naar de Plaju-rivier is gekapt, worden in de vroege ochtend van de zestiende juni landingstroepen aan wal gezet, met veldgeschut en lichte bootjes om de Plaju over te steken. Terwijl deze troepen naar de Plaju oprukken, verplaatsen de schepen zich verder stroomopwaarts. Op 20 juni wordt de gezamenlijke actie tegen de verdedigingswerken uitgevoerd. De aanval mislukt: bij de Plaju beletten verscheidene goedbewapende Palembangse prauwen, gesteund door de er achter gelegen batterijen, de oversteek, terwijl het zware kanonvuur van Kembara en Plaju de schepen dwingt zich uit hun vooruitgeschoven posities terug te trekken.

In de nacht van 23 op 24 juni zet de Nederlandse vloot een tweede aanval op beide vestingwerken in. $\mathrm{Na}$ enige tijd kunnen op Kembara troepen aan wal worden gezet, die het fort weten te veroveren. Vervolgens worden de achter het paalwerk gelegen waterbatterijen tot zwijgen gebracht en in brand gestoken en tegen de middag valt ook het Plaju-bolwerk in Nederlandse handen. Met behulp van de kiellichters wordt een opening in het paalwerk gemaakt en dan ligt de verdere weg naar Palembang voor de expeditie open.

De Kock stuurt de sultan nu een sommatie tot onmiddellijke overgave op lijfsbehoud, waarop Badaruddin verzoekt tenminste in Palembang te mogen blijven. Dit kan de opperbevelhebber niet toestaan, aangezien 
hij opdracht heeft de sultan volgens het bekende recept naar Batavia op te zenden. Nadat Badaruddin nog tot tweemaal toe op zijn verzoek is teruggekomen, trekt De Kock de vloot vóór het kratoncomplex samen en laat een landing uitvoeren. Palembang biedt geen tegenstand meer en laat in de avond van de zevenentwintigste juni komen de "oude" en de "jonge" Pangéran Adipati namens de sultan de onvoorwaardelijke overgave aanbieden. Op 1 juli is de kraton door de Hollandse troepen bezet.

Badaruddin brengt zijn laatste dagen te Palembang door als logé van zijn broer, de oude Pangéran Adipati. Op last van De Kock had hij de regalia aan de nieuwe sultan en de staatskas, die veel minder bleek te bevatten dan men verwacht had, aan de overwinnaars overgedragen. Het geld werd later onder de deelnemers aan de expeditie verdeeld. Ondanks zijn herhaald verzoek om uitstel moet Badaruddin zich reeds de derde juli, vergezeld van zijn naaste familieleden, inschepen op een fregat, dat drie dagen later samen met een deel van de vloot naar Batavia vertrekt en daar op 28 juli aankomt. Acht maanden later wordt de sultan naar Ternate overgebracht, waar hij - in het genot van een toelage van $f 800$, - per maand - tot zijn dood, op 26 november 1852 , geïnterneerd blijft.

Inmiddels is te Palembang zowel het militaire als het civiele gezag opgedragen aan Overste Keer, de resident tevens militair commandant van Banka. Hij wordt de twaalfde juli geïnstalleerd en van een uitgebreide instructie voorzien. Vier dagen later vindt de plechtige inhuldiging van Sultan Ahmad Najamuddin plaats. Op 20 juli keert de opperbevelhebber met de laatste schepen naar Batavia terug. Slechts één schip, de hulk "Nassau", in de Palembangse kronieken vermeld als het grootste vaartuig van de vloot, blijft voor Palembang achter. Het was zo zwaar beschadigd, dat het, nadat zijn bewapening en lading op de andere schepen was overgebracht, in zinkende toestand ter plaatse moest worden achtergelaten.

In Batavia èn in Nederland, waar het bericht van de verovering van Palembang respectievelijk op 10 juli en 6 november 1821 aankomt, wordt dit wapenfeit op luisterrijke wijze en met veel vertoon van nationale trots gevierd. De afkondiging gaat gepaard met een saluut tot het maximale aantal van 101 schoten. Aan een groot aantal officieren en manschappen van de expeditie wordt de hoogste Nederlandse militaire onderscheiding, de Militaire Willemsorde, verleend. Een gedenkpenning wordt geslagen en er verschijnen tal van lofdichten op de overwinning. In een zitting van de Tweede Kamer der Staten-Generaal wordt aan 
het feit aandacht besteed en Koning Willem I biedt de GouverneurGeneraal mede namens de Staten-Generaal gelukwensen aan. Uit al deze reacties blijkt, welk gewicht van Nederlandse zijde aan de verovering van Palembang werd gehecht.

Met de verbanning van Mahmud Badaruddin breken voor het Sultanaat Palembang de nadagen aan, waarin het gezag van het aloude vorstengeslacht steeds verder door de Nederlandse bestuursinvloed wordt verdrongen. Deze gang van zaken is de resultante van de incompetentie van de nieuwbakken sultan en het duidelijke streven van het Nederlandse bestuur, vertegenwoordigd door Commissaris Jan Izaak van Sevenhoven en later door Resident Joan Cornelis Reijnst, zich voorgoed in Palembang te handhaven en actief in de bestaande situatie in te grijpen. In november 1821 neemt Van Sevenhoven te Palembang het bestuur van Overste Keer over. Zijn voornaamste opdracht is een onderzoek in te stellen naar de heersende toestanden en verhoudingen op economisch en sociaal-politiek gebied en de centrale regering te adviseren terzake van het te voeren beleid. Op grond van zijn bevindingen doet Van Sevenhoven de regering te Batavia vèrstrekkende voorstellen tot liquidatie van het feodale gezag in Palembang, welke hij als een eerste voorwaarde voor de doorvoering van de gewenste hervormingen beschouwt.

Met machtiging van het opperbestuur sluit de commissaris op 9 oktober 1822 een voorlopige overeenkomst met de sultan, waarbij deze zich bereid verklaart tegen een vast inkomen van gouvernementswege voor hemzelf, de hofadel en de overige regeringsfunctionarissen afstand te doen van de inkomsten uit de belastingopbrengst van het land, hem bij het verdrag van 28 april 1821 toegekend. Vooral met het oog op de hieraan verbonden financiële consequenties wordt de commissaris opgedragen terzake nader onderzoek te doen en daarna voor besprekingen naar Batavia over te komen. Dit overleg, waarbij het gehele bestuursprogram van de commissaris wordt betrokken, heeft in mei en juni 1823 plaats. Na zijn terugkomst te Palembang sluit Van Sevenhoven op 18 augustus een definitief contract met de sultan, dat bij regeringsbesluit van 7 oktober 1823 wordt bekrachtigd. De sultan doet hierbij officieel afstand van de souvereiniteit over Palembang ten behoeve van het Nederlandse gouvernement, waarvan hij nu volledig financieel afhankelijk wordt.

Met een rechtstreeks tot de bevolking gerichte proclamatie van de commissaris wordt de nieuwe aera voor Palembang ingeluid. Onder het nieuwe bestel zal er, zoals de proclamatie in gloedvolle bewoordingen aankondigt, geen plaats meer zijn voor slavernij, pandelingschap, heren- 
diensten en drukkende belastingen, heeft iedereen gelijkelijk aanspraak op de natuurlijke rijkdommen van het land en de vrije beschikking over de vruchten van eigen arbeid, wordt de opkoop van bevolkingsprodukten door het bestuur geregeld, het districts- en dorpsbestuur onder gouvernementstoezicht gesteld en een onpartijdige rechtspraak verzekerd.

$\mathrm{Nu}$ de grondslagen van het nieuwe bestuursbeleid aldus zijn gelegd, is Van Sevenhovens taak als commissaris afgelopen. $\mathrm{Na}$ het bestuur aan Reijnst te hebben overgedragen, die sedert juli 1822 zijn naaste medewerker was geweest, keert Van Sevenhoven begin december 1823 naar Batavia terug. Reijnst blijft tot december 1825 resident van Palembang. Onder zijn leiding wordt de rechtspraak met uitzondering van de zogenaamde godsdienstige rechtspraak in zaken van huwelijks- en erfrecht geheel aan de invloed van het Palembangse hof onttrokken en komen allerlei nieuwe regelingen tot stand op het gebied van bestuur en politie, handel en verkeer.

Het spreekt vanzelf dat sultan en suhunan de drastische inperking van hun bevoegdheden en van hun invloed slechts noodgedwongen hadden geaccepteerd en dat ook de representanten van de Palembangse adel en bureaucratie, die veelal met een ontoereikend gouvernementsinkomen genoegen moesten nemen, het nieuwe systeem slecht gezind waren. De toenemende ontevredenheid aan het ontluisterde hof leidt in november 1824 tot een laatste, zwakke poging om de vroegere machtspositie op het Nederlandse gouvernement te heroveren.

$\mathrm{Na}$ een mislukte poging het Nederlandse garnizoen door vergiftiging buiten gevecht te stellen doet de sultan, met medeweten van de suhunan maar overigens zonder diens steun, in de vroege ochtend van de tweeentwintigste november 1824 met een vierhonderd slechtbewapende Palembangers een wilde aanval op de kraton, waar sedert het herstel van het Nederlandse gezag de resident gevestigd is. De resident was kort tevoren ingelicht omtrent de plannen van de sultan door diens oom Abdulrahman en broer Jayaningrat, de troonpretendent van 1819 die in 1821 voor het sultanschap was gepasseerd, en zo kon de aanval na een ongelijke strijd van nog geen uur, waarin volgens de Nederlandse berichten aan Palembangse zijde verscheidene tientallen doden vielen, definitief worden afgeslagen.

Reijnst gelast suhunan en sultan nu zich gereed te houden voor opzending naar Batavia. Eerstgenoemde geeft aan dit bevel gehoor, wordt ingescheept op een particuliere brik, door de resident voor $f 4000$, - ingehuurd, en is 6 december al in Batavia. Een paar maanden 
later, op 22 februari 1825, overlijdt hij daar aan een ziekte.

De sultan is daarentegen met enkele tientallen getrouwen naar het binnenland uitgeweken, waar hij zich in het uiterste westen van het land nog acht maanden weet te handhaven.

Van Sevenhoven, sinds een jaar resident van Surakarta, wordt eind januari 1825 ten tweeden male als commissaris van het opperbestuur naar Banka en Palembang afgevaardigd. Na een verblijf te Muntok van drie maanden steekt hij naar Palembang over om samen met Resident Reijnst de achtervolging van de sultan te organiseren, die zich tenslotte eind juli in het gebied van de bovenloop van de Ogan overgeeft en 9 augustus op de hoofdplaats terug is. Hij wordt onmiddellijk aan boord van de oorlogskorvet gebracht waarmee Van Sevenhoven is gekomen, en daar tot 19 oktober vastgehouden. De dag daarop vertrekt hij met een particuliere brik onder militair geleide naar Batavia. Op 5 november aldaar aangekomen wordt de laatste sultan van Palembang, in de Palembangse genealogieën vanwege zijn amok tegen het Nederlandse gezag aangeduid als "sultan (yang) ngamuk", dezelfde maand nog verbannen naar Banda. In 1841 wordt hij naar Menado overgebracht, waar hij in 1844 is overleden.

Van zijn laatste getrouwen worden door de nieuwe rechtbank onder voorzitterschap van de resident er vijf tot de doodstraf en vierendertig tot levenslange gevangenisstraf veroordeeld. De doodvonnissen worden op 17 augustus en 6 september 1825 ter plaatse voltrokken.

Van Sevenhoven keert eind augustus naar zijn standplaats Surakarta terug en vier maanden later wordt ook Reijnst, om gezondheidsredenen, naar Java teruggeroepen. 
HOOFDSTUK II

\title{
DE HANDSCHRIFTEN
}

\author{
Inventarisatie, Beschrijving, Rubricering en Selectie
}

\section{INVENTARISATIE}

Bij de inventarisatie van de Maleise handschriften die tot de kennis omtrent de geschiedenis van Palembang in de jaren 1811-1825 zouden kunnen bijdragen, heb ik ook de handschriften betrokken waarin eerdere perioden uit de Palembangse geschiedenis worden beschreven. Anderzijds heb ik handschriften waarin slechts zijdelings of terloops aandacht aan de geschiedenis van Palembang wordt geschonken, niet in de inventarisatie opgenomen. Het resultaat van de volgens deze richtlijnen uitgevoerde inventarisatie bestaat uit een reeks van enkele tientallen handschriften van uiteenlopende aard, zoals kronieken, min of meer legendarische verhalen, brieven, genealogieën, politieke contracten en zelfs een gedicht. Deze handschriften behoren tot het bezit van vijf verschillende instellingen, te weten:

1 het Koninklijk Instituut voor Taal-, Land- en Volkenkunde te Leiden;

2 de Bibliotheek van de Rijksuniversiteit te Leiden;

3 het Museum Pusat te Jakarta;

4 het Koninklijk Instituut voor de Tropen te Amsterdam;

5 het Algemeen Rijksarchief te 's-Gravenhage.

Kortheidshalve zullen de handschriften in het vervolg naar de beherende instelling worden onderscheiden als respectievelijk hss-KI, hss-UBL, hss-MP, hss-TR en hss-ARA.

Niet al deze handschriften zijn behoorlijk gecatalogiseerd. Alleen de hss-MP zijn zonder uitzondering in een gedrukte catalogus beschreven, maar de hss-KI en de hss-UBL zijn slechts voor een deel en de hss-TR en de hss-ARA zelfs helemaal niet op een dergelijke manier toegankelijk gemaakt. De hss-MP vindt men beschreven in Van Ronkels catalogus van 1909, ${ }^{1}$ de hss-KI behoudens één uitzondering in Van Ronkels cata- 
logus van $1908 .^{2}$ Van de hss-UBL zijn er vier in Juynbolls catalogus van $1899^{3}$ en is er één in de supplement-catalogus van Van Ronkel uit $1921^{4}$ opgenomen. Een uitvoerige beschrijving van de door Juynboll onder één nummer opgenomen brievencollectie geeft Klinkert in zijn brievencatalogus van $1882 .{ }^{5}$ De overige hss-UBL vindt men - onder de trefwoorden "Palembang" en "Stamboom van Madjapahit" - vermeld (niet: beschreven) in een getypte "Alfabetische klapper op de aanvullingstitels Maleis", welke bij de afdeling Oosterse handschriften van de Leidse universiteitsbibliotheek berust. De "aanvullingstitels Maleis" zelf zijn met de hand geschreven catalogusfiches, geordend volgens codexnummer en tot zogenaamde Leidse boekjes samengevoegd. De op deze fiches vermelde gegevens zijn uiterst summier; in de regel is volstaan met vermelding van formaat en omvang van het handschrift en voorts met aanduidingen als "Geschiedenis van Palembang", "Stamboom van de vorsten van Palembang" en dergelijke. De hss-TR zijn, als boeken gecatologiseerd, in de kaartcatalogus van de Centrale Bibliotheek van het Tropeninstituut opgenomen; de hss-ARA zijn op geen enkele wijze gecatalogiseerd. De laatsten maken deel uit van de bij het Algemeen Rijksarchief berustende "Verzameling Wolterbeek". ${ }^{6}$

Aan een beknopte beschrijving van het beschikbare handschriftenmateriaal zal ik een eenvoudige opsomming ervan laten voorafgaan. Hierbij wordt door vermelding van het eventuele codex- of registratienummer en het eventuele catalogusnummer danwel van enig ander kenmerk de identititeit van elk handschrift vastgesteld en voorts ter bekorting een eigen aanduiding, bestaande uit de bovenaangegeven onderscheiding naar beherende instelling en een volgnummer, ingevoerd, die ook bij de verdere behandeling van de handschriften zal worden gebezigd.

Wat de volgorde van opsomming en beschrijving der handschriften betreft: van de verschillende theoretische mogelijkheden, zoals een chronologische indeling naar de datering van het handschrift of naar de daarin beschreven periode van de geschiedenis, een indeling naar het literair genre of de aard van de tekst en een indeling naar beherende instelling, bleek de laatstgenoemde methode misschien niet de meest zinvolle, maar in de gegeven situatie, waarin de andere zojuist genoemde criteria wegens gebrek aan gegevens of om in de aard van het materiaal zelf gelegen redenen geen consequente toepassing konden vinden, praktisch de enig bruikbare te zijn. Binnen het kader van deze ordening worden de handschriften van één auter of afschrijver onmiddellijk na elkaar genoemd en beschreven, volgt een transcriptie direct het daarmee 
corresponderende origineel en is overigens bij het bepalen van de volgorde met duidelijke onderlinge relaties van andere aard waar mogelijk rekening gehouden.

De inventarisatie omvat de volgende handschriften:

\begin{tabular}{|c|c|c|}
\hline$H s s-K I$ & & \\
\hline $\begin{array}{l}\text { volg- } \\
\text { nummer }\end{array}$ & $\begin{array}{l}\text { registrati } \\
\text { nummer }\end{array}$ & \\
\hline KI 1 & Ms. or. & 196 \\
\hline KI 2 & , , & 201 \\
\hline KI 3 & " , & $201 \mathrm{a}$ \\
\hline KI 4 & $"$ & 414 \\
\hline KI 5 & " & 531 \\
\hline KI 6 & , " & 537 \\
\hline KI 7 & 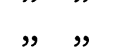 & 532 \\
\hline KI 8 & 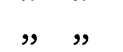 & 527 \\
\hline KI 9 & , , & 527 \\
\hline KI 10 & ” , & 203 \\
\hline KI 11 & „, , & 203 \\
\hline KI 12 & " & 586 \\
\hline KI 13 & ", & 541 \\
\hline
\end{tabular}

catalogiseringsgegevens

Van Ronkel-KI, nr XXX, pp. 216-217

$\mathrm{nr}$ XXXI, p. 217

nr XXXII, pp. 217-218

nr XXVII, pp. 214-215

nr XXVIII, pp. 215-216

nr XXXIII, p. 218

nr XXXIV, pp. 218-219

KI $8 \quad$, , 527

KI $9 \quad$, $\quad 527$

nr XXIX, p. 216

nr XXIX, p. 216

Inventaris Mal. stukken uit $\mathrm{H} 590$ a

Oost. hss. KI over gesch. v. Palembang

Van Ronkel-KI, nr XVIII, pp. 206-207

, nr XVII, pp. 205-206

$H s s-U B L$

$\begin{array}{ll}\text { volg- } & \text { registratie- } \\ \text { nummer } & \text { nummer }\end{array}$

UBL 1 a Cod. or. 1914

UBL 1 b $, \quad, 2304$ a

UBL $2 \Longrightarrow 8245$

UBL $3 \leadsto, \quad, 7653$ a

UBL $4 \leadsto, 7653 \mathrm{~b}$

UBL $5 \gg, \quad, 7653 \mathrm{c}$

UBL $6 \quad, \quad 7653 \mathrm{~d}$

UBL $7 \Longrightarrow 2276 \mathrm{c}$

UBL 7 a $, \quad, 8377$ a-d

UBL $8 \quad, \quad, 7304$

UBL 9 ", $2276 \mathrm{~d}$

UBL $10 \#, \quad, 2241$

UBL $11 \quad, \quad$ \% 8402

UBL 12,2285

catalogiseringsgegevens

Alf.klapper s.v. Palembang

Juynboll, 1899, nr CCLXV, pp. 251-252

Alf.klapper s.v. Palembang

Van Ronkel-UBL, nr 100, p. 40

Juynboll, 1899, nr CCLII,

p. 243

”,$\quad$ nr CCCLXVIII, p. 314/

Klinkert, 1882,

pp. $86-89$

Alf.klapper s.v. Palembang

Juynboll, 1899, nr CCLXIX, p. 254 


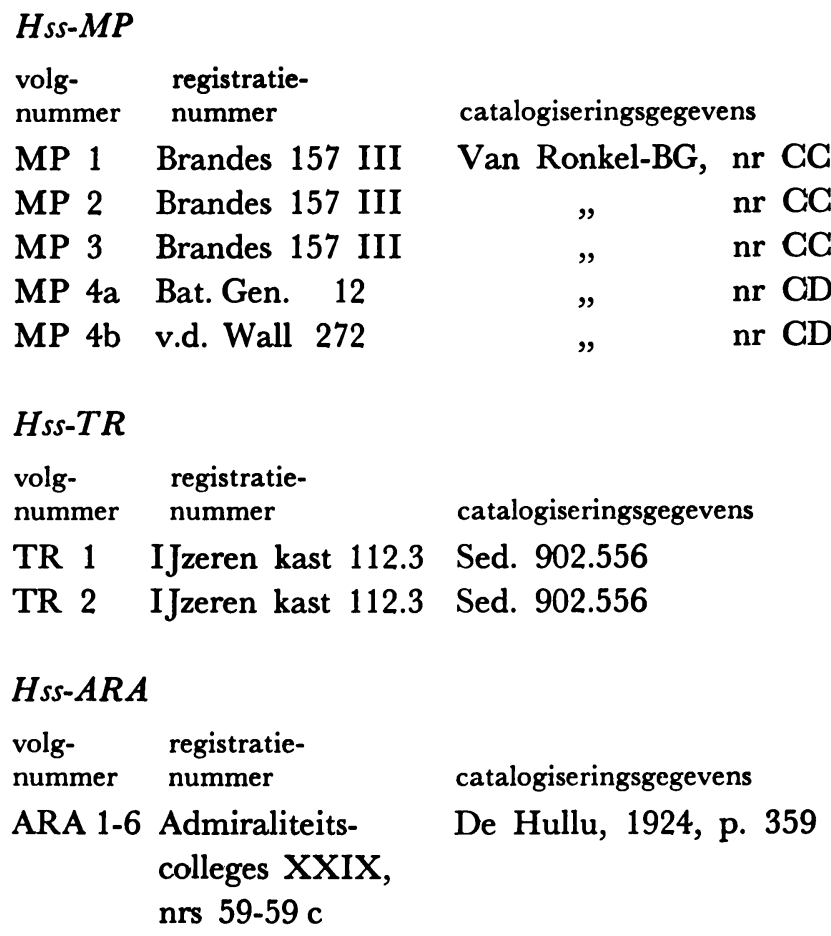

\section{BESCHRIJVING}

Handschriften - KI

KI 1-3

Deze drie handschriften zijn in 1842 of in elk geval binnen de periode 1842-1844 door Pangéran Temenggung Karta Menggala geschreven op verzoek van de toenmalige resident van Palembang, A. $\mathrm{H}$. W. baron de Kock, ${ }^{7}$ zoon van generaal-majoor H. M. de Kock, de commandant van de Nederlandse militaire expeditie tegen Palembang van 1821. Ze zijn in latijns schrift gesteld op papier van $33 \times 20 \mathrm{~cm}$, gemerkt "London superfine".

De auteur behoort, zoals de titel pangéran reeds aangeeft, tot de Palembangse adel. Volgens de beschikbare genealogieën, die later beschreven zullen worden, is hij in de mannelijke lijn een rechtstreekse afstammeling van Sultan Muhammad Mansur ( \pm 1706-1714) en via zijn grootmoeder van vaderszijde een achterkleinzoon van Mansurs 
zoon, Sultan Mahmud Badaruddin I ( $\pm 1724-1757)$. Als zijn functie wordt in sommige genealogieën genoemd kepala divisi, in andere demang polisi. De Regeringsalmanak van het voormalige Nederlands-Indië vermeldt een "Pangerang Toemenggoeng Karta Menggala" als "hoofd der policie" ter hoofdplaats Palembang gedurende de periode 1830-1847 en als "divisiehoofd van de Ogan Oeloe" in de jaren 1852-1864. Dat het hier steeds één en dezelfde persoon betreft, kan ik niet bewijzen, maar lijkt, gelet op de aanduidingen demang polisi en kepala divisi in de genealogieën, wel waarschijnlijk.

KI 2, dat - zoals uit verwijzingen in de eerste en de laatste alinea van KI 1 en op p. 1 van KI 3 blijkt $^{8}$ - van de drie handschriften het eerst werd geschreven, bevat in de aanhef de uitvoerige vermelding van het verzoek van de resident. ${ }^{9}$ In KI 1 volstaat de auteur met een meer summiere aanduiding daarvan, ${ }^{10}$ terwijl in KI 3 een dergelijke aanduiding geheel ontbreekt en het verband met de twee andere handschriften slechts wordt gelegd door de eerdergenoemde verwijzing naar KI 2.

De naam van de auteur, die met de ondertekening "P. T. Karta Mengala" — na de woorden "De Perboeat oleh" — van KI 2 is gegeven, komt in de beide andere handschriften niet voor. Dat deze laatste niettemin van de hand van dezelfde schrijver zijn, wordt aangetoond door de daarin voorkomende verwijzingen naar KI 2 en bevestigd door de duidelijke overeenkomst in schrift der drie, bovendien op éénzelfde soort papier geschreven handschriften. Ook de datering (1842) komt alleen in KI 2 voor. Aangezien deze tekst zoals we zagen het eerst werd opgesteld, moeten de beide andere handschriften van 1842 of later dateren. Als terminus ante quem levert de publikatie in het Tijdschrift voor Neêrland's Indië van een Nederlandse bewerking ervan, waarover hieronder nader, voor KI 31844 en voor KI 1 1846. Het feit dat de tekst die het eerst werd geschreven, KI 2, als laatste in Nederlandse bewerking is verschenen, namelijk in 1846, nog nà KI 1 , toont wel aan dat het jaar waarin deze bewerkingen in het tijdschrift zijn opgenomen, als aanwijzing voor de datering van de handschriften zelf nauwelijks van betekenis kan worden geacht. Daar anderzijds KI 3, waarvan de bewerking in 1844 het licht zag, als laatste van de drie handschriften tot stand kwam, geldt dit jaar uiteindelijk als terminus ante quem voor het gehele in de drie teksten vervatte werk.

Wat de inhoud betreft vormt KI 2, hoewel het eerder werd geschreven, chronologisch het tweede deel of in de woorden van de auteur: "cerita pasal yang kedua" van het totale Palembangse geschiedverhaal, waarvan 
KI 1 als "cerita pasal yang pertama" wordt aangeduid. KI 3 geeft - in nauwelijks negen bladzijden - een nadere uitwerking van de in KI 2 binnen het kader van de geschiedenis van de dynastie van Palembang behandelde regeringsperiode van Sultan Mahmud Badaruddin II (1804-1812).

KI 1, groot 36 bladzijden van 27 regels, is getiteld "Tjerita Palembang". Het bevat na de aanhef, waarin het verzoek van de resident wordt vermeld, in de eerste zestien bladzijden de - behoudens geringe afwijkingen - letterlijke tekst van de passage 1.20 - 2.17 uit de Sejarah Melayu volgens de lezing van Abdullah (Situmorang-Teeuw, 1952, pp. 20-31), met dien verstande dat de later als officiële inhuldigingsformule. (ciri) gecanoniseerde lofrede van Bat (hier Buto genaamd) tot Sang Suparba, evenals in sommige handschriften van de Sejarah Melayu het geval is, wel in de tekst is opgenomen. ${ }^{11}$ Dit eerste gedeelte van KI 1 wordt besloten met de woorden: "Syahadan maka tiadalah disebutkan ceritanya Sang Saprabo keluar dari Palémbang, melainkan sekaliannya sudah dihikayatkan didalam cerita Sejarah Melayu", een uitdrukkelijke bevestiging van het feit dat de Sejarah Melayu de auteur van KI 1 bekend was.

De rest van het verhaal, van p. 16 regel 11 tot p. 36, behandelt de verdere legendarische geschiedenis van Palembang, waarin achtereenvolgens Sultan Nur Alam, diens jongere broer Raja Baginda alias Sultan Mugni, Maharaja Léla Kebun Jati en zijn jongere broer Gedé Pakuwon, en tenslotte Arya Dilah of Arya Damar een rol spelen. Het verhaal eindigt met een genealogie, waarin de afstamming van de Palembangse dynastie wordt herleid tot de profeet Muhammad. Dat het hier een geijkte traditie betreft, blijkt uit het voorkomen van dezelfde genealogie in KI 4, KI 8, UBL 1 a, UBL 1 b, UBL 2, UBL 6, MP 1 en TR 2.

KI 2, groot 16 bladzijden van 31 regels en 1 bladzijde van 3 regels, is getiteld: "Tjarieta dariepada atoeran Radja Radja diedalam Nigrie Palembang". De Nederlandse titel op de omslag luidt: "Geschiedenis van het Palembangsche Rijk". De tekst geeft, zoals de auteur het in zijn voorwoord zegt zowel op grond van mondelinge als van schriftelijke overlevering, een overzicht van het gehele tijdperk van de Palembangse geschiedenis, dat begint met de vlucht in H. 969 (A.D. 1562/'61) ${ }^{12}$ van de grondlegger der dynastie, Geding Sura, uit het in die tijd door de sultan van Pajang overweldigde Demak naar Palembang en dat eindigt met de terugkomst na het Engelse tussenbestuur van de Nederlandse commissaris Muntinghe in 1818.

KI 3 tenslotte, groot 9 bladzijden van 32 regels, geeft een close-up 
van de regeringsperiode van Sultan Mahmud Badaruddin II (18041812) en loopt vervolgens evenals KI 2 door tot de terugkeer van Muntinghe in Palembang.

Een vrije, op vele plaatsen sterk verkorte maar hier en daar ook wel met niet in de Maleise tekst terug te vinden aanvullingen uitgebreide Nederlandse vertaling van de drie handschriften is anoniem en zonder bronvermelding verschenen in de jaargangen 1844 en 1846 van het Tijdschrift voor Neêrland's Indië. De vertaling van $\mathrm{K}$ I3 verscheen onder de titel "Het leven van Machmoed Badaroedin, laatste alleenheerschende Sultan van Palembang" ${ }^{13}$ als nummer V van een reeks van zes artikelen, die onder de verzameltitel "Aanteekeningen en schetsen over Palembang" zijn opgenomen in de delen 3 en 4 van jaargang 6 (1844) van het tijdschrift. De vertaling van KI 1, getiteld "Oude Palembangsche legenden", ${ }^{14}$ en de vertaling van KI 2, getiteld "Latere geschiedenis van Palembang" en aangevuld met een als zodanig aan het handschrift ontbrekende "Naamlijst der bekende Palembangsche vorsten", ${ }^{15}$ vormen respectievelijk nummer VI en VII in een serie van zeven artikelen, die in het derde deel van jaargang 8 (1846) van het tijdschrift zijn verschenen onder de verzameltitel "Schetsen van Palembang". ${ }^{16}$ Wij zullen zien dat deze anoniem gepubliceerde bijdragen afkomstig zijn van degene, op wiens instigatie de drie handschriften tot stand zijn gekomen.

Van twee dezer bijdragen zijn de manuscripten bewaard gebleven en onder de codexnummers $\mathrm{H} 307, \mathrm{H} 186$ en $\mathrm{H} 272$ in de verzameling westerse handschriften van het Koninklijk Instituut voor Taal-, Landen Volkenkunde opgenomen, ${ }^{17}$ terwijl een gedeeltelijke vertaling van KI 1, namelijk van p. 19 tot het eind, onder nummer 201* bij de Maleise handschriften is ondergebracht en gedeponeerd in $\mathrm{KI} 2 .{ }^{18}$

H 307, waarvan de eerdergenoemde resident A. H. W. De Kock de auteur is, bevat onder meer het manuscript van de Nederlandse bewerking van KI 2. Op de eerste bladzijde daarvan heeft de auteur aangetekend: "Tijds. N.I. 8 Jaarg. 3 dl p. 356 - door mij geleverd". Op de laatste bladzijde komt de datering "Palembang Decemb. 1842" voor. Een tweede manuscript van hetzelfde artikel, ditmaal uitgebreid met de in het Maleise handschrift ontbrekende maar in de bijdrage in het Tijdschrift voor Neêrland's Indië wel opgenomen lijst van vorsten, treft men aan in $\mathrm{H} \mathrm{186.} \mathrm{Het} \mathrm{zeer} \mathrm{markante} \mathrm{schrift} \mathrm{van} \mathrm{H} 186$ is onmiskenbaar gelijk aan dat van $\mathrm{H} 307$. Het manuscript van de bewerking van $\mathrm{KI} 1$, eveneens van de hand van De Kock, zomede een incompleet exemplaar ervan, dat het complement vormt van de onder nummer 201* bij KI 2 
bewaarde gedeeltelijke vertaling van $\mathrm{KI} 1$, zijn onder $\mathrm{H} 272$ in de verzameling opgenomen. Ook de Nederlandse bewerking van KI 3, waarvan het manuscript niet bewaard is gebleven, moet wel van de hand van De Kock zijn, getuige de titel "Het leven van Machmoed Badaroedin", die in het handschrift van De Kock op de omslag van KI 3 is gesteld.

Behalve van deze Palembangse kroniek heeft De Kock ook van een niet uitdrukkelijk op zijn verzoek geschreven kroniek betreffende het buurland Jambi een vrije vertaling gepubliceerd, welke eveneens anoniem in het Tijdschrift voor Neêrland's Indië is verschenen. ${ }^{19}$ De Maleise tekst van deze kroniek is ons overgeleverd in de handschriften 205 en 207 van het Koninklijk Instituut voor Taal-, Land- en Volkenkunde. ${ }^{20}$ De korte, slechts acht pagina's tellende tekst van 207 vormt daarbij niet een onmiddellijk vervolg op de tekst van 205 , welke drieëndertig bladzijden beslaat, maar is eerder een nadere uitwerking van het laatste gedeelte ervan en verhoudt zich tot de tekst van 205 dus ongeveer zoals de tekst van KI 3 tot die van KI 1-2. Beide teksten over Jambi zijn in Latijns schrift geschreven, op hetzelfde soort papier ("London superfine") en onmiskenbaar door dezelfde hand als KI 1-3.

Het ligt daarom voor de hand te veronderstellen dat ook de kroniek van Jambi is geschreven door Pangéran Temenggung Karta Menggala, hoewel zijn naam in deze beide handschriften evenmin wordt vermeld als in KI 1 en KI 3. Toch is deze Palembanger niet tevens de auteur van de kroniek van Jambi geweest. Hs 205 blijkt namelijk een vrijwel gelijkluidende, hier en daar wat verkorte weergave in Latijns schrift te zijn van een oudere tekst, geschreven in 1837 te Muara Kompeh (Jambi) ${ }^{21}$ Hiervan bestaat ook nog een latere kopie in Arabisch schrift, van 1861 en eveneens van de hand van een Palembangse afschrijver. ${ }^{22}$

Als directe bron blijken KI 2 en KI 1 tenslotte nog te hebben gediend voor de bijdrage van P. de Roo de la Faille in de Feestbundel van het Bataviaasch Genootschap, getiteld: "Uit den Palembangschen Sultanstijd". ${ }^{23}$ KI 2 wordt er geciteerd op p. 318 als "hs. no. 31", overeenkomende met het catalogusnummer XXXI, en voorts - nu weer onder het codexnummer 201 - genoemd op p. 323 en geciteerd op p. 324, terwijl KI 1 zonder als bron vermeld te worden ten grondslag ligt aan de passage van pp. 319-321.

KI 4

Dit handschrift is in Arabisch schrift uitgevoerd op ongemerkt papier van $34 \times 20,5 \mathrm{~cm}$ en omvat 37 bladzijden van 33 regels, waarvan alleen de linkerhelft beschreven is. Op de omslag staat in Arabisch schrift: 
"Alamat ini sila-sila raja-raja didalam negeri Palémbang adanya" en daaronder in Latijns schrift: "Inie silasila atsal Radja di negrie Palembang".

Het handschrift vermeldt geen auteursnaam en is niet gedateerd. De tekst behelst ten aanzien van dit laatste punt echter wel een indicatie. De vermelding op p. 29 van 2 Rajab 1277 (d.i. 14 januari 1861) als overlijdensdatum van Sultan Ahmad Najamuddin, de zoon van Suhunan Mahmud Badaruddin II, verschaft ons namelijk een terminus post quem. De terminus ante quem - 1871 - alsmede de naam van de auteur Mohidin - ontlenen wij aan W. L. de Sturler (1802-1879), die enige belangrijke publikaties betreffende Palembang op zijn naam heeft staan en wiens concept voor een uitvoerige, nimmer gepubliceerde verhandeling over Palembang in manuscript bewaard is gebleven als nummer H 371 a van de collectie westerse handschriften van het Koninklijk Instituut voor Taal-, Land- en Volkenkunde. ${ }^{24}$ Onder het "Voorberigt" van dit manuscript, dat compleet met titelblad en al voor de druk is gereedgemaakt, staat geschreven: "'sGravenhage 1874". In dit voorwoord nu brengt de auteur onder meer dank aan J. F. R. S. van den Bossche, "thans Oud-Raad van Indië", aan wie hij zegt verschuldigd te zijn "een oorspronkelijk afschrift van de "Oendang-Oendang" niet alleen, maar ook het bezit van de zeer merkwaardige Maleische "kronijk", onder de titel van "Sila-sila atsal Radja di negrie Palembang" (Geslachtslijst der vorsten van het Palembangsche rijk), opgesteld door den ervaren Demang Mochiedin in Arabisch letterschrift, en ... vertaald door den Heer van den Bossche ...". Deze bestuursambtenaar, reeds in 1843 als derde kommies, vier jaar later als controleur der tweede klasse en vanaf 1853 als "adsistent-resident" in de residentie Palembang werkzaam, was van 1860 tot 1862 Resident van Banka en Onderhoorigheden, van november 1862 tot april 1868 Gouverneur van Sumatra's Westkust en Onderhoorigheden en vervolgens tot zijn pensionering in $1871 \mathrm{Lid}$ van de Raad van Nederlandsch-Indië. Of hij KI 4 in zijn Banka- dan wel in zijn S.W.K.-tijd heeft verkregen, is niet bekend, al ligt de veronderstelling dat het eerste het geval zal zijn geweest, gezien de relaties tussen Banka en Palembang, voor de hand. In elk geval zal hij het handschrift vóór zijn repatriëring wel in zijn bezit hebben gehad. De datering van KI 4 kan dus veilig tussen 1861 en 1871 en met een grote mate van waarschijnlijkheid tussen januari 1861 en november 1862 worden gesteld.

Over de auteur verschaft de Regeringsalmanak mogelijk nog enige nadere informatie. Deze vermeldt namelijk een "Tommongong Poespa 
di Natta Mochidien" over de periode 1837-1846 als lid van de "Regtbank van Burgerlijke en Lijfstraffelijke Regtspleging" te Palembang. Vermoedelijk is deze functionaris dezelfde als de door De Sturler genoemde "ervaren Demang Mochiedin".

De tekst van het handschrift bestaat uit twee gedeelten, te weten:

- een geschiedverhaal, dat tot ongeveer 1825 loopt, maar verder nog jaartallen geeft tot 1861 (pp. 1-29);

- een opstel betreffende adellijke titels, hofgebruiken, kleding- en andere adatvoorschriften, waarin korte historische schetsen zijn verwerkt (pp. 31-37).

Het eerste gedeelte beschrijft de geschiedenis van Palembang vanaf de aankomst uit Java van de "eerste" bewoners en bevat zowel elementen uit de Sejarah Melayu als uit de Javaanse en Zuidsumatraanse overlevering. Ook de traditionele van elders reeds bekende genealogie ${ }^{25}$ en allerlei regionale afstammingsmythen zijn in de tekst opgenomen. Het grootste deel van het geschiedverhaal, namelijk pp. 1-22, is aan de min of meer legendarische geschiedenis en de tijd der eerste Palembangse vorsten gewijd. De latere geschiedenis, omvattende de periode H. 981 (A.D. 1573/'74) tot H. 1240 (A.D. 1825), wordt vrij summier behandeld in het laatste van de vijftien hoofdstukken (fasal) waarin de stof is ingedeeld (pp. 22-29). In dit stuk komen veel jaartallen en data voor, die zoals wij zagen, doorlopen tot in 1861 .

Ook dit handschrift heeft De Roo de la Faille geraadpleegd ten behoeve van zijn eerdergenoemde bijdrage in de Feestbundel van het Bataviaasch Genootschap. Citaten eruit geeft hij op pp. 317, 321 en 323.

\section{KI 5}

Een fraai uitgevoerd handschrift in Arabisch schrift op papier van $34 \times 21 \mathrm{~cm}$, omvattende 23 bladzijden van 25 regels. De beginwoorden van alinea's zijn met rode inkt geschreven. Het papier draagt het watermerk van de Hollandse tuin met de woorden "Pro patria", waaronder de hoofdletter B, en met als contramerk de gekroonde initialen G en $R^{26}$ Het handschrift is niet gedateerd. Auteur noch kopiïst worden genoemd. Op de omslag is in Arabisch schrift als titel vermeld: "Cerita raja-raja didalam negeri Palémbang".

Het verhaal, dat blijkens het abrupt einde midden in een zin niet is voltooid, begint met het overlijden van Sultan Muhammad Mansur in H. 1126 ("dan kepada tahun itungan orang putih 1710" ${ }^{27}$ ). Daarna volgt een gedetailleerde beschrijving van de na het overlijden van Sultan 
Mansur uitgebroken strijd om de macht tussen diens bij testament als troonopvolger aangewezen broer Seri Teruna, de latere Sultan Kamaruddin alias Sultan Agung, enerzijds en de oudste twee zoons van de overleden vorst, die zich door het testament van de troonopvolging zien uitgesloten, anderzijds. De laatsten worden al spoedig uitgewezen. $\mathrm{Zij}$ steken met een grote vloot over naar Banka, keren later naar Palembang terug en vluchten vervolgens weer naar Lingga. Hun wederwaardigheden tijdens deze omzwervingen vullen het grootste deel van het verhaal, dat tenslotte afbreekt op het moment dat de vluchtelingen op uitnodiging van de vorst van Singapura uit Lingga naar Singapura zullen vertrekken. De in deze tekst behandelde periode beslaat slechts enkele jaren, ongeveer de periode 1714-1720, uit de Palembangse geschiedenis. Dezelfde periode vindt men ook beschreven in KI 2 en UBL 3, maar veel beknopter.

Een vertaling in zeer gebrekkig Nederlands, die zonder twijfel van de hand van een niet-Nederlander, misschien wel van een Indonesiër is en waarvan de titel luidt "De Geschiedenis der Palembangsch vorsten", bevindt zich onder nummer H 184 in de verzameling westerse handschriften van het Instituut. ${ }^{28}$

\section{KI 6-7}

Deze handschriften in Arabisch schrift op ongemerkt papier van $31 \times 20,5 \mathrm{~cm}$, die respectievelijk 6 en 9 bladzijden beslaan, bevatten de Maleise tekst van de achtereenvolgens op 2 juni 1722 en 25 december 1775 tussen de sultan van Palembang en de Oost-Indische Compagnie gesloten contracten. De stukken zijn niet ondertekend noch van enig ambtsstempel voorzien, zodat ze niet zonder meer als de officiële Maleise tekst van de contracten beschouwd kunnen worden. De Nederlandse tekst van het contract van 1772 is te vinden in deel IV (1935) van het Corpus diplomaticum Neerlando-Indicum, pp. 536-543, het contract van 1775 wordt vermeld in deel VI (1955), pp. 394-395, zonder dat de tekst zelf is opgenomen (ter plaatse wordt verwezen naar de tekst van het mutatis mutandis gelijkluidende contract dd. 15 juni 1763, dat in extenso is afgedrukt op pp. 222-227 van hetzelfde deel). Vergelijking van de Maleise met de Nederlandse tekst levert geen grond voor verschillen in interpretatie van de gesloten contracten en verschaft evenmin opheldering omtrent de vraag of de Maleise tekst een vertaling is van de Nederlandse, hetgeen overigens wel voor de hand ligt, of andersom. 


\section{$K I \quad 8-9$}

Onder het nummer ms.or. 527 zijn twee plano handschriften in Latijns schrift bijeengebracht, waarop in totaal zes verschillende stambomen zijn getekend, die deels van een geschreven toelichting zijn voorzien. Sommige van deze stambomen zijn aangevuld met een verhalende tekst en vormen dus in zekere zin een overgang tussen de zuivere geslachtslijst of silsilah en het eerder met woorden als hikayat, kissah, riwayat of cerit(er)a aangeduide kroniekverhaal, zoals ook de doorgaans sejarah genoemde Maleise geschriften - zij het in een meer geïntegreerde vorm - een combinatie van deze elementen te zien geven.

KI 8 en KI 9 zijn blijkens de ondertekening vervaardigd door Radén Mokhtar bin Radén Rangga Astrawijaya Abdullah op respectievelijk 22 en 24 januari 1869. Radén Mokhtar komt in de Palembangse genealogieën voor als een rechtstreekse afstammeling van Sultan Muhammad Mansur, evenals de auteur van KI 1-3, Pangéran Temenggung Karta Menggala, die een achterneef van Mokhtars vader is. Evenals Karta Menggala bekleedt Mokhtar een niet onaanzienlijke ambtelijke positie: in de genealogieën wordt hij aangeduid als kepala divisi en de Regeringsalmanak van 1859 vermeldt hem als divisiehoofd van Lematang Oeloe. Ook zijn vader, Radén Rangga Astrawijaya Abdullah, wordt in de genealogieën kepala divisi genoemd; hem treffen wij in de Regeringsalmanak van 1857 en 1858 aan als divisiehoofd van Ampat Lawang.

Op beide handschriften verklaart Radén Mokhtar met de woorden "diperboeat salinan" respectievelijk "disalinken", dat hij slechts als kopiïst is opgetreden. Over het model dat hem daarbij tot voorbeeld zou hebben gediend en over de auteur daarvan is ons niets met zekerheid bekend, al bestaat er zoals wij nader zullen zien een stellige relatie met UBL 2 en al liggen genealogieën en verhalen uit de Sejarah Melayu en in mindere mate ook uit de Babad-en de Serat Kanda-traditie aan een deel van het werk ten grondslag. ${ }^{20}$

Het papier dat voor KI 8 en KI 9 gebruikt is, vertoont het watermerk "Pro patria" met het randschrift "Eendragt maakt magt" en de initialen V D L als contramerk. ${ }^{30}$

$K I 8$ dd. 22 januari 1869, groot $129 \times 98 \mathrm{~cm}$, bevat vier stambomen, te weten:

1. Van Adam, in 68 generaties (gilir), via de profeet Muhammad (gilir 41) tot de samensteller Radén Mokhtar zelf, die hiermee bewijst voor wat dit onderdeel van zijn werk betreft meer dan louter afschrijver te zijn geweest. Het Palembangse vorstenhuis begint met 
"Kiai Hang Soero" of "Geding Soero toewa" (gilir 57), die uit Java kwam en de grondlegger van de dynastie zou worden.

2. Van Alexander de Grote ("Soltan Askandar Zolkarnain, Radja Alam") via de vorsten uit het geslacht van Raja Kida Hindi en de vorsten van Amdan Negara, Singapura en Melaka tot Sultan Mansur Syah ("Radja Abdúlla gelar Soltan Mantar Sach"). Een vrij uitgebreide stamboom met verscheidene historisch-legendarische aantekeningen, die de genealogie van de Sejarah Melayu op de voet volgt. Ook de anekdotes en de afstammingsmythen uit het corresponderende eerste gedeelte van de Sejarah Melayu, zoals bijvoorbeeld het verblijf van Raja Suran in het rijk op de bodem van de zee, de lotgevallen van zijn zoon Bicitram Syah, de latere Sang Suparba (hier "Sapurba") Sri Tribuana, het verhaal van Puteri Tunjung (hier "Tandjung") Buih, de aanval van de zwaardvissen (todak) op Singapura, vindt men in de geschreven tekst bij deze stamboom, welke eindigt met de succesvolle aanval van Sultan Mansur Syah op Pahang, beknopt vermeld.

3. Van Raja Sulan van Amdan Negara via Sultan Mugni en Demang Lébar Daun tot diens kinderen Wan Sendari en Tun (hier "Tan") Telani. Omvat slechts veertien namen. Nadere bijzonderheden met betrekking tot de afstamming van de bevolking van Palembang en haar geschiedenis, waarop in deze genealogie de nadruk valt, zijn in een aantal kanttekeningen bijgeschreven.

4. Van Brawijaya VII via Arya Damar "iang digelar Ario Dilla" tot diens zoon Radén Husin, hier aangeduid als "Kemas Koessèn"."31 Omvat naast deze namen nog slechts die van Arya Damars halfbroers Radén Punca Negara en Radén Patah alias Panembahan Palémbang. Met uitvoerige begeleidende tekst onder de titel " $\mathrm{Ri}$ waijat Radja Madjapahit djawa", waarbij is aangetekend, in een andere hand: "Tapi ini roewaijat Ario Dilla bersalahan dengan orang Djawa".

Het zou ons te ver voeren, als we op de hierbedoelde verschillen met de Javaanse traditie nader zouden ingaan. Bij vergelijking van de lezing van KI 8 met de overeenkomstige passage uit de Babad Tanah Jawi en de Serat Kanda ${ }^{32}$ vallen er inderdaad op een aantal punten verschillen te constateren, waarvan ik als één der voornaamste wil noemen, dat Arya Damar, met de hulp van de reuzen, hier niet zoals in het Javaanse verhaal voor een jachtpartij van Brawijaya het wild op het kratonplein van Majapahit bijeendrijft, maar ter plaatse in één nacht een stenen 
stad doet verrijzen. Opmerkelijk is voorts, dat de auteur van KI 8 de zoon van Arya Damar overeenkomstig de lezing van de Serat Kanda Kusèn noemt en niet Husèn, zoals de Babad.

Als een gemeenschappelijke eigenaardigheid in de uitvoering van de stambomen, genoemd onder 2, 3 en 4, kan tenslotte nog worden vermeld dat van de belangrijkste personen de vorstelijke waardigheid door middel van vlaggetjes in verschillende kleuren is aangegeven. De betekenis van elk vlaggetje wordt in een verklarende legenda omschreven.

KI 9 dd. 24 januari 1869, groot $127 \times 119 \mathrm{~cm}$, bevat twee stambomen, te weten:

1. Een uitgebreide, ruim driehonderd namen tellende genealogie van de Palembangse adel, beginnend by Sayyidina Hussin, kleinzoon van de profeet Muhammad, en eindigend bij de tijdgenoten van de samensteller. Ook hier is gebruik gemaakt van vlaggetjes om rang en functie van de voornaamste personen aan te geven.

2. Een stamboom van de vorsten van Jambi, die als vallende buiten het kader van ons onderzoek verder onbesproken kan blijven.

Het werk van Radén Mokhtar vertoont na aftrek van stamboom 2 van KI 9 en stamboom 1 van KI 8 veel overeenkomst met de stambomen die verwerkt zijn in het nog te bespreken handschrift UBL 2. De stambomen 2 en 3 van KI 8 komen conform in UBL 2 voor, de stambomen 4 van KI 8 en 1 van KI 9 met enige verschillen.

\section{KI $10-11$}

Onder codexnummer ms.or. 203 vindt men in een stofmap enige Maleise stukken bijeen, die uit westers handschrift $\mathrm{H} 590 \mathrm{a}^{33}$ zijn gelicht en naar de verzameling oosterse handschriften overgebracht. Van deze stukken zijn er twee voor ons doel van belang.

KI 10. Dit is een getypte genealogie van de Palembangse adel. Latijns schrift, 43 bladzijden ongemerkt papier van $27,5 \times 21,5 \mathrm{~cm}$. Volgens de eveneens onder de stukken van ms.or. 203 opgenomen brief van de burgemeester van Palembang dd. 2 februari 1937, waarbij deze het typoscript toezendt aan de heer J. W. J. Wellan te 's-Gravenhage, is de genealogie samengesteld door het toenmalige lid van de gemeenteraad van Palembang Radén Muhammad Akib. Laatstgenoemde, die volgens de Regeringsalmanak reeds sedert 1931 gemeenteraadslid was en in 1940 wethouder werd, stamt blijkens de genealogie uit een geslacht van ambtenaren: zijn vader wordt demang politie van Palembang Ilir genoemd en zowel zijn grootvader als zijn overgrootvader van vaderszijde 
worden vermeld als kepala divisi. In de Regeringsalmanak, waarin van 1865 af de buiten de hoofdplaats geplaatste inheemse bestuursambtenaren niet meer worden opgenomen, heb ik hen niet kunnen traceren. Van moederszijde is Radén Muhammad Akib een achterkleinzoon van de auteur van KI 1-3, Pangéran Temenggung Karta Menggala.

Deze zeer uitgebreide genealogie, waarin bijna 1600 personen zijn opgenomen, begint bij Kiai Geding Sura, de jongste zoon van de eerdergenoemde Kiai Hang Sura en ter onderscheiding van zijn gelijknamige oudere broer ook wel Kiai Geding Sura Muda, maar meestal, naar de benedenstrooms van de hoofdplaats gelegen plek waar zijn graf zich bevindt (kampung 1 Ilir, Palembang Lama) Kiai Geding Ilir genoemd, en behandelt vervolgens in $66 \mathrm{fasal}$ de adellijke families tot op de tijd van de samensteller. De tekst loopt parallel met die van UBL 4, welke afgezien van een aantal omissies in beide handschriften gelijk is aan MP 3, en verder met de tekst van UBL 6, die behoudens verschillen van ondergeschikt belang weer gelijk is aan MP 1, maar hij bestrijkt een langere periode. Pp. 1-31 (fasal 1-42) is nagenoeg gelijkluidend met UBL 4/MP 3; het tekstgedeelte van pp. 32-36 (fasal 43-52) ontbreekt in UBL 4/MP 3, maar komt wel voor in UBL 6/MP 1. Het laatste gedeelte van KI 10, dat in beide zojuist genoemde handschriften UBL/MP ontbreekt, namelijk pp.37-43 (fasal 53-66), is te beschouwen als het resultaat van het doortrekken der genealogische lijnen tot circa 1937.

Een tweede exemplaar van deze tekst, waaraan enerzijds de uitwerking van de genealogie van Muhammad Akibs eigen familie (p. 40, fasal 64) ontbreekt, maar dat anderzijds de passage betreffende de "voor-historische" periode (p. 17, fasal 16) vollediger weergeeft, bevindt zich in de centrale bibliotheek van het Tropeninstituut te Amsterdam (TR 2). De genealogische gegevens, vervat in KI 10/TR 2, zijn de meest volledige waarover wij voor Palembang kunnen beschikken.

KI 11. Een lichtdruk-kopie, $130 \times 84 \mathrm{~cm}$, van een in Arabisch schrift opgestelde genealogie, getiteld: "Setambum dari raja-raja di Palémbang serta turun temurunnya". Deze stamboom, die begint met vorst Prabu Brawijaya VII van Majapait en via Kiai Geding Sura in het Palembangse vorstengeslacht overgaat om tenslotte met diens in de tweede helft van de negentiende eeuw levende nakomelingen te eindigen, loopt in grote lijnen parallel met stamboom 1 van $\mathrm{KI}$ 9, maar is veel uitgebreider.

\section{KI 12}

Een handschrift van 34 x $21 \mathrm{~cm}, 145 \mathrm{pp}$. van 34 regels. Het papier heeft als watermerk de gekroonde Nederlandse leeuw met het randschrift 
"Concordia res parvae crescunt" en voorts de naam van de Haagse fabrikant H. E. de Charro \& Zonen. ${ }^{34}$ De enkele vellen waarop een soort nawoord en de inhoudsopgave zijn geschreven, zijn van $\mathrm{V}(\mathrm{an})$ $\mathrm{d}(\mathrm{er}) \mathrm{L}(\mathrm{ey}) \cdot{ }^{35} \mathrm{De}$ tekst is in Latijns schrift geschreven. Als auteur wordt in de aanhef en in de colofon genoemd: "Toemoenggong Kerta Negara". In de colofon vindt men bovendien de datum vermeld waarop het afschrift tot stand kwam: "Telah tersalin ini tjerita kapada tahoen Holanda 2 Júly 1861 tahoen Melajoe 23 Dzoelhadji 1277" De naam van de afschrijver wordt niet genoemd. Het geschrift behandelt in 29 hoofdstukken (fatsal) de geschiedenis van Banka tot 1820, waarbij ook aan de bestuursorganisatie en de rechtsbedeling aandacht wordt geschonken. Zo zijn er onder meer de officiële instructies van de sultan van Palembang voor de verschillende hoofden op Banka in opgenomen. Deze tekst, die primair betrekking heeft op Banka, heb ik niettemin bij de inventarisatie betrokken, omdat van de regering van Suhunan Abdulrahman van Palembang af (tweede helft van de zeventiende eeuw) ook de geschiedenis van Palembang, die sedertdien in toenemende mate met die van Banka verweven raakt, erin wordt beschreven. Dit heeft tot gevolg dat ruim tweederde van de tekst ook voor de kennis van de Palembangse geschiedenis van belang is.

\section{KI 13}

Een handschrift van $25 \times 18 \mathrm{~cm}, 113 \mathrm{pp}$. à 17 regels. Het papier vertoont afwisselend als watermerken de tweekoppige gekroonde adelaar en de halve maan, al dan niet in combinatie met òf de initialen $A$ en $G$ ò de volledige naam van de Italiaanse fabrikant Andrea Galvani te Pordenone ${ }^{36}$ De in fraai Arabisch schrift geschreven tekst is gelijk aan die van KI 12, met dien verstande dat het nawoord en de inhoudsopgave die aan de eigenlijke tekst van KI 12 zijn toegevoegd, hier ontbreken. De colofon vermeldt noch de naam van de auteur noch die van de kopiist, maar wel de datering Mentok, 17 Ramadan 1295 (= 14 september 1878).

Over dit handschrift heeft F. S. A. de Clercq de beschikking gehad voor het maken van zijn in 1895 onder de titel "Bijdrage tot de geschiedenis van het eiland Bangka. Naar een Maleisch handschrift." verschenen Nederlandse bewerking van de tekst. ${ }^{37}$ In de inleiding tot wat hij "een eenigszins vrije vertaling" van de Maleise tekst noemt, deelt De Clercq mede dat hij, "eenige jaren geleden voor dienstzaken te Muntok vertoevende", ${ }^{38}$ het handschrift heeft gekregen van "den onder- 
wijzer aan de inlandsche school, Hadji Idris", die de tekst zelf zou hebben "samengesteld". Onder dit laatste zullen wij, aangezien KI 12 uitdrukkelijk Temenggung Kerta Negara als auteur aanwijst, wel moeten verstaan: "afgeschreven". Het handschrift zelf heeft De Clercq, nadat hij het aldus had vertaald, "ter mogelijke raadpleging door belangstellenden, aan de Bibliotheek van het Instituut ... afgestaan". ${ }^{39}$

\section{Handschriften - UBL}

\section{$U B L 1 a$}

Deze in Arabisch schrift uitgevoerde stamboom op een vel ongemerkt papier van $90 \times 34 \mathrm{~cm}$ bevindt zich samen met verscheidene andere handschriften, waaronder ook een aantal niet-Maleise, in een portefeuille die geregistreerd is als cod.or. 1914. De stukken zijn in juli 1868 door de universiteitsbibliotheek te Leiden verworven uit de nalatenschap van de op 25 februari 1868 overleden hoogleraar in het Mohammedaanse recht aan de Bestuursacademie te Delft, mr. dr. S. Keyzer.

De inhoud van UBL 1 a bestaat uit een aanhef, waarin de naam van de afschrijver en de datum van het afschrijven worden genoemd, ${ }^{40}$ gevolgd door een genealogie, waarvan het eerste gedeelte in een zeer summiere verteltrant is weergegeven en de rest in de vorm van een stamboom, die het overgrote deel van het handschrift uitmaakt. Naast deze stamboom is een lijst van de - zestien - vorsten van Palembang (van Kiai Geding Ilir tot Suhunan Husin Dia'uddin) in chronologische volgorde opgesteld, met vermelding van het aantal jaren dat elk hunner geregeerd heeft. Als afschrijver wordt in de aanhef genoemd: Kiagus Zainuddin ibn Demang Puspa Nandita Safiuddin ibn Ngabéhi Carik Sepusang en als datum: hari Juma ${ }^{c}$ at, 4 Sawal 1265, dat is: donderdag, 23 augustus 1849. De naam van de kopiïst, noch die van zijn vader of grootvader komen in één van de beschikbare Palembangse genealogieën voor. Hij behoort, zoals zijn titel kiagus reeds doet vermoeden, dus niet tot de adel, maar komt - te oordelen naar de titels van zijn vader en grootvader - uit een geslacht van lagere en middelbare bestuursambtenaren. Misschien heeft hij het zelf tot divisiehoofd gebracht: de Regeringsalmanak vermeldt een "Kiagoes Zeimoedin" als divisiehoofd in 1858 van Lematang Oeloe en in 1859-1861 van Ilieran en Banjoeassin.

Het beschrijvende eerste gedeelte van de genealogie begint bij Sayyidina Hussin en eindigt met de mededeling, dat Kiai Geding Ilir acht 
kinderen had, waarvan Nyai Geding Pembayun de oudste is. Met deze acht kinderen begint de eigenlijke stamboom van het Palembangse vorstengeslacht, die rond honderdveertig namen omvat en bij de generatie van Sultan Mahmud Badaruddin II ophoudt.

$\mathrm{Bij}$ het handschrift is een transcriptie in Latijns schrift gevoegd, welke getuige de daarbij in het Nederlands gestelde aantekeningen waarschijnlijk door een Nederlander is vervaardigd, echter niet door Keyzer zelf, wiens handschrift duidelijk anders is. ${ }^{41}$ Eén dezer aantekeningen luidt: "Links staat de opvolging der Pal. vorsten, te vergelijken met het laatste werk over Pal. pag. 80". Daaruit valt af te leiden, dat de trancriptie tot stand is gekomen na 1855, in welk jaar dit "laatste werk over Pal.", een boek van W. L. de Sturler, is verschenen. ${ }^{42}$

\section{$U B L 1 b$}

Dit handschrift in Arabisch schrift op een vel ongemerkt papier van $143 \times 60 \mathrm{~cm}$ is vrijwel eensluidend met UBL 1 a. Alleen ontbreekt hier de aanhef van UBL 1 a en dus de naam van de kopiïst en de datering, terwijl het beschrijvende gedeelte der genealogie hier met "Alkissah" begint in plaats van met de woorden "Bahwa ini" van UBL 1 a. De eigenlijke stamboom zelf is in UBL $1 \mathrm{~b}$ op grotere schaal en fraaier uitgevoerd; de namen der voornaamste figuren zijn door versieringen omgeven. Het schrift is op enkele plaaten door beschadiging van het papier onleesbaar geworden. Het is niet onmogelijk dat de tekst oorspronkelijk met een dergelijke aanhef als van UBL 1 a is begonnen en dat dit gedeelte later is afgescheurd en verloren gegaan: de tekst begint onmiddellijk onder de niet-gave bovenrand van het papier en het bovenste stuk van het handschrift is om verdere beschadiging te voorkomen op ander papier geplakt.

Het handschrift is tijdens de Sumatra-expeditie (1877-1879) te Surulangun, residentie Palembang, in het bezit gekomen van één der deelnemers aan de expeditie, A. L. van Hasselt, die de genealogie met uitzondering van het beschrijvende eerste gedeelte - in transcriptie en met vertaling van de daarvoor in aanmerking komende tekstgedeelten heeft ingelast in het door hem geschreven derde deel van het werk waarin de resultaten van de expeditie zijn neergelegd. ${ }^{43}$ De door beschadiging onleesbaar geworden plaatsen in de tekst zijn door Van Hasselt verantwoord met de aanduiding "onleesbaar". De transcriptie is op vele plaatsen incorrect. Het handschrift zelf is in juli 1882 door het Aardrijkskundig Genootschap aan de Leidse universiteitsbibliotheek 
geschonken. Uit de publikatie van deze tekst in "Midden-Sumatra" blijkt dat Van Hasselt niet op de hoogte was van het feit dat de universiteitsbibliotheek te Leiden reeds sedert juli 1868 in het bezit was van een compleet en goed-leesbaar exemplaar van dezelfde genealogie, het hierboven beschreven handschrift UBL 1 a.

\section{$U B L 2$}

Wederom een handschrift met een genealogische inhoud, geschreven in Arabisch schrift op enkele aan elkaar geplakte vellen ongemerkt papier tot een totale oppervlakte van $237 \times 70 \mathrm{~cm}$. Het maakt deel uit van het legaat Snouck Hurgronje. Het schrift is zeer fraai en het geheel maakt een uiterst verzorgde indruk.

Zoals bij de bespreking van KI 8 en KI 9 reeds werd opgemerkt, vinden wij vier van de zes stambomen die in deze handschriften worden weergegeven, in UBL 2 terug. Ook hier gaat de stamboom van Brawijaya VII van Majapait, evenals dit bij stamboom 4 van KI 8 het geval is, vergezeld van het verhaal over Arya Dilah. Het is in klein doch duidelijk schrift geschreven binnen een cirkel met een straal van $13 \mathrm{~cm}$ en stemt in grote lijnen met de tekst in KI 8 overeen.

Behalve de vier stambomen, die eveneens in KI 8 en KI 9 voorkomen en hier dus niet nader behandeld behoeven te worden, bevat UBL 2 nog een "Peringatan zaman raja di Palémbang zamannya menjadi raja", een chronologische lijst van vijftien Palembangse vorsten met vermelding van aanvang en duur van elke regeringsperiode, te vergelijken met cen soortgelijke opgave bij de stamboom van UBL $1 \mathrm{a} / 1 \mathrm{~b}$. Als eerste vorst wordt genoemd Kiai Geding Sura (H. 954-976), als laatste Suhunan Mahmud Badaruddin (H.1207 - ...; het einde van de regeringsperiode is hier niet ingevuld). De in deze lijst gegeven data zijn onbetrouwbaar.

\section{$U B L 3-6$}

Onder nummer cod.or. 7653 a-d zijn vier in Latijns schrift geschreven handschriften in een portefeuille bijeengevoegd. Ze zijn afkomstig uit de nalatenschap van prof.dr. C. Snouck Hurgronje, die ze in 1898 had gekregen van de bestuursambtenaar J. A. van Rijn van Alkemade, zoals uit de desbetreffende potloodaantekening op elk der handschriften blijkt. Snouck Hurgronje bevond zich toen in Aceh, waar Van Rijn van Alkemade "wd. assistent-resident voor de politieke aanrakingen met de Atjehsche onderhoorigheden en hoofden ter Oost- en Noordkust" was, 
met standplaats Kotaraja. ${ }^{44}$ UBL 3 wijkt qua papiersoort, formaat en hand van schrijven af van de drie overige handschriften, die op deze punten een volledige overeenkomst vertonen. Van geen der handschriften is de auteur of de afschrijver bekend. Het gebezigde papier vertoont geen water- of ander merk.

$U B L$ 3. Formaat: $20 \times 16,5 \mathrm{~cm}$; $121 \mathrm{pp}$; zonder datering.

Evenals bij KI 4 treffen wij hier een combinatie aan van geschiedverhaal en adatvoorschriften. Het eerste deel (pp. 1-26) geeft in negenentwintig pasal lokale genealogie en adatvoorschriften op allerlei gebied; pasal 30 (pp. 26-121) beschrijft de Palembangse geschiedenis, die begint bij Depati Karang Widara (dit is Raja Bungsu, de zoon van Demang Lébar Daun) en eindigt in de tijd van Sultan Mahmud Badaruddin II. Het verhaal, waarin geen enkel jaartal wordt genoemd, heeft niet het karakter van een kroniek. De verteltrant is eerder die van de Maleise hikayat, waarbij tal van anekdoten in het grondpatroon van de geschiedschrijving zijn verwerkt. Dienovereenkomstig vertoont de behandeling van de gehele periode die beschreven wordt geen gelijkmatig beeld, maar spitst de geschiedschrijving zich veeleer toe op bepaalde episoden uit het verleden van Palembang, die klaarblijkelijk als glansperioden of hoogtepunten daarvan worden beschouwd. Zo is er met name aan Arya Dilah's rol in de Palembangse geschiedenis, aan de regeringsperiode van de beroemde Suhunan Abdulrahman, naar de plek waar hij begraven ligt ook wel Suhunan Candi Walang genoemd, en aan de onrustige tijd na Sultans Mansurs dood, waarbij de heldendaden van de verbannen prinsen tijdens hun verblijf op Banka breed worden uitgemeten, een ruime plaats ingeruimd. Het geschiedverhaal, dat ergens midden in een zin afbreekt, is niet voltooid. ${ }^{45}$

$U B L 4-6$. Deze drie handschriften op papier van $21,5 \times 17 \mathrm{~cm}$ zijn, te oordelen naar uiterlijke kentekenen, van de hand van één afschrijver. De inhoud van de teksten vormt geen samenhangend geheel: UBL 4 en 6 zijn zuivere genealogieën, die qua inhoud grotendeels met elkaar samenvallen, UBL 5 daarentegen is een echte kroniek. Een aanwijzing dat ze niettemin als bij elkaar horend zijn beschouwd, levert het nog te bespreken handschrift 157 III uit de collectie Brandes van het Museum Pusat te Jakarta (MP 1-3). Afgezien van een duidelijke lacune, van verschillen in spelling en van de omissies die nu eens in de Leidse en dan weer in de Jakartaanse handschriften optreden, is MP 1-3 gelijkluidend aan UBL 4-6, maar dan in omgekeerde volgorde. De drie delen, die in de Leidse versie afzonderlijke eenheden vormen, zijn in MP 1-3 slechts door een extra spatie op de lopende bladzijde van elkaar ge- 
scheiden. De onderlinge spellingsverschillen en de vele schrijffouten, die zelden in beide versies op dezelfde plaats voorkomen, maken het onwaarschijnlijk dat één der beide teksten van de andere zou zijn afgeschreven, doch doen eerder vermoeden dat beide teruggaan op een - in Arabisch schrift geschreven - gemeenschappelijk model. ${ }^{46}$ Wat de datering van dit model betreft, deze is met de beginwoorden van UBL 4/MP 3, luidende: "Adalah pada" (UBL 4 heeft "Adapun") "tahun 1267" ( = A.D. 1851/'50) "bahwa aku himpunkan didalam surat ini ...", gegeven. In UBL 5-6/MP 2-1 komt een dergelijke aanduiding niet voor.

UBL 4 en UBL 6, respectievelijk 107 en 104 pp., zijn beide genealogieën in strikte zin van het Palembangse vorstenhuis. Er worden geen andere gebeurtenissen dan geboorte, huwelijk en overlijden in vermeld. Elke tijdsaanduiding ontbreekt. Wat de inhoud betreft zijn deze uitvoerige genealogieën, die naar schatting 1300 tot 1400 namen omvatten en tot de achterkleinkinderen van de laatste twee souvereine sultans doorlopen, aan elkaar gelijk, behalve dat UBL 4 wat eerder begint en UBL 6 wat verder doorloopt. Wij hebben hier echter niet met twee kopieën van één tekst te doen; daarvoor is de redactie van de teksten te zeer verschillend.

In de aanhef van UBL 4 zegt de auteur dat hij voor zijn werk zowel uit schriftelijke bronnen ("surat orang yang dahulu-dahulu kala") als uit mondelinge overlevering ("perkhabaran daripada orang yang tuatua") heeft geput. In UBL 6, op de omslag waarvan de titel "Kitab toeroenan Radja2 diedalam negerie Palembang" voorkomt, ontbreekt een dergelijke inleiding. De tekst begint meteen met de genealogie van Sayyidina Hussin enz., die ook het beschrijvende eerste gedeelte van UBL 1 uitmaakt.

UBL 5, 78 pp., is een afschrift van een kroniek betreffende de periode 1818-1825 uit de Palembangse geschiedenis. Deze kroniek begint op p. 5. In de eerste drie pagina's worden de vorsten van Palembang opgenoemd, van Kiai Geding Sura tot en met Mahmud Badaruddin II, met vermelding van de duur der regeringsperioden, waarna - op p. 4 - terloops de tijd van het Engelse tussenbestuur (1812-1816) genoemd wordt. Op de omslag van het handschrift staat vermeld: "Kitab Toeroenan radja2 Palembang", een titel die strikt genomen alleen op de inhoud van pp. 1-3 van toepassing is. Aan de tekst gaat een lijst van de elkaar opvolgende Palembangse vorsten vooraf, geschreven op dikker papier, dat het watermerk van de gekroonde Nederlandse Leeuw binnen het randschrift "Concordia res parvae crescunt" vertoont met de naam van de fabrikant Van Gelder als contramerk. ${ }^{47}$ Deze lijst, die een weergave 
vormt van de inhoud van de eerste drie bladzijden van het handschrift en gedateerd is "di Palembang den 16 Maart 1871", heeft Van Rijn van Alkemade - zonder verwijzing - opgenomen in een noot bij zijn artikel "De hoofdplaats Palembang", verschenen in het Tijdschrift van het Aardrijkskundig Genootschap, eerste serie, deel 7 (1883), pp. 51-69.

De kroniek van UBL 5 vertoont veel overeenkomst met de beschrijving van dezelfde periode van de geschiedenis in UBL 7. Sterker nog is de overeenkomst met de tekst van het later te bespreken handschrift TR 1, dat in zijn geheel hetzelfde tijdvak behandelt en zelfs op precies hetzelfde punt eindigt als UBL 5 .

\section{$U B L 7$}

Dit handschrift, groot 79 pp. van 14 regels, in Arabisch schrift geschreven op papier van $19 \times 15,5 \mathrm{~cm}$, dat het watermerk "Keferstein \& Sohn 1863 " draagt, ${ }^{48}$ is in maart 1880 door de universiteitsbibliotheek te Leiden aangekocht van J. S. G. Gramberg ${ }^{49}$ en moet dus tot stand zijn gekomen tussen 1863 en 1880. Aangezien Gramberg eind 1866 van Palembang naar Batavia verhuisde om nog geen jaar later wegens ziekte het toenmalige Nederlands-Indië te verlaten, acht ik een nadere datering tussen 1863 en 1867 verantwoord. Dat hij het niet tezamen met de eind 1865 aan het Bataviaasch Genootschap aangeboden handschriften heeft afgestaan, ${ }^{50}$ zou kunnen betekenen dat hij UBL 7 op dat tijdstip nog niet in zijn bezit had, al bewijst het dat natuurlijk niet.

Het schrift van UBL 7 is weinig fraai. Voor het schrijven van beginwoorden van alinea's en andere "accentwoorden" is rode inkt gebruikt. De naam van de auteur wordt niet genoemd, noch die van de eventuele afschrijver. De inhoud bestaat uit een kroniek betreffende de periode 1720-1825, waarvan de jaren 1804-1821 het uitvoerigst zijn beschreven. In dit gedeelte komen ook de meeste data voor. Daar het verhaal, al wordt het dan niet in de loop van een zin afgebroken, toch enigszins abrupt eindigt, krijgt men de indruk dat het niet voltooid is; het is in elk geval niet afgesloten met een colofon.

Als bron voor zijn geschiedverhaal noemt de auteur in zijn inleiding zowel schriftelijke als mondelinge overlevering en hij doet dit in vrijwel dezelfde bewoordingen als de auteur van UBL 4/MP 3.51 Misschien hebben we hier met een voor zo'n inleiding min of meer stereotiepe omschrijving te maken, maar meer voor de hand liggend lijkt de veronderstelling, dat UBL 4/MP 3 en UBL 7 van één en dezelfde auteur zijn dan wel op een gemeenschappelijk model teruggaan. Deze veronderstelling vindt steun in de reeds eerder ${ }^{52}$ gesignaleerde sterke overeen- 
komst tussen UBL 7 en de immers aan de auteur van UBL 4 toe te schrijven tekst van UBL 5.

Tot de vele Maleise handschriften die Van der Linden heeft geraadpleegd in het kader van zijn onderzoek naar "de Maleische visie op den Europeaan", voor zover deze tot uitdrukking komt in de geschreven Maleise literatuur, ${ }^{53}$ behoren ook UBL 7 en een vijftal andere teksten die op de geschiedenis van Palembang betrekking hebben en derhalve in onze inventarisatie thuishoren. Twee ervan, KI 3 en MP 1-3, die in verband met de doelstelling van de schrijver "niets nieuws" opleverden, worden door hem slechts "volledigheidshalve" vermeld (p. 171). Van de overige Palembangse teksten: UBL 9, welke samen met UBL 7 wordt behandeld (pp. 147-160), UBL 12 (pp. 179-181) en MP 4a (pp. 160171), wordt in een met citaten gedocumenteerd relaas de inhoud vrij uitvoerig weergegeven. Het is jammer, maar gelet op het grote aantal handschriften dat hij heeft moeten doornemen misschien wel begrijpelijk, dat de auteur ten aanzien van de transcriptie van de door hem geciteerde tekstgedeelten niet steeds de vereiste nauwkeurigheid heeft betracht. Hierdoor komt hij nogal eens tot verkeerde interpretaties, die hem soms weer tot het maken van onjuiste gevolgtrekkingen verleiden. Wanneer wij straks de volledige tekst van sommige van deze handschriften laten volgen, komen wij hier vanzelf nog op terug.

\section{UBL $7 a$}

Een transcriptie in Latijns schrift van UBL 7, vervat in een viertal schoolschriften. Op het etiket van het eerste van deze schriften is met potlood aangetekend: "terugontv. van Mevr. de Wed. Moquette 1927" en daaronder, in een andere hand: "Eigendom Dr. Rinkes". ${ }^{54}$ In de tekst zijn met zwarte inkt verbeteringen aangebracht, naar het schrift te oordelen door een ander dan de transcribent.

De transcriptie is over het algemeen correct, afgezien van twee omissies van respectievelijk één en driekwart regel en voorts behoudens wat onnauwkeurigheden en fouten, zoals bijvoorbeeld Rasboen voor Rabsoen, Misman voor Mista Saman, Meting voor Ménténg, Hadji voor Djambi.

\section{$U B L 8$}

Een in een duidelijke, gelijkmatige hand op ongemerkt papier geschreven kopie in Arabisch schrift van een tekst, die geregistreerd als v.d. Wall nr 191 (Van Ronkel-BG nr CCCLIV, pp. 274-275) deel uitmaakt van het handschriftenbezit van het Museum Pusat te Jakarta. Dit 
laatste handschrift telt $341 \mathrm{pp}$. van $33 \times 21 \mathrm{~cm}$ à 27 regels en is, zoals de colofon vermeldt, in de periode 23 Safar -8 Rabicul-akhir 1272 (4 november -18 december 1855) geschreven door Tengku Sacid in opdracht van "Tuan Pandarwal, asistén-residén komisi didalam Sikudana". ${ }^{55}$ Het afschrift UBL 8, dat tot de collectie Snouck Hurgronje behoort en in Van Ronkel-UBL dan ook onder het collectienummer Sn.H. 78 is opgenomen, telt 647 pp. van $22 \times 17 \mathrm{~cm}$ à 15 regels. Op het titelblad staat: "Inilah cetera Raja Iskandar Zulkarnaini. Tertulis didalam negeri Betawi kepada 24 Yuni 1893". Als kopiïst wordt in de colofon genoemd: Muhammad Nuruddin Acéh, die op 11 Zulhijah 1310 "kepada hari Sabtu" te Batavia zijn werk voltooide. ${ }^{56}$ Een tweede kopie van de tekst, in machineschrift met Arabische lettertekens, heeft de uiversiteitsbibliotheek te Leiden in 1933 ten geschenke gekregen van de bekende malaicus Sir R. O. Winstedt; dit typoscript is onder het nummer cod.or. 6342 in de verzameling oosterse handschriften opgenomen.

De inhoud van de eerste 401 pagina's tekst van UBL 8 komt in grote trekken overeen met de Sejarah Melayu. In de rest van het verhaal wordt de latere geschiedenis van het gebied rond Straat Malakka beschreven, waarbij aan Raja Akil van Siak ${ }^{57}$ een centrale plaats wordt toegekend. Ook al is het grootste deel van de tekst dus aan de Sejarah Melayu gewijd, toch hebben wij hier eerder met een "Hikayat Raja Akil" te maken dan met een Sejarah Melayu-versie, zoals de beschrijving van het handschrift v.d.W. 191 in Van Ronkel-BG zou doen vermoeden. ${ }^{58}$ De visie op de tekst als zijnde primair het verhaal van Raja Akil, waaraan de Sejarah Melayu is voorgevoegd, sluit aan bij het ook elders in de Maleise historiografie en met name ook in sommige van de hier behandelde teksten (KI 1, KI 4, in het algemeen de genealogieën) te constateren verschijnsel, dat een sterke drijfveer van de geschiedschrijver wordt gevormd door de behoefte om de heersende dynastie aan het in de Sejarah Melayu gecanoniseerde roemrijke verleden te verbinden en daardoor haar gezag te rechtvaardigen en tevens magische kracht en sacrale luister bij te zetten. Een verschijnsel overigens, dat in zijn algemeenheid, los van de S.M.-traditie, niet tot de Maleise cultuursfeer beperkt blijft, maar ook - met name door Berg ${ }^{59}$ - met betrekking tot de Javaanse geschiedschrijving is opgemerkt en trouwens op analoge wijze ook in westerse culturen valt waar te nemen.

Hoe dit zij, voor ons doel is alleen de op het Sejarah Melayu-gedeelte volgende beschrijving van de latere geschiedenis van belang, met name voor zover deze op Palembang betrekking heeft. Daarin komt Palembang voor het eerst ter sprake op p. 414, zij het vooralsnog zijdelings en 
terloops. Eerst wanneer Raja Akil zijn diensten aanbiedt aan Muntinghe, wordt het toneel van handeling volledig naar Palembang verplaatst (p. 599 v.v.). De Palembang-episode eindigt met het vertrek van Raja Akil naar Pontianak, waarna het slot van het verhaal zich verder op West-Borneo, voornamelijk in het gebied van Sukadana, afspeelt (pp. 639-647).

\section{$U B L 9$}

Een handschrift in Arabisch schrift, 95 pp. van 17 regels, groot 20,5 x 16 $\mathrm{cm}$, geschreven op papier met als hoofdmerk de gekroonde Nederlandse Leeuw binnen het randschrift "Concordia res parvae crescunt" en als contramerk de initialen VDL. ${ }^{60}$ Het schrift is niet bijzonder fraai, maar het geheel maakt met de in rood geschreven beginwoorden van alinea's en dergelijke een verzorgde indruk. De tekst staat vanwege de belangrijke plaats die Daendels in het verhaal inneemt bekend onder de titel "Hikayat Marsekalek". Auteur, kopiïst en datering van de tekst zijn met de beginwoorden ervan gegeven. Als auteur wordt genoemd: Syaikh Abdullah, afkomstig uit Kedah en wonende te Pontianak; als kopiïst: Kiai Rangga Satyanandita (gespeld: s-t-c-a-n-n-d-i-t) Ahmad bin Kiai Ngabéhi Mastung te Palembang, die in H. 1247 ( = A.D. 1831) '32) op een zaterdag om 9 uur "bermula menyurat hikayat ini". ${ }^{11}$

De eigenlijke Hikayat Marsekalek, die op p. 41 eindigt en ook uit een tweetal andere handschriften bekend is, speelt op Java tijdens Daendels en Janssens en is dus voor ons onderzoek van geen belang. ${ }^{62}$ De rest van het verhaal, van p. 41 regel 13 tot p. 95, bestrijkt het tijdvak 1812-1819 uit de Palembangse geschiedenis. Hierbij wordt de meeste aandacht geschonken aan de rivaliteit tussen de om beurten door de Europese machthebbers te Palembang gesteunde broers, de sultans Mahmud Badaruddin II en Ahmad Najamuddin II, de latere Husin Dia'uddin. Het werk is onvoltooid gebleven: in de loop van een zin breekt het verhaal af.

De verhouding tussen de beide delen van UBL 9, die ofschoon ze ongemerkt in elkaar overgaan qua inhoud evenwel geheel van elkaar onafhankelijke geschiedverhalen bevatten, is onduidelijk. Het tweede deel, waarin de geschiedenis van Palembang wordt beschreven, ontbreekt in de beide andere handschriften van de Hikayat Marsekalek, die wel zijn voltooid en zelfs afgesloten met een formele colofon. In de colofon van cod.or. 6057 staat vermeld dat het oorspronkelijke werk is geschreven in H. 1234 ( = A.D. 1819/'18) ${ }^{63}$ Indien deze datering juist is, kan zij onmogelijk voor het tweede deel van UBL 9 gelden, aan het slot 
waarvan immers de aankomst van de Hollandse vloot onder commando van Generaal-Majoor De Kock voor de monding van de Sungsang (17 mei 1821) wordt vermeld. Voorts kan in dit verband worden gereleveerd dat UBL 9, de enige van de drie teksten waarin een stuk typisch lokale Palembangse geschiedenis wordt beschreven, van de hand van een Palembangse kopiïst is, terwijl de beide andere handschriften in de Riau-archipel zijn vervaardigd, te weten door de toenmalige schrijver van het residentiekantoor te Tanjung Pinang respectievelijk door diens zoon op het eilandje Penyengat.

Als een laatste bijzonderheid waardoor UBL 9 zich van de beide andere teksten onderscheidt, noem ik het feit dat laatstbedoelde handschriften, met name cod.or. 6057, meer citaten in het Arabisch bevatten dan de Maarschalk-geschiedenis in het eerste gedeelte van UBL 9, terwijl in het tweede - Palembangse - deel daarvan zelfs helemaal geen Arabisch voorkomt.

Op grond van bovenstaande gegevens meen ik te mogen aannemen, dat het tweede - Palembangse - deel van de Hikayat Marsekalek van het oorspronkelijke werk geen deel heeft uitgemaakt en derhalve als een op onopvallende wijze aan de Hikayat gekoppeld zelfstandig verhaal moet worden beschouwd, dat hetzij aan de - Palembangse - afschrijver als auteur moet worden toegeschreven, hetzij door deze aan een bestaande tekst werd ontleend. Tegen de mogelijke hypothese, dat het Palembangse deel door een andere, onbekend gebleven auteur of kopiïst werd toegevoegd, pleit vooral dat er qua papiersoort en met name voor wat het schrift betreft geen caesuur tussen de beide gedeelten valt aan te wijzen, terwijl het bovendien toch wel als ongebruikelijk moet worden beschouwd dat iemand een uitdrukkelijk door een ander begonnen verhaal zou voortzetten zonder daarvan op de een of andere wijze te doen blijken of zelfs maar zijn identiteit kenbaar te maken. Hoe dit alles zij, stijl en inhoud van dit geschrift, waarin op levendige wijze en met veel dialoog verslag wordt gegeven van een episode uit de Palembangse geschiedenis die in geen andere overlevering zo "van binnen uit" is belicht als hier, wettigen de veronderstelling dat de auteur niet alleen een tijdgenoot, maar zelfs een ooggetuige is geweest, die bij de minutieus beschreven gebeurtenissen persoonlijk betrokken is geweest. Of deze omschrijving op de in de aanhef van UBL 9 als afschrijver genoemde Kiai Rangga Satyanandita Ahmad van toepassing is, valt moeilijk te bewijzen, omdat wij nu eenmaal niet over nadere biografische gegevens beschikken. Het enige wat hierover gezegd kan worden, is dat de wel zeer gedetailleerde beschrijving van de lotgevallen van een zekere rangga, 
die in het verhaal een rol speelt als boodschapper in het contact tussen de sultan te Palembang, Ahmad Najamuddin, en de na de komst van de Engelsen naar het binnenland gevluchte oude sultan Mahmud Badaruddin, het aantrekkelijk maakt deze met de rangga Satyanandita Ahmad te identificeren. Zou men misschien zelfs, wanneer hij onderaan op p. 66 deze boodschapper aanduidt als "kiai inilah", aan de toevoeging "inilah" de betekenis mogen toekennen, dat de auteur-kopiïst zich hier op indirecte wijze met die boodschapper vereenzelvigt?

De Regeringsalmanak tenslotte vermeldt in de jaren 1830-1834 een zekere "Karanga Satja Nindita" als "lid van de regtbank" ter hoofdplaats Palembang. Wellicht is deze de (auteur-) kopiïst van UBL 9. Aangezien de Regeringsalmanak vóór 1830 geen gegevens over de leden van de rechtbank bevat en bovendien over de jaren 1835 en 1836 voor Palembang de gebruikelijke personalia wegens mij onbekende redenen niet zijn opgenomen, valt niet vast te stellen of met het tijdvak 1830-1834 wel de volle ambtsperiode van de rangga is weergegeven.

UBL 10

Onder dit nummer heb ik de dertien Palembangse brieven uit de in oktober 1878 door de Leidse universiteitsbibliotheek verworven en als cod.or. 2241 geregistreerde brievencollectie Van der Vlis bijeengenomen. Ze zijn geschreven in de periode 1791-1808, op papier van verschillend formaat en met verschillende watermerken. De gehele collectie is in 1882 gecatalogiseerd door H. C. Klinkert. ${ }^{64}$

De Palembangse brieven zijn behalve de nrs 10 en 12 afkomstig van de sultan van Palembang en bestemd voor de Hoge Regering te Batavia. Ze zijn, geheel in overeenstemming met de status van afzender en geadresseerde, van fraai uitgevoerde opschriften en onderschriften voorzien en dragen het in zwart afgedrukte ambtsstempel van de sultan van Palembang, hier nader aangeduid als Dar-as-Salam. De nrs 1-7 zijn van Muhammad Baha'uddin, de nrs 8, 9, 11 en 13 van zijn zoon en opvolger Mahmud Badaruddin. Het ambtsstempel bevat onder meer de in het Arabisch gestelde aanduiding (in woorden, niet in cijfers) van het jaar, waarin de betrokken sultan de regering heeft aanvaard. Dit jaartal luidt voor Muhammad Baha'uddin H. 1190 (= A.D. 1776/'77) en voor Mahmud Badaruddin H. 1218 (= A.D. 1803/'04) ${ }^{65}$ Brief nr 8, gedateerd 15 Muharram 1219 (= 26 april 1804), is van belang voor de datering van het overlijden van Muhammad Baha'uddin en de troonsbestijging door Mahmud Badaruddin, hier gesteld op maandag, 21 Zulhijah 1218 (= 2 april 1804), te 4 uur. 
Met betrekking tot het gebezigde briefpapier kan ik nog het volgende meedelen.

Nrs 1 en 2 (beide van 1791): papier van de Britse fabrikant S. Lay met als hoofdmerk de posthoorn in gekroond schild en daaronder de initialen $\mathrm{G}$ en $\mathrm{R}$; als contramerk de naam van de fabrikant met eronder de letter $\mathbf{C}^{.68}$

Nrs 3 en 4 (respectievelijk van 1793 en 1795): waarschijnlijk Frans papier met als hoofdmerk de druiventros in gekroond schild; als contramerk een kleine Franse lelie tussen de initialen $R$ en $\mathbf{M}^{{ }^{67}}$

Nrs 5, 6, 7, 8 en 11 (van het tijdvak 1798-1806): papier van de Noordhollandse fabrikant J. Honig \& Zoonen met als hoofdmerk de Franse lelie in gekroond schild en daaronder de initialen $\mathrm{J} \mathrm{H} \& \mathrm{Z}$; als contramerk de naam van de fabrikant voluit. ${ }^{88}$

Nr 9 (van 1804): eveneens papier van J. Honig \& Zoonen met als hoofdmerk de Nederlandse Leeuw en eronder de initialen J H \& Z; als contramerk weer de naam van de fabrikant voluit. ${ }^{69}$

Nr 13 (van 1808): papier van de Britse fabrikant Lloyd \& Co met als hoofdmerk de Franse lelie in gekroond schild en daaronder de initialen $\mathrm{G}$ en $\mathrm{R}$; als contramerk de naam van de fabrikant en het jaartal $1798 .^{70}$

Het papier van de brieven die niet van de sultan afkomstig zijn is van mindere kwaliteit en heeft geen watermerk, zoals $\mathrm{nr} 12$, òf vertoont slechts, zoals $\mathrm{nr} 10$, de initialen I en V, welke in deze tijd vooral door de Noordhollandse fabrikant C. \& I. Honig als contramerk gebruikt werden. $^{\text {11 }}$

\section{UBL 11}

Dit is een brief van Sultan Ahmad Najamuddin (Prabu Anom) aan Gouverneur-Generaal Van der Gapellen dd. vrijdag 6 juli 1821. De sultan meldt daarin zijn behouden terugkeer (uit Batavia) te Palembang, de succesvolle militaire expeditie onder commando van Generaal-Majoor De Kock tegen Sultan Mahmud Badaruddin II en diens ontzetting uit de vorstelijke waardigheid om vervolgens zijn dank uit te spreken voor het feit dat hij op donderdag 28 juni 1821 in de plaats van zijn oom tot sultan is verheven.$^{72} \mathrm{De}$ in deze brief vermelde feiten en data komen geheel overeen met hetgeen terzake uit Nederlandse bron, met name uit de rapporten en journalen der expeditie, bekend is.

De brief, die op 15 maart 1951 door de Gemeente-Archivaris van 's-Gravenhage aan de universiteitsbibliotheek te Leiden werd overgedragen uit de nalatenschap van jhr. Harco Theodorus Hora Siccama, is geschreven op papier van G. \& I. Honig en heeft het watermerk van 
de bijenkorf met de naam van de fabrikant eronder en voorts het daarbij behorende contramerk. ${ }^{73}$ Het ambtsstempel van Sultan Ahmad Najamuddin komt overeen met dat op de sultansbrieven van UBL 10, met dien verstande dat het jaartal hier, conform de inhoud van de brief, H. 1236 ( = A.D. 1821) luidt.

\section{$U B L 12$}

Dit is een in Arabisch schrift geschreven exemplaar van de tekst betreffende de geschiedenis van Banka, die ons ook bewaard is gebleven in de reeds beschreven handschriften KI 12 en KI 13. Het telt 97 pp. van 18 regels, het formaat van het papier, waarvan ik het zeer onduidelijke watermerk niet heb kunnen thuisbrengen, is $26 \times 19 \mathrm{~cm}$ en het handschrift lijkt qua uitvoering veel op KI 13. Aan die uitvoering is hier echter nog meer zorg besteed, bijvoorbeeld door het gebruik van rode inkt voor het aangeven van de beginwoorden van alinea's en dergelijke en voor opschriften ter aanduiding van de hoofdstukken en van de artikelen der instructies voor de hoofden. De titel, die in Latijns schrift geschreven is op een soort etiket dat voorin het "boek" is geplakt, luidt: "Soerat tjerita atsal tanah dan orang jang mendijami tanah Banka". Als datum waarop dit afschrift werd voltooid ("telah selesai menyalin surat ini"), vermeldt de colofon: Mentok, 10 Safar 1296 (= 3 februari 1879); het is dus slechts enkele maanden na KI 13 tot stand gekomen. ${ }^{74}$ De naam van de auteur en van de kopiïst worden nergens vermeld. Het handschrift is op 28 september 1881 door de toenmalige resident van Banka, Ch. M. G. A. M. Ecoma Verstege, ${ }^{75}$ aan de universiteitsbibliotheek te Leiden geschonken.

\section{Handschriften - MP}

MP 1-3

Van deze in Latijns schrift geschreven en totaal 195 pagina's tellende handschriften stond mij een microfilm ter beschikking, welke inmiddels in het fotoarchief van de afdeling Oosterse handschriften van de universiteitsbibliotheek te Leiden is opgenomen.

De titel luidt volgens Van Ronkel-BG: "Asal toeroenan radja-radja didalam negrie Palembang". De inhoud is, zoals hiervóór reeds werd opgemerkt, ${ }^{76}$ gelijk aan die van UBL 6-4, met dien verstande, dat een deel van de tekst van UBL 6, namelijk van p. 2 regel 19 tweede woord tot p. 14 regel 21 vierde woord, hier ontbreekt en dat er overigens kleine onder- 
linge verschillen - met name in de spelling - en hier en daar ook omissies te constateren zijn, die echter bij een vergelijking van de teksten als van ondergeschikt belang buiten beschouwing kunnen blijven. De tekst van UBL 6 vindt men terug op pp. 1-71, door mij angeduid als MP 1, de tekst van UBL 5 correspondeert met de passage op pp. 71-129 (= MP 2) en die van UBL 4 met het tekstgedeelte pp. 129-194 (= MP 3). Pagina 195 tenslotte is een ten onrechte als laatste bladzijde opgenomen duplicaat van p. 2 van het derde woord van de derde regel af, aangevuld met enkele regels van het corresponderende tekstgedeelte van UBL 6, dat zoals wij boven zagen aan MP 1 ontbreekt. Evenmin als in UBL 4-6 worden in MP 1-3 de namen van de auteur of van de kopiïst genoemd. Van deze laatste kunnen we alleen vaststellen dat hij Nederlands kent. Op enkele plaatsen in MP 2 geeft hij achter een woord van de tekst tussen haken een Nederlandse vertaling, zoals bijvoorbeeld: "kilat halontar (bliksem)", "kalem kaboet (duister)", "mentjar (schitteren)", "oedara (wolken)", soms ook een toelichting als "(een plaats nabij de Soempang)" of "(beneden 14 oeloe)" achter plaatsnamen. In het algemeen valt verder de Nederlandse schrijfwijze op van woorden als officier, thee, Singapore, waar UBL 5 opsir, tèh en Singapura heeft. Overigens treft men ook verklaring door middel van Maleise synoniemen aan, zoals bijvoorbeeld: "mengoetjap (menjeboet)", "hanja (malemken", waarmee "melainkan" moet zijn bedoeld), "boelan ramdon (boelan poeasa)", "sambil (stenga)", "njeloesoer (toeroet)".

\section{$M P 4 a$ en $M P 4 b$}

Ook van deze beide in Arabisch schrift gestelde handschriften, bestaande uit $35 \mathrm{pp}$. van $20 \times 16,5 \mathrm{~cm}$ à 16 regels, respectievelijk $30 \mathrm{pp}$. van $33,5 \times 21 \mathrm{~cm}$ à 18 regels, kon ik middels een thans op de universiteitsbibliotheek te Leiden gedeponeerde microfilm kennisnemen. Het zijn beide exemplaren van een gedicht, dat 260 strofen telt en waarvan de titel, die als zodanig alleen op MP $4 \mathrm{~b}$ uitdrukkelijk wordt vermeld, "Syacir Perang Ménténg" luidt. Ze zijn behoudens een aantal weinig belangrijke verschillen in spelling en woordkeus eensluidend.

In dit gedicht worden op een geëngageerde wijze de vijandelijkheden beschreven die in 1819 hebben plaatsgevonden tussen de Palembangers en de Hollanders onder de toenmalige commissaris Muntinghe (Ménténg). Uit de mededeling in strofe 257, dat de sya cir in H. 1235 ( = 20 oktober 1819 - 8 oktober 1820) in enkele dagen tijds werd geschreven, blijkt dat het gedicht niet lang na afloop van de erin beschreven gebeurtenis- 
sen tot stand is gekomen. Gezien de vermelding in strofen 250-255 van het echec van de expeditie-Wolterbeek (eind oktober 1819) en zelfs van Muntinghe's terugkeer via Muntok naar Batavia (eind december 1819) ware de datering evenwel niet vóór januari 1820 te stellen.

In 1967 heeft Atja, "associate curator" van de afdeling Bahasa dan Sastra van het Museum Pusat te Jakarta, een tekstuitgave van de syacir het licht doen zien, vergezeld van een historische inleiding, een woordenlijst en een beknopte bibliografie. ${ }^{77}$ Voor deze tekstuitgave van wat hij de "Syacir Perang Palémbang" noemt heeft Atja zowel MP 4 a als MP $4 \mathrm{~b}$ geraadpleegd zonder consequent één van de twee versies te volgen. $\mathrm{Nu}$ eens volgt hij naar eigen keuze de lezing van het ene dan weer van het andere handschrift, terwijl de alternatieve lezing dan wordt verantwoord in een niet geheel volledig kritisch apparaat.

De naam van de dichter en die van de kopiïsten zijn ons niet bekend. Van der Linden, die in het kader van zijn onderzoek naar de plaats van de Europeaan in de Maleise literatuur ook de Syacir Perang Ménténg behandelt, beweert dat "de auteur blijkens aanteekening van den schenker, den heer Gramberg, een half-Arabische pangéran Moehammad is". ${ }^{78}$ Met deze "aanteekening" wordt de toelichting bedoeld die Gramberg in zijn aanbiedingsbrief van 28 december 1865 aan de directie van het Bataviaasch Genootschap bij de syacir geeft ${ }^{79}$ en waaraan gerefereerd wordt in een waarschijnlijk van de toenmalige bibliothecaris van het Genootschap afkomstige aantekening op MP 4 a. Deze toelichting bevat vreemd genoeg evenwel geen enkele aanwijzing dat Pangéran Muhammad de auteur van de syacir zou zijn; ook Van Ronkel ${ }^{80}$ vermeldt geen auteur. De bewering van Van der Linden mist dan ook elke grond. Integendeel wordt zowel door de toelichting van Gramberg als door de eerste verzen van het gedicht zelf de mogelijkheid dat Pangéran Muhammad het zou hebben geschreven, zo goed als uitgesloten.

Volgens de notulen van de directievergaderingen van het Bataviaasch Genootschap van $1877^{81}$ heeft D. Gerth van Wijk bij brief dd. Fort de Kock, 23 januari 1877 een transcriptie in Latijnse karakters van de syacir (volgens de lezing van MP 4 a of van een ander, onbekend handschrift) met inleiding en noten aan het Genootschap aangeboden. L. W. C. van den Berg, in wiens handen het stuk wordt gesteld om prae-advies, acht het een leemte dat er geen vertaling aan toegevoegd is en wijst op het nut van raadpleging van de tekst volgens de lezing van MP 4 b. Gerth van Wijk conformeert zich bij brief van 23 maart aan dit advies en vraagt laatstbedoeld handschrift ter inzage, waarop in de vergadering van 10 april wordt besloten "den heer Gerth van Wijk 
de beide hss." (blijkbaar MP 4 a en -4 b) "in een aangeteekend pakket te zenden". Omtrent de oorspronkelijke transcriptie met inleiding en noten vernemen wij daarna in de notulen niets meer.

\section{Handschriften - TR}

\section{TR 1-2}

In de Centrale Bibliotheek van het Koninklijk Instituut voor de Tropen te Amsterdam bevindt zich de doorslag, op papier van 33 x 20,5 cm met het watermerk "KOSMOS", 82 van een in Latijns schrift getypte Maleise tekst, waarin achtereenvolgens een kroniek van Palembang en een genealogie van het Palembangse vorstenhuis zijn vervat. Deze als afzonderlijke teksten te beschouwen twee delen, die elk een eigen pagitering hebben, worden door mij onderscheiden als TR 1 en TR $2 .^{83}$

TR 1, groot 44 pp., bevat na de bekende lijst der Palembangse vorsten met een ditmaal merendeels onjuiste opgave van regeringsperioden het relaas van de geschiedenis van Palembang over de jaren 1818-1825, te vergelijken met de kroniek van UBL 5 .

De inhoud van TR 2, dat 62 pp. telt, bestaat uit een genealogie in strikte zin van het Palembangse vorstenhuis, welke behoudens de bij de bespreking van KI 10 reeds opgemerkte verschillen geheel met de feitelijke inhoud van KI 10 overeenstemt.

De bibliotheek van het Tropeninstituut bezit nog een tweede Maleis typoscript, dat op dezelfde manier als het hierboven behandelde is uitgevoerd en samen met TR 1-2 in één portefeuille wordt bewaard. ${ }^{84} \mathrm{Dit}$ typoscript van $145 \mathrm{pp}$. behelst een sterk bekorte en abrupt eindigende versie van de Sejarah Melaju, welke op verscheidene plaatsen van alle andere tot nu toe bekende lezingen afwijkt. ${ }^{85}$ Mogelijk is de "schriftelijke overlevering", waarover L. C. Westenenk, van medio mei 1920 tot medio februari 1921 resident van Palembang, ${ }^{86}$ in zijn in 1923 verschenen artikel over de Bukit Seguntang en de Mahameru ${ }^{87}$ spreekt en die hem "in Palembang is ter hand gesteld", een exemplaar (in Arabisch schrift? ${ }^{88}$ ) van dezelfde tekst geweest. Immers de passage uit dat handschrift die hij daar vergelijkt met de lezing van dezelfde passage in twee andere S.M.-handschriften, valt vrijwel letterlijk samen met de lezing van de corresponderende passage in het typoscript van het Tropeninstituut. Waar het handschrift van Westenenk is gebleven, heb ik niet kunnen vaststellen. Het is voor zover mij bekend niet in een openbare verzameling opgenomen.

Omtrent het tijdstip waarop de hier besproken typoscripten zijn ver- 
vaardigd, bevatten de teksten geen enkele mededeling, evenmin als over de identiteit van de auteur of van de typist-kopiïst. Ook de bibliotheek van het Tropeninstituut kon mij terzake niet inlichten. Toen ik daar naar de herkomst der stukken informeerde, verklaarde men niet over de middelen te beschikken om na te gaan, wanneer, van wie en op welke wijze de bibliotheek de typoscripten had verworven. Het catalogusfiche vermeldt, vermoedelijk op grond van een schatting door Voorhoeve, "circa 1925" als datering.

Uitgaande van de relatie met de S.M.-versie die indertijd in het bezit van Westenenk is geweest, heb ik de verbeteringen die met potlood op verscheidene plaatsen in de getypte tekst (vooral in die van TR 1 en -2) zijn aangebracht, qua handschrift vergeleken met de brieven van Westenenk, met name uit zijn Palembang-tijd, die in het Koninklijk Instituut voor Taal-, Land- en Volkenkunde bewaard worden. Het resultaat van dit onderzoek luidt, dat de potloodverbeteringen naar alle waarschijnlijkheid niet van Westenenk afkomstig zijn. Hiermee ontviel elk bewijs aan mijn aanvankelijke hypothese, dat de typoscripten in 1920 in opdracht van resident Westenenk te Palembang zouden zijn vervaardigd aan de hand van het model in Arabisch schrift, waarvan het bezit voor Westenenk wellicht slechts van tijdelijke aard had kunnen zijn.

Eén van die potloodaantekeningen echter bleek bij nadere beschouwing een indicatie voor de datering te kunnen bevatten. Op p. 30 van TR 1 vindt men bij de passage waarin het jaartal $\mathrm{H}$. 1236 wordt genoemd, ditzelfde jaartal nog eens met potlood in de marge geschreven, met erboven het jaartal 1331 en eronder het getal 95, zijnde het verschil tussen beide klaarblijkelijk van elkaar afgetrokken jaartallen. Dit zou kunnen betekenen dat degeen die de getypte tekst heeft nagezien en hier en daar gecorrigeerd, in de kantlijn even een rekensommetje heeft gemaakt om te zien hoe lang geleden de daar op p. 30 vermelde gebeurtenis wel had plaatsgevonden en zodoende onopzettelijk het jaar zou hebben vastgelegd waarin de potloodaantekening werd gesteld en vermoedelijk ook de typoscripten zelf zijn tot stand gekomen: H. 1331 ( $=$ A.D. $\left.1913 /{ }^{\prime} 12\right){ }^{89}$

Voor de datering van de oorspronkelijke tekst die aan de typoscripten van het Tropeninstituut ten grondslag ligt, geeft een mogelijke datering van deze laatsten overigens weinig houvast. Vaststaat immers dat de auteur over veel oudere bronnen moet hebben beschikt, die gelet op de overeenkomst tussen TR 1 en UBL 5 minstens tot het midden van de negentiende eeuw teruggaan. 


\section{ARA $1-6$}

\section{Handschriften - ARA}

Onder de in het Algemeen Rijksarchief te 's-Gravenhage bewaarde stukken uit de nalatenschap van Constantijn Johan Wolterbeek, de commandant van de Nederlandse expeditie tegen Palembang van 1819, bevinden zich zes originele brieven van Sultan Mahmud Badaruddin, die van hetzelfde ambtsstempel zijn voorzien als de brieven nrs 8, 9, 11 en 13 van UBL 10. Twee van de zes, namelijk de brieven van respectievelijk 25 en 27 Zulhijah 1234 (= 15 en 17 oktober 1819), zijn gericht aan Wolterbeek en Muntinghe, de toenmalige commissaris voor Palembang, samen; de overige vier brieven, die gedateerd zijn 4, 6, 20 Muharram en 20 Safar 1235 ( $=23,25$ oktober, 9 november en 8 december 1819), aan Wolterbeek alleen. Zij maken deel uit van de diplomatieke correspondentie die vóór en na de beslissende nederlaag van de Hollanders op 21 oktober 1819 tussen partijen is gevoerd. Van het Hollandse aandeel daarin zijn - eveneens in de "Verzameling Wolterbeek" bij het Algemeen Rijksarchief - de in het Nederlands gestelde concepten bewaard gebleven.

Deze briefwisseling heeft van Hollandse zijde ten doel de sultan aanvankelijk tot overgave en later tot het voeren van onderhandelingen te bewegen, terwijl de sultan er zich toe bepaalt de sommatie tot overgave te negeren en de verlangde onderhandelingen met vele vriendelijke woorden op de lange baan te schuiven. $\mathrm{Zij}$ vormt een aardige illustratie van de krachtsverhoudingen tussen partijen in die tijd. De sultansbrief van 9 november en Wolterbeeks antwoord daarop van 17 november werpen bovendien een helder licht op de - gespannen - verhouding tussen de sultan en Muntinghe en op de eveneens gespannen verhouding tussen Muntinghe en Wolterbeek.

Het papier dat voor deze brieven is gebruikt, is van Brits fabrikaat. Het papier van ARA 1, 2 en 5 is het produkt van Ruse \& Turners, ${ }^{90}$ dat van ARA 3 en 4 van C. Ansell ${ }^{91}$ en het papier van ARA 6 is van Gater. ${ }^{92}$ Dit blijkt uit de volgende watermerken:

ARA 1 : de naam Ruse \& Turners voluit met eronder het jaartal $1814 .^{93}$

ARA 2 en 5: de gekroonde Franse lelie met eronder de initialen $\mathrm{R} \& \mathrm{~T}^{94}$

ARA 3 en 4: als hoofdmerk het watermerk "Britannia" en als contramerk de naam van de fabrikant C. Ansell met eronder het jaartal $1812 .{ }^{95}$

ARA 6 : de naam Gater met eronder het jaartal 1812. 


\section{RUBRICERING EN SELECTIE}

$\mathrm{Nu}$ het beschikbare materiaal is geïnventariseerd, doet zich met het oog op onze doelstelling, te weten door publikatie van een aantal Maleise teksten zo mogelijk enig nader licht te werpen op de geschiedenis van Palembang tussen 1811 en 1825 , de behoefte gevoelen aan rubricering en selectie van dat materiaal. Hiertoe lijkt het gewenst:

a uit het materiaal datgene te elimineren wat als een duplicaat of transcriptie danwel als het Maleise equivalent van een Nederlandse tekst werd onderkend; en

b in hetgeen daarna overblijft onderscheidingen aan te brengen naar vorm en inhoud der teksten, waarbij de vraag, op welke periode uit de Palembangse geschiedenis een tekst betrekking heeft, het voor de uiteindelijke selectie doorslaggevende criterium vormt.

De handschriften die op de onder a genoemde gronden verder buiten beschouwing kunnen blijven, zijn:

- UBL $1 \mathrm{~b}$, zijnde een tengevolge van beschadiging incompleet en op enkele plaatsen onleesbaar duplicaat van UBL $1 \mathrm{a}$;

- UBL 7 a, zijnde een transcriptie van UBL 7;

- KI 6-7, bevattende de Maleise tekst van de in 1722 en 1775 tussen de sultan van Palembang en de Oost-Indische Compagnie gesloten contracten, welke voor de interpretatie van die contracten van geen betekenis bleek te zijn.

Ten aanzien van de overige gehele of gedeeltelijke dupliceringen die we bij onze inventarisatie konden constateren geldt dat eliminatie van één der lezingen van een bepaalde tekst niet verantwoord is, zodra die lezingen elkaar op enig punt blijken aan te vullen, te verduidelijken of te verbeteren. In evidente gevallen van twee of meer produkten van één en dezelfde traditie heb ik de verschillende lezingen echter wel als een eenheid aangeduid, zoals bijvoorbeeld MP 1-3/UBL 6-4, MP 4 a/-4 b, KI 12/-13/UBL 12. De genealogieën, waaraan duplicering in zekere zin inhaerent is, komen in dit opzicht vanzelf ter sprake bij de onderscheiding van het ons resterende materiaal in verschillende categorieën, welke thans aan de orde is.

In een monarchie, waarin de vorst zijn waardigheid immers ontleent aan zijn afstamming, is het belang van de genealogie van het vorstenhuis evident. Zolang het magisch-religieuze aspect van de vorstelijke waardigheid nog op de voorgrond staat, zal daarbij de genealogische 
band van de vorst met de mythische stamvader of de heros, of eventueel met de stichter van de godsdienst niet mogen ontbreken. Waar bovendien de geschiedschrijving zich nog voornamelijk met de geschiedenis van de vorsten bezighoudt, spreekt het vanzelf dat de dynastieke genealogie een integrerend onderdeel van de gehele historiografie uitmaakt. Het behoeft daarom geen verwondering te wekken dat binnen het kader van de Maleise historische literatuur de genealogie een voorname plaats inneemt en zelfs als de meest oorspronkelijke vorm van deze literatuur geldt.

In een sfeer waarin de genealogische benadering zozeer primair is, ligt het voor de hand bij de voorgenomen rubricering van het handschriftelijke materiaal allereerst het genealogische aspect tot maatstaf te nemen. Volgens dit criterium kan het materiaal worden ingedeeld in genealogieën enerzijds en andere geschiedbronnen anderzijds. Deze indeling is in zoverre arbitrair, dat zich aan weerszijden van de scheidslijn een overgangstype voordoet, dat qua opzet tot de ene categorie moet worden gerekend, maar waarin tevens elementen zijn verwerkt die tot de andere categorie behoren, zoals bijvoorbeeld het geval is enerzijds bij de van historisch-legendarische aantekeningen voorziene genealogieën van KI 8, KI 9 en UBL 2, anderzijds bij het met genealogieën doorspekte geschiedverhaal van KI 4. Deze overgangstypen kunnen bij de indeling gevoegelijk begrepen blijven onder de hoofdrubriek waartoe zij behoren, mits niet wordt verzuimd de andersoortige elementen bij een eventueel vergelijkend onderzoek binnen de andere hoofdrubriek te betrekken.

Naar formele kenmerken kunnen de genealogieën worden onderscheiden in stambomen en beschrijvende genealogieën, de overige geschiedbronnen in prozaverhalen, brieven en een gedicht in syacir-vorm. Binnen de groep prozaverhalen valt incidenteel het type van de kroniek te onderkennen, waarbij een objectieve weergave van de feiten en een nauwkeurige tijdsaanduiding worden nagestreefd, zoals bijvoorbeeld in KI 2 en KI 3, in UBL 7 en in de aan elkaar verwante teksten van UBL 5/MP 2 en TR 1. Daarnaast treft men hier en daar wel het eerder tot het type van de hikayat te rekenen verhaal aan, waarbij de grens tussen historisch feit en legende vervaagt en zowel de chronologie als de datering op het tweede plan staan of zelfs geheel veronachtzaamd worden, zoals het geval is bij de teksten van KI 1, KI 5 en UBL 3. Maar dit op zichzelf reeds niet altijd even scherpe onderscheid in wat wij met enige vrijheid als literair genre zouden kunnen aanduiden valt uiteindelijk toch in onvoldoende mate met de begrenzing van de betrokken 
handschriften als individuele eenheden samen om tot een verantwoorde en consequente tweedeling van de groep prozaverhalen te kunnen leiden.

Waar het om de behandeling van historisch materiaal gaat, praevaleert boven alle tot dusver gemaakte onderscheidingen de indeling der bronnen naar de periode van de geschiedenis die erin wordt beschreven. De hierbedoelde periodicering levert nieuwe scheidslijnen op die dwars door de andere grenzen heen lopen en zodoende weer nieuwe combinaties doen ontstaan. Is deze periodicering voor de achttiende- en negentiende-eeuwse geschiedenis vrij exact te geven, voor wat de oudere, deels legendarische geschiedverhalen en de genealogieën betreft zal met een meer globale indeling en begrenzing moeten worden volstaan. Het gaat bij deze periodicering, die immers uitsluitend grenzen in de tijd stelt, om een eerste grove indeling, waarbij we voorbijgaan aan verschillen in de breedte en in de diepte die samenhangen met de mate van volledigheid waarmee de gebeurtenissen worden beschreven of - bij genealogieën - de bloed- en aanverwanten worden opgenomen.

Zo zijn wij thans gekomen tot het volgende schematisch overzicht:

GENE A L O G I E EN

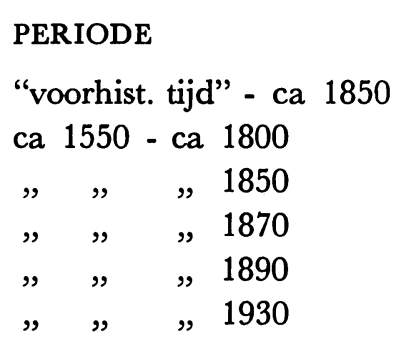

\section{STAMBOMEN}

KI 8

UBL 1 a

KI 11

KI 9

UBL 2
BESCHRIJVENDE GENEALOGIEEN

\author{
UBL 4/MP 3 \\ UBL 6/MP 1
}

KI 10

TR 2

Met uitzondering van KI 10 en UBL 4/MP 3 gaat aan alle genealogieën van het Palembangse vorstenhuis een genealogie van het legendarische voorgeslacht volgens Maleise, Sumatraanse of Javaanse tradities vooraf, die afwisselend teruggaat tot Adam, Alexander de Grote, Raja Sulan van Amdan Negara, Brawijaya van Majapait, de profeet Muhammad of diens kleinzoon Sayyidina Hussin. KI 8 bestaat, de vermelding van een aantal leden van het Palembangse vorstenhuis als voorvaders van de afschrijver-auteur daargelaten, zelfs uitsluitend uit dit soort niet specifiek-Palembangse genealogieën. 


\section{ANDERE GESGHIEDBRONNEN}

$\begin{array}{llll}\text { PERIODE } & \begin{array}{l}\text { PROZA- } \\ \text { VERHALEN }\end{array} & \text { BRIEVEN } & \text { GEDICHT } \\ \text { "voorhist. tijd" - ca } 1550 & \text { KI } 1 & & \\ \text { ca } 1715-\text { ca } 1725 & \text { KI } 5 & & \\ \text { ca } 1350-\text { ca } 1805 & \text { UBL } 3 & & \\ 1791-1808 & & \text { UBL } 10 & \\ \text { ca } 1550-1818 & \text { KI } 2 & & \\ 1804-1818 & \text { KI } 3 & & \\ 1812-1819 & \text { UBL } 9 & & \\ 1818-1819 & \text { UBL } 8 & & \\ 1819 & & \text { ARA } 1-6 & \text { MP } /-4 \mathrm{~b} \\ \text { ca } 1650-1820 & \text { KI } 12 /-13 / & & \\ 1821 & \text { UBL } 12 & & \\ \text { "voorhist. tijd" - } 1825 & \text { KI } 4 & & \\ \text { ca } 1720-1825 & \text { UBL } 7 & & \\ 1818-1825 & \text { UBL } 5 / \text { MP } 2 & \\ & \text { TR } 1 & \end{array}$

Gaan wij tenslotte over tot de uiteindelijke selectie van het materiaal met het oog op de voorgenomen publikatie van een aantal teksten die geheel of gedeeltelijk betrekking hebben op de periode 1811-1825 uit de Palembangse geschiedenis.

Wat dan in de eerste plaats de genealogieën betreft, wegens hun als het ware structurele eenzijdigheid lijken deze voor de kennis van de lokale geschiedenis overigens bijzonder waardevolle bronnen in het verband van ons onderwerp voor publikatie minder geschikt. De daarin vervatte gegevens zullen, voor zover ze betrekking hebben op personen die in de te publiceren teksten voorkomen, evenwel worden verwerkt in het register bij die teksten, achterin dit boek. Van de overige bronnen bevatten de brieven voor de kennis van de geschiedenis van Palembang te weinig bijzondere informatie om onder de te publiceren teksten te worden opgenomen. Voor wat de prozaverhalen aangaat ben ik bij de keuze van de teksten die bij uitstek voor publikatie in aanmerking komen allereerst uitgegaan van het criterium of het verhaal van de tekst zich geheel of althans grotendeels binnen het tijdvak 1811-1825 afspeelt, een criterium waaraan de enige beschikbare poëtische bijdrage in dit geheel, de syacir van MP $4 \mathrm{a} / 4 \mathrm{~b}$, volledig beantwoordt. Hoewel 
KI 3 eveneens aan het gestelde criterium voldoet, heb ik van publikatie van deze tekst afgezien. De tekst maakt deel uit van de als één geheel te beschouwen kroniek KI 1-3 en zou daarom beter in een integrale tekstuitgave van die kroniek passen. Bovendien is de tekst van KI 3 op zichzelf wel erg kort en bestaat er, zoals wij zagen, een Nederlandse bewerking van in het Tijdschrift voor Neêrland's Indië.

De teksten waarbij de beschrijving van de geschiedenis van Palembang geen hoofddoel is maar eerder als een bijprodukt beschouwd moet worden, zoals het geval is bij de kroniek van Banka (KI 12/-13/UBL 12) en bij het Sejarah Melayu/Raja Akil-verhaal van UBL 8, leken om die reden voor integrale publikatie in dit bestek minder geschikt.

Op grond van deze overwegingen heb ik mijn keuze tenslotte bepaald op de teksten van UBL 7, UBL 9, MP 4 a/4 b en TR 1 . Vanwege de talrijke jaartallen en andere chronologische gegevens betreffende het door ons gekozen tijdvak, die de laatste bladzijden van het eerste deel van KI 4 bevatten, heb ik gemeend in dit geval van de algemene regel, dat gedeeltelijke publikatie van een handschrift dient te worden vermeden, te mogen afwijken teneinde dit tekstgedeelte (p. 26, regel 16 p. 29), dat in kort bestek een overzicht geeft van de gehele periode, aan de zojuist genoemde integraal te publiceren teksten te laten voorafgaan. Ten aanzien van de keus van TR 1 past nog een nadere verklaring. De teksten van TR 1 en UBL 5/MP 2 vertonen, zoals reeds bij de beschrijving van deze handschriften werd opgemerkt, een zo grote overeenkomst, dat publikatie van beide teksten een weinig zinvolle duplicering zou opleveren. Hoewel TR 1 op een aantal punten historisch minder betrouwbaar blijkt te zijn dan UBL 5/MP 2, heb ik niettemin op grond van overwegingen van literaire vormgeving aan eerstgenoemde tekst de voorkeur gegeven. De werkelijk materiële verschillen van de lezing volgens UBL 5/MP 2 ten opzichte van die volgens TR 1 zullen ter vermijding van een overmaat aan voetnoten in een afzonderlijk overzicht achter de vertaling van de tekst worden opgenomen en aldus verantwoord. 


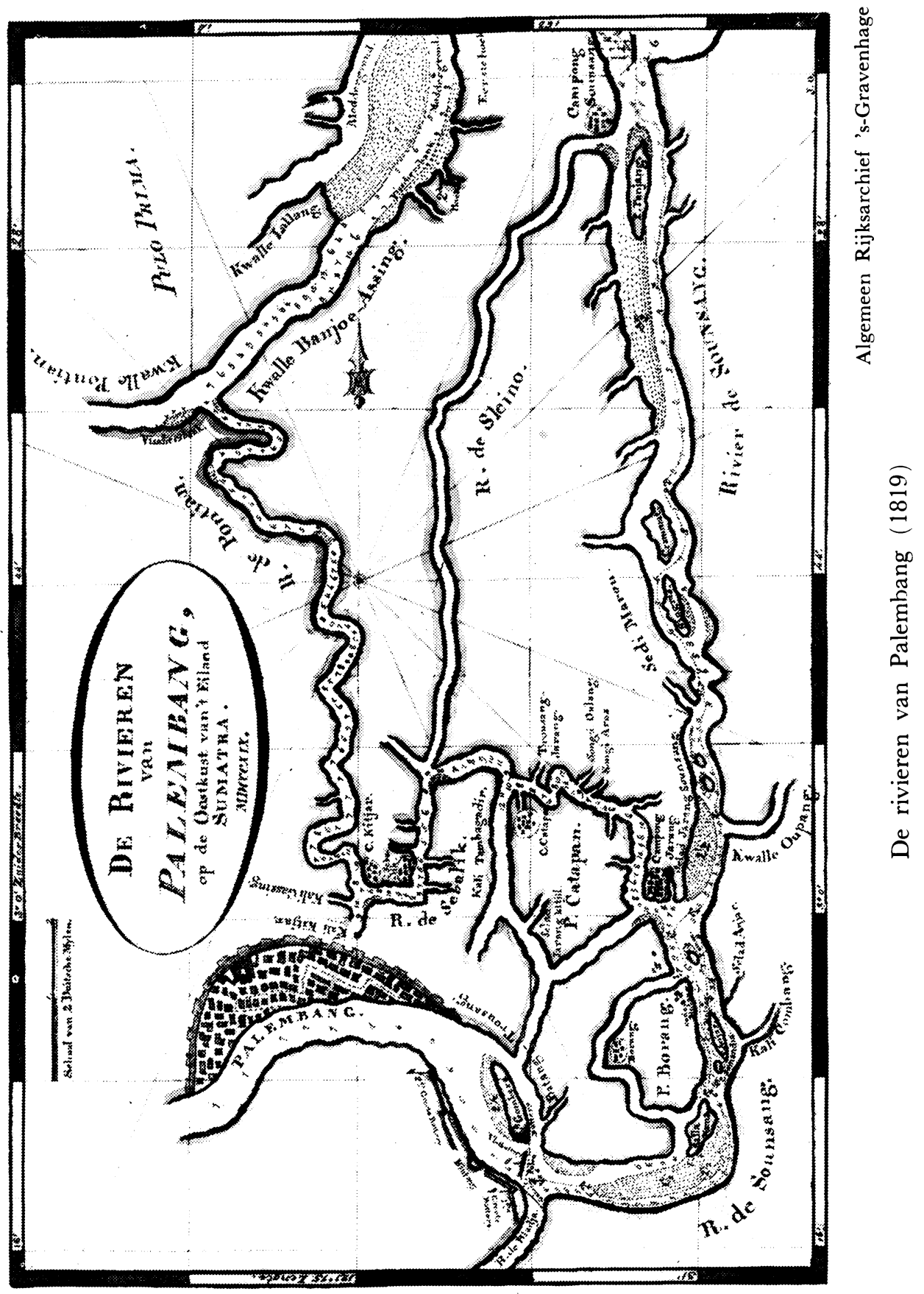




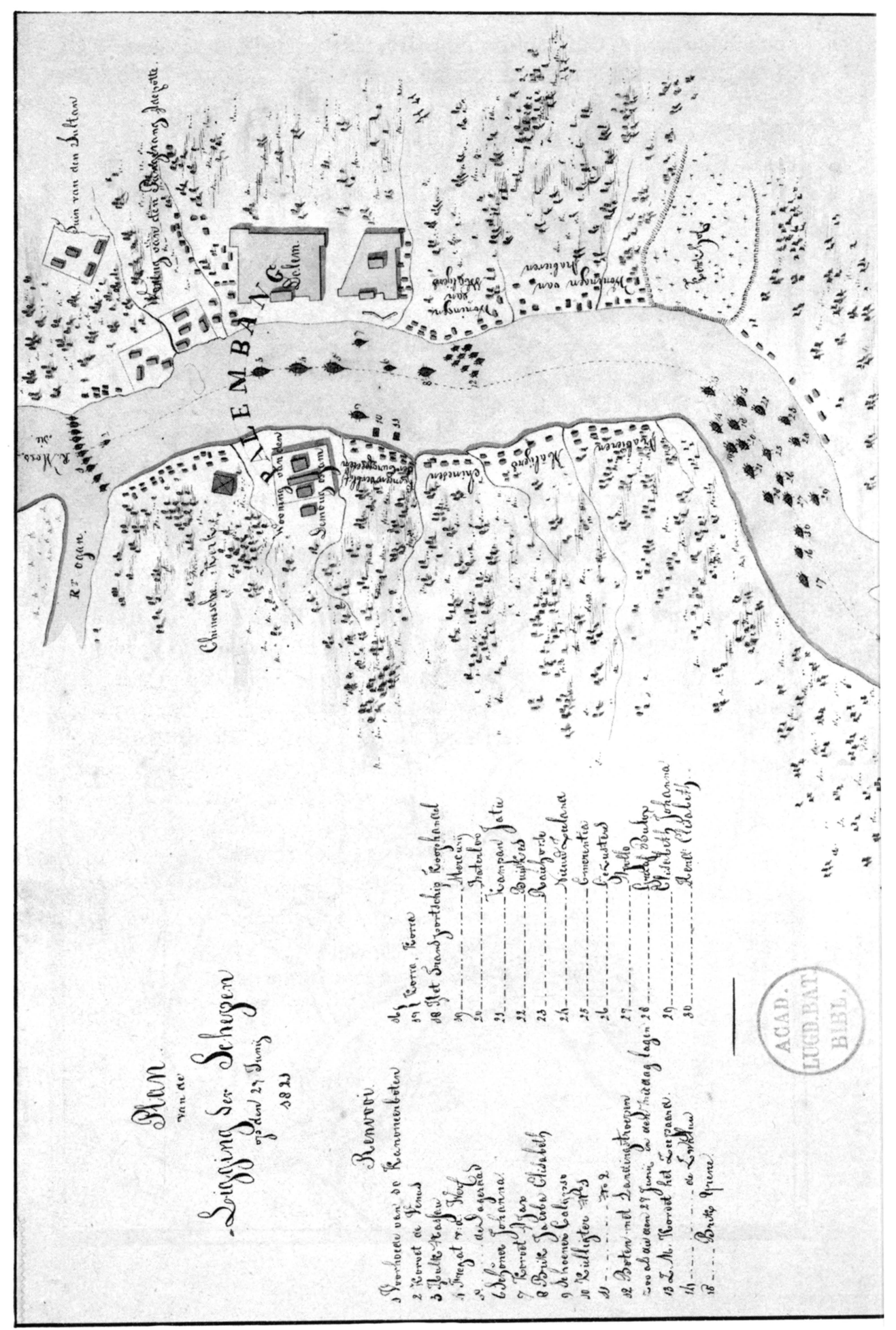




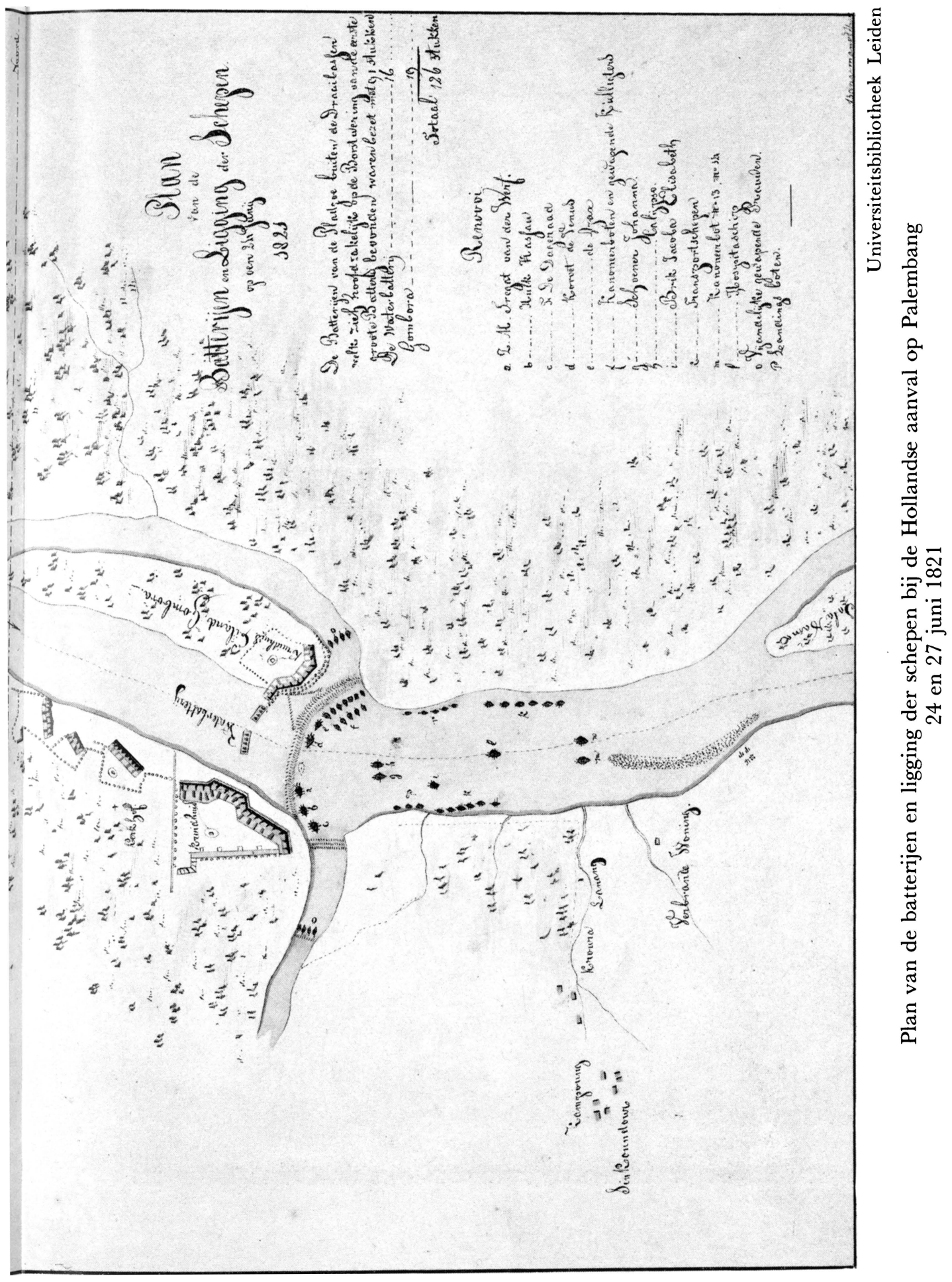




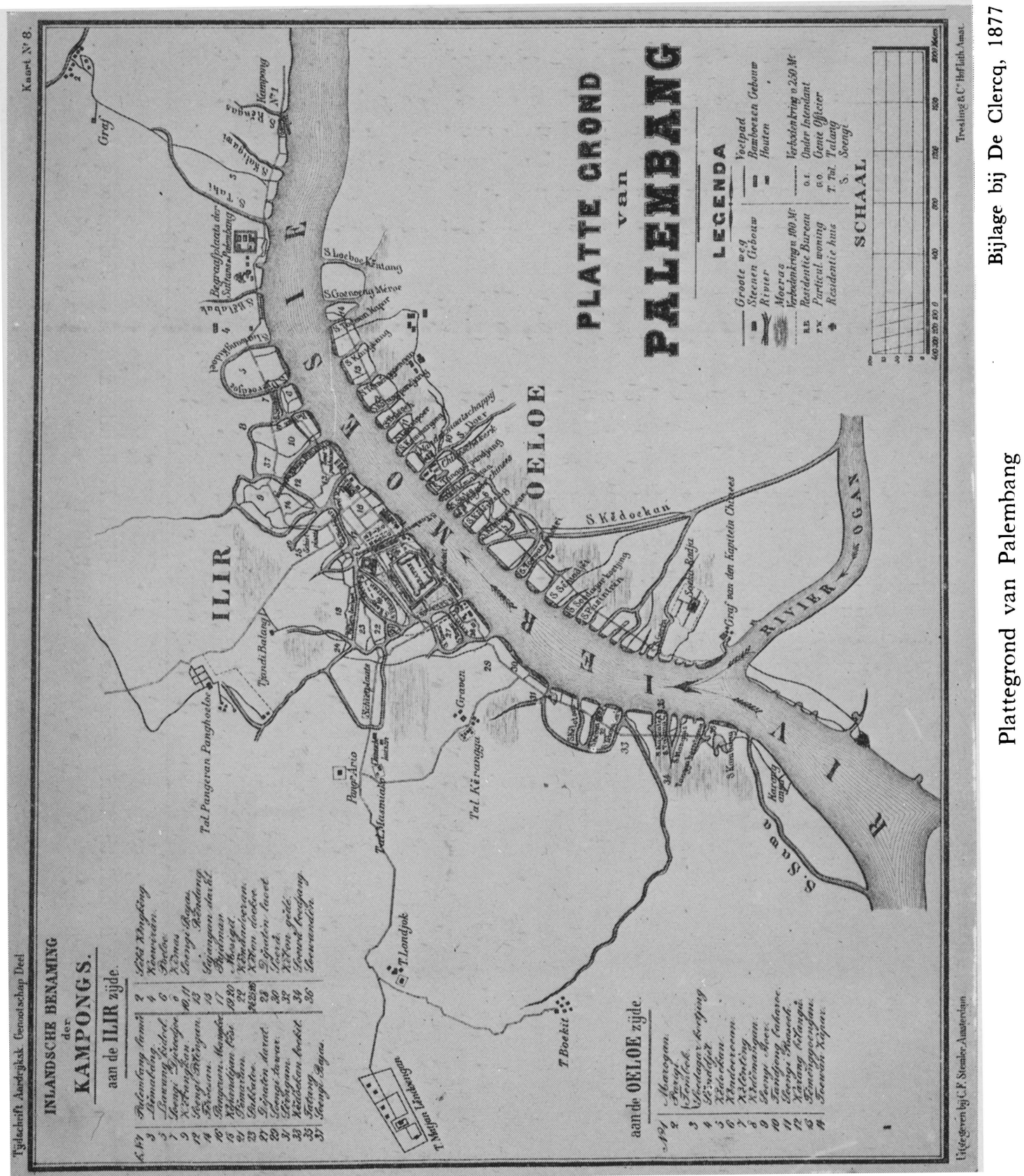




\section{DE TEKSTEN}

Hieronder volgt de tekst van de handschriften UBL 7, TR 1, UBL 9 en MP 4b, voorafgegaan door de tekst van het gedeelte p. 26, r. 16 - p. 29 van KI 4.

De onderverdeling van de teksten UBL 7, TR 1 en UBL 9 in hoofdstukken en paragrafen is van mij. De buiten de kantlijn geplaatste cijfers geven de paginering van het handschrift aan; het einde van een pagina van het handschrift wordt in de gedrukte tekst gemarkeerd door een /-teken.

Bij de transcriptie van de in Arabisch schrift geschreven teksten evenals bij de weergave van het in Latijns schrift gestelde typoscript TR 1 heb ik over het algemeen de regels van de op 17 augustus 1972 ingevoerde officiële spelling van het Indonesisch in acht genomen (zie Pedoman edjaan, 1972). Dit heeft tot gevolg gehad dat van elkaar onderscheiden fonemen, die in het (Maleis-) Arabische schrift door verschillende lettertekens worden weergegeven, in deze tekstuitgave door één letterteken van het Latijnse schrift gerepresenteerd kunnen zijn. Met andere woorden:

$$
\begin{aligned}
& \text { t kan staan voor: tā' en tầ'; } \\
& \text { s ” " , : thā', sīn en șād; } \\
& \text { h " " , : ḥā' en hā'; } \\
& \text { d „ , , , dāl en ḍād; } \\
& \text { z ” ” , : dhāl, zā' en zāa'; } \\
& 1 \text { ” , , : ḍãd, zâà en lām; } \\
& \text { g ” , , : ghain en ga; } \\
& \text { k „ , , : k kāa en kāf. }
\end{aligned}
$$

Waar de spelling van de tekst in voetnoten wordt verantwoord, zijn de fonemen wel onderscheiden. Hierbij is het transcriptiesysteem van de Encyclopaedia of Islam gevolgd. 
Op enkele punten is van de officiële Indonesische spelling afgeweken:

1. Voor hamzah en 'ain worden respectievelijk de tekens' en ' gebruikt, terwijl bij de transcriptie de volgende gedragslijn is gevolgd:

- de hamzah wordt in Arabische eigennamen als Baha'uddin en Dia'uddin weergegeven door '; hij wordt overigens, conform het Indonesische spellingsgebruik, intervocalisch verwaarloosd (laut, naik, perkataan) en aan het eind van een woord hetzij eveneens verwaarloosd (bawa, minta), hetzij weergegeven door $k$ (bésok, masuk);

- de cain wordt in middenpositie weergegeven door c (rac yat, syacir) en in beginpositie niet geschreven( alamat, arif).

2. Van de regel, dat $d i$ en $k e$ los van het daarop volgende woord worden geschreven (di ilir, di mana, ke sana, ke barat, enz.), ben ik afgeweken bij een aantal veel voorkomende combinaties die als voorzetsel of ook als werkwoord fungeren: diatas, dibawah, keluar (ook als werkwoord), kedalam, enz.

Eigenaardigheden in de spelling van een tekst zullen, voor zover ze frequent voorkomen, in een samenvattend overzicht en, voor zover ze slechts incidenteel voorkomen, in afzonderlijke noten bij de tekst verantwoord worden. Ten aanzien van bijzonderheden van morfologische aard wordt een analoge werkwijze gevolgd. 


\section{TEKST KI 4}

(p. 26, r. 16 - p. 29)

Adapun lamanya Sultan Muhammad Baha'uddin dalam kerajaan 28 tahun sebulan 17 hari. Maka iapun mati pada Hijrat 1218, pada hari Isnin, 22 Zulhijah, ${ }^{1}$ pukul 3; dan umurnya 70 tahun 4 bulan 8 hari.

Setelah itu maka diganti oléh anaknya bernama Susyuhunan Mahmud Badaruddin. Dan tatkala sampai 7 tahun 8 bulan 7 hari lamanya Susyuhunan Mahmud Badaruddin diatas kerajaan, maka dirubuhkan oléh Susyuhunan tempat Holanda di Sungai Aur serta kaptén dibunuh, sebab datang suruhan dengan surat Inggeris yang memukul Betawi mengajak Susyuhunan bersahabat. Tatkala Inggeris sudah mengalahkan Betawi, maka Inggeris menda ${ }^{c}$ wa Susyuhunan. Pada Hijrat 1227, malam Sabtu, 12 Rabicul-akhir, pada siangnya Susyuhunan mudik Rawas, sebab kapal Jénderal Galispi ${ }^{2}$ Inggeris masuk Palémbang, ${ }^{3}$ cuma antara 7 bulan 11 hari dari merubuhkan tempat Holanda di sungai.

Syahadan telah 20 hari Jénderal Galispi di Palémbang, lalu mengangkat Susuyunan Husin ${ }^{4}$ Dia'uddin, anak Sultan Muhammad Baha'uddin, jadi raja Palémbang bergelar Sultan, asalnya Pangéran Dipati. Kemudian dari itu setahun sebulan 14 hari maka $\mathrm{Su}<$ syu $>$ -

27 hunan Badaruddinpun kembali keatas / takhta kerajaan didalam negeri Palémbang, Hijrat 1228 pada hari Khamis, 17 Rajab. Dan kemudian daripada itu satu bulan maka masuk kedalam negeri Palémbang Kaptén Aliat, ${ }^{5}$ anak Raja Menggala, bangsa Inggeris, pada hari Sabtu, 17 $\mathrm{Sa}^{\mathrm{C}}{ }^{\mathrm{ban}}{ }^{6}{ }^{6} 5$ Hari di Palémbang, maka Kaptén Aliatpun menurunkan Susyuhunan Mahmud Badaruddin dan menaikkan Susyuhunan Husin Dia'uddin raja, dalam Hijrat 1228, hari Khamis, $22 \mathrm{Sa}^{c}$ ban.

Kemudian daripada itu 3 tahun 4 bulan 28 hari kembali Holanda duduk di muara Sungai Aur mengganti Inggeris, didalam Hijrat 1232, hari Selasa, 21 Muharram, pukul 7. Kemudian daripada itu satu tahun 6 bulan 8 hari maka masuk negeri Palémbang Idelir Ménténg, Holanda. Dan pada Hijrat 1233, malam Khamis, 30 Rajab, antara 23 hari maka Susyuhunan Mahmud Badaruddin kembali diatas takhta kerajaan, 
mupakat dengan Idelir Ménténg waktu hari Jumªt, $22 \mathrm{Sa}^{\mathrm{c} b a n}$.

Kemudian daripada itu 8 hari sampai Kaptén Saman, Inggeris, serta beberapa soldadu kepada negeri Palémbang, datangnya dari negeri Bengkulu akan pertolongan kepada Susyuhunan Husin Dia'uddin; sebab Susyuhunan Husin mengadukan hal kepada Inggeris. Dan adalah pada ketika itu Inggeris masih duduk di Bengkulu. Yaitu pada sehari Ramadan, hari Sabtu, maka Kaptén Saman itu disuruh oléh Idelir Ménténg keluar dari negeri Palémbang. Dan 5 bulan 10 hari kemudian daripada hari sampai Kaptén Saman maka Susyuhunan Husin Dia'uddin itu dikeluarkan oléh Idelir Ménténg dari bandar Palémbang, didalam Hijrat 1234, hari Isnin, 2 hari Safar, dibawa di Sianjur. ${ }^{7}$

Dan 6 bulan 17 hari kemudian daripada keluar Susyuhunan Husin Dia'uddin maka berperanglah Susyuhunan Mahmud Badaruddin dengan Idelir Ménténg, yaitu pada hari Sabtu, 19 Sacban. Dan 3 hari berperang, maka keluar semua Holanda pulang di Betawi, dalam Hijrat 1234, hari Selasa, $22 \mathrm{Sa}^{\mathrm{c} b a n}$. Dan antara sebulan 29 hari daripada keluar Holanda, maka Susyuhunan digelar Susyuhu<nan $>$ Mahmud Badaruddin dan <a>naknya digelar Sultan Ahmad Najamuddin. Tetapi kerajaan masih pada Susyuhunan; ia, Sultan Ahmad, dahulunya Pangéran Ratu.

Sebermula tersebut pula pada masa Sultan Husin Dia'uddin bergelar Susyuhunan dan anaknya Prabu Anom digelar Sultan Ahmad Najam28 uddin. Tatkala / masa Jénderal Betawi Baron Pandar Kapélan ${ }^{8}$ maka Susyuhunan Husin Dia'uddin berdua anaknya Sultan Ahmad Najamuddin disuruh oléh Jénderal masuk Palémbang. Dan kepada tahun 1236 Jénderal Dekok, ${ }^{9}$ Holanda, membawa Susyuhunan Husin Dia'uddin dengan Sultan Ahmad Najamuddin masuk Palémbang. Maka pada hari Isnin, 11 Ramadan berperanglah 3 kapal yang dua baris meriam sebelah, 2 kapal yang sebaris sebelah dan beberapa banyak kici dan langbut perang dengan bénténg Palémbang di tanjung Muara Plaju dan di Pulau Kembara. Maka pada malam Ahad, 24 Ramadan itu juga, pukul 4 mulai perang; hingga pukul 6, maka bénténg di Pulau Kembara terbakar. Dan kemudian daripada itu maka Susyuhunan Mahmud Badaruddin dan anaknya Sultan Ahmad Najamuddin dibawa ke luar dari Palémbang pergi di Jawa, dalam Hijrat 1236, hari Khamis, 5 Sawal. ${ }^{10}$ Dan pada masa itulah permulaan Kompeni Holanda duduk dalam kota batu Palémbang dan Susyuhunan Husin Dia'uddinpun duduk di Sua $<$ k $>$ bata dan anaknya Sultan Ahmad Najamuddin duduk di hampir tepi Sekanak, kanan masuk, hampir dengan kota. Maka Susyuhunan Husinpun tiadalah seperti kerajaan raja lagi. Sebermula 
yang membuat kota batu Palémbang yang baru itu Sultan Muhammad Baha'uddin, dalam Hijrat 1191.

Syahadan kembali ceritera antara 3 tahun 5 bulan 24 hari sesudah keluar Susyuhunan Mahmud Badaruddin maka Sultan Ahmad Najamuddin, anak Susyuhunan Husin Dia'uddin, mengamuk kota, tiada dapat sebab orang yang mendatangi mundur, hanya empat orang jua lalu mengamuk. Maka pada tahun 1240, malam Isnin, sehari bulan Rabicul-akhir; dan pada siang hari itu juga Sultan Ahmad Najamuddin lari ke uluan Palémbang. Dan pada malam Selasa itu juga Susyuhunan Husin Dia'uddin dikeluarkan dari negeri Palémbang oléh Résidént Rinis, ${ }^{11}$ Holanda. Dan pada masa itulah permulaan tiada lagi sultan didalam negeri Palémbang. Dan 3 bulan 3 hari kemudian daripada hari keluar Susyuhunan Husin Dia'uddin, maka Susyuhunan Husin Dia'uddin matilah di negeri Betawi, pada Hijrat 1240, kepada hari 4 Rajab, hari Isnin, pukul 4; umurnya 56 tahun 9 bulan 3 hari. /

29 Syahadan pada tahun 1241 Sultan Ahmad Najamuddin, anak Susyuhunan Husin Dia'uddin, tertangkap dari uluan, lantas dibuang di Menado. Maka antara 19 tahun 10 bulan 17 hari maka Sultan Ahmad Najamuddin bin Susyuhunan Husin Dia'uddin mati di negeri Menado, dalam Hijrat 1260 dan 10 Jumadil-awal; jumblah ${ }^{12}$ umurnya 49 tahun 3 bulan 7 hari.

Adapun Susyuhunan Mahmud Badaruddin di Ternati ${ }^{13}$ mati dalam Hijrat 1269, pada hari Jumcat, 14 bulan Safar, pukul 6 pagi; umurnya 87 tahun 7 bulan 13 hari 7 jam. Maka adalah antara mati Susyuhunan Husin Dia'uddin dengan mati Susyuhunan Mahmud Badaruddin 28 tahun 7 bulan 9 hari 12 jam. Dan dari Susyuhunan Mahmud Badaruddin keluar dari Palémbang hingga hari matinya jadi 32 tahun 4 bulan 10 hari. Kuburnya di Ternati.

Maka antara 8 tahun 4 bulan 16 hari 21 jam dengan Susyuhunan Mahmud Badaruddin maka mati Sultan Ahmad Najamuddin didalam negeri Ternati, dalam Hijrat 1277, malam Ahad, 2 hari bulan Rajab, pukul 3. Dan umurnya 71 tahun 2 bulan 16 hari 21 jam adanya. 
管

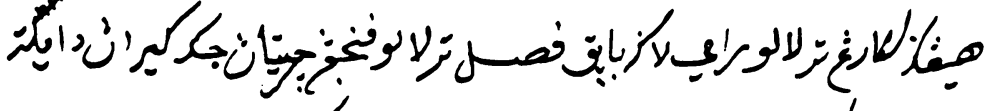

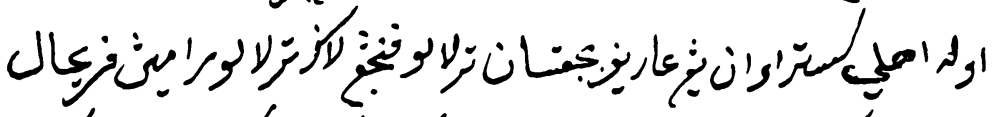

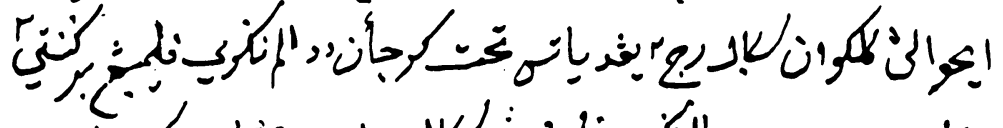

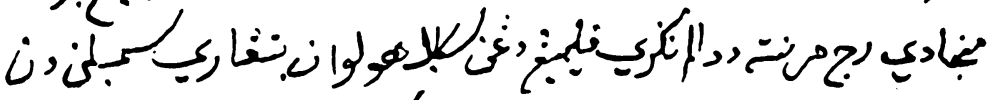

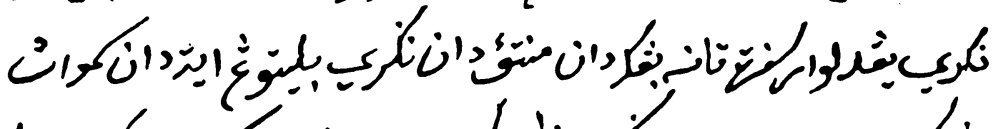

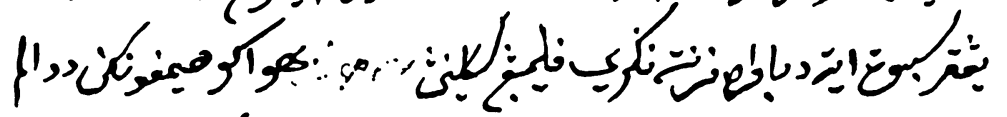

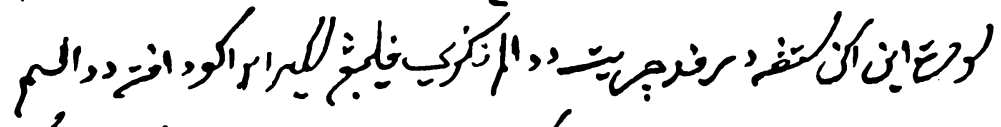

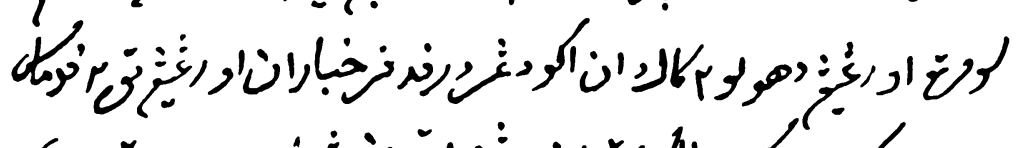

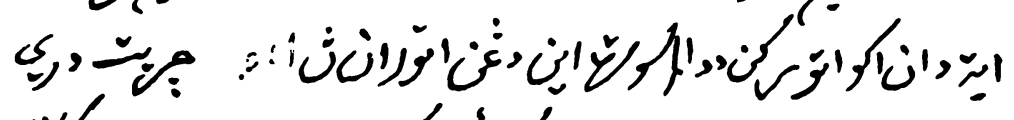

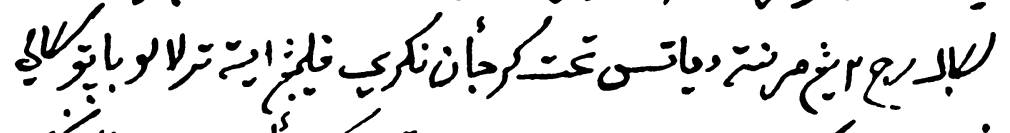

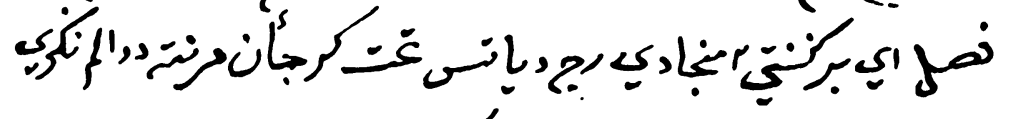

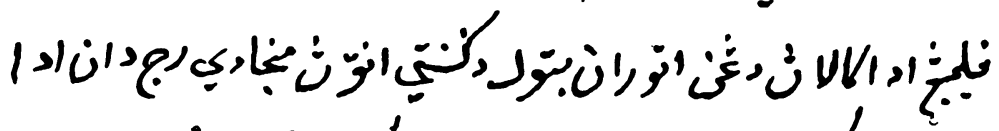

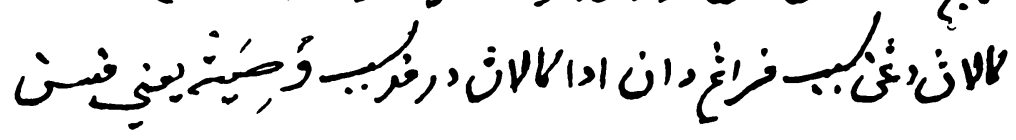

UBL 7, eerste pagina 


\section{TEKST UBL 7}

In deze tekst doen zich ten aanzien van de spelling de volgende bijzonderheden voor:

1. Bij woorden die eindigen op - $a$ wordt de open slotsyllabe in de regel afgesloten met een $h$ : mudah, tuah, bendérah, adindah.

2. In eigennamen die eindigen op -diraja, zoals bijvoorbeeld Kramadiraja, wordt dit naamdeel steeds -diratja gespeld.

3. Tutup en (perahu) top worden consequent gespeld met $b$ in plaats van met $p$ op het eind: tutub, (perahu) tob.

4. Cianjur en cuaca worden steeds gespeld Sinjur en suaca.

5. Takhta en tarikh worden steeds gespeld tahta en tarih.

6. Naast besar en pasirah komen besyar en pasyirah voor.

7. Said wordt afwisselend met en zonder tashdīd op de $y \vec{a}$ ' geschreven.

8. Hujan wordt gespeld ujan.

Ten aanzien van woordvorm en woordkeus doen zich de volgende bijzonderheden voor:

1. Naast de gebruikelijke $m e$-vormen worden op ruime schaal genasaleerde werkwoordsvormen zonder het praefix $m e$ - aangetroffen: merintah, masang, mukul, megang, meriksa, nerima, ngeluarkan, ngimpunkan, nyebelah, nyikap.

2. Het gebruik van telah en sudah voor setelah en sesudah, van menengar voor mendengar en van mendari voor dari (dit laatste ook in MP 4a). 
1.

1 1.1. Alkissah maka tersebut perkataan cerita dari negeri Palémbang pada zaman dahulu hingga sekarang. Terlalu ramai lagi banyak fasal, terlalu panjang ceritanya, jika kiranya diikat oléh ahli sasterawan yang arif bijaksana. Terlalu panjang lagi terlalu ramainya perihal ihwalnya kelakuan segala raja-raja yang diatas takhta kerajaan didalam negeri Palémbang berganti-ganti menjadi raja merintah didalam negeri Palémbang, dengan segala huluan Batangari Sembilan dan negeri yang di luar seperti tanah Bangka dan Mentok dan negeri Belitung itu; dan semuanya yang tersebut itu dibawah perintah negeri Palémbang sekaliannya.

Sebermula bahwa aku himpunkan didalam surat ini akan setengah daripada cerita didalam negeri Palémbang, sekira-kira aku dapat didalam surat orang yang dahulu-dahulu kala dan aku dengar daripada perkhabaran orang yang tua-tua pada masa itu; dan aku aturkan didalam surat ini dengan aturannya.

1.2. Adapun cerita dari segala raja-raja yang merintah diatas takhta kerajaan negeri Palémbang itu, terlalu banyak sekali fasal ia bergantiganti menjadi raja diatas takhta kerajaan merintah didalam negeri Palémbang. Adakalanya dengan aturan betul diganti anaknya menjadi raja dan adakalanya dengan sebab perang dan adakalanya daripada

2 sebab wasiat, ya ${ }^{\complement}$ ni pesan. / Tatkala masanya raja lagi hidup, berwasiat kepada sekalian punggawa menterinya dan orang besar-besar sekalian dengan sumpah: "Jikalau aku mati, sianu yang akan mengganti aku; tiada aku sukai anakku mengganti akan menjadi raja." Demikianlah yang dikerjakan oléh segala punggawa menteri dan sekalian orang didalam negeri Palémbang sepertimana yang wasiat itu juga. Dan adakalanya dengan sebab berperang dengan orang putih, yaitu Holanda. Dan apabila alah daripada perang itu, Raja Palémbang undur di hulu, tiada lagi mau ilir di Palémbang, menyuruh saudaranya menjadi ganti jadi raja diatas takhta kerajaan didalam negeri Palémbang menahan bicara orang putih.

Syahdan terlalu banyak fasal perkaranya raja-raja didalam negeri Palémbang; jika disurat, terlalu panjang ceritanya berperang dan berdamai dengan orang putih, bukan satu kali zaman dahulu-dahulu.

2.1. Sebermula maka adalah yang diceritakan ini darij)ada zaman 
perdamaian Palémbang dengan Holanda; yang menjadi aman sentosa negeri Palémbang dimulai daripada zaman Seri Paduka Sultan Mahmud Badaruddin yang kuburnya di Lemabang yang di kubah Kawah Terkurap itu. Maka disebut orang negeri Palémbang namanya Sultan Lemabang, sebab Sultan Mahmud Badaruddin itulah yang memulai 3 membuat / kota dan kubah perkuburan di Lemabang itu. Hingga sekarang segala raja-raja yang mati didalam negeri Palémbang ditanam di Lemabang. Adapun asalnya Sultan Mahmud Badaruddin itu bernama Pangéran Jayawikrama.

Beberapa banyak fasal dan sebab kerananya maka ia itu dapat pikiran disertai oléh segala punggawa menteri didalam negeri Palémbang mupakat bicara dengan Holanda menjatuhkan kerajaan dia punya saudara yang tua itu dariatas kerajaan negeri Palémbang, bernama Sultan Muhammad Alamuddin yang disebut orang Palémbang sekarang bernama Sultan Anom yang kuburnya di Kebun Gedé itu. Dan adalah sebabnya maka dijatuhkan kerajaannya itu kerana dia punya anak yang paling tua sekali, bernama Pangéran Dipati, yang bakal ganti Sultan Anom itu menjadi raja didalam negeri Palémbang maksudnya. Maka Pangéran Dipati itulah yang banyak bicaranya yang tiada baik didalam negeri Palémbang dengan pangkat orang yang besar-besar didalam negeri Palémbang dan perintahnya kepada sekalian $\mathrm{ra}^{c}$ yat negeri. Maka segala racyat dan punggawa menteripun mupakatlah dengan Pangéran Jayawikrama, adinda Sultan Anom itu. Syahdan mupakatan semuanya itu akan mencari yang aman sentosanya didalam

4 negeri Palémbang, supaya / kesenangan racyat negeri dan orang kecil-kecil dapat kehidupan dengan sentosa aman didalam negeri Palémbang dengan segala jajahan diluar negeri dan pucukan Batangari Sembilan di hulu negeri sekaliannya.

2.2. Sebermula telah ketahuanlah kepada Sultan Anom itu punggawa menteri negeri Palémbang banyak mupakat kepada adindanya Pangéran Jayawikrama itu, maka Sultan Anom dengan anaknya bernama Pangéran Dipati itu akan mencari daya hendak membunuh Pangéran Jayawikrama itu, tiada nampak padahal rupanya itu baik. Dan beberapa kali Pangéran Jayawikrama itu diamuk orang, malam dan tiada ketahuan orang yang mengamuk itu. Dan adakalanya dibedil orang, fajar di tangganya. Maka Pangéran Jayapun jatuh di air, tiada luka itu, tangga putus dimakan peluru itu. Maka telah berapa lamanya demikian itu Pangéran Jayawikrama berjaga-jaga didalam kampungnya yang nama Kadipan itu dengan segala racyatnya dan $<$ tiada $>$ lah 
lagi pergi mengadap kakandanya Sultan Anom itu serta berjaga keras didalam kampungnya sendiri, siang malam tiada léna. Dan apabila $\mathrm{ra}^{c}$ yat dari sebelah Kadipan itu kedapatan di jalan, dibunuh oléh rac ${ }^{c} y a t$ Pangéran Dipati dan racyat Sultan Anom.

Syahdan berapa lamanya rusuh didalam negeri Palémbang itu. /

5 Malam-malam orang berbunuh-bunuhan sama senegeri, tiada boléh léna. Dan makananpun terlalu mahal, sebab dagang dari laut tiada datang dan orang dari hulupun takut milir. Dan terlalu susah pada masa itu didalam negeri Palémbang; dan di hulu negeri dan di ilir negeripun terlalu banyaklah orang samun-menyamun.

2.3. Sebermula pada masa itulah Pangéran Jayawikrama utusan ke Betawi dengan bersembunyi minta tolongan; dan utusan Pangéran Jayawikrama itu tiadalah ketahuan kepada Sultan Anom. Dan daripada sebab Sultan Anom terlalu keras jaganya kepada orang Kadipan - kalau bertemu, disuruh bunuh -, maka dengan takdir Allah subhanahu wa tacala juga yang akan menjadi akan hambanya maka tiba-tiba utusan Pangéran Jayawikrama itu sampailah ke Betawi dengan selamatnya serta membuat kontrak antara Palémbang dengan Holanda. Kalau Kompeni tolong menjatuhkan kerajaan Sultan Anom itu dariatas takhta kerajaan negeri Palémbang itu dan Pangéran Jayawikrama sanggup menjadi raja serta mengamankan antara Palémbang dengan Kompeni.

Maka utusan itupun membuatlah kontrak perjanjian selama-lamanya antara Palémbang dengan Kompeni. Dan perjanjian:

Mau bayar satu kali itulah empatpuluh laksa / ringgit dengan budak laki-laki empatpuluh dan budak perempuan empatpuluh orang. Dan Pangéran Jayawikrama jika sudah menjadi raja didalam negeri dan apa-apa peruntungan didalam negeri Palémbang melainkan jual pada Kompeni, seperti gading dan cula dan sahang, semuanya tiada dijual tempat lain. Dan semua yang tersebut itu kalau orang negeri jual pada lain orang, rampas.

Dan lagi akan membuat parit timah di tanah Bangka: pada tiap-tiap tahun berapa yang dapat timah dijual kepada Kompeni dengan harga delapan ringgit dalam seratus ${ }^{1}$ kati dan sekali-kali tiada boléh jual kepada orang lain. Dan kalau ada periai Palémbang berjual kepada orang lain, dirampas dibuang oléh Sultan Palémbang; dan jikalau ada orang kecil-kecil kedapatan ia berjual timah kepada lain bangsa, dirampas daripada Kompeni dibunuh oléh Sultan Palémbang. 
Dan lagi Kompeni boléh duduk membuat loji di Palémbang, di ulu muara Sungai Aur, akan tetapi kota bambu. Dan pasang bendéra boléh kalau hari Minggu, lain hari daripada hari Minggu tiada boléh.

Dan lagi Palémbang jangan perahu perang masuk, tiada boléh. Dan Kompeni jika sudah duduk di Palémbang: jikalau hendak ia pergi di Palémbang bermain-main ke hulu negeri, beritahu kepada menteri Palémbang. Jikalau bermain-main / berjalan atawa berperahu ke hulu negeri tiada memberitahu kepada menteri yang juluk temenggung kertanegara itu dibunuh orang jahatjahat, tiada suatu bicaranya. Dan jikalau berjalan atawa berperahu ke hilir negeri, tiada suatu apa larangan.

Dan lagi tiap-tiap tahun utusan menteri dari Palémbang dengan perahu kici dan pergat bermuat timah itu dinaikkan di Pulau Underus di laut Betawi. Dan apabila timah sudah diterima semuanya, dibayarlah harganya kepada utusan, serta surat Sultan Palémbang diarak. Dan lamanya utusan menteri dari Palémbang itu tiga bulan Kompeni tanggung makan; dan jikalau lebih dari tiga bulan, makan sendiri. Dan jikalau utusan Palémbang pulang, mesti membawa surat Jénderal Betawi. Sampai di Palémbang, diarak dengan Kompeni yang tinggal di Palémbang dengan segala $\mathrm{ra}^{\mathrm{c} y a t}$ negeri Palémbang, dengan masang meriam dan senapang terlalu ramainya. Dan surat dari Betawi itu dibaca dengan terang di hadap Raja Palémbang dan segala < racyat> negeri, dengan beberapa terima kiriman dari Betawi. Dan aturan itulah yang datang kepada akhirnya di Palémbang, selagi ada loji Holanda di Palémbang.

Sebermula setelah sudah utusan Pangéran Jayawikrama itu membuat 8 kontrak perjanjian antara Palémbang dengan Holanda, maka / utusan Pangéran Jayawikrama itupun <kembali di $>$ Palémbang, ${ }^{2}$ tiada ketahuan kepada Anom. Telah utusan itu datang kepada Pangéran Jayawikrama, maka Pangéran Jaywikramapun terlalu suka dengan sekalian punggawa menteri yang mupakat dengan dia itu, sebab hasil bicara dan mupakat antara dengan Kompeni selama-lamanya. Maka Pangéran Jayawikramapun berkemaslah obat dan peluru didalam kampungnya yang bernama Kadipan itu.

2.4. Syahdan telah berapa lama antaranya itu, maka masuklah komisaris dengan kapal perang dari Betawi. Sampai masuk Palémbang, lalu 
kepada Sultan Anom, tiada perdulikan Pangéran Jayawikrama. Telah datang pada suatu hari diterima oléh Sultan di pemarakan, terlalu ramainya mengarak surat dari Betawi itu dengan punggawa menteri dan segala $\mathrm{ra}^{c}$ yat negeri dan orang besar-besar didalam negeri Palémbang, semuanya berhimpun kepada pemarakan Sultan Anom itu. Terlalu ramainya makan dan minum, masang meriam dan senapang, kerana komisaris itu akan mendamaikan antara Sultan Anom dengan saudaranya Pangéran Jayawikrama. Setelah selesai bicaranya, maka komisaris-

9 pun berkata kepada Sultan Anom / ini perkara telah selesai, dia mau pulang di Betawi, hendak memberi selamat di negeri mau pasang meriam di kapal dua hari, serta pésta. Maka jawab Sultan Anom: "Baiklah". Maka komisarispun turunlah pulang di kapal.

Telah berapa hari lamanya, maka suatu hari dari kapal perang itupun masang meriam, serta péstanya ${ }^{3}$ rupanya. Syahdan kepada hari yang kedua itu kapal itupun masang meriam dengan pelurunya memasang kota keraton Palémbang, yaitu tempat pedalaman sultan itu, serta Pangéran Jayawikramapun memasang meriam dan léla dari Kadipan itu dengan tempik dan sorak segala racyatnya. Setelah kota keraton tempat Sultan Anom itu dipasang dari kapal perang serta dipasang Pangéran Jaya dari Kadipan itu tiada lagi sempat membalas sebab terkejut, maka segala racyat Sultan Anompun habislah lari bercerai-berai, tiada ketahuan lagi ke mana-mana ia melepaskan dirinya serta membawa anak-isterinya. Maka Sultan Anompun tinggallah didalam kota keraton dengan sekalian anak-isterinya, dengan beberapa punggawa menterinya yang telah bersetia dengan dia. Telah demikian,

10 kepada hari itu juga Sultan Anompun tiada tahan, lalu berlari / keluar kota dengan sekalian anak dan isterinya, dengan sekalian punggawa menteri racyat semuanya yang lagi adalah setia. Maka Sultan Anompun bertahan di ulu kota bernama Kampung Candi, membuat bénténg mengimpunkan racyat di situ terlalu teguh.

Sebermula akan Pangéran Jayawikramapun, setelah Sultan Anom itu keluar daridalam kota keraton itu, maka Pangéran Jayawikrama itupun sigeralah menyuruh punggawa menteri dan racyat masuk kedalam kota keraton Palémbang itu dengan alat senjata, semuanyapun sedia dengan meriam dan léla, senapang, pemuras dan tombak, pedang, keris, tiada terkata lagi. Dan takut kalau direbut oléh Sultan itu pula; sebab kapal perang komisarispun sudah milir, kerana didalam perjanjian: apabila Sultan itu sudah lari keluar daridalam kota keraton, Kompeni tidak tolong lagi. 
2.5. Maka telah komisaris itupun sudah pulang di Betawi, maka tinggallah Pangéran Jayawikrama itu dengan Sultan Anom berperang, sama-sama orang Palémbang. Dan Pangéran Jayawikrama itu berteguh didalam kota keraton dan setengah racyatnya dalam kampungnya di Kadipan berbénténg. Dan Sultan Anompun berteguh didalam bénténg11 nya di Kampung Candi. / Terlalu besar lagi banyak kepadanya punggawa menteri dan racyat Palémbangpun berhimpun kepadanya, kerana Sultan Anom itu Raja Palémbang lagi banyak hartanya dan alat senjatanya. Jadi orang Palémbangpun banyaklah turut lagi kepada Sultan Anom itu; istiméwa pula kepada sekalian orang fakir dan miskin, sebab turut makan. Kerana negeri lagi rusuh, makananpun terlalu mahal. Adapun akan Pangéran Jaya $<w i>$ krama itupun tiada berapa banyak racyatnya; akan tetapi banyak pahlawan mendari laut: bangsa orang Timur dan Alimdana ${ }^{4}$ dan orang Bugis dan Burnai dan Johor, semuanya itu biasa tempur berperang.

Maka terlalu ramainya antara Pangéran Jayawikrama dengan Sultan, saudaranya Sultan Anom itu, tiada terkira-kira lagi. Akan mengatur cerita kissahnya itu terlalu banyak lagi panjang, berbagai-bagai rupa orang perang serang-menyerang dan datang-mendatang, rampokmerampok. Dan berapa banyak periai dan menteri dan $\mathrm{ra}^{\mathrm{c}}$ yat antara kedua belah itu matinya, sama-sama anak Palémbang. Tiada boléh bertemu antara ${ }^{5}$ orang Kadipan dengan racyat Kampung Candi itu: berapa kali bertemu, beramuk beberapa banyak mati di jalan, tiada

12 berketahuan yang mati dengan membunuh. / Istiméwa pula pada malam hari itu angkatan besar dari kampung Kadipan, beberapa banyak punggawa menteri dan racyat, melanggar akan merebut bénténg Sultan Anom ${ }^{6}$ di Kampung Candi. Maka dari sebelah Sultan Anompun beberapa banyak punggawa menteri dan racyatpun keluar dari Kampung Candi dengan alat senjatanya, jikalau malam hari melanggar akan merebut kota keraton besar dan akan merebut bénténg di kampung Kadipan. Dan apabila bertemu di jalan kedua belah angkatan itu, maka beramuklah semalam-malam itu hingga siang, maka berhenti. Maka beberapa punggawa menteri dan $\mathrm{ra}^{\mathrm{c}}$ yat yang mati kedua belah itu. Dan apabila pagi-pagi hari, datanglah sanak kedua belah itu yang tiada mengikut berperang itu, semuanya mengambil mayit orang yang mati-mati itu dan orang yang luka-luka yang sangat tiada lagi kuawa berjalan. Demikianlah negeri Palémbang pada masa itu rusuh.

2.6. Telah berapa lamanya berperang itu, maka Sultan Anom itupun undurlah dari negeri Palémbang dengan anak-isterinya dan punggawa 
menterinya; semuanya itu turun ke perahu beberapa banyaknya membawa alat senjata, lalu mudik ke hulu masuk Batangari Rawas. Telah

13 sampai ke hulu Rawas, maka Sultan Anom itupun lari / berjalan darat dengan sekalian balatenteranya semuanya, lalu nyebelah ke negeri Jambi. Maka telah datang di negeri Jambi, diterimalah oléh Sultan di Jambi, sekaliannya itu dimasukkannya kedalam negeri Jambi dan Sultan dengan anak-isterinya itu dimasukkan oléh Sultan Jambi itu kedalam kota keraton bersama dengan dia. Maka telah berapa lamanya Sultan itu duduk di negeri Jambi mencari daya hendak merebut negeri Palémbang, maka Sultan Jambi itupun beristeri anak Sultan Anom, bernama Dénayu Benderang. Maka tetaplah Sultan Anom itu duduk di negeri Jambi serta bermenantukan Sultan Jambi.

2.7. Alkissah maka tersebutlah pula perkataan negeri Palémbang. Apabila Sultan Anom sudah berlari di Jambi itu, maka beberapa orangorang dan gundik Sultan Anom yang tinggal di Palémbang di negeri Palémbang semuanya dipeliharalah oléh Pangéran Jayawikrama. Maka telah selesailah negeri Palémbang, segala $\mathrm{ra}^{c}$ yat negeri yang lari-lari itu semuanya sudah pulang di negeri seperti lama juga.

Sebermula telah demikian, maka mupakatlah sekalian punggawa menteri dan orang besar-besar didalam negeri Palémbang dengan segala racyat; dan pasirah pucukan, perwatin segala marga huluan milir ke Palémbang membawa persembahan dan timbang pesalin. Dan semuanya 14 dari negeri sampai kepada / huluan Batangari Sembilan sekaliannya mupakat dengan sukahatinya hendak mendirikan Pangéran Jayawikrama itu sultan merintahkan negeri Palémbang dengan segala jajahan semuanya. Syahdan maka pada waktu itulah berdirinya Paduka Pangéran Jayawikrama menjadi raja di negeri Palémbang bergelar nama Seri Paduka Sultan Mahmud Badaruddin, duduklah diatas kerajaan negeri Palémbang; dan puteranya yang tua sekali digelar nama Pangéran Ratu. Maka Sultan Mahmud Badaruddin itu membuat menteri punggawa dan lurah, sepertimana adat raja didalam negeri Palémbang. Maka tetaplah Sultan Mahmud Badaruddin itu diatas kerajaan negeri Palémbang.

2.8. Maka masuklah Kompeni dari Betawi membuat loji. Diberi tempat di ulu muara Sungai Aur itu berkota bambu; dan besar kota Kompeni di situ semuanya sudah didalam kontrak. Maka telah sempurnalah negeri Palémbang. Adapun tatkala Sultan Mahmud Badaruddin menjadi raja itu: kepada tarikh seribu seratus tigapuluh enam tahun, 
kepada tujuhlikur hari bulan Jumadil-akhir, kepada hari Khamis, pukul satu. Maka tetaplah negeri Palémbang antara dengan Holanda berkasih-kasihan. Pada tiap-tiap tahun utusan Palémbang pergi di Betawi mengantarkan timah dari tanah Bangka; berapa banyak Kompeni beli dengan harga delapan ringgit satu pikulnya. Dan tiada boléh / 15 orang-orang negeri Palémbang berjual timah kepada yang lain daripada Kompeni; kalau ketahuan, dibunuh oléh Sultan Palémbang serta dirampas. Beberapa yang kedapatan, orang Mentok dan orang Palémbang, dibunuh oléh Sultan Palémbang, sebab kerana berjual timah kepada Inggeris.

2.9. Sebermula ada sepuluh tahun lamanya Sultan Mahmud Badaruddin menjadi raja didalam negeri Palémbang itu, maka puteranya Pangéran Ratu mati diamuk oléh orang Bali empatpuluh orang, yaitu budak sendiri, sebab terkena cucuk rasan dari Sultan Anom dari Jambi. Maka semuanya orang Bali itu semuanya dibunuh. Maka adalah Paduka Pangéran Ratu diamuk Bali itu kepada tarikh seribu seratus empatpuluh tahun, kepada delapan hari bulan Rajab, pagi-pagi hari Jumªt, pukul delapan. Maka diganti oléh adindanya bergelar pula Pangéran Ratu.

2.10. Setelah itu, maka sentosalah negeri Palémbang. Pada zaman itu maka Sultan Mahmud Badaruddin membuat kota batu yang disebut orang Palémbang kota lama. Kepada tarikh seribu seratus limapuluh tahun, kepada empat hari bulan Jumadil-akhir, hari Isnin, pukul enam, masa itulah membuat kota lama. Maka adalah kepada tarikh seribu seratus enampuluh satu tahun Sultan Mahmud Badaruddin membuat mesjid Palémbang yang ada sekarang, kepada delapanlikur

16 hari bulan Jumadil-awal, hari / Isnin, ${ }^{7}$ pagi-pagi hari.

Syahdan maka amanlah negeri Palémbang pada zaman itu. Pada tiap-tiap musim perahu dagang segala rupa masuk Palémbang dan dari tanah Bangka keluar timah dan dari Belitung keluar besi, semuanya itu peruntungan negeri Palémbang; beberapa banyak peruntungan negeri.

3.

3.1. Maka adalah lamanya Sultan Mahmud Badaruddin itu menjadi raja diatas takhta kerajaan negeri Palémbang itu tigapuluh lima tahun; ia wafat kepada tarikh seribu seratus tujuhpuluh satu, kepada tiga hari bulan <Muharram $>$, pada malam Sabtu, waktu magrib. Maka diganti 
oléh puteranya menjadi sultan, yaitu Pangéran Ratu, bernama Sultan Ahmad Najamuddin naik diatas kerajaan negeri Palémbang dan puteranya yang tua sekali dijenengkan Pangéran Ratu.

Sebermula Sultan Ahmad Najamuddin menjadi raja itu menetapkan bagaimana juga aturan Palémbang dengan Kompeni. Pada tiap-tiap tahun utusan ke Betawi membawakan timah dan tiap-tiap tahun mengarak surat dari Betawi bersama-sama dengan pétor dan kapitan di Palémbang.

3.2. Maka tiada berapa lamanya datang surat dari Betawi: Kompeni minta hendak membuat kota batu, sebab Kompeni banyak rugi dan susah pada tiap-tiap tahun bekerja kota bambu itu. Maka dikabulkan oléh Sultan Palémbang. Maka baharu kota loji Kompeni di Palémbang

17 kota batu / itu pada zaman Sultan Ahmad Najamuddin. Serta Kompeni banyak nerima kasih, berapa kiriman dari Betawi kepada Sultan Palémbang. Maka bertambah-tambahlah berkasih-kasihan antara Kompeni dengan Palémbang. Setelah berapa lamanya, maka Sultan Ahmad Najamuddin itupun bergelar nama Sunan Ahmad Najamuddin dan ${ }^{8}$ puteranya Pangéran Ratu itu diangkat nama Sultan Muhammad Baha'uddin.

3.3. Dan berapa <lamanya >, maka masuk pula komisaris membawa kapal perang ke Palémbang, mendapatkan Suhunan Ahmad Najamuddin minta utang perjanjian negeri Palémbang empatpuluh laksa ringgit dan bujang empatpuluh dan gadis empatpuluh. Serta komisaris itu menunjukkan surat keterangan Sultan Mahmud Badaruddin dahulu. Maka jawab Suhunan Ahmad Najamuddin itu belum ada yang dibayarkan. Maka komisarispun keluarlah dari negeri Palémbang pulang ke Betawi. Demikianlah hal negeri Palémbang sentosa aman seperti yang sudah juga.

4.

4.1. Maka adalah lamanya Suhunan Ahmad Najamuddin diatas takhta kerajaan merintah negeri Palémbang itu duapuluh lima tahun; ia wafat kepada tarikh seribu seratus sembilanpuluh, betul kepada duapuluh hari bulan Zulkacédah ${ }^{9}$ pada malam Isnin, pukul lima subuh. Maka diganti oléh puteranya Sultan Muhammad Baha'uddin itu naik diatas takhta kerajaan negeri Palémbang dan puteranya yang tua diangkatnya 18 nama / Pangéran Ratu. Maka pada zaman Sultan Muhammad 
Baha'uddin itu terlebih pula ma`mur dan aman sentosa didalam negeri Palémbang, dengan adil murah kepada segala racyat negeri dan orang dagang lagi banyak kasihan kepada fakir dan miskin.

4.2. Syahdan tiada berapa lamanya Sultan Muhammad Baha'uddin itu menjadi raja merintah negeri Palémbang dengan sekalian jajahan itu, maka Sultan Muhammad Baha'uddin itupun membuat kota besar di Palémbang yang ada ditunggu Kompeni sekarang. Telah sudah kota besar dengan segala rumah dan taman, maka Sultan Muhammad Baha'uddin itupun berpindahlah di kota besar itu kepada tarikh seribu duaratus sebelas tahun, kepada tigalikur hari bulan Syacban, hari Isnin, pagi-pagi hari. Maka Pangéran Ratu pula mengganti duduk didalam kota yang lama itu dengan beberapa $\mathrm{ra}^{c}$ yat punggawanya diluar kota itu.

Maka zaman itu bertambah-tambah berkasih-kasihan dengan Kompeni. Pada tiap-tiap tahun utusan dan mengarak surat dari Betawi dan di Betawi demikian juga mengarak surat dari Sultan Palémbang. Demikianlah pada tiap-tiap musim sepertimana ketetapan yang sudah juga dalam kontrak perjanjian negeri, tiada berubah-ubah.

4.3. Setelah beberapa tahun lamanya Sultan Muhammad Baha'uddin itu menjadi raja diatas takhta kerajaan negeri Palémbang, maka suatu 19 tahun / datanglah pula komisaris membawa kapal perang masuk Palémbang, mendapatkan Sultan Muhammad Baha'uddin minta <utang> perjanjian negeri Palémbang empatpuluh laksa ringgit. Serta komisaris menunjukkan surat keterangan Sultan Mahmud Badaruddin, masa lagi Pangéran Jayawikrama minta pertolongan ke Betawi. Maka pada masa itu gemparlah segala orang kecil seisi negeri Palémbang melihatkan kapal perang. Angkatan komisaris itu naik ke darat, mendapatkan Sultan Palémbang dengan beberapa alat.

Syahdan maka Sultan Muhammad Baha'uddin itupun berbicaralah dengan komisaris dari hal utang perjanjian negeri Palémbang empatpuluh laksa ringgit itu: "Betullah ada utang saya punya nénék dahulu kepada Kompeni. Boléh saya bayar semuanya, akan tetapi orang kecilkecil sakit ngeluarkan itu. Jika membayar setengah, yaitu boléh kita bayarkan duapuluh laksa ringgit itu." Maka setelah demikian bicara Sultan Muhammad Baha'uddin itu serta dengan permintaan kepada Kompeni, maka kabulkan oléh komisaris sepertimana permintaan Sultan Palémbang itu. Maka membayarlah Sultan Palémbang pada masa itu kepada komisaris hanya duapuluh laksa ringgit, lain tiada. Maka 
surat cap keterangan itu dipulangkan oléh komisaris kepada Sultan Muhammad Baha'uddin.

20 4.4. Maka selesailah antara Palémbang dengan Betawi. / Tiada sesuatu apa-apa permintaan dari Palémbang yang pantas Kompeni turut dan apa-apa permintaan dari Kompeni yang pantas Sultan Palémbang turut. Demikianlah pada tiap-tiap tahun utusan itu di Palémbang membaca surat perjanjian di hadapan seisi negeri, siapa suka dengar. Waktu mengarak surat dari Betawi itu terlalu ramainya, pada tiap-tiap tahun masang meriam dan senapang beberapa banyak di hadapan Raja Palémbang dengan pétor. Berhimpunlah sekalian punggawa menteri dan orang yang pangkat besar didalam negeri Palémbang, sama mengadap di pemarakan besar, makan dan minum. Demikianlah pada tiaptiap tahun.

Dan tempat kota Kompeni itu orang panggil loji pada zaman itu atawa orang panggil gudang Holanda. Demikianlah jikalau Raja Palémbang jalan berperahu ke hilir, maka loji Kompeni itu masang meriam hormat kepada Sultan Palémbang itu. Dan jika Sultan Palémbang berperahu ke hulu, tiada masang meriam di loji Kompeni, sebab tiada kelihatan dari loji Kompeni itu. Selama-lamanya aturan begitulah sudah didalam kontraknya. Kompeni dengan Raja di Palémbang bertambah-tambah berkasih-kasihan.

Dan kerap kali periai Palémbang terampas oléh Sultan Palémbang, sebab berjual timah kepada Inggeris. Dan banyak orang suka mencuri berjual timah kepada Inggeris itu, sebab harganya enambelas ringgit satu pikulnya dan ${ }^{10}$ turut berjual kepada Kompeni di Betawi delapan

21 ringgit satu pikulnya, sebab perjanjian / negeri Palémbang dengan Kompeni didalam kontraknya telah demikianlah selama-lamanya.

Negeri Palémbang bertambah-tambah aman sentosa selama berdamai dengan Kompeni. Dan rac ${ }^{c}$ at seisi negeri dengan segala jajahan itupun banyak beruntung, sebab negeri sentosa. Segala dagangpun banyak masuk dari laut dan dari darat dan dari hulu, kerana Raja Palémbang pada zaman itu terlalu adil sentosa perintahnya meliharakan segala racyat negeri dan sekalian dagang.

5.

5.1. Syahdan maka adalah lama zamannya Seri Paduka Sultan Muhammad Baha'uddin menjadi raja diatas takhta kerajaan negeri Palémbang yaitu duapuluh tujuh tahun lamanya; maka iapun wafatlah 
kepada tarikh seribu duaratus delapanbelas tahun, kepada selikur hari bulan Zulhijah ${ }^{11}$ hari Isnin, pukul empat. Maka kepada hari itu puteranya Pangéran Ratu mengganti kerajaan Seri Paduka Ayahandanya diatas takhta kerajaan negeri Palémbang, bernama Sultan Mahmud Badaruddin, di hadapan sekalian punggawa menteri dan tuan dan orang alim-alim dan segala racyat Palémbang; dan puteranya yang tua sekali bernama Pangéran Ratu.

Adapun Sultan Mahmud Badaruddin itu empat bersaudara laki-laki yang tunggal. Dan adindanya yang tua itu, bernama Pangéran Adimenggala, diangkatnya nama Pangéran Dipati dan adindanya muda,

22 bernama Pangéran / Adikesuma, diangkatnya nama Pangéran Aryakesuma dan adindanya yang muda sekali, bernama Pangéran Natakesuma, diangkatnya nama Pangéran Suryakesuma. Dan beberapa banyak saudara Sultan Mahmud Badaruddin itu yang lain ibu, laki-laki dan perempuan, tiada disebutkan di sini.

Sebermula maka tetaplah Sultan Mahmud Badaruddin itu menjadi raja di negeri Palémbang duduk didalam kota keraton besar dan Pangéran Ratu, puteranya itu, duduk didalam kota dekat di situ juga tempatnya. Dan aturan negeri Palémbang itu tetap sepertimana dahulu juga, punggawa menteri dan aturan bagaimana juga yang telah sudah teradat didalam negeri Palémbang selama-lamanya. Istiméwa pula antara dengan Kompeni bertambah-tambah kasih-berkasihan, tiap-tiap tahun utusan seperti yang sudah juga. Adapun pada zaman itu segala bawah angin ini Holanda sekalian, hanya ada Inggeris didalam negeri Pulau Pinang itulah, lain tiada.

5.2. Syahdan telah berapa lamanya Sultan Mahmud Badaruddin itu mengganti ayahandanya menjadi raja duduk diatas takhta kerajaan negeri Palémbang itu, pada suatu tahun Jénderal Betawi itu berganti bernama Jénderal Maskalek. Terlalu keras perintahnya terkhabar kepada Sultan Palémbang dan lagi harga timah dari Palémbang diutangnya, belum dibayarnya, hendak dibayarnya dengan beras. Utusan

23 Palémbang / tidak mau terima, sebab bukan perjanjian demikian itu; dan jika pada tahun ini tiada bayar uang, barangkali tahun di muka tiada keluar timah dari Palémbang sebab tiada modalnya.

Maka kata Jénderal Maskalek: jikalau timah tiada keluar, misti negeri Palémbang dimasuki baris dan lagi harga timah diturunkannya dari aturan selamanya. Maka utusan Palémbang tiada terima, sebab bukan perjanjian dan lagi banyak pula yang lain-lain aturan berubah. Maka utusan pulang ke Palémbang, dikatakannya kepada Sultan Pa- 
lémbang sepertimana bicara Jénderal Maskalek itu.

Maka ada pula Sultan Palémbang dapat khabar Jénderal Maskalek itu hendak melanggar Palémbang. Maka Sultan Palémbangpun ngimpunkan $\mathrm{ra}^{c}$ yat dan segala punggawa menteri membuat bénténg di ilir negeri; namanya tempat itu Borang, <ya >itu seberang-menyeberang bénténg. Dan segala pucukan Batangari Sembilanpun disuruh milir bekerja bénténg di Borang itu. Terlalu ramainya segala periai dan menteri itupun semuanya berhimpun di Borang bekerja. Dan tuanya saudara Sultan, yaitu Pangéran Aryakesuma. Dan pada masa itu Holanda masih ada didalam loji di Palémbang.

6.

6.1. Adapun tiada berapa lamanya, maka Sultan Palémbang dapat khabar daripada tuan Arab-Arab mengatakan Inggeris di Pulau Pinang itu megang segala perahu dagang, tiada diberinya keluar. Maka Sultan

24 Palémbangpun terkejut serta dapat khabar / Inggeris itu. Maka ia megang segala dagang tiada diberinya keluar, sebab itu Inggeris mau perang, entah di mana-mana belum tahu.

Maka Sultan Palémbang itupun menyuruh dua menteri utusan kepada Inggeris dengan bersembunyi, tiada ketahuan kepada Holanda di Palémbang. Maka dua menteri itupun pergilah membawa surat Sultan Palémbang ke Pulau Pinang, tiada nampak di Palémbang. Setelah datang kepada Inggeris utusan Sultan Palémbang itu, maka diarak Inggeris surat Sultan Palémbang itu serta katanya kepada menteri utusan itu mengatakan Inggeris hendak mukul Betawi, lagi menghimpunkan soldadu. Maka jawab utusan Palémbang: "Bagaimana Tuan dari hal Holanda di Palémbang itu ?" Maka kata Inggeris: "Usir, ialah Sultan keluarkan segala Holanda yang di Palémbang itu! Kalau ia melawan, mana Sultan Palémbang punya suka, sebab dia kuasa negerinya sendiri. Tetapi jikalau negeri Betawi sudah kalah oléh Inggeris, jangan lagi diapa-apakan, biarlah Inggeris ngeluarkan Holanda itu semuanya dari negeri Palémbang. Dan jika Sultan Palémbang hendak ngeluarkannya, masa inilah, sebab Inggeris belum melanggarnya, mana suka Sultan, sebab dia punya negeri." Maka jawab utusan Palémbang: "Bagaimana Tuan? Kerana loji Holanda di Palémbang kota batu, terlalu teguh dengan meriamnya dan soldadunya cukup; kerana negeri

25 Palémbang kurang senjata lagi / orang Palémbang tiada biasa perang." Maka didalam khabar dikirimi Inggeris Sultan Palémbang beberapa peti senapang dengan obat pelurunya. Maka utusan itupun pulanglah. 
6.2. Telah sampai di Palémbang, disampaikannya kepada Sultan Palémbang segala bicara Inggeris itu. Maka Sultan di Palémbang itupun bertambah-tambah jaga negeri. Di Sungsang beberapa menteri yang jaga dan di Mentokpun beberapa pula menteri menunggu di sana berganti-ganti; kalau ada perahu Inggeris dan perahu Holanda dari Betawi, Sultan hendak sigera tahu. Adapun mupakatan segala kepalakepala bicara di Palémbang 12: "Akan ngeluarkan Kompeni di Palémbang itu semuanya menurut bagaimana bicara Inggeris, itu baik kalau Betawi dapat oléh Inggeris. Kalau tidak dapat negeri Betawi oléh Inggeris jadi tiada baik, kerana Holanda sahabat Palémbang selamalamanya. Dan melainkan kita nantikan siapa juga yang menang akan perang Betawi itu."

Telah demikian mupakat bicara di Palémbang, maka dari itulah sebabnya maka ada menteri berjaga di Sungsang dan di Mentok. Kalau dapat khabar Betawi kalah atawa tiada oléh Inggeris, jangan nampak kepada segala ${ }^{13}$ orang negeri. Kalau tahu Holanda di Palémbang! Kerana perahunya Inggeris terlalu banyak sudah dari barat menyeberang ke tanah Jawa. Dan pada waktu itu tiada seorang dagang datang dari Jawa ke Palémbang atawa ke barat, jadi tiadalah tahu /

26 kepada khabar Betawi. Dan orang Palémbangpun masa itu banyak di tanah Jawa tiada seorang yang datang atawa suratnyapun tiada khabarnya. Pada waktu itu tiada satu perahu dagang yang berlayar di laut tanah Jawa melainkan perahu Inggeris juga, hingga Kompeni di Palémbangpun tiada juga dapat surat dari Betawi. Adalah masa itu susahlah racyat Palémbang, sebab tiada dagang datang dari Jawa.

6.3. Maka Sultan Palémbang itupun bertambah-tambah keras jaga negeri dan di kuala. Dan bertambah-tambah keras periai dan menteri bekerja bénténg: di Borang itu beberapa meriam dan orang yang jaga di situ; dan di Pulau Anyar itu suatu bénténg dengan beberapa meriam dengan orang yang jaga di situ; dan mudik ke hulu di Rawa-Rawa Sekampung itu suatu bénténg dengan beberapa meriam dengan orang yang jaga di situ; dan di ilir Palémbang Lama suatu bénténg dengan beberapa meriam dan orang yang jaga di situ; dan di Batu Ampar itu suatu bénténg dengan beberapa meriam dan orang yang jaga di situ; dan di Gunung Méru itu suatu bénténg dengan beberapa meriam dan orang yang jaga di situ. Dan semuanya bénténg itu di tepi laut dengan telah bertentu kepalanya beberapa pangéran; dan menteri hulubalang, racyat Palémbang dan ulupun, semuanya pasirah uluan dipanggil milir semuanya. / 
27 Telah berapa lamanya negeri Palémbang berjaga-jaga itu, serta menanti-nantikan perkhabaran dari Betawi. Beberapa menteri yang jaga di kuala Sungsang dan di Mentok pada masa itu, tiap-tiap dagang perahu kecil-kecil masuk diperiksa keras.

6.4. Sebermu $<$ la $>$ maka adalah pada suatu malam datang seorang Arab nama Said Zain Bafakih, dibawa orang mengadap Sultan di Palémbang. Dan Said Zain Bafakih itu orang lari dari tanah Jawa, entah bagaimana buatannya dia lari itu. Dan Said Zain Bafakih itulah yang membawa khabar yang sungguh terang dengan nyatanya mengatakan negeri Betawi sudah dapat oléh Inggeris dan beberapa perahu dagang di laut Betawi yang binasa oléh Inggeris, témpoh datang mukul Betawi itu. Yang lambat lari dipasangnya dengan meriam; beberapa orang dagang yang mati, anak Palémbangpun ada juga yang mati di perahu dagang itu. Dan Said Zain Bafakih itu berkhabar kepada Sultan Palémbang, dia melihat sendiri Jénder $<$ al $>$ di negeri Betawi itu sudah undur dengan sekalian racyatnya. Negeri Betawi sudah ditunggu Inggeris, sudah lain atura $<\mathrm{n}>$.

6.5. Syahdan tatkala masa Said Zain Bafakih itu bertemu dengan Sultan, pada waktu pukul duabelas malam. Maka waktu siang hari itu keluarlah Sultan kepada pengadapan mengimpunkan punggawa menteri

28 dan $\mathrm{ra}^{c}$ yat semuanya, disuruh ngeluarkan semuanya/Kompeni Holanda daripada lojinya.

Maka pergilah periai dan menteri dengan membawa racyat serta alat senjata, sampai penuh loji Kompeni itu oléh racyat, periai dan menteri itu. Maka sekalian Kompeni itupun terkejut. Maka semuanya orang besar-besar dan soldadu Holanda dan Jawa dengan anak-isterinyapun dikeluarkan oranglah, turun ke perahu tob; dan orang Jawa satu perahu tob juga. Kedua perahu itu ${ }^{14}$ dilabuhkan di laut pangkalan Kidemang Saléh.

Adalah pada masa semuanya Kompeni dikeluarkan daridalam kotanya itu kepada tarikh seribu duaratus duapuluh enam tahun, kepada delapanlikur hari bulan Syacban, hari Selasa, pukul empat. Dan kepada tiga hari bulan Ramadan, pada hari Ahad disuruh keluarkan dari kuala Sungsang keduanya perahu itu. Maka kepada tiga hari bulan Ramadan Sultan menyuruh memulai merubuh kota dan rumah Kompeni itu semuanya.

Maka habislah Kompeni Holanda dalam negeri Palémbang, hingga anak kecilpun tiada lagi. Hanya satu Holanda, Tuan Bilam ${ }^{15}$ namanya, 
dan umaknya, orang Palémbang, itu juga yang lepas sebab lari di hutan; terpegang oléh orang negeri pada lain hari. Sudah selesai itu, maka disuruh Sultan buang ke hulu, kepada dusun Buri namanya, dimasukkan kepada agama Islam. Maka telah habis rubuh kota 29 Holanda, / di Palémbangpun bertambah-tambah keras membuat bénténg dan membaiki alat senjata.

7.

7.1. Telah berapa lamanya, maka datanglah suruhan daripada Inggeris masuk Palémbang, kepada Sultan meriksa di mana Holanda yang di Palémbang itu semuanya. Maka kata Sultan: "Sudah lama dikeluarkan dari Palémbang. Sedatang perintah daripada Inggeris dahulu sudah disuruh keluar itu, sebelum Betawi dapat oléh Inggeris." Maka Inggeris hendak melihat di mana tempat loji Holanda dahulu. Maka kata menteri-menteri di Palémbang: "Jauh dari sini, di situ banyak orang jahat-jahat." Adapun utusan itu didudukkan di rumah Kidemang Saléh, serta dipelihara bagaimana adat orang besar-besar. Telah demikian, maka utusan Inggeris itupun pulanglah ke Betawi.

Maka tiada berapa lamanya, maka masuk pula utusan Inggeris, dua orang Arab, namanya Pangéran Syarif Muhammad dengan Said Bakar Rum. Keduanya itu masuk Palémbang kepada Sultan. Entah apa-apa kerananya, belum berapa hari, maka utusan itupun lari keduanya keluar dari Palémbang, pada sangkanya akan dibunuh oléh Sultan Palémbang.

7.2. Sebermula maka telah berapa lamanya, maka Sultan Palémbang itupun menyuruh utusan ke Betawi dengan sepertinya bagaimana adat Palémbang selama-lamanya. Maka dua menteri yang disuruh jadi utusan itu; dan nama Temenggung Suranandita dengan Temenggung

30 Suradiraja, utusan kepada Jénderal / Raflis di Betawi. Maka sampailah utusan itu di Betawi, maka diterima Inggeris bagaimana juga adat Holanda dahulu. Maka Jénderal Raflis bertanya: "Di mana Holanda semuanya yang ada di Palémbang?" Maka jawab utusan Palémbang: "Sudah lama dikeluarkan, sebelum Betawi dapat oléh Inggeris." Kata Jénderal Raflis: "Ke mana perginya? Tidak sampai di sini." Maka jawab utusan Palémbang: "Kalau ia pergi, berlayar ke barat." Adapun dua-dua temenggung utusan itu dipeliharanya betul oléh Inggeris.

Syahdan tiada berapa lamanya utusan Palémbang di Betawi, maka datanglah Pangéran Syarif Muhammad dengan Said Bakar Rum itu mengadu kepada Jénderal Raflis di Betawi: serta ia kedua disuruh ke 
Palémbang, hendak dibunuh oléh Sultan Palémbang; jika lambat ia lari, misti mati keduanya. Dan dari hal Holanda semuanya yang di Palémbang: serta Betawi sudah diganti Inggeris, maka semuanya Holanda itu di Palémbang itu dikeluarkan oléh Sultan Palémbang; sampai diluar kuala Sungsang, habis mati semuanya.

Adapun Pangéran Syarif Muhammad itu asal dahulunya anak Palémbang; ibunya itu dénayu Palémbang, bapanya Arab. Maka Pangéran Syarif Muhammad itu beristeri orang Mentok yang bangsa Yang. Maka dibawanya ke Palémbang, ketahuan Sultan Palémbang. Tiada boléh beristerikan orang Mentok bangsa Yang itu lain daripada Raja Palém-

31 bang. Maka diceraikan dengan isterinya itu oléh / Sultan Palémbang. Maka Pangéran Syarif Muhammad itupun kecil hati sebab isterinya diceraikan itu. Maka Pangéran Muhammad itu lari dari negeri Palémbang, duduk di negeri Kedah; kemudian maka masuk pekerjaan Inggeris. Demikianlah asalnya Pangéran Syarif Muhammad itu.

8.

8.1. Sebermula maka tersebutlah akan Jénderal Raflis. Serta menengarkan pengaduan Pangéran Syarif Muhammad mengatakan segala Holanda di Palémbang sudah habis semuanya dikeluarkan sudah Betawi diganti Inggeris, maka Jénderal Raflis itupun terkejut. Pada suatu hari Jénderal Raflis keluar di kantor bicara negeri Betawi memanggil dua temenggung utusan Palémbang itu. Telah datang, diperiksa itu utusan tiada mengaku akan bicara Holanda di Palémbang itu. Maka dua utusan itupun diambillah kerisnya, lalulah dibawa di kapal perang, ditutub keduanya. Dan perahu utusan Palémbang itu semuanya dirampas, dibuang tali-talinya semuanya.

Maka pada masa itu juga Jénderal Raflis menyuruhkan Jénderal Galispi ${ }^{16}$ membawa angkatan masuk Palémbang. Dan utu $<$ san $>$ Palémbang itu dibawa didalam kapal tempat Jénderal Galispi itu dan Pangéran Syarif Muhammad di situ juga. Maka Jénderal Galispi itupun pergilah ke Palémbang dengan beberapa membawa kapal dan perahu lainnya, semuanya itu alat perang sekaliannya.

8.2. Alkissah maka tersebutlah perkataan Seri Paduka Sultan Mahmud

32 Badaruddin / yang bertakhta kerajaan didalam negeri Palémbang itu; senantiasa membaiki negeri dan membaiki bénténg di Borang dan di negeri. Dan meriam diatas kota batu itu sekaliannya dibaiki, serta keduanya kota di Palémbang itu telah ditentukan orang yang jaga. 
Dan menghimpunkan segala rac ${ }^{c} y a t$ Bangka dan rac $^{c} y a t$ Belitung. Dan semuanya orang hulu dikerahkan milir ke Palémbang membawa alat senjata. Dan istiméwa pula punggawa menteri dan pangéran-pangéran semuanya bertunggulah di bénténg Borang dan lain-lain bénténg itu, masing-masing dengan yang tunggunya. Maka adalah Sultan Palémbang itupun takutkan Inggeris kalau datang melanggar negeri Palémbang, kerana sebab sudah banyak khabar yang tiada baik.

8.3. Sebermula maka adalah lamanya Seri Paduka Sultan Mahmud Badaruddin itu menjadi raja di Palémbang sembilan tahun, maka datanglah angkatan Inggeris yang berjénderal Galispi. Kepada tarikh seribu duaratus duapuluh tujuh tahun, kepada sebelas hari bulan Rabicul-akhir angkatan Jénderal Galispi sampainya di bénténg Borang. Adapun kepalanya di bénténg Borang itu Pangéran Dipati yang wakil mutlak daripada Sultan Palémbang dengan saudaranya Pangéran Aryakesuma dan Pangéran Surya. Syahdan tiadalah lagi dilanjutkan kalamnya di sini.

Pada suatu malam di bénténg Borang itu Pangéran Dipati memberi /

33 perintah kepada sekalian punggawa menteri dan rac $^{c}$ yat sekaliannya bésok pagi-pagi angkatan Jénderal Galispi hendak masuk ke Palémbang jangan dibedil, kerana hendak bicara baik. Maka pada pagi-pagi hari Pangéran Dipati itupun mudiklah ke Palémbang dengan Pangéran Arya dan Pangéran Surya dengan sekalian punggawa menteri dan racyat sekaliannya, sama berebut pulang ke Palémbang. Maka bénténg itupun tinggallah, tiada satu orang lagi dalamnya sekalian bénténg itu. Maka angkatan Jénderal Galispi itupun masuklah ke Palémbang, semuanya perahu besar kecil itu.

8.4. Sebermula adapun Sultan di Palémbang menengar angkatan Jénderal Galispi sudah dekat sampai di bénténg Borang itu, maka iapun bersikaplah; jikalau bénténg Borang dapat oléh Inggeris, hendak melawan di Palémbang. Serta Sultan di Palémbang itupun ngeluarkan sekalian perempuan seisi kota turun ke perahu beberapa banyak, dan menurunkan emas dan rial beberapa perahu dengan alat senjata. Semuanya itu disuruh berseméper mudik satu hari dari negeri bernama Muara Belidah ${ }^{17}$; di situlah tempat berhenti seisi kota dan segala harta. Dan Sultanpun tinggallah di kota dengan punggawa menteri dan racyat menantikan musuh datang.

Setengah demikian, maka Pangéran Dipati itupun datanglah mendari 34 Borang. Ia / mengadap Sultan mengatakan bénténg Borang sudah 
kena oléh Jénderal Galispi, kerana orang Palémbang habis lari semuanya. Maka Sultanpun terkejut katanya: "Baiklah kita melawan di sini bersama-sama." Maka sembah Pangéran Dipati: "Di kota ini sekarang orang kecil-kecil, di luar itu sudah habis lari semuanya. Silakanlah Paduka Kakanda mudiklah ke hulu, kerana segala isi kota sudah di perahu semuanya. Biarlah adinda menantikan Jénderal Galispi itu. Apa sukanya, mau perang atawa bicara, adindalah lawannya itu." Maka diserahkanlah oléh Sultan kota dan segala bicaranya dengan Inggeris itu.

Syahdan maka Seri Paduka Sultan Mahmud Badaruddin itupun keluarlah dariatas kerajaan negeri Palémbang itu, turun ke perahu lalu mudik kepada duabelas hari bulan Rabicul-akhir, malam Sabtu, pukul delapan, pada tarikh seribu duaratus duapuluh tujuh tahun. Adapun sudah Sultan turun ke perahu lalu mudik itu, maka Pangéran Dipati itupun mintar pula. Ia menjauhkan perempuan ke dusun Tanjung Saga dan Pangéran Arya dengan Pangéran Surya mudik menjauhkan perempuan ke dusun Tempiri.

Adapun Jénderal Galispi masuk kedalam kota Palémbang kepada tigabelas hari bulan Rabicul-akhir, malam Ahad, pukul delapan. Dan

35 Inggeris masang bendéra Inggeris / diatas kota Palémbang kepada delapan<belas $>$ hari bulan itu juga, hari Jumcat, pukul enam. Maka adalah Pangéran Dipati bertemu dengan Jénderal Galispi kepada sembilanbelas hari bulan itu juga, hari Sabtu.

8.5. Syahdan maka Jénderal Galispi itupun suruhan mudik kepada Sultan Palémbang di Muara Belidah: akan jénderal hendak bertemu dengan Sultan; kalau Sultan tiada mau bertemu dengan dia, nanti dia buat lain raja di Palémbang. Maka jawab Sultan: tiada mau lagi jadi raja; siapa yang suka, buatlah oléh jénderal. Serta Sultan Mahmud Badaruddin itu memberi cap: "Siapa suka jadi raja, buatlah; aku jangan dituntut lagi."

Telah datang utusan itu kepada Jénderal Galispi itu, maka Jénderal Galispi itupun berbicara dengan Pangéran Dipati hendak dibuatnya raja di Palémbang. Maka jawab pangéran: dia terima, jikalau Sultan Mahmud Badaruddin menyukai ia jadi raja; minta lagi cap satu lagi.

Maka Jénderal Galispi itupun suruhan pula kepada Sultan Mahmud Badaruddin. Maka diberikannya pula satu surat dengan dibubuhnya cap yang dia menyukai Pangéran Dipati jadi raja di negeri Palémbang. Maka suruhan itu kembalilah kepada Jénderal Galispi memberikan surat daripada Sultan itu. Maka Jénderal Galispi itupun memberikan 
36 surat itu kepada Pangéran Dipati; dan / yang satu surat itu dipegang jénderal.

8.6. Maka berhimpunlah balatentera Inggeris dan segala punggawa menteri dan racyat Palémbang semuanya itu di balai bandung didalam kota Palémbang. Di hadapan Jénderal Galispi mendirikan Pangéran Dipati menjadi raja diatas takhta kerajaan negeri Palémbang bergelar Seri Paduka Sultan Ahmad Najamuddin, kepada tarikh seribu duaratus duapuluh tujuh tahun, kepada dua hari bulan Jumadil-awal, hari Khamis, pukul sembilan. Dan pada masa itu juga turun bendéra Inggeris dariatas kota Palémbang, berganti dengan bendéra putih.

Dan kepada enam hari bulan itu juga keluarnya Jénderal Galispi daridalam kota Palémbang, turun ke perahu sekaliannya, lalu ilir semuanya ke Sungsang. Dan adalah lagi Inggeris yang tinggal di Palémbang itu; Sultan Ahmad Najamuddin yang minta, kerana negeri lagi gentar. Dan nama kepala Inggeris itu Belahrubi, ${ }^{18}$ didudukkan ${ }^{19}$ oléh Sultan di kota lama menjagai Palémbang.

9.

9.1. Sebermula maka tersebutlah perkataan Sultan Mahmud Badaruddin dengan segala racyat balatenteranya sekalian lalu mudik Batangari Musi sampai di dusun Pulaupanggung. Ada sebulan lamanya di situ, maka Sultan Mahmud Badaruddinpun terdengarlah khabarnya 37 adindanya sudah dijadikan Inggeris Raja Palémbang, / bergelar Sultan Ahmad Najamuddin. Maka Sultan Mahmud Badaruddin itupun milirlah pula dengan segala racyatnya, bertahan di dusun Buaya Langu, membuat bénténg serta menghimpunkan racyat dan orang Melayu beberapa banyaknya dengan alat senjata. Dan bénténg itu seberangmenyeberang batangari dengan beberapa periai dan menteri yang turut dia.

Syahdan maka terdengarlah khabarnya kepada Sultan di Palémbang itu Kakanda di Buaya Langu terlalu teguh lagi beberapa banyak orangorang berhimpun di situ dengan alat senjatanya, hendak milir ke Palémbang akan merebut negeri Palémbang. Setelah itu, maka Sultan Ahmad Najamuddin itupun memberitahu kepada Inggeris di Mentok. Maka dikhabarkan kepadanya Sultan Mahmud Badaruddin milir bertahan di dusun ${ }^{20}$ Buaya Langu, membuat bénténg terlalu teguh, lagi banyak orang berhimpun di situ dengan alat dan senjatanya lengkap akan milir pula ke Palémbang hendak merebut Palémbang. 
9.2. Serta Inggeris menengar demikian itu, maka masuklah angkatan soldadu beberapa banyak mendari Mentok masuk Palémbang, lalu mudik. Dan nama kepalanya Méjir Mir. Dengan beberapa ia membawa periai dan menteri dari Palémbang dengan beberapa perahu. Angkatan mudik itu, tiada berapa lamanya maka sampailah ke dusun Buaya Langu. Maka lalu peranglah Inggeris dengan Sultan Mahmud Badar38 uddin/itu, terlalu ramainya beberapu perahu di laut perang sama perahu. Maka Inggerispun undur naik ke darat dari ilir bénténg, beberapa soldadu daridalam hutan. Maka pada hari itu juga bénténg Buaya Langu dapat oléh Inggeris. Tetapi kepalanya Méjir Mir itu luka terus di perutnya; lalu undur dan bénténg dibakar.

Dan beberapa banyak orang mati dan radénpun ada juga yang mati dan luka. Maka kenalah oléh Inggeris itu patih dari Sultan Ulu tertangkap, nama Pangéran Wiradinata; dibawanya milir oléh Inggeris milir, diberikannya kepada Sultan di Palémbang. Maka Sultan di Palémbang menyuruh bawa ke Betawi. Lalu dibawanya ke Betawi, mati di jalan. Adapun Méjir Mir yang luka perang itu, sampai di Tanjung Kalian, di Mentok mati.

9.3. Sebermula tersebutlah perkataan Sultan Mahmud Badaruddin yang di hulu itu. Setelah bénténg Buaya Langu itu dapat oléh Inggeris dan Inggerisnya sudah undur milir ke Palémbang, maka Sultan Ulupun mudiklah. Semuanya bertahan di Muara Rawas, membuat bénténg besar serta ngimpunkan orang hulu dan Melayu ulu Jambi dan Melayu Padang; semuanya berhimpun di bénténg Muara Rawas dengan alat senjatanya lengkap. Maka Inggerispun tiada lagi datang melanggar.

39 Maka Sultan / yang di Palémbang itupun menyuruh beberapa pangéran dan menteri membuat pula bénténg di ilir Muara Rawas itu, berjaga kalau Sultan Ulu milir merebut Palémbang. Dan orang mudik tiada boléh dan milir boléh. Tiada lagi boléh mudik ke hulu, maka banyak juga beramuk-amukan malam Palémbang dengan orang Melayu. Demikianlah tiada berhenti saling pasang setinggar dan senapang orang Palémbang dengan Melayu, racyat Sultan Ulu.

9.4. Sebermula ada tengah dua tahun lamanya demikian itu Sultan Ulu di Muara Rawas, maka adalah nama Kemas Muhammad Hanafi itu minta dari Palémbang mudik ke Rawas akan bertemu saudaranya yang jadi isteri Sultan. Maka Kemas Muhammad itu telah sampai di Muara Rawas, cakap mendamaikan Sultan Ulu dengan Inggeris. Maka berjanjilah Sultan Ulu dengan Kemas Muhammad itu: jikalau boléh damai antara dengan Inggeris itu boléh milir duduk di Palémbang 
dalam kota, bésok Kemas Muhammad diambil mantu oléh Sultan. Maka telah putuslah bicara Sultan Ulu itu dengan Kemas Muhammad itu. Maka Kemas Muhammad itupun milirlah ke Palémbang, tiada seorang yang tahukan bicaranya itu, pura-pura bertemu saudaranya saja di Muara Rawas itu.

Setelah datang ke Palémbang, maka kemas itupun lalu menyeberang ke Mentok, kerana pada waktu Inggeris orang besarnya di Mentok. Maka kemas itupun mengakulah utusan daripada Sultan Ulu akan 40 minta damai. Jikalau boléh ampun / Sultan Ulu boléh milir ke Palémbang, kota yang besar itu dibeli dengan harga empatpuluh laksa ringgit dengan tunai, dengan aturan jual-beli: tiada merintah, lagipun jadilah dan cuma dalam kota itu sahaja yang punya Sultan. Maka bicara itupun ${ }^{21}$ hasil diterima Inggeris.

9.5. Maka tiada berapa lamanya, ${ }^{22}$ maka masuklah nama Méjir Rabsun itu ke Palémbang, tiada berapa ia membawa soldadu. Lalu ia mendapatkan Sultan yang di Palémbang, katanya ia minta perahu akan mudik mendapatkan Sultan yang di Muara Rawas itu: apa sudahnya berjaga-jaga dan berbénténg! Maka diberi oléh Sultan Palémbang perahu dan beberapa orang yang turut, padahal Sultan di Palémbang itu tiada tahu akan bicara Sultan Ulu itu.

Demikian maka telah lengkap perahunya, maka mudiklah angkatan Méjir Rabsun itu, beberapa banyak perahunya dan orang-orang temannya itu. Maka telah datang kepada bénténg Sultan Palémbang, maka segala periai dan menteri kepala-kepala bénténg itu disuruh Méjir Rabsun turun membawa perahu satu persatu. Maka semuanya periai dan menteri itu dibawa Méjir Rabsun mudik kepada Sultan Ulu.

Setelah Méjir Rabsun itu sampai di Muara Rawas, maka bertemulah dengan Sultan Ulu di bénténg di Muara Rawas, dengan masang bedil, 41 makan dan minum ${ }^{23}$ terlalu / ramainya. Adapun segala periai dan menteri yang daripada bénténg Palémbang itu disuruh oléh Méjir Rabsun itu sujutan minta ampun kepada Sultan Ulu.

Sebermula pada masa itulah Sultan Ulu Mahmud Badaruddin milir dari Muara Rawas dengan racyatnya sekalian ke Palémbang. Maka Sultan Mahmud Badaruddin yang dari hulu itupun masuklah kedalam kota besar itu, sebab sudah dibeli empatpuluh laksa ringgit; dan Sultan yang muda Ahmad Najamuddin berpindah duduk di kota lama dengan sekalian racyatnya. Adapun méjir yang menjumputi Sultan di Muara Rawas, diberinya persén limaribu ringgit. 
10.

10.1. Setelah selesailah Sultan Mahmud Badaruddin itu duduk didalam kota besar itu, maka Méjir Rabsun itu pergi ke Betawi, membawa Pangéran Ratu dan Pangéran Adimenggala, anak Sultan Tua, menerima kasih dapat damai itu lagi diampuni Inggeris. Maka Pangéran Ratu dengan Pangéran Adimenggala itupun pergilah ke Betawi dengan beberapa periai dan menteri temannya itu, dibawa oléh Méjir Rabsun bersama-sama utusan dari Sultan yang muda Ahmad Najamuddin itu.

Maka telah datang ke Betawi, maka Pangéran Wiradiraja, suruhan

42 daripada Sultan Muda Ahmad Najamuddin itu, / ${ }^{24}$ memberitahu kepada Jénderal Galispi yang dia diturunkan daripada kota besar, dipindahkan di kota lama tiada dengan suatu kesalahan dan Sultan Ulu kembali naik kerajaan di Palémbang. Maka Jénderal Raflis itupun terkejut siapa yang punya aturan. Maka nyatalah Méjir Rabsun punya bicara menerima uang harga kota itu empatpuluh laksa ringgit itu Jénderal Raflis tiada suka. Maka Méjir Rabsun itupun terkena tutub di Betawi empat jam lamanya.

10.2. Maka Jénderal Raflis itu ${ }^{25}$ menyuruhkan anak Raja Menggala ke Palémbang hendak menurunkan Sultan Mahmud Badaruddin itu dari kota besar dipindahkan di kota lama, menaikkan Sultan Muda Ahmad Najamuddin di kota besar. Dan Pangéran Ratu terpegang di Betawi, sebab banyak lagi fitnah dari Palémbang; dan Pangéran Adimenggala dengan sekalian periai semuanya boléh pulang di Palémbang. Maka pergilah anak Raja Menggala itu membawa soldadu hampir duaribu. ${ }^{26}$ Sampai di Palémbang menurunkan Sultan Tua dan menaikkan Sultan yang muda Ahmad Najamuddin itu naik kota besar. Dan Sultan yang tua berpindah di kota lama, tiada lagi merintah negeri, tinggal diam.

43 10.3. Adapun Kemas Muhammad yang membicarakan / perdamaian itu, masa itulah diambil menantu oléh Sultan Mahmud Badaruddin, dijadikan dengan puteranya gundik, maka dijenengkan nama Pangéran Kramadiraja. Maka Pangéran Kramadiraja itulah yang jadi kepala bicara Sultan Mahmud Badaruddin menjadi kepala utusan pergi di Menggala bersama-sama dengan Méjir Rabsun. Adapun yang pergi disuruh oléh Sultan Mahmud Badaruddin menjadi utusan di Menggala itu pertama Pangéran Kramadiraja dan Pangéran Natadiwangsa dan Pangéran Sutadiwangsa dan Temenggung Kertanegara dan Rangga 
Ahmad dan ngabéhi lagi. Dan semuanya itu pergilah naik kapal Inggeris bersama-sama Méjir Rabsun dari Betawi ke Menggala.

Telah berapa lamanya, maka sampailah di Menggala, diterimanya oléh Jénderal Menggala seperti adat utusan. Maka berbicaralah utusan Palémbang itu sekaliannya kepada Jénderal Menggala, ditolong oléh Méjir Rabsun itu. Maka putuslah masa itu bicara di Menggala yang Sultan Mahmud Badaruddin tiada boléh lagi menjadi raja didalam negeri Palémbang, lagi sudah memberi surat dengan dibubuh cap menyukai adindanya Pangéran Dipati menjadi sultan di Palémbang.

Maka tetaplah Sultan Mahmud Badaruddin itu duduk di kota lama, tiada lagi merintah; dan dapat beras dan dapat kuli sahaja daripada / 44 adindanya Sultan Ahmad Najamuddin. Itu perintah dari Menggala. Dan dari hal rial empatpuluh laksa ringgit harga kota besar di Palémbang dipulangkan Jénderal Menggala serta diberinya éntrés sepertimana aturan uang dagang. Dan Pangéran Ratu yang terpegang di Betawi itu boléh pulang di Palémbang; demikianlah boléh utusan di Menggala itu. Maka Sultan Mahmud Badaruddin itu tinggal diam di kota lama, tiada masuk perkara apa-apa lagi; tiap musim menyuruh Pangéran Kramadiraja itu ke Betawi, entah apa-apa bicaranya itu.

10.4. Sebermula Sultan yang muda Ahmad Najamuddin itulah yang diatas takhta kerajaan merintah negeri Palémbang seperti dahulukala juga. Akan tetapi tanah Bangka tinggal lagi setengah punya Sultan Palémbang dan setengahnya sudah diambil oléh Inggeris. Dan setahun lamanya, maka datang surat dari Betawi kepada Sultan Palémbang: "Dari itu tanah Bangka, setengah yang tinggal kepada Sultan Palémbang kalau mau dijual, boléh Inggeris beli." Maka dijual oléh Sultan Palémbang kepada Inggeris tanah Bangka yang setengahnya itu; diterima emas lima peti, entah berapa harganya itu.

Make selesailah antara Palémbang dengan Inggeris <se>bagaimana keadaan dengan Holanda dahulu: Inggeris duduk di Palémbang tiada

45 masuk merintah suatu apa-apa, semua perkaranya / sultan punya kuasa. Dan beberapa Sultan Ahmad Najamuddin itu menjenengkan pangéran dan menteri. Adapun saudaranya Pangéran Aryakesuma dan Pangéran Suryakesuma ${ }^{27}$ disalin nama; dan Pangéran Aryakesuma diangkat nama Pangéran Dipati dan Pangéran Suryakesuma diangkat nama Pangéran Aryakesuma. Dan putera Sultan Ahmad Najamuddin itu yang tua sekali dinamainya Prabu Anom dan yang muda Pangéran Jayaningrat dan yang muda lagi Pangéran Jayakrama, yang muda lagi Pangéran Citradiningrat. Dan antara Palémbang dengan Betawi seperti- 
mana keadaan Holanda dahulu juga, utusan pada tiap-tiap tahun, kepalanya nama Pangéran Wiradiraja.

11.

11.1. Syahdan tujuh tahun lamanya Sultan Ahmad Najamuddin itu menjadi raja di Palémbang, maka berganti Inggeris itu, yaitu Kompeni Holanda pula di Palémbang, sebab di Betawi sudah Geburnur ${ }^{28}$ Jénd $<$ er $>$ al Holanda. Belum berapa lama Holanda di Palémbang, maka Sultan Tua yang di kota lama itu menyuruh Pangéran Kramadiraja berbicara dengan Holanda, entah apa-apa tiada ketahua $<n>$.

Maka masuklah orang besar bernama Idelir Ménténg dengan kapal perang satu, masuk Palémbang hendak menurunkan Sultan Muda 46 Ahmad Najamuddin itu di kota lama dan hendak menaikkan / Sultan yang tua Mahmud Badaruddin di kota besar. Maka Sultan yang muda Ahmad Najamuddin itu tiada mau menurut turun berpindah di kota lama itu. Maka dengan kuat perintah Idelir Ménténg itu, tiada juga ia mau pindah di kota lama, sekadar turun dari dalam kota selapis. Tempat rumah tamannya sendiri di Lawang Buratan sebelah ilir dia tutub antaranya dengan kota kayu, < jangan > orangnya ${ }^{29}$ keluar masuk dari Lawang Bura $<\tan >$ itulah. Maka Sultan yang tua Mahmud Badaruddin itupun naik berpindah di kota besar, duduk di sirap, yaitu rumah raja besar. Maka kota lama itu tinggal, sebab Sultan Muda Ahmad Najamuddin itu masih duduk dalam Lawang Buratan di kota besar itu juga, tiada mau ia keluar.

11.2. Maka Sultan Muda Ahmad Najamuddin itu utusan kepada Inggeris di Bangkahulu mengatakan ia diturunkan Idelir Ménténg dariatas takhta kerajaan negeri Palémbang tiada dengan satu sebab, digantinya dengan Sultan Tua yang diturunkan Inggeris di kota lama dahulu. Setelah itu, maka Inggerispun datanglah berjalan darat dari Bangkahulu membawa soldadu tigaratus sipai; nama kepalanya Mista Saman, membawa pula raja-raja Bangkahulu tiga orang, namanya Raja 47 Bangsawan dan Radén Arif dan Radén / Karim.

Maka angkatan Inggeris itu sampailah di dusun Muara Beliti. Maka soldadunya tinggal di Muara Beliti itu, sebab belum banyak perahu membawanya milir ke Palémbang. Hanya yang milir dahulu kepalanya bernama Mista Saman dan Raja Bangsawan dan Radén Arif dan Radén Karim; dan membawa soldadu Bugis tiga orang. Maka lantaslah ke Palémbang dengan sigera. 
Telah sampai di Palémbang, diterima oléh Sultan yang muda itu, didudukkannya di kota lama. Maka sudah bertemu dengan Sultan yang muda itu, maka Inggeris itupun mendirikan bendéra Inggeris diantara kota dua itu. Maka racyat Palémbang pada masa itupun gemparlah, kerana Sultan Muda ditolong Inggeris dan Sultan yang tua ditolong Holanda. Maka racyat Sultan Muda itupun bertambah-tambah banyaklah, hingga Arab-Arabpun banyak, berhimpunlah racyat Sultan Muda itu dengan sikap senjata. Dan periai dan menteripun ada juga dalam Buratan itu menjagai Sultan Muda itu.

Maka Inggeris itupun tidur satu malam di kota lama. Pagi-pagi hari itu datang opsir satu, disuruh Idelir Ménténg kepada Inggeris itu. Maka Mista Saman dengan raja-raja Bangkahulu itupun pergilah menyeberang 48 mendapatkan Idelir Ménténg; / dan semuanya itu tiada lagi kembali di kota lama. Sudah bertemu Idelir Ménténg, entah apa-apa bicaranya, maka Inggeris itupun lalu turun ke perahu, diantar pulang ke Bangkahulu, dari laut berlayar.

11.3. Syahdan pada masa itu gemparlah segala racyat Sultan yang muda Ahmad Najamuddin di Lawang Buratan, semuanya bersikap senjata menengar Inggeris sudah keluar dari kota lama mendapatkan Idelir Ménténg dan bendéra Inggeris itupun masih ada terdiri diantara kota dua itu. Adapun di kota besar sebelah Sultan yang tua Mahmud Badaruddin itupun gemparlah pula segala punggawa menteri dan racyatnya, semua dengan menyikap senjata hendak menolong Holanda merubuhkan bendéra Inggeris di Lawang Buratan itu.

Setelah itu, maka datanglah soldadu Holanda dengan rac ${ }^{c}$ yat Siak, kepalanya Raja Akil, dan racyat dari Sultan Tua Mahmud Badar<uddin> itu, semuanya dengan nyikap senjata mengiringkan soldadu Holanda itu berjalan semuanya di Lawang Buratan itu hendak membuangkan bendéra Inggeris itu, sebab ra $^{c}$ yatnya Sultan yang muda itu banyak dengan alat senjatanya menjagai bendéra itu. Setelah datang angkatan baris Holanda dan racyat sebelah Sultan Tua itu, hampirlah

49 berkelahi dengan rac $^{c}$ yat / Sultan yang muda itu, sebab sama banyak dengan senjatanya senapang pemuras dan tombak pedang tiada terkirakira lagi pada masa itu. Dan kapal perang Holanda itupun sudah mendekat di tepi darat itu dengan siaganya. Maka soldadu Holanda itupun selalu berjalan dengan racyat sebelah Sultan Tua Mahmud Badaruddin itu. Maka telah sampai antara kota dua itu, maka ${ }^{30}$ ditebang oranglah tiang bendéra Inggeris itu. 
11.4. Sudah dibuangkan bendéra Inggeris itu, maka muara Lawang Buratan, tempat Sultan Muda Ahmad Najamuddin itupun, dijaga soldadu tiga lusin dari Holanda dengan racyat Sultan Tua Mahmud Badaruddin. Maka orang masuk Lawang Buratan itu tiada boléh, dilarangkan oléh soldadu Holanda; dan orang keluar boléh. Antara berapa lamanya, maka diberi kunci pintu itu oléh Holanda; terbuka cuma tiga kali sehari orang ambil air di kali. Dan periai dan menteripun ada juga yang lagi dalam tutub sama-sama Sultan Muda Ahmad Najamuddin didalam Lawang Buratan itu dan Pangéran Dipatipun ada turut ditutub dalam Buratan itu. Demikianlah halnya.

Adapun Sultan Tua Mahmud Badaruddin itulah yang diatas kota 50 besar merintah negeri Palémbang bersama dengan / Idelir Ménténg. Dan adindanya Pangéran Aryakesuma diangkat oléh Sultan Tua itu Pangéran Dipati. Maka menjadi dualah nama Pangéran Dipati di Palémbang: Dipati yang tua ada didalam tutub bersama-sama Sultan Muda didalam Buratan dan Pangéran Dipati yang muda turut Sultan Tua merintah Palémbang. Demikianlah pada masa itu. Adapun Sultan yang muda didalam Buratan itu kira-kira ada tiga bulan lamanya, maka Pangéran Dipati Tua itupun dikeluarkan oléh Idelir Ménténg daridalam Buratan itu, dipulangkan di kampungnya sendiri, dijaga soldadu ${ }^{31}$ Holanda satu lusin di kampung Pangéran Dipati itu.

Maka tiada berapa lamanya, Sultan Muda itu turunlah di kapal dengan sekalian anak-anaknya dan segala periai yang turut itu, semuanya dibawa di Betawi. Telah sampai di Betawi, lalu dibawa di Sinjur ${ }^{32}$ Sultan Muda itu dan periai yang turut itu setengahnya didudukkan di Sumedang dengan dipelihara betul dengan gajih sekaliannya itu.

12.

12.1. Alkissah maka tersebutlah pula di Palémbang. Sesudah keluar Sultan Muda itu ke Betawi, maka Idelir Ménténg itupun hendak mudik Musi, sebab soldadu Inggeris tigaratus itu masih bertunggu di dusun Muara Beliti belum tahukan tuannya sudah pulang ${ }^{33}$ berperahu ke

51 Bangkahulu itu. Maka / Idelir Ménténg itupun minta beberapa perahu dan orang dan periai menteri kepada Sultan Mahmud Badaruddin. Maka mudiklah Idelir Ménténg itu dengan angkatan besar sepertimana adat raja di Palémbang membawa beberapa soldadu dan racyat daripada Sultan Palémbang itu. Telah berapa lamanya mudik itu, maka sampailah di Muara Beliti, bertemulah dengan Inggeris itu. Maka Inggeris itupun pulanglah semuanya ke Bangkahulu. Setelah demikian, 
maka Idelir Ménténg itupun milirlah pula ke Palémbang, duduk bagai selamanya berkasih-kasihan dengan Sultan di Palémbang.

12.2. Syahdan telah berapa lamanya, maka Idelir Ménténg itupun mendapat $<$ kan $>$ Sultan di pemarakan. Di hadapan sekalian punggawa menteri dan orang besar-besar sekaliannya itu berhimpun, maka Idelir Ménténg itupun menerimalah segala pucukan negeri Palémbang, yaitu segala huluan Batangari Sembilan itu semuanya lepaslah daripada Sultan Palémbang, terserahlah kepada Idelir Ménténg sekaliannya itu. Hingga désa-désa pegangan periai dan menteri itu Idelir Ménténg semua yang punya kuasa, tiada lagi kepada Sultan Palémbang; melainkain ada juga lagi yang tinggal kepada Sultan Palémbang beberapa dusun, pegawainya dan pemakannya itu.

12.3. Sebermula telah selesailah segala désa-désa pucukan itu semua52 nya / kepada Idelir Ménténg, maka tiada berapa lamanya antara itu maka Idelir Ménténg itupun minta beberapa perahu kepada Sultan, kerana ia hendak mudik akan meriksa dan menjatuhkan perintah kepada segala huluan. Maka telah selesai, maka Idelir Ménténg itupun mudiklah dengan angkatan besar, membawa beberapa soldadu dan periai dan menteri, semuanya turut dengan membawa racyatnya. Maka telah angkatan itu sudah jauh ke hulu, maka orang huluan yang jauh-jauh itu banyak menakal dan melawan dan mencuri-curi membunuh ra ${ }^{C} y a t$ Holanda, tiada boléh léna. Dan di dusun Semangus kepalanya pangéran mati dipasang Holanda, sebab hendak membuat jahat kepada Holanda. Maka sudah jauh ke hulu angkatan itu, bertambah-tambah keras berjaga, kerana orang jahatpun bertambah-tambah banyak, orang Melayu dan lainnya. Maka Idelir Ménténg itupun suruhan ke Palémbang. Milir sampai di Muara Rawas, kelihatan ada bénténg Melayu di Muara Rawas itu. Banyak orang berhimpun di situ dengan alat senjatanya cukup, hendak menanti Holanda milir itu. Maka ada satu menteri Sultan dari Palémbang disuruh mudik kepada Idelir Ménténg. Setelah datang kepada Idelir Ménténg itu, ditangkap, disuruh Idelir Ménténg tutub.

53 Entah apa-apa bicaranya orang kecil tiada tahu, / maka berapa lamanya demikian itu maka Idelir Ménténg itupun milirlah dengan sekalian racyatnya. Telah sampai di Muara Rawas, maka peranglah dengan bénténg Melayu itu. Pada ketika itu juga bénténg itu dapat, orang Melayu itupun habis lari semuanya. Maka angkatan Idelir Ménténg itu selalulah milir. Maka sampailah di Palémbang pada siang 
hari. Dan pada masa itu dua kapal perang di Palémbang dan dua sikunyir perang dan satu kora-kora. Dan angkatan milir itu terlalu ramainya masang senapang dan dari kapal perangpun memasang meriam memberi selamat. Dan pangéran itupun disuruh Sultan memberi selamat kepada Idelir Ménténg. Maka perahu Pangéran Ratu itu disuruh usir, jangan mendekat perahu Idelir Ménténg. Dan Pangéran Dipati Muda sahaja yang boléh memberi selamat bertemu dengan Idelir Ménténg itu.

13.

13.1. Dan telah Idelir Ménténg di Palémbang, maka kota lama yang tinggal itu disuruh Idelir Ménténg tunggu dengan soldadu Holanda seratus tujuhpuluh banyaknya didalam kota lama itu. Maka antara beberapa hari Idelir Ménténg itupun menyuruh syahbandar Holanda nama Parkenan ${ }^{34}$ dengan Pangéran Syarif Muhammad mendapatkan Sultan Mahmud Badaruddin itu; tiada lagi berhenti datang. Entah apa-apa $\mathrm{da}^{\mathrm{C}}$ wa Idelir Ménténg tiada tahu; hanya yang nyata kepada 54 segala racyat / negeri Idelir Ménténg minta Pangéran Ratu dengan beberapa pangéran-pangéran yang dibawah Sultan itu hendak dibawa ke Betawi semuanya.

Dan pada masa itu datanglah rusak antara Sultan Palémbang dengan Idelir Ménténg. Dan sehari-hari dia minta juga itu Pangéran Ratu serta sekaliannya pangéran-pangéran yang dibawah Sultan itu, tak dapat tidak. Demikianlah jawab Sultan: "Memberikan tidak, melawan tiada." Dan orang negeri Palémbangpun gemparlah dan Sultanpun jaga hari malam, menyuruh membaiki meriam diatas kota dan masukkan obat peluru kedalam ${ }^{35}$ kota. Maka kapal perang itupun mendekatlah dimuka kota, <satu> sebelah ulu dan satu di sebelah ilir, dan sikunyir perang dan kora-kora itu semuanya menutub muara Ogan, jaga di sana. Maka Palémbangpun goyanglah, segala haji-hajipun pada berhimpun di mesjid dan orang negeri dan orang hulupun banyaklah masuk kota sultan.

Sebab kata suruhan Idelir Ménténg kepada Sultan jika Pangéran Ratu tiada diberikan pada hari itu, kota sultan itu hendak dipasang oléh kapal perang dengan meriam, satu jam boléh rata dengan bumi, maka dalam kotapun sikaplah sekalian alat senjata. Dan diatas kota sebelah ulu kepala perangnya menantu Sultan nama Pangéran Krama55 diraja dan diatas / kota yang sebelah ilir kepala perangnya Pangéran Kramajaya, mantu Sultan juga, dan diatas kota sebelah darat, gandok sebelah ilir itu, kepala perangnya Pangéran Citra dan di pintu kota besar itu empat menteri. 
Dan semuanya yang tersebut itu dengan beberapa $\mathrm{ra}^{c}$ yatnya bersedia menantikan perintah Sultan. Maka segala haji-haji itu disuruh berhimpun diluar kota didalam pemarakan pada hari itu dan semuanya hajihaji itu pada berzikir, terlalu ramainya dengan berkuat suaranya. Setelah demikian, kedengaranlah kedalam kota lama kepada Holanda suara ramai-ramai itu.

13.2. Maka datanglah satu opsir dengan soldadu Jawa satu pergi kepada pemarakan itu meriksa apa suara orang ramai-ramai itu. Telah datang opsir dengan satu soldadu itu di pemarakan itu, maka sekalian haji-haji itu gempar berangkat semuanya mengunus senjatanya. Maka opsir dan soldadu satu itu lari masuk kota lama. Diusir juga oléh haji itu semuanya masuk kota lama, maka dipasang oléh soldadu banyak itu. Maka haji itupun kembali. Yang laju mengamuk itu Kemas Said dan Haji Zain dan Haji Lanang; semuanya itu mati <dipasang > baris Holanda didalam kota lama itu.

Maka dipasang orang dariatas kota besar itu soldadu di kota lama 56 itu dengan beberapa meriam dan léla. / Kerana dekat di situ, maka buluwarti kota ulu dan ilir itu membedillah kapal perang itu hingga tiga kali. Maka kapal perangpun membalaslah keduanya memasang meriam, membedil kota sultan itu; dan dari kota lama itu masang senapang juga membedil kota sultan, dan perahu perang yang di muara Ogan itu semuanya sama membedil kota sultan.

Maka peranglah terlalu ramainya dengan tempik dan soraknya segala racyat Palémbang yang diatas kota sultan itu, kerana peluru kapal itu tiada mengapa, kena kota itu kira-kira masuk di batu kota $\mathrm{cu}<\mathrm{ma}>$ satu kilan. Adapun orang Palémbang yang banyak kena peluru itu: yang diatas kota pegawai meriam itu. Dan kapal perang itu semuanya tiada perdulikan orang negeri semua; hanya yang dibedil kapal itu kota sultan itu juga.

13.3. Adapun mula-mula tampil berperang itu pukul tiga siang dan pukul enam malam berhenti. Dan buka siang pagi-pagi pukul setengah enam tampil pula perang itu semuanya kapal perang dengan kota sultan. Kira-kira pukul sepuluh maka naik baris Holanda beberapa banyak. Maka pintu kota itu ditutub teguh. Maka penuhlah baris itu ${ }^{38}$ diluar pintu kota itu, mengapak pintu itu akan dibuka soldadu

57 hendak / masuk kota. Maka dapat lobang sedikit dikapak itu. Maka ditombak orang daridalam kota itu, kena tukang tambur, lalu mati. Maka undur sedikit soldadu semuanya itu, maka dibedil orang Palém- 
bang dariatas pintu kota itu dengan meriam dan léla dan pemuras ${ }^{37}$ dan senapang. Maka soldadu itupun undurlah semuanya.

13.4. Sebermula pada hari itu juga datang suruhan Idelir Ménténg. Yang disuruhnya itu Raja Akil, orang Siak, kepada Pangéran Dipati Tua, Idelir Ménténg minta témpoh empat hari. Maka disampaikan oléh Pangéran Dipati Tua kepada Sultan; maka dikabulkan oléh Sultan. Dan menengar Holanda minta témpoh itu, bertambah-tambah banyaklah orang negeri masuk kota itu membawa senjata.

Syahdan setelah genaplah témpohnya empat hari itu, maka perang pula dari pagi-pagi. Tengah hari semuanya kapal dan perahu perang itupun undurlah keluar sekaliannya, Holanda dalam Palémbang tiada lagi. Maka yang menteri-menteri Palémbang yang masuk pekerjaan Idelir Ménténg itu pengalasan dibunuh Sultan, dipotong léhérnya di pangkalan pasar. Dan Demang Wiralaksana disuruh bunuh di dusun Belidah dan Kemas Abang dan Kemas Kusin, jurutulis Idelir Ménténg, 58 dibunuh keduanya di dusun Belidah; dan $/{ }^{38}$ beberapa banyak orang yang dibuang oléh Sultan pada masa itu. Dan Pangéran Syarif Muhammad dan kapitan-demang orang Cina semuanya itu turut Holanda keluar itu. Beberapa banyak orang Cina yang lari dari Palémbang pada masa itu, dibawa oléh wangkang. Dan orang Palémbangpun ada juga yang lari turut Holanda pada masa itu.

\section{4.}

14.1. Adapun Sultan di Palémbang, sudah Holanda habis keluar itu, maka bersikaplah kota dua itu. Beberapa meriam itu dan léla diatur diatas kota dua itu. Dan di tepi laut dari tangga kota sampai di Sungai Tengkuruk dibuat bénténg, diatur meriam beberapa banyak pula di situ. Dan semuanya orang hulu diilirkan membuat pula bénténg di ilir negeri, di muara Plaju, dinamai Tambakbaya. Dan membuat pula bénténg di ulu Tambakbaya itu bernama Martapura dan beberapa pula bénténg antara Tambakbaya dengan Martapura itu bénténg lain-lain. Dan di seberang kanan mudik itu, di buntut Pulau Kembara suatu bénténg, kepalanya Pangéran Suradilaga, dengan beberapa pangéranpangéran dan punggawa menteri di situ. Di Tambakbaya itu kepalanya Pangéran Kramadiraja, mantu Sultan, dengan beberapa periai dan menteri di situ. Dan di bénténg Martapura itu tempat Pangéran Ratu 59 dan Pangéran Dipati keduanya. / Maka ditengah laut itu dibuatkan 
pulau perahu kici dan penjajab dimuati batu, ditenggelamkan di situ. Dan orang milir mudik sampai di pulau itu menjatuhkan batu satu hambung. Maka jadilah pulau, dibuat bénténg beberapa meriam dan léla di situ, dinamai Pulau Manguntama. Kepalanya di situ Pangéran Wirasentika, dengan beberapa periai dan menteri di situ.

Maka dibuatkan pula cerocok namanya: kayu besar-besar lalau itu dari seberang kiri sampai di seberang kanan dengan batang-batang pula kayu besar menutub batangari itu. Dan muara itu ditutub dengan cerocok dan di selat Pulau Kembara itu diberi cerocok dengan berapa penjajab dan perahu pakai ampilan jaga di selat itu, di muara Plaju itu demikian juga. Syahdan dengan rakit api beberapa banyak, kerana tiap orang Cina di Palémbang satu rakit, satu memberikan rakit api dimuati kayu. Setelah kukuh di Palémbang, maka di Batangari Komering pula dijagai dibuatkan bénténg, kerana di situlah jalan menyebelah di Lampung kerana di Lampung itu Holanda. Maka kepalanya di bénténg dusun Kurungan Nyawa itu Pangéran Wiradiwangsa dengan beberapa periai dan menteri temannya jaga di situ. Maka di situpun kerap kali perang dengan Holanda dari Lampung itu.

60 14.2. Sebermula maka / didalam tahun itu juga masuk angkatan Jénderal Sekaubenah, beberapa kapal perang dan sampan pukat orang Cina. Dan angkatan itu datang dengan Idelir Ménténg serta membawa anak Sultan Ahmad Najamuddin yang di Sinjur itu, nama Pangéran Jayaningrat. Dan Pangéran Jayakrama dan patih Sultan Ahmad Najamuddin itupu $\langle\mathrm{n}\rangle$ turut juga dibawa angkatan itu. Adapun jikalau dapat negeri Palémbang pada masa itu, dijanjikan Pangéran Jayaningrat jadi sultan di Palémbang. Maka masuklah angkatan Jénderal Laut bernama Jénderal Sekaubenah itu serta sekalian kapal perang dan perahu perang itu. Adapun orang Sungsang pada masa itu sudah pindah di Palémbang semuanya. Maka angkatan itu telah berapa lamanya mudik itu, di jalan-jalan itu kena bedil maling, yaitu meriam dari hutan. Setelah datang di ilir bénténg nama Sungai Kundur, berhentilah angkatan itu sekalian di situ; kelihatan dari bénténg, tetapi tiada datang peluru.

Idelir Ménténg dengan jénderal itupun utusan kepada Sultan di Palémbang. Yang disuruhnya itu nama Si Gangsa, orang Palémbang, budak Pangéran Wirakrama, patih Sultan yang di Sinjur itu. Maka datanglah Si Gangsa itu di perahu sampan pukat ke bénténg Tambak-

61 baya / memberikan surat daripada Idelir Ménténg, beberapa kali dan dibalas Sultan beberapa kali surat itu. Entah apa bicara dalam surat 
itu tiada tahu. Dan utusan Sultan kepada Idelir Ménténg di kapal itu namanya Si Kodak. ${ }^{39}$ Maka tiada juga dapat bicara damai itu.

14.3. Maka pada suatu hari angkatan itu mendekat bénténg, lalu menjadi perang besarlah pada hari itu. Sekalian kapal dan perahu perang itu berebut cepat membedil bénténg itu semuanya dan segala bénténg itupun sama berebut orangnya membedil kapal itu. Maka seperti ujanlah peluru sebelah-menyebelah itu, seperti bunyi ribut; dan jatuh di laut itu seperti kawanan ikan. Maka berguncanglah sekalian bénténg itu sebab gentar meriam itu, istiméwa pula meriam kapal perang itu seperti kilat seribu terlalu cepat. Maka asap bedil itupun penuhlah lautan itu. Padang terang suaca menjadi kelamkabut, tiada kelihatan lagi kapal itu, hanya kilat meriam itu juga yang nampak daripada bénténg itu. Semuanya $\mathrm{ra}^{c}$ yat itu sama berebut masang meriam, tiada ingatkan mati lagi. ${ }^{40}$

Maka empat jam lamanya perang itu, maka berhenti. Semuanya kapal 62 itu undurlah semuanya, / lalu milir selalulah ke Sungsang, lalu berlayar ke luar semuanya. Setelah sudah Holanda itu tiada lagi perahu semuanya itu, maka segala punggawa menteri itu mudik ke Palémbang mengadap Sultan. Maka sekaliannya itu diberi pesalin, hingga pasirah perwatin, masing-masing dengan kadarnya.

14.4. Maka bénténgpun bertambah-tambah teguh. Segala akal Palémbang dan ulu semuanya itu dibuat segala. Maka segala bénténg itu mangkin bertambah-tambah ramainya sepertimana negeri, kerana orang hulu semuanya berhimpun di situ. Adapun pada masa itu beras terlalu murah. Dan yang mahal garam, sebab dagang Jawa tiada datang; cuma perahu kecil-kecil dari Lingga itulah yang membawa garam. Tetapi orang Palémbang sudah bisa membuat garam. Dan membuat obat dan membuat peluru meriampun sudah tahu. Maka banyaklah utusan raja-raja Melayu datang kepada Sultan di Palémbang, seperti Lingga dan Riau dan Sambas, semuanya menolong obat dan peluru.

Sebermula telah berapa lamanya, maka Sultan Palémbang bergelar nama Suhunan Mahmud Badaruddin dan Pangéran Ratu diangkat nama Sultan Ahmad Najamuddin ditengah pemarakan di hadapan punggawa menteri dan orang besar-besar dan segala orang alim-alim

63 dan / tuan Arab dan pasirah huluan, semuanya berhimpun pada masa itu terlalu ramainya makan dan minum.

Maka telah selesailah daripada itu berapa lamanya, maka datanglah pula Pangéran Ratu Jambi akan menolong perang dengan Holanda; 
maka diterima oléh Suhunan Palémbang. Maka dibuatkan pula satu pulau di kiri Pulau Manguntama, tempat Pangéran Wirasentika itu, dengan beberapa meriam dan léla, dengan $\mathrm{ra}^{c}$ yatnya dengan alat senjatanya lengkap, dinamai Pulau Pangéran Ratu Jambi. Demikianlah Palémbang pada masa itu. Tiada berhenti lagi Suhunan menyuruh membaiki bénténg dan meriam dan membuat obat dan membuat peluru, serta dengan bersuka-sukaan didalam negeri, <se-> bagaimana aturan raja pada masa zaman dahulukala.

15.

15.1. Alkissah maka tersebutlah pula Sultan Ahmad Najamuddin yang di Betawi itu. Sudah tiga tahun lamanya ia duduk di negeri Sinjur itu, maka pada masa angkatan Holanda undur daripada perang Palémbang maka pada suatu ketika Sultan Ahmad Najamuddin itu dipanggil Geburnur-Jénderal Kapélah itu di negeri Bogor dengan sekalian punggawa menterinya dan racyatnya semuanya. Maka Sultan Ahmad Najamuddin itupun bertemulah dengan Geburnur-Jénderal Kapélah itu di negeri Bogor.

Dan pada masa itulah Sultan Ahmad Najamuddin itu diangkat oléh 64 Jénd<er>al Kapélah nama / Suhunan Husin Dia'uddin dan anaknya yang tua nama Prabu Anom itu diangkat nama Sultan Ahmad Najamuddin. Adapun negeri Palémbang itupun dipulangkan kepada Suhunan Husin Dia'uddin sepertimana keadaan lama juga. Dan apabila sampai di Palémbang, buatkan kota bambu Kompeni di seberang; maka Suhunan Husin Dia'uddin itu masuk kota seperti lama juga, dan semuanya itu dengan kontraknya.

Adapun yang asal hendak diangkat sultan itu Pangéran Jayaningrat, anak Suhunan Husin Dia'uddin itu yang turut perang Palémbang. Maka Suhunan Husin Dia'uddin itupun minta, kerana telah aturan dari dahulu-dahulu selamanya di Palémbang anak yang tua itulah menjadi raja; maka sebab itulah maka Prabu Anom dijadikan sultan. Maka kata Geburnur-Jénd<er>al: "Jika demikian, sampai di Palémbang jangan yang lain dibawah Sultan Prabu Anom itu melainkan Pangéran Jayaningrat juga, semua bicara negeri dibawah Sultan Prabu Anom itu."

Syahdan tatkala mengangkat nama Suhunan Husin Dia'uddin dengan anaknya Sultan Ahmad Najamuddin itu di negeri Bogor terlalu ramainya. Segala tuan-tuan dan orang besar-besarpun berhimpun semuanya di hadapan Geburnur-Jénderal, serta masang meriam dan baris, dengan 
beberapa persén Geburnur-Jénderal kepada Suhunan Husin Dia'uddin 65 itu hingga anak-anaknya sekalian. Maka setelah / selesai daripada itu, maka Suhunan Husin Dia'uddin itupun dengan Sultan Ahmad Najamuddin itu disuruh pulang ke Palémbang bersama-sama dengan Tuan Jénderal Dekok ${ }^{41}$ melanggar Palémbang. Syahdan tiadalah lagi dilanjutkan perkhabaran itu di sini.

15.2. Maka Jénderal Dekok itupun berangkatlah dari Betawi, angkatannya beberapa kapal perang dan perahu perang, disuruh GeburnurJénderal Kapélah melanggar Palémbang bersama-sama dengan Suhunan Husin Dia'uddin dan Sultan Ahmad Najamuddin. Adapun Suhunan Husin Dia'uddin itu anak-beranak di perahu kici besar dengan beberapa tuan-tuan meliharakan dia. Maka angkatan Jénd<er>al Dekok itupun berlayarlah. Telah berapa lamanya, maka sampailah di Palémbang, lalu masuk di Sungsang, lantas dimuka bénténg, tetapi tiada datang peluru dari bénténg. Di sanalah semuanya angkatan itu berlabuh, nama sungai Kun $<d>$ ur, penuhlah laut itu oléh perahu angkatan itu. Dan pada tatkala itu orang Sungsang tiada sempat mudik ke bénténg, lalu turut kepada Suhunan Husin Dia'uddin. Dan orang Sungsang itulah yang memberitahu di mana-mana meriam dalam hutan, yaitu bedil maling; semuanya dibuang oléh Holanda.

15.3. Sebermula Palémbangpun gentarlah melihat angkatan Holanda datang itu. Maka segala punggawa menteri dan pangéran-pangéranpun pergilah milir ke bénténg, masing-masing di mana-mana tempat meriam

66 tungguannya. / Dan orang Arab-Arab dan orang Cina semuanya itu pada pergi di bénténg membawa senjata masing-masing; dan beberapa $\mathrm{ra}^{\mathrm{C}}$ yat yang bersediakan rakit api, dibawa di bénténg.

Adapun di muara Plaju itu kepala bénténg Tambakbaya itu Pangéran Kramajaya, menantu Suhunan juga, kerana Pangéran Kramadiraja itu sakit terlalu sangat kurusnya. Itu sebab maka diganti o<léh $>$ Pangéran Kramajaya jadi kepala sekalian punggawa menteri di Tambakbaya ${ }^{42}$ itu. Dan di bénténg Pulau Kembara itu Pangéran Kramadilaga jadi kepala sekalian punggawa menteri di situ. Dan di Pulau Manguntama yang baharu dibuat itu Pangéran Wirasentika jadi kepala sekalian punggawa menteri di situ. Dan di pulau yang baharu dibuat tempat Pangéran Ratu Jambi itu maka Pangéran Ratu Jambi itulah kepalanya di situ. Dan beberapa pula perahu penjajab dan perahu berampilan dan perahu Bugis yang tolongan mendari Lingga itu, kepala Bugis itu Cik Nauk namanya. Dan semua perahu-perahu itu di kanan kiri pulau 
ditengah laut itu juga. Dan beberapa bénténg berjalan, yaitu rakit diberi meriam, mengapit pulau ditengah laut itu dengan Pulau Pangéran Ratu Jambi itu. Adapun di bénténg Martapura itulah tempat Sultan dan Pangéran Dipati keduanya dan Pangéran Bupati. Dan orang besar-

67 besar semuanya banyak di situ dan orang Arab-Arab, / itupun segala bénténg ada orang Arab, masing-masing dengan senjatanya. Maka semuanya bénténg itu sama bersikap menantikan angkatan Holanda itu mendekat perang. Terlalu ramai bénténg itu berjaga-jaga malam dan siang, makan dan minum bersuka-sukaan segala punggawa menteri demikianlah.

15.4. Syahdan pada masa itu tiada lagi utusan orang membawa surat dari Jénderal Dekok dan Suhunan. Dari laut itu surat dihanyutkan, diberi tunggul putih. Itu surat dimasukkan didalam botol, ditutub teguh; dan diambil dari bénténg, diberikan kepada Sunan di Palémbang. Dan Sunan di Palémbang itupun membalas surat kepada jénderal, begitu juga dihanyutkan milir dalam botol, dikasih tanda tunggul putih. Beberapa kali sudah berkirim surat dari kapal dan dari Palémbang berbalas-balasan beberapa hari itu. Entah apa-apa bicara itu tiada tahu orang kecil.

15.5. Maka pada suatu hari Holanda berbabat jalan didalam hutan. Kepalanya Kirangga Wirasentika, ${ }^{43}$ menteri Sunan yang dari Betawi itu. Adalah membuat jalan itu hendak menjalankan soldadu Holanda turun ke Batangari Plaju itu dengan sampan, hendak mengambil belakang bénténg Tambakbaya itu. Dan belum sempat turun soldadu itu semuanya, maka ketahuanlah perahu Palémbang banyak yang jaga di

68 Batangari Plaju itu. Lalu perang / soldadu Holanda didalam hutan dan perahu Palémbang semuanya dari Batangari Plaju, terlalu ramainya dengan tempik dan sorak. Sebentar perang itu, maka orang Palémbang itupun pada naik ke darat hendak beramuk. Maka Holandapun undurlah. Haripun malam, maka apa-apa yang dapat orang Palémbang didalam hutan itu disembahkan kepada Sunan di Palémbang. Adapun jika hari malam, Holanda masangkan meriam, dengan sampan mendekat bénténg. Dari bénténg itupun demikian juga malam-malam memasang kapal itu dengan meriam. Demikianlah kelakuan bénténg dan kapal itu sebelum perang besar itu.

15.6. Syahdan telah berapa hari lamanya angkatan besar itu semuanya di pelabuhan, maka pada suatu malam Arbac, pukul lima, angkatan 
besar itu mendekat bénténg. Kepada sembilan $<$ belas $>{ }^{44}$ hari bulan Ramadan, hari Arbac, pukul enam, tarikh seribu duaratus tigapuluh enam tahun, maka memulai perang itu. Pukul enam maka menjadi perang besarlah antara bénténg sekaliannya itu dengan kapal perang dan perahu perang itu, semuanya sama berebut cepat membedil bénténg dan pulau di laut itu semuanya serta dengan memasangkan gurnat, tiada lagi berhenti. Dan dari bénténg itu semuanya sama berebut cepat memasang kapal dan perahu perang itu, dengan tempik dan sorak terlalu ramainya gegak gempita, tiadalah kedengaran apa-apa lagi. Maka seperti ujanlah peluru meriam sebelah-menyebelah itu, seperti 69 bunyi ribut; / dan jatuh di laut itu seperti kawanan ikan. Maka berguncanglah segala bénténg itu sebab gentar meriam, beserta tempik dan sorak dengan segala bunyi-bunyian didalam bénténg itu sekaliannya. Istiméwa pula meriam dari kapal itupun terlalu cepat pelurunya. Terkena bénténg itu bergoyang seperti akan rungkat rasanya bergoyang. Dan beberapa kayu di hutan itu pada putus dan rubuh terkena peluru kapal dan perahu perang itu semuanya. Maka asap bedil itupun penuh batangari dan hutan itu. Padang terang suaca menjadi kelamkabut, tiadalah kelihatan lagi kapal itu, hanya kilat meriam juga yang nampak daripada bénténg itu. Maka segala orang bénténg itupun berebut cepat masang meriam kepada kapal itu, tiadalah ingatkan mati lagi, dengan tempik soraknya gegak gempita seberang-menyeberang terlalu ramainya. ${ }^{45}$

15.7. Maka kira-kira pukul dua berhentilah perang itu. Angkatan itupun undurlah, semua kapal dan perahu perang itupun milir kembali $<$ ke $>$ tempat labuhannya lama. Maka tinggallah itu perahu Holanda dua langbut lapis tembaga. Dapat oléh Pulau Manguntama satu, lalu dibakar; dan satu dapat di Pulau Kembara, tiada dibakar. Meriam langbut itu tembaga besar dinaikkan di Pulau Kembara, yang satunya

70 besi dinaik juga di bénténg Pulau Kembara itu. / Dan perahu langbut yang dapat oléh bénténg Pulau Kembara itu dibawa ke Palémbang, kepada ${ }^{46}$ Sunan. Dan langbut yang dibakar di pulau Pangéran Wirasentika itu meriam tembaga besar itu jatuh dalam air dan meriam besi yang di burinya itu diambil dinaik di Pulau Manguntama itu. Dan kapal Nasu pada masa itu putus tiang haluannya dan putus cucurnya, kena bedil bénténg Tambakbaya nama Si Goyang itu terlalu besar. Dan tiap-tiap kapal yang undur itu jangkarnya besi itu tinggal, diambil oléh orang bénténg. 
15.8. Sebermula selang empat hari dari hari itu, kepada malam Ahad, pukul empat, angkatan Holanda itupun mendekat pula ia di bénténg, beberapa kapal perang dan perahu perang. Maka pukul enam memulai perang itu; terlebih keras dari semula semuanya kapal itu memasang bénténg itu semuanya. Maka jadilah perang besar itu, dari kapal dan dari bénténg sama berebut cepat masang meriam, dengan tempik dan sorak. Adapun pada malam itu Sultanpun ada di Palémbang dan periai dan punggawa menteri itupun banyak di Palémbang, kerana pada sangka-sangka hatinya sekalian tiada akan Holanda melanggar, sebab bésok pagi hari Minggu. Maka Sultan dan pangéran-pangéran itu didalam perang itu juga ia masuk di bénténg dan punggawa menteri itu masing-masing pulang kepada tempat bénténgnya.

71 Maka perang itupun / bertambah-tambah keras dan bertambah besar dan cepatnya dari kapal itu semuanya. Dan gurnat itupun jatuh ke bénténg itu tiada lagi berhenti, pecah didalam dan diluar bénténg itu semuanya. Maka kira-kira pukul tujuh bénténg Pulau Kembara dapat oléh Holanda; maka bersalinlah bénténg Pulau Kembara itu bendéra Holanda. Dan Pangéran Ratu Jambipun membakar bénténgnya sendiri, sebab melihat bénténg Pulau Kembara itu sudah dapat ditunggu Kompeni itu. Adapun bénténg Muara Plaju dan bénténg Martapura itupun semuanya masih perang. Adapun dua perahu langbut masuk selat Pulau Kembara itu, mudik ke hulu akan datang dari belakang bénténg itu sekaliannya. Setelah langbut dua itu datang dari hulu bénténg itu, maka semuanya bénténg itu berhentilah daripada membedil kapal itu semuanya. Maka Sultan dan periai dan menteripun pulanglah berjalan darat ke Palémbang semuanya; dan pukul satu dapat bénténg sekaliannya itu oléh Holanda. Maka segala soldadupun menaiklah sama membakar bénténg itu sekaliannya. Maka berhentilah di situ Jénderal Dekok dengan Suhunan Husin Dia'uddin.

15.9. Syahdan dari hal Suhunan di Palémbang itu bersikap didalam kota dua itu, akan melawan itu terlebih teguh daripada bénténg sekaliannya. Kira-kira tiga hari lamanya orang kecil-kecilpun habislah

72 lari, maka Suhunan Palémbang/pun lalu bicara damai dengan Jénderal Dekok. Maka segala kapal itupun mudiklah ke Palémbang semuanya. Maka Sultan, anak Suhunan dari Betawi itu, pergilah mengadap Suhunan di Palémbang. Maka Suhunan Palémbangpun berpindahlah ke luar daridalam kota, lalu duduk di rumah Pangéran Dipati Tua dengan sekalian racyatnya. Dan tiga hari Suhunan Palémbang itu di rumah Pangéran Dipati Tua, maka turunlah semuanya di kapal perang dengan 
sekalian anak-anaknya. Tiada berapa ha $<$ ri $>$, lalulah mintar ke Betawi. Maka telah sampai di Betawi, naik di Cilincing. Beberapa hari di situ, maka ${ }^{47}$ turunlah pula di kapal, lalu dibawa di Pulau Mengarai, didudukkan dalam bénténg, diambil segala hartanya. Beberapa bulan di situ, lalu dibawa di Teranati ${ }^{48}$ dengan sekalian anak-anaknya. Maka duduklah Suhunan Mahmud Badaruddin itu di negeri Teranati dengan sekalian racyatnya itu, semuanya dipeliharakan dari Holanda, makan dan pakaian segala rac $^{c}$ yatnya.

16.

16.1. Alkissah maka tersebutlah perkataan Suhunan Husin Dia'uddin dengan anaknya Sultan Ahmad Najamuddin itu. Setelah dapat Palémbang, maka Suhunan itupun belum masuk kota. Sebab Holanda minta buatkan tempat di seberang, kota bambu saja; apabila Holanda sudah pindah di seberang, maka Suhunanpun masuk kota.

Maka negeri Palémbangpun pulanglah kepada Suhunan Husin 73 Dia'uddin, / hingga désa-désa sekaliannya masing <-masing> dipegang punggawa menteri seperti lama juga. Dan cuma pabéan itulah yang kepada Kompeni, lain tiada; dan segala bicara negeri besar kecil pulang kepada Sultan. Dan Pangéran Adiwijaya, menantu Suhunan itu, digelar nama Pangéran Perdana Menteri; ialah memegang bicara dibawah Sultan. Syahdan maka Suhunan Husin Dia'uddin itupun duduklah di Suakbata, sementara lagi hendak membuatkan tempat Holanda di seberang; sudah dibuka, beberapa rumah-rumah di kampung Kelénténg itu dirubuh. Maka Pangéran Dipati Tua dinamai oléh Suhunan Pangéran Bupati Panembahan dan Pangéran Jayaningrat, anak Sunan itupun, digelar nama Pangéran Dipati Jayaningrat dan anak Sunan nama Pangéran Jayakrama digelar nama Pangéran Aryakesuma.

16.2 Dan setengah demikian di Palémbang, maka masuklah komisaris ke Palémbang meriksa di mana-mana tempat harta Suhunan Mahmud Badaruddin yang di Teranati itu. Beberapa pangéran yang dibawa ke Betawi dan Pangéran Bupati Panembahanpun ditutub di kapal perang tujuh bulan lamanya. Kampung dan rumahnya dibongkar oléh kom$<$ is $>$ aris. Telah tiada dapat, maka Panembahan itu pulang dan pangéran-pangéran yang ke Betawi itu semuanya pulanglah di Palémbang sekaliannya. 
16.3. Dan tiada berapa lamanya, maka Pangéran Perdana Menteri 74 itupun / membuat salah besar hendak membunuh orang. Belum terbuat, dikatakan Pangéran Dipati Jayaningrat kepada komisaris. Maka Pangéran Perdana Menteri Adiwijaya itupun disuruh komisaris berhenti; désa-désanya sekalian diambil oléh Sultan. Maka dipanggil komisaris Pangéran Kramajaya, menantu Suhunan yang di Teranati itu, dibuat oléh komisaris Pangéran Perdana Menteri, megang perkara dibawah Sultan. Maka Pangéran Dipati Jayaningrat itupun tiadalah lagi baik dengan Suhunan. Keluarlah ia <dari> Suakbata, pulang di kampungnya sendiri. Lalu ia pergi ke Betawi bersama-sama dengan komisaris; maka masuk Palémbang bersama-sama dengan komisaris juga.

16.4. Maka berapa lamanya, maka Sultan Ahmad Najamuddin mupakat dengan Sunan di Suakbata itu memberikan segala pucukan Batangari Sembilan semuanya itu kepada komisaris. Dia minta gajih, ada juga lagi désa-désa yang pegawai kepada Sultan tinggalnya. Maka segala désa-désa kepada periai dan menteri itupun dicabut, diganti dengan gajih semuanya. Tiada lagi di Palémbang yang megang désa, melainkan aturan gajih.

16.5. Syahdan setelah Sultan di Palémbang itu aturan gajih, maka komisaris itupun membuat aturan rat. Kepala rat itu Sultan. Tiap-tiap

75 hari Isnin dan hari Khamis / Sultan masuk kota dengan beberapa menteri pakai alat. Dan jika Sultan sakit, rat itu terhenti. Maka telah berapa lamanya Sultan itu jadi kepala rat besar didalam kota itu, maka banyaklah fitnah daripada saudaranya Pangéran Dipati Jayaningrat itu kepada Sultan. Maka periai dan menteripun tiada lagi kepada Suhunan atawa kepada Sultan, sebab tiada lagi megang désa, sudah aturan gajih daripada Kompeni. Telah berapa lamanya, maka komisaris itupun keluarlah pulang ke Betawi. Tuan Rinis ${ }^{49}$ yang tinggal jadi Résidént ${ }^{50}$ Palémbang, kepala rat besar dengan Sultan Palémbang.

17.

17.1. Tiada berapa lamanya dengan takdir Allah subhanahu wa tacala, maka suatu ketika Sultan itupun menghimpunkan racyat mengamuk kota, kepada tahun seribu duaratus empatpuluh, betul kepada sembilanlikur hari bulan Rabicul-awal, malam Isnin, pukul empat fajar. Dan kepada waktu itu juga Sultanpun undur dengan segala racyatnya itu, 
bertahan di Suakbata, di tempat Suhunan Husin Dia'uddin itu. Dan racyat Sultan yang mati diluar kota masa malam mengamuk itu: Pangéran Citra Putang, ${ }^{51}$ kedua Radén Gubir, ${ }^{52}$ ketiga Khatib Jabar76 uddin, keempat nama Si Luncuk. Adapun malam Sultan / mengamuk itu Pangéran Dipati Muda dengan Pangéran Dipati Jayaningrat ada dalam kota dan Pangéran Bupati Panembahan undur di Kertapati membawa anak-isterinya.

Dan pada siang hari itu Suhunan Husin Dia'uddinpun turunlah; pada malam yang kedua pergi ke Betawi, diséwakan oléh Résidént Rinis di kici Masagus Caguk. Dan kepada masa itu tiada ada kapal perang di Palémbang. Maka Suhunan Husin Dia'uddin itu mintarlah ke Betawi dengan sekalian racyatnya.

17.2. Adapun Sultan yang mengamuk itu tiada mau mengikut, lari dengan racyatnya mudik ke hulu Musi, ngimpunkan racyat di Muara Beliti. Maka Pangéran Dipati Muda, saudara Suhunan itu juga, disuruh résidént mudik membawa punggawa menteri dengan alat senjata. Dan janji: jikalau Sultan itu dapat, maka Pangéran Dipati Mudalah yang jadi sultan di Palémbang. Maka perahu-perahu Suhunan dan Sultan itupun terserahlah kepada Pangéran Dipati itu; gajihnya seribu rupiah dan Pangéran Dipati Jayaningrat seribu rupiah. Maka Pangéran Dipati Muda itupun mudiklah dengan periai dan menteri dengan alat senjatanya lengkap.

Tiadalah berapa lamanya, maka sampailah di ilir dusun Muara

77 Beliti, / tempat Sultan itu. Maka Sultanpun tiada mau bicara damai, maka dinaiki oléh ${ }^{53}$ Pangéran Dipati, dari hutan seberang dusun itu dipasang dengan bedil. Dan beberapa kali dipasang itu, maka Sultan itupun terkejut, lalu berlari dengan segala racyatnya lari ke hulu membuat bénténg, di ulu Ogan satu dan di ulu Lematang satu, serta ngimpunkan orang Pasemah dan segala marga dengan alat senjatanya lengkap. Maka Pangéran Dipati Muda itupun sakit, lalu milir segala angkatan dari Palémbang itu. Maka telah waras Pangéran Dipati Muda itu, maka mudik pula angkatan Pangéran Dipati dari Palémbang itu dengan periai dan menteri, beberapa banyak perahunya dengan alat senjatanya lengkap. Maka Kirangga Wirasentika mudik pula, lain angkatan dari batangari lain. Maka Pangéran Dipati Muda itupun belum berapa jauh angkatannya mudik, maka sakit pula; milir, lalu mati di rantau.

Syahdan maka Rangga Wirasentika itupun bertahan di dusun Limbun. Disuruh Sultan langgar kepada Pangéran Jayadilaga; namanya 
masagus, diangkat Sultan nama kemas di ulu itu juga. Maka angkatan 78 Pangéran Jayadilaga / itupun bertemulah dengan angkatan Kirangga Wirasentika, lalu perang sama-sama di darat terlalu ramainya. Maka Pangéran Jayadilaga itupun kena peluru kepalanya, jatuh, lalu mati. Dan banyak juga temannya itu mati. Maka semuanya racyat Sultanpun lari.

Adapun terdengarlah kepada Sultan di bénténg besar itu Pangéran Jayadilaga mati, sudah dipotong Rangga Wirasentika, kepalanya dibawanya milir kepada Résidént Rinis, maka Sultan itupun ${ }^{54}$ tiadalah ia percaya lagi kepada orang hulu dan orang Palémbang, melainkan orang Pasemah itu juga tempat Sultan percaya. Nama kepala Pasemah itu Pangéran Bajau. Maka Sultan itupun berangkatlah dengan racyat Pasemah itu, hendak nyebelah di Ogan, kepada bénténgnya di ulu Ogan itu. Maka sampai ditengah jalan, maka Sultan itupun diamuk oléh racyat Pasemah itu, sebab pangéran itu sudah dicucuk rasan oléh Rangga Wirasentika. Maka Pangéran Bajau itu mati, ditombak oléh Sultan. Maka habislah racyat Sultan itu lari bercerai-berai, tiada berketahuan lagi.

17.3. Maka tinggallah Sultan itu dengan Pangéran Puspadiprana / 79 yang dipanggil orang Palémbang Pangéran Cingot itu; ialah kepala bicara, makanya Sultan jadi mengamuk kota itu. Setelah racyat sudah habis lari itu, maka Sultan dan Pangéran Cingot dan Masagus Abduljamil lalu milir dari Ogan ke Palémbang menyerahkan diri kepada Kompeni. Masa itu komisaris sudah ada di Palémbang. Sultan lagi di ulu negeri, disuruhnya temenggung polisi menjumputi Sultan itu dengan perahu tunggul kuning. Maka Sultanpun setelah sampai ia ke Palémbang, naiklah kepada kapal perang. Dipelihara makan pagi soré dari Kompeni. Temenggung Astramenggala punya kerja mengantarkan makanan Sultan itu pagi soré dengan sepertinya adat raja-raja Palémbang. Demikianlah kira-kira tujuh bulan lamanya Sultan Ahmad Najamuddin itu di kapal perang di Palémbang itu, maka keluarlah dari Palémbang di kapal perang itu juga, dibawa di negeri Bandan. 


\section{TEKST TR 1}

De spelling van TR 1 vertoont een aantal kenmerken van de in het toenmalige Nederlands-Indië gebruikelijke spelling van het Maleis in Latijns schrift en komt met name sterk overeen met de spelling van het Maleis in Klinkerts Zakwoordenboek van 1910. Daarnaast doen zich nog enkele bijzonderheden voor, die we deels ook in andere Palembangse teksten tegenkomen. Deze bijzonderheden zijn:

1. Herhaaldelijk maar niet consequent wordt in een gesloten slotsyllabe een $e$ geschreven waar ook de toen gangbare spelling een $a$ heeft: dapet, dalem, deket, mengadep, tete $p$, membales.

2. Tussen een willekeurige consonant en de daarop volgende $r$ wordt vaak geen $e$ geschreven: sebrang, prahoe, negri, tjidra, istri, mantri, poetra. Ook het moderne Indonesisch kent dit spellingsgebruik.

3. Waar de tegenwoordige schrijfwijze $a i$ heeft, vinden we afwisselend $i$, ei of $e$ gespeld: ranti, bagimana, berdami; ramei, soengei, sampei; rame, bangke.

4. De slotconsonant van grondwoorden wordt bij suffigering van -an of $-i$ soms verdubbeld: oetoessan, rampassan, toelissan, kakoewattan, kabanjakkan, makannan; membalessi. Verdubbeling van consonanten doet zich ook voor in de handschriften KI 1-3, op veel ruimere schaal zelfs, niet alleen bij suffigering van -an of $-i$, maar ook in woorden als tella, olleh, sebelloem, bessar, massanja. In MP 4b, geschreven in Arabisch schrift, wordt de verdubbeling van consonanten gerealiseerd door middel van de tashdīd. Ook in verscheidene andere Maleise handschriften is ditzelfde verschijnsel geconstateerd. Dat het niet als een spellingskwestie zonder meer kan worden afgedaan heeft Ras uitvoerig betoogd in zijn aan het voorkomen van lange consonanten in enige Indonesische talen gewijde studie in BKI (Ras, 1968-70).

5. Waar de hedendaagse Indonesische spelling een $h$ spelt in Arabische woorden, gebruikt TR 1 een ch: chadlir, chakim, chadji, chadjat, chasil, sachabat. 
6. In eigennamen die eindigen op -diraja, zoals bijvoorbeeld Natadiraja, wordt dit naamdeel steeds -diratdja gespeld.

7. Er doen zich enkele gevallen voor van invoeging van $m$ vóór $b$ of $p$ ò van $b$ na $m$, waardoor vormen ontstaan als ampilan, djomblah, (me)njembelah, ngambai.

Ten aanzien van woordvorm en woordkeus doen zich de volgende bijzonderheden voor:

1. Naast de gebruikelijke $m e$-vormen worden op beperkte schaal genasaleerde werkwoordsvormen zonder het prefix me- aangetroffen: meriksa, merintah, ngantinkan, njembelah, njemboer.

2. Soms vinden we een gejavaniseerde vorm naast of in de plaats van het Maleise equivalent: kadji, kasil, memerang, separo, seseg, temtoe.

In een aantal gevallen, waarin de spelling van een woord in de tekst onvast bleek te zijn, heb ik de spelling genormaliseerd volgens de schrijfwijze die het meest frequent voorkwam. Zo heb ik bijvoorbeeld de spelling kasil, kerana, masih, pecah, perkakas genormaliseerd tot hasil, karena, misih, picah, pekakas. Wanneer het verschil in schrijfwijze uitsluitend bestond in het al dan niet schrijven van een $h$ voor een klinker, zoals bijvoorbeeld in (h)abis, (h)ampir, (h)ilir, (h)utan, heb ik niet genormaliseerd, maar telkens de spelling van de tekst gevolgd.

Er komen in de tekst enkele tientallen tikfouten voor, die ik stilzwijgend heb verbeterd. Ook in de interpunctie, die op sommige plaatsen in de tekst onlogisch of zelfs bepaald onjuist bleek te zijn, heb ik hier en daar wijziging gebracht. 
1 Bahwa adalah asal permulaan yang jadi raja didalam negeri Palémbang:

Raja no 1. Pada tahun 966. Yaitu Keding Suroh; lamanya ia jadi raja dualikur tahun... . . . . 22 tahun

, $2 . \quad, \quad$,

\begin{tabular}{|c|c|c|c|c|}
\hline & " & 3. & " & , \\
\hline " & " & 4. & " & , \\
\hline " & " & 5. & פو & , \\
\hline " & " & 6. & " & \\
\hline " & " & 7. & " & \\
\hline & & 8. & & \\
\hline
\end{tabular}

, , $9 . \quad, \quad$,

,, 10

968. Diganti saudaranya Keding Ilir, lamanya setahun; tetapi dia berjuluk juga $\mathrm{Ke}$ ding Suroh . . . . . .

977. Diganti puteranya Emas Dipati . . . . . . 12 ,

989. Diganti saudaranya Pangéran Medang Suka . . . 35 ,

1024. Diganti adindanya Pangéran Madi Alit . . . . . 1 ”

1025. Diganti adindanya Pangéran Siding Pura . . . 7 "

1032. Diganti keponakannya $\mathrm{Pa}$ ngéran Siding Kenayan . 12 ,

1044. Diganti oléh misanannya, yaitu Pangéran Siding Pesarian

1045. Diganti anaknya Pangéran Siding Rajak, yang di Saka Tiga makamnya . . . . 8 ,

1053. Diganti saudaranya Suhunan Abdurrahman, Cinde Walang . . . . . . 45 "

" $11 . \quad$ „ 1098. Diganti puteranya Sultan Muhammad Mansur . . 12 ,

, , $12 . \quad, \quad$,

1118. Diganti saudaranya Sultan Agung Kamaruddin, yang makamnya di Palémbang Lama . . . . . . . 10 „/ 
2 Raja no 13. Pada tahun..... Diganti anak saudaranya Sultan Mahmud Badaruddin di Kawa Tekurap .. tahun

$» \quad$ "14. $\quad$ $\quad \ldots .$. Diganti puteranya Suhunan Ahmad Najamuddin . . .. ,

" $15 . \quad$ " 1120 . Diganti puteranya Sultan Muhammad Baha'uddin, Lemabang . . . . . . 27 ”

„16. „ „ 1207. Diganti puteranya Suhunan Mahmud Badaruddin, Ternati; lebih kurang 10 tahun 10 ,

Diganti oléh saudaranya Suhunan Husin Dia'uddin, 7 tahun merintah kota besar oléh karena Bangsawan Inggeris. Kemudian kembali lagi Suhunan Mahmud Badaruddin oléh karena Olanda lebih kurang 6 tahun. Wallahu aclam.

Adalah kepada tahun 1227 sampai kepada tahun 1237 Palémbang sudah ditunggu oléh Olanda sampai sekarang ini. /

2.

3 2.1. Bahwa pada menyatakan yang didalam zaman Suhunan Mahmud Badaruddin: didalam tahun 1207, yaitu dia menjadi raja bertakhta merintah negeri Palémbang, sampai kepada tahun 1227. Maka masa itulah Inggeris datang di Palémbang. Perlakuannya seperti akan menceraikan daripada orang yang bersentosa berhimpun; akan tetapi didalam rahasianya, wallahu aclam.

Syahadan setelah Inggeris datang di Palémbang, bermaksud ia akan mengambil Palémbang dengan kekuatan perang; akan tetapi sekadar Inggeris berhajat kepada Suhunan Mahmud Badaruddin juga. Maka dengan dipéndékkan ceriteranya di sini, yang Suhunan Mahmud Badaruddin bersingkirkan dirinya mudik di hulu Muara Rawas dengan segala racyatnya.

Setelah Suhunan Mahmud Badaruddin sudah hilang dari Palémbang, maka didudukkan Inggeris akan Suhunan Husin Dia'uddin diatas takhta kerajaan memerintah negeri Palémbang. Dan setengah daripada ingatan orang tua-tua: tatkala Inggeris menjadikan raja Suhunan Husin Dia'uddin itu tiada mau, sebab Suhunan Mahmud Badaruddin misih maujud kuasanya yang bukan alah oléh perangan. 
2.2. Setelah itu ialah Inggeris terus mudik dengan angkatan perang menyusul Suhunan Mahmud Badaruddin di hulu Rawas. Setelah Inggeris sampai di Rawas, lalu berperang Inggeris dengan Suhunan Mahmud Badaruddin, terlalu ramainya. Maka dengan takdir Allah penghulu soldadu Inggeris yang bernama Mista Saman kena pélor ${ }^{1}$ rupanya patah. ${ }^{2}$ Maka picahlah perangnya; undur ke Palémbang, lalu terus pulang ke Betawi. Tetapi itu waktu Suhunan Dia'uddin didudukkan Inggeris memerintah kota besar menjadi raja di Palémbang, serta mendirikan bendéra Inggeris. Syahadan setelah Mista Saman Inggeris pulang di Betawi tiadalah tersebut lagi. Hanya ada kabarnya dia terus pulang di Benggala membawa semuanya harta Palémbang yang diam-

4 bilnya dari gedung / Palémbang waktu Suhunan Mahmud Badaruddin lari ke Rawas itu.

2.3. Dan dapat kabar lagi yang negeri Betawi sudah ditukarnya oléh Inggeris dengan Melaka kepada Kompeni Olanda. Adapun sesudahnya tetap di negeri Betawi sudah ditunggu oléh Olanda. Maka dengan bagaimana hikmat Allah tacala yang berlaku atas hambanya, lalu bersahabat Suhunan Mahmud Badaruddin kepada Gubernur-Jénderal di Betawi; dengan bagaimana halnya wallahu aclam.

2.4. Syahadan kira lebih kurang dari dua tahun Suhunan Mahmud Badaruddin di Muara Rawas, ialah datang suruhan Jénderal dari Betawi pada Olanda yang ada berkuasa bernama pétor, datang di Palémbang duduk di seberang Sungai Aur. Ada antara berapa lamanya pétor duduk di Palémbang, ialah antara <dengan> Suhunan Husin Dia'uddin dipekatkannya supaya berhimpun. Dan Suhunan Mahmud Badaruddin akan didudukkan di kota lama.

Setelah sudah pekat kepada Suhunan Husin, maka diperintahkan pétor dan Suhunan Husin beberapa menteri yang tua-tua pergi menjumputi ke Muara Rawas. Mengadaplah sekalian utusan itu kebawah Duli Suhunan akan memohonkan supaya pulang di Palémbang, dihendaki oléh Tuan Pétor serta Paduka Seri Suhunan Dia'uddin. Maka Tuan Suhunan berkirim tabé kepada pétor minta itu Pangéran Paharuddin disuruhkan datang di Rawas. Setelah itu pulanglah kembali suruhan itu ke Palémbang, mengadap pétor menyampaikan apa-apa titah perintah Suhunan itu. Setelah itu maka menitahkan pétor akan Pangéran Paharuddin pergi di Muara Rawas. Maka Pangéran Paharuddinpun mudiklah dengan beberapa temannya membawa alat kerajaan. Setelah sampailah di Muara Rawas, maka bertemulah Pangéran 
Paharuddin dengan Seri Suhunan Mahmud Badaruddin. Dan apa-apa bicaranya antara keduanya tiada mengetahui dia. Melainkan Seri Suhunan pulanglah ke Palémbang mendapatkan pétor.

Setelah demikian maka Seri Suhunan didudukkan pétor di kota / 5 lama. Dan Suhunan Husin tetap di kota besar. Tidak ${ }^{3}$ bersekutuan pada antaranya itu. Melainkan semuanya hal ihwal Suhunan Mahmud Badaruddin dengan beserta pétor. Dan yang anak-anak negeri waktu itu banyaknya conderong, misih menurut perintah Suhunan Mahmud Badaruddin. Maka didalam waktu itu rapatlah Suhunan Mahmud Badaruddin kepada Gubernur-Jénderal di Betawi dengan bersahabat.

3.

3.1. Kemudian sampailah kepada masanya Suhunan akan mengantinkan Pangéran Ratu. Maka dengan musyawaratnya pétor jadi menumpang bekerja ngantinkan di sirap; sebab anak cucu yang tua tiada patut di kota lama tiada seupama alatnya. Melainkan Suhunan Husin tiadalah terkata-kata lagi; hanyalah dengan dipaksa oléh pétor ialah Suhunan Husin berpindah ke kota lama. Dan Suhunan Mahmud Badaruddin pindahlah di kota besar, duduk bertakhta di sirap memerintah negeri dan bendéra kerajaanpun berdirilah seperti dahulu. Dan bendéra Inggeris diangkat dirubuhkan. Maka pada masa itu meskillah hal Palémbang.

3.2. Maka tiada berapa lamanya daripada antara itu maka datang angkatan Inggeris. Datangnya dari Bengkulu. Setelah demikian itu maka pétor bersiaplah dengan angkatan besar, berangkat mudik mendapat angkatan Inggeris. Setelah ketemu antara Olanda dan Inggeris itu, maka bagaimanalah rahasia antara keduanya tiada yang tahu. Melainkan Inggeris kembali pulang ke Bengkulu; dan pétor pulang ke Palémbang. Maka kutika itu harubirulah Palémbang. Dan didalam kota besar dan kota lama rupanya besarlah perseteruan.

3.3. Maka pada masa itu datanglah Idelir Ménténg dari Betawi, banyak membawa soldadu dan kapal perang. Maka yang sebelah kota lama keras berjaga waktu itu. Setelah dike $<$ ta $>$ hui oléh Idelir Ménténg hal kelakuan antara kedua suhunan itu, maka Idelir Ménténg menyuruh soldadu jaga di pintu kota lama. Tiada boléh seorang keluar, melain6 kan Pangéran Dipati Tua yang dikeluarkan, / disuruh pulang ke kampungnya. 
Maka gemparlah kutika itu didalam kota lama. Setelah demikian maka setipu dayanya putera-putera dan suri, selir, semuanya perempuan lari keluar dari belakang kota, lalu masuk di kota besar mengadap Suhunan Mahmud Badaruddin. Setelah diketahui oléh Suhunan Husin hal isi dalam abis itu, maka Suhunan Husinpun turut menyembelah, menutul segala putera-putera suri itu di kota besar. Maka bertemuanlah keduanya, serupa akan mufakat. Maka Seri Suhunan Mahmud Badaruddin suruhan kepada Idelir Ménténg memberitahu hal Suhunan Husin telah datang padanya berhimpun di kota besar. Maka diperintahkan Idelir Ménténg semuanya menteri-menteri yang ada didalam kota lama itu dipanggil turun ke kapal, satu tiada yang tinggal.

3.4. Maka Idelir Ménténg menyuruh memanggil Pangéran Jayaningrat. Setelah datang, maka perintah Idelir Ménténg menyuruh Suhunan Husin pergi di Betawi sendiri berminta ketetapan antara dua saudara siapa yang ditetapkan jadi raja, serta boléh unjuk itu surat angkatan Inggeris kepada Suhunan Husin yang menjadi raja itu. Maka Pangéran Jayaningrat pulanglah dari mendapatkan Idelir Ménténg itu, lalu mengadap Suhunan Husin. Telah dipersembahkannya apa-apa bicara Idelir Ménténg itu. Maka berkenanlah kepada Suhunan; karena surat Inggeris itu serupa kuat gunanya jadi kekuatan, karena Inggeris terbesar pangkatnya dari Olanda.

Maka pada malam itu Suhunan Husin disuruh Suhunan Mahmud Badaruddin duduk di Lawang Buratan ${ }^{4}$ didalam rumah taman besar, pada semuanya putera-putera dan selir-selirnya. Dan Pangéran Jayaningrat di taman laut. Setelah pagi hari maka turunlah Suhunan dengan segala ahli-ahlinya laki-laki dan perempuan, lalu naik kapal perang. Maka berlayarlah hingga datang di Betawi. Wallahu aclam akan hal rahasianya. Hingga didudukkan Suhunan itu di Cianjur ${ }^{5}$ tetaplah 7 dengan dipelihara / Gubernement segala ongkosnya.

3.5. Syahadan maka tersebutlah perkataan Idelir Ménténg telah menetapkan Suhunan Mahmud Badaruddin memerintah negeri Palémbang. Maka Idelir Ménténg menyuruh Suhunan suruhan kepada Inggeris ke Benggala mengambil hartanya yang diambil oléh Mista Saman dahulu itu. Ialah dititahkan Suhunan Pangéran Umar pergi di Benggala membawa surat dan bertanda tangan Idelir Ménténg. Setelah Pangéran Umar pergi di Benggala, maka itu uang dan harta-harta semuanya dikembalikan, tiada yang kurang. Setelah pulang kembali di Palémbang, maka Pangéran Umar digelar Pangéran Prabumenggala. Dan waktu 
itu juga ubi menggala itu dilarangkan namanya ubi menggala, dinamakan ubi kayu.

3.6. Dan pada antara itu Suhunan Mahmud Badaruddin telah menyerahkan segala pucukan tanah uluan kepada Idelir Ménténg. Hanyalah yang misih tinggal kepada Suhunan désa Pegagan semuanya; dan Panang Karubelah, ${ }^{6}$ Penukal, Sungai Keruh, Lingkis, Dana Luar ${ }^{7}$ dan Perwatin Lima dan Belidah. Maka yang lain-lain daripada itu semuanya sudah terserah kepada Idelir Ménténg. Dan hasil semuanya bagi dua.

3.7. Setelah berapa lamanya daripada antaranya perserahan itu, maka Idelir Ménténgpun mudik membawa angkatan soldadu dan $\mathrm{ra}^{c}$ yat Palémbang, penghulunya Raja Akil dan Pangéran Syarif Muhammad serta dengan beberapa periai-periai dan menteri-menteri, dititahkan oléh Suhunan mengikut Idelir Ménténg mudik itu. Maka dimulai mudik dari Batangari Musi. Maksud hendak jalan kuliling semuanya pucukan; tetapi belum terus, melainkan Idelir Ménténg memeriksa di dusun Muara Beliti. Maka kedapatan Inggeris baru datang, akan terus ke Palémbang maksudnya. Sebab Inggeris sudah mengasih contract kepada Husin menyerahkan hal Palémbang hasilnya dibahagi dua kepada Inggeris. Setelah itu maka Idelir Ménténg menunjukkan halnya Suhunan Husin sudah punya mau sendirinya pergi di Betawi. Dan bagaimana8 mana bicaranya Idelir / Ménténg dan Inggeris itu, maka Inggeris itu pulanglah ia ke Bengkulu dengan jalan darat.

3.8. Setelah selesai dari hal Inggeris itu, maka Idelir Ménténgpun lalu commissie di tiap-tiap dusun-dusun, hingga sampailah ia ke Semangus. Maka itu orang Semangus menakal, tiada mau ditulis masuk buku. Maka dititahkan Idelir Ménténg pasang dengan soldadu. Maka kenalah Pangéran Semangus pélor, lalu mati. Maka Idelir Ménténg terus mudik. Maka sejalan-jalan perahu Idelir Ménténg dipasang orang dari darat didalam utan.

Maka Idelir Ménténg berkirim surat kepada Seri Suhunan di Palémbang bermaclumkan dari hal yang tersebut itu. Maka suruhan itupun milirlah ke Palémbang. Setelah sampailah ke Palémbang, lalu mengadap Seri Suhunan, mengaturkan surat Idelir Ménténg yang dibawanya itu. Setelah dibaca Seri Suhunan, maka Seri Suhunan menitahkan Ngambai Balmi pergi mudik mendapatkan Idelir Ménténg.

Tetapi ngambai mudik itu sampai di Rantau Menitang telah mendapat kabar yang orang Melayu sudah kumpul di Muara Rawas, membuat 
bénténg serta lengkap dengan alat senjatanya akan melawan Idelir Ménténg. Daripada itu Ménténg lazimlah bersangka Seri Suhunan buat aniaya padanya dengan tipu di tanah ulu. Setelah itu Ngambai Balmi datang mendapatkan Ménténg, terus dipegangnya didalam penjara. Maka sekalian orang yang turut ngambai itu milir semuanya ke Palémbang mempersembahkan perihal Ngambai Balmi sudah dipenjara Idelir Ménténg.

Setelah itu maka ada berapa lamanya maka Idelir Ménténg sampai di Muara Rawas. Maka dibedil oranglah dari bénténg Muara Rawas. Setelah itu maka angkatan Idelir Ménténgpun merapatkanlah segala perahu angkatan itu dan sekalian soldadu naiklah ke darat memasang bénténg dengan beberapa meriam dan gurnat, léla, senapan, tiadalah berhenti lagi. Ramailah kutika itu; banyaklah orang Rawas mati, daripada pagi <sampai> waktu asar. Maka picahlah perang bénténg

9 Muara Rawas, undurlah segala orang di/dalam bénténg. Maka dapatlah bénténg itu oléh soldadu semuanya dirampas. Sudah itu maka Idelir Ménténg terus ia milir ke Palémbang.

3.9. Setelah dekat maka kabarpun disampaikan oranglah kepada Seri Suhunan. Maka sigeralah Seri Suhunan menitahkan putera Dalem, Pangéran Ratu, memapag Idelir dengan beberapa menteri-menteri yang tua-tua, semuanya berangkat mudik mapag Idelir Ménténg itu. Setelah sampailah kepada perahu Idelir Ménténg, maka dengan bagaimanalah halnya perahu Pangéran Ratu diusirnya oléh Idelir, akan perahu Pangéran Ratu tiada diberinya dekat; dan yang lain-lain perahu semuanya mendekat serta diterimanya baik oléh Idelir Ménténg. Hanyalah perahu Pangéran Ratu juga yang diusirnya. Setelah itu maka Pangéran Ratu pulang kembali ke Palémbang; pagi-pagi datang di Palémbang. Lalu mengadap Seri Paduka Ayahda Baginda Suhunan Mahmud Badaruddin, dipersembahkannya akan perihal yang tiada diterima oléh Idelir Ménténg itu. Maka Seri Suhunan berdiam, tiada katanya.

4.

4.1. Setelah keésokan harinya Idelir Ménténg sampailah di Palémbang. Maka Idelir Ménténg menyuruh sahbandar Olanda serta Pangéran Syarif Muhammad mendapatkan Seri Suhunan akan minta Pangéran Ratu serta pangéran-pangéran yang dibawahnya akan dibawa ke Betawi. Setelah sampailah suruhan itu mengadap Seri Suhunan nyampaikan permintaan Idelir Ménténg itu, maka Seri Suhunan menyahut: "Me- 
lawan tiada, dikasihkan tiada." Maka kembalilah suruhan Ménténg itu. Setelah disampaikan perkataan Seri Suhunan demikian itu, maka disuruhnya kembali pula, minta itu Pangéran Ratu sekarang juga. Maka seperti yang tersebut itulah jawab Seri Suhunan.

4.2. Maka antara Ménténg dan Seri Suhunan akan jadi perceraian rupanya. Maka Idelir Ménténg menitahkan kapal perang mendekat dimuka bénténg kota. Setelah demikian gemparlah negeri Palémbang. Maka Seri Suhunan mehimpunkan orang haji-haji semuanya masuk kedalam kota; serta menitahkan bersiapkan segala pekakas perang dan 10 meriam diatur diatas buluwarti keempat penjuru. / Dan diatas loténg dijaga semuanya dengan pemuras, senapan, tombak, pedang semuanya. Dan diperbaiki segala hati $\mathrm{ra}^{c}$ yat-racyat dan hulubalang pahlawan semuanya masing-masing dengan kepalanya menteri-menteri. Dan diatas buluwarti diatur dengan temtu orangnya yang jaga kepala didalam satu-satu penjurunya kota, yaitu diatas buluwarti.

4.3. Setelah siap pekakasnya alat peperangan didalam kota, maka Seri Suhunan menitahkan Pangéran Dipati Tua dan Pangéran Dipati Muda mendapatkan Ménténg, memberitahu ada seorang miji Suhunan mati dipasang oléh soldadu dari kota lama. Adapun itu kota lama selamanya berkusut di Palémbang, sudah ada menunggu didalam itu kota ada duaratus limapuluh banyaknya, ditetapkan Ménténg kepada Seri Paduka Suhunan.

Maka itu keduanya pangéran suruhan Suhunan sampailah kepada Idelir Ménténg menyampaikan hal suruhan Seri Suhunan yang tersebut itu. Maka Ménténg terlalu gusarnya, mérah mukanya serta ia bicara dengan keras. Bicaranya: "Apa Suhunan punya mau, baris Olanda sudah sedia. Melainkan sekarang, jika itu Pangéran Ratu tiada diantarkan sekarang juga, melainkan pukul tiga ini hari juga kapal perang memasang kota!" Dan kedua Pangéran Dipati ditahan oléh Ménténg, tiada diberinya pulang. Tetapi keduanya pangéran keras minta pulang: "Manakala Idelir Ménténg tiada kasih saya pulang, melainkan saya pulang juga. Sebagaimana adat orang jadi utusan: jahat dan baik, misti disuruh pulang. Tida teradat raja-raja menahan utusan." Setelah didengar Ménténg perkataan kedua pangéran demikian itu, maka Idelir Ménténg sangat malunya, seperti tiada kenal kepada aturan raja-raja. Dari sebab itu lantas disuruhnya pulang kedua pangéran itu. Maka pulanglah pangéran ke tempatnya sendiri masing-masing. Tiadalah ia mengadap lagi Seri Suhunan. 
4.4. Syahadan dari hal Seri Paduka Suhunan didalam kota sudah 11 mastaib lengkap dengan alat senjata semuanya. Dan orang-/orang yang diatas kota sudah ditemtukan satu-satu bagian. Dan di sebelah ulu buluwarti yaitu menantu Suhunan, yaitu Pangéran Kramadiraja. Dan di buluwarti sebelah ilir menantu Suhunan, yaitu Pangéran Kramajaya. Dan di buluwarti sebelah darat yang sebelah ilir yaitu Pangéran Citra Saléh. Maka sekalian tiga penjuru buluwarti itu diatas satu-satu kepalanya ditutup serta dijagai didalamnya dengan beberapa hulubalang pahlawan dan racyat. Dan Lawang Buratan sebelah ulu dan ilir keduanya ditutup serta dijagai didalamnya dengan beberapa hulubalang pahlawan, periai-periai lengkap dengan segala senjatanya. Dan istiméwa lawang loténg dijaga oléh beberapa menteri-menteri hulubalang dan $\mathrm{ra}^{\mathrm{C} y a t}$ semuanya dengan memegang senjata dan léla, pemuras, senapan.

4.5. Adapun yang orang haji-haji semuanya yang akan mengangkat sabilullah itu dikumpulkan diluar kota, yaitu di pemarakan jaba, lengkap dengan alat sabilullah, serta berzikir dan mengucap selawat dan tahlil tiada berhenti lagi. Maka terlalulah gemuruh bunyinya hébat, didengar segala-segala manusia; dan memberi keras diatas hati segala yang melawan dan memberi dahsat pada segala yang penakut.

Maka daripada sangat gempar bunyinya itu, maka datanglah satu officier Olanda dengan soldadu meriksa kedalam kota besar. Setelah masuk pintu loténg, terlihatlah oléh haji-haji itu. Maka ia semuanya berangkat mengunus senjata, lalu diusirnya officier itu hendak dibunuhnya. Maka officier dan soldadu iapun larilah masuk kota lama. Maka diusirnya juga. Lalu dipasang oléh baris Olanda daridalam kota. Maka banyaknya orang sabilullah itu 70 orang banyaknya. Undurlah oléh kena pasang soldadu duaratus itu. Hanya <yang laju mengamuk $>^{8}$ Haji Zén dan Haji Lanang dan Kemas Said bin Kemas Haji Ahmad.

4.6. Maka kutika itu maka Pangéran Citra Saléh membedil dengan 12 meriam dari buluwarti sebelah darat itu. Maka banyaklah / soldadu baris itu mati dan luka. Setelah itu maka membedil pula buluwarti sebelah ulu dan sebelah ilir kepada kapal perang. Maka membalaslah kapal perang membedil kota. Maka selalulah timbal-menimbal, balasmembalaslah antara kota dan kapal perang itu, tiadalah berhenti lagi. Maka kelamkabutlah oléh asap bedil itu dan bergeraklah bumi dan berguncanglah air laut. Maka gegak gempitalah negeri Palémbang, gemuruh seperti langit akan rubuh. Dan bunyi meriam seperti bunyi halontar membelah bumi bunyinya. Tiadalah nampak sesuatu lagi oléh 
asap bedil, hanyalah kilat meriam juga yang nampak muncar ke langit. Demikianlah halnya perang itu terlalu besarnya. Dan tiadalah kedengaran suatu lagi apa-apa, hanya bunyi meriam dan sorak segala rac ${ }^{c} y a t$ laut dan darat. Dan waktu itu dahsatlah orang yang penakut dan lupalah kepada matinya orang yang berani.

4.7. Setelah hari malam maka berhentilah kedua pihak, kapal perang dan kota itu. Dan segala mayit orang syahid itu diperintahkan Suhunan tanam didalam kota juga; dan adapun dari ongkos kematian semuanya meréka yang mati itu, Suhunan yang mengasih secukupnya tiap-tiap seorang. Dan yang bangkai Olanda yang mati di kota lama itu diambil oléh Olanda, dibawanya di kapal; maka didirikannya seperti orang hidup.

Demikianlah maka pada malam itu Sultan, yaitu Pangéran Ratu, dititahkan Suhunan memeriksa kota yang kena peluru kapal perang itu, beserta beberapa temannya periai-periai dan menteri-menteri. Maka diperiksa semuanya. Maka kedapatan yang paling besar pelurunya itu cuma masuk kedalam kota sejengkal juga. Setelah itu maka diaturkan kebawah Duli Suhunan daripada pendapatan periksaan itu, hanya sejengkal juga masuk peluru itu. Setelah itu maka diperintahkan pada ésok hari pagi-pagi mulai perang membedil dengan jarang-jarang juga.

4.8. Setelah siang hari maka membedil dari kapal perang sehingga empat lima kali. Maka membalas keempat kali bedil kapal itu dengan /

13 sekali membedil dari buluwarti itu. Maka kapal perangpun selalulah membedil dari kapal seperti ribut besar bunyinya. Dan pelurunya yang lalu keatas kota lalu ke darat di kampung menyambar pohon-pohon durian dan kemang; banyaklah yang rubuh dan putus-putus dahannya. Dan kelamkabutlah oléh asap meriam itu. Gentarlah dengan sebagai gentar lindu yang besar oléh peluru kebanyakan menempuh dari kapal di kota. Maka banyaklah yang keluar air matanya sebab takutnya. Dan banyak nyang tertawa-tawa sebab beraninya. Dan tiada nampak sesuatu lagi; melainkan kilat meriam juga yang lagi nampak-nampak cahayanya.

4.9. Setelah demikian maka tiadalah membalas meriam dari kota. Maka kapal perangpun berhentilah memasang meriam; pada sangkanya orang didalam kota sudah lari. Maka Idelir Ménténg memerintahkan segala soldadu turun di sampan naik di kota. Maka turunlah segala soldadu naik ke darat seperti semut. Setelah sampai dekat di pintu kota, maka 
tukang tamburnya mendekat pintu. Maka hulubalang dari dalam membuat lobang pintu kota itu dengan boor besar. Setelah berlobang, maka oléh pahlawan daridalam kota itu menyorongkan tombaknya pada lobang itu. Kenalah tukang tambur, lalu mati. Maka harubirulah soldadu banyak itu lari menjauh pintu kota, lalu dibedil dariatas loténg meriam dan léla dan pemuras. Maka banyaklah matinya soldadu itu. Maka barispun larilah turun ke sampan; dan bangkainya yang mati-mati semuanya dibawanya turun kekapal. Maka dibedil pula dari buluwarti ilir dan hulu, tiada berhenti lagi.

Dan waktu itu semuanya isi sirap sudah lari keluar dari Lawang Buratan menurut jalan ke Suakbata. Setelah ketahuan Seri Suhunan hal demikian itu, maka Seri Suhunan sendiri menyusul. Sampai di jalan ketemu, lalu dibawa kembali masuk kota. Serta titahnya: "Tetap juga kota selamat kemenangan perang ini." Setelah itu haripun malamlah. Maka berhentilah bedil dari buluwarti. / $^{9}$

14 4.10. Setelah malamlah hari maka datanglah Raja Akil dan Temenggung Sura, disuruh Idelir Ménténg mendapatkan Pangéran Dipati Tua akan berminta berdamai. Dan jika tiada mau berdamai, melainkan Idelir Ménténg minta témpo empat hari. Setelah sampailah, suruhan itu mengadap Pangéran Dipati Tua itu menyampaikan permintaan Idelir Ménténg yang tersebut itu. Maka Pangéran Dipatipun lalu mengadap Seri Suhunan menyembahkan akan permintaan Idelir Ménténg itu. Maka titah Suhunan: "Berdamai tiada mau, dari témpo empat hari ditémpokan." Maka kembalilah Pangéran Dipati kepada utusan Idelir Ménténg yang tersebut itu, menyampaikan titah perintah Seri Suhunan tiada mau damai; dan témpo empat hari boléh. Maka kembalilah utusan itu. Setelah disampaikannya semuanya perintah Suhunan itu, maka Idelir Ménténgpun mengilirkan kapal perang Nasu itu di ilir kota. Dan semuanya sampan-sampan dan koci, semuanya itu dirapatkan beratur.

4.11. Syahadan yang didalam kota siaplah, semuanya meriam-meriam dan léla-léla diatur. Dan meriam diluar kota semuanya pesumbu $<$ an $>$ nya ditebuk dengan ancir. Dan periai-periai yang berumah diluar kota semuanya disuruh masuk kedalam kota; siapa yang tiada mau hendak dibedil dari buluwarti. Maka semuanya berkumpullah masuk kedalam kota. Maka semuanya periai-periai dan menteri-menteri disuruh Suhunan bersumpah, jangan wilut. Dan Radén Kijing dititahkan membuat rakit akan dibakar, ada empat lima rakit. Dan beberapa batang meranti yang besar sedia akan $<$ di $>$ hanyutkan. 
4.12. Setelah sampailah témpo empat hari itu, maka dari pagi-pagi kira pukul lima berbunyilah meriam kapal membedil kota. Setelah dua tiga kalinya, maka dibalaslah dari kota dengan tiada berselang lagi dari cepatnya memasang meriam dan léla. Maka kapal perang Nasu itu ${ }^{10}$

15 seperti ayakan, semuanya lobang/-lobang. <Dan kapal perang Nasu itu maka kapal terlalu besarnya. Sekira-kiranya ia melintang, memenuhi laut Palémbang. $>^{11}$ Oléhnya kapal besar, misih bertahan juga. Tetapi pekakas yang keemas-keemas dan segala harta sudah dipindahkan oléh Olanda di kapal lain yang kecil.

Setelah kira dua jam berperang itu, maka penuhlah negeri Palémbang oléh asap meriam; tiadalah melihat satu apa-apa lagi, hanyalah kilat meriam juga yang kelihatan, menerus cahayanya ke langit. Maka gemuncanglah rasa bumi dan bergoyanglah kota, seperti kena lindu yang besar. Maka banyaklah ketakutan yang penakut. Ada yang terkencing, terbérak di kain; ada yang terbérak sambil berjalan, cerit-berit nyembur tahinya dan kencingnya. Demikianlah halnya orang penakut didalam kota. Maka banyaklah orang tertawa melihatnya.

Setelah itu kira pukul sembilan berperang, maka datang rakit api dan batang meranti menempuh segala kapal dan sekoci. Maka kapal Nasu waktu itulah tenggelam, sebab kebanyakan kena peluru dari kota. Ialah sauhnya dinaikkan di natar gudang garam yang dahulu itu.

Setelah itu undurlah Olanda. Dan rakit apipun terdamparlah di kampung Kebumén. Maka apipun makanlah rumah-rumah yang pinggir laut, sampailah di kampung Radén Kijing habislah semuanya dimakan api. Syahadan maka semuanya tempat Idelir Ménténg itu semuanya dibakar orang sama sekali, tiadalah yang tinggal lagi; melainkan jadi abu semuanya. Dengan beberapa orang Olanda yang sakit-sakit yang ada didalam rumah sakitnya itu habislah mati tertunu. Setelah itu Idelir Ménténgpun teruslah berlayar dengan segala tentaranya pulang ke Betawi.

4.13. Syahadan Seri Suhunan daripada sepeninggal Olanda sudah kalah itu, maka Seri Suhunan menitahkan paduka anakda Baginda, Pangéran Ratu, bersiapkan didalam kota dengan beberapa perkhémahan ${ }^{12}$ dan ketempatan, masing-masing bakal tempat segala rac ${ }^{c} y a t$ dan menteri hulubalang dan menteri yang periai-periai dan menteri yang luaran dan segala kerabat, permili, zuriat, segala yang besar-besar.

16 Maka setelah mastaiblah segala tempat persediaan / itu, maka Seri Suhunan menitahkan memotong kerbau empatpuluh dan itik ayam beratus-ratus. Maka ditemtukanlah kepada harinya, dengan pesuruhan 
Seri Suhunan memanggil pada sekalian yang racyat mengangkat perkuta ${ }^{13}$ itu. Maka berhimpunlah sekalian permainan adat bahri dan gamelan semuanya berbunyilah tujuh hari tujuh malam, dengan sekalian permainan itu tiada seupama lagi. Gegak gempita sorak segala $\mathrm{ra}^{c}$ yat. Dan yang permainan daripada segala pucukan uluan, masingmasing dengan permainannya: tapuk, tari, sambi, gandi, ujungan. Istiméwa permainan Palémbang: wayang, nopéng, ronggéng, gebejuk dan wayang krucil dan Siam. Maka ramailah negeri Palémbang waktu itu, tiada terkira-kira lagi; gemuruh segala bunyian. Dan banyaklah yang lupa kepada lakinya, dan banyak pula yang lupa kepada bininya. Demikian juga anaknya kepada ibunya dan ibu-bapa kepada anaknya. Tiadalah tahu ulu dan ilir, darat dan laut dari kebanyakan manusia yang berhimpun itu. Maka didalam tujuh hari tujuh malam itu Seri Suhunan menjamu pada sekalian menteri hulubalang luaran dan dalam dan segala $\mathrm{ra}^{\mathrm{c} y a t}$ hulubalang pahlawan dengan makan dan minum, masing-masing dengan pangkatnya diatur. Setelah selesai daripada pekerjaan jamu itu, maka Suhunan menitahkan mengeluarkan isi gedung dari pitis dan pakaian berjenis-jenis dan ringgit, dengan sigerasigera ${ }^{14}$ dikeluarkan kepada yang dikurniai, masing-masing dengan kadarnya. Telah selesai daripada hal demikian itu adanya. Maka ma ${ }^{c}$ murlah negeri Palémbang waktu itu serta mashurlah kepada segala pucukan uluan.

5.

5.1. Setelah itu maka Seri Suhunan menitahkan membuat bénténg di muara Plaju, dengan masing yang berkuasa pada $<$ nya $>$ jadi kepalanya pada tiap-tiap satu bénténg.

<No 1.> Maka bénténg yang bernama Tambakbaya, tempatnya di muara Plaju di sebelah kanan keluar dari negeri. Adalah kepalanya itu Pangéran Kramajaya yang berkuasa; dan beberapa menteri-menteri

17 yang dibawahnya serta $\mathrm{ra}^{c}$ yat / hulubalang pahlawan, serta cukup alat senjatanya dan beberapa léla diatur. Dan meriam yang bernama Seri Palémbangpun jadi penghulu segala meriam.

No 2. Bénténg di kepala Pulau Kembara, bernama Taméngratu. Kepalanya Pangéran Suradilaga, dengan menteri-menteri dan racyat pahlawan dibawahnya, serta beberapa meriam dan léla dan alat senjatanya.

No 3. Bénténg di Rawa-Rawa Sekampung, bernama Martapura. Dan kepalanya Pangéran Ratu, dan beberapa menteri-menteri yang dibawah- 
nya serta racyat hulubalang pahlawan, sekalian memegang alat senjata; dan beberapa meriam dan léla dan pemuras dan sekalian pekakas perang cukup adanya.

No 4. Bénténg ditengah laut, dinamai Pulau Manguntama. Kepalanya Pangéran Kramadiraja berdua Pangéran Wirasentika; sertanya beberapa menteri hulubalang dibawahnya serta racyat cukup alat senjatanya. Dan adapun bénténg lain-lain yang kecil-kecil, daripada periai-periai, yaitu daripada bénténg yang tiada ternama. Dan Pangéran Dipati tua dan muda sertanya periai-periai yang tua semuanya ikut kepada Pangéran Ratu, pada bénténg Martapura yang tersebut.

Syahadan yang di Palémbang membuat bénténg dari tangga dalam sampai Sungai Tengkuruk; serta cukup alat senjatanya, beberapa puluh meriam dan léla, pemuras, senapan, setinggar. ${ }^{15}$ Dan yang menjaga bénténg itu sekalian pengalasan sertanya miji dan ngawin dan yang tua-tuanya dari menteri yang kesepuhan. Maka sempurnalah persediaan itu. Setelah selesai daripada hal yang demikian itu, maka mastaiblah segala bénténg-bénténg itu, seperti kawan menunggukan lawannya. Demikianlah yang disebutkan oléh yang mengarang hikayat ini. Wallahu aclamu bissawab.

5.2. Alkissah tersebutlah yang Olanda yang sudah undur pulang ke Betawi itu. Maka Idelir Ménténg mengadukan halnya kepada GubernurJénderal daripada perihal perlakuan perang Palémbang itu. Maka

18 Gubernur-Jénderal berkirim rapport ke negeri Olanda kepada / Seri Maharaja Willem Een.

Maka kira setahun lamanya dan balasan ke Betawi, lantas menitahkan pula Gubernur-Jénderal kepada Jénderal Sukubanah membawa Idelir Ménténg dan yaitu putera Suhunan Dia'uddin Pangéran Jayaningrat dan Pangéran Jayakrama <dan Pangéran Wirakrama> Gubir, pepatih Suhunan Dia'uddin. Serta membawa empat kapal perang besar dan empat kici perang dan beberapa banyak langbut besar, lengkap dengan pekakas perang; dan seribu soldadu.

5.3. Maka semuanya itu lalu masuk Palémbang. Adapun dusun Sungsang sudah tinggal, semuanya berkumpul ke Palémbang. Dan dusun Sungsang abis dibakar Olanda, satu tiada berkari lagi. Setelah sampailah angkatan Olanda itu ke Sungai Kundur, maka berlabuhlah di sana sekalian angkatan itu. Dan yang kutika itu tiap-tiap bénténg telah sedia meriam yang sudah diisi pélor pada tiap-tiap bénténg.

Setelah keésokan hari pagi, tiadalah dengan berutusan lagi, tiba-tiba 
berbunyilah meriam daridalam hutan raya ${ }^{18}$ daripada bénténg Tambakbaya. Maka kenalah tukang kunci jénderal kapal perang besar itu, lalu mati. Maka harubiru didalam kapal. Maka banyaklah turun soldadu kepada langbut besar, mendekat ke bénténg membawa pinakawan Pangéran Wirakrama Gubir jadi utusan jénderal kepada Seri Suhunan. Naiklah ia ke bénténg, lalu ia terus ke Palémbang, mengadap Seri Suhunan serta diaturkannya surat itu. Maka disuruh Seri Suhunan sambut kepada menteri agama. Setelah dibuka Suhunan surat itu, lalu dibaca. Setelah sudah dibaca Suhunan, maka Seri Suhunan tersenyum sedikit. Maka Seri Suhunan menyuruh menteri agama membalasi surat itu. Setelah sudah, maka diserahkan ke tangan Si Gangsa itu, lalu ia menyembah, lalu pulang ke bénténg, lalu ke kapal. Maka diserahkannya kepada Jénderal Sukubanah. Setelah sudah baca surat itu oléh jénderal, maka dikumendirkannya semua kapal itu mendekat ke bénténg, masing dengan hadap.

19 5.4. Maka memulai peranglah itu. Gemuruhlah bunyinya / meriam dan léla dan gurnat. Maka kelamkabutlah oléh asap meriam. Dan tiada berhenti lagi kedua pihak memasang meriam, hingga berguncanglah ${ }^{17}$ bénténg dan berombaklah laut; daripada kebanyakan kici langbut penuh sesak laut Sungai Kundur itu. Maka tiadalah ketahuan ulu dan ilir, darat dan laut. Hanyalah kelihatan kilat meriam juga yang kelihatan.

Syahadan dengan takdir Allah yang waktu jam berperang tiada putus di tiap-tiap bénténg membaca selawat dan tahlil dan doca semuanya; menderam bunyinya sebagai repoh. Istiméwa bénténg Tambakbaya yang berlebihan amalnya. Dan didalam bénténg Tambakbaya itu meriamnya Seri Palémbang, akan pélornya dibacakan yasin empatpuluh kali pada pélornya itu. Maka dengan kuasa Allah tacala manakala dibedilkan, mistinya itu peluru jatuh di kapal seperti mengamuk. Maka lantaran meriam Seri Palémbang itu banyaklah kapal perang yang cidera dan banyaklah soldadu yang mati. Dan demikian juga bénténg Martapura: beberapa kici yang sudah cidera pekakasnya dan beberapa langbut yang tenggelam. Dan yang kepada hari itu, setiap-tiap bénténg terlalu keras melawannya, tiada berhenti lagi daripada membedil sekalian kapal perang. Dan yang Pangéran Jayaningrat dan Pangéran Wirakrama Gubir ${ }^{18}$ belumlah sampai hajatnya, waktu itu semuanya ikhtiar jadi lemahlah.

5.5. Maka dengan takdir Allah picahlah perang Olanda; dan undurlah segala kapal perang dan kici dan langbut. Maka ramailah suaranya 
sorak segala $\mathrm{ra}^{c}$ yat di bénténg-bénténg, seperti bunyi tagar di langit. Apalagi bunyi genderang serunai bertimbal-timbalan terlalu azmat bunyinya. Setelah itu jauhlah sudah kapal, tiada kelihatan lagi.

Setelah itu segala kepala-kepala bénténg dikumpulkan oléh Pangéran Ratu. Dan Pangéran Ratu Jambipun berkumpullah, beserta orang Bugis yang menolong perang itu. Setelah kumpullah, maka Pangéran Ratu yang jadi kepala beratur pulang ke Palémbang dengan bermasing20 masing perahu. Serta sorak terlalu ramainya, dengan / genderang kesukaanpun dipalu oranglah. Dan beberapa gamelan dan serunai ditiup orang. Maka terlalu azmat bunyinya.

Setelah kedengaranlah ke Palémbang kepada Seri Suhunan, maka Baginda menitahkan memapag dengan menteri-menteri yang tua-tua berdiri di tangga dalam, dengan tabuh-tabuhan genderang dan gamelan. Maka Seri Suhunan sedia menanti di balai bandung, mastaib dengan alat kerajaan. Setelah sampailah sekalian orang-orang itu, lalu mengadap semuanya kebawah Duli Suhunan, semuanya menyembah, duduk beratur. Maka Pangéran Ratu yang mengaturkan hal perang, bénténgnya telah selamatlah, Olanda sudah lari undur keluar kuala Sungsang. Maka Seri Suhunan mengangkatkan kedua tangannya mengucap: "Alhamdu lillah". Maka menjawablah sekalian: "Amin". Setelah itu maka Suhunan menitahkan kepada hari Senén pagi berkumpul sekalian yang mengangkat perang datang di majelis pemarakan, semuanya besar kecil, tua dan muda, para menteri periai. Maka berdirilah Pangéran Ratu menyampaikan akan titah perintah Suhunan itu kepada sekalian yang hadir. Maka mengabulkan sekalian serta menjunjungkan tangan sekalian keatas kepala. Setelah itu maka Suhunan berangkatlah masuk kedalam istana; tiadalah disebutkan lagi. Maka masing-masinglah pulang sekalian kepada rumahnya.

5.6. Syahadan setelah sampailah kepada hari yang dijanjikan itu, maka berkumpullah sekalian meréka itu datang mengadap di balai bandung; penuh sesaklah kedua balai bandung itu. Setelah itu Seri Suhunan keluarlah dari dalam, lalu bertakhta diatas takhta kerajaan. Maka sujudlah sekalian menjunjung Duli Seri Suhunan. Maka berdirilah Pangéran Dipati Tua menyampaikan titah Seri Suhunan yang sekarang ini dinyatakan kepada sekalian yang hadir: dari Pangéran Ratu telah dijenengkan Sultan Ahmad Najamuddin bin Seri Suhunan Mahmud Badaruddin. Maka menderamlah ${ }^{10}$ sekalian mengucap: "Amin", serta

21 menjunjungkan kedua tangan / meréka itu keatas kepala. Setelah itu maka datanglah beberapa hidangan, diangkat orang ketengah majelis. 
Diatur masing-masing dengan pangkat tertibnya: menteri samanya menteri, periai samanya periai; dan hulubalang dan racyat, masingmasing pada bagainya. Hingga secukupnya pada segala orang yang berhadir itu. Setelah sudah cukup, maka dititahkan oléh Seri Suhunan santaplah sekalian meréka itu. Setelah sudah santap, maka minuman pula diangkat orang. Setelah selesai daripada makan dan minum, maka kutika itu juga Pangéran Adimenggala diangkat dijenengkan Pangéran Bupati.

6.

6.1. Syahadan adalah kepada suatu hari datang orang Sungsang mengadap Sultan Ahmad Najamuddin; mempersembahkan ia akan kapal perang Olanda jaga di laut kuala Sungsang melarangkan kapal dan kici akan masuk di Palémbang, tiada diberinya. Setelah sultan mendengar pengaduan orang Sungsang itu, maka sigeralah Baginda aturkan kebawah Duli Seri Baginda Suhunan. Maka Seri Suhunan mendengar atur anakda Baginda itu, maka Baginda menitahkanlah segala menterimenteri berkekes segala pekakas perang dan meneguhi bénténg-bénténg semuanya. Dan membuat batang melintang laut Muara Plaju; dan rantai besarpun dipasang dari seberang Muara Plaju sampailah ke seberang sebelah Pulau Kembara, supaya kapal dan kici atau sampan langbut sekalipun tiada boléh lalu masuk kedalam bénténg. Setelah sudah semuanya, maka Baginda menitahkan lagi membuat obat dan peluru. Dan itu membuat obat: sebab orang Palémbang jadi pandai, karena seorang Olanda yang minta kehidupan pada Idelir Ménténg yang bermula. Lalu ia masuk Islam. Dari sebab itulah orang Palémbang tahu membikin obat dan senapan peluru. Kemudian dia minggat pulang ke Betawi, wallahu aclam jadinya.

Sebermula setelah $\mathrm{ma}^{\mathrm{c}}$ mur didalam negeri Palémbang pada zaman itu, maka Seri Suhunan melakukan kesukaan, senantiasa tiada berhingga lagi, hingga beberapa tahun. Kata setengah daripada peringatan /

22 orang tua-tua ada empat tahun lamanya, dan ada yang berkata 5 tahun lamanya, dan ada yang berkata tiga tahun lamanya yang didalam aman $\mathrm{ma}^{\mathrm{C}}$ murnya negeri Palémbang adanya.

6.2. Alkissah peri menyatakan Olanda yang kalah itu. Maka Olanda sudah muafakat kepada Suhunan Husin Dia'uddin yang dibuang di Cianjur itu, jadi bersahabatlah antara dengan Gubernur-Jénderal dan Idelir Ménténg. Senantiasa Idelir Ménténg datang di Cianjur berjumpa 
kepada Suhunan Husin. Ialah kepada suata hari Idelir Ménténg bicara pada Suhunan Husin, katanya: "Adakah Tuan Suhunan suka bersamasama menjadi raja di Palémbang dengan Suhunan Mahmud Badaruddin?" Maka jawab Suhunan Husin: "Suka, kalau jadi mufakat yang betul." Maka kata Idelir Ménténg: "Saya boléh bikin sepakat Tuan Suhunan Mahmud Badaruddin dengan Tuan Suhunan Husin. Tetapi ongkos Palémbang punya hasil Tuan Suhunan punya separuh dan Suhunan Mahmud Badaruddin punya separuh. Tetapi antara Tuan Suhunan berdua separuh juga didalam hasil; yang satunya Suhunan kepada Gubernemén. Dan Gubernemén sekadar menumpang membuat loji di kampung Kelénténg, di seberangnya Palémbang." Maka kabullah permintaan Idelir Ménténg itu.

Setelah itu ialah Suhunan Husin dipanggil Gubernur-Jénderal ke Betawi. Setelah Suhunan Husin bertemuan dengan Gubernur-Jénderal itu, maka kata Jénderal: "Saya kira kalau Tuan Suhunan suka jadi raja Palémbang, lebih baik Tuan Suhunan jadi raja sendiri. Apa guna berdua raja?! Nanti barangkali tida jadi pakat." Maka jawab Suhunan Husin: "Itu lebih baik." Maka kata Jénderal: "Apa Tuan Suhunan sanggup itu Palémbang boléh dapat?" Maka sahut Suhunan: "Boléh dapat." Maka kata Jénderal: "Kalau begitu, sekarang boléh bikin surat contract perjanjian yang saya minta. Manakala Palémbang dapat, melainkan

No 1. Tuan Suhunan menjadi raja sendiri.

23 No 2. Hasil Palémbang / bahagi dua kepada Gubernemén.

No 3. Gubernemén berkuasa dari fasal kantoor pabéan, yaitu kantoor boom; Tuan Suhunan tiada boléh campur kuasa.

No 4. Manakala orang asing dagang datang di Palémbang, sampai satu tahun dia duduk di Palémbang, melainkan Tuan Suhunan punya kuasa.

No 5. Yang dari adat aturan negeri misih tetap selamanya menurut bagaimana aturan yang telah selamanya terpakai.

No 6. Tuan Suhunan misti kasih ketempatan orang Olanda, di seberang kota di kampung tempatnya tinggal Idelir Ménténg yang dahulu itu juga."

Maka yang didalam ini 6 fasal semuanya diperkenankan oléh Suhunan. Syahadan maka ditetapkanlah dengan perjanjian yang tersebut itu. Setelah demikian itu maka Jénderal menyuruhkan Idelir Ménténg membuat itu contract dimuka segala hakim-hakim di Betawi.

Serta Jénderal menitahkan sepuluh kapal perang besar dan satu 
kapal perang tempat Suhunan Husin Dia'uddin, serta orang-orang yang dibawanya; dan sepuluh langbut besar dan beberapa sekonyar dan kici, semuanya berpekakas perang. Setelah cukuplah, maka ditemtukan harinya berangkat dari Betawi. Jumblah semuanya dengan soldadu ada limaribu orang $\mathrm{ra}^{\mathrm{C}} \mathrm{yat}$ Olanda.

6.3. Maka berangkatlah dari Betawi dengan angkatan besar. Antara berapa hari lamanya berlayar itu, sampailah di kuala Sungsang. Maka Suhunan menyuruh dengan satu suruhan mengasih tahu kepada kepala orang Sungsang dan kepada kepala perahu pair, yaitu kruis Palémbang, menyatakan Suhunan Dia'uddin yang jadi kepala perang dari sebelah Kompeni Olanda. Maka orang Sungsang dan pair semuanya datang mengadap Suhunan di kapal perang. Lalu ditanya oléh Suhunan apaapa rahasia didalam negeri Palémbang. Maka semuanya dibilangkan oléh orang Sungsang: di tempat bénténg dengan begini-begini halnya, dan orangnya sianu-sianu. Setelah itu maka diperbaiki Suhunan akan hatinya orang yang memberi rahasia itu, dengan berapa-berapa dinu-

24 gerahi kurnia. Setelah / itu Seri Suhunan berapa pucuk membuat surat kepada Pangéran Dipati Tua, suruh sampaikan kepada orang Sungsang. Setelah itu maka masuklah semuanya kapal perang angkatan itu ke Palémbang.

6.4. Dan adalah terlangkah riwayatnya. Maka tersebutkan dibawah ini.

Maka yang waktu Jénderal sudah membuat contract perjanjian itu, maka Suhunan minta témpo tiga bulan. Ialah Suhunan menyuruh akan isterinya nama Nyimas Taipah pulang di Palémbang, dengan membuat sebabnya sudah dicerai oléh Suhunan dia akan pulang di Palémbang. Maka disuruh antar $<$ ke $>$ kapal perang yang jaga kuala di Sungsang. Setelah sampai di kapal perang, maka diantar di kuala Sungsang, diserahkan di perahu pair; maka terus diantarkan di Palémbang. Setelah Nyimas Taipah sudah datang di Palémbang, maka dengan bagaimanalah rahasia kepada Pangéran Dipati Tua dan periai-periai nyang sebelah Suhunan Dia'uddin tiadalah seorang yang mengetahui dia, melainkan sehinggalah sampai surat kepada Suhunan di Cianjur daripada Palémbang, yang sudah mengasih rahasia besar kepada Suhunan Husin Dia'uddin. Maka dengan demikian itu Suhunan jadi membuat itu contract kepada Jénderal akan mengalahkan Palémbang; ialah Suhunan berangkat ke Palémbang, yang telah tersebut diatas itu tulisannya. 
6.5. Syahadan setelah sampailah angkatan itu di Sungai Kundur, maka berlabuhlah segala kapal-kapal dan kici-kici dan langbut semuanya di laut Sungai Kundur, hingga penuhlah laut Sungai Kundur itu. Dan adalah kepala angkatan itu bernama Jénderal Dekok berdua Idelir Ménténg. Dan adalah di bénténg Muara Plaju itu semuanya sudah mastaib, sedia menanti masing-masing pada tiap-tiap bénténg itu dengan tiadalah sunyi daripada mengucap selawat dan tahlil pada siang dan malam.

Setelah itu maka Jénderal Dekok tiadalah menyuruhkan lagi orang 25 yang / menjadi utusan ke Palémbang, melainkan dengan diperbuatkannya satu rakit kecil dengan satu setoplés gelas, di dalamnya surat kepada Seri Suhunan Mahmud Badaruddin. Setelah air pasang, maka dihanyutkan rakit itu kepada bénténg Martapura, tempatnya Sultan Ahmad Najamuddin dan Pangéran Dipati Tua. Setelah sampailah rakit itu ke bénténg, maka diambil orang bénténg gelas dan surat itu, dipersembahkan kepada Sultan Ahmad Najamuddin. Setelah dilihat pada alamatnya, kepada Seri Suhunan Mahmud Badaruddin, maka Sultan tiadalah berani membukanya. Lalu disuruhnya persembahkan ke Palémbang, kepada Seri Paduka Ayahda Baginda Suhunan Mahmud Badaruddin. Setelah sampailah kepada Suhunan di Palémbang dan sudah dibaca, maka disuruh balasi, wallahu aclam di dalamnya. Setelah sudah surat itu dibawa di bénténg Martapura, lalu ditaruh pada rakit itu, ditaruhkan surat itu didalam setoplés yang dikirim dahulu itu juga. Setelah air surut, maka dihanyutkan pula pada kapal perang itu. Setelah sampai, maka diambil orang kapal, dikasihkan kepada Jénderal Dekok dan Idelir Ménténg.

6.6. Setelah itu maka sampan kotak-kotak dari kapal-kapal perang itu mendekatlah ke bénténg serta memasang gurnatnya, tiada berhenti lagi. Setelah dibalas dari bénténg Tambakbaya itu dan lain-lain bénténg, maka sampan kotak lari. Demikianlah permulaan perang itu.

Setelah itu maka Olanda bertebas pada hutan Muara Plaju akan membuat jalan memintas kepada belakang bénténg Tambakbaya. Maka ketahuan oléh Pangéran Kramajaya, kepala bénténg Tambakbaya itu, lalu disuruhnya jaga di laut Sungai Plaju dengan beberapa perahuperahu ampilan, menanti di Sungai Plaju dengan meriam dan léla dan pemuras. Dan sampailah sudah soldadu Olanda itu di pinggir Sungai Plaju itu, baru ia hendak menurunkan sampannya dari tebing, maka dibedil oléh orang ampilan dari Sungai Plaju itu kedalam hutan, 26 tempatnya / soldadu banyak itu. Maka berangkatlah kutika itu balasmembalas, dari laut dan dari utan. Serta dengan tempik sorak segala 
racyat Palémbang membedil dari perahu ampilan itu dan berbunyilah meriam dari bénténg Tambakbaya, menuju pelurunya kedalam hutan tempat soldadu Olanda itu dengan tiadalah berhentinya lagi. Sehingga naiklah rac ${ }^{c}$ yat Palémbang ke tebing, lalu menyerang ke tempat soldadu itu. Setelah bertemuan, maka racyat Palémbangpun mengamuk pada tentara soldadu itu, serta dengan tempik soraknya, sampai ke langit seperti guruh; dan terlalu keras amuknya. Maka tiadalah bertahan $\mathrm{ra}^{\mathrm{C}}$ yat soldadu itu, lalu lari turun di langbutnya, lalu di kapal perang.

Maka setelah dilihat racyat Palémbang soldadu sudah undur itu, maka ia bersoraklah seperti guruh bunyinya. Dan banyaklah rampasan sepatu-sepatu dan pakaian dan senapan yang tertinggal didalam hutan itu. Lagipun terlalu banyak makanan, buah-buahan yang ada di negeri Palémbang, seperti beléwah, semangka, jeruk kuwik-kuwik dan lainlain. Maka menjadi héranlah racyat Palémbang dari mana datangnya itu buah-buahan dari Palémbang, padahal jaga sampai keras. Dan ada juga kedapatan soldadu mati, maka dipotong kepalanya. Maka semuanya itu dipersembahkan oléh racyat ampilan itu ke bénténg Tambakbaya, lalu disembahkan ke Palémbang, kepada Seri Suhunan Mahmud Badaruddin. Maka Suhunan berubahlah cahaya mendengarkan persembahan orang bénténg Tambakbaya, tetapi tiadalah apa suatu perintahan.

6.7. Syahadan setelah beberapa harilah berperang itu, maka segala kapal perang itu pada mendekat di bénténg Martapura dan Manguntama dan di Rawa-Rawa Sekampung, tetapi tiadalah mendekat di bénténg Tambakbaya. Dan adalah didalam riwayatnya orang tua-tua, yang lain-lain bénténg itu pélor meriamnya sekadar mengasih perisén ${ }^{20}$ buah jeruk buat keramas kapal perang. Demikianlah didalam riwayat-

27 nya orang tua-tua Palémbang. / Hanyalah bénténg Tambakbaya satu juga yang berpélor besi. Maka tiadalah sampai memberi mudarat pada yang menahan kapal perang berpuluh-puluh itu. Tetapi satu kapal perang yang terbesar daripada segala kapal itu, bernama Kerambang, terlalu besar-besar meriamnya. Maka kapal itu yang berhadap kepada bénténg Tambakbaya, membedil pélornya menempuh bénténg Tambakbaya itu; seperti akan rungkat rasanya, serta bunyinya seperti bunyi halontar membelah bumi. Demikianlah halnya.

Syahadan jadi perang besarlah pada hari itu; bunyi sorak dan bunyi meriam, léla, senapan seperti akan kiamat. Tetapi setelah mendekat semuanya kapal perang itu, maka Sultan Ahmad Najamuddin sendiri jumeneng melihatkan orang memasang itu, ialah baharu dipasang dengan pélor besi pada tiap-tiap bénténg. 
6.8. Setelah demikian maka undurlah segala kapal itu. Dan dua langbut besar serta dengan pekakasnya, satu dapat oléh bénténg Manguntama, Pangéran Wirasentika, dan satu dapat di bénténg Pulau Kembara, Pangéran Suradilaga. Kedua langbut itu lapis tembaga; dan meriam tembaga, panjang tiga depa, dan $<$ di $>$ burinya $<$ meriam $>$ besi. ${ }^{21}$ Dan demikian juga langbut satunya. Maka meriam itu dinaikkan ke bénténg Pulau Kembara, dinamai Seri Betawi. Dan meriam yang di langbut dapat oléh Pangéran Suradilaga akan dinaikkan ke bénténg Tambakbaya, lalu jatuh ke laut, tiada dapat lagi. Dan pelurunya terlalu banyak pada langbut kedua itu; dan lain-lain barangpun terlalu banyak boléh rampasan. Dan perang itulah kapal Rambang yang besar rubuh tiang luan dan patah cucurnya.

6.9. Maka malam yang kedua, yaitu malam Ahad, langbut-langbut dan segala kapal-kapal perang semuanya mendekat bénténg. Maka pukul tiga malam angkatan datanglah dimuka bénténg-bénténg itu; dan setengah enam pagi mulai berperang. Tetapi yang kepada malam Ahad itu semuanya orang pulang di Palémbang; hanya tinggal orang jaga

28 juga. Sebab didalam perjanjian malam dan siangnya / ${ }^{22}$ tiap-tiap hari Ahad tiada boléh berperang. Setelah pagi-pagi, bunyi meriam terlalu ramainya, seperti tagar. Hanyalah Tambakbaya sendiri yang meladéni perang itu. Maka segala racyat dan Sultanpun kembali pula ke bénténg. Tetapi semuanya kapal sudah rapat ke bénténg semuanya, serta dengan memasang meriam tiada berhenti lagi, seperti ribut dan guruh. Semua kapal itu pada carem memasang ke bénténg. Dan yang lepas pélornya dari bénténg menyambar pohon kayu-kayu di hutan, banyaklah rubuh. Serta soraknya semua soldadu di kapal itu seperti guruh bunyinya. Maka dahsatlah hati yang penakut; dan lupalah kepada matinya orang yang berani. Dan yang hal di bénténg-bénténg pada ramailah membaca selawat dan tahlil, senantiasa tiada berhenti lagi. Tetapi sebagaimana pintanya dan doca dan melawan, manakala sudahlah takhsis iradat Allah tacala tiadalah siapa yang boléh menegahkan dia. Maka waktu itulah masanya perhentian daripada fasal raja Islam di negeri Palémbang akan gantilah kepada kafir.

6.10. Maka kepada hari itulah picahlah bénténg Pulau Kembara itu, larilah sekalian orangnya ke Palémbang. Maka Olanda naiklah ke bénténg, lalu merubuhkan bendéra dan mendirikan bendéranya.

Setelah dilihat oléh Pangéran Ratu Jambi hal bénténg Pulau Kembara sudah dapat oléh Olanda itu, maka ia lalu membakar bénténgnya sendiri; dia lalu mudik ke Palémbang. 
Yang kepada bénténg Tambakbaya yang misih keras melawan tiada berhenti lagi memasang meriam Seri Palémbang serta dengan membaca yasin dan selawat dan tahlil. Maka banyaklah kapal perang itu putusputus tiangnya dan banyak soldadunya $<$ mati $>$. Kalau sekira dua tiga kapal perang, kendati besar-besar sekalipun, niscaya hancurlah oléh tiada tertahan daripada pélor daripada bénténg Tambakbaya itu. Sekadar mati empat lima ratus soldadu, padahal kapal perang terlalu banyaknya.

Dan setelah dilihat Pangéran Wirasentika Pangéran Ratu Jambi itu sudah lari dan bénténgnya sudah terbakar, maka ia meninggalkan / 29 bénténgnya, lalu masuk kepada bénténg Martapura bersama-sama segala orang Bugis. Setelah demikian maka Pangéran Dipati Tuapun membawa Sultan pulang ke Palémbang. Maka segala bénténg-bénténg yang kecil-kecil itupun habis sudah dibakar oléh Olanda.

6.11. Setelah Sultan sudah pulang lari, hanyalah bénténg Tambakbaya juga yang semangkin melawannya, yang memberi kuatir kepada Olanda. Tiadalah boléh diampiri oléh langbut, sebab pembedilnya terlalu keras. Maka dipintas oléh limaratus soldadu dari belakang bénténg Tambakbaya, dipasangnya dengan senapan sama sekali, seperti bunyi ribut. Maka harubirulah bénténg Tambakbaya itu. Maka dilihat oléh Pangéran Kramajaya hal demikian itu soldadu terlalu banyak akan menempuh kepada bénténg itu, maka Pangéran Kramajaya berkekeslah akan mengamuk serta segala racyatnya. Maka sigeralah paduka ayahdanya Pangéran Natadiraja dan Pangéran Haji Kramanandita dipeluknya, tiadalah diberinya; serta dipegangnya tangan keduanya, dipimpinnya dibawa lari ke sebelah ilir tempat datang soldadu itu. Setelah dilihat oléh soldadu orang bénténg sudah lari itu, maka sigeralah soldadu masuk kedalam bénténg, merampas barang apa ada yang ditinggal; serta dibakarnya bénténg Tambakbaya itu habis. Setelah itu berhentilah perang hari itu.

6.12. Maka yang lain-lain kapal perang semuanya berlabuh diluar cerucup. ${ }^{23}$ Hanyalah kapal perang tempat Suhunan Husin Dia'uddin juga yang masuk pada sebelah kedalam cerucup. Hingga empat hari berlabuh di situ, maka pada malamnya itu datanglah Pangéran Dipati Tua mendapatkan Suhunan Husin di kapalnya. Setelah sudah bertemuan, maka disuruh Suhunan Pangéran Dipati Tua bawa kepada Jénderal Dekok pada malam itu juga. Setelah ketemu, maka Pangéran Dipati Tua bicara akan minta damai antara perang itu oléh Suhunan Mahmud Badaruddin. Dan Pangéran Dipati Tua minta sendirinya 
30 dari karang-kampungnya minta aman, jangan dibinasakan. / Maka kata Jénderal Dekok: "Boléh damai, tetapi dengan satu perjanjian. Jika betul sudah habis ini perkara, bénténg tiada lagi perang, Palémbang boléh aman dan ramai. Dan jika lagi akan berperang, di Palémbang niscaya pukul terus, tiada boléh aman dan ramai. Mistinya harta dirampas soldadu punya bahagian dan negeri mistinya dibakar sama sekali. Dan yang di atas: Kompeni Olanda tiada kurang soldadu dan ongkos perang; sepuluh kali lagi angkatan dari sini boléh Kompeni kelarkan!" Setelah itu maka Pangéran Dipatipun memberi putus bicaranya, yang tiada sekali-kali akan berperang di kota Palémbang. Setelah sudah habis bicara itu, maka Pangéran Dipati memberi tabé pulang ke Palémbang, lalu mengadap Seri Suhunan menyembahkan apa-apa bicaranya Jénderal Dekok itu. Maka Suhunanpun tiadalah berdaya lagi. Karena oléh memikir seperti seorang diri. Melainkan apa-apa yang dibicarakan Pangéran Dipati Tua itu sehingganya diterima.

6.13. Setelah tetaplah dari hal bicara damai itu, maka segala kapal perang masuklah ke Palémbang, berlabuh di laut tangga dalam. Dan Seri Suhunan berpindahlah di kampung Pangéran Dipati Tua. Maka kapal perang itu beratur di laut Palémbang, dari muara Ogan sampai di Sungai Bayas. Dan pada waktu itu adalah didalam Hajrat al Nabi 1236.

Setelah itu maka naiklah kepala ${ }^{24}$ yang besar-besar dan duaribu soldadu terus masuk kedalam kota. Setelah itu maka Suhunan Mahmud Badaruddin menitahkan puteranya Pangéran Prabukesuma dan Pangéran Kramajaya menyerahkan kota dengan Olanda, dengan isi-isinya ${ }^{25}$ gedung semuanya harta-harta dan harta mal hak yatim. Maka diterimalah oléh kepala Olanda semua perserahan itu. Setelah habis kerja itu, maka Pangéran Prabukesuma berdua Pangéran Perdana Menteri Kramajayapun pulanglah kembali mengadap Suhunan, mengaturkan yang sudah selesai diserahkan kepada Olanda.

Setelah keésokan hari, maka Idelir Ménténg dan Suhunan Husin

31 Dia'uddin/pun naiklah masuk kedalam kota, duduk di sebelah tempat Olanda, karena Olanda menunggu janji akan dibuatkan tempatnya di seberang kampung Kelénténg. Setelah berapa hari Suhunan Husin duduk didalam kota bercampur dengan Olanda itu, tiadalah tahan sebab orang Olanda lain aturannya; maka berpindah ia ke Suakbata.

6.14. Sebermula tersebutlah Suhunan Mahmud Badaruddin turunlah di kapal perang, dengan segala kerabat ahli-ahlinya sekalian yang suka mengikut. Telah tiga hari kapal perang berlabuh di pangkalan Pangéran Dipati Tua itu, lalu berlayar ke Betawi. 
Syahadan sesudah Suhunan berlayar itu, maka Jénderal Dekokpun naiklah masuk kedalam kota dengan Suhunan Husin dan Prabu Anom; dan beberapa orang Olanda besar-besar, dan menteri-menteri dan segala racyat negeri dan orang Arab dan Cina, semuanya berkumpul kedalam kota. Penuh sesaklah ${ }^{26}$ didalam kota. Setelah itu maka jénderal menitahkan Olanda yang berpangkat menaik diatas singgasana berdiri. Serta Jénderal Dekok dan Idelir Ménténg dan Suhunan Husin Dia'uddin didatangkanlah akan surat contract itu dengan bertempat yang sempurna, dengan berbungkus teluki kuning. Setelah dibuka, maka membacalah oléh Olanda yang dititahkan jénderal yang tersebut itu, yaitu bernama Tuan Setulur, lalu dibacanya.

Maka yang pertama bunyi surat itu, yang Suhunan Mahmud Badaruddin telah diputuskan perintahnya; serta Sultan Ahmad Najamuddin serta lain-lain puteranya tiada berkuasa lagi. Dan mulai sekarang Suhunan Husin Dia'uddin turun-menurun menjadi raja diatas takhta kerajaan di negeri Palémbang, hingga segala désa-désa uluan Palémbang, melainkan cuma pabéan, yaitu kantoor boom, diganti oléh Kompeni. Manakala orang dagang sampai setahun lamanya tinggal di

32 Palémbang, melainkan Suhunan punya kuasa. Dan dari / Palémbang, akan adatnya misih ditetapkan sebagai zaman bahari juga.

Syahadan setelah habis itu surat dibaca, maka diberikan oléh Tuan Setulur kepada Suhunan. Maka berbunyilah meriam di kapal, disahuti pula dari buluwarti. Maka ramailah waktu itu dengan beberapa bunyibunyian semuanya dipalu oranglah. Serta beratur baris duaribu dari tangga dalam sampailah di balai bandung, semuanya memberi selamat kepada Suhunan naik kerajaan itu.

Setelah selesailah daripada pekerjaan itu, maka jénderal menitahkan menurun segala meriam dan léla di kapal perang. Hanyalah misih tinggal meriam pusaka Palémbang yang dipinta Suhunan misih tinggal. Maka jénderal dan Idelir Ménténg semuanya pulang ke Betawi membawa angkatan itu.

7.

7.1. Setelah selesai daripada hal itu, maka Suhunan di Suakbata menjenengkan pada sekalian bawahannya dengan masing-masing jenengnya:

No 1. Puteranya Prabu Anom berjeneng Sultan Ahmad Najamuddin.

No 2. Puteranya Pangéran Jayaningrat berjeneng Pangéran Dipati.

No 3. Pangéran Jayakrama berjeneng Pangéran Aryakesuma. 
No 4. Pangéran Dipati Tua dijenengkan Pangéran Bupati Panembahan.

No 5. Dan Pangéran Wirakrama berjeneng Pangéran Purbanegara.

No 6. Dan Radén Said dijenengkan Pangéran Martakesuma.

No 7. Radén Badaruddin dijenengkan Pangéran Natawijaya.

No 8. Dan Aluddin dijenengkan Pangéran Natawiguna.

No 9. Dan Pangéran Sumadilaga dijenengkan Pangéran Natakrama.

No 10. Radén Tokid dijenengkan Pangéran Natawijana.

No 11. Dan Masagus Keling dijenengkan Pangéran Temenggung Mentaun.

No 12. Dan Ngambéhi Carik dijenengkan Temenggung Yudawijana.

No 13. Dan Demang Wirasentika dijenengkan Kiai Rangga Wirasentika.

No 14. Dan Pangéran Adiwijaya dijenengkan Pangéran Perdana Menteri; merintah bicara negeri.

No 15. Dan Radén Zakiuddin dijenengkan Pangéran Natanandita.

33 No 16. Dan Radén Ajid dijenengkan Pangéran Krama/nandita.

No 17. Dan Nayu Hanipa dijenengkan Nayu Reksapura.

No 18. Dan Saripah Zainah dijenengkan Ratu Saripah.

No 19. Dan Radén Mahpi dijenengkan Pangéran Sutanandita.

No 20. Dan Radén Muksin dijenengkan Pangéran Sutakrama.

No 21. Dan Radén Cingot dijenengkan Pangéran Puspadiprana.

No 22. Dan Masagus Putang dijenengkan Pangéran Citra.

Maka setelah selesai daripada itu, ialah Pangéran Bupati Panembahan membuat rumah di Suakbata, dekat Suhunan.

7.2. Maka waktu itulah berbicara akan membuat kota di seberang, bakal tempat Olanda. Maka menitahkanlah pada sekalian pucukan uluan minta buluh. Dan dibukalah kampung Kirangga Usman di Kelénténg.

Setelah berapa lamanya maka datanglah buluh, dibawa orang dari ulu; kira cukuplah kota bakal tempat Olanda itu. Setelah buluh sudah datang itu, maka Pangéran Dipati Jayaningrat mengadap Suhunan menyembahkan buluh sudah datang itu. Tetapi dipohonkannya jangan dibuat itu buluh akan kota, sebab lekas buruk. Lebih baik dibuat kayu, boléh tahan lama. Maka dikabulkan Suhunan sebagai pikiran Pangéran Dipati itu. Lalu menitahkan pula minta kayu balok petaling akan segala pucukan itu, akan diperbuat kota Olanda, supaya tahan lama. Syahadan antara berapa lamanya maka datanglah pula segala orang 
dari uluan membawa balok itu, beribu-ribu balok petaling ke Palémbang. Maka sigeralah dipersembahkannya oléh Pangéran Dipati kepada Suhunan. Maka Suhunan menitahkanlah berkumpul tukang akan bekerja membuat kota di seberang itu.

Setelah itu maka Pangéran Dipati memohonkan pula: "Jangan dibuat itu kota kayu, karena tiada lama buruk juga. Melainkan kita juga yang punya kerugian, bukannya Kompeni punya rugi. Lebih baik sekali kita buatkan kayu itu diganti batu. Jika ${ }^{27}$ jadi, cuma sekali menanggung rugi; meskipun besar ongkosnya, cuma rugi sekali. Akan tetapi didalam itu atur patik, yang manalah titah perintah boléh dikerjakan." Maka Suhunan pikir dari kemauan Pangéran Dipati itu terlalu benarnya. Dan lagi yang waktu di Betawi dahulu, melainkan ini Pangéran Dipati yang akan dijadikan sultan; tetapi Suhunan minta Prabu Anom. Dengan pikiran demikian itu lantas diturut Suhunan ${ }^{28}$ permintaan Pangéran Dipati itu akan membikin kota batu. Padahal Suhunan /

34 tiada ingat kepada hal Pangéran Dipati itu sudah menaruh dendamnya, karena dia orang menjadi sultan itu yang senantiasa ia cari akal akan merusakkan didalam kerajaan Suhunan itu.

7.3. Setelah itu Suhunan menitahkan membikin kota batu itu, ongkos tiada ada. Maka sembahnya Pangéran Dipati: "Kita boléh pinjam kepada Jénderal seratus ribu." Maka titah Suhunan: "Baiklah engkau pergi ke Betawi!" Maka sembahnya: "Baiklah! Siapa teman patik?" Maka titah Suhunan: "Pangéran Purbanegara akan temanmu."

Setelah itu jadilah Pangéran Dipati Jayaningrat itu utusan ke Betawi berdua Pangéran Purbanegara. Maka berlayarlah keduanya membawa sepucuk surat Suhunan kepada Jénderal. Setelah sampailah ke Betawi, maka bertemulah kepada Pangéran Dipati Abdurrahman dan Pangéran Natadiraja dan Pangéran Kramajaya dan Pangéran Wirasentika dan dipati Belidah. Semuanya itu kerja berluruan daripada segala harta Suhunan Mahmud Badaruddin. Dan waktu itu Suhunan Mahmud Badaruddin sudah dibawa Olanda di Ternati. Dan adalah puteranya yang tinggal di Betawi: Nayu Purbaya Cik Jaro dan Pangéran Sutakrama Akil dan Pangéran Sutawijaya Usman dan Pangéran Sutadiraja Bakar dan Pangéran Puteradinata Ali. Semuanya itu lagi bicara hendak pulang ke Palémbang.

Sebermula maka Pangéran Dipati Jayaningrat bersama-sama Pangéran Purbanegara lalu mengadap Jénderal memberikan surat kiriman dari Suhunan Husin Dia'uddin. Maka disambut Jénderal, lalu dibaca. Tersebut Suhunan akan pinjam uang seratus ribu, akan dibuat bakal 
ongkos membikinkan kota tempat Kompeni di Palémbang. Setelah sudah dibaca, maka jawab Jénderal: "Itu kota tempat Kompeni boléh sekarang Tuan Suhunan bikin bambu saja. Bésok manakala Tuan Suhunan sudah dapat ongkos hasil negeri, mana suka, bikin batu atau besi." Maka Jénderal berkata lagi kepada Pangéran Dipati Jayaningrat: "Itu uang seratus ribu, kalau mau bikin ongkos akan melawan merebut kota Palémbang." Maka jawab Pangéran Dipati: "Barangkali." Syahadan jadi rusaklah wa ${ }^{c}$ at dan janji dari perkara Palémbang oléh karena demikian itu. Maka Pangéran Dipati memberi tabé, lalu pulang ke tempatnya tinggal. Setelah berapa hari duduk di Betawi, maka Pangéran Purba jatuh sakit. Pada malam itu juga tiada dapat melihat 35 lagi ${ }^{29}$; lalu pulang / ke Palémbang. Dan Pangéran Wirasentika sakit, lalu mati di Betawi; kerandanya dibawa pulang ke Palémbang.

7.4. Setelah itu maka Jénderal menitahkan commissaris pergi ke Palémbang. Dan Pangéran Dipatipun mengikutlah commissaris, merapatkan dirinya kepada commissaris. Setelah sampai di Palémbang, maka $\mathrm{Pa}$ ngéran Dipati itu tiadalah lagi mau dia datang mengadap Suhunan. Melainkan dia menghampirkan dirinya juga kepada commissaris.

Setelah berapa lamanya commissaris sepakat dengan Pangéran Dipati Jayaningrat itu, maka Pangéran Dipatipun mendatangkanlah satu pengaduan, yaitu yang Pangéran Adiwijaya, perdana menteri, hendak membunuh satu perempuan selir Suhunan Husin Dia'uddin. Sebab dikatakan orang salah perbuatan. Ialah lantas diperiksa commissaris akan halnya. Maka nyatalah terang daripada pengaduan Pangéran Dipati itu. Maka itu perempuan selir Suhunan yang tersebut diambil commissaris. Dan Pangéran Adiwijaya Perdana Menteri diperhentikan kuasanya perdana menteri. Dan digantikan akan gantinya Pangéran Kramajaya, diangkat jadi perdana menteri. Syahadan waktu itu sunyilah di Suakbata; tiada lagi orang mengadukan hal perkara, kembalilah kepada Pangéran Kramajaya, perdana menteri di Sungai Tengkuruk. Dan Pangéran Bupati Panembahan tiada lagi tinggal di Suakbata, berpindah ia di kampung sendiri di dekatnya ${ }^{30}$ Sekanak.

Syahadan setelah hal <yang> demikian itu ${ }^{31}$, sudah merasailah Suhunan Husin Dia'uddin yang dia sudah ada didalam rencana puteranya sendiri. Jadi picahlah apa-apa yang diwacat-janjikan kepada Kompeni Olanda didalam contract, tiadalah berguna lagi. Melainkan tiadakan jadi betul lagi akan akhirnya.

7.5. Maka bersigeralah Suhunan mendapatkan commissaris, menye- 
rahkan segala désa-désa uluan semuanya. Yang ditinggalkan Suhunan buat bakal permakan ahli-ahlinya: no 1 Perwatin Lima Belidah, 2 dan Pegagan Ilir, 3 Panang Karubelah, ${ }^{32} 4$ Dana Luar, ${ }^{33} 5$ Pemulutan, 6 Teloko, 7 Penukal, 8 Sungai Keruh. Dan yang lain-lain daripada itu telah diserahkan Suhunan kepada commissaris. Maka diterima commissaris, tetapi tiada dikabulkan dari 8 tempat permintaan yang tersebut itu. Melainkan dengan dikabulkan diganti dengan gajih tiap-tiap bulan, diatas satu-satu periai-periai putera keluarga Suhunan, sehingga Su36 hunan juga dikasih / permakan.

7.6. Maka telah selesai daripada segala hal yang tersebut itu, maka commissarispun membuat raat, yaitu perkumpulan daripada memeriksa dan mehukumkan perkara-perkara anak negeri terus sampai di uluanuluan di tiap-tiap dusun. Dengan ada kepalanya berjuluk dipati dan bawahannya kria dan penggawa. Dan dengan satu afdeelingnya dengan ada satu-satu politienya dengan digajih. Dan yang dari kepala-kepala dusun dan bawahannya kadar dikasih persén daripada hasil dusun dan marga, daripada cukai juga.

Dan adalah yang raat di Palémbang itu, semuanya digajih: no 1 Pangéran Perdana Menteri Kramajaya, 2 dan Kemas Temenggung Kertanegara, 3 Kemas Rangga Hasan, 4 dan Kirangga Tamin, 5 Kirangga Ahmad, 6 dan Kirangga Jalil. Maka semuanya itu digajih duaratus rupiah satu bulan. Melainkan Pangéran Perdana Menteri sendiri gajihnya limaratus rupiah. Dan di tiap-tiap hari raat Suhunan Husin Dia'uddin turut jadi kepala raat beserta Pangéran Penghulu Agama, gajihnya seratus limapuluh rupiah. Dan ditemtukan raat itu pada hari Khamis dan Isnain; dan manakala Suhunan tiada masuk waktu raat, maka raat tiada jadi.

7.7. Setelah tetaplah sudah aturan di Palémbang demikian itu, maka commissaris pulanglah ke Betawi. Diadakan wakil raja di Palémbang Resident Ris yang memerintah negeri Palémbang dan uluan. Syahadan yang Seri Suhunan Husin menerima gajih tiap-tiap bulan pensiun. Setelah itu maka Tuan Resident membuatlah aturan jalan-jalan didalam kampung Palémbang seberang-menyeberang, perintah dari politie dan jaga kampung. Maka semuanya itu perintah dari commissaris telah dijalankan oléh resident. Tetaplah itu aturan selama-lamanya.

8.

8.1. Sebermula beberapa lamanya Suhunan Husin Dia'uddin bertakhta di Suakbata, maka daripada sampailah watas Palémbang akan ber- 
pindah masanya, maka dari Sultan Ahmad Najamuddin Prabu Anom yang didalam beberapa lamanya Suhunan jumeneng menjadi raja menurut contract yang telah tersebut itu. Maka Sultan didalam sementara itu sultan, dengan sekonyong-konyongnya dia menurut pengajaran patihnya Pangéran Puspadiprana Cingot buat keniatan salah kepada Kompeni Olanda. Dengan beberapa banyaknya orang sudah menurut 37 pengajarnya buat wilut bicaranya kepada Kompeni / ${ }^{34}$ Olanda, yang kepada Suhunan di Suakbata sekali-kali tiada kenal akan hal rahasia itu.

Maka adalah kepada suatu hari Sultan membuat pitnah, memanggil pada segala menteri-menteri yang duduk di raat dan lain-lain periai disuruh Sultan pergi di Suakbata, dipanggil oléh Suhunan. Maka sekalian menteri-menteri dan periai-periai semuanya pada pergi ke Suakbata akan mengadap Suhunan. Setelah sampailah di Suakbata, penuh sesak duduk di pemarakan menunggu Suhunan. Setelah diketahui oléh Suhunan hal demikian itu, maka Suhunan tiadalah terkata-kata lagi oléh perbuatannya Sultan. Setelah itu Sultan datanglah di Suakbata, menahan semuanya itu tiada boléh pulang, disuruhnya menunggu Suhunan. Iapun ${ }^{35}$ pulanglah ke Sekanak akan bersiapkan orang-orang ada hadir itu semuanya sudah bersiap akan sabil.

Setelah Sultan turun ke perahunya, ia menoléh di belakang, dilihatnya Pangéran Perdana Menteri berjalan, akan pulang rupanya. Maka bersigera Sultan kembali, menaiklah ia mendapatkan Pangéran Perdana Menteri, serta ia menyakep parang panjang. Setelah dekat maka Sultan lalu mengangkat akan memarang ${ }^{36}$ Pangéran Perdana Menteri itu. Maka bersigeralah Pangéran Bupati Panembahan menangkap tangan Sultan dari belakang. Dan Sultanpun memegang Pangéran Perdana Menteri, tiadalah dilepaskan. Dan Pangéran Bupati Panembahan merebut parang itu dari tangan Sultan; sampailah bergelut. Dan Pangéran Perdana Menteripun terlepaslah dari pegangan Sultan itu. Maka yang lain teman Sultanpun menumbuk dan menujah dengan keris dari belakang Pangéran Perdana Menteri itu; maka bajunya juga yang picah-picah. Tetapi Pangéran Perdana Menteri didalam peliharaan Allah tacala, tiadalah kena satu apa-apa. Melainkan baju dan kain saja yang picah-picah. Dan kerisnya diambil orang tiada ketahuan. Setelah itu datanglah Suhunan sendiri mengambil Pangéran Perdana Menteri, dibawanya ke balai bandung, terus dimasukkan di reban kambing. Dan Pangéran Bupati Panembahan memeluk Sultan, lalulah pulang ke Sekanak; maka haripun malam. Dan Panembahanpun sigeralah membawa segala anak-isterinya di Kertapati.

Adapun yang Pangéran Dipati Jayaningrat sudah masuk kota mem- 
beritahu resident. Maka Pangéran Dipati Abdurrahman pada malam itu juga dipanggil resident kedalam kota; dan temenggung politie dan /

38 Hasanuddin keduanya masuk kedalam kota dengan segala anakisterinya. Dan yang Sultan sudah siap, berhimpun beberapa banyak orang dengan alat senjata, semuanya lagi menunggu waktu sangatnya akan mengamuk masuk kota. Dan beberapa banyak suruhan resident akan meriksa hal, semuanya disuruh Sultan tangkap; dan di Suakbata demikian juga.

Syahadan yang Pangéran Perdana Menteri didalam maksud orang akan ditunu dengan reban kambing itu juga; tetapi belum sampai azal bilangannya. Lantas ketahuan di Sungai Tengkuruk wartanya itu. Dan Kedukan ${ }^{37}$ maka berhimpunlah di Sungai Tengkuruk, kira ada empatpuluh orang. Maka paduka ayahdanya Pangéran Natadiraja dan Pangéran Haji Kramananditapun sigeralah pergi ke Suakbata. Maksudnya akan mengamuk Suhunan. Setelah sampai di Suakbata, maka diberi orang tahu yang Pangéran Perdana Menteri didalam reban kambing; lantas diambil oranglah dengan paksa. Dan orang banyakpun sedia di luar dengan mengunus senjata, semuanya racyat dari Kedukan.

Maka waktu Pangéran Haji Kramanandita mengeluarkan Pangéran Perdana Menteri dari reban kambing itu, tiadalah yang berani mengapakan dia, sebab takut terlalu banyak orangnya diluar pintu sudah sedia senjata terhunus semuanya. Maka lalu keluar, dibawa pulang. Setelah bersalin pakaian, maka dibawa serta orang-orang putera-putera dan ahli-ahli perempuan-perempuanpun masuk kedalam kota. Setelah resident berdapat pada Pangéran Perdana Menteri itu, maka resident terlalu suka. Maka lalu resident menyuruh Kirangga Tamin membawa surat kepada Sultan. Maka setelah datang kepada Sultan, terlepas surat Kirangga Tamin ditahan, tiada diberi pulang.

8.2. Syahadan setelah jam pukul 4, maka berjalanlah angkatan Sultan itu dengan beberapa periai-periai dan haji-haji semuanya lengkaplah dengan membawa senjata yang sudah terhunus, serta dengan bunyi zikirullah dan mengucap selawat atas Nabi dan tahlil. Maka gemuruhlah bunyinya. Maka malam itu terlalu gelap, tiada kelihatan apa-apa, serta turun hujan rintik-rintik. Yaitu malam itu pada duapuluh sembilan Rabicul-awal tahun seribu duaratus empatpuluh betul, 1240, maka sampailah angkatan itu kehadapan kota. Maka Panglima Batuapi mem-

39 bedil dengan / pemuras, penuju kepada pintu kota. Maka sigeralah dibalas oléh baris dari pintu kota, empatratus banyaknya membedil sama sekali, tiadalah berdiam lagi. Dan meriam diatas kotapun 
berbunyilah dan meriam kapal juga di lautpun berbunyilah. Maka Pangéran Putang, penghulu amuk itu, masuk larén besar serta keluar sudah dibelakang soldadu, bersama-sama dengan Haji Jabaruddin. Maka ia mengamuklah. Setelah beramuk, haripun sianglah. Maka angkatan Sultan itupun undurlah, masing-masing membawa dirinya. Dan adalah racyat Sultan yang mati Pangéran Putang dan Radén Gubir ${ }^{38}$ dan Khatib Jabaruddin dan Si Luncuk, pinakawan Sultan. Maka Sultan itu larinya ke Suakbata, haripun teranglah. Setelah abislah amuk itu, tiada ketahuan lagi ke mana perginya.

8.3. Maka resident menyuruhkan segala menteri-menteri yang kepala raat pergi memeriksa Suhunan. Setelah datang di Suakbata, maka semuanya menteri-menteri itu pada mengadap Suhunan Husin Dia'uddin. Maka Suhunan bertitahlah dengan lembut suaranya kepada segala menteri-menteri itu, titahnya: "Ketahui oléh kamu yang hal Sultan punya perbuatan aku tiada sekali-kali kenal." Setelah itu maka Demang Umar mengadu hal kerisnya hilang di pemarakan waktu malam tadi. Maka diganti Suhunan keris lain yang berharga. Dan juga Pangéran Perdana Menteri kerisnya hilang, diganti dengan keris yang berharga. Setelah sudah maka menteri kepala raat itu bermohonlah pulang, lalu masuk kota. Dipanggil oléh Tuan Resident, maka semuanya itu mendapatkan resident semuanya.

Setelah itu resident memanggil Pangéran Dipati Abdurrahman; disuruhnya membawa surat kepada Suhunan. Maka Pangéran Dipatipun pergilah. Setelah datang di Suakbata, maka diaturkan Pangéran Dipati surat resident itu. Maka disambutnya oléh Suhunan, lalu dibacanya. Adalah bunyinya menyuruh Suhunan ke Betawi mengadap Jénderal mintakan ampun dosanya Sultan itu; sekarang juga perahu sudah sedia. Maka Suhunan memanggil Pangéran Bupati Panembahan. Telah datang, maka dititahkan Suhunan mendapatkan resident, bicarakan yang ini hari Suhunan menurut resident punya pikiran sukalah Suhunan pergi di Betawi.

Setelah Panembahan sampailah pada resident ${ }^{39}$ menyampaikan titah 40 itu, maka resident menyuruh sedia kici; / Panembahanpun pulanglah mengadap Suhunan. Maka Suhunanpun berkemaslah. Maka pada malam itu juga turunlah Suhunan di kici itu. Adapun yang mengikut Suhunan itu Pangéran Adiwijaya dengan saudaranya Pangéran Wirakrama dan puteranya Radén Bakar; dan yang lain-lain putera lelaki tiada ada mengikut, melainkan perempuan juga yang seisi dalam semuanya mengikut. Dan Pangéran Dipati Abdurrahman ditetapkan 
resident mengantar sampai ke Mentok dan Kirangga Tamin disuruh resident mengantar sampai di Betawi. Setelah sudah maka milirlah kici itu pada malam itu. Dan malam itu juga rumah kampung Suhunan di Suakbata dibakar sampai abis, tiada yang tinggal.

Syahadan Sultan telah gaiblah, di Palémbang tiada sekali-kali nampak; dicari orang, khabarpun tiada.

8.4. Adapun setelah berapa hari Suhunan berlayar itu, sampailah di Mentok. Maka Resident Mentok menyuruhkan mengantar ransun pada Suhunan yang secukupnya. Dan Pangéran Dipati Abdurrahmanpun naiklah ke Mentok; dan kicipun berlayarlah menuju ke negeri Betawi. Antara berapa lamanya berlayar itu, sampailah ke Betawi. Maka naiklah Suhunan ke Betawi, menuju pada tempat yang sudah disediakan tempatlah Suhunan. Sementara itu diberi permakan pada tiap-tiap bulan dengan secukupnya. Dan Kirangga Taminpun pulanglah ke Palémbang. Dan yang Pangéran Dipati Abdurrahman setelah ia pulang ke Palémbang, maka ditetapkan resident gajihnya seribu rupiah. Dan Kirangga Tamin dapat persén limaratus rupiah. Demikianlah halnya.

8.5. Sebermula maka tersebutlah perkataan Sultan Ahmad Najamuddin, lari dari Palémbang masuk hutan rimba belantara beserta temantemannya. Hingga sampailah ia ke Muara Beliti. Dan banyaklah pasirah perwatin yang mengikut perintahnya. Maka membuatlah Sultan perteguhan bénténg di Muara Beliti.

Setelah sampailah kabarnya ke Palémbang kepada resident, maka resident menyuruh Pangéran Dipati Abdurrahman mudik mendapatkan Sultan di Muara Beliti. Maka Pangéran Dipatipun pergilah mudik dengan membawa angkatan perang dengan beberapa perahu ampilan dengan pekakas perang alat senjata cukup. Setelah beberapa lamanya di rantau, beberapa melalui désa-désa, maka sampailah di Muara

41 Beliti. Maka Pangéran Dipati menyuruhkan / pepatihnya akan mengaturi Sultan turun ke perahu akan pulang di Palémbang. Dan yang dari kesalahan Sultan sudah dima ${ }^{c}$ afkan oléh resident; serta beberapa banyak lagi perkataan yang lemah-lembut. Maka Sultan tiada mau.

Setelah itu maka Pangéran Dipati Abdurrahman naiklah dari seberangan bénténg Sultan itu. Setelah dekat maka disuruh Pangéran Dipati pasang dengan léla dan meriam senapan, tiada berhenti lagi. Maka Sultan undurlah dari sana, lalu ia ke Muara Énim di dusun Limbun, lalu membuat bénténg. Dan di ulu Ogan sudah ada bénténgnya Sultan. Dan Masagus Dengkak pada masa itu dijenengkan Sultan Pangéran 
Jayadilaga dan Pangéran Puspa Cingot dijenengkan Pangéran Jayadiraja.

Syahadan yang Pangéran Dipati Abdurrahman sesudahnya berperang itu, jatuhlah sakit, lalu milir ke Palémbang. Adapun yang dari sepeninggal Pangéran Dipati Abdurrahman mudik di Muara Beliti itu, resident menyuruhkan Pangéran Kramajaya mudik Komering dengan membawa alat senjata. Dan Kirangga Wirasentika disuruh mudik masuk Lematang membawa alat senjata perang. Dan Pangéran Dipati Jayaningrat disuruh mudik masuk Ogan dengan membawa alat senjata perang.

Syahadan setelah Pangéran Dipati Abdurrahman sudah sembuh dari sakitnya itu, maka disuruh resident mudik pula masuk Ogan. Sampai di rantau, ketemu Pangéran Dipati Jayaningrat milir sakit. Dan Pangéran Dipati Abdurrahman terus mudik. Antara beberapa perjalanan itu, maka jatuh pula sakit keras, lalu milir. Sampai di dusun Pegayut, lalu wafat di perahu itu, hingga teruslah di Palémbang. Sampai di Palémbang, maka dikuburkan. Maka beberapa hormatan resident, mengantar dengan seratus baris sampai di kubur.

8.6. Sebermula maka tersebutlah perkataan Kirangga Wirasentika, sampailah ia ke ulu Énim, diketahuinya tempat bénténg Sultan itu. Maka Kirangga Wirasentika membuat pula bénténg pada tentangan bénténg Sultan itu. Setelah itu maka datanglah suruhan Sultan Pangéran Jayadilaga membawa angkatan akan melanggar bénténg Kirangga Wirasentika itu. Maka berperanglah racyat Sultan dengan racyat Kirangga Wirasentika. Maka dengan takdir Allah Pangéran Jayadilaga

42 kena peluru kepalanya, lalu mati. Dan Radén Utama kena / peluru, mati juga. Setelah itu maka undurlah Sultan, hendak ke sebelah bénténgnya di ulu Ogan.

Maka banyak orang Pasemah yang turut Sultan ada di bénténg itu. Kepalanya bernama Pangéran Bajau; tetapi itu Pangéran Bajau sudah kena rasan oléh Kirangga Wirasentika. Maka Sultan sampai ke tengah jalan, maka terkabarlah kepada Sultan yang orang Pasemah menunggu bénténg di ulu Ogan sudah nyembelah kepada Kirangga Wirasentika. Maka dengan sebentar itu juga Pangéran Bajau datanglah akan melawan Sultan. Setelah dekat maka Sultan mengunus tombaknya, lalu ditikamkannya kepada Pangéran Bajau kepada dadanya terus, lalu mati. Setelah itu maka gemparlah segala orang yang menurut Sultan itu; perempuan laki-laki semuanya habislah lari, masing-masing meninggalkan Sultan, mengikutlah semuanya kepada Kirangga Wirasentika. Dan Sultan tinggal Pangéran Jaya $<$ di $>$ raja dan Masagus Abduljamil. 
8.7. Setelah Sultan memandang tinggal dua temannya itu, maka Sultan milirlah dari Batanghari Awal. Setelah sampai ke dusun, kebetulan Temenggung Mahidin, kepala depisi Ogan Ulu, ada di situ. Maka Sultan naiklah ke perahu Temenggung Mahidin bersama Pangéran Jayadiraja Cingot dan Masagus Abduljamil akan menyerahkan dirinya kepada resident. Maka Temenggung Mahidin milirlah ke Palémbang. Antara berapa hari lamanya milir itu, maka sampailah di dusun Pegayut. Maka berlabuhlah perahu Temenggung Mahidin di Pegayut. Maka menyuruhlah orangnya membawa surat kepada resident.

Setelah sampai di Palémbang, maka pada masa itu commissaris ada di Palémbang, serta kapal perang jaga Palémbang. Maka suruhan temenggung menyampaikan surat kepada resident; maka surat itu disuruh antarkan kepada commissaris. Setelah dibaca commissaris, surat itu menyatakan Temenggung Mahidin sudah membawa Sultan akan menyerahkan dirinya kepada resident. Setelah itu maka sigeralah commissaris menyuruhkan temenggung politie berdua Temenggung Aminuddin menjumputi Sultan dengan perahu alat kerajaan. Setelah sampai kepada Temenggung Mahidin, maka Sultan ketiganyapun turunlah ke perahu itu. Setelah sampai ke Palémbang, lalu mendekat pada kapal 43 perang. Maka Sultan dan Pangéran Jayadiraja dan Masagus / Jamilpun naiklah di kapal perang.

8.8. Adapun dibelakang itu telah datang suruhan Kirangga Wirasentika membawa Kemas Usman, orang kampung Karangberahi yang turut Sultan, dan poyang orang Ogan. Dan kepala Pangéran Jayadilaga yang kena pélor itu dibawa orang kepada commissaris. Maka perintah commissaris itu kepala disuruh tanam. Dan dua orang masuk tutupan.

Maka commissaris suruh timbang di raat didalam kota akan semua perkara itu. Maka kepada hari waktu akan buka raat maka itu orangorang dibawalah masuk kota. Maka kepala-kepala raat sudah memeriksa dari awal hingga akhirnya. Setelah habis periksaan, maka semuanya orang keluarlah. Setelah sudah tetap hukuman didalam timbangan, maka semuanya orang-orang dihadirkan di majelis raat. Maka dijatuhkan hukum, empat orang dihukum mati. Maka kepada hari itu Pangéran Jayadiraja Cingot dan Masagus Jamil dan Kemas Usman dan poyang orang Ogan itu dimatikan keempatnya dimuka kota. Telah habislah perkara itu.

Kemudian datang Kirangga Wirasentika ke Palémbang membawa Radén Sanusi dan segala perempuan-perempuan yang turut Sultan yang masih ketinggalan di ulu, semuanya diserahkan kepada commis- 
saris. Maka semuanya yang dibawa oléh kirangga itu dibuang di Ambon, bersama tempatnya pada orang-orang yang turut Sultan ngamuk itu, semuanya sudah dibuang di Ambon lebih dulu. Adapun isteri Pangéran Jayadiraja Cingot dan Nyimas Irang, keduanya dibuang di dusun Tanjunglaga, Iliran Palémbang.

8.9. Syahadan yang Sultan di kapal perang itu ada tujuh bulan lamanya; lalu dibawa kapal perang berlayar ke negeri Bandan, tetap dibuang di situ. Dan yang waktu Sultan dibuang di Bandan itu Suhunan Dia'uddin sudah wafat di Betawi, dengan Pangéran Wirakrama dan Nayu Kamariah, puteranya Suhunan juga. Dan sesudahnya waktu wafat Suhunan itu, maka segala racyat kerabatnya disuruh oléh Jénderal semuanya pulang di Palémbang.

Dan dari hal gajih Sultan dan Suhunan Dia'uddin itu ditambahkan kepada Pangéran Aryakesuma dan ditambahkan kepada Pangéran Bupati Panembahan Hamim. Dan yang Pangéran Dipati Jayaningrat 44 gajihnya diturunkan oléh commissaris, $/{ }^{40}$ tinggal empatratus limapuluh rupiah daripada asalnya seribu. Dan apa sebabnya wallahu aclam. 


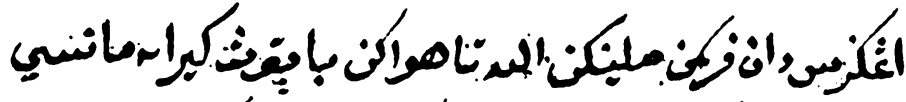

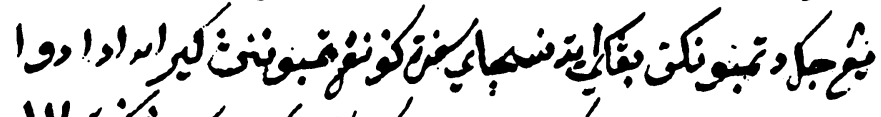

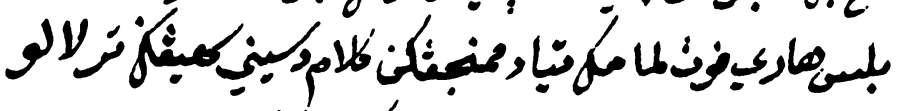

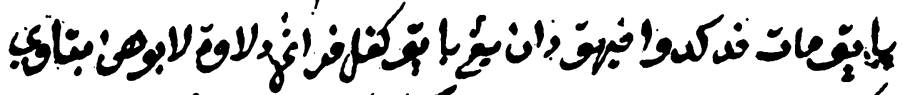

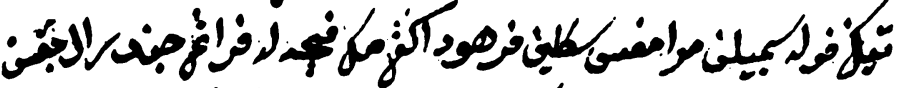

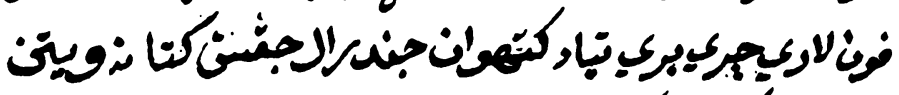

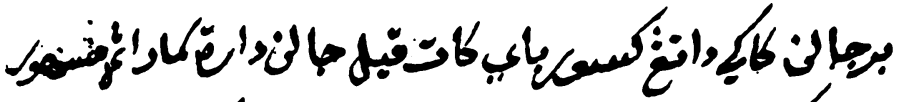

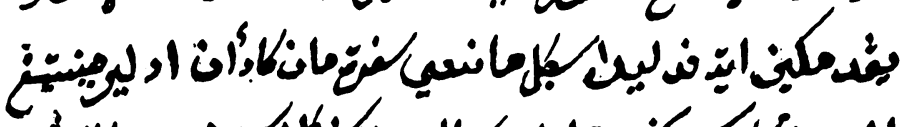

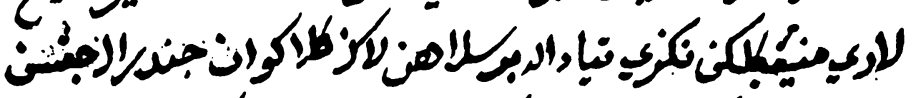

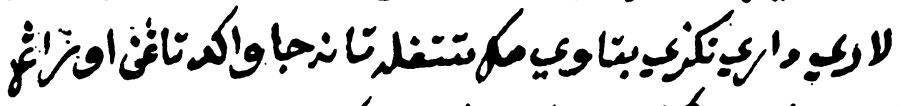

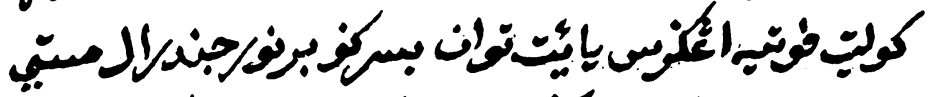

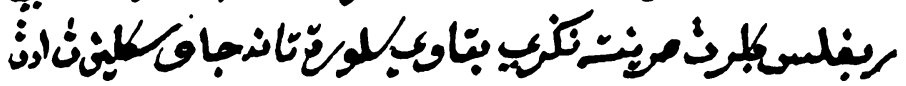

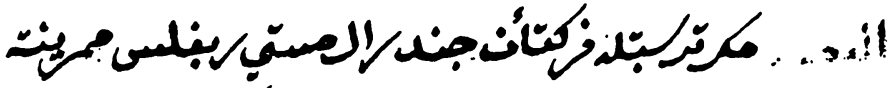

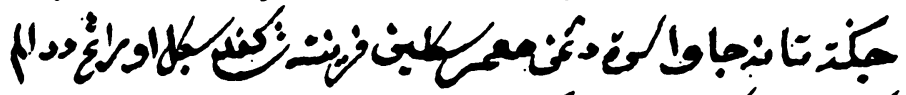

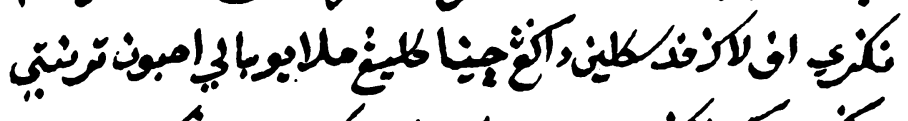

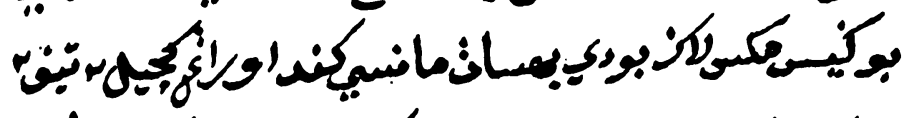

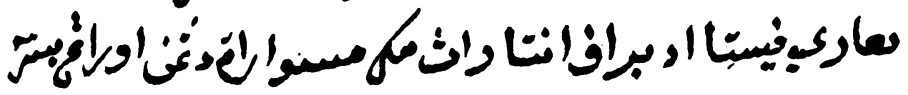

Cod.or. $2276 \mathrm{~d}$, pagina 41

Begin van UBL 9 op regel 13 


\section{TEKST UBL 9}

In deze tekst doen zich ten aanzien van de spelling de volgende bijzonderheden voor:

1. Bij woorden die eindigen op - $a$ of $-a i$ wordt de open slotsyllabe soms afgesloten met een $h$ : mudah, belanjah, hambah; sampaihkan, cindaih, mengintaih.

2. Bij woonden die eindigen op $-a h$ of $-u h$ wordt de slot- $h$ als regel niet geschreven: singga, bua, suda, susa, perna, kebawa; suru, sepulu, tuju, sunggu, penu, berlabu.

3. Sommige woorden die in de regel met $s$ worden gespeld, worden geheel willekeurig ook wel gespeld met sy: besyar, pasyirah, opsyir. Anderzijds vindt men bij woorden die in de regel met $s y$ worden gespeld vaak weer de spelling met s: mustari, masgul, saricat, séh (sékh), sarat, supacat, sukur.

4. Kramadiraja wordt hier evenals in de andere teksten Kramadiratja gespeld.

5. Kurnia en cunia worden meestal gespeld kurnnya en cunnya. Vgl. elders, ook nog bij Klinkert, 1930: tersennyum.

6. Ook hier doen zich enkele gevallen voor van invoeging van $m$ vóór $b$ of $p$, òf van $b$ na $m$ : menyembelah, ampilan, jumblah.

7. Naast menjunjung vinden we de spelling menjungjung.

8. Takhta, ikhwal, ikhtiar worden meestal tahta, ihwal, ihtiar gespeld.

9. Pegang wordt meestal pégang (pigang) gespeld. Voor segera en jenis staat altijd sigera en jinis.

10. Mahmud, maksud, nasib worden herhaaldelijk gespeld Mahmut, maksut, nasip.

Ten aanzien van woordvorm en woordkeus doen zich de volgende bijzonderheden voor:

1. Naast de gebruikelijke $m e$-vormen worden genasaleerde werkwoordsvormen zonder het praefix me- aangetroffen: meriksa, merintah, masang, nyesal. 
2. Er komen enkele gevallen van een afwijkende nasalering voor: menyatur (p. 57), menyukupi (p. 63), menyukupkan (p.64).

3. Van p. 86 af vinden we naast het in de meeste Palembangse teksten gebruikelijke Suhunan de vormen Susuhunan en Susyuhunan. Terwille van de uniformiteit heb ik beide laatstgenoemde vormen in deze tekstuitgave genormaliseerd tot Suhunan.

1.

41, 1.1. Alkissah maka tersebutlah perkataan Jénderal Misti Rabpelis ${ }^{1}$ r. 13 merintah jagat tanah Jawa serta dengan ma ${ }^{`}$ mur sekalian perintahnya kepada segala orang didalam negeri apalagi pada sekalian dagang Cina, Keling, Melayu, Bali, Ambon, Ternati, Bugis, Makasa. Lagi budi bahasanya manis kepada orang kecil-kecil; tiap-tiap hari pésta.

Ada berapa antaranya maka mesuarat dengan orang besar-besar /

42 hendak menyuruh meriksa ke negeri Palémbang, karena khabar orang loji Wilanda yang di Palémbang itu telah dirubuhkan oléh Sultan Mahmud Badaruddin, dengan sekalian orang putihnya habis, tiada tinggal; satu orang putih telah dimasukkannya agama Islam. "Itu pekerjaan jikalau tiada kita tuntut! Sehabis-habis pikir yang kita kulit putih!"

1.2. Maka waktu itu Jénderal Misti Rabpelispun menyuruh tiga orang, pertama Misti Léhér ${ }^{2}$ dan Misti Pilim ${ }^{3}$ dan Misti Khaf, ${ }^{4}$ pergi ke negeri Palémbang. Tiada berapa lama berlayar, sampai di kuala Sungsang. Orang yang jaga kuala memberitahu ke negeri. Maka Sultan Mahmud Badaruddinpun menyuruh empat menteri menjumputi Misti Léhér dan Misti Pilim dan Misti Khaf. Tiga orang itu sigera dibawa menteri. Yang tiga itu serta sampai, selalu dibawa bandar mengadap Sultan.

Ia sudah memberi surat Jénderal Misti Rabpelis, Sultanpun menanyakan:5 "Jénderal apa khabar? Tuan Besar sekarang ini baik?" Maka jawab misti tiga orang itu: "Sekarang kita punya Tuan ada baik. Tuan Sultan ada baik?" Jawabnya: "Baik!" Maka Sultan membuka surat itu dari lipatannya. Maka diberikan Sultan kepada tangan seorang menteri, maka dibaca dari asal surat sampai habis. Maka dijamu makan dan minum di dalam hari itu. Maka Sultan menyuruh menteri mem43 bawa / Misti Léhér dan Misti Pilim dan Misti Khaf itu, diberi rumah 
Demang Saléh tempat ia, serta dua orang menteri yang melihara makan dan minumnya.

Ada berapa lamanya maka ia minta pulang kembali ke negeri Betawi. Hendak sigera karena perjanjian Jénderal Misti Rabpelis dua minggu kembali ke Betawi, sekarang sudah sampai tiga minggu. Maka Sultan menyuruh empat lima menteri mengantar Misti Léhér tiga orang itu pergi di Sungsang. Demikian adanya.

\section{2.}

2.1. Alkissah maka kemudian daripada itu antara dua bulan maka datang khabar dari tanah Bangka mekhabarkan banyak perahu, kapalkapal dan lanca-lanca dan but-but dan lancang tiada terbilang berlabuh di Pulau Nangka, sekaliannya memasang bendéra Inggeris, datangnya dari timur. Ada duabelas hari datang perahu kecil berlabuh di kuala Sungsang. Maka jurulés ${ }^{6}$ Sungsang pergi meriksa itu kapal. Tiga hari tiada diberinya oléh kaptén kapal itu, maka orang Sungsang memberitahu ke Palémbang hal demikian itu. Maka Sultan menyuruh menteri-menteri, pertama temenggung, rangga dan demang, ngabéhi meriksa di kuala. Tiada dikhabarkan kapal itu apa bangsanya lagi datangnya belum dapat khabar hendak dipersembahkan kebawah Duli, tiada yang cakap lihat kapal itu.

Syahdan maka ada seorang menteri datang dari tanah Bangka cakap hendak meriksa keadaan kapal; lalu itu sekalian menteri memberi 44 makan / "karena kita tiada cakap pergi". Maka menteri itupun pergi ia ke kapal duabelas dan kici, lanca, sekonyar dan but dan cunia lagi, banyaknya ${ }^{\top}$ tiada boléh tahu, sehingga penuh laut itu. Maka hari itu juga masuk kuala Sungsang kapal satu kici ${ }^{8}$ satu, di dalamnya penuh dengan soldadu: orang putih dan Ambon dan Bali. Waktu itulah baharu tahu keadaan kapal banyak itu angkatan Inggeris dari Betawi, suruhan Jénderal Misti Rabpelis, Raja Betawi. Syahdan adalah yang jadi kepala perang dalam itu kapal Jénderal Galipi; ${ }^{9}$ dan Méjer Mir dan berapaberapa banyak opsir didalam itu kapal.

2.2. Maka tersebutlah perkataan menteri banyak yang jaga kuala habis lari cerai-berai, tiada ketahuan melepaskan diri masing-masing; ada yang selalu mudik, ada yang masuk sungai, ada yang jalan darat. Maka kapal itu selalu mudik seperti perahu yang kecil-kecil sekalian. Dua hari mudik kapal itu kelihatan dari bénténg Borang. Waktu itu adalah 
saudara Paduka Sultan Mahmud Badaruddin, gelarnya Pangéran Adipati, jadi kepala merintah didalam bénténg.

Kemudian dari itu maka datang suruhan Sultan satu nama Pangéran Marta dan sertanya empat orang menteri, satu temenggung satu rangga dan satu demang satu ngabéhi, membawa sepotong surat di dalam

45 bicara akan kebajikan serta membawa tolak bahala. Sampai / semuka Jénderal Galipi: "Dengan pangéran dan menteri empat itu surat tiada diterima dan bicarapun tiada guna kepada gua; yang gua tiada disuruh bicara yang gua punya kerja. Di mana tempat raja-raja yang besar kepala, ${ }^{10}$ di situ gua bicara. Sekarang ini gua mau lihat Sultan punya kepala mana besar sama gua punya kepala!" Maka Pangéran Marta dan temenggungpun minta kembali mengadap Sultan khabarkan hal dan ihwal itu.

Haripun malam, Pangéran Adipatipun kembali ke negeri. Sampai ke hadapan paséban, penuh sekalian periai menteri, haji, beberapabeberapa banyak manusia lain, lagi tuan-tuan Arab; dan lain tempat kota Cina dan orang gunung beribu-ribu, tiada yang akan hundak. ${ }^{11}$ Maka Sultanpun terpandang kepada Pangéran Adipati berlinang-linang air mata serta berpeluk bercium dua bersaudara. Maka bersabda Sultan kepada sekalian periai dan menteri: "Apa ikhtiar kamu banyak kepada negeri ini? Karena negeri ini bukan aku sendiri yang punya, engkau sekalian punya. Pada lahir dan batin sekadar aku mintakan yang jangan kamu jadi rusuh ${ }^{12}$ karena kamu banyak bangsa!" Maka mendatangkan sembah sekalian orang banyak itu: "Ampun Tuanku, beriburibu ampun! Harap diampuni sembah patik sekalian kebawah lebu Duli Tuanku! Apa juga titah Duli Tuanku atas patik sekalian, seboléhboléhnya patik sekalian junjung atas batu kepala patik. Tetapi dengan 46 syarat." Maka Sultan menengar / kata itu: "Apa itu syarat? Belanja hamba tiada kurang!" Maka sembah sekalian menteri-menteri itu: "Ampun Tuanku! Bukan belanja yang patik sembahkan." Maka Sultanpun sangat masgul menengar perkataan orang banyak itu.

Dan kepada lain harinya sekalian periai dan menteri-menteri yang tunggu bénténg telah habis lari, selalu mengadap Sultan persembahkan bénténg sudah ditunggu soldadu Inggeris, meriam sudah dipakunya, dari obat peluru dibuangnya dalam air. Dan periai ada yang selalu melarikan anak-bini, tiada kembali lagi ke negeri. Maka kemudian daripada itu datanglah seorang anak Arab dua orang menteri mengadap kepada Sultan Mahmud Badaruddin berkhabar kapal-kapal, kici, lanca, but sekalian itu selalu mudik.

Maka Sultan Mahmud Badaruddin keluar dari kota membawa anak- 
anak-isterinya didalam sacat musytari, malam hari daripada bulan Ramadan tigalikur hari didalam Hijrat 1226 . Demikianlah ${ }^{13}$ adanya. Sultan masukkan Batanghari Musi masuk Belidah dan Pangéran Adipati membawa anak-isterinya masuk Ogan.

Adapun Jénderal Galipi selalu masuk kota dengan alat senjatanya, soldadu sekalian selalu merampas. Maka Jénderal Galipi duduk didalam kota batu dengan sekalian opsir. Dan soldadu ada yang dalam kota 47 ada yang diluar kota, setiap-tiap ${ }^{14}$ rumah / yang di hulu kota penuh sesak oléh soldadu kulit putih dan soldadu Ambon dan Bali.

2.3. Maka Jénderal Galipi mesuarat dengan kepala opsir hendak mengambil Pangéran Adipati dan periai yang lari itu. Maka Jénderal Galipi suruh satu Pangéran Citrakesuma kedua Radén Muhammad yang bersama Jénderal Galipi dari Betawi pergi mengambil Pangéran Adipati. Dan sekalian periai dan orang kecil-kecil yang meninggalkan negeri itu sekalian disuruh jénderal kembali ke negeri: "Telah Tuan Besar Jénderal ampuni sekalian dosa yang sudah". Maka pangéran itu masuk Sungai Ogan, berdapat Pangéran Adipati dan periai-periai, selalu dibawa oléh pangéran itu milir ke negeri, masuk kota mendapatkan Tuan Besar Jénderal.

Serta sampai Pangéran Adipati memberi hormat dan khidmat. Maka jénderal berpegang tangan. Maka duduk diatas kursi disisi Tuan Jénderal Galipi di balai bandung serta kepala perang banyak. Penuh sesak di balai bandung. Maka Jénderal Galipi bertanya kepada waktu itu: "Tuan pangéran punya saudara, Sultan Mahmud Badaruddin, sekarang di mana larinya?" Jawab pangéran: "Saya kurang periksa. Khabar orang mudik Musi. Sekarang ini belum dapat khabar yang tentu tempat Sultan Mahmud itu berhentinya." Maka jénderal berkata: "Tuan pangéran suruh kembali sekalian orang yang sudah lari-lari!

48 Jangan ia takut sama / gua! Sekarang gua mau lihat negeri ini jadi baik. Kapan negeri Palémbang ini jadi kembali baik, gua punya nama boléh orang puji. Baik tuan pangéran suruhi dengan sigera. Guapun mau kembali di Betawi, gua janji sama Tuan Jénderal Rabpelis satu bulan kembali ke negeri Betawi. Satu tuan Méjer Mir tinggal bersamasama opsir banyak dengan soldadu barang empat ratus dan kapal dua dan kici dua, langbut tujuh, lanca kecil barang sepuluh."

Telah jénderal berkata demikian, maka Pangéran Dipati disuruh jénderal pulang ke dalamnya sendiri. Maka dijaga dengan soldadu dua kaptén. Dan di dalam itu pangéran satu hendak masuk mengadap kepada Pangéran Adipati. Maka disuruh pangéran soldadu keluar, 
tiada mau keluar. Lalu ditombak soldadu dengan senapang sangkuh, dua tiga soldadu menumbuk. Tiadalah boléh tahan ${ }^{15}$ pangéran itu sampailah mati syahid. Demikianlah adanya.

Ada sepuluh hari kemudian daripada itu maka Jénderal Galipipun hendak menaik Paduka Pangéran Adipati jadi sultan akan merintah negeri Palémbang mupakat dengan segala periai dan tuan-tuan Arab. Digelar dengan nama Sultan Ahmad Najamuddin diatas kerajaan negeri Palémbang serta dengan nama Maharaja Inggelan dibawah perintah Gupernemén Tuan Jénderal Misti Rabpelis yang merintah

49 jagat tanah / Jawa sekalian. Telah tentu Sultan atas takhta kerajaan negeri Palémbang, maka Jénderal Galipipun keluar berlayar kembali ke negeri Betawi.

\section{3.}

3.1. Maka Sultan diatas takhta kerajaan merintah itu serta mupakat dengan Tuan Méjer Mir hendak membuat satu pangéran jadi pepatih dan penghulu dan kerta dan tanda dan kaptén Cina. Setelah itu telah digelar semua, apalagi menteri-menteri: pertama temenggung dan rangga, demang, ngabéhi, pengalasan; sekalian itu tiap-tiap hari hadir di pengadapan mengadap Sultan.

Ada kepada satu hari Méjer Mir minta kebawah Duli Sultan hendak mengambil Sultan Mahmud Badaruddin mudik Musi serta membawa soldadu sipai barang seratus. Maka disertai Sultan, disuruh pangéranpangéran dan menteri-menteri dan pangéran-pangéran Komering, jadi jumlah sekalian periai menteri ada tujuhpuluh buah perahu lain dari Méjer Mir ada sepuluh buah perahu, sekalian dengan lengkap alat senjatanya.

Maka berkata Méjer Mir kepada Sultan Ahmad Najamuddin: "Jikalau Sultan Mahmud Badaruddin melawan, selalu perang gua bersama-sama soldadu, dari orang Palémbang apa dia punya suka?". Maka Sultan bertitah kepada pangéran-pangéran dan kepada menterimenteri sekalian itu: "Apa perintah Méjer Mir engkau sekalian turut! Jangan engkau salahi lagi akan Méjer Mir itu! Jika engkau mening-

50 galkan pekerjaan itu, tiada salah kepadaku. / Itulah pesanku pada segala kamu, jangan lupa! Dan lagi khabar orang itu di dusun Buaya Langu ${ }^{16}$ teguh bénténg Tuan Pangéran Wiradinata dan menteri rangga tiga dan demang dua dan pangéran empat, periai masagus banyak dan radén-radén. Engkau sekalian itu hendaklah mupakat barang apa pekerjaan orang putih itu!" Demikianlah titah Sultan. 
Maka sekalian pangéran-pangéran dan menteri menjunjung Duli berganti-ganti sekaliannya. Maka keluar makanan berjinis-jinis menjamu Méjer Mir hendak mudik itu bersama-sama satu méja dengan Sultan. Telah sudah makan minum, maka Méjer Mir berpegang tangan dengan Sultan, selalu turun ke perahu pencalang, Paduka Sultan mengantar ke jambatan. Méjer Mirpun turun, selalu mintar serta memasang bedil meriam duapuluh satu dan senapang seperti memalu, tiada penengar lain lagi melainkan bunyi bedil meriam seperti guruh di langit kelakuan méjer mudik itu. Kemudian dari itu maka Sultan kembali ke istana.

3.2. Ada berapa hari antara lima enam hari datang suruhan Pangéran Citrakesuma dan Pangéran Sumanegara membawa surat persembahkan kebawah Duli tengah dihadap sekalian periai dan menteri perwatin pucukan, penuh sesak di paséban agung. Maka Sultanpun membuka surat itu. Serta terlihat, tahulah di dalam. Selalu Paduka Sultan bersabda kepada periai sekalian dan menteri dan perwatin: 51 "Demikian didalam surat ini: orang / sebelah ulu lagi setengah membaiki bénténg dusun Buaya Langu. Aku punya rasa tiada boléh tahan bermusuh orang kulit putih Inggeris itu". Maka sembah sekalian periai menteri: "Ampun Tuanku, beribu-ribu ampun! Harap diampuni yang patik tiada boléh tahan melainkan lari, karena Paduka Kakanda itu tiada didalam bénténg, sekadar periai dan menteri segala; tiada masuk kepada akal patik yang orang itu melainkan lari".

Ada berapa antara dua tiga hari orang jaga memberitahu melihat perahu pencalang terlalu banyak. Maka dipersembahkan orang kebawah Duli Sultan: "Ada perahu suruhan dari Méjer Mir. Patik lihat satu pencalang dari ulu sigera perkejaannya". Belum sampai sekapur sirih datang miji ${ }^{17}$ Pangéran Citrakesuma kebawah Duli membawa surat itu mekhabarkan angkatan Méjer Mir itu didalam tiga hari ini pecah perang bénténg itu. Maka sabda Sultan kepada yang membawa surat itu: "Apa hémat engkaulah <tahan> tiada bénténg itu?" Maka sabdanya: "Ampun Tuanku, berkat daulat Tuanku! Tiada tahan orang di ulu itu, karena Paduka Kakanda tiada didalam bénténg, sekadar periai menteri yang jaga bénténg, Paduka Kakanda tinggal di dusun Sekayu. Didalam hémat patik sekarang sudah selesai perkejaan bénténg Buaya Langu itu".

Ada waktu lohor datang pula surat dari Pangéran Citrakesuma.

52 Didalamnya: "Hari ésok pagi ${ }^{18}$ / patik pecahkan perang bénténg. Khabar orang yang jadi kepala bénténg Pangéran Wira $<$ di $>$ nata dan menteri enam. Jika didalam hémat patik, tiada berapa jam dapatlah 
bénténg itu. Demikianlah sembah patik. Melainkan daulat Paduka Seri juga yang patik sekalian harap mengerjakan perkejaan Duli Tuanku itu. Sungguh habis jiwa patik sekalian, dengan réla patik."

3.3. Ada dua hari kemudian daripada itu, maka datang orang jaga memberitahu ada perahu banyak milir. Maka Sultan sigera menyuruh menteri-menteri melihat perahu milir itu. Serta berdapat, selalu bertanya menteri itu: "Apa khabarnya tuan-tuan sampai ini?" Maka jawab orang perahu: "Khabar baik!19 Perang menang, bénténg Buaya Langu sudah dibakar. Tetapi kepala kita Tuan Méjer Mir kena pélor perutnya sangat. Didalam hémat sekalian orang hati itu sesak. Maka kami sekalian milir ini. Jika tiada demikian, kami sekalian selalu mudik".

Maka menteri-menteri mendengar khabar itu sigera kembali persembahkan perkhabaran itu. Serta sampai kebawah Duli, maka Sultanpun berangkat, selalu turun ke perahu melihat Méjer Mir itu. Serta terlihat, tiada tahu satu apa khabar lagi, sekadar ia berkhabar hendak selalu minta hantar ke Mentok, "ini hari juga". Maka Sultan menyuruh menteri mengantar Méjer Mir itu sigera tiada berhenti. Maka Sultanpun

53 sangat masgulnya, / didalam enam tujuh hari kuranglah sukanya. Terhentilah perkara itu.

4.

4.1. Alkissah maka tersebutlah perkataan Sultan Mahmud Badaruddin telah berteguh bénténg di Muara Rawas serta mengumpulkan sekalian orang pucukan Musi, Beliti, Batu Kuning, Kikim, Rawas. Sekalian pucukan itu orang yang kepala-kepalanya sudah bersumpah memotong kerbau makan bersama-sama Sultan serta berwa'at mati sama mati, hidup sama hidup. Selalu waktu itu Sultan menggelar panglima Melayu empat orang. Pertama digelar panglima perang besar, kedua digelar panglima di dalam raja, ketiga digelar panglima besar raja, keempat digelar panglima muda. Dan keempat panglima itu dikurniai persalin kain baju, saputangan dan ikat pinggang cindai panjang duabelas hasta dan pedang, satu seorang. Selalu bersetia yang teguh.

Kemudian daripada itu membuatlah bénténg tiga tanam tonggak: satu di tanjung Muara Rawas, kedua diseberang Musi, ketiga di tanjung Rawas Mata. Adalah bénténg tiga itu sangat kukuh lagi tiaptiap gandok dijaga menteri dengan anak-isterinya serta alat senjata. Jikalau didengar khabar orang yang melihatnya, keadaan bénténg itu tiadalah boléh dicapai-capai oléh sama kulit hitam, walau yang sudah kulit putih sekalipun banyaklah matinya selama sebelah-menyebelah; 
karena kukuh tempatnya lagi teguh setia. Itupun khabar orang Melayu 54 datang / tiada keputusannya perahu belongkang Melayu, enam tujuh orang satu perahu. Jikalau penglihatan orang yang berkhabar itu, tiada kurang daripada tiga laksa orang Melayu dengan orang Rawas yang sedia didalam bénténg itu. Siang bersorak orang menyabung seperti guruh dan malam sorak orang judi, bersuit-suit orang jaga. Jikalau penglihatan itu, tiadalah boléh ikhtiar boléh masuk kedalamnya, jikalau tiada orang yang bélot didalamnya. Adapun orang yang bélot itu tiada dapat; karena sekalian cukup makanan murah, belanja dikurniai, makan minum setiap hari dikurniai. Dan perempuan banyak; jikalau ada orang yang suka nikah, dengan sacat itu juga Sultan nikahkan. Demikianlah keadaan di Muara Rawas itu adanya.

4.2. Syahdan kemudian dari itu Sultan mesuarat dengan sekalian pangéran-pangéran dan sekalian menteri-menteri hendak menyuruh mudik meriksa Sultan Mahmud Badaruddin membawa surat. Adalah yang jadi kepalanya dua orang: Pangéran Citrakesuma kedua Pangéran Sumanegara ${ }^{20}$ dan menterinya Demang Surayuda. Ada membawa perahu, duapuluh perahu. "Engkau berhenti kepada satu désa; jikalau lalu perahu banyak itu, mudik! Ada antara dua hari sampai kepada

55 tempat Sultan Mahmud Badaruddin, baharu engkau bicara / siapa yang patut salah satu engkau pergi hantar surat!" Telah habis bicara itu, titah Sultan: "Sigeralah engkau sekalian baiki perahu! Didalam sehari dua ini semua mintar serta membawa alat perang. Janganlah léngah barang $\mathrm{a}<\mathrm{pa}>$ per $<\mathrm{ke}>\mathrm{jaan}$ semua! Karena khabar orang banyak Melayu sudah kumpul itulah, hendaklah engkau sekalian mupakat. Demikianlah adanya!" Maka Sultanpun berangkat masuk ke istana.

Ada berapa hari antaranya, maka Pangéran Citrakesuma dan Pangéran Sumanegara telah sudah siap, sekalian perahu periai dan menteri di tangga, sekadar menanti hendak menjunjung Duli Sultan sahaja. Sekalian pangéran-pangéran dan menteri-menteri hadir di pengadapan, maka Sultan keluar ke pengadapan. Maka diangkat orang persantapan akan jamu sekalian pangéran-pangéran dan menteri-menteri dan pangéran ulu dan perwatin pasirah-pasirah. Maka berhenti jamu itu, maka Sultan bertitah kepada sekalian pangéran dan menteri-menteri: "Engkau di hulu itu jangan putus sehari dua datang suruhan engkau ke Palémbang!" Maka sekalian pangéran dan menteri itu menjunjung Duli Sultan berganti-ganti. Telah sudah junjung itu, selalu turun sekalian pangéran dan menteri ke perahu, lalu mintar serta membaca selawat 
tiga kali. Selalu masang bedil setiap perahu itu dan sorak gemuruh. Dan orang melihat, Sultanpun masuk istana.

56 4.3. Maka tersebut perkataan pangéran-pangéran / yang mudik itu. Ada kira duabelas hari sampai ke dusun Kasema $<$ ra $>$ n, berhenti sekalian perahu itu. Hanya kedua pangéran yang lalu mudik, pertama Pangéran Citrakesuma dan Pangéran Sumanegara dan demang modin. Dan Pangéran Citrakesuma tinggal di dusun Kemang dan Pangéran Sumanegara selalu mengadap Duli Sultan Mahmud Badaruddin persembahkan surat.

Maka disambut oléh Sultan Mahmud Badaruddin surat itu. Serta dibuka daripada lipatan surat itu, lalu muhun Paduka Sultan, tiada terbaca lagi selalu dilipatnya surat itu. Maka Sultanpun bertanya kepada Pangéran Sumanegara: "Apa khabar kamu orang negeri adik sekalian ibu-bapa sekarang?" Maka sembah pangéran: "Ampun Tuanku! Berkat daulat Tuanku! Pecil-pecil Duli Tuanku yang didalam negeri pada waktu ini belumlah satu apa marabahayanya; hanya paduka mamanda Pangéran Dita pulang ke rahmatullah. Demikianlah sembah patik." Maka Pangéran Sumanegara mohon kembali ke perahu. Maka titah Duli Yang Mahamulia: "Kapan engkau hendak milir? Dapatlah seperti maksud Dipati itu, tetapi tiada seperti maksud didalam surat. Sabar! Sehari dua ini hamba menyuruh mendapatkan engkau." Maka pangéran itu menjunjung Duli, selalu pulang ke perahu menanti di dusun Kemang tiga buah: perahu Pangéran Citrakesuma dan perahu Pangéran Su-

57 manegara dan perahu demang modin; tiga buah / perahu berhenti di dusun Kemang menanti titah Seri Paduka Yang Mahamulia di Muara Rawas.

4.4. Ada lima hari berhenti itu, datang suruhan Paduka Sultan Mahmud Badaruddin satu pangéran satu menteri bertanya kepada pangéran kedua itu hal ihwal pekerjaan pangéran kedua itu. Maka jawab pangéran kedua itu: "Perkejaan kami kedua ini disuruh membawa surat; kami tiada tahu yang didalam itu surat. Dan kepada kami kedua ini melainkan mencari akan kebajikan antara kedua pihak, tiada lain. Di Palémbang gusti, di hulu ini gusti. Didalam titah kami hendak melihat kebajikan antara keduanya. Tetapi yang gusti kita yang di Palémbang tiada menaruh syarat. Jadi apa hal yang raja miskin, akhirnya menaclim atas racyatnya! Itulah yang kata kami kedua akan kebajikan antara kedua gusti kita itu."

Maka berkata menteri yang dari Rawas: "Pangéran khabarkan yang 
maksud Sultan kepada Paduka Kakandanya yang di hulu ini!" Pangéranpun bersumpah: "Kedua yang kami mudik dititahkan dari Palémbang hendak menyatur ${ }^{21}$ kebawah Duli bangun kota di seberang dikehendaki dari Betawi tigaratus ribu ringgit. Jikalau tiada keluar, didalam hémat kami itulah sebab maka kami dititahkan membawa surat mengadap ini. Lebih-lebih maclum kamu yang banyak dibawah Duli

58 Yang Mahamulia!" Maka jawab / menteri kepada pangéran kedua itu: "Yang saya dibawah Duli tiada satu apa sekadar kasihani melihat Duli Yang Mahamulia dengan anak-anak kecil didalam teluk rantau. Itulah sebab maka saya sekalian tiada sampai hati akan meninggalkan; karena lagi Duli Yang Mahamulia didalam kota limpah kurnianya atas sekalian periai atawa menteri apalagi orang kecil-kecil. Itulah hal saya sekalian tiada tertinggal Duli Yang Mahamulia. Itulah sebabnya yang negeri Palémbang itu tiada lepas dari mata hati sekalian saya."

Maka kata pangéran kedua itu: "Apalah ikhtiar kamu kedua akan perkejaan kami ini, supaya sigera kembali ke Palémbang?" Maka jawab menteri itu: "Hamba pangéranpun cakap juga meikhtiar yang dapatnya itu. Jikalau seperti sabda pangéran tigaratus ribu itu, hamba pangéran tiada cakap, karena tiada hamba pangéran lihat atawa dengar sebanyak itu. Sehabis-habis banyak yang terbawa oléh Duli Yang Mahamulia limapuluh ribu. Mana yang sudah keluar belanja setiap hari tigaratus dawam perkejaan itu. Maclumlah paduka pangéran sahaja miara orang banyak!" Maka kata pangéran: "Dari itu berapa yang dikurniai makan kita boléh tolak jika begitu." Sabda menteri ${ }^{22}$ : "Hamba pangéran cakap meikhtiarkan." Maka jawab pangéran: "Baik!" Maka pangéran kedua <menteri> itu minta mudik kembali ke Muara Rawas dan pangéran kedua duduk menanti di dusun Kemang.

59 4.5. Dan pangéran dan menteri yang / dititahkan itupun sampai, selalu mengadap Paduka Duli serta persembahkan hal ihwal Pangéran Citrakesuma dan Pangéran Sumanegara itu sekaliannya. Maka Duli Mulia bersabda kepada menteri itu: "Jikalau kepada engkau, apa yang kita terima bicaranya itu?" Maka sembah menteri itu: "Ampun, beribu-ribu ampun! Harap diampuni sembah patik kebawah Duli Tuanku! Jikalau tiada dikabulkan permintaan itu, barangkali jadi rusuh; karena orang yang datang itu banyak perahunya lengkap dengan alat senjata, lagipun sekalian perahunya itu pakai sekalian ampilan. Didalam hémat patik Duli Tuanku kurniailah sekadar berapa patut kabawah Duli." Maka sabda Paduka Yang Mahamulia: "Baik! Boléh kita beri barang limapuluh ribu ringgit?" Maka sembah menteri itu: "Ampun, beribu-ribu 
ampun! Sangat limpah kurnia Duli Tuanku itu jika demikian!" Maka sabda Yang Mahamulia: "Berapa kiramu?" Maka menteri itu menjunjung Duli serta sembahnya: "Ampun Tuanku! Jika dibenarkan sembah patik, dikurniai barang duapuluh lima ribu ringgit. Empat lima hari sekali beri barang sepuluh ribu, boléh barang satu bulan cukup duapuluh lima ribu. Pangéran kedua itu suruhkan kembali ke Palémbang membawa uang itu. Duli Tuanku masukkan didalam surat kepada ${ }^{23}$ adinda: Itulah dahulu; kemudian barang tiga bulan atawa empat bulan suruh kembali, karena Duli Tuanku lagi hendak mengumpulkan. Karena

60 banyak tempat, / tiada satu tempat; lagipun per $<\mathrm{ke}>$ jaan Duli Tuanku bénténg habis kerjanya, orangpun banyak datang." Maka sabda Duli Yang Mahamulia: "Engkau pergi dapatkan orang kedua itu, khabarkan padanya yang seperti ikhtiarmu itu. Jika ia suka, engkaulah yang membawa uang. Dan jangan engkau membawa orang lain; anakmu kecil itu bawa, jangan tinggal. Baik-baik hématmu, jangan kita jadi lemah setia!" Maka menteri itu selalu menjunjung Duli, lantas mendapatkan pangéran kedua itu yang menanti di dusun Kemang.

4.6. Serta datang menteri itu berdapat kedua pangéran, sigera ditegur oléh pangéran kedua akan menteri itu. Sabda pangéran: "Apa khabar ikhtiar kita membawa ringgit?" Maka jawab menteri itu: "Belumlah dapat. Yang kata Duli Yang Mahamulia: Tiada dapat seperti sabda pangéran dahulu tigaratus ribu. Di mana ada yang demikian itu? Sekadar sepuluh, limabelas ribu barangkali dapat." Maka kata kedua pangéran itu: "Apa juga ikhtiarmulah, yang kami kedua ini harap supaya kami boléh sigera milir." Maka jawab menteri itu: "Seboléhboléhnya hamba pangéran ikhtiarkan. Apa yang hamba pangéran cari melainkan kebajikan antara kedua paduka yang mahamulia. Karena pengapak kepala datuk nénék hamba pangéran sampai kepada hamba pangéran, tiada boléh yang lain daripada zuriat yang ${ }^{24}$ boléh merintah hamba pangéran. Itulah sebabnya maka diikut Duli Yang Mahamulia,

61 tiada sampai hati hamba hendak / meninggal < kan > Duli Yang Mulia didalam teluk rantau dengan racyatnya kecil. Jikalau ada belas dan kasihan paduka pangéran kedua kepada Paduka Yang Mahamulia, apa ikhtiar paduka pangéran kedua kebawah Duli Yang Mahamulia di Palémbang? Melihat yang demikian itu nama siapa yang tersebut didalam itu? Lebih-lebih maclum paduka pangéran kedua, bukan hamba pangéran ajar atawa nyesal pekerjaan itu, tiada sekali-kali! Demikianlah sembah hamba pangéran." Maka sabda pangéran kedua: "Hai mak rangga! Yang saya kedua serta kepada mak rangga, dari banyaknya 
apa kata mamak rangga tiada kami kedua menyalahi. Karena perkejaan ini hendak sigera; maclumlah mamak rangga perkejaan orang kulit putih Inggeris demikianlah." Maka jawab menteri itu: "Jikalau sungguh sabda pangéran demikian itu, hamba pangéran kerjakanlah. Didalam hémat hamba pangéran kabul berkat syufa ${ }^{` a t . " ~ M a k a ~ m o h o n-~}$ lah kembali menteri itu kepada pangéran kedua.

4.7. Tiada disinggah lagi, selalu mengadap kebawah Yang Mahamulia persembahkan kebawah Duli hal ihwal dititahkan kepada Pangéran Citrakesuma kedua Pangéran Sumanegara sekalian perkara itu. Maka sabda Yang Mahamulia: "Boléhlah engkau kumpulkan barang berapa yang hendak engkau berikan, ambil kepada Hamzah dan Si Acu. Sudah kusuruh sediakan enambelas ribu, masuk rupiah pakai dua satu ringgit jadi jumlah enambelas ribu. Engkau khabarkan kepadanya tujuh hari beri pula <se>berapa dapat, lagi hendak dikumpulkan karena banyak

62 tempat. Demikianlah adanya." / Maka sembah menteri itu: "Patik mohon hendak menyuruh kepada tempat pangéran kedua itu surat terima uang. Jikalau dibenarkan sembah patik, pecil patik Muhammad yang pergi memberitahu suruh pangéran kedua itu mudik Muara Rawas, terima uang di situ." Maka sabda Paduka Yang Mahamulia: "Suruhlah Muhammad itu!" Maka ia pergi.

4.8. Ada waktu asar Pangéran Sumanegarapun datang, berhenti di Muara Rawas. Maka Muhammadpun memberitahu kepada ayahanda mengatakan Pangéran Sumanegarapun datang. Maka ayahanda sigera mengadap Seri Paduka Yang Mahamulia persembahkan Pangéran Sumanegara datang hendak menerima uang. Maka Seri Yang Mahamulia kata: "Engkau <ambillah> ${ }^{25}$ uang kepada Hamzah! Enambelas ribu engkau berikan dahulu; nanti kemudian empat lima hari suruh terima lagi, hendak dikumpulkan." Maka menteri itupun pergilah membawa itu uang enambelas ribu, ia tiga beranak.

Sampai kepada Pangéran Sumanegara, selalu ia berbilang uang. Telah sudah ia berbilang, maka pangéran dan demang modin menerima itu uang cukup enambelas ribu. Maka menteripun kembali dan pangéran yang terima itu uang kembali ke dusun Kemang. Dan menteri itu persembahkan kedua pangéran sudah menjunjung kurnia kebawah Duli dan yang kemudian itu diharap didalam sehari dua ini. "Karena hendak sigera milir didalam bulan ini juga, supaya kami kedua mendapat puasa di Palémbang. Tolonglah, mamanda yang kami harap sembahkan

63 kebawah Duli Yang Mahamulia / sembah kami kedua!" 
4.9. Telah sudah sekalian hal ihwal yang demikian itu, maka Seri Paduka Yang Mahamulia bertitah kepada pangéran-pangéran dan pada sekalian menteri-menteri dan pasirah-pasirah perwatin dan pada sekalian panglima-panglima dan pada $\mathrm{ra}^{c}$ yat-rac ${ }^{c}$ yat yang banyak: "Sekarang ini apa perkejaan kamu banyak?" Maka sekalian persembahkan kebawah Duli Yang Mahamulia: "Ampun Tuanku! Beribu-ribu ampun sembah patik sekalian! Dari pekerjaan Duli Tuanku bénténg lagi tinggal sedikit; hémat patik tengah bulan Ramadan ini habis sekalian perkejaan itupun. Jikalau datang masa seorang hendak hakékat jahat kebawah Duli, boléh melawan; musuh empatribu orang datang, patik semua boléh melawan!" Maka sabda Paduka Yang Mahamulia kepada sekalian itu: "Kamu hendaklah mupakat, jangan léngah barang apa perkejaan adanya!"

4.10. Syahdan ada enam hari antaranya maka Seri Paduka Yang Mahamulia menitahkan mengantar uang empatribu ringgit kepada kedua pangéran. Maka pergi pula menteri itu berdua anaknya membawa uang empatribu ringgit. Serta sampai kepada pangéran kedua itu, maka diterimanya oléh demang modin kepada tangan menteri yang dahulu itu. Maka kata pangéran kedua itu: "Hai mak rangga! Kapan mamak rangga menyukupi yang seperti janji mamak rangga pada saya itu? Tinggal sedikit lagi." Maka jawab menteri itu: "Pangéran kedua itu banyak-banyak rahim atas hamba pangéran yang tua ini. Dari itu

64 uang yang tinggal itu, jikalau tiada / datang aral atas hamba pangéran yang besar, tiga empat hari ini hamba pangéran datang mengadap serta membawa uang menyukupkan janji hamba pangéran sembahkan dahulu. Jangan paduka pangéran khawatir! Bukan ini hamba yang tua bukan seperti hamba yang baharu didalam témpo, belum melihat keluasan dunia! Paduka pangéran terlebih maclum!" Maka pangéran mengucap: "Sukur! Mamak ranggalah yang saya harap sepenuh-penuh harap." Maka minta menteri itu kembali, selalu mengadap kebawah Duli Paduka Yang Mahamulia persembahkan uang telah diterima pangéran kedua itu. Maka titah: "Apa katanya?" "Tiada satu apa. Yang patik janji tujuh hari lagi patik hantarkan limaribu jadi cukup duapuluh lima ribu ringgit."

4.11. Kemudian sampai tujuh hari titah Seri Paduka Yang Mahamulia: "Hantarkanlah uang janjimu itu, ambil pada Hamzah! Dan katakan kepada pangéran kedua tiga bulan suruh ${ }^{26}$ ia datang, jangan membawa perahu banyak-banyak. Bukan ${ }^{27}$ malu dilihat orang lagi terkhabar ke negeri yang lain sianu punya malu seperti kata orang didalam hutan 
kuranglah malunya, karena tiada pernah berdapat dengan orang baik, melihat pintau monyét sahaja tiap-tiap hari. Itulah pesanku engkau sampaikan! Karena ia itu bukan orang lain, sepupu padaku; kemalu$\mathrm{a}<\mathrm{n}>\mathrm{ku}$ kemaluannya juga." Maka menteri itupun menjunjung Duli, selalu mengantarkan uang yang lagi tinggal limaribu itu.

Maka menteri kedua beranak itu sampai ke dusun Kemang, maka 65 pangéran kedua itu mengucap: "Sukur! Mamak rangga / sampai hari hamba sudah siap. Jika mak rangga belum sampai hari ini, saya hendak menyuruh mendapatkan mamak rangga. Jika demikian, boléh saya milir ke Palémbang hari ésok." Maka jawab menteri dua beranak itu: "Barangkali Seri Paduka Yang Mahamulia hendak berkirim surat kebawah Duli Yang Mahamulia di Palémbang." Maka sabda pangéran kedua: "Jikalau demikian, mak rangga pohonkan kebawah Duli hari ini; maka kami boléh hari ésok milir. Lagi mamak rangga sembahkan kebawah Duli yang kedua kami mohon ampun, beribu-ribu ampun; yang rahim Duli Yang Mahamulia mengurnia dua<puluh> lima ribu itu terjunjunglah diatas batu kepala kami kedua; pada rasa hati kami seperti mendapat gunung mas. Rasa hati lagipun ini, akan pem $<b>$ alas kami kedua kepada mamak rangga waktu ini tiada satu apa yang kami bawa. Kemudian jika lagi umur, kami balas juga yang mamak itu punya susah pergi datang."

Telah diterima uang itu demang modin, maka menteri minta kembali. "Ésok hari hamba pangéran kembali. Barangkali Seri Paduka Yang Mahamulia hendak berkirim surat atawa hendakkan paduka pangéran sendiri." Maka sabda pangéran: "Mamak rangga sigera mudik, selalu mengadap kebawah Duli persembahkan 'jikalau dibenarkan ${ }^{28}$ sembah kami kedua, pagi ésoklah kami milir'. Mamak rangga beri khabar hari ini juga, jangan tidak. Dan lagi mamak rangga sampaikan sembah kami kedua kepada paman-paman dan salam kami kepada adik-adik / 66 sekalian!"

4.12. Maka menteri itupun datang mengadap kebawah Duli Yang Mahamulia persembahkan hal ihwal pangéran kedua itu. Maka sabda Paduka Yang Mahamulia: “Apa hendak engkau?" Maka sembah menteri itupun: "Tuanku! Sembah patik Duli Tuanku kirim surat kepada Paduka Adinda menyatakan uang yang dibawa pangéran kedua itu banyaknya duapuluh lima ribu itu; Duli Tuanku nyatakan kepada Paduka Adinda supaya tahu. Manusia punya hati tiada boléh tahu, melainkan Allah juga yang tahu." Maka titah Duli Paduka Yang Mahamulia: "Baiklah! Sekarang aku buat surat." Lagi sembah menteri itu: 
"Tuanku masukkan didalam surat: Gusti patik, Ratu Agung, masukkan cinta kasihnya, tiada lepas didalam siang dan malam, tiada lupa barang sesa ${ }^{\complement}$ at. Demikianlah sembah patik kebawah Duli Tuanku." "Jika demikian katamu, aku buat surat seperti maksudmu itu. Sekarang aku buat, boléh pagi ésok engkau antarkan kepadanya."

Maka menteri itupun kembali ke bénténg, tempatnya sekalian menteri yang banyak dan tempat panglima-panglima Melayu Minangkabau menyabung dan judi yang ramai itu. Dan haripun malam, paginya datang embok dalam dititahkan Seri Paduka Yang Mahamulia panggil kiai bersama-sama hamba kiai inilah. Maka menteri itupun sigera turun mengadap kebawah Duli. Serta datang, selalu menjunjung Duli Seri Yang Mahamulia. Maka titah: "Engkau pergi berikan surat ini kepada

67 Mas Utih ${ }^{29}$ / kedua Mausub ${ }^{30}$ !" Menteri itupun sigera selalu pergi mendapatkan pangéran ke dusun Kemang.

4.13. Serta sampai, selalu surat itu berikan. Maka pangéran kedua itupun menyambut surat dengan taclimnya. Maka katanya: "Mamak rangga! Hamba ini milir. Dari mamak rangga baik jangan percaya sangat orang Melayu banyak itu, karena ia bukan sebabat kita." Maka jawab menteri itu: "Apa akal juga, tiada milir orang banyak. Apa jadi pekerjaan paduka pangéran? Pikirlah! Duli Yang Mahamulia meninggalkan kota-negeri, sekurang-kurangnya sangka orang banyak membawa mas, intan apalagi uang entah berapa ${ }^{31}$ Maka hamba pangéran kumpulkan orang banyak itu, tiada ramailah yang bangsa Minangkabau, Kerinci, Rejang sama Ulu Mata, ${ }^{32}$ sekalian yang macam-macam adanya. Itupun ada dengan satu kepalanya menteri yang merintah barang satu perkejaan didalam satu-satu bénténg dengan makan paginya serta madunya. Dari petang hari sampai siang tiada perkejaan lain hanya judi berjinis-jinis, siang sorak sabung bertalu-talu ${ }^{33}$ bénténg seberang menyeberang. Melainkan harap doca paduka pangéran berkat syufacat Marhum yang di Lemabang akan hamba sekalian memeliharakan yang mendapat bahala ini; jikalau lagi daulat yang kemudian."

5.

5.1. Maka pangéran kedua itu milir dan menteri itupun mudik kembali mengadap kebawah Duli Seri Paduka Yang Mahamulia persembahkan

68 kedua pangéran sudah milir hari / itu juga. Maka titah Seri Yang Mahamulia kepada sekalian periai dan menteri-menteri dan kepada sekalian pasirah perwatin dan kepada semua panglima mulia: "Hai 
kamu sekalian! Hendaklah sungguh-sungguh barang apa pekerjaan lagi mupakat akan yang kemudian itu! Tiada boléh tidak orang dari Palémbang itu datang minta uang lagi, karena janji tiga bulan ia datang. Dan yang kita satu ringgit tiada sigera memberi. Dari kita punya perkejaan belum sudah, jadi kita beri supaya boléh lapang. Perkejaan kita habis sedia, boléh kita melawan manakala orang dari Palémbang datang, boléh kita mengeras, karena dahulu sudah diberi duapuluh lima ribu ringgit. Tiada <boléh $>$ tidak orang dari Palémbang itu datang, janji tiga bulan ia sampai hendak menerima. Jikalau sampainya itu dengan keras, engkau lawanlah dengan sungguh-sungguh. Karena kita menjalankan syaricat, yang ia itu sebahat orang kulit putih. Jika kita mati syahid, akhirat; jika ia mati, durhaka kepadanya itu. Dan yang kamu sekalian bersungguh-sungguh hati mengerjakan yang demikian itu!" Maka sembah periai dan menteri-menteri ${ }^{34}$ dan pasirah banyak itu: "Ampun Tuanku, Séh Alam! Yang rasa hati patik, sekalikali ini tiadalah mungkir lagi, karena wajib atas patik mengerja."

5.2. Tiada berapa antara itu dari sebelah Jambi orang Melayu mekhabarkan Paduka Sultan Jambi ada datang dari Jambi, ada di dusun 69 Surulangun..$^{35}$ / Maka Seri Paduka Yang Mahamulia mendengar khabar itu sigera menyuruh jumputi Paduka Sultan Jambi itu kepada pasirah dusun Rawas. Ada berapa hari Paduka Sultan itu sampai serta selalu dibawa orang mengadap kebawah Duli Seri Yang Mahamulia.

Manakala bertemu antara dua itu, maka berjabat selalu berpelukcium certa bertangis-tangisan. Kemudian maka sabda Paduka Yang Mahamulia: "Hai Paman! Sudah perintah Yang Mulia Raya!" Maka jawab Paduka Sultan Jambi: "Hai Anakda paman! Ini sudah nasib, Paduka Anakda juga tiada bersalahan lagi. Tetapi paman tiada masuk bangsa lain. Ada bangsa Arab yang masuk Paduka Anakda yang sekulit putih Inggeris. Demikianlah berlaku atas hambanya! Sekali ini bagaimana maksud Paduka Anakda Palémbang itu ${ }^{36}$ kepada Paduka Anakda ini ?" Maka sabda Paduka Yang Mahamulia: "Maclum, Paman! Siapa yang tiada suka didalam kota batu, maka jadi demikian ini. Pamanpun demikian adanya, artinya jangan disebut-sebut lagi."

6.

6.1. Alkissah tersebut perkataan orang datang dari negeri Palémbang. Satu haji berkhabar, diluar gelanggang waktu ia hendak mudik ada 
satu periai dan satu menteri, namanya Radén Muksim ${ }^{37}$ dan demang modin; hendak menerima uang kebawah Duli Paduka Yang Mahamulia; empat lima hari ini sampai. Maka perkhabaran itu selalu dipersembahkan menteri kebawah Duli Yang Mahamulia khabar itu. Maka titah: 70 "Apa maksudnya?" Sembah menteri: "Hendak menerima / ${ }^{38}$ uang, jikalau Duli Tuanku kurniai." Maka sabda Yang Mahamulia: "Jika ia sampai, orang itu jangan diperdulikan. Sekalian kamu lihat rupanya apa tingkah, hendaklah jaga baik-baik! Jikalau ia datangnya dengan perahu banyak, salah rupanya. Apa kehendak kamu sekalian? Bénténg kita sudah sedia!" Maka sembah sekalian periai dan menteri semuanya itu: "Apa juga titah perintah Duli Tuanku, patik sekalian kerjakan. Selagi ada jiwa sekalian patik, jangan Duli Tuanku khawatir akan perkejaan itu!"

Syahdan tiada berapa harinya datang suruhan dari Palémbang dua perahu, satu Radén Muksim dan satu demang modin; perkejaannya hendak minta uang tambah uang yang dahulu serta membawa surat Paduka Sultan. Dipersembahkan oranglah kebawah Duli, maka titah Paduka Yang Mulia kepada sekalian periai dan menteri-menteri: "Hai kamu sekalian dengar kataku! Orang yang datang itu sekali-kali jangan kamu sekalian perdulikan! Sekali-sekali lihat oléh kamu apa maksudnya kepada kita!"

6.2. Yang jadi ada satu bulan tiada satu apa, maka radén berdua demang itu berpesan kepada orang gunung: "Minta sampaikan pesan kepada satu menteri, khabarkan: "Apalah hal kami ini? Jikalau ada belas dan kasihan kepada kami, minta sembahkan kebawah Duli atawa kami boléh mengadap atawa persembahkan surat yang kami bawa ini."'” Maka menteri itupun ${ }^{39}$ selalu mengadap kebawah Duli Paduka Yang Mahamulia persembahkan khabar<itu. Maka titah:> "Apa yang baik

71 kepadamu?" / Maka sembah menteri itupun: "Tuanku! Jika kepada patik, baik Duli Tuanku suruhan periksa, boléh Duli Tuanku tahu maksud Paduka Adinda di Palémbang itu tentu akan jahat atawa baiknya." Maka titah: "Siapa yang patut kita suruh kemudian? Engkau juga pergi!" Maka sembah menteri itu: "Jikalau patik Duli Tuanku dititahkan, patik mohonkan wangsa-wangsa Duli Tuanku. Karena abdi kebawah Duli kuranglah pembilang kepada patik; jikalau wangsa Duli Tuanku itu, malu orang Palémbang. Didalam itu perintah juga yang patik junjung." Maka titah Paduka Yang Mahamulia: "Siapa patutnya kepada engkau?" Maka sembah menteri: "Pangéran Wiradiwangsa itu yang patik pohonkan." Maka titah: "Engkau ajaklah bersama-sama!" 
6.3. Maka pangéran dan menteri itupun pergilah mendapatkan Radén Muksim kedua demang modin. Maka pangéran bertanya khabar Palémbang. Maka jawab radén kedua demang itu: "Waktu ini baik tiada." "Dan perkejaan radén kedua demang ini apa maksud sebenar-benarnya?" Maka jawab radén kedua demang itu: "Kami kedua ini dititahkan oléh Sultan dari Palémbang membawa surat kebawah Duli Yang Mahamulia akan menerima uang tambah yang diterima Pangéran Sumanegara kedua Pangéran Citrakesuma. Tahu, jikalau ada alim atas ${ }^{40}$ kami kedua ini, hendak mohonkan kebawah Duli pemohonkan jikalau sembah pangéran kedua menteri, maka Duli yang dimohonkan

72 kebawah Duli tambah tiga bulan beri. / Itulah perkejaan kedua kami mudik ini. Didalam itu apa juga alim atas kami kedua." Maka jawab pangéran kedua menteri yang dari hulu itu: "Barang apa radén nanti, barang lima hari. Jika tiada khabar didalam hari itu, apa ikhtiar radén kedua demang!"

Maka sampai seperti janji itu, maka radén kedua demang mesuarat: "Ada kita dapat akan uang itu apakah tidak?" Maka kata demang: "Pada rasa hati saya tiada dapat kita akan uang itu." Kata radén: "Apa sebab maka kita tiada dapat? Inilah rupanya yang kita tunggu disangka sampai empatpuluh hari tiada yang perduli atawa tanya! Didalam hémat saya lebih baik kita milir. Apa yang kita tunggu-tunggu? Jika akan boléh, baik juga!" Maka kata radén: "Apa ikhtiar mamak demanglah? Milir kita, marilah! Barangkali kita dipanggil Sultan mudik ke Muara Rawas; maka kita kedua dipegangnya, apa kita boléh melawan? Jikalau demikian, baiklah kita milir malam ini juga. Hamba tiada énak-énak hati, barangkali tiada baik kita dapat."

Maka radén dan demang modin milir dengan masgulnya, karena sudah lama meninggalkan Palémbang satupun yang dapat uang tiada, suratpun tiada dibalas orang itu. "Jikalau dapat perkataan yang baik, boléh juga kita muka manis kebawah Duli. Hai demang! Jangan kita singgah-singgah lagi di jalan, supaya sigera perkejaan kita. Sapa tahu, barangkali Paduka Sultan murka hendak menyuruh perahu perang."

73 6.4. Ada tiga hari radén / demang itu sampailah ke negeri; selalu mendapatkan paduka kakanda Pangéran Sumanegara ${ }^{41}$ dan Pangéran Citrakesuma, khabarkan hal ihwal perkejaan pergi mudik itu. "Usahkan mendapat uang, perkhabaran yang baik pun tiada, surat tiada dibalas orang itupun. Jikalau tiada berkat daulat Paduka Yang Mahamulia, tiada diambil orang ke hulu. Didalam hémat kami serta pelihatan kami: jika dikehendaki seratus ribu, dahulu niscaya diberinya; karena orang 
waktu itu belum banyak lagi bénténgnya belum ada kukuh. Itulah sebabnya maka ia meminta témpo tiga bulan. Sampai tiga bulan bénténgnya sudah dan orang pucukanpun kumpul semuanya, Melayu Minangkabaupun datang banyak, Sultan Jambipun datang serta membawa anak-anak raja berapa banyak. Itulah sebabnya maka kami kedua jadi demikian ini. Jikalau angkatan banyak, janganlah dicapai-capai lagi; karena sikapnya sudah cukup, belanjapun banyak. Khabar orang setiap hari memberi belanja dan persalin tiada hingganya."

Serta pangéran kedua itu mendengar khabar radén kedua demang itu, maka pangéran kedua itu mérah-padam mukanya, selalu dibawanya radén dan demang mengadap kebawah Duli Paduka Yang Mahamulia persembahkan hal ihwal perkejaan dan khabar itu.

\section{7.}

7.1. Serta mendengar khabar itu, Seri Padukapun murka serta berangkat masuk paséban dalam. Titah: "Panggil Pangéran Citrakesuma 74 kedua / Pangéran Sumanegara!" Serta datang pangéran kedua itu, maka Seri Paduka bertitah demikian: "Apa bicara kamu banyak akan perkejaan itu? Jangan léngah! Sekalian kamu pergilah sediakan perahu dengan alat senjatanya, limapuluh perahu! Engkau sekalian pergilah! Menteri-menteri jangan ada yang tinggal; didalam negeri biarlah aku jaga dengan orang putih serta sipai!"

Dan ada berapa hari telah siaplah sekalian perahu itu dengan alat senjatanya berlabuh di laut pangkalan dalam, sekadar menanti perintah daribawah Duli sahaja. Maka pangéran kedua dan sekalian menteri: rangga, demang, ngabéhi dan pangéran Komering dan perwatin dan lurah Sungsang serta racyatnya itupun hadir di pengadapan, maka titah Yang Mahamulia: "Hari Isnin pukul tujuh sekalian engkau mintarlah!" Waktu itu maka sembah sekalian periai menteri menjunjung titah itu. Maka Seri Padukapun ${ }^{42}$ berangkat masuk ke istana.

Maka kepada hari Isnin pukul tujuh sekalian periai menteri-menteripun siap, masing-masing hadir dalam perahunya. Maka Seri Yang Mahamulia keluar melihat perahu banyak itu. Maka titah daribawah Duli kepada pangéran sekalian dan pada menteri semua suruh pasang bedil sekalian perahu. Selalu mintar serta sorak. Seperti guruh di langit bunyi bedil dan sorak, kelamkabut dunia adanya.

7.2. Alkissah maka tersebutlah perkataan Seri Paduka Sultan Mahmud menanti-nanti orang dari Palémbang yang akan datang itu. "Apa 75 maksudnya? / Jikalau hendak membinasakan, ${ }^{43}$ kitapun menanti hen- 
dak menyobok ${ }^{44}$ bénténg kita ini. Jika orang Palémbang yang akan datang, rasaku belumlah jodohnya bénténg kita; jika orang putih, di situ baharu kelihatan perempuan laki-lakinya. Khabar orang sudah ditengah jalan banyak perahu-perahunya, limapuluh buah tempat makan." Maka sembah menteri dan periai dan sekalian panglima: "Patik-patik ${ }^{45}$ ini menantikan titah Duli Tuanku." Maka titah daribawah Duli: "Engkau sekalian sedia perahu! Malam-malam engkau papak perahu tengah ia berlabuh banyak itu!"

Maka sekalian itu mohon pergi, ada tujuh buah perahu milir. Sampai ke dusun Kasemaran berhenti. Malamnya menyuruh perahu kecil hendak meluluk itu; sampai di ilir dusun Ulak Tebru diluluk oléh orang sebelah ulu. Tiada satu apa orang dari Palémbang dan dari hulu, siang harinya orang Palémbang selalu membedil tiga buah perahu tiada $<\mathrm{di}>$ perhentikannya; maka itu dilawannya dengan bermain-main. Haripun malam maka orang yang sebelah ulu itu naik ke dusun Kemang menjaga hendak meluluk. Ada pukul delapan perahu orang Palémbang itupun sampailah ke dusun Kemang; selalu berlabuh perahu banyak itu. Maka dibedil oléh orang dari sebelah ulu itu, maka iapun kalah. Orang dari Palémbang selalu membakar dusun dan orang dusun itu habis lari kedalam hutan. Pada malam itu orang dari hulu kembali 76 ke hulu. Serta sampai, bersiap bénténg / seberang-menyeberang. Sorakpun gemuruh, talu-bertalu bunyi gendang serta egung serunai; pencak Melayu Kerinci tiada berhenti siang malam, apalagi jinis judi tiada lagi tinggal.

Maka tersebutlah perkataan angkatan dari Palémbang membuat bénténg berkeliling dusun Kemang. Bilang puncak gandok bertunggu demang dan ngabéhi dan pangéran Komering. Dan jaganya keras, apalagi orang baru ada limabelas orang yang berkeliling, satu jam sekali berganti. Maka Pangéran Citrakesuma kedua <Pangéran Sumanegara $>$ mupakat sekalian pangéran dan menteri sekalian hendak mudik Muara Rawas hendak menyobok bénténg Sultan Mahmud Badaruddin. Maka perkejaan itu telah diketahui orang, maka menteri yang penghulu panglima Melayu itu membuat korok ${ }^{46}$ seberang-menyeberang Batanghari Musi. Satu korok dua orang mengintai dengan setinggar, tiada kelihatan orang didalam tanah. Itulah rupanya perkejaan Melayu ${ }^{47}$ Minangkabau.

7.3. Maka tersebutlah perkataan orang dari Palémbang siap hendak melanggar bénténg Muara Rawas, Pangéran Citrakesuma dan Pangéran Sumanegara dan pangéran-pangéran Komering. Maka mudik perahu 
banyak itu serta sorak tiada berhenti lagi. Tiada berapa lamanya kelihatan bénténg yang di muara Rawas dan bénténg sebelah Musi dan bénténg Muara Rawas, sekalian orang jaga serta dengan gendang perang, sorak bertalu-talu. Demikianlah adanya. Maka perahu orang

77 Palémbang serta melihat bénténg tiga / buah itu, datanglah geram hatinya pangéran-pangéran dan menteri-menteri. Serta didekatnya, keluarlah satu orang Melayu dari korok serta membedil Pangéran Citrakesuma. Tiadalah termudik lagi, selalu menyeberang sekalian itu. Sampai ke seberang, dibedil oléh orang yang didalam korok. Belum dibedil orang dari Palémbang, maka selalu undur kembali ke Kemang, mesuarat dengan periai menteri dan pangéran Komering hendak melanggar jalan darat. "Suruh orang ambil anak kayu panjang sedepa buat bénténg berjalan! Dalam empat lima hari ini kita coba langgar dari belakang bénténgnya. Demikianlah!" Kemudian orang Muara Rawaspun sudah tahu akan maksud orang dari Palémbang itu, maka orang sebelah ulu membuat bénténg di darat jalan orang pergi dari tempat orang Palémbang itu. Dijaga bénténg itu sepuluh orang, senjata senapang lima, setinggar empat pucuk.

Ada satu hari orang didalam bénténg itu keluar tiga orang panglima perang hendak mencari buah-buah. Berdapat di jalan orang banyak ada tigaratus orang melanggar bénténg ditengah jalan, pengulunya Demang Singayuda, pangéran Komering. Serta terlihat kepada orang tiga itu, selalu diserotnya. Maka orang tiga itu lari ke bénténgnya. Maka dikejarnya oléh orang Palémbang hingga sampai dekat bénténg78 nya. Maka orang didalam bénténg / melihat kawannya dikejar orang Palémbang, maka keluar serta bersorak. Orang Palémbang mendengar itu kembali, disangkanya orang Melayu sekurang<-kurang >nya duaratus atawa tigaratus, selalu lari tiada ketahuan larinya. Maka lalu dikejarnya, dapatnya satu orang; lalu diikatnya serta $<$ di $>$ keratnya kepala. Maka disembahkannya kebawah Duli Seri Mahamulia, maka dibayar duapuluh ringgit. Telah perjanjian sekalian Melayu jikalau dapat tigas, dibayar duapuluh ringgit; jika dapat hidup, dibayar juga duapuluh ringgit. Jikalau kawan Palémbang datang sendiri, dikurniai kain pakaian secukupnya dan uang belanja sepuluh ringgit. Jikalau orang Melayu pergi mengadang di hilir bénténg, dikurniai belanja; dapat senapang atawa pemuras, dibeli dan barang lain jadi rampasan yang pergi sahaja. Demikianlah perkejaan bénténg Muara Rawas dengan jaganya sangat keras.

Adapun perkejaan periai Kemang, tiap-tiap hari membuat bénténg siang malam tiada berhenti, takut diluluk Melayu tiap-tiap malam 
datang; dan siang memasang ranjau, malam dicurinya, oléh orang jaga tiada melihat. "Apa akal kita pada perkejaan ini melainkan kita berkukuh?! Tiada habis enam tujuh hari atawa bulan kita menunggu, kita langgar mudik tiada terhémat dan perintah Paduka Sultan mudik. Mudah-mudahan datang suruhan dari Palémbang menyuruh kita se-

79 kalian milir atawa datang orang putih membawa soldadu / barang duaratus, di situ kalau kita boléh milir! Dan ${ }^{48}$ Paduka Seri Sultan Tua itu apa kepada kita gustiku apa seteru?" Maka kata pangéran kedua: "Maka jadi demikian ini! Jikalau kita lagi dua muka, tiada jadi angkat orang punya perkejaan. Baiklah jika lagi ada umur kita kembali ke negeri; semua perkara aturan kita ini boléh tersebut. Sekarang kita sekalian cari patut. Dari orang jaga gandok dan yang orang ronda keliling jangan léngah, karena risau di Muara Rawas itu orang Melayu Kerinci dan Pegagan!"

Ada kepada kutika pukul tiga malam datang pencuri Pegagan dari hulu naik gandok bénténg orang dusun Kemang, diambil bedil léla pemuras diambilnya. Orang yang jaga tidur itu dibedilnya luka, satu orang ampir mati. Maka pencuri Pegagan kembali membawa bedil léla kira-kira berat dua pikul setengah. Maka dipersembahkan menteri kebawah Duli Seri Paduka. Maka titah kepada menteri: "Beri ringgit, seratus ringgit, dan kain baju secukupnya! Jangan engkau kurangkan, supaya dilihat oléh kawan-kawan banyak suka sekali-kali itu!" Tiada berani lagi orang dari Palémbang keluar melanggar bénténg atawa cari buah-buah kayu atawa bénténg yang di seberang itu. Maka orang Muara Rawas telah masuk bénténg di Kemang, empat lima bénténg didalam semalam. Setiap hari setiap malam perang, jadi orang bénténg Kemang tiada boléh keluar lain dari turun naik ke perahu, takut kepada Melayu itu.

7.4. Ada kira tiga bulan perang itu juga, boléh bertemu-temuan yang / 80 orang Palémbang sama Palémbang jangan masuk orang Melayu, kemudian Sultan Mahmud Badaruddin menyuruh seorang periai berdapat dengan pangéran-pangéran Palémbang dan menteri-menteri Palémbang. "Jika engkau berdapat, khabarkan aku punya cinta-kasih, rindu-dendamku tiada berkeputusan kepada sekalian sanak saudara dan sahabatku itu. Lagi engkau khabarkan padanya yang aku dari kecil belum tahu bercerai barang satu hari. Ini sudah nasib atasku setiap hutan tempatku anak-beranak tiada seorang sanak saudara yang cinta kepadaku. Maka datang sanak saudara akan hendak mengambil jiwaku, didalam aku punya kira datangnya hendak mencari akan kebajikan. Itulah maka 
aku jadi mengumpulkan orang Melayu dan Jambi banyak ini akan jadi sanak saudara, karena tiada mempunya sanak yang sebabatku."

Maka periai yang pergi itu menjunjung Duli, selalu pergi mendapatkan bénténg di seberang Kemang. Pada malam hari itu bertemu dengan pangéran-pangéran dan menteri-menteri, sigera ditegur-tegur oléh pangéran-pangéran dan menteri sekalian. Maka periai itu menyampaikan pesan Duli Yang Mahamulia itu. Habis dikhabarkannya sekalian kata Yang Mahamulia, maka sekalian pangéran-pangéran dan menterimenteri itu mendengar bunyi khabar itu maka sekaliannyapun keluar air mata mengenang akan témpo zaman dahulu. Maka mesuaratkan ${ }^{40}$ sekalian periai dan menteri itu hendak mengadap kebawah Duli serta

81 hendak persembahkan keris memohon ampun, / beribu<-ribu> ampun; serta hendak mengadap kebawah Duli malam hari waktu sunyi, supaya jangan ketahuan Pangéran Citrakesuma dan Pangéran Sumanegara.

7.5. Maka malam hari sekalian periai dan menteri itu mengadap ke Muara Rawas kebawah Duli, pertama Pangéran Natawikrama dan Sutawikrama dan menterinya Demang Singayuda dan Kemas Rakria; yaitu empat orang itu yang mengadap kebawah Duli. Lain tiada lepas hendak mengadap, takut ketahuan pangéran kedua; sekadar persembahkan keris dibawa pangéran kedua dan menteri kedua. Maka sabda Duli Yang Mahamulia kepada pangéran kedua: "Engkau sampaikan cinta-kasihku kepada sekalian yang bercinta lagi padaku serta salamku kepada sekalian yang aku belum lupa padanya, walau ia sekalipun membuat aku serupa ini. Yang aku tiada terlintas padanya, semua karena sudah nasibku, apa boléh buat! Yang ia lagi cinta padaku, aku banyak terima kasih."

Ada kira pukul satu maka pangéran kedua itu mohonkan hendak kembali ke perahu di dusun Kemang. Serta sampai ke perahu, maka sekalian menteri dan periai yang tinggal itu datang bertanya hal perkejaan dan Seri Paduka Sultan. Maka pangéran kedua itu mekhabarkan perkejaan Muara Rawas itu bukan jodohnya orang hitam, walau orang putihpun tiada gampang; bukan daripada orangnya, daripada tempat bénténgnya itu tanam tonggak, lain-lain tanah. Kemudian daripada itu pangéran kedua menyampaikan salam serta tulus dan ikhlas Seri Pa-

82 duka / Sultan "pada sanak saudara Kita". Perkejaan itu hanya Pangéran Citrakesuma dan Pangéran Sumanegara ${ }^{50}$ yang tiada tahu akan perbuatan periai dan menteri-menteri yang sudah demikian itu. Lagi orang didalam bénténg sebelah-menyebelah bermain judi, pergi datang tiap-tiap malam. 
8.

8.1. Ada kira-kira tiga bulan datang Tuan Sékh Abdulrahman Mesri mudik Muara Rawas. Ada antara setengah bulan datang orang putih Inggeris, namanya Kaptén Dégelar ${ }^{51}$ dan yang satunya Berikmil, ${ }^{52}$ berhenti di dusun Kemang, khabar hendak mengadap Sultan. Maka dititahkan putera Pangéran Bupati dan Pangéran Prabu, dan temenggung dan rangga dan demang ngabéhi mengiring putera, menjumput orang putih ke Muara Rawas.

Maka putera dan sekaliannya mintar hilir, ada sepuluh buah perahu. Tatkala sampai ke dusun Kemang, pangéran kedua bersaudara berpegang tangan kedua orang putih. Maka orang putih menanyakan: "Sultan ada baik?" Maka jawab pangéran kedua saudara: "Saya punya bapa sekarang ini baik dan lagi saya punya bapa kirim tabik begitu banyak. Yang saya sama temenggung rangga demang ngabéhi ini disuruh saya punya orang tua suruh jumputi tuan kedua serta dengan perahu, satu apa tuan punya barang jangan tinggal, disuruh saya punya bapa bawa." Maka jawab tuan kaptén kedua: "Baik! Saya lebih suka mau

83 ketemu lekas sama Tuan Sultan." / Maka kata pangéran kedua bersaudara itu: "Pukul berapa boléh kita mudik?" Maka jawab kaptén kedua: "Nanti sebentar! Saya belum habis buat surat, mau kirim sama Tuan Besar di Palémbang bilang tahu yang kita sudah ketemu sama tuan pangéran kedua disuruh Tuan Sultan Mahmud Badaruddin ambil kita dari dusun Kemang bawa mudik ke Muara Rawas."

Ada kira pukul sebelas sekalian perahu siap, selalu mudik ke Muara Rawas. Ada antara setengah jam nampak bénténg, Sultanpun datang memapak. Serta dekat kedua perahu, maka Sultan naik perahu kaptén. Maka kaptén kedua itu sigera naik ke perahu Sultan berpegang tangan. Dan orang bénténgpun masang bedil serta gendang, orang bermain pedang Melayu, sorak seperti guruh. Maka habis pertanyaan selalu Sultan berpegang tangan dengan kaptén, lalu naik ke darat didalam rumah besar dengan tempat tidurnya.

8.2. Dan ada antara satu bulan terkhabar $P a d u<k a>$ Tuan Besar Palémbang mudik ke Muara Rawas. Tiada berapa hari khabar itu, maka Tuan Besar sampai ke dusun Kemang, hendak mudik membawa sekalian pangéran-pangéran dan menteri-menteri; hendak disuruh Méjer Rabsan ${ }^{53}$ minta ampun kebawah Duli Paduka Sultan, karena pangéranpangéran dan menteri-menteri sudah mendurhaka ${ }^{54}$ kebawah Duli. Manakala Seri Sultanpun menyuruh pangéran-pangéran dan menterimenteri segala sigera menjumputi Méjer Rabsan ke dusun Kemang, / 
84 dan Seri Sultanpun membawa anak-anak kecil menanti di Muara Rawas. Maka Méjer Rabsanpun mudik. Bertemu perahu antara kedua, maka Seri Sultan berpegang tangan dengan Méjer Rabsan, lalu naik perahu. Méjer Rabsanpun memberi hormat dan khidmat dan Sultan menerima kasih; selalu mudik menuju bénténg yang <di> Muara Rawas.

Serta sampai dekat bénténg, bedilpun berbunyilah seperti tagar bunyinya. Maka tersebut Sultan dengan Méjer Rabsan berpegang tangan naik bénténg bersama Sultan. Dan pangéran dan menteri yang dari dusun Kemang itu mengiring, jadi campur periai menteri Palémbang dan menteri periai Muara Rawas. Maka Méjer Rabsan duduklah didalam rumah serta dengan soldadu sipai, orang ulu jaga didalam itu. Setiap hari siang malam menteri dan periai pergi meriksa hal ihwal.

8.3. Ada tiga hari Méjer Rabsan hendak milir ke Palémbang. Maka Paduka Pangéran Ratu dan kemas rangga mengantar Tuan Méjer Rabsan milir <ke > Palémbang ada membawa barang-barang. Kepada hari itu juga Méjer Rabsanpun milir ke Palémbang bersama-sama Paduka Pangéran Ratu dan Kemas Kecik dan menteri kemas, Rangga Kumbang.

Dan ada sepuluh hari datang Pangéran Ratu, saudara Sultan, menju $<\mathrm{m}>$ puti Kakanda Sultan Tua ${ }^{55}$ milir dengan perintah Méjer Rabsan

85 hendaklah sigera; / karena hendak berlayar pulang ke Betawi, lagi menanti Paduka Sultan sampai ke Palémbang, itu hari juga Méjer Rabsan berlayar.

Tiada berapa hari Paduka Sultanpun milir dari Mua<ra $>$ Rawas sekalian perahu dan racyat. Empat hari lagi di jalan Paduka Sultan sampai berhenti di Karang Anyar. Maka Paduka Sultan menyuruh Kaptén Dégelar memberitahu Méjer Rabsan "yang Kita sampai". Maka Kaptén Dégelar menyuruh Berikmil.

8.4. Maka Sultan menyuruh seorang menteri bersama orang putih menjumputi ${ }^{56}$ Méjer Rabsan masuk kota. Maka Paduka Seri Sultan berpegang tangan dengan Méjer Rabsan turun ke perahu hendak menjumputi Seri Paduka Sultan Mahmud Badaruddin datang dari Muara Rawas. Maka sampailah pencalang Méjer Rabsan kepada perahu pencalang Paduka Seri Sultan. Maka Paduka Seri Sultan naik kepada perahu Méjer Rabsan, duduk bersama-sama tiga kursi: Paduka Sultan Tua duduk kepala méja dan Sultan Muda duduk di kiri Paduka Kakanda dan Méjer Rabsan duduk di kanan Sultan Mahmud Badaruddin. 
Tiada berapa lama sampai ke tangga dalam. Méjer Rabsanpun memegang Sultan Tua sebelah kanan dan memegang Paduka Sultan Muda sebelah kiri. Maka Méjer Rabsan berjalan naik bersama tengah paduka sultan kedua, sebelah kiri jadi s-u-m-ng-i-gh ${ }^{57}$ masuk loténg, selalu naik tangga batu, lalu masuk sirap di dalam.

86 Antara satu jam maka Méjer Rabsan hendak keluar / bersama Paduka Sultan Muda. Maka Méjer Rabsan berpegang tangan, selalu mengantar Sultan ke kota lama. Maka didalam kota lama, Tuan Méjer Rabsanpun kembali di seberang rumah kaptén Cina yang di hulu. Sementara tetaplah Paduka Sultan Mahmud Badaruddin atas kerajaan dan Paduka Sultan Muda tetaplah duduk di kota lama.

8.5. Ada sembilan hari Tuan Méjer Rabsan mengadap Sultan hendak berlayar ke Betawi mengadap Tuan Guburnur-Jénderal serta dengan Tuan Sultan punya anak Pangéran Ratu kedua Pangéran Adimenggala, dan Pangéran Kramadiraja, menantu, dan paduka adinda Pangéran Suryakesuma dan Natawikrama, dan Pangéran Sutadiwangsa dan Pangéran Puterakrama, dan menterinya Kemas Temenggung Kerta dan Demang Darpateruna dan Ngabéhi Darpacita dan Kemas Demang Ahmad dan Ngabéhi Pinding dan Ngabéhi Ahmad dan Ngabéhi Keling, mengikut Méjer Rabsan hendak terima kasih kebawah sepatu Tuan Guburnur-Jénderal. Syahdan Paduka Sultan mekurnia sekalian pangéran dan menteri-menteri yang tersebut itu.

Tiada ${ }^{58}$ berapa lamanya Méjer Rabsanpun mintar. Paduka Seri Sultan kedua bersaudara mengantar Méjer Rabsan sampai di Lemabang. Méjer Rabsan selalu milir dan pangéran dan sekalian yang mengantar milirlah bersama-sama Méjer Rabsan. Dan Paduka Sultan Mahmud Badaruddin selalu ziarah ${ }^{59}$ ke Lemabang, kepada Marhum

87 Seri Sultan dan Paduka Suhunan. Dan / ${ }^{60}$ Paduka Sultan habis ziarah, maka ia pulang ke istana kota baharu. Dan Paduka Sultan Mudapun kembali ke kota lama.

Syahdan maka tersebut pula perkataan Méjer Rabsan dan Paduka Pangéran Ratu dan Pangéran Suryakesuma dan Pangéran Adimenggala dan Pangéran Nata dan Pangéran Wangsa dan Pangéran Putera dan Kemas Temenggung Kerta dan menteri yang lain itu sekalian diberi Jénderal satu rumah batu besar serta dijaga soldadu serta dengan makan dan lilin pasang malampun secukupnya. Demikianlah peliharaan Jénderal kepada pangéran-pangéran. Tetapi Paduka Pangéran Adimenggala dan Pangéran Surya kedua pangéran itu yang boléh ketemu Jénderal. 
8.6. Tiada berapa harinya datang khabar <kepada> Jénderal Galipi mekhabarkan Sultan Mahmud Badaruddin <di>kembalikan Méjer Rabsan kerajaan negeri Palémbang, Sultan Muda $<$ di $>$ turunkan Méjer Rabsan dari kerajaan, ditaruh di kota lama. Dengan masgul maka Jénderal Galipi mendapatkan Jénderal Misti Raplis, mengempaskan cepiaunya diatas méja serta katanya kepada Jénderal Misti Raplis: "Siapa kasih kuasa sama Méjer Rabsan ambil Sultan Mahmud Badaruddin dari gunung, kasih kembali jadi raja negeri Palémbang?! Gua mau pergi ke Palémbang, mau lihat muka Sultan Mahmud Badaruddin; dan Sultan Muda, gua punya sahabat, orang buat begitu rupa gua tiada

88 suka!" Maka Jénderal Misti Raplis / menyuruhkan anak Raja Benggala dengan beberapa opsir serta dengan soldadu ke negeri mengembalikan Sultan Muda dalam kerajaan negeri Palémbang; dan Sultan Mahmud Badaruddin turun dari kerajaan, pindah di kota lama.

Tetaplah Sultan Muda jadi raja negeri Palémbang tiga tahun setengah. Tapi kepada waktu itu adanya Sultan Muda naik kerajaan <negeri> bergelar suhunan. ${ }^{61}$ Tiada berapa lama atas takhta kerajaan dan perintah dari Betawi Idelir Ménténg mengembalikan Sultan Mahmud Badaruddin jadi raja Palémbang. Demikianlah pusing-memusing tipu-menipu bijaksana orang kulit putih.

\section{9.}

9.1. Dan ada antara dua bulan Idelir Ménténg di Palémbang, datang orang putih bangsa Inggeris dari negeri Bengkulu membawa soldadu. Enampuluh orang yang sampai ke negeri Palémbang dan soldadu sipai ada duaratus milir dari hulu, lagi ditengah jalan milir sama rakit, belum sampai. Maka ditaruh di kota lama. Kepada malam hari datang suruhan Idelir Ménténg opsir dan soldadu seratus orang, datang mengambil Inggeris yang di kota lama itu; Paduka Sultan Muda duduk dalam Buratan. Inggeris selalu dibawa ke Betawi disuruh Idelir Ménténg kepada hari itu juga.

Dan Idelir Ménténgpun hendak mudik mendapatkan soldadu Inggeris milir berakit itu. Maka Idelir Ménténg minta kepada Paduka 89 Sultan Mahmud Badaruddin / perahu pencalang tiga buah perahu serta dengan orang yang ${ }^{62}$ boléh pegang senapang, satu perahu sepuluh orang lain dari kepala perahu: yaitu menteri-menteri dan pangéranpangéran, lain dari Pangéran Adipati dan Pangéran Adimenggala dan Pangéran Putera dan Seri Paduka Sultan. Maka mudiklah Idelir Ménténg masuk Musi; sepuluh hari sampai di Muara Beliti. Ada satu bulan 
Idelir Ménténg milir ke Palémbang. Dan Paduka Sultan Mahmud Badaruddin bergelar Suhunan Mahmud Badaruddin.

Syahdan maka Sultan Muda dibawa ke Betawi dengan anak-isterinya, ditaruh ${ }^{63}$ di désa Sinjur ${ }^{64}$; dan menterinya dan periai setengah ditaruh di désa Sumedang. ${ }^{65}$ Dan Paduka Seri Sultan diberi ramsum ${ }^{68}$ dan sekalian menteri periai ada dengan secukupnya, ada yang duapuluh rupiah, ada yang limabelas rupiah tiap<-tiap> bulan.

9.2. Kemudian harinya datang perintah Idelir Ménténg membuat pesona ${ }^{67}$ yang bukan patut kepada Suhunan Mahmud Badaruddin; sekalian perbuatan Idelir Ménténg tiada yang disalahinya oléh Suhunan.

Maka Idelir Ménténg hendak mudik Beliti minta perahu dengan cukup alat senjatanya serta menteri sebilang perahu akan jadi kepalanya. Maka Idelir Ménténgpun mudik sampai ke Muara Beliti. Ada antara berapa lama maka Idelir Ménténgpun pulang ke Palémbang dengan masam mukanya, karena ia perang di Muara Rawas dengan Said Hamzah dan Demang Arsad dan Melayu Minangkabau. Jadi sang90 kanya masuk bicara / Suhunan didalam itu, sekali-kali tiada Suhunan tahu akan hal ihwal perkejaan itu.

Maka Suhunan menyuruh Pangéran Ratu dan Pangéran Adipati memapak Idelir Ménténg. Serta Pangéran Ratu sampai ke perahu Idelir Ménténg, tiada diberinya Pangéran Ratu naik perahu Idelir Ménténg itu. Maka Pangéran Adipati yang dipanggil naik perahunya dan Pangéran Ratu tinggal di laut tangga.

Dan Pangéran Adipati turun pulang menyeberang bersama Anakda Pangéran Ratu, selalu mengadap Paduka Ayahanda Suhunan persembahkan hal ihwal Idelir Ménténg: "Dari mudik itu pekerjaan di hulu banyak kotor sekali dari Melayu dan dari orang Musi. Pangéran Semangus nampak jahatnya sudah mati kita pasang. Sampai milir ke Muara Rawas, perang sama Said Hamzah dan Demang Arsad didalam bénténg Muara Rawas; kawannya Melayu habis lari. Demikianlah perkejaan. Gua kira itu pekerjaan tiada patut orang kecil-kecil pun <ya $>$ pekerjaan. Gua kira kemudian hari lihatlah kepada kita sekalian orang didalam dunia ini. Boléh tuan pangéran ingat-ingat dan perintahkan yang seperti orang piutang boléh disuruh bayar, yang membunuh disuruh bunuh. Tiada lama lagi, gua ampir témponya, alamat sudah datang." Maka khabar itu sekaliannya disembahkan Pangéran Adipati kebawah Duli Suhunan, maka sabda Duli Yang Mahamulia: "Jika demikian kita disangkanya, apa boléh buat! Tetapi kita satu apa tidak / 91 tahu." 
9.3. Maka Idelir Ménténg membuat $<$ se $>$ sukahatinya. Dari perahuperahu dagang béa-membéa dan membuat pabéan dan membuat kaptén Cina; apa sukanya didalam negeri Palémbang tiada dengan mesuarat Paduka Suhunan. Dan Idelir Ménténg menyuruh Pangéran Muhammad mengambil bedil nama Seri Padah, pusaka Palémbang, di muka loténg tiada dengan hormat barang satu apa kebawah Duli atawa kepada periai duduk diluar loténg. Jadi masgul Paduka Suhunan melihat pekerjaan Idelir Ménténg yang demikian itu.

Tiada berapa bulan lama $<$ nya $>$ datang khabar kebawah Duli yang Idelir Ménténg hendak membuat sesukahatinya, dan Paduka Suhunanpun sudah sedia. Manakala salah penglihatan, sekalian menteri dan periai tiada sempat persembahkan kebawah Duli, karena <itu> titah sudah terdahulu kepada sekalian menteri periai serta siap. Jikalau ada rupa salah daripada yang sudah terpakai dari zaman dahulu-dahulu, itulah alamat akan negeri Palémbang habis témponya perdamaian rajaraja yang dahulu-dahulu dengan Kompeni Wilanda. ${ }^{68}$

10.

10.1. Syahdan maka Idelir Ménténg menyuruh opsir empat orang duduk di kota lama dengan soldadu seratus orang; dan kapal tiga satu berlabuh di laut kota. Dan pada waktu itu Paduka Suhunan rasa: "Tiada lagi akan kebajikan negeri Palémbang ini oléh Idelir Ménténg. Baiklah kita siap, seboléh-boléhnya kita lawan, seboléh-boléhnya kita menjalankan jalan syaricat, lagi kita mati syahid akhirnya." Maka Paduka Mahamulia mengumpulkan sekalian menteri periai pangéran

92 dan tuan-tuan / dan haji-haji dan $\mathrm{ra}^{c}$ yat-rac $y$ at yang didalam negeri Palémbang dan perwatin uluan sekalian. Telah hadir mengadap, maka titah kepada haji-haji sekalian: "Engkau berbuat peramalan di pengadapan bersungguh-sungguh serta kerjakan ratib!" Maka haji-hajipun menjunjung Duli Seri Paduka Suhunan, dikurniai belanja masingmasing adanya. Maka haji-hajipun mengerjakan apa yang dititahkan itu; bersungguh-sungguhlah sekalian haji-haji, periai dan menteri itu.

Maka datanglah satu Wilanda dari kota lama melihat haji berzikir itu. Lalu diajaknya ${ }^{68}$ oléh haji berzikir itu, usahkan ${ }^{70}$ satu khatib bernama sangat garang; maka dikejarnya, maka ia lari kembali ke kota lama. Maka soldadu di kota lama itupun siaplah. ${ }^{71}$ Maka haji-haji mupakat hendak sabil mengamuk ke kota lama. Selalu pergi ada empatpuluh orang. Dan empat lima orang haji yang selalu masuk kota lama dan yang banyak kembali ke kota mengadap Seri Paduka Suhu- 
nan; ada yang kembali masing-masing ke rumahnya, tiada kembali lagi mengadap.

10.2. Kemudian daripada itu jadi peranglah Suhunan dengan Idelir Ménténg. Kapalpun membedil kota dan kota membedil kapal. Baris soldadupun datanglah kemuka pintu kota, pintupun sigera ditutup; dan soldadupun kembali ke kota lama. Waktu itu sangatlah rusuh negeri Palémbang. Ada dua hari perang itu banyak orang Wilanda mati dan orang di kota Suhunan mati satu orang. Dan kepada tiga harinya perang itu lantas opsir dan soldadu turun kembali ke kapal, banyak yang mati dan yang luka. Dan Paduka Suhunan keluar dari kota /

93 membawa anak-anak; ada tiga jam Paduka Suhunan kembali masuk kota. Kepada hari itu juga kapal tiga itu undur dari kota, selalu milir. Idelir Ménténgpun lari dari kota seberang, naik kapal, selalu milir. Sampai di Sungsang, tiada singgah di kuala lantas berlayar ke Betawi.

11.

11.1 Ada antara tiga bulan datang kembali khabar Idelir Ménténg hendak melanggar negeri Palémbang membawa kapal tujuh, kici empat, langbut sepuluh buah. Khabar itu sampai kepada Suhunan, pun sudah siap bénténg muara Plaju, digelar Tambakbaya; itulah tempat raja-raja dan temenggung, rangga, demang, ngabéhi, apalagi tuan haji-haji dan pangéran-pangéran uluan serta dengan racyatnya beribu-ribu orang. Dan kedua bénténg satunya di sebelah ulu Pangéran Citra dan periai dan perwatin Ogan dan Pegagan, Martapura, sekalian racyat-racyat dan putera-putera dan tuan-tuan Arab dan rac $^{c} y a t-\mathrm{ra}^{c}$ yat Palémbang. Dan ketiga bénténg yang ditengah sungai pangéran patih, gelarnya Pangéran Wirasentika, serta menteri-menteri. Dan satu bénténg ditengah sungai juga yang ditunggu Pangéran Ratu Jambi serta racyatnya. Dan bénténg Pulau Kem $<\mathrm{b}>$ ara yang ditunggu saudara Suhunan, gelarnya Pangéran Suradilaga, ${ }^{72}$ serta temenggung dan rangga dan kaptén Cina dan perwatin Kikim dan demang dan jenang. Demikianlah setiap hari tiada berhenti dengan pekerjaan, malam siang tiada berhenti. Apalagi didalam negeri, diatas kota dan tanah bénténg; dan rakit dua tiga lapis sedia akan dibakar.

94 Ada antara tiga / bulan datang jaga kuala Sungsang mekhabarkan banyak perahu: kapal dan kici, but, lanca dan penjajap, kira ada barang empatpuluh besar kecil. Pada waktu itu Seri Paduka Sultan setiap hari pergi meriksa bénténg: kurang kukuh, titah suruh kukuhkan; kurang senjata, tambah senjata. Adalah bénténg Tambakbaya meriamnya se- 
ratus enampuluh delapan, lagi léla diatas bénténg tiada terbilang akan banyaknya. Didalam itu periai pangéran-pangéran dan menteri-menteri temenggung, rangga, demang, ngabéhi, pasirah ${ }^{73}$ perwatin uluan, piniwayah ${ }^{74}$ Sungsang g-i-r-a-n- ${ }^{75}$ jaga belakang bénténg dan pangéran, temenggung, rangga, demang, ngabéhi jaga meriam, satu menteri satu meriam satu léla, serta dengan $\mathrm{ra}^{\mathrm{C}}$ yat empatpuluh lain dengan anak dan sanak. Penuh sesak didalam bénténg dan bénténg yang lain itu demikian juga adanya. Lagi bedil curi di jalan ada juga di jalan. Demikianlah adanya.

11.2. Syahdan maka tersebutlah perkataan dari Betawi kapal Idelir Ménténg empat kapal, enam kici, lima langbut, tujuhbelas penjajap mudik sekalian perahu itu. Sampai di kuala Opang, maka satu pangéran pergi menilik. Dibedil dengan bedil renta $<\mathrm{ka}\rangle$, maka terkejut orang didalam kapal itu, pangéranpun lari mudik. Maka kapal sekalianpun mudik.

Ada tiga hari tiga malam nampak dari bénténg perahu banyak itu, penuh di laut. Maka periai menteri siap seperti orang hendak menga95 dapkan hidangan nasi akan santap rasanya, ada / antara dua tiga boléh makan. Bedilpun berbunyi selalu tiada berhenti malam siang dan asap sendawa kelam, tiada kelihatan satu apa.

Dua hari perang, dapatlah langbutnya satu dengan rampasan meriam tembaga satu dan obat dan pélor dan buji sekoci. Kepada waktu itu sekalian kapal dan kici dan langbut dan penjajappun undur semua, satu tiada yang tinggal; habis milir hingga sampai di kuala. Idelir Ménténgpun selalu berlayar ${ }^{76}$ ke Betawi, satu kapal perang disuruh Idelir Ménténg jaga di kuala. Waktu itu ada orang dagang dari selat hendak berjual-beli di Palémbang, sampai di kuala Sungsang itu datang sekoci kapal ikut perahu-perahu orang yang hendak masuk kuala. Maka lari sekalian perahu-perahu dagang; ada yang dapat, ada yang lepas, ada yang orang didapatnya selalu digantungnya.

11.3. Ada antara satu tahun setengah datang khabar orang dari kuala Sungsang melihat kapal banyak di laut kuala. Maka disembahkan orang kebawah Duli. Maka titah Yang Mahamuliapun menitahkan paduka adinda Pangéran Panembahan meriksa sampai di kuala Sungsang membawa soldadu sipai. Sampai di kuala, kapal banyakpun masuklah ke kuala Sungsang.

Ada antara........ 

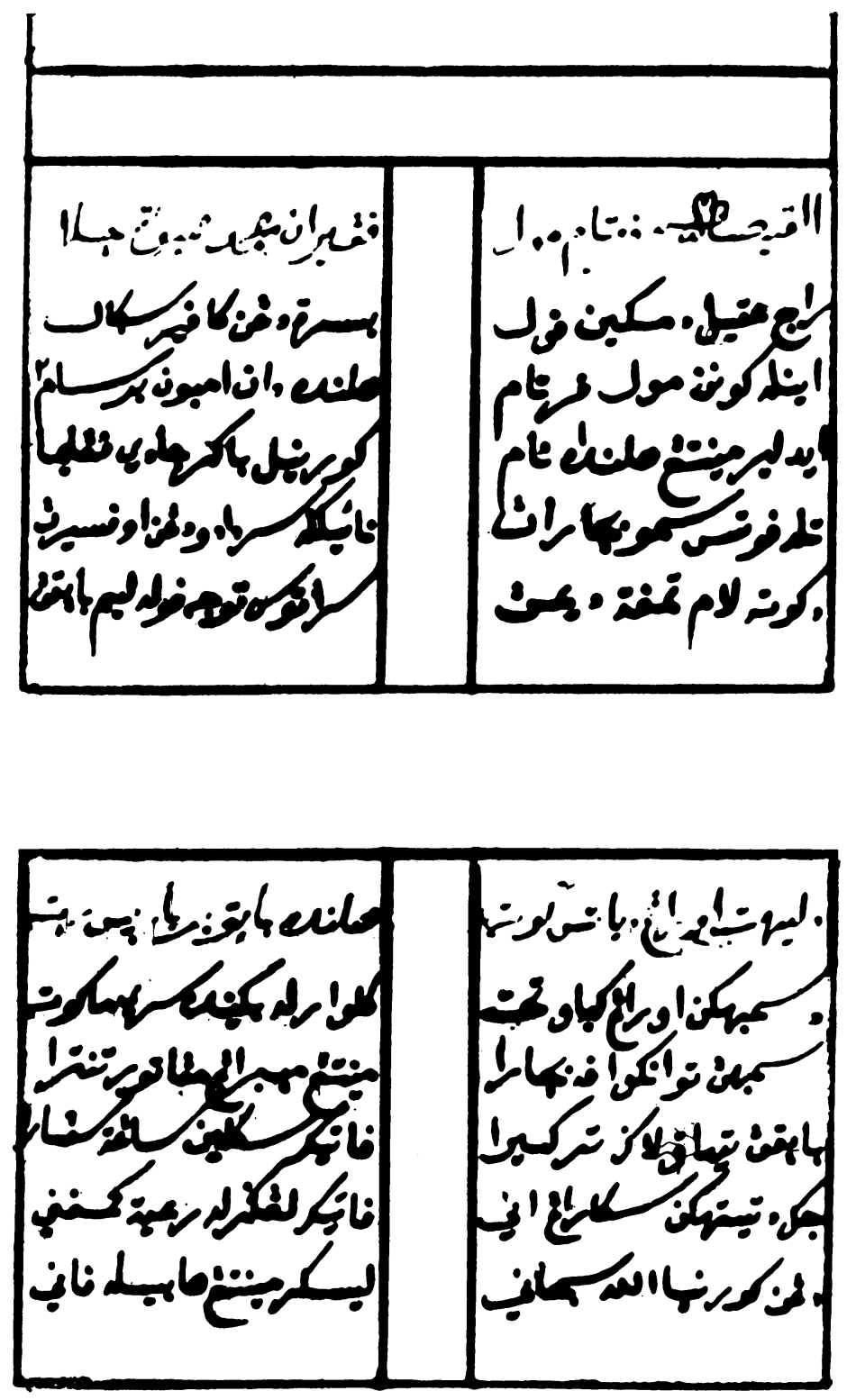

\section{MP 4a, pagina's 2 en 3}

Eerste twee pagina's van de tekst 


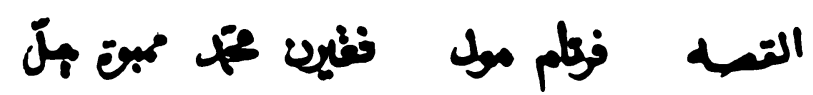

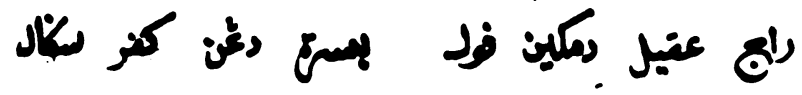

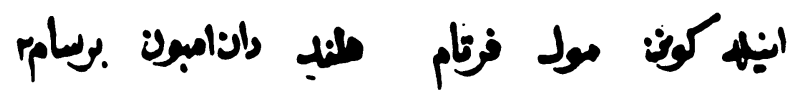

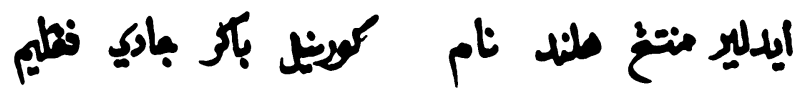

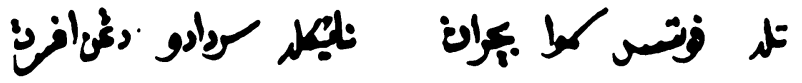

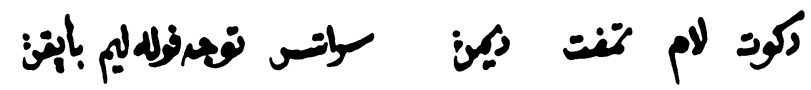

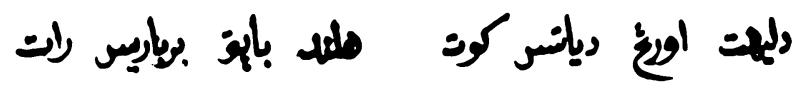

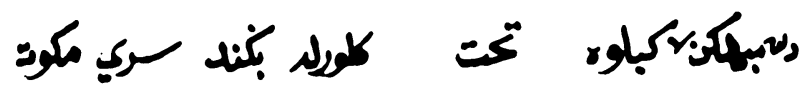

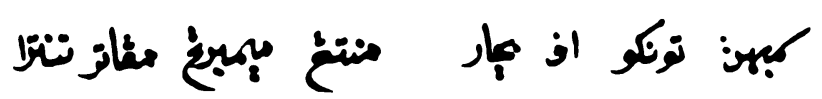

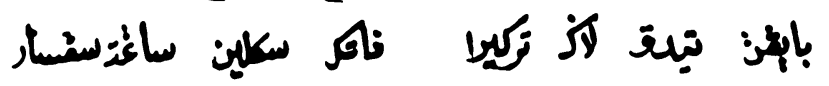

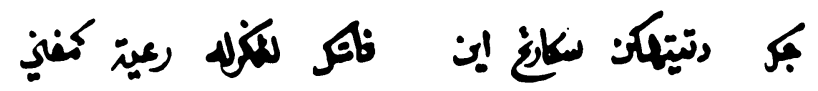

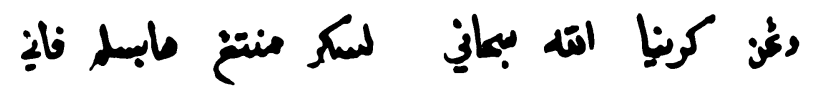

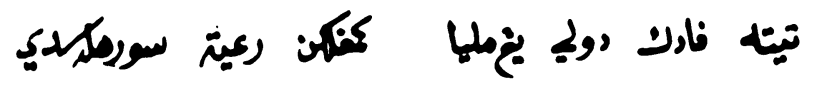

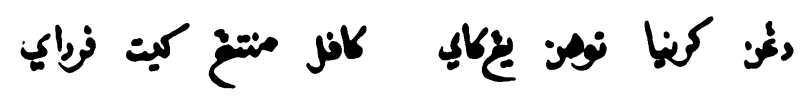

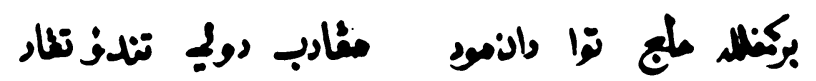

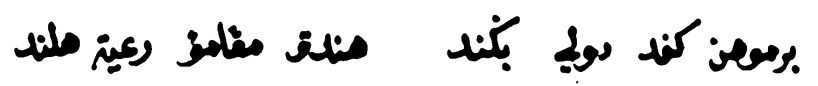

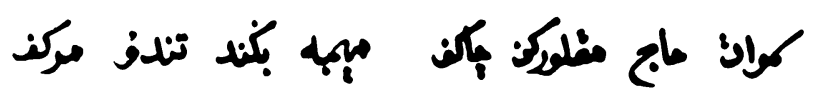

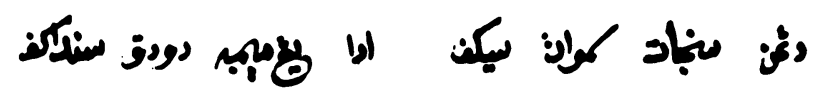

MP $4 b$, eerste pagina 


\section{TEKST MP 4b}

\section{SYACIR PERANG MÉNTÉNG}

\section{Inleiding tot de tekstuitgave}

De Syacir Perang Ménténg is ons overgeleverd in de - ongedateerde handschriften MP 4a en MP 4b. Omdat elke mogelijkheid tot datering ontbreekt en voorts beide versies volledig en vrij van klaarblijkelijk corrupte plaatsen zijn, heb ik niet kunnen vaststellen welke van de twee de oorspronkelijke is of deze - voor het geval geen van beide de oorspronkelijke tekst weergeeft - het dichtst benadert. Voor een poging tot reconstructie van de oorspronkelijke tekst leverden de beschikbare handschriften geen aangrijpingspunt op, zodat besloten moest worden tot publikatie van de tekst volgens het ene handschrift met vermelding van de in het andere gevonden verschillen. Aan publikatie van de tekst van MP 4b heb ik de voorkeur gegeven, omdat dit handschrift het duidelijkst geschreven is en bovendien op enkele plaatsen (strofe 109, regels 117b, 133b-c, 135d, 139a, 178b, 207a +d, 212c) een voor mijn gevoel bevredigender lezing heeft dan MP 4a. De varianten van dit laatste handschrift zijn verantwoord in het kritisch apparaat achter de tekst. Daarin heb ik tevens de gevallen vermeld, dat Atja in zijn tekstuitgave van 1967 of Van der Linden in zijn proefschrift van 1937, pp. 160-171, een afwijkende lezing geeft.

De vier regels van een strofe worden in het kritisch apparaat aangeduid door het volgnummer van de strofe met één van de letters a-d, de woorden van een regel door toevoeging van een volgnummer. Voorbeeld: 128d 3: bertanding. De lezing van Atja en die van Van der Linden worden aangegeven als A respectievelijk $\mathrm{L}$. Voorbeelden: $53 \mathrm{~b} 1$, A: diiringi; 46d 3, L: berasa.

Bij de transcriptie van het Arabisch schrift heb ik terwille van de uniformiteit in de presentatie van de verschillende teksten de ook bij 
de transcriptie van UBL 7 en UBL 9 toegepaste en hiervóór reeds omschreven regels in acht genomen. De spellingsbijzonderheden van MP $4 b$ die in de transcriptie worden verwaarloosd, zijn:

1. Het consequente gebruik van slot- $b$ in plaats van slot- $p$ in mengadab (8b, 108d, 114d, 176b, 246d), atab (95c) en $u k u b$ (178c), waar MP 4a mengadap, atap en ukup spelt.

2. Het gebruik van het Arabische verdubbelingsteken tashdīd, dat in MP 4a niet voorkomt. Het wordt bij de transcriptie verwaarloosd, behalve in Arabische titels en eigennamen.

3. Invoeging van $m$ vóór $b$ in menyemberang ( $5 \mathrm{~b}$ en $59 \mathrm{a}$, terwijl menyeberang voorkomt in 181b), en van $b$ na $m$ in Kombering (93a). MP 4a heeft steeds menyeberang en Komering, maar kent daarentegen weer invoeging van $m$ vóór $p$ in berampilan (219d).

4. Invoeging van $n$ voór $n y$ in (ter) sennyum (118a, 157b, 160a tegenover tersenyum in 51c). MP 4a volgt dezelfde spelling en past deze bovendien toe op mennyusul (223c) en kurnnya (6c, 7c, 99c, 218a).

5. Invoeging van $t$ vóór $j$ in het naamdeel -diraja van de eigennamen Kramadiraja en Puspadiraja, zodat dit -diratja gespeld wordt, zoals ook in de andere Palembangse teksten gebruikelijk is. Bij de eigennaam Satyagati (38c en 173a), waarvan het eerste deel, Satya, in deze tekst Satja wordt gespeld, heb ik de foutieve schrijfwijze van dit Sanskriet-leenwoord verbeterd door niet de $t$, maar de $j$ te elimineren en deze te vervangen door $y$ : Satyagati. Elders komt ook de schrijfwijze Satca voor: de kopiïst van UBL 9, Satyanandita Ahmad, spelt zijn eigen naam zo.

In het voorafgaande zijn vanzelf reeds enige van de spellingsverschillen van MP 4a ten opzichte van de te publiceren tekst volgens MP 4b ter sprake gekomen. $\mathrm{Zij}$ zullen hieronder verder systematisch behandeld worden, evenals de verschillen in woordvorm en woordkeus, voor zover deze een zekere frequentie of stelselmatigheid vertonen. De aldus behandelde verschillen zullen dan niet meer stuk voor stuk in het kritisch apparaat opgenomen behoeven te worden.

De spellingsvarianten van MP 4a ten opzichte van MP 4b kunnen worden gerubriceerd als volgt: 
1. Een meer uitgebreid gebruik van de vocaaltekens alif, wau en $y \vec{a}$ :

\begin{tabular}{ll}
\multicolumn{1}{c}{$M P$ 4a } & \multicolumn{1}{c}{$M P 4 b$} \\
g-a-g-a-k & g-g-k \\
l-é-l-a & l-é-l \\
d-p-a-l-u-k-n & d-p-l-u-k-n \\
d-u-r-j-a & d-r-j \\
k-u-m-p-u-l-k-n & k-m-p-l-k-n \\
t-o-l-o-ng & t-o-l-ng \\
k-a-f-i-r & k-f-r \\
b-é-n-t-(é)-ng & b-n-t-ng \\
s-m-b-i-l & s-m-b-l
\end{tabular}

Sederhana wordt in MP 4a zelfs gespeld s-d-a-r-h-a-n-h, dekat soms d-a-k-t, merendahkan m-r-a-n-d-a-h-k-n.

2. Een zeer frequent gebruik van de $h$ ter afsluiting van de open slotsyllabe bij woorden eindigend op -a: lélah, pulah, terkenah, laksanah, kotah, makotah, bungah, ditubah, gembirah, lancah, tuah, kakandah. Anderzijds ontbreekt de slot- $h$ in gevallen waarin deze doorgaans wel wordt geschreven: kebawa, méra, susanya, suda, wajanya, pecakan, rumanya, disuru, musu, jatu, penu, sunggu, berlabu, berkayu, leti, serpi.

3. Voorkeur voor het gebruik van de hamzah ter aanduiding van de glottisslag aan het eind van een woord, waar MP 4b meestal $k$ heeft: masu', tundu', béso', kapa', nampa', beda'.

4. Spelling van de woorden khabar, khidmat, khatib, khamis, khelembak, khilaf met $h$ in plaats van kh. Héran en héwan worden evenwel - wederom in afwijking van de spelling van MP 4b - als khéran en khéwan geschreven.

5. Spelling zonder $h$ van: andalan (53d), diempaskan (81b), teritung (206c), ayuai (259a), waar MP 4b handalan, dihempaskan, terhitung, ayuhai spelt. De verschillen van deze aard blijven tot deze vier gevallen beperkt.

6. De spelling cilaka, sigera(kan), jéntera, memégang, léskar in alle gevallen waarin MP 4b celaka, segera(kan), jentera, memegang, laskar heeft. 
7. De spelling dingding, menjungjung waar MP $4 \mathrm{~b}$ de gebruikelijke schrijfwijze dinding, menjunjung volgt.

8. De spelling met $s$ in een aantal woorden waarin MP 4b sy schrijft: Sacban, sétan, Séh/Saikh, mustari, samsu, swarga. Daarentegen heeft MP 4a gusyar waar MP 4b gusar spelt (247a).

9. Spelling met $k$ in plaats van met $g$, zoals MP $4 \mathrm{~b}$ doet: kari (passim), dikéndong (43a), kimbul (94a).

10. Voorts vinden we nog de volgende verschillen van uiteenlopende aard: telanjur (79d 2), berteriak (139a 2), alang-kupalang (158c), sorban (193b), menjelis (238d), kerana (260c) tegenover respectievelijk terlanjur, beteriak, alang-kepalang, serban, mejelis, karena bij MP 4b.

11. Tenslotte behoren in dit overzicht thuis de verschillen tussen de beide versies van de syacir die reeds zijn genoemd bij de opsomming van de spellingsbijzonderheden van MP 4b onder de nrs 1-4.

De verschillen in woordvorm en woordkeus van MP 4a ten opzichte van MP 4b laten zich groeperen als volgt:

1. Voorkeur voor werkwoordsvorming door nasalering zonder voorvoeging van me-: ngampiri (22b), neriakkan (37d), ngobati (46a), nuju (68c), mancarlah (71d), ngeras (72d), nyembunyikan (83d), masang (93b, 97b, 152c, 186a), mukul (105c), nyorangkan (110b), ngunang (134b), ngenangkan (189b), mandang (197d, 217c), ngeluari (219d), ngeluarkan (235b), ngarang (260c).

2. Het gebruik van de (versteende) $u m$-vorm c.q. van de genasaleerde vorm in plaats van de grondwoordelijke vorm: mundur(lah) voor undur(lah) in 27d, 39d, 43a, 45a, 101c; milir(lah) voor ilir(lah) in 139b, 216a, 217b, 218b, 251a; nampak(lah) voor tampak(lah) in 171d, 199a, 209a.

3. Afwijkingen ten aanzien van het Maleise nasaleringsprocédé: menyabut voor mencabut $(111 \mathrm{c}, 159 \mathrm{c}, 185 \mathrm{~b})$, mengosok voor menggosok (254c), pengrasaan voor perasaan (95d).

4. Het gebruik van menengar en penengaran waar MP 4b de meer gebruikelijke vormen mendengar en pendengaran gebruikt: 102b, $127 \mathrm{c}, 229 \mathrm{c}, 244 \mathrm{a}$ en $78 \mathrm{~b}$. 
5. Een ruimer gebruik van de suffixen -nya en -lah. Elk van deze suffixen treft men tienmaal aan op een plaats waar het bij MP $4 b$ ontbreekt. Het omgekeerde doet zich - eveneens voor wat elk van deze suffixen betreft - slechts driemaal voor.

6. Een ruimer gebruik van het praefix ber-, dat zesmaal optreedt waar MP $4 \mathrm{~b}$ het enkele grondwoord heeft. Het omgekeerde doet zich op twee plaatsen voor.

7. Het gebruik van een "vollediger" woordvorm of uitdrukking dan in MP 4b: setelah voor telah (123a, 124a), setengah voor tengah (80a), jikalau voor jika (120a), buah anggur voor anggur (43b, $96 \mathrm{~b}, 168 \mathrm{~b})$, kedengan voor dengan (28d, 74c, 90c, 91d, 138b, 248c), mendari voor dari (225c). Kedengan en mendari komen, naar Teeuw heeft geconstateerd, ook in sommige handschriften van de Syacir Kén Tambuhan voor, mendari zijn we ook herhaaldelijk in UBL 7 tegengekomen.

8. Het gebruik van tidak in plaats van tiada (26a, 71c, 85a, 125a, 204a) of in plaats van tiadalah (195c). Daartegenover heeft MP 4a éénmaal tiadakan waar men bij MP 4b tidakan leest (149d).

9. Het gebruik van aan het Javaans ontleende of mede in het Javaans voorkomende woorden waar MP $4 \mathrm{~b}$ het meer gebruikelijke Maleise woord geeft: perkosa voor perkasa (63c, 176a), menyemperong voor meneropong (66a), garuda voor gerda (69b, 89c), mantu voor menantu (73a, 76a), sepangat voor syafacat (75c), pelataran voor pelantaran (100c), kaptén voor kapitan (131a), sangatnya voor sacatnya (145c), silam voor dalam (233c). 


\section{SYACIR PERANG MENTENG}

1 Alkissah pertama mula Pangéran Muhammad membuat cela Raja Akil demikian pula beserta dengan kafir segala

2 Inilah konon mula pertama Holanda dan Ambon bersama-sama Idelir Ménténg Holanda nama Kornél Bakar jadi panglima

3 Telah putus semua bicaranya naiklah serdadu dengan opsirnya di kota lama tempat diamnya seratus tujuhpuluh lima banyaknya

4 Dilihat orang diatas kota Holanda banyak berbaris rata disembahkan orang kebawah takhta keluarlah Baginda Seri Makota

5 Sembahnya Tuanku apa bicara Ménténg menyeberang mengatur tentara banyaknya tidak lagi terkira patik sekalian sangat sengsara

6 Jika dititahkan sekarang ini patik langgarlah $\mathrm{ra}^{\mathrm{c}} \mathrm{yat}$ Kompeni dengan kurnia Allah subhani laskar Ménténg habislah fani

7 Titah Paduka Duli Yang Mulia kumpulkan rac$^{c}$ at suruhlah sedia dengan kurnia Tuhan Yang Kaya kapal Ménténg kita perdaya

8 Berkumpullah haji tua dan muda mengadap Duli tunduk tengadah bermohon kepada Duli Baginda hendak mengamuk $\mathrm{ra}^{\mathrm{c}} \mathrm{yat}$ Holanda 
9 Semuanya haji mengeluarkan cakap menyembah Baginda tunduk merakap dengan senjata semuanya sikap ada yang menyembah duduk sendakap

210 Delapanbelas harinya Sabtu bulan Syacban ketika waktu pukul empat jamnya itu haji berzikir di pemarakan tentu

11 Haji ratib di pengadapan berkampung bagai mengadap ayapan tidaklah ada malu dan sopan ratib berdiri berhadapan

12 La ilaha illa llahu dipalukan ke kiri kepada hati nama sanubari datanglah opsir meriksa berdiri haji berangkat opsirpun lari

13 Diikutlah segala haji yang garang Haji Zain kepalanya sekarang itulah mula jadi berperang di kota lama sampai diserang

14 Haji mengikut berlari-lari didalam baris menyerbukan diri memarangkan pedang kanan dan kiri serdadu Holanda habislah lari

15 Haji berteriak Allahu akbar datang mengamuk tak lagi sabar dengan tolong Tuhan Malik al-Jabbar serdadu Ménténg habislah bubar

16 Keluar sekalian hulubalang panglima menolong haji bersama-sama opsirnya mati empat dan lima hajipun sampai di kota lama

17 Haji mengusir kanan dan kiri memarangkan pedang ke sana ke mari serdadu Holanda habislah lari hanya komandan juga terdiri 
18 Haji berteriak sambil memandang hai kafir marilah tandang syurga bernaung di mata pedang bidadari hadir dengan seléndang

319 Di situlah haji lama terdiri dikerubungi serdadu Holanda pencuri lukanya tidak lagi terperi fanalah haji lupakan diri

20 Datanglah komandan bersungguh hati membedil haji tiada berhenti pelurunya datang menuju pasti di sanalah tempat haji nan mati

21 Syahidlah haji dua dan tiga akan pengisi didalam syurga bidadaripun banyak tiada berhingga datang menyambut haji berida

22 Darahnya mengalir bagai kesturi bidadaripun banyak datang mengampiri suka dan ramai tepuk dan tari merebut mayat haji jauhari

23 Datanglah Pangéran Prabukesuma durja laksana bulan purnama sikapnya bagai Maharaja Boma bilakan dapat bandingnya sama

24 Pangéran Prabu datang membantu pelurunya emas sepuluh mutu petunang élok sahaja tertentu kenalah Perancis matilah satu

25 Bersoraklah racyat sekalian rata terlalu ramai gegak gempita pahlawan seperti gajah yang meta membedil Perancis dariatas kota

26 Pangéran membedil tiada terkira bahananya sampai keatas udara racyat kornél sangat sengsara rupanya bagai lutung dan kera 
27 Adapun putera Duli Baginda dikerubungi racyat Perancis Holanda ia bertahan berbénténg dada satu tapak undur tiada

428 Holanda Perancis menjadi satu Ambon dan Jawa datang membantu Raja Akil pula suatu dengan Ménténg ia sekutu

29 Seri pangéran putera yang tua kepada perang tidak kecéwa membakar léla sambil tertawa opsir Ménténg matilah dua

30 Pangéran naik di buluwarti membedilkan senapang tiada berhenti sikapnya bagai Ratu Masapati Holanda Perancis banyaklah mati

31 Holanda semua banyaklah lari diusir hulubalang ke sana ke mari Raja Akil Siak pencuri didalam rakit melindungkan diri

32 Itulah raja yang sangat hina di tanah Melayu tidak berguna di tanah Belitung membuat pesona masuk Kompeni pergi ngelana

33 Masuk Kompeni kafir harabi anggur dimakannya dengan surabi patutlah rupanya bagai labi-labi hampirlah akan memakan babi

34 Senantiasa membuat durhaka patutlah jadi isi naraka jalan Islam tiada suka itulah orang yang kena murka

35 Tersebutlah orang perang di darat ada yang menikam ada yang mengerat soraknya bagai gelombang barat racyat Baginda habislah larat 
36 Larilah racyat orang negeri diusir baris ke sana ke mari tiada ketahuan sembilu dan duri tiada lagi ingatkan diri

$5 \quad 37$ Datanglah pula opsir seorang di luan serdadu terlalu garang pintu loténg lalu diparang suaranya besar meneriakkan orang

38 Loténg dikapak bersungguh hati dipukulnya tiada lagi berhenti datanglah Rangga Satyagati ditombaknya terus tukang tambur mati

39 Keluarlah menteri Duli Baginda berhadapan dengan racyat Holanda ada yang menikam ada yang menggada satu tapak undur tiada

40 Orang membedil dari buluwarti pelurunya datang tiada berhenti kenalah kepala dan hulu hati racyat Holanda banyaklah mati

41 Kemas Said keluar menyerbu amat gembira didalam kalbu mati sepuluh baris seribu dekat pintu kota Kemas nan rubuh

42 Datanglah satu opsir mendekati membedil Kemas tiada berhenti pelurunya datang menuju hati di sanalah tempat Kemas nan mati

43 Undurlah baris senapang digéndong kena anggur sabung-menyabung hari yang terang menjadi rundung baris tiada tempat berlindung

44 Dibedil orang di buluwarti meriam dan léla berganti-ganti baris Ménténg banyaklah mati tengah hari perang berhenti 
45 Baris undur tersebut pula menyuruh kembali $\mathrm{ra}^{\mathrm{c}} \mathrm{yat}$ segala pulang ke kapal senapang dihéla ada yang luka pecah kepala

646 Datanglah dokter pula mengobati darahnya mengalir tiada berhenti Ménténg melihat susahlah hati malunya sudah serasa mati

47 Ménténg berkata terlalu gopoh hendak disuruh minta témpoh tiga hari lagi rac $^{c}$ yat menempuh serdadu banyak luka dan lumpuh

48 Dibenarkan oléh segala panglima perkataan Ménténg raja utama menyuruh Pangéran Nataagama disuruh lekas janganlah lama

49 Pangéran pergi bersungguh hati berkayuh tidak lagi berhenti menuju Paduka Pangéran Bupati telah berdapat berkatalah pasti

50 Katanya disuruh Ménténg menggari mengadap kakanda Makota Negeri minta témpoh barang tiga hari pangéran jangan takut dan ngeri

51 Pangéran bertitah seraya memalis menjawab pantas ditengah majelis tersenyum sedikit mengangkat alis masakan takut kepada iblis

52 Boléh disampaikan maksud Holanda minta témpoh kepada kakanda entah diterimanya atau tiada nantilah di sini dahulu mamanda

53 Berangkatlah pangéran lalu berjalan diiringkan rac ${ }^{C}$ at beberapa tolan beserta sikapnya yang kebetulan kiri dan kanan $\mathrm{ra}^{c} \mathrm{yat}$ handalan 
54 Telah sampai kedalam puri berdapatlah Baginda di balai seri khidmat menyembah sepuluh jari Ménténg bertangguh tiga hari

755 Telah didengar Seri Paduka mérah padam warnanya muka lalu bertitah dengan seketika berilah témpoh kafir celaka

56 Berilah témpoh barang sehari supaya kita berkemas diri janganlah racyat ke sana ke mari kita bersiap didalam puri

57 Titah Baginda Duli Syéh Alam kepada menteri wazir al-alam pagi-pagi hari waktu yang kelam bedil kapalnya supaya tenggelam

58 Berangkat pangéran raja utama mendapatkan Pangéran Nataagama pinta Ménténg kakanda terima pulanglah mamanda janganlah lama

59 Pulanglah pangéran lalu menyeberang waktu ketika cuaca yang terang berdapatlah Ménténg Holanda yang garang sukanya bukan sebarang-barang

60 Pangéran berkata memegang jari menyampaikan titah Paduka Seri diberinya témpoh tiga hari baiklah tuan berkemas diri

61 Jawab Ménténg yang kedengaran terima kasih tuan pangéran bésok saya punya pikiran nanti dibalas dengan aturan

62 Kepada opsir Ménténg berkata menyuruh membaiki segala senjata kapal dan kici perintah rata kita rubuhkan pintu kota 
63 Kepada selikur hari Selasa pukul tujuh ketika masa Baginda membedil sangat perkasa kapal Ménténg rusak binasa

864 Ménténg terkejut tercakar-cakar bunyi bedil bagai berbongkar datanglah gembira Kornél Bakar memasang bedil bunyi bertagar

65 Kapal membedil asapnya kelam padang yang terang seperti malam datang bersampan Sényur Bilam mengatakan orang banyak di dalam

66 Ménténg meneropong sambil berjalan menuju kota dengan kebetulan dilihatnya loténg seperti bulan didalam hatinya sangat kemasgulan

67 Sebabnya terang diatas kota melihat Haji Bustam berdiri nyata hancur luluh rasa anggota mengempaskan cepiau tiada berkata

68 Semuanya kapal membedil rata bahana gemuruh gegak gempita pelurunya menuju keatas kota kena meriam patah dan leta

69 Dibalas Pangéran Kramayuda sikapnya bagai burung gerda memegang pedang Seri nan Baginda hendak memotong kepala Holanda

70 Dibantu Demang Wiratenaya sikapnya laksana Maharaja Salya durjanya bagai cempaka mulia kepadanya banyak tipu dan daya

71 Opsir melihat terlalu marah muka jang pucat menjadi mérah ia membedil tiada mengarah barang yang kena memancarlah darah 
72 Opsir membedil memerintah tentara pelurunya deras tiada terkira banyaklah racyat hadir dan mara barang yang kena sangat sengsara

973 Adalah menantu Paduka Seri Kramadiraja pangéran jauhari diatas kota ia berdiri melihat laku Holanda negeri

74 Ménténg Holanda memakan ubi lupalah kepada agama $\mathrm{Nabi}$ minum arak dengan babi patutlah rupanya bagai labi-labi

75 Pangéran membaca doca selamat dengan berkat segala keramat syafacat Nabi Sayyid al-ka'inat racyat Ménténg hancur dan lumat

76 Keduanya menantu raja bangsawan Kramajaya pangéran pahlawan beserta hulubalang amat setiawan dengan komandan ia berlawan

77 Komandan menémbak tiada berhenti membedil pangéran di buluwarti dibalas pangéran diamat-amati kenalah komandan lalulah mati

78 Bersoraklah $\mathrm{ra}^{\mathrm{c}} \mathrm{yat}$ paduka pangéran diatas kota gegak pendengaran Holanda melihat terlalu héran alamat perang Ménténg kelaran

79 Setelah dilihat penghulu perang racyat Holanda habislah terang susahnya bukan sebarang-barang sudah terlanjur juga sekarang

80 Tengah demikian Kornél Bakar datanglah rakit api dibakar hendak undur terlalu sukar kapal semua menetas jangkar 
81 Kornél Perancis demikian pula cepiau dihempaskan dariatas kepala Raja Akil seperti gila padudan candunya jadi berhala

1082 Raja Mansur sangatlah béda di tanah Melayu mengada-ngada cakapnya hendak melawan Baginda sekarang jadi pacal Holanda

83 Tersebutlah perkataan Holanda yang gari di Sungai Aur terlari-lari lakunya bagai jin dan peri dibalik dinding menyembunyikan diri

84 Dibedil hulubalang sekalian rata dengan léla diatas kota soraknya gemuruh gegak gempita pelurunya deras tidak terkata

85 Pelurunya sampai tiada ketahuan baris lari berkawan-kawan lakunya bagai binatang héwan patutlah bunuhan pinakawan

86 Temenggung haji datang berlari lakunya bagai Déwa Sahperi Holanda yang tinggal disuruhnya gari dibedil habis mati dan lari

87 Tersebutlah pula perkataan Idelir diatas méja semuanya kalér komandan sekalian air liur melélér diatas kursi gulu terpalér

88 Berkatalah pula Kornél Bakar perang kita terlalu sukar Sultan Ratu sangat pendékar akhirnya kita jadi belukar

89 Dijawab Ménténg penghulu Holanda perang kita sangatlah béda orang Palémbang seperti gerda katanya di sini rupanya tiada 
90 Berkatalah seorang opsir yang garang ésok hari kita menyerang bawalah kapak dengan parang pintu loténg pecahkan sekarang

1191 Pukul enam paginya hari hari Ahad sacat musytari peranglah Baginda Raja bestari dengan Holanda didalam negeri

92 Lima buah payung terkembang dibawahnya anak raja Palémbang racyatnja bagai déwa dan mambang semuanya memandang hatinya bimbang

93 Beraninya sangat orang Komering memasang meriam sambil baring bunyinya besar peluru berdering kapal Ménténg hampir termiring

94 Kenalah gembol terus kesebelah kustabal melihat kapalnya belah perangnya ini bukannya olah jika demikian niscaya kalah

95 Dibalas gurnat terlalu amat itulah bicara Pangéran Muhammad atap loténg hancur dan lumat perasaan tidak lagi selamat

96 Dibalas meriam di buluwarti dengan anggur dibalaskan pasti bunyi bahananya bukan seperti racyat Holanda beberapa yang mati

97 Dibalas kapal Kornél Bakar memasang meriam bunyi bertagar pelurunya menuju tempat yang sukar Sayyid Zain téwas obat terbakar

98 Bersoraklah Holanda racyat Ménténg dengan bersilat melanting-lanting dipasangnya meriam menuju loténg habis pecah batu dan genting 
99 Dibalas Temenggung Astrawijaya mulut meriam keluarlah cahaya dengan kurnia Tuhan Yang Kaya racyat Ménténg tiada bergaya

12100 Saktinya temenggung ilmu terkandung hari yang panas menjadi rundung diatas pelantaran duduk bertenung baris tiada tempat berlindung

101 Temenggung membaca isim al-wara kapal Ménténg seperti jentera banyak undur sedikit mara kelasi kapal sangat sengsara

102 Kornél menémbak tiada berhenti mana yang kena habislah mati bangkit gembira Pangéran Bupati melawan kornél bersungguh hati

103 Beberapa banyak serdadu mati dibedil pangéran di buluwarti Citrawijaya hulubalang yang sakti baris Ménténg banyaklah mati

104 Baris membedil sambil berlari didalam bilik melindungkan diri lakunya bagai jin dan peri didalam jamban setengah berdiri

105 Seri Paduka suka terlalu memandang baris perang bertalu memukul gendang canang dipalu alamat Ménténg beroléh malu

106 Pangéran membedil beberapa kali perintah daripada bawah Duli dipalu orang gendang kembali serdadu lari berbuta-tuli

107 Dibedil orang di buluwarti gemuruh tidak lagi berhenti Holanda Perancis banyaklah mati haripun sudah petanglah pasti 
108 Malam berhenti daripada perang berkumpul pula semuanya orang sekalian $\mathrm{ra}^{\mathrm{c}}$ yat hulubalang yang garang mengadap Baginda durja yang terang

13109 Baginda melungguh sambil berkata kepada menteri semua yang pokta apalah bicara sekalian kita perang Holanda terlalu meta

110 Sultan bertitah tiada sopan serta menyorongkan ni $^{\text {c }}$ mat santapan makan dan minum dengan kelengkapan suka dan ramai racyat berhadapan

111 Bercakaplah Khatib Muhammad Saléh menjunjung Duli peluh meléléh mencabut pedang sambil menoléh Kornél Bakar yang dipilih

112 Bercakap Pangéran Puspawijaya wajahnya laksana bunga raya menjunjung Duli Raja Yang Mulia Pangéran Muhammad patik perdaya

113 Bercakap Pangéran Wirasentika kepada perang rupanya suka menjunjung Duli Seri Paduka hendak mengamuk kafir celaka

114 Bercakap Pangéran Wiradiwangsa sikapnya élok lagi perkasa sukar bandingnya ketika masa patutlah mengadap raja berbangsa

115 Bercakap Pangéran Puspadiraja martabatnya hampir kepada raja lakunya élok sebarang kerja manis kepada menentang durja

116 Haji Abdulrahim bertepuk jari mengangkat tangan sepuluh jari janganlah Tuanku takut dan ngeri Ménténg tu hendak patik tampari 
117 Haji $\mathrm{Mas}^{\complement}$ ud cakap dikeluarkan menjunjung Duli dibawah telapakan jika patik Tuanku titahkan telinga mayur patik pulaskan

14118 Manis tersenyum Seri Paduka berseri-seri warnanya muka musuh kita kafir celaka janganlah kamu membuat jenaka

119 Jikalau perang sabil di darat sekalian dosa habis $\mathrm{ma}^{\mathrm{c}}$ irat hati di dalam sangat gairat hanya hak al-Adam masih tersirat

120 Jika perang sabil di laut tidaklah lagi sangkut dan paut roh diambil malak al-maut lantas ke syurga bidadari maut

121 Inilah pahala orang sabil Allah segala dosa diampuni Allah tidak berpayah tidak berlelah ma' al-kausar dirasailah

122 Dari hal isteri hidup yang gari jika ibadat merendahkan diri jadilah penghulu bidadari didalam syurga ke sana ke mari

123 Telah sudah hari nan terang keluarlah semua hulubalang yang garang ada menémbak ada memarang Holanda Ambon habislah terang

124 Telah dilihat oléh penghulunya Holanda dan Ambon banyak matinya terlalu sangat rupa marahnya bagai harimau jantan lakunya

125 Kapal menémbak tiada berhenti keduanya kapal berganti-ganti kapal mudik datang mendekati tidaklah lagi takutkan mati 
126 Bangkitlah Rangga Darpacita menjunjung Duli Seri Makota sikapnya hébat tidak terkata membakar meriam diatas kota

15127 Meriam dipasang dengan sebentar gemuruh bunyinya bagai halontar semua yang mendengar hatinya gentar ada yang bersorak silat berkitar

128 Kenalah bebawan kapalnya perang terlalu banyak matinya orang Holanda dan Ambon habislah terang bersoraklah racyat berbanding garang

129 Dibalas oléh mayur yang tua itulah opsir Ambon dan Jawa pelurunya menuju dibawah sawa hulubalang Baginda syahidlah dua

130 Dibedil Temenggung Citradita dengan meriam dariatas kota sikapnya laksana maharaja buta rakit Cina habislah rata

131 Dibedil oléh Kapitan Jungkur bunyi meriam bagai diukur $\mathrm{ra}^{c}$ yat Baginda syahid tersungkur berlindung di kota duduk terpekur

132 Dibalas Pangéran Citrawijaya bangsanya asal raja yang mulia tombak dan pedang semuanya sedia suatu tidak mara dan bahaya

133 Pelurunya datang berebut-rebut asap lotangnya kelam dan kabut bahana gemuruh seperti ribut banyaklah mati nyawa tercabut

134 Pangéran membedil dengan petunang rambutnya ikal patah mengunang harumnya laksana bunga pinang gemuruh bunyinya gung dan canang 
135 Ménténg melihat terlalu marah muka yang pucat menjadi mérah semuanya racyat disuruh kerah rakit api datangnya méwah

16136 Beberapa rakit sudah dibakar diisinya penuh kayu dan akar menuju kapal Kornél Bakar bersoraklah $\mathrm{ra}^{\mathrm{c}} \mathrm{yat}$ silat pendékar

137 Datanglah api bernyala-nyala besarnya bagai Bukit Serila marahnya Ménténg seperti gila sekalian opsir menggerakkan kepala

138 Kapalnya undur lancapun datang menahan rakit dengan satang ada yang malang ada yang melintang rakitpun hanyut seperti batang

139 Ménténg beteriak bunyi bekembur kapalnya hilir memukul tambur dibedil orang simbur-menyimbur kapal Ménténg hancur dan lebur

140 Ménténgpun marah bukan kepalang membakar meriam berulang-ulang menyuruh jaga sekalian hulubalang seperti anjing menggigit tulang

141 Ménténgpun marah tiada tertahan mupakat jénderal perlahan-lahan jénderal laut punya perintahan kepada Suhunan baik suruhan

142 Surat dibawa lalu disembahkan kepada Suhunan minta terimakan bunyi surat tidak diperkenankan hendak damai tiada disukakan

143 Perdamaian zaman Paduka Nénda bersahabat dengan Raja Holanda utus-mengutus tiadalah béda mengantar bingkisan barang yang ada 
144 Dibalas surat tidak berlelah kita dibawah perintah Allah jika dengan dirélai Allah pergi ke Mentok kita suruhkanlah

17145 Jénderal laut terlalu marah hari Khamis bulan Asyurah pukul satu sacatnya zohrah kapal dan kici mengalih arah

146 Orang bénténg semua hadirlah pangéran dan menteri akan sabil Allah kapal mendekat lalu dibedillah kici dan kapal habis serpihlah

147 Pelurunya sampai ketengah médan Kramadiraja usulnya yang dandan Holanda seperti mabuk dan édan hancur luluh semuanya badan

148 Di Tambakbaya perang besarlah tiada undur tiada kalah orang bénténg hendak sabil Allah menantikan tolong kodrat Allah

149 Bénténg itu sangatlah teguh pangéran dan menteri di sana melungguh jénderal membedillah bersungguh-sungguh disangkanya rubuh tidakan teguh

150 Puspadiraja pangéran yang tua kepada perang tidak kecéwa tiada menaruh nafsu dan hawa diatas bénténg suka tertawa

151 Pangéran membedil tidak terkira bahana gemuruh atas udara yang berani sangat ketara yang penakut sangat sengsara

152 Ramainya perang bukan kepalang gemuruhlah sorak sekalian hulubalang memasang meriam berulang-ulang racyat jénderal banyaklah hilang 
153 Bangkai kerambangan seperti raba hanyut seperti ikan dituba darah seperti air kesumba beberapa luka teraba-raba

18154 Air laut berlinang-linang mérah laksana air jernang di manakan jénderal hatinya senang racyatnya mati banyak dikenang

155 Beribu mati serdadu menjelis seperti perang Jénderal Ruplis beberapa rugi diitung jurutulis bagai dilontar syaitan iblis

156 Jénderal membedil sahajakan pasti tiada lagi ia berhenti menyuruh opsir datang mendekati Ménténg melihat susahlah hati

157 Bangkitlah Pangéran Puspakrama tersenyum manis sajak panglima saputangan angkinnya bunga delima di bénténg tidak bandingnya sama

158 Berbaju hijau emas cemerlang berkancing dada intan berselang éloknya bukan alang-kepalang disinar syamsu gilang-gemilang

159 Semua azimat sudah terkena lakunya bagai Sang Rajuna mencabut pedang hulu kencana gurnat datang tidak mengena

160 Pangéran bangkit sambil tersenyum manis seperti serbat diminum laksana delima masaknya ranum diatas bénténg Pangéran Anum

161 Jénderal melihat terlalu marah mukanya seperti keluar darah ia membedil tidak mengarah semuanya racyat disuruhnya kerah 
162 Kapal membedil sambil berlayar disangkanya bénténg habislah buyar tolongan Tuhan Malik al-Jabbar racyat Ménténg habislah bubar

19163 Kapal membedil tidak terkira haluan menuju Pulau Kembara kapal dan kici semuanya mara orang di bénténg sangat gembira

164 Bangkit Pangéran Sutadiwangsa lakunya bagai orang angkasa ia membedil senantiasa $\mathrm{ra}^{c}$ yat jénderal rusak binasa

165 Pangéran membedil bagai bayangan dengan kornél berpandangan jénderal melihat bimbang-bimbangan laksana Indera dari kayangan

166 Sumawijaya pangéran yang muda ia membedil dekat kakanda memasang tunggul tulis perada pusaka zaman Paduka Nénda

167 Tunggul dipasang cahayanya permai sekalian orang héran termamai dilihat Holanda disangkanya damai lancapun datang bedilpun ramai

168 Lancapun sudah segera dilayari kena anggur tidak terperi nyimpang di teluk melindungkan diri lanca penjajab semuanya lari

169 Pangéran membedil sangat pendékar bahananya bagai dunia terbongkar susahlah hati Kornél Bakar banyaklah mati serdadu laskar

170 Jénderal melihat sangat marahnya serta menyuruh semua racyatnya serta dengan sekalian laskarnya Pulau Kembara hendak dibongkarnya 
171 Dibedil Rangga Darpacita lakunya bagai Maharaja Denta bahana gemuruh gegak gempita kapal Ménténg tampaklah rata

20172 Dibedil Temenggung Astrawijaya itulah wazir yang amat mulia wajahnya persih lagi bercahaya seperti bunga cempaka mulia

173 Datanglah Rangga Satyagati janggutnya bagai bunga melati dengan tolong Rabb al-izzati lepaslah bahaya luka dan mati

174 Kapal membedil berperai-perai memasang meriam kanan dan kiri lakunya bagai jin dan peri semuanya yang memandang takut dan ngeri

175 Dibalas Pangéran Suradilaga lakunya bagai ular dan naga pelurunya menyusup tempat yang lega kenalah kapal lapis tembaga

176 Pangéran membedil sangkat perkasa mengadap lawan beribu laksa dengan tolong Tuhan Yang Esa racyat Ménténg rusak binasa

177 Kapal membedil bersama-sama lakunya bagai hulubalang panglinia dibalas Pangéran Sutakesuma hulubalang jénderal matilah lima

178 Pangéran itu hulubalang yang bijak tubuhnya sedang sederhana pandak jika memakai ukup dan bedak baunya harum seperti khelembak

179 Jénderal membedil sahaja tertentu haluan menuju Pulau Batu orang di bénténg semuanya mutu hulubalang pangéran matilah satu 
180 Wirasentika pangéran bernama putera Pangéran Wirakesuma sikapnya bagai Maharaja Boma bertahan di Pulau Manguntama

21181 Di situ pula ramai berperang pelurunya sampai seberang-menyeberang ditahan panglima hulubalang yang garang racyat jénderal habislah terang

182 Kapal membedil tiada berhenti menuju bénténg Pangéran Bupati dibalas pangéran diamat-amati kenalah komandan lalulah mati

183 Dibedil mendari Martapura pelurunya bagai hujan bara racyat Holanda sangat sengsara muka Ménténg seperti kera

184 Jénderal kafir yang la`nat meriam diisi peluru gurnat disangkanya bénténg hancur dan lumat pelurunya jatuh tidak selamat

185 Pangéran Bupati sangat berani mencabut pedang besi khersani dari sekadar Holanda nasrani tambahan lagi $\mathrm{ra}^{c}$ yat Kompeni

186 Semuanya bénténg memasang meriam terang cuaca menjadi kelam air pasang sangatlah dalam kapal jénderal hampir tenggelam

187 Dibedil Demang Darpayuda sikapnya bagai Déwa Narada ia bertahan berbénténg dada hendak mengerat léhér Holanda

188 Datanglah Pangéran Natadiwangsa lakunya bagai orang angkasa maksud hendak membuat jasa hati di dalam belum sentosa 
189 Susah rasanya bukan kepalang mengenangkan isterinya yang baharu hilang rasanya hendak bertindih tulang sukanya bukan lagi kepalang

22190 Temenggung haji berdiri terpekur menantikan tolong Aziz al-Gafur membaca isim hatinya hudur supaya jangan iman tercebur

191 Dikabulkan oléh Rabb al-akwan berkat Syaikh Kutub al-sulwan menolong muridnya mendapat lawan jénderal hampir terkena tawan

192 Lalu dibedil Sayyid Abdulrahman jénderal menjadi tidak siuman dengan tolong Tuhan Malik al-Rahman muka Ménténg bagai siluman

193 Tuan membedil tidak tertamban cemerlang warna ikatan serban daripada sangat garib-gariban laksana budak dahagakan laban

194 Tuan membedil terlalu suka mérah padam warnanya muka tidak ingatkan adik dan kaka menuju kepada Ménténg celaka

195 Sayyid Husin panglima dalam senantiasa memasang meriam ia membedil tiadalah diam beberapa Holanda mati tersembam

196 Tuan membedil ke sana ke mari lakunya bagai orang menari semua yang memandang takut dan ngeri sukar duanya didalam negeri

197 Sayyid Akil bin Muhammad ia membedil terlalu hémat saputangan di kepala memakai azimat semua yang memandang takutnya amat 
198 Sayyid Ahmad bin Ali datang membantu lakunya élok sahaja tertentu hatinya keras seperti batu amal yang dawam yang lima waktu

23199 Tuan membedil tampak kelihatan sikapnya bagai harimau jantan memasang bedil meriam Seri nan Sultan menuju kapal Holanda syaitan

200 Orang membedil bersungguh hati dengan meriam tiada berhenti racyat Kompeni banyaklah mati jénderal melihat susahlah hati

201 Kapal dan kici semuanya undur peluru nan deras tiada kendur $\mathrm{ra}^{c}$ yat jénderal hancur dan lebur kapalpun lari di Sungai Kundur

202 Di sanalah kapal lama berhenti air surut pasang dinanti orang membedil bersungguh hati hari tu hampir malamlah pasti

203 Setelah siang sudahlah hari bangkit hulubalang raja bestari ia membedil ke sana ke mari kapal jénderal habislah lari

204 Hulubalang membedil tiada berhenti meriam dan léla berganti-ganti tolongan Tuhan Rabb al-izzati panglima Siak kenalah mati

205 Undurlah musuh bersama-sama kicinya dua kapalnya lima diusir sekalian hulubalang panglima larilah kapal di Salahnama

206 Cina lari tak dapat untung topékong tidak tempat bergantung Holanda lari tidak terhitung ada yang luka ada yang kutung 
207 Larilah pukat tiada terhingga beserta pula lapar dan dahaga haluan menuju negeri Lingga ditipu Ménténg orang Holanda

24208 Janji Ménténg hendak digajinya sampai ke Palémbang terima semuanya sepuluh rupiah seorang diberinya datang di Palémbang perang disuruhnya

209 Raja Akil tampak kelihatan lakunya bagai hantu di hutan susahnya hati bukan buatan menurutkan hawa diharu syaitan

210 Bersoraklah racyat sekalian rata diatas bénténg gegak gempita pahlawan seperti gajah yang meta hendak mengusir kafir yang dusta

211 Keluarlah pangéran menteri bangsawan hendak mengusir jénderal pahlawan Ménténg itu hendak dilawan Pangéran Dipati disuruh melawan

212 Ajaib sungguh didalam hati orang Siak punya pekerti Raja Akil arif mengerti mengikut Ménténg suka sama mati

213 Membuang diri kedalam naraka kepada Islam tiada suka meninggalkan sekalian adik dan kaka mengikutkan Ménténg membuat celaka

214 Iman terbang didalam dadanya mengikut iblis jadi tentaranya perintah syaricat dibuangkannya didalam naraka tempat diamnya

215 Suhunan bertitah kepada Sultan meriam bawalah kedalam hutan Ménténg itu seperti syaitan orang bersembunyi jangan kelihatan 
216 Semua racyat disuruh hilirlah pergi ke bénténg suruh hadirlah pangéran menteri yang biasalah kapal dekat suruh bedillah

25217 Telah demikian canang dipalu Pangéran Bupati hilir dahulu semuanya memandang hatinya pilu laksana merak mengibarkan bulu

218 Dengan kurnia Tuhan Yang Esa racyat hilir beribu laksa soraknya sampai atas angkasa alamat Ménténg akan binasa

219 Adalah antara duapuluh hari kapalnya berlabuh di kuala negeri gaduhlah racyat ke sana ke mari pencalang berapilan yang mengeluari

220 Puspadilaga pangéran panglima di Kadipan tidak bandingnya sama periai menteri bersama-sama lakunya bagai Déwa Brama

221 Orang Sungsang masuk ke negeri membawa semua anak dan isteri kepada Suhunan menyerahkan diri hendak melawan Ménténg seturi

222 Semua rumahnya habis terbakar dusunnya habis jadi belukar setelah dilihat Kornél Bakar disangkanya hendak melawan bertukar

223 Semuanya kapal berlayar kain lakunya bagai orang bermain haluan menuju menyusul angin semua yang memandang terlalu ingin

224 Di Pulau Bayak kapal berhenti orang di hutan sudah menanti dibedil orang sahajakan pasti serdadu Holanda banyaklah mati 
225 Semuanya kapal habis larat di Selat Jaran membuang pendarat dibedil orang dari darat bunyinya bagai gelombang barat

26226 Ménténg tidak kuat kuasa lakunya bagai buta rasaksa menyuruh orang nama Si Gangsa membawa surat diberi kuasa

227 Pergilah Si Gangsa orang berempat ia berkayuh terlalu cepat di Pulau Borang ia berdapat Puspadiraja pangéran jang limpat

228 Di situ dapat khabar dan nama mengatakan Pangéran Wirakrama didalam kicinya bersama-sama masagus satu kawannya lima

229 Disembahkan kepada raja budiman bunyi suratnya minta aman Suhunan mendengar tiadalah nyaman Ménténg menjalankan tipu siluman

230 Dibalas surat bunyi baiklah apa juga dengan perintah Allah jika hendak damai kapal keluarlah jika tak mau baik langgarlah

231 Seri Paduka bertitah serta menyuruh membaiki alat senjata bénténg dan parit sekalian rata istiméwa pula loténg dan kota

232 Buluwarti minta kerjakan batang-batang minta segerakan cerucup di laut segera betulkan rakit api baik lekaskan

233 Telah demikian titah Syah Alam bekerjalah orang siang dan malam bénténg dan parit sangatlah dalam tempat menahan kafir jang kelam 
234 Pangéran Bupati jadi penghulu berkeliling negeri canang dipalu dengan berteriak bertalu-talu kamu bekerja janganlah malu

27235 Pangéran bertitah sahaja tertentu sekalian rumah mengeluarkan batu dibawa ke pulau dibuangkan di situ itulah perintah Duli Sang Ratu

236 Adalah bénténg Pangéran Bupati Martapura namanya pasti jika dipandang diamat-amati patutlah buatan raja yang sakti

237 Bénténg Pangéran Dipati Muda dekat bénténg paduka kakanda lengkap alat sekalian ada akan menahan kafir Holanda

238 Di Tambakbaya tempat dikerja bénténg Pangéran Kramadiraja beriringan Pangéran Puspadiraja sikap mejelis dipandang durja

239 Di Pulau Kembara tempatnya jaga bénténg Pangéran Kramadilaga siang dan malam nafsunya dahaga hendak berperang pikirnya juga

240 Orang bekerja mulia dan hina di selat pulau bénténgnya Cina papan dan kayu semua terkena buatan Demang Jayateruna

241 Alkissah suatu cerita orang Sungsang memberi warta Ménténgpun sedia sekalian rata hendak menyerang Duli Makota

242 Kepada Suhunan disembahkan orang Ménténg datang angkatan perang kapalnya berlabuh di Malang Semirang racyatnya banyak bukan sebarang 
243 Kapalnya enam kicinya dua serdadunya banyak Ambon dan Jawa Bugis dan Bali Butun Sumbawa didalam kapal suka tertawa

28244 Suhunan mendengar khabar yang pasti bertitah kepada Pangéran Bupati Ménténg itu adinda lihati jika hendak perang kita menanti

245 Canang dipalu berkeliling negeri sekalian racyat disuruh ke mari kita sekalian berkemas diri kita melawan janganlah lari

246 Berkumpullah rac yat mulia dan hina penuh sesak berbagai warna adalah Koci adalah Cina mengadap Paduka yang bijaksana

247 Yang turut Holanda kenalah gusar dosanya itu terlalu besar didalam syaricat Sayyid al-basyar patut dipancung ditengah pasar

248 Orang Mentok demikian pula mengikut Ménténg kafir yang cela tak tahu dosa dengan pahala masuk Palémbang membuat gila

249 Ménténg itu Holanda penakut bukannya seperti Tuan Méjer Kut Lingga dan Riau semua mengikut orang Cina sekalian tunggut

250 Di situ tiada berapa antara kapalnya berlabuh ditengah segara maksudnya hendak pulang ke negara rasanya hati sangat sengsara

251 Hilirlah kapal berperai-perai haluan menuju kuala negeri setengah racyatnya habis lari entah ke mana membawa diri 
252 Sampai di Sungsang menjatuhkan duga kapalnya tiga disuruhnya jaga racyatnya semua banyaklah dahaga mencari sungai dengan telaga

29253 Kapalnya berlayar sangatlah laju negeri Mentok yang dituju racyatnya makan roti dan kéju ada bercelana ada berbaju

254 Hati Ménténg sangatlah béda naik ke darat tunduk tengadah diatas kursi menggosok dada hendak pulang ke negeri Holanda

255 Angkatan Ménténg berlayar segera ke tanah Jawa semua ngembara susahnya hati tidak terkira sampailah Ménténg ke negeri Jakatra

256 Tamatlah syacir sahaya mengarang hati nin bebal bukannya terang tatkala zaman Palémbang berperang jénderal laut datang menyerang

257 Mengarang syacir tiadalah lama dua hari bulan hingga ke lima kepada Hijrat al-Nabi Utama seribu duaratus tigapuluh lima

258 Jénderal laut disebut orang ke sana sini datang menyerang itulah mulanya bénténg berperang jénderal laut lari beroléh wirang

259 Tamatlah syacir ayuhai tuan mengarang nin lelah bukan kelakuan ampun $\mathrm{ma}^{\mathrm{c}}$ af semua sasterawan banyak yang khilaf tidak ketahuan

260 Tidak ketahuan lebih dan kurang melainkan macaf diharap sekarang karena baharu berlajar mengarang ampun diharap sekalian orang 


\section{KRITISCH APPARAAT BIJ DE TEKSTUITGAVE}

9a 3-4: pada bercakap

11a 2: beratib

11b 1: berkepung

13a 2: semua

$17 \mathrm{~b}$ 3-6, A: ke kanan ke kiri

19a 1-2: di situlah lama

20b 3-4, L: bersungguh hati

21d 2-4: memapak tidak terduga

22b 1, A: bidadari

24c 4: bertentu

26b 3: atas

31a 2, A: semuanya

35b 5: ontbreekt

37b 1-2, A: dilawan

37d 3, L: menarikkan

38c 3, A: Setijagati

39c 5: ontbreekt

42b 3-4: berpasti-pasti

43a 4, A: dikandung

43b 3-4, A: sambung-menyambung

44b 4-5: bermakanlah pasti

45c 2: di

46d 3, L: berasa

47b 2: suruhan

48a 3: sekalian

49b 2, A: tiada

51c 1: senyum

$53 \mathrm{~b} 1$, A: diiringi

54d 2: bertunggu

57a 4, A: Syah

59b 4: ontbreekt

62c 4-5: suruh bertata

62d 3: pintunya

64b 4: terbongkar

64d 3-4: sangat pendékar

65c 1, A: datanglah

68c 3: diatas

69c 3-4, A: sérénan

72a 3-4: terlalu keras

72b 2-4: sampai sangatlah deras

72c 3-5: khatir dan maras

72d 4-5: hatinya ngeras

74d 1, L: patut

76d 4, A: berkawan
$78 \mathrm{~b} 3$ : tidak

80b 4, A: terbakar

80d 2: semuanya

81b 2, L: dihampuskan

81b 3: atas

84d 3, A: tiada

85c 2, L: seperti

87a 1: Tersebut

87a 2, L: ontbreekt

87b 4, L: hadir

87c 3: ontbreekt

88c 3, A: sangatlah

90a 4-5, L: bergarang

90b 2: harilah

92d 1: semua yang

92d 1, A: semua

93b 4: berbaring

93d 4, L: tersérong

94b 4, L: kalah

94c 1: perang

94c 2, L: itu

97b 3-4: sangat pendékar

98d 1: habislah

99a 1: Dibalaslah

99b 1: di mulut

99d 3, L: tidak

100c 3-4: laksana kudung

102a 3-4: peluru berantai

102b: semua yang menengar lesu dan letih

103a 2, A: ontbreekt

103c 1, A: Cakerawijaya

104a 4, A: berdiri

105b 3-4: perangnya talu

106b: pendékar sangat pantas sekali

106c 3: genderang

106d 3-4: buta-tuli

108b 1: berkumpullah

109a 3-4: tiada berbanding

109b: durja berseri laksana gading

109b 1 (MP 4a), A: duduk

109b 3 (MP 4b), A: ontbreekt

109c: seputar alam tiadalah tanding

109c 1 (MP 4a), A: seperti 
109c 1 (MP 4b), A: apakah

109d: nyatalah paras tiada bertanding

111a 3, A: Haji

112a 1: Bercakaplah

113a 1: Bercakaplah

114a 1: Bercakaplah

114b 2-4: bagai déwa kuasa

114b 2-4 (MP 4a), A: bagai déwa-

115a 1: Bercakaplah kusuma

115c 3-4: lagi bersahaja

115d 3: penentang

116a 2, A: Abdu'r-rahman

116b: menjunjung Duli seolah menari

117b: menjunjung Duli rupanya sungkan

117d 1: cuping

119b 4, A: memerat

119c 3: sangatlah

119d 2, A: hakk adami

120d 5, A: memaut

123a 4, A: yang

125c 1: kapalnya

128d 3: bertanding

130c 4: Sita

133a 2-4: sampai sebagai ribut

133b: pemandangan ke méga terlalu sabut

133b 2 (MP 4a), A: ontbreekt

133c 3-4: asap berkabut

134b 4, A: memunang

134d 1-2: gemuruhlah bunyi

135c 3: disuruhnya

135d: mintarlah kapalnya masang bendéra

136b: isinya

137a 3-4, A: menyala-nyala

138a 1: Kapal

139a 3-4: sebagai lebur

139a 4 (MP 4a), L: liar

144c 3: dikurniai

144c 3 (MP 4a), A: dikerélai

144d 2-3, A: kemantu

145d 4-5: semuanya mara

147b 2 (MP 4b), A: asal

147b 2-4: tiada berpadan

149c 2-4: membedil bersungguh

150a 3, A: ontbreekt

153d 2: yang luka

154c 1-2, L: dimanakah

154d 1, L: racyat 156d 3, L: sukalah

157c 3: angkinan

157d 1-2, A: di belakang

158b 3-4: amat pertilang

158d 1, A: disinari

159c 1, A: menyambut

159d 2: melintang

160c 3: yang masak

160d 3-4: memégang tunam

162d 2: jénderal

167b: kerajaan Pangéran

Mangkubumi

168a 2-4: sigera pada berlari

$168 \mathrm{c} 1, \mathrm{~A}$ : numpang

168c 5, A: ontbreekt

168d 3-4: tidak yang kari

170b 1: beserta

170d 4: dibongkar

171a 3, A: Derpadacita

172c 2, A: permai

173c 3-5: Tuhan Rabb al-izzati

174a 3-4, A: berperi-peri

174d 1: semua

176c 2, A: tolongan

178b 2: amat

181b 3-4: bukan sebarang

182d 1: kena

183a 2, A: Mandari

183b 4, L: barat

183d 4, L: kramat

184a 4, L: onleesbaar

184b 2: diisinya

185b 3-4: baru dicanai

185b 4 (MP 4a), A: dicapai

185b 4 (MP 4b), A: persani

188c 1: maksudnya

189b 3-4: baharulah

190b 3-5: Rabb al-Gafur

191a 3-5, A: Rabbu'l-arwah

193b 3, A: ikatnya

194c 1-2: tidaklah mengikutkan

194c 4, A: dari

195c 4: ngelayam

195d 4: tersembayam

197c 2: ontbreekt

197c 4: pakai

199c 3-6: mencipta ingatan

201a 1: Kapalnya

$201 \mathrm{~b} 3$, A: dirasa

202a 4: tersanggat

202b: airpun surut tiada berangkat

202c 3-4: bertambah cakat

202d 5: dekat 
203b 1: bangkitlah

203d 3-4: habis berlari

204b 4-5: bermakanlah pasti

205d 3-5, A: di sanalah nama

205d 3-5, L: disalah nama ("dat hun naam geschandvlekt is"!)

207a 4: terduga

207a 4 (MP 4a), L: terdosa

207d 3-4: tiada terduga

207d 4 (MP 4a), L: terdosa

208b 2: di

208d 2: ke

212c 1: Maharaja

216a: Semuanya racyat suruh milirlah $^{c}$

216b 2: di

216c 3: yang telah

216d 2: mendekat

218b 3-4, A: beribu-ribu

221a 4, A: ontbreekt

222b 3: kari

224a 3, A: banyak

224c 3-4 (MP 4a), A: kena mati

225a 3, A: hadir

225a 3-4: pada melarat 226b 4, A, L: raksasa

226d 3: diberinya

227c 3, A: Burung

229a 1, A: Disembahnya

230a 3: bunyinya

233a 3-5: titahnya Dalam

235c 1-2: bawa di

239d 1, A: hendaknya

240c 4, A: semuanya

242c 3-5, A: malang-semirang

243d 4, A: ketawa

244d 5, A: hendaki

245b 3, A: disuruhnya

245d 3-4: jangan berlari

249c 4-5, A: semuanya ngikut

251a 3-4, A: berperi-peri

251b 1, A: haluannya

251c 3-4: pada berlari

253d 1-2, L: ada yang bercelana

254a 3, L: sangat

256a 3: saya

258d 1-2: jénderalnya

259c 2: dan macaf

260c 3, A: belajar 
HOOFDSTUK IV

\section{VERTALING VAN DE TEKSTEN}

Hieronder volgt een Nederlandse vertaling van de in het vorige hoofdstuk gepubliceerde teksten. Om de aan het slot van hoofdstuk II genoemde reden is aan de vertaling van TR 1 een vergelijkend overzicht toegevoegd van in de tekst UBL 5/MP 2 aangetroffen verschillen ten opzichte van de lezing volgens TR 1.

\section{VERTALING}

\section{KI 4}

$$
\text { (p. 26, r. } 16 \text { - p. 29) }
$$

Wat de regeringsperiode van Sultan Muhammad Baha'uddin betreft, deze duurde achtentwintig jaren, één maand en zeventien dagen. Hij overleed in het hijrah-jaar 1218, op maandag 22 Zulhijah om drie uur; en zijn leeftijd was zeventig jaren, vier maanden en acht dagen.

Hij werd opgevolgd door zijn zoon, Susuhunan Mahmud Badaruddin genaamd. Toen Susuhunan Mahmud Badaruddin gedurende zeven jaren, acht maanden en zeven dagen aan de regering was geweest, werd de Hollandse factorij aan de rivier de Aur door de susuhunan afgebroken en de kapitein gedood; want er was een boodschapper gekomen met een brief, waarin de Engelsen, die een aanval hadden gedaan op Batavia, probeerden de susuhunan ertoe over te halen een vriendschapsverdrag met hen aan te gaan. Maar toen de Engelsen Batavia eenmaal overmeesterd hadden, stelden zij de susuhunan in staat van beschuldiging. In het hijrah-jaar 1227, op zaterdag 12 Rabicul-akhir, des ochtends vroeg vertrok de susuhunan stroomopwaarts naar de Rawas; want de schepen van de Engelse generaal Gillespie waren Palembang binnengevaren, slechts zeven maanden en elf dagen nadat de afbraak van de Hollandse factorij aan de rivier had plaatsgevonden. 
Toen General Gillespie twintig dagen in Palembang was, stelde hij Susuhunan Husin Dia'uddin, zoon van Sultan Muhammad Baha'uddin, aan als vorst van Palembang met de titel sultan; zijn oorspronkelijke titel was pangéran dipati. Eén jaar, één maand en veertien dagen later

27 keerde Susuhunan Badaruddin terug op de vorstelijke troon in de stad Palembang, namelijk in het hijrah-jaar 1228, op donderdag 17 Rajab. En één maand daarna kwam Captain Elliot, de zoon van de koning van Bengalen, een Engelsman, de stad Palembang binnen; dat was op zaterdag 17 Syacban. Toen hij vijf dagen in Palembang was, zette Captain Elliot Susuhunan Mahmud Badaruddin af en verhief hij Susuhunan Husin Dia'uddin tot vorst; dat gebeurde in het hijrah-jaar 1228, op donderdag 22 Syacban.

Drie jaren, vier maanden en achtentwintig dagen later kwamen de Hollanders terug en vestigden zich weer aan de uitmonding van de rivier de Aur als opvolgers van de Engelsen; dit geschiedde in het hijrah-jaar 1232, op dinsdag 21 Muharram om zeven uur. Eén jaar, zes maanden en acht dagen daarna kwam de Hollandse Edeleer Muntinghe de stad Palembang binnen. En in het hijrah-jaar 1233, op woensdagavond 30 Rajab, drieëntwintig dagen later, keerde Susuhunan Mahmud Badaruddin terug op de troon en hij sloot een contract met Edeleer Muntinghe op vrijdag 22 Syacban.

Acht dagen daarna kwam de Engelse Captain Salmond met een aantal soldaten in Palembang aan; ze waren uit Benkoelen gekomen om Susuhunan Husin Dia'uddin te helpen, want Susuhunan Husin had bij de Engelsen over de gang van zaken zijn beklag gedaan. In die tijd zaten de Engelsen nog in Benkoelen. Het was op zaterdag de eerste Ramadan, dat Captain Salmond door Edeleer Muntinghe werd gesommeerd Palembang te verlaten. Vijf maanden en tien dagen na de dag waarop Captain Salmond was aangekomen, werd Susuhunan Husin Dia'uddin door Edeleer Muntinghe uit de haven van Palembang weggevoerd, namelijk in het hijrah-jaar 1234, op maandag 2 Safar, en naar Cianjur gebracht.

Zes maanden en zeventien dagen na het vertrek van Susuhunan Husin Dia'uddin raakte Susuhunan Mahmud Badaruddin slaags met Edeleer Muntinghe, dat was op zaterdag $19 \mathrm{Sya}$ cban. $\mathrm{Na}$ drie dagen van strijd trokken de Hollanders weg en keerden terug naar Batavia; dit geschiedde in het hijrah-jaar 1234, op dinsdag 22 Syacban. En één maand en negenentwintig dagen na de uittocht van de Hollanders kreeg de susuhunan de titel Susuhunan Mahmud Badaruddin en zijn zoon de titel Sultan Ahmad Najamuddin. Maar de heerschappij bleef in han- 
den van de susuhunan. Wat Sultan Ahmad betreft, die was voordien pangéran ratu.

Spreken wij nu van de tijd dat Sultan Husin Dia'uddin de titel susuhunan droeg en zijn zoon Prabu Anom Sultan Ahmad Najamuddin 28 werd genoemd. Ten tijde van de Generaal van Batavia Baron Van der Capellen werd Susuhunan Husin Dia'uddin met zijn zoon Sultan Ahmad Najamuddin door de Generaal naar Palembang gestuurd. En zo bracht in het jaar 1236 de Hollandse generaal De Kock Susuhunan Husin Dia'uddin met Sultan Ahmad Najamuddin Palembang binnen. Op maandag 11 Ramadan leverden drie schepen met aan weerszijden een dubbele rij boordkanons, twee schepen die aan weerszijden één enkele rij geschut hadden, zomede een aantal brikken en sloepen slag met de Palembangse forten op de landtong van Muara Plaju en op het eiland Kembara. Zaterdagnacht, de vierentwintigste van diezelfde maand Ramadan, om vier uur begon de strijd, die tot zes uur duurde; toen vloog het fort op het eiland Kembara in brand. Daarna werden Susuhunan Mahmud Badaruddin en zijn zoon Sultan Ahmad Najamuddin uit Palembang weggevoerd en op transport gesteld naar Java; dat gebeurde in het hijrah-jaar 1236, op donderdag 5 Sawal. Het was in die tijd, dat de Hollandse Compagnie zich voor het eerst in de stenen kraton van Palembang vestigde; Susuhunan Husin Dia'uddin ging in Suakbata wonen en zijn zoon Sultan Ahmad Najamuddin dichtbij de rechteroever van de Sekanak als men de rivier opvaart, in de onmiddellijke nabijheid van de kraton. Susuhunan Husin trad evenwel niet meer op als regerend vorst. Die nieuwe stenen kraton van Palembang was gebouwd door Sultan Muhammad Baha'uddin, in het hijrah-jaar 1191.

Hervatten wij ons verhaal. Drie jaren, vijf maanden en vierentwintig dagen na het vertrek van Susuhunan Mahmud Badaruddin ondernam Sultan Ahmad Najamuddin, de zoon van Susuhunan Husin Dia'uddin, een aanval op de kraton, welke echter geen succes had, omdat de aanvallers terugtrokken en alleen maar vier man de aanval doorzetten. Dit geschiedde in het jaar 1240, in de nacht van zondag op maandag, de eerste van de maand Rabicul-akhir; diezelfde dag nog vluchtte Sultan Ahmad Najamuddin naar de binnenlanden van Palembang. En in de avond van diezelfde maandag werd Susuhunan Husin Dia'uddin door de Hollandse resident Reijnst uit Palembang verwijderd. Sedertdien was er geen sultan meer in Palembang. Drie maanden en drie dagen na de dag waarop hij uit Palembang was vertrokken, overleed 
Susuhunan Husin Dia'uddin te Batavia, in het hijrah-jaar 1240, op maandag 4 Rajab om vier uur, in de leeftijd van zesenvijftig jaren, negen maanden en drie dagen.

29 In het jaar 1241 werd Sultan Ahmad Najamuddin, de zoon van Susuhunan Husin Dia'uddin, gearresteerd, uit het binnenland overgebracht en vervolgens verbannen naar Menado. Negentien jaren, tien maanden en zeventien dagen later overleed Sultan Ahmad Najamuddin, zoon van Susuhunan Husin Dia'uddin, te Menado, in het hijrah-jaar 1260 op 10 Jumadil-awal, in de leeftijd van negenenveertig jaren, drie maanden en zeven dagen.

Wat Susuhunan Mahmud Badaruddin in Ternate betreft, deze overleed in het hijrah-jaar 1269, op vrijdag 14 Safar om zes uur 's ochtends, in de leeftijd van zevenentachtig jaren, zeven maanden, dertien dagen en zeven uren. Zo ligt er tussen de dood van Susuhunan Husin Dia'uddin en het overlijden van Susuhunan Mahmud Badaruddin een tijdsverloop van achtentwintig jaren, zeven maanden, negen dagen en twaalf uren. En de periode vanaf het vertrek van Susuhunan Mahmud Badaruddin uit Palembang tot aan de dag van zijn overlijden beliep tweeëndertig jaren, vier maanden en tien dagen. Zijn graf bevindt zich in Ternate.

Acht jaren, vier maanden, zestien dagen en éénentwintig uren na Susuhunan Mahmud Badaruddin overleed ook Sultan Ahmad Najamuddin te Ternate, namelijk in het hijrah-jaar 1277, in de nacht van zaterdag op zondag 2 Rajab om drie uur. En zijn leeftijd was éénenzeventig jaren, twee maanden, zestien dagen en éénentwintig uren. 


\title{
VERTALING
}

\section{UBL 7}

\author{
1.
}

1 1.1. Dit is een verhaal betreffende de geschiedenis van het rijk Palembang, van vroeger tijden tot op heden. Er is in die tijd heel wat voorgevallen en er hebben zich tal van kwesties voorgedaan, die een heel lang verhaal zouden opleveren, gesteld dat het door een kundig en geleerd schrijver zou worden geschreven. Zeer talrijk en bijzonder rijk aan wederwaardigheden zijn de lotgevallen geweest van al de koningen die elkaar op de troon in Palembang zijn opgevolgd als regerend vorst over het Palembangse rijk, de oorsprongsgebieden van de Negen Rivieren en de buitengewesten zoals Banka, Muntok en Billiton inbegrepen, want al die genoemde gebieden stonden onder de heerschappij van Palembang.

Ik heb in dit geschrift een gedeelte van de verhalen betreffende Palembang bijeengebracht, voor zover ik ze heb aangetroffen in de geschriften van mensen uit vroeger tijden en voor zover ik ze indertijd heb vernomen uit mondelinge mededelingen van hoogbejaarde lieden en ik heb die verhalen in dit boek in de juiste volgorde opgesteld.

1.2. Wat nu het geschiedverhaal betreft van de vorsten die hebben geregeerd op de troon van Palembang, het is op tal van verschillende manieren geweest dat zij elkaar als koning op de troon in de regering over het rijk Palembang zijn opgevolgd. Soms had de troonopvolging plaats in overeenstemming met de geldende regel dat de vorst als zodanig wordt opgevolgd door zijn zoon, soms was een troonswisseling het gevolg van een oorlog en soms ook geschiedde de opvolging krachtens

2 testament, dat wil zeggen krachtens opdracht. Dit laatste was het geval wanneer een vorst nog bij zijn leven tegenover al zijn ambtenaren en alle hooggeplaatste personen onder het afleggen van een eed als zijn laatste wil had uitgesproken: "Na mijn dood moet die bepaalde persoon mij opvolgen, want ik wens niet dat mijn zoon mij als vorst opvolgt." Daaraan werd dan door de ambtenaren en alle ingezetenen van Palem- 
bang uitvoering gegeven, geheel overeenkomstig de wilsbeschikking. Het is ook voorgekomen, dat de troonswisseling werd veroorzaakt door een oorlog met de blanken, in dit geval met de Hollanders. Toen hij die oorlog had verloren, trok de vorst van Palembang zich terug in het binnenland, wilde niet meer naar Palembang terugkeren en droeg zijn broer op hem als vorst op de troon in Palembang op te volgen en de plannen der blanken zoveel mogelijk te dwarsbomen.

Er hebben zich zóveel kwesties en verwikkelingen voorgedaan bij de verschillende vorsten in het rijk Palembang, dat als ze zouden worden te boek gesteld, dan zou het een te lang verhaal worden van oorlogvoeren en vrede sluiten met de blanken, wat in vroeger tijden bepaald niet slechts éénmaal is voorgekomen.

\section{2.}

2.1. Ons verhaal nu begint met een periode van vrede tussen Palembang en de Hollanders, toen Palembang in een toestand van rust en orde verkeerde, en wel met de regeringsperiode van Zijne Majesteit Sultan Mahmud Badaruddin, wiens graf zich te Lemabang bevindt, in de grafheuvel Kawah Terkurap. Hij wordt door de Palembangers Sultan Lemabang genoemd, omdat het Sultan Mahmud Badaruddin is geweest die een begin heeft gemaakt met de bouw van de kraton en van de 3 begraafplaats te Lemabang. Tot op heden zijn alle vorsten die in Palembang zijn overleden, in Lemabang begraven. Oorspronkelijk heette die Sultan Mahmud Badaruddin echter Pangéran Jayawikrama.

Ten gevolge van een aantal kwesties en door een reeks van oorzaken kwam hij tot het plan om met steun van het gehele ambtenarencorps in Palembang en in overleg met de Hollanders de heerschappij van zijn oudste broer over het rijk Palembang ten val te brengen, namelijk van Sultan Muhammad Alamuddin, die door de Palembangers van nu Sultan Anom wordt genoemd en wiens graf zich in Kebon Gedé bevindt. De aanleiding om zijn heerschappij ten val te brengen was dat zijn oudste zoon, Pangéran Dipati geheten, bestemd was om Sultan Anom als vorst in Palembang op te volgen. Die Pangéran Dipati nu was steeds bezig boze plannen te beramen om de positie van de hoge regeringsfunctionarissen in het rijk Palembang en hun bestuursbeleid jegens de bevolking te ondermijnen. Vandaar dat het volk zowel als de ambtenaren de zijde kozen van Pangéran Jayawikrama, de jongere broer van Sultan Anom. $\mathrm{Zij}$ allen waren het erover eens dat men moest streven naar een toestand van rust en veiligheid in Palembang, opdat 
4 de bevoking zich op zijn gemak zou voelen en de kleine man in rust en vrede zou kunnen leven in het rijk Palembang, de buitengewesten en alle districten van de Negen Rivieren in het binnenland inbegrepen.

2.2. Toen het aan Sultan Anom bekend geworden was dat de ambtenaren van Palembang in groten getale gekozen hadden voor zijn jongere broer Pangéran Jayawikrama, zon Sultan Anom met zijn zoon, Pangéran Dipati genaamd, op middelen om Pangéran Jayawikrama te doden, niet openlijk maar integendeel onder de schijn dat hij hem goed gezind was. Een paar keer werd Pangéran Jayawikrama 's nachts overvallen, zonder dat de aanvallers bekend werden. Het is ook voorgekomen dat hij 's ochtends vroeg werd beschoten, terwijl hij op de trap voor zijn huis zat. Pangéran Jaya viel toen in het water maar bleef ongedeerd, terwijl die trap door de kogels was doorboord en afbrak. Deze toestand duurde zo een tijdje voort, terwijl Pangéran Jayawikrama met al zijn volk voortdurend op zijn hoede was in de wijk waar hij woonde, Kadipan genaamd; hij ging niet meer zijn opwachting maken bij zijn oudere broer Sultan Anom, maar hield in zijn eigen wijk streng de wacht, dag en nacht zonder een ogenblik te verslappen. Wanneer mensen uit Kadipan op de weg werden aangetroffen, werden ze door het volk van Pangéran Dipati en het volk van Sultan Anom gedood.

Zo was het een tijdlang onrustig in Palembang. Zodra de duisternis 5 inviel, vermoordden de mensen van één en hetzelfde land elkaar, zodat men geen moment rust had. Het voedsel was zeer schaars, omdat de handelaars van overzee wegbleven en ook de mensen uit het binnenland bang waren om naar het laagland af te zakken. Zeer groot waren in die tijd de moeilijkheden in de stad Palembang en zowel in het binnenland als in de kuststreken werden enorm veel roofovervallen gepleegd.

2.3. In die tijd zond Pangéran Jayawikrama een gezantschap naar Batavia om in het geheim hulp te vragen, zonder dat Sultan Anom van het zenden van dat gezantschap door Pangéran Jayawikrama op de hoogte was. Omdat Sultan Anom de mensen van Kadipan zeer scherp in de gaten hield - wanneer men hen tegenkwam, moest men hen doden -, was het slechts dank zij de wil Gods - lof zij Hem en ver-

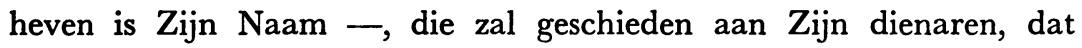
plotseling het gezantschap van Pangéran Jayawikrama veilig en wel in Batavia arriveerde en een contract sloot tussen Palembang en de Hollanders. De Compagnie zou helpen de heerschappij van Sultan Anom ten val te brengen en hem van de troon van Palembang te stoten, terwijl 
Pangéran Jayawikrama op zich nam vorst te worden en tevens de vrede te handhaven tussen Palembang en de Compagnie.

Zo bracht dat gezantschap een eeuwigdurend verdrag tot stand tussen Palembang en de Compagnie met de volgende bepalingen:

Een betaling ineens van vierhonderd duizend rijksdaalders zomede levering van veertig slaven en veertig slavinnen. Wanneer Pangéran Jayawikrama eenmaal vorst zal zijn geworden in het land, zullen alle voortbrengselen van Palembang uitsluitend aan de Compagnie worden verkocht, zoals ivoor, rhinoceroshoorn en peper, dat alles zal niet naar elders verhandeld worden. Als de ingezetenen één der genoemde produkten aan anderen verkopen, wordt het in beslag genomen.

Wat voorts de ontginning van de tinmijnen op Banka betreft, de totale jaaropbrengst aan tin wordt aan de Compagnie verkocht tegen de prijs van acht rijksdaalders per honderd kati, verkoop aan anderen is volstrekt niet toegestaan. Indien leden van de Palembangse adel aan anderen verkopen, worden hun goederen verbeurdverklaard en worden zijzelf door de Sultan van Palembang verbannen; als de kleine man wordt betrapt op de verkoop van tin aan mensen van andere landaard, dan vindt vanwege de Compagnie verbeurdverklaring plaats en wordt de dader door de Sultan van Palembang ter dood gebracht.

Voorts mag de Compagnie zich in Palembang vestigen en er een loge bouwen, stroomopwaarts van de uitmonding van het riviertje de Aur, maar de muren moeten uit bamboe worden opgetrokken. 's Zondags mag men er de vlag hijsen, op andere dagen dan op zondag mag dat niet.

Voorts mogen er geen oorlogsvaartuigen Palembang binnenkomen, dat is niet toegestaan. Wanneer de Compagnie eenmaal te Palembang gevestigd zal zijn, moet zij, als zij in Palembang een pleziertocht wil ondernemen naar het binnenland, hiervan kennisgeven aan de bevoegde Palembangse ambtenaar. Indien men zich te voet of per boot op plezierreis naar het binnenland begeeft zonder hiervan kennis te geven aan de ambtenaar die de ambtstitel temenggung kertanegara voert en men wordt door booswichten vermoord, dan heeft men geen enkel verhaal. Voor een tocht te voet of per boot naar het kustgebied echter geldt geen enkele verbodsbepaling.

Voorts zal er jaarlijks een gezantschap ambtenaren van Palem- 
bang worden uitgezonden met brikken en fregatten, beladen met tin, die gelost zal worden op het eiland Onrust in de baai van Batavia. Nadat alle tin in ontvangst is genomen, wordt de prijs ervan aan de gezanten betaald en tevens de brief van de Sultan van Palembang op ceremoniële wijze in optocht rondgedragen. Voor de duur van drie maanden is de Compagnie verantwoordelijk voor de voeding van het gezantschap ambtenaren uit Palembang, maar voor zover ze langer dan drie maanden blijven, moeten ze zelf in hun levensonderhoud voorzien. Wanneer de Palembangse gezanten terugkeren, moeten ze een brief van de Generaal van Batavia meenemen, die na aankomst te Palembang in optocht wordt rondgedragen ten aanschouwe van de Compagnie die in Palembang verblijf houdt en van de gehele bevolking van de stad Palembang, terwijl ter opluistering van de plechtigheid kanonen geweerschoten worden gelost. Die brief uit Batavia wordt dan overluid voorgelezen ten overstaan van de vorst van Palembang en de gehele burgerij, terwijl de geschenken die uit Batavia zijn meegezonden in ontvangst worden genomen. Dat is de regeling die tot het eind toe in Palembang heeft gegolden, zolang er een Hollandse loge in Palembang is geweest.

Nadat de gezanten van Pangéran Jayawikrama er zo in waren geslaagd een contract tussen Palembang en de Hollanders tot stand te 8 brengen, keerden die gezanten van Pangéran Jayawikrama in Palembang terug zonder dat het aan Anom bekend werd. Toen de gezanten bij Pangéran Jayawikrama kwamen, was Pangéran Jayawikrama met alle ambtenaren die aan zijn zijde stonden zeer verheugd over het resultaat van de gevoerde besprekingen en het met de Compagnie voor altijd gesloten akkoord. Pangéran Jayawikrama legde intussen voorraden buskruit en kogels aan in zijn wijk, Kadipan genaamd.

2.4. Enige tijd later kwam er een commissaris met een oorlogsschip uit Batavia de rivier binnenvaren. In Palembang aangekomen wendde hij zich tot Sultan Anom zonder enige notitie te nemen van Pangéran Jayawikrama. Op zekere dag werd er door de sultan een ontvangst gehouden in de audiëntiezaal, waarbij met groot ceremonieel de brief uit Batavia werd rondgedragen ten aanschouwe van het ambtenarencorps, de burgerij en de aanzienlijken in de stad Palembang, die met z'n allen waren samengestroomd naar de audiëntiezaal van Sultan Anom. Er werd een groot feestmaal aangericht en er werden saluutschoten gelost 
met kanonnen en geweren, omdat de commissaris vrede zou stichten tussen Sultan Anom en zijn broer Pangéran Jayawikrama. Na afloop van de besprekingen zei de commissaris tegen Sultan Anom dat hij 9 nu deze zaak was afgehandeld - naar Batavia wilde terugkeren en bij wijze van afscheidsgroet aan de stad het scheepsgeschut twee dagen lang vreugdeschoten wilde laten afvuren. Daarop antwoordde Sultan Anom: "Dat is goed." Toen ging de commissaris naar boord terug.

Nadat er enige dagen waren verstreken, werden er op een dag vanaf het oorlogsschip kanonschoten gelost, die naar het scheen als vreugdeschoten bedoeld waren. Op de tweede dag dat het schip kanonschoten afvuurde, beschoot het met zijn kogels de kraton van Palembang, dat is het paleis van de sultan, terwijl Pangéran Jayawikrama tegelijkertijd met zwaar geschut en kleinere kanonnen vanaf Kadipan het vuur opende, onder luid krijgsgeschreeuw van al zijn volk. Nadat de kraton, waar Sultan Anom verbleef, van het oorlogsschip af en tevens door Pangéran Jaya vanuit Kadipan onder vuur was genomen, sloeg het volk van Sultan Anom, van de schrik geen kans meer ziende het vuur te beantwoorden, tot de laatste man in wanorde op de vlucht en zocht met vrouw en kinderen in 't wilde weg en naar alle kanten een goed heenkomen. Zo bleef Sultan Anom met zijn gezin en met de ambtenaren die hem trouw gezworen hadden in de kraton achter. Onder deze omstandigheden hield Sultan Anom het diezelfde dag al niet meer uit en vluchtte

10 vervolgens met zijn gehele gezin en met alle ambtenaren en burgers die hem trouw gebleven waren de kraton uit. Stroomopwaarts van de kraton, in de wijk die Candi genaamd wordt, hield Sultan Anom stil, legde er zeer sterke vestingwerken aan en trok het volk daar samen.

Wat nu Pangéran Jayawikrama betreft: nadat Sultan Anom de kraton had verlaten, gaf Pangéran Jayawikrama de ambtenaren en het volk terstond bevel de kraton van Palembang binnen te rukken met hun volle bewapening en uitgerust met zware en lichte kanonnen, met geweren en donderbussen en met speren, sabels en krissen, teveel om op te noemen. Hij vreesde namelijk dat de kraton door de sultan zou worden heroverd; want het oorlogsschip van de commissaris was al vertrokken, op grond van de afspraak dat de Compagnie geen hulp meer zou verlenen, wanneer de sultan eenmaal uit de kraton zou zijn weggevlucht.

2.5. Na de terugkeer van de commissaris naar Batavia bleven Pangéran Jayawikrama en Sultan Anom met elkaar in oorlog, hoewel ze toch allebei Palembangers waren. Pangéran Jayawikrama verschanste zich in 
de kraton, terwijl een deel van zijn volk in hun woonwijk in Kadipan in stelling was gegaan. Sultan Anom op zijn beurt verschanste zich in zijn fort in de wijk Candi. Zijn aanhang onder de ambtenaren was

11 bijzonder machtig en talrijk en ook het gewone volk van Palembang sloot zich in groten getale bij hem aan, want Sultan Anom was immers de vorst van Palembang en bovendien was hij zeer rijk en beschikte hij over veel wapentuig. Zo kwam het dat de Palembangers nog in groten getale Sultan Anom volgden, met name alle armen en behoeftigen, omdat ze dan te eten kregen; want de onrust in het land was nog groot en het voedsel dus zeer schaars. Pangéran Jayawikrama daarentegen beschikte over niet zoveel volk, maar wel over een groot aantal voorvechters van overzee, zoals Timorezen, lieden van Alimdana, Buginezen en mensen uit Borneo en Johor, allemaal ervaren krijgslieden.

Er speelde zich zo heel wat af tussen Pangéran Jayawikrama en zijn broer Sultan Anom, meer dan men zich kan voorstellen. Het relaas van die gebeurtenissen zou zeer veelomvattend en lang worden, want er was een grote verscheidenheid aan strijdenden, die elkaar alsmaar aanvielen, overrompelden en beroofden. Onder de edelen, de ambtenaren en het gewone volk vielen er aan beide zijden heel wat doden, allemaal Palembangers. Tussen de lieden van Kadipan en het volk van de wijk Candi kon geen ontmoeting plaatsvinden of het kwam - bij elke ontmoeting weer - tot een steekpartij, waarbij er op de weg talrijke doden vielen en de verwarring zo groot was, dat men niet meer wist wie moordden

12 en wie vermoord werden. Vooral 's nachts placht een grote gewapende macht uit de wijk Kadipan, bestaande uit een flink aantal ambtenaren en burgers, aanvallen te doen teneinde het fort van Sultan Anom in de wijk Candi te veroveren. Van de kant van Sultan Anom trok, wanneer de avond was gevallen, een hele groep ambtenaren en burgers op hun beurt vanuit de wijk Candi gewapend ten aanval om de grote kraton en het fort in de wijk Kadipan te veroveren. En wanneer die beide legers elkaar onderweg ontmoetten, werd er de hele nacht verwoed gevochten tot het licht werd en eerst dan werd de strijd gestaakt. Aan beide zijden sneuvelden verscheidene ambtenaren en gewone burgers en wanneer het ochtend geworden was kwamen van beide partijen de bloedverwanten die niet aan de strijd hadden deelgenomen met $z$ 'n allen de lijken van de gesneuvelden halen en de zwaargewonden die niet meer konden lopen. Zo verkeerde de stad Palembang in die tijd in een toestand van onrust.

2.6. Toen die oorlog een tijdlang geduurd had, trok Sultan Anom zich 
met zijn gezin en met zijn ambtenaren uit de stad Palembang terug. $\mathrm{Zij}$ allen scheepten zich met een flinke hoeveelheid wapens in, voeren vervolgens naar het binnenland en gingen de Rawasrivier op. Aan de

13 bovenloop van de Rawas aangekomen vluchtte Sultan Anom over land verder met zijn hele leger en zette koers naar Jambi. $\mathrm{Na}$ aankomst te Jambi werden ze door de Sultan van Jambi ontvangen en allen door deze binnen de stad Jambi toegelaten, terwijl de sultan met zijn gezin door de Sultan van Jambi bij hem in de kraton werd ondergebracht. Toen de sultan reeds enige tijd in Jambi woonde terwijl hij op middelen zon om Palembang te veroveren, huwde de Sultan van Jambi een dochter van Sultan Anom, die Dénayu Benderang heette. Zo bleef Sultan Anom in Jambi wonen, terwijl hij de Sultan van Jambi tot schoonzoon had gekregen.

2.7. Nu speelt ons verhaal zich weer af in de stad Palembang. Na de vlucht van Sultan Anom naar Jambi werden de mensen die bij Sultan Anom hoorden en zijn bijvrouwen, voor zover ze in Palembang waren achtergebleven, ter plaatse allemaal door Pangéran Jayawikrama onderhouden. De stad Palembang was weer tot rust gekomen; alle inwoners die op de vlucht waren geweest waren naar de stad teruggekeerd en woonden er weer net als vroeger.

In deze situatie beraadslaagden de ambtenaren en aanzienlijken in de stad Palembang met het volk, terwijl de districtshoofden van buiten en de dorpshoofden uit de marga's in de bovenlanden met huldegaven voor de vorst en geschenken naar Palembang waren gekomen. En de 14 gehele bevolking, van de stad tot in het oorsprongsgebied van de Negen Rivieren toe, was het er van ganser harte over eens dat men Pangéran Jayawikrama tot sultan moest verheffen om te regeren over het rijk Palembang met al zijn onderhorigheden. Op dat tijdstip werd Zijne Hoogheid Pangéran Jayawikrama dus geïnstalleerd als vorst in het Palembangse rijk met de naam en de titel Zijne Majesteit Sultan Mahmud Badaruddin en nam hij plaats op de Palembangse rijkstroon; en zijn oudste zoon ontving de titel Pangéran Ratu. Sultan Mahmud Badaruddin stelde verschillende ambtenaren, beambten en dorpshoofden aan overeenkomstig het in Palembang geldende vorstelijk gebruik. Zo bezette Sultan Mahmud Badaruddin voorgoed de troon van het Palembangse rijk.

2.8. Toen verscheen de Compagnie uit Batavia ter plaatse om een loge te bouwen. Stroomopwaarts van de uitmonding van het riviertje de 
Aur werd een terrein ter beschikking gesteld voor de bouw van een fort van bamboe. De totale grootte van het fort dat de Compagnie daar zou hebben was in het contract vastgelegd. Nu was alles in Palembang volmaakt in orde. Het tijdstip waarop Sultan Mahmud Badaruddin vorst werd viel in het jaar 1136, op de zevenentwintigste dag van de maand Jumadil-akhir, donderdag om één uur. Palembang en de Hollanders bleven steeds op goede voet met elkaar. Jaarlijks ging een Palembangs gezantschap naar Batavia om er het tin uit Banka af te leveren, dat de Compagnie dan in zijn geheel opkocht tegen een prijs van acht rijks15 daalders per pikol. De Palembangers mochten geen tin aan anderen dan de Compagnie verkopen; als bekend werd dat ze dit toch deden, werden ze door de Sultan van Palembang ter dood gebracht en werd het tin in beslag genomen. Degenen die betrapt werden - het waren lieden van Muntok en mensen van Palembang - werden door de Sultan van Palembang ter dood gebracht wegens verkoop van tin aan de Engelsen.

2.9. Toen Sultan Mahmud Badaruddin tien jaar vorst was in Palembang, werd zijn zoon Pangéran Ratu overhoop gestoken door veertig Baliërs - het waren zijn eigen slaven -, omdat ze daartoe vanwege Sultan Anom uit Jambi waren opgestookt. Die Baliërs werden daarop allemaal om het leven gebracht. Die overval door de Baliërs op Zijne Hoogheid Pangéran Ratu vond plaats in het jaar 1140, op de achtste dag van de maand Rajab, vrijdagochtend om acht uur. Hij werd opgevolgd door zijn jongere broer, die op zijn beurt de naam Pangéran Ratu kreeg.

2.10. Daarna was het weer rustig in Palembang. In die tijd bouwde Sultan Mahmud Badaruddin een kraton van steen, die door de Palembangers de oude kraton wordt genoemd. In het jaar 1150, op de vierde dag van de maand Jumadil-akhir, maandag om zes uur, op dàt tijdstip werd de bouw van de oude kraton voltooid. En het was in het jaar 1161, dat Sultan Mahmud Badaruddin de moskee van Palembang bouwde, die nu nog bestaat; op de achtentwintigste dag van de maand Jumadil-

16 awal, op maandag 's ochtends vroeg werd de bouw voltooid. Er heerste rust in Palembang in die tijd. Tijdens elk geschikt seizoen liepen allerlei handelsvaartuigen Palembang binnen en werd uit Banka tin en uit Billiton ijzer uitgevoerd; dat waren allemaal bronnen van inkomsten voor Palembang en zo had het land ettelijke bronnen van inkomsten. 
3.1. De regeringsperiode van Sultan Mahmud Badaruddin als vorst op de troon van het rijk Palembang duurde vijfendertig jaar; hij overleed in het jaar 1171, op de derde dag van de maand Muharram, vrijdagavond tegen zonsondergang. Hij werd door zijn zoon als sultan opgevolgd, namelijk door Pangéran Ratu, die onder de naam Sultan Ahmad Najamuddin de troon van Palembang besteeg, terwijl aan diens oudste zoon de naam Pangéran Ratu werd verleend.

Sultan Ahmad Najamuddin bestendigde als vorst de bestaande regeling van Palembang met de Compagnie. Elk jaar werd er een gezantschap naar Batavia gezonden, dat er tin aanvoerde en jaarlijks werd de brief uit Batavia in een optocht meegedragen, in tegenwoordigheid van het hoofd van de factorij en de militaire commandant te Palembang.

3.2. Niet lang daarna kwam er een brief uit Batavia, waarin de Compagnie vergunning vroeg voor de bouw van een stenen fort, omdat het jaarlijks onderhoud van het uit bamboe opgetrokken fort voor de Compagnie veel kosten en moeite met zich bracht. De gevraagde vergunning werd door de Sultan van Palembang verleend en zo werd de Compagniesloge te Palembang ten tijde van Sultan Ahmad Najamuddin

17 voor het eerst een stenen fort. Uit dankbaarheid zond de Compagnie uit Batavia verscheidene geschenken aan de Sultan van Palembang. Zo nam de wederzijdse vriendschap tussen de Compagnie en Palembang steeds verder toe. Na verloop van enige tijd nam Sultan Ahmad Najamuddin de titel aan van Sunan Ahmad Najamuddin en werd zijn zoon Pangéran Ratu verheven tot Sultan Muhammad Baha'uddin.

3.3. Enige tijd later verscheen er weer een commissaris met een oorlogsschip in Palembang. Hij wendde zich tot Suhunan Ahmad Najamuddin met het verzoek om afdoening van de bij contract vastgestelde schuld van Palembang, bestaande uit vierhonderd duizend rijksdaalders, veertig jongemannen en veertig jonge meisjes. Daarbij toonde de commissaris de vroegere verklaring van Sultan Mahmud Badaruddin. Suhunan Ahmad Najamuddin antwoordde dat hij de middelen nog niet had om te betalen. Daarop verliet de commissaris de stad Palembang en keerde naar Batavia terug. Zo bleef het rustig en vredig in Palembang, zoals het tevoren steeds geweest was. 
4.1. Het tijdvak waarin Suhunan Ahmad Najamuddin op de troon over Palembang regeerde, duurde vijfentwintig jaar. Hij overleed in het jaar 1190, precies op de twintigste dag van de maand Zulkacédah, in de nacht van zondag op maandag, 's ochtends vroeg om vijf uur. Hij werd door zijn zoon Sultan Muhammad Baha'uddin op de troon van het Palembangse rijk opgevolgd en deze benoemde zijn oudste zoon tot

18 Pangéran Ratu. Ten tijde van Sultan Muhammad Baha'uddin heerste er meer dan ooit welvaart, rust en vrede in Palembang; zowel het eigen volk als de vreemdelingen werden rechtvaardig en mild bejegend en aan de armen en behoeftigen werd veel liefdadigheid bewezen.

4.2. Sultan Muhammad Baha'uddin was nog niet zo lang aan de regering als vorst over Palembang en onderhorigheden, toen hij de grote kraton te Palembang bouwde, die tegenwoordig door de Compagnie wordt geoccupeerd. Nadat de grote kraton met alle woningen en aanplantingen gereedgekomen was, verhuisde - in het jaar 1211, op de drieëntwintigste dag van de maand Syacban, maandagochtend vroeg Sultan Muhammad Baha'uddin naar de grote kraton. Pangéran Ratu ging toen in zijn plaats in de oude kraton wonen, terwijl sommigen van zijn volk en van zijn ambtenaren buiten de kraton bleven wonen.

In die tijd werden de vriendschapsbanden met de Compagnie steeds meer aangehaald. Elk jaar werd er een gezantschap gezonden en werd de brief uit Batavia in optocht rondgedragen; in Batavia werd evenzo de brief van de Sultan van Palembang met groot ceremonieel ingehaald. Zo werd er elk seizoen precies volgens de bepalingen van het officiële contract gehandeld, zonder dat daarvan ook maar in 't minst werd afgeweken.

4.3. Toen Sultan Muhammad Baha'uddin al een aantal jaren vorst was op de troon van het Palembangse rijk, kwam er in zeker jaar weer een

19 commissaris met een oorlogsschip Palembang binnen om Sultan Muhammad Baha'uddin een bezoek te brengen en hem om de betaling van vierhonderd duizend rijksdaalders te verzoeken, waartoe Palembang zich bij verdrag had verbonden. Daarbij toonde de commissaris de verklaring van Sultan Mahmud Badaruddin die deze had afgegeven, toen hij, nog als Pangéran Jayawikrama, aan Batavia om hulp had gevraagd. Op dat ogenblik raakten, bij het zien van het oorlogsschip, de eenvoudige lieden in de hele stad Palembang in opschudding. De commissaris en de zijnen 
gingen intussen aan wal en begaven zich, voorzien van hun waardigheidstekenen, naar de Sultan van Palembang.

Sultan Muhammad Baha'uddin had toen een gesprek met de commissaris over die bij overeenkomst vastgestelde schuld van Palembang ten bedrage van vierhonderd duizend rijksdaalders en zei: "Het is inderdaad waar dat er een oude schuld bestaat van mijn grootvader jegens de Compagnie. Ik zou die schuld misschien wel in zijn geheel kunnen aflossen, maar de kleine man zou het heel wat moeite kosten dat bedrag op te brengen. Als we nu eens de helft betaalden, met andere woorden kunnen we de zaak niet afdoen met betaling van tweehonderd duizend rijksdaalders?!" Nadat Sultan Muhammad Baha'uddin zo gesproken had en daarbij een zodanig verzoek aan de Compagnie had gedaan, ging de commissaris met het voorstel van de Sultan van Palembang akkoord. Derhalve betaalde de Sultan van Palembang destijds slechts tweehonderd duizend rijksdaalders aan de commissaris, meer niet. De gezegelde verklaring werd toen door de commissaris aan Sultan Muhammad Baha'uddin teruggegeven.

4.4. Zo waren de zaken tussen Palembang en Batavia dus geregeld. Er 20 werd geen enkel verzoek van de kant van Palembang gedaan, of de Compagnie willigde het in en evenzo willigde de Sultan van Palembang elk redelijk verzoek van de Compagnie in. Het was zó, dat elk jaar de gezanten in Palembang het contract kwamen voorlezen voor alle ingezetenen van de stad, wie het maar horen wilde. Tijdens de plechtige optocht, waarin de brief uit Batavia werd rondgedragen, was het een geweldige drukte en werden er telkenjare met kanonnen en geweren een aantal saluutschoten gelost in tegenwoordigheid van de vorst van Palembang en het hoofd van de factorij. Alle ambtenaren en al degenen die een hoge positie bekleedden in de stad Palembang kwamen dan bijeen, maakten gezamenlijk hun opwachting in de grote audiëntiezaal en namen deel aan de maaltijd. Zo ging het elk jaar.

Het fort van de Compagnie noemde men in die tijd de loge of het Hollandse pakhuis. Wanneer de vorst van Palembang zich per vaartuig op weg begaf naar de kuststreken, loste de loge van de Compagnie een kanonschot als eerbewijs voor de Sultan van Palembang, maar als de Sultan van Palembang met de boot op reis ging naar het binnenland, werd er in de loge van de Compagnie geen kanonschot gelost, omdat men dat vanuit de Compagniesloge niet zien kon. Dat was in het contract voor altijd al zo geregeld. De vriendschappelijke betrekkingen van de Compagnie met de vorst in Palembang werden steeds inniger. 
Meermalen kwam het voor dat de goederen van Palembangse edelen door de Sultan van Palembang in beslag werden genomen, omdat ze tin aan de Engelsen verkochten. Veel mensen verkochten graag clandestien tin aan de Engelsen, omdat zij een prijs van zestien rijksdaalders per pikol betaalden, terwijl deze bij verkoop aan de Compagnie te Batavia acht rijksdaalders per pikol bedroeg, want dat was nu eenmaal

21 in het contract van Palembang met de Compagnie voorgoed zo overeengekomen.

Zolang Palembang met de Compagnie in vrede leefde, namen de rust en de veiligheid er steeds meer toe. De bevolking van het hele land met al zijn onderhorigheden beleefde een tijd van grote voorspoed, omdat er rust heerste in het land. De handelaars kwamen in groten getale binnen, zowel van overzee als van de vaste wal en uit het binnenland. Want de vorst van Palembang voerde in die tijd een zeer rechtvaardig en goedgeordend bestuur en beschermde zowel het eigen volk als de vreemdelingen.

5.

5.1. De regeringsperiode van Zijne Majesteit Sultan Muhammad Baha'uddin als vorst op de troon van het rijk Palembang duurde zevenentwintig jaar. Hij overleed in het jaar 1218, op de éénentwintigste dag van de maand Zulhijah, 's maandags om vier uur. Op die dag volgde zijn zoon Pangéran Ratu zijn vorstelijke vader op de troon van Palembang op onder de naam Sultan Mahmud Badaruddin. Dit geschiedde voor het forum van het gehele ambtenarencorps, de vreemdelingen, de geestelijkheid en het gewone volk te Palembang. Zijn oudste zoon kreeg toen de naam Pangéran Ratu.

Sultan Mahmud Badaruddin nu had drie volle broers. Aan de oudste van zijn jongere broers, Pangéran Adimenggala geheten, verleende hij de naam Pangéran Dipati, aan zijn in leeftijd op deze volgende broer,

22 Pangéran Adikesuma genaamd, verleende hij de naam Pangéran Aryakesuma en aan zijn jongste broer, die Pangéran Natakesuma heette, verleende hij de naam Pangéran Suryakesuma. De broers en zusters van Sultan Mahmud Badaruddin die een andere moeder hadden blijven hier onvermeld.

Als regerend vorst te Palembang resideerde Sultan Mahmud Badaruddin in de grote kraton, terwijl Pangéran Ratu, zijn zoon, in de kraton woonde die daar vlakbij was. De staatsinrichting van Palembang bleef precies zoals zij tevoren geweest was, de gehele ambtelijke organi- 
satie en alle instellingen bleven intact zoals ze in Palembang van oudsher gegolden hadden. Vooral werden de vriendschappelijke betrekkingen met de Compagnie steeds inniger en elk jaar werden er net als vroeger gezantschappen gezonden. In die tijd namelijk was de Maleis-Indonesische archipel in zijn geheel Hollands gebied; alleen op het eiland Pinang zaten de Engelsen, nergens anders.

5.2. Het was reeds enige tijd geleden dat Sultan Mahmud Badaruddin zijn vader als vorst op de troon van het Palembangse rijk was opgevolgd, toen in een bepaald jaar de Generaal van Batavia werd opgevolgd door een zekere Generaal Maarschalk. Zijn bewind was zeer streng, zo werd de Sultan van Palembang gerapporteerd, en verder bleef hij de prijs voor het tin uit Palembang schuldig; die had hij nog niet betaald, hij zou wel met rijst betalen. De gezanten van Palembang wilden dit niet

23 accepteren, want zo was de afspraak niet en als er dit jaar geen geld werd betaald, zou er volgend jaar wellicht geen tin uit Palembang worden uitgevoerd, omdat men dan geen werkkapitaal zou hebben.

Daarop zei de Generaal Maarschalk dat als er geen tin zou worden uitgevoerd men er van op aan kon dat troepen de stad Palembang zouden binnenrukken en dat hij dan bovendien de tinprijs zou verlagen tot beneden het peil dat tot dusver steeds gegolden had. De gezanten van Palembang accepteerden dit evenwel niet, omdat het niet de afspraak was en omdat ook nog vele andere regelingen gewijzigd waren. Toen keerden de gezanten naar Palembang terug en vertelden aan de Sultan van Palembang wat de Generaal Maarschalk precies gezegd had.

Ook kreeg de Sultan van Palembang bericht dat de Generaal Maarschalk van plan was Palembang aan te vallen. Daarom verzamelde de Sultan van Palembang het volk en het hele ambtenarencorps om benedenstrooms van de stad versterkingen aan te leggen, en wel op Borang en op de vastewal er tegenover; en de inwoners van de districten in het gebied van de Negen Rivieren kregen order de rivier af te zakken om ook aan die versterkingen op Borang te werken. Het was een drukte van belang, toen alle edelen en ambtenaren op Borang bijeen waren om te werken. Hun hoofd was de broer van de sultan, namelijk Pangéran Aryakesuma. In die tijd zaten de Hollanders nog in de loge van Palembang.

6.

6.1. Niet lang daarna ontving de Sultan van Palembang van de kant van de Arabieren de tijding dat de Engelsen op het eiland Pinang alle 
handelsvaartuigen vasthielden en geen vergunning gaven om uit te 24 varen. De Sultan van Palembang schrok, toen hij dat nieuws over de Engelsen vernam. Dat zij de handelaars binnenhielden en hen niet lieten uitvaren vond zijn oorzaak in het feit dat de Engelsen oorlog wilden voeren, waar precies was nog niet bekend.

Daarom zond de Sultan van Palembang in het geheim twee ambtenaren als gezanten naar de Engelsen, buiten medeweten van de Hollanders in Palembang. Die twee ambtenaren nu vertrokken met een brief van de Sultan van Palembang naar het eiland Pinang zonder dat men het in Palembang merkte. Nadat de gezanten van de Sultan van Palembang bij de Engelsen waren aangekomen, werd de brief van de Sultan van Palembang door de Engelsen met groot ceremonieel ontvangen en werd aan die ambtenaren-gezanten te kennen gegeven dat de Engelsen van plan waren Batavia aan te vallen en nog bezig waren soldaten op de been te brengen. De gezanten van Palembang antwoordden daarop: "Wat, mijnheer, moet er dan met de Hollanders in Palembang gebeuren?" Toen zeiden de Engelsen: "Laat de Sultan alle Hollanders die in Palembang zijn wegjagen, dat wil zeggen het land uitzetten. Als ze zich verzetten, moet de Sultan van Palembang maar naar eigen goeddunken handelen, want hij heeft het in zijn eigen land voor het zeggen. Maar wanneer Batavia eenmaal door de Engelsen is overmeesterd, mag hun niets meer worden aangedaan; dan moet het aan de Engelsen worden overgelaten om de Hollanders met z'n allen uit Palembang te verwijderen. Als de Sultan van Palembang hen uit het land wil zetten, dan staat hem dat op dit moment, nu de Engelsen immers nog niet tot de aanval zijn overgegaan, geheel vrij, want het is zijn land." Daarop antwoordden de Palembangse gezanten: "Hoe zou dat mogelijk zijn, mijnheer? Immers de Hollandse loge in Palembang is een stenen fort, dat heel sterk is en over voldoende kanonnen en soldaten beschikt, 25 terwijl de stad Palembang wapens te kort komt en bovendien de Palembangers niet gewend zijn oorlog te voeren." Volgens de berichten gaven de Engelsen toen voor de Sultan van Palembang enige kisten met geweren mee met de bijbehorende munitie, waarna de gezanten huiswaarts keerden.

6.2. $\mathrm{Na}$ aankomst te Palembang deelden zij al wat de Engelsen gezegd hadden aan de Sultan van Palembang mede. Daarop liet de Sultan te Palembang de waakzaamheid in het land verhogen. In Sungsang werden enige ambtenaren op de uitkijk gezet en ook in Muntok nog enkele ambtenaren, die daar om beurten de wacht hielden; als er een Engels 
of een Hollands vaartuig uit Batavia zou aankomen, wilde de sultan het terstond weten. Alle raadslieden in Palembang hadden als hun eenstemmig oordeel uitgesproken: "Wat het verdrijven van de Compagnie te Palembang conform het advies van de Engelsen betreft, dat zou juist zijn voor het geval Batavia door de Engelsen zou worden veroverd. Ingeval Batavia niet door de Engelsen zou worden veroverd, zou dat echter verkeerd zijn, aangezien de Hollanders van oudsher de vrienden van Palembang zijn geweest. Er blijft ons dus niets anders over dan af te wachten wie de strijd om Batavia zal winnen."

Omdat men bij het overleg in Palembang tot deze conclusie was gekomen, dáárom stonden er in Sungsang en in Muntok dus ambtenaren op de uitkijk. Wanneer men bericht zou krijgen of Batavia al dan niet door de Engelsen was veroverd, moest men ervoor waken dat het aan geen enkele inwoner van de stad bekend werd, want anders zouden de Hollanders in Palembang het wel eens te weten kunnen komen. Er waren immers al heel veel Engelse vaartuigen uit het westen overgestoken naar Java. In die tijd kwam er geen enkele handelaar uit Java

26 naar Palembang of naar het westen, zodat men niet op de hoogte was van het nieuws uit Batavia. Ook van de Palembangers, die toentertijd in groten getale op Java verbleven, was er niet één die overkwam; er kwam zelfs geen brief of tijding van hen. Behalve de Engelse schepen was er in die tijd niet één handelsvaartuig dat op de Javazee voer, zodat ook de Compagnie te Palembang geen enkele brief uit Batavia ontving. Het volk van Palembang verkeerde toen in moeilijke omstandigheden, doordat er geen handelaars aankwamen uit Java.

6.3. De Sultan van Palembang hield niet op de bewaking van de stad en aan de riviermonding te verscherpen, steeds harder werkten edelen en ambtenaren aan de vestingwerken: een fort op Borang met een batterij kanonnen en een bezetting, op het eiland Anyar een fort met een batterij en een bezetting, verder stroomopwaarts in Rawa-Rawa Sekampung een fort met een batterij en een bezetting, benedenstrooms van oud-Palembang een fort met een batterij en een bezetting, te Batu Ampar een fort met een batterij en een bezetting en op de berg Méru een fort met een batterij en een bezetting. Al die forten lagen aan de oever van de rivier; ze hadden een aantal pangérans als vaste commandanten en verder een bezetting van ambtenaren, officieren en manschappen zowel uit Palembang als uit de bovenlanden, want alle hoofden van de bovenlanddistricten waren naar Palembang opgeroepen.

27 Een tijdlang was de stad Palembang zo voortdurend waakzaam, 
steeds maar wachtend op nieuws uit Batavia. Verscheidene ambtenaren hielden in die tijd de wacht aan de monding van de Sungsang en in Muntok en elk binnenkomend handelsvaartuig, hoe klein ook, werd streng onderzocht.

6.4. Op zekere avond arriveerde er een Arabier, Said Zain Bafakih genaamd, die bij de Sultan in Palembang werd gebracht. Die Said Zain Bafakih was een vluchteling uit Java, die er op de een of andere wijze in geslaagd was te ontkomen. Deze Said Zain Bafakih was 't die het betrouwbare en stellige nieuws meebracht dat Batavia door de Engelsen was veroverd en dat verscheidene handelsvaartuigen op de rede van Batavia door de Engelsen waren vernietigd, toen deze Batavia kwamen beoorlogen. De schepen die te laat op de vlucht waren geslagen, hadden ze met kanonvuur bestookt; verscheidene handelaars hadden de dood gevonden en er waren ook Palembangers op die handelsvaartuigen omgekomen. Said Zain Bafakih rapporteerde aan de Sultan van Palembang dat hij zelf had gezien dat de Generaal te Batavia zich met al zijn troepen had teruggetrokken. Batavia was nu in Engelse handen en er heerste een ander régime.

6.5. Toen Said Zain Bafakih die ontmoeting had met de sultan, was het twaalf uur in de nacht. De volgende morgen begaf de sultan zich naar de audiëntiezaal, riep alle ambtenaren en burgers bijeen en gaf hun 28 bevel de hele Hollandse Compagnie uit haar loge te verdrijven.

Toen gingen de edelen en de ambtenaren er met volk en wapens heen, zodat de Compagniesloge tenslotte vol burgers, edelen en ambtenaren was. Zo werd de hele Compagnie verrast. Allen, de vooraanstaande personen alsmede de Hollandse en Javaanse soldaten, werden met vrouwen en kinderen naar buiten gedreven en op een vrachtvaartuig ingescheept, de Javanen op een aparte vrachtboot. Die beide vaartuigen werden in de rivier voor anker gelegd ter hoogte van de aanlegplaats van Kidemang Saléh.

Het tijdstip waarop de Compagnie uit haar fort werd verdreven, viel in het jaar 1226, op de achtentwintigste dag van de maand Syacban, dinsdag om vier uur; en op de derde dag van de maand Ramadan, op zondag, werd bevel gegeven die beide vaartuigen uit de monding van de Sungsang te doen uitvaren. Voorts liet de sultan op de derde Ramadan een begin maken met de afbraak van het fort en van alle woningen van de Compagnie.

Zo was er een einde gekomen aan het bestaan van de Hollandse 
Compagnie in Palembang, zó dat er zelfs geen klein kind meer aanwezig was. Slechts één Hollander, meneer Willem genaamd, en diens moeder, die een Palembangse was, wisten te ontkomen door het bos in te vluchten, waar ze later door de bevolking werden opgepikt. Vervolgens liet de sultan hem naar het binnenland verbannen, naar het dorp Buri, en werd hij opgenomen in de Islam. Nadat de afbraak van het Hollandse

29 fort voltooid was, werd er in Palembang nóg harder gewerkt aan de aanleg der versterkingen en de verbetering van de bewapening.

7.

7.1. Enige tijd later arriveerde er een gezantschap van de Engelsen in Palembang, dat bij de sultan navraag kwam doen, waar de Hollanders die in Palembang gevestigd waren geweest allemaal gebleven waren. De sultan zei: "Die zijn al lang geleden uit Palembang verwijderd. Zodra daartoe eertijds van Engelse zijde het bevel was gegeven, zijn ze weggestuurd, nog voordat Batavia door de Engelsen was veroverd." Toen de Engelsen wilden zien waar de Hollandse loge vroeger gestaan had, zeiden de ambtenaren te Palembang: "Dat is hier ver vandaan en er is daar veel slecht volk." Die gezanten waren ondergebracht ten huize van Kidemang Saléh en kregen een verzorging zoals voor hoge functionarissen gebruikelijk was. Vervolgens keerden de Engelse gezanten naar Batavia terug.

Niet lang daarna kwamen er weer Engelse gezanten binnen: twee Arabieren, namelijk Pangéran Syarif Muhammad en Said Bakar Rum. Die beiden kwamen in Palembang en begaven zich naar de sultan. Om welke reden dan ook, na enkele dagen reeds vluchtten die gezanten met z'n beiden uit Palembang weg, want ze hadden het vermoeden dat ze door de Sultan van Palembang vermoord zouden worden.

7.2. Na verloop van enige tijd zond de Sultan van Palembang op zijn beurt een gezantschap naar Batavia, zoals het behoorde volgens aloud Palembangs gebruik. De twee ambtenaren die als gezanten werden uitgezonden heetten Temenggung Suranandita en Temenggung Suradiraja en ze werden afgevaardigd als afgezanten naar General Raffles te

30 Batavia. Toen die gezanten in Batavia arriveerden, werden ze door de Engelsen op dezelfde wijze ontvangen als vroeger de Hollanders dat plachten te doen. Daarna vroeg General Raffles: "Waar zijn de Hollanders gebleven die in Palembang waren?" De Palembangse gezanten antwoordden: "Die zijn al lang geleden het land uitgezet, nog voordat 
Batavia door de Engelsen werd veroverd." Toen zei General Raffles: "Waar zijn ze naar toe gegaan? Want hier zijn ze niet aangekomen." Daarop antwoordden de Palembangse gezanten: "Toen ze vertrokken, zeilden ze in westelijke richting." Wat de verzorging van die twee temenggungs-gezanten door de Engelsen betreft, daar viel niets op aan te merken.

De Palembangse gezanten waren nog niet zo lang in Batavia, of daar kwamen Pangéran Syarif Muhammad en Said Bakar Rum met de volgende klacht bij General Raffles te Batavia. Toen zij met z'n tweeën naar Palembang waren uitgezonden, waren ze bijna door de Sultan van Palembang vermoord; als ze niet bijtijds gevlucht waren, zouden zij beiden vast en zeker gedood zijn. En wat de Hollanders betreft die in Palembang waren: zodra Batavia in Engelse handen was overgegaan, waren alle Hollanders daar in Palembang door de Sultan van Palembang naar buiten gedreven en, buiten de monding van de Sungsang aangekomen, tot de laatste man gedood.

Die Pangéran Syarif Muhammad nu was van afkomst een Palembanger; zijn moeder was een Palembangse dénayu, zijn vader was een Arabier. Pangéran Syarif Muhammad had een Muntokse vrouw getrouwd, die tot de bevolkingsgroep der Yang behoorde. Toen hij haar meenam naar Palembang, werd dit de Sultan van Palembang bekend. Niemand mocht een Muntokse uit de Yang-groep tot vrouw nemen behalve de vorst van Palembang. Daarom werd hij door de Sultan

31 van Palembang van die vrouw van hem gescheiden. Pangéran Syarif Muhammad was zeer gegriefd vanwege het feit dat zijn vrouw hem was ontnomen. Daarom trok Pangéran Muhammad uit Palembang weg en vestigde zich in Kedah; later trad hij in dienst van de Engelsen. Zo is de voorgeschiedenis van Pangéran Syarif Muhammad.

8.

8.1. Keren wij terug tot General Raffles. Toen hij de aanklacht van Pangéran Syarif Muhammad hoorde, namelijk dat de Hollanders in Palembang tot de laatste man waren verdreven nadat Batavia in Engelse handen was overgegaan, was General Raffles hevig geschrokken. Op een dag kwam op het bestuurskantoor van Batavia General Raffles naar buiten en ontbood de twee temenggungs-gezanten van Palembang. Nadat ze verschenen waren, werden ze ondervraagd, maar die gezanten gaven niet toe wat er over de Hollanders in Palembang gezegd was. Daarop werd die twee gezanten hun kris afgenomen; vervolgens werden ze aan boord van een oorlogsschip gebracht en allebei opgesloten. Het 
vaartuig van de Palembangse gezanten werd verbeurd verklaard en geheel onttakeld.

In die tijd nu gaf General Raffles bevel aan General Gillespie om met een vloot naar Palembang te gaan. De Palembangse gezanten werden aan boord gebracht van het schip waarop General Gillespie zich bevond, en Pangéran Syarif Muhammad eveneens. Toen vertrok General Gillespie naar Palembang met verscheidene schepen en andere vaartuigen, voorzien van een complete oorlogsuitrusting.

8.2. De geschiedenis verhaalt nu weer over Zijne Majesteit Sultan 32 Mahmud Badaruddin, die de vorstelijke heerschappij uitoefende in $\mathrm{Pa}$ lembang. Deze nu was voortdurend bezig de toestand van de stad te verbeteren en de vestingwerken op Borang en in de stad te versterken. De kanonnen op de stenen wallen werden allemaal in orde gebracht en voor de beide kratons in Palembang was een vaste bezetting aangewezen. Voorts verzamelde hij al het volk van Banka en het volk van Billiton. Ook werden alle mensen van het binnenland opgeroepen om gewapend naar Palembang te komen. De ambtenaren en de pangérans met name waren allemaal op hun post in het fort Borang en in de andere vestingwerken, die elk een eigen bezetting hadden. De Sultan van Palembang was namelijk bang dat de Engelsen misschien een aanval op de stad Palembang zouden komen doen, want er was veel slecht nieuws binnengekomen.

8.3. Zijne Majesteit Sultan Mahmud Badaruddin was negen jaar vorst in Palembang, toen de Engelse expeditie onder General Gillespie verscheen. Op 11 Rabicul-akhir van het jaar 1227 kwam de vloot van General Gillespie bij het fort Borang aan. Commandant in het fort Borang was Pangéran Dipati, die de officiële vertegenwoordiger was van de Sultan van Palembang, en met hem waren daar zijn broers Pangéran Aryakesuma en Pangéran Surya. Daarover zullen we hier nu niet verder uitweiden.

Op een avond gaf Pangéran Dipati in het fort Borang aan alle amb-

33 tenaren en aan het gehele volk bevel om, indien de vloot van General Gillespie de volgende ochtend vroeg naar Palembang zou doorvaren, niet te schieten; want hij was van plan vredesonderhandelingen te voeren. Heel vroeg in de morgen voer Pangéran Dipati stroomopwaarts naar Palembang, met Pangéran Arya en Pangéran Surya en met alle ambtenaren en al het volk, om 't hardst haastten zij zich terug naar Palembang. Zo kwam het, dat het fort geheel verlaten was en er in dat 
hele complex van vestingwerken niemand meer aanwezig was. Toen voer de vloot van General Gillespie door naar Palembang, met alle vaartuigen, groot en klein.

8.4. Zodra de Sultan in Palembang vernam dat de vloot van General Gillespie al dicht in de buurt was en het fort Borang had bereikt, maakte hij zich klaar voor de strijd; wanneer het fort Borang door de Engelsen zou worden veroverd, wilde hij stand houden in Palembang. Tevens evacueerde de Sultan te Palembang alle vrouwen uit de kraton met een aantal vaartuigen, liet goud en realen aan boord brengen en belaadde enkele vaartuigen met wapens. Men kreeg opdracht aan wal te gaan op een plek die één dag varen stroomopwaarts van de stad was gelegen en Muara Belidah heette; dàt was de plaats waar de kratonbewoonsters zich voorlopig met de bezittingen moesten vestigen. De sultan echter bleef in de kraton met de ambtenaren en het gewone volk de komst van de vijand afwachten.

Intussen arriveerde Pangéran Dipati uit Borang. Hij verscheen voor 34 de sultan en vertelde dat het fort Borang in handen van General Gillespie was gevallen, omdat de Palembangers tot de laatste man gevlucht waren. De sultan schrok en zei: "Laat ons hier gezamenlijk standhouden!" Daarop sprak Pangéran Dipati eerbiedig: "Hier in de kraton bevinden zich nu alleen nog maar onaanzienlijke lieden en daarbuiten zijn allen zonder uitzondering op de vlucht geslagen. Gaat $U$, mijn vorstelijke oudere broer, maar naar het binnenland als $U$ wilt, want allen die in de kraton woonden zijn reeds met goederen en al aan boord van de vaartuigen. Laat mij maar de komst van General Gillespie afwachten. Wat hij ook wil, hetzij oorlog hetzij onderhandelingen, ik zal zijn tegenpartij zijn." Daarop werden hem door de sultan de zorg voor de kraton en de regeling van de zaken met de Engelsen toevertrouwd.

Op vrijdag de twaalfde Rabicul-akhir van het jaar 1227, 's avonds om acht uur verliet Zijne Majesteit Sultan Mahmud Badaruddin de troon van het rijk Palembang, scheepte zich in en vertrok. Nadat de sultan aan boord gegaan en naar het binnenland was vertrokken, vertrok op zijn beurt Pangéran Dipati ook. Hij evacueerde de vrouwen naar het dorp Tanjung Saga, terwijl Pangéran Arya met Pangéran Surya verder stroomopwaarts voer om de vrouwen te evacueren naar het dorp Tempiri.

Op zaterdag, de dertiende Rabicul-akhir, 's avonds om acht uur trok General Gillespie de kraton van Palembang binnen en op vrijdag de 
35 achttiende van dezelfde maand, 's ochtends om zes uur hesen de Engelsen de Engelse vlag op de kraton van Palembang. Zaterdag, de negentiende van diezelfde maand had Pangéran Dipati een ontmoeting met General Gillespie.

8.5. General Gillespie zond toen iemand naar de Sultan van Palembang in Muara Belidah met de boodschap dat de generaal een ontmoeting wilde hebben met de sultan. Als de sultan hem niet wilde ontmoeten, zou hij straks een ander als vorst in Palembang aanstellen. De sultan antwoordde dat hij geen vorst meer wilde zijn en dat de generaal maar als vorst moest aanstellen wie zulks begeerde. Daarbij gaf Sultan Mahmud Badaruddin een gezegelde verklaring af, luidende: "Wie vorst worden wil, die stelle men als zodanig aan; op mij moet men niet meer rekenen."

Nadat de gezant met die boodschap bij General Gillespie was aangekomen, zei General Gillespie tegen Pangéran Dipati dat hij hem als vorst in Palembang wilde aanstellen. De pangéran antwoordde dat hij dit zou accepteren, indien Sultan Mahmud Badaruddin ermee instemde dat hij vorst werd, maar dat hij graag nog een tweede verklaring op zegel wilde hebben.

Toen zond General Gillespie nogmaals een boodschapper naar Sultan Mahmud Badaruddin. Deze gaf wederom een van het ambtsstempel voorziene verklaring af dat hij ermee instemde dat Pangéran Dipati vorst zou worden in Palembang. De boodschapper keerde naar General Gillespie terug en gaf hem de verklaring van de sultan. General Gillespie overhandigde die verklaring vervolgens weer aan Pangéran Dipati, ter-

36 wijl de eerste verklaring door de generaal werd behouden.

8.6. Toen verzamelden de Engelse troepen en alle ambtenaren en burgers van Palembang zich in de uit twee gedeelten bestaande ontvangzaal binnen de Palembangse kraton. Ten overstaan van General Gillespie werd Pangéran Dipati geïnstalleerd als vorst op de troon van het Palembangse rijk met de titel Zijne Majesteit Sultan Ahmad Najamuddin; dit geschiedde op donderdag, de tweede Jumadil-awal, van het jaar 1227, om negen uur. Tegelijkertijd werd de Engelse vlag van de kraton van Palembang neergehaald en vervangen door de witte vlag.

Op de zesde dag van diezelfde maand verliet General Gillespie de kraton van Palembang, waarna allen zich inscheepten en vervolgens de rivier afvoeren naar Sungsang. Er bleven nog wel Engelsen in Palembang achter; Sultan Ahmad Najamuddin had dat gevraagd, omdat de 
stad nog in opschudding verkeerde. De naam van de commandant van die Engelsen was Villarubi en ze werden door de sultan in de oude kraton gelegerd om Palembang te bewaken.

9.

9.1. Nu wordt weer verteld over Sultan Mahmud Badaruddin, die met al zijn volk en zijn hele troepenmacht verder de rivier de Musi was opgevaren tot aan het dorp Pulaupanggung. Toen hij daar een maand was, kwam Sultan Mahmud Badaruddin het nieuws ter ore dat zijn jongere broer door de Engelsen tot vorst van Palembang was aangesteld,

37 met de titel Sultan Ahmad Najamuddin. Daarop voer Sultan Mahmud Badaruddin met al zijn volk weer stroomafwaarts, hield stil in het dorp Buaya Langu, legde er versterkingen aan en riep de bevolking en een flink aantal Maleiers bijeen. Die versterkingen werden aangelegd aan weerszijden van de rivier en bemand met de edelen en ambtenaren die hem gevolgd waren.

Het kwam de Sultan in Palembang ter ore dat zijn oudere broer zich in Buaya Langu terdege had verschanst en dat bovendien heel wat mensen zich daar verzameld hadden mèt hun wapens en van plan waren naar Palembang af te zakken teneinde de stad Palembang te veroveren. Vervolgens gaf Sultan Ahmad Najamuddin daarvan kennis aan de Engelsen te Muntok en berichtte hun dat Sultan Mahmud Badaruddin op zijn tocht stroomafwaarts in het dorp Buaya Langu had stilgehouden en er zeer sterke vestingwerken had aangelegd, terwijl voorts vele mensen daar verzameld waren met hun volledige uitrusting en bewapening en op het punt stonden verder naar Palembang af te zakken om Palembang te veroveren.

9.2. Zodra de Engelsen dat gehoord hadden, voer er een flinke militaire macht vanuit Muntok naar Palembang en vervolgens verder stroomopwaarts. Hun commandant heette Major Meares. Hij nam een aantal edelen en ambtenaren uit Palembang mee en een paar vaartuigen. $\mathrm{Na}$ enige tijd bereikte die vloot op zijn tocht stroomopwaarts het dorp Buaya Langu. Vervolgens ontbrandde er een hevig gevecht tussen de

38 Engelsen en Sultan Mahmud Badaruddin, waarbij ettelijke vaartuigen midden op de rivier met elkaar slag leverden. Toen trokken de Engelsen zich terug en gingen benedenstrooms van de vestingwerken aan wal, waarna ze met een groep soldaten vanuit het bos oprukten. Diezelfde dag nog werden de vestingwerken van Buaya Langu door de Engelsen 
ingenomen. Maar hun commandant Major Meares raakte zwaargewond door een schot in zijn buik; toen trokken ze terug en werden de vestingwerken in brand gestoken.

Er waren heel wat gesneuvelden, ook onder de radéns waren doden en gewonden. De patih van de binnenland-sultan, Pangéran Wiradinata genaamd, was in Engelse handen gevallen; hij werd door de Engelsen op hun terugtocht meegenomen en aan de Sultan in Palembang overgeleverd. De Sultan in Palembang gaf het bevel hem naar Batavia over te brengen. Vervolgens werd hij op transport gesteld naar Batavia, maar onderweg overleed hij. Wat Major Meares betreft, die in de strijd gewond was geraakt, deze stierf na aankomst op Kaap Kalian in Muntok.

9.3. Keren wij nu weer terug tot Sultan Mahmud Badaruddin, die daar in het binnenland verbleef. Nadat de vestingwerken van Buaya Langu door de Engelsen veroverd waren en de Engelsen zich naar Palembang hadden teruggetrokken, voer de binnenland-sultan verder stroomopwaarts. Met al de zijnen hield hij stil in Muara Rawas, legde er een groot fort aan en verzamelde de binnenlandbevolking, de Maleiers van de Jambise bovenlanden en de Maleiers van Padang; zij allen kwamen in het fort van Muara Rawas bijeen met hun volledige bewapening. Maar de Engelsen verschenen niet meer om een aanval te doen.

39 Toen beval de sultan die in Palembang zat een aantal pangérans en ambtenaren benedenstrooms van Muara Rawas ook een fort te bouwen en er de wacht te houden voor het geval de binnenland-sultan misschien de rivier zou afzakken om Palembang te gaan veroveren. Stroomopwaarts varen werd hun verboden, slechts stroomafwaarts varen was toegestaan. Hoewel men dus niet nog verder het binnenland in mocht varen, vonden er toch herhaaldelijk nachtelijke steekpartijen plaats tussen de Palembangers en de Maleiers over en weer. Zo gebeurde het dat zij elkaar onophoudelijk met lontgeweren en gewone geweren beschoten, de Palembangers en de Maleiers die tot het volk van de binnenlandsultan behoorden.

9.4. Het was al anderhalf jaar zo dat de binnenland-sultan in Muara Rawas verblijf hield, toen een zekere Kemas Muhammad Hanafi toestemming vroeg om van Palembang naar Rawas te gaan teneinde zijn zuster op te zoeken, die één van de vrouwen van de sultan was. Na zijn aankomst in Muara Rawas nam Kemas Muhammad op zich de binnenland-sultan met de Engelsen te verzoenen. De binnenland-sultan kwam toen met Kemas Muhammad overeen dat indien er een verzoening met 
de Engelsen tot stand zou komen en hij zou mogen terugkeren om zich te Palembang weer te vestigen in de kraton, dat de sultan Kemas Muhammad dan tot schoonzoon zou nemen. Nadat de binnenlandsultan dit met Kemas Muhammad had afgesproken, keerde Kemas Muhammad naar Palembang terug, zonder dat iemand iets afwist van wat er besproken was; zogenaamd had hij alleen maar zijn zuster opgezocht daar in Muara Rawas.

In Palembang aangekomen vervolgde de kemas zijn reis en stak over naar Muntok, want in de Engelse tijd was het opperbestuur in Muntok gevestigd. Daar presenteerde de kemas zich als afgezant van de binnenland-sultan, uitgezonden om om vrede te vragen. Als de binnenland-

40 sultan vergiffenis zou krijgen en toestemming om naar Palembang terug te keren, dan zou hij de grote kraton kopen voor de prijs van vierhonderd duizend rijksdaalders in contant geld, met de regeling dat de koop zou doorgaan ook al kwam hij niet meer aan de regering en al zou dus alleen de kraton het eigendom van de sultan worden. Het resultaat van die besprekingen was dat het voorstel door de Engelsen werd aanvaard.

9.5. Niet lang daarna arriveerde een zekere Major Robison in Palembang; hij had maar een gering aantal soldaten bij zich. Vervolgens bracht hij de sultan te Palembang een bezoek en zei hem dat hij vaartuigen wilde hebben om de sultan die zich in Muara Rawas bevond te gaan opzoeken, want waar zou dat voortdurend de wacht houden en zich verschansen op uitlopen! Daarop werden door de Sultan van $\mathrm{Pa}$ lembang vaartuigen ter beschikking gesteld en een aantal lieden die mee zouden gaan; maar terwijl hij dat deed was de sultan daar in Palembang niet op de hoogte van de plannen van de binnenland-sultan.

Zo vertrok, toen de vaartuigen volledig uitgerust waren, de expeditie van Major Robison, bestaande uit een flink aantal vaartuigen en het meegegeven geleide, naar het binnenland. Bij het fort van de Sultan van Palembang aangekomen beval Major Robison de edelen en ambtenaren die over dat fort het commando voerden het fort te verlaten en hun boten stuk voor stuk mee te nemen. Al die edelen en ambtenaren nam Major Robison mee op zijn tocht verder stroomopwaarts naar de binnenland-sultan.

Nadat Major Robison in Muara Rawas was aangekomen, had hij een ontmoeting met de binnenland-sultan in het fort te Muara Rawas, terwijl er bij die gelegenheid saluutschoten gelost werden en een geweldig feest-

41 maal werd gehouden. En de edelen en ambtenaren die uit het Palembangse fort afkomstig waren, moesten op bevel van Major Robison de 
binnenland-sultan op hun knieën om vergiffenis smeken.

Toen voer binnenland-sultan Mahmud Badaruddin met al zijn volk van Muara Rawas terug naar Palembang. Sultan Mahmud Badaruddin uit het binnenland nu nam zijn intrek in de grote kraton, want die had hij immers gekocht voor vierhonderd duizend rijksdaalders; en de jonge sultan, Ahmad Najamuddin, verhuisde met al zijn volk naar de oude kraton. Aan de majoor, die de sultan in Muara Rawas had afgehaald, gaf deze een beloning van vijfduizend rijksdaalders.

10.

10.1. Toen Sultan Mahmud Badaruddin eenmaal goed en wel in de grote kraton woonde, vertrok Major Robison naar Batavia. Pangéran Ratu en Pangéran Adimenggala, de zoons van de oude sultan, nam hij mee om te gaan bedanken voor het feit dat de sultan verzoening had verkregen en dat hem door de Engelsen vergiffenis was geschonken. Zo gingen Pangéran Ratu en Pangéran Adimenggala naar Batavia in gezelschap van een aantal edelen en ambtenaren die door Major Robison werden meegenomen, tezamen met een afgezant van de jonge sultan Ahmad Najamuddin.

$\mathrm{Na}$ aankomst te Batavia deelde Pangéran Wiradiraja, de gezant van 42 de jonge sultan Ahmad Najamuddin, aan General Gillespie mee dat de jonge sultan uit de grote kraton was gezet en overgebracht naar de oude kraton zonder dat hij iets misdaan had en dat de binnenlandsultan weer de troon had bestegen in Palembang. General Raffles schrok en vroeg wie dat zo geregeld had. Het bleek duidelijk dat Major Robisons beleid om voor de kraton een prijs van vierhonderd duizend rijksdaalders aan te nemen niet de instemming van General Raffles had. Daarom werd Major Robison te Batavia gevangen gehouden, vier uur lang.

10.2. Toen gaf General Raffles de zoon van de koning van Bengalen bevel naar Palembang te gaan om Sultan Mahmud Badaruddin uit de grote kraton te zetten en naar de oude kraton te doen verhuizen en de jonge sultan Ahmad Najamuddin zijn intrek te laten nemen in de grote kraton. Pangéran Ratu werd in Batavia vastgehouden, omdat er uit Palembang nog veel meer intriges bekend geworden waren; Pangéran Adimenggala en de edelen mochten echter allemaal naar Palembang terugkeren. De zoon van de koning van Bengalen vertrok toen met bijna tweeduizend soldaten. In Palembang aangekomen liet hij de oude sultan 
de grote kraton ontruimen en de jonge sultan Ahmad Najamuddin er zijn intrek nemen. De oude sultan verhuisde naar de oude kraton, regeerde niet meer over het land, maar trok zich geheel uit de staatszaken terug.

10.3. Wat Kemas Muhammad betreft die de verzoening had bewerk43 stelligd, deze werd door Sultan Mahmud Badaruddin toen als schoonzoon aangenomen; hij werd in het huwelijk verbonden met een dochter van de sultan bij een bijvrouw, waarna hij Pangéran Kramadiraja werd genaamd. Pangéran Kramadiraja was het die de woordvoerder werd van Sultan Mahmud Badaruddin en als leider van een gezantschap samen met Major Robison naar Bengalen ging. Degenen die in opdracht van Sultan Mahmud Badaruddin als gezanten naar Bengalen werden gezonden, waren ten eerste Pangéran Kramadiraja en verder Pangéran Natadiwangsa en Pangéran Sutadiwangsa, Temenggung Kertanegara, Rangga Ahmad en nog een ngabéhi. Zij allen vertrokken aan boord van een Engels schip samen met Major Robison van Batavia naar Bengalen.

$\mathrm{Na}$ enige tijd kwamen zij in Bengalen aan, waar ze door de Generaal van Bengalen werden ontvangen op de wijze waarop men gezanten pleegt te ontvangen. Toen voerden die Palembangse gezanten gezamenlijk besprekingen met de Generaal van Bengalen, daarin bijgestaan door Major Robison. Er werd toen in Bengalen uiteindelijk besloten dat Sultan Mahmud Badaruddin geen koning meer zou zijn in Palembang; trouwens hij had nu eenmaal een gezegelde verklaring afgegeven dat hij er mee instemde dat zijn jongere broer, Pangéran Dipati, sultan werd in Palembang.

Sultan Mahmud Badaruddin zou in de oude kraton blijven wonen, niet meer regeren en slechts rijst en werkvolk krijgen van zijn jongere

44 broer Sultan Ahmad Najamuddin. Zo luidde het bevel uit Bengalen. Wat het geldsbedrag van vierhonderd duizend rijksdaalders, de prijs van de grote kraton te Palembang, betreft, dit werd door de Generaal van Bengalen gerestitueerd, en wel met rente, overeenkomstig de regels die ten aanzien van handelsgelden van toepassing zijn. Pangéran Ratu, die te Batavia werd vastgehouden, mocht naar Palembang terugkeren en de gezanten in Bengalen eveneens. Sultan Mahmud Badaruddin bleef dus als ambteloos burger in de oude kraton wonen en liet zich met geen enkele zaak meer in. Maar elk geschikt jaargetijde zond hij Pangéran Kramadiraja naar Batavia uit; wat er dan allemaal besproken werd, is niet bekend. 
10.4. De jonge sultan Ahmad Najamuddin was nu degeen die als vorst op de troon de regering uitoefende over Palembang, net als vroeger. Alleen behoorde Banka nog maar voor de helft toe aan de Sultan van Palembang, de andere helft hadden de Engelsen aan zich getrokken. $\mathrm{Na}$ een jaar kwam er een brief uit Batavia, gericht aan de Sultan van Palembang: „Wat dat Banka betreft, als het gedeelte dat aan de Sultan van Palembang was blijven behoren te koop was, dan zouden de Engelsen dat wel willen kopen." Toen werd dat deel van Banka door de Sultan van Palembang aan de Engelsen verkocht; er werden vijf kisten goud voor ontvangen, hoeveel dat waard was weten we niet.

De verhouding van Palembang met de Engelsen was nu op overeenkomstige wijze geregeld als eertijds met de Hollanders: de Engelsen waren wel in Palembang gevestigd, maar ze mengden zich volstrekt niet

45 in het bestuur; alle staatszaken bleven tot de competentie van de sultan behoren. Aan verscheidene pangérans en ambtenaren gaf Sultan Ahmad Najamuddin nu een nieuwe naam. Zijn broers Pangéran Aryakesuma en Pangéran Suryakesuma kregen een andere naam: Pangéran Aryakesuma werd verheven tot Pangéran Dipati en Pangéran Suryakesuma tot Pangéran Aryakesuma. Aan zijn oudste zoon gaf Sultan Ahmad Najamuddin de naam Prabu Anom, de in leeftijd op hem volgende de naam Pangéran Jayaningrat, de in leeftijd weer op deze volgende de naam Pangéran Jayakrama en de jongste de naam Pangéran Citradiningrat. Tussen Palembang en Batavia waren de betrekkingen precies als vroeger tijdens de Hollanders: er werd elk jaar een gezantschap gezonden, dat onder leiding stond van Pangéran Wiradiraja.

11.

11.1. Toen Sultan Ahmad Najamuddin zeven jaar vorst was in Palembang, werden de Engelsen opgevolgd, dat wil zeggen de Hollandse Compagnie kwam toen weer in Palembang, omdat er in Batavia al een Hollandse Gouverneur-Generaal was. De Hollanders waren nog niet zo lang in Palembang, toen de oude sultan, die in de oude kraton woonde, Pangéran Kramadiraja uitzond om overleg te plegen met de Hollanders, waarover precies is niet bekend.

Toen kwam er een hooggeplaatst persoon, Edeleer Muntinghe genaamd, met een oorlogsschip in Palembang aan, van plan om de jonge 46 sultan, Ahmad Najamuddin, te doen verhuizen naar de oude kraton en de oude sultan, Mahmud Badaruddin, zijn intrek te doen nemen in de grote kraton. De jonge sultan Ahmad Najamuddin wilde het bevel om 
naar de oude kraton te verhuizen echter niet opvolgen. Met hoeveel kracht Edeleer Muntinghe ook aandrong, hij wilde beslist niet naar de oude kraton verhuizen en was slechts bereid zich uit het met één muur omwalde binnenste gedeelte van het kratoncomplex terug te trekken. Zijn eigen buitenverblijf in het stroomafwaarts gelegen Lawang Buratan sloot hij af met een houten palissade, zodat men Lawang Buratan niet in- of uitkon. De oude sultan, Mahmud Badaruddin, verhuisde naar de grote kraton en installeerde zich in de troonzaal, dat is het grote vorstenverblijf. Zo bleef de oude kraton onbewoond, want de jonge sultan, Ahmad Najamuddin, bleef in Lawang Buratan wonen, dat toch ook tot het complex van de grote kraton behoorde, en wilde er niet uit.

11.2. De jonge sultan Ahmad Najamuddin zond toen een gezantschap naar de Engelsen in Benkoelen met de mededeling dat hij door Edeleer Muntinghe zonder enige reden van de troon van het rijk Palembang was gestoten om plaats te maken voor de oude sultan, die eertijds door de Engelsen was afgezet en naar de oude kraton was verwezen. Daarna kwamen de Engelsen over land uit Benkoelen met driehonderd sepoysoldaten. Hun commandant heette Mister Salmond en ze hadden ook drie Benkoelense vorsten bij zich, namelijk Raja Bangsawan, Radén Arif en Radén Karim.

47 Toen die Engelse expeditie het dorp Muara Beliti had bereikt, bleven de soldaten ervan daar in Muara Beliti achter, omdat er nog niet genoeg vaartuigen waren om hen naar Palembang te vervoeren. Hun commandant, Mister Salmond genaamd, Raja Bangsawan, Radén Arif en Radén Karim gingen alléén vooruit met drie Buginese soldaten en reisden vervolgens met spoed door naar Palembang.

$\mathrm{Na}$ aankomst te Palembang werden ze door de jonge sultan ontvangen en ondergebracht in de oude kraton. $\mathrm{Na}$ hun ontmoeting met de jonge sultan hesen de Engelsen tussen de twee kratons in de Engelse vlag. Het volk van Palembang raakte toen in opschudding, omdat de jonge sultan werd geholpen door de Engelsen en de oude sultan door de Hollanders. De aanhang van de jonge sultan werd steeds groter - zelfs de Arabieren sloten zich in groten getale aan - en dat volk van de jonge sultan had zich verzameld en stond met de wapens gereed voor de strijd. Er waren ook edelen en ambtenaren in Buratan, die de jonge sultan bewaakten.

De Engelsen nu sliepen één nacht in de oude kraton. De volgende ochtend vroeg verscheen er een officier, die door Edeleer Muntinghe naar de Engelsen was gestuurd. Daarop ging Mister Salmond met de 
Benkoelense vorsten naar de overkant van de rivier om Edeleer Mun48 tinghe op te zoeken en geen van allen keerden ze meer in de oude kraton terug. Na hun ontmoeting met Edeleer Muntinghe - wat er besproken werd is niet bekend - begaven de Engelsen zich vervolgens aan boord van een vaartuig, waarmee ze over zee naar Benkoelen werden teruggebracht.

11.3. De volgelingen van de jonge sultan Ahmad Najamuddin in Lawang Buratan kwamen op dat moment in beroering en hielden zich met z'n allen gereed voor de strijd, toen ze hoorden dat de Engelsen de oude kraton verlaten hadden en naar Edeleer Muntinghe waren gegaan, terwijl de Engelse vlag tussen de twee kratons nog overeind was blijven staan. In de grote kraton, aan de kant van de oude sultan Mahmud Badaruddin, waren op hun beurt de ambtenaren en hun volk eveneens in beroering gekomen; ze stonden nu met z'n allen gewapend klaar om de Hollanders te helpen de Engelse vlag daar in Lawang Buratan neer te halen.

Toen kwamen de Hollandse soldaten eraan met de Siakse troepen onder aanvoering van Raja Akil. De manschappen van de oude sultan Mahmud Badaruddin volgden allen met de wapens in de vuist de Hollandse soldaten, die op weg waren naar Lawang Buratan om de Engelse vlag weg te halen, terwijl het volk van de jonge sultan in groten getale en gewapend die vlag bewaakte. Toen de Hollandse legergroep en het volk dat aan de kant van de oude sultan stond ter plaatse waren aangekomen, raakten ze bijna slaags met het volk van de jonge sultan,

49 want beide partijen waren op dat ogenblik even sterk en gewapend met talloze geweren, donderbussen, speren en zwaarden. De Hollandse oorlogsschepen intussen waren de oever reeds dicht genaderd, gereed om te vuren. De Hollandse soldaten nu rukten steeds verder op, tezamen met het volk van de oude sultan Mahmud Badaruddin. Toen men tussen de twee kratons was aangekomen, kapte men de vlaggestok met de Engelse vlag eraan om.

11.4. Nadat de Engelse vlag was weggehaald, werd aan de uitmonding van Lawang Buratan, de verblijfplaats van de jonge sultan Ahmad Najamuddin, door drie dozijn Hollandse soldaten met krijgsvolk van de oude sultan Mahmud Badaruddin de wacht betrokken. Men mocht Lawang Buratan niet binnenkomen, dat werd door de Hollandse soldaten verboden; maar men mocht er wel uit. $\mathrm{Na}$ verloop van enige tijd werd de poort door de Hollanders op slot gedaan; hij ging slechts drie- 
maal per dag open, wanneer men water ging halen in het riviertje. Er waren ook edelen en ambtenaren die samen met de jonge sultan Ahmad Najamuddin in Lawang Buratan gevangen zaten en ook Pangéran Dipati zat daar in Buratan opgesloten. Zo stonden de zaken.

De oude sultan Mahmud Badaruddin, díe voerde in de grote kraton het bewind over Palembang, samen met Edeleer Muntinghe. Zijn

50 jongere broer Pangéran Aryakesuma benoemde de oude sultan tot Pangéran Dipati. Zo kwam het dat er twee personen met de naam Pangéran Dipati in Palembang waren: de oude Dipati bevond zich samen met de jonge sultan in gevangenschap in Buratan en de jonge Pangéran Dipati nam deel aan het bestuur van de oude sultan over Palembang. Zo was het in die tijd. Toen de jonge sultan ongeveer drie maanden in Buratan zat, werd Pangéran Dipati de Oudere door Edeleer Muntinghe uit Buratan weggehaald, naar zijn eigen woonplaats teruggestuurd en onder bewaking van een dozijn Hollandse soldaten gesteld daar in de wijk van Pangéran Dipati.

Niet lang daarna ging de jonge sultan met al zijn kinderen en de edelen die hem gevolgd waren aan boord van een schip, waarna ze met z'n allen naar Batavia werden gebracht. $\mathrm{Na}$ aankomst te Batavia werden de jonge sultan en de edelen die meegegaan waren verder naar Cianjur vervoerd, terwijl sommigen van hen in Sumedang werden ondergebracht; ze kregen allemaal een behoorlijke verzorging en een onderstand.

12.

12.1. Nu komen wij weer terug op de gebeurtenissen in Palembang. Na het vertrek van de jonge sultan naar Batavia wilde Edeleer Muntinghe langs de Musi het binnenland in varen, omdat die driehonderd Engelse soldaten nog steeds de wacht hielden in het dorp Muara Beliti, nog

51 niet wetende dat hun chef al per boot naar Benkoelen was teruggekeerd. Daarom vroeg Edeleer Muntinghe aan Sultan Mahmud Badaruddin om een aantal vaartuigen met bemanning en een aantal edelen en ambtenaren. Toen vertrok Edeleer Muntinghe zoals het de gewoonte van de vorsten in Palembang was met een grote vloot stroomopwaarts, verscheidene soldaten en het vanwege de Palembangse sultan ter beschikking gestelde volk met zich voerende. Na gedurende enige tijd stroomopwaarts gevaren te hebben, bereikte hij Muara Beliti, waar hij een ontmoeting had met de Engelsen. De Engelsen keerden daarop met z'n allen naar Benkoelen terug. Vervolgens voer Edeleer Muntinghe op zijn 
beurt terug naar Palembang en bleef daar, als altijd in goede verstandhouding met de Sultan te Palembang, gevestigd.

12.2. Enige tijd later bracht Edeleer Muntinghe de sultan een bezoek in de audiëntiezaal. In tegenwoordigheid van de ambtenaren en aanzienlijken, die allen ter plaatse bijeen waren, aanvaardde Edeleer Muntinghe het beheer over de buitendistricten van het rijk Palembang, dat wil zeggen dat alle oorsprongsgebieden van de Negen Rivieren aan het gezag van de Sultan van Palembang werden onttrokken en aan Edeleer Muntinghe overgedragen. Zelfs de apanagegebieden van de edelen en ambtenaren kwamen onder het gezag van Edeleer Muntinghe en behoorden voortaan niet meer toe aan de Sultan van Palembang, met uitzondering evenwel van een aantal dorpen, die dienst- en leverplichtig bleven aan de Sultan van Palembang.

12.3. Niet lang nadat de overdracht van al die landstreken aan Edeleer 52 Muntinghe had plaatsgevonden, vroeg Edeleer Muntinghe de sultan om een aantal vaartuigen, omdat hij een tocht naar het binnenland wilde ondernemen teneinde de bovenlanden te inspecteren en onder bestuur te brengen. Toen alles geregeld was, vertrok Edeleer Muntinghe met een grote vloot, waarop hij verscheidene soldaten meevoerde, terwijl er ook verscheidene edelen en ambtenaren meegingen, allen vergezeld van hun volk. Toen de expeditie al diep in het binnenland was doorgedrongen, kwam het veelvuldig voor dat de bewoners van die verre binnenlanden de Hollanders lastig vielen, tegenwerkten of door sluipmoord van het leven beroofden, zodat men geen ogenblik rust had. In het dorp Semangus werd het hoofd, die een pangéran was, door de Hollanders doodgeschoten, omdat hij van plan was de Hollanders kwaad te doen. Hoe dieper de expeditie in het binnenland doordrong, des te waakzamer werd zij, want de opstandelingen, Maleiers zowel als anderen, werden steeds talrijker. Edeleer Muntinghe zond toen een bode naar Palembang. Toen deze op zijn tocht stroomafwaarts in Muara Rawas aankwam, zag hij dat er daar in Muara Rawas een fort was van de Maleiers. Een groot aantal lieden had zich daar met voldoende bewapening samengetrokken om de Hollanders op hun terugweg naar Palembang op te wachten. Uit Palembang nu was er een ambtenaar van de sultan naar Edeleer Muntinghe uitgezonden. Toen hij bij Edeleer Muntinghe aankwam, werd hij gegrepen en liet Edeleer Muntinghe hem gevangen zetten.

Wat er zich precies heeft afgespeeld weet de kleine man niet, maar 
53 enige tijd later vertrok Edeleer Muntinghe met al zijn volk stroomafwaarts. In Muara Rawas aangekomen leverde hij strijd met het fort van de Maleiers. Vrijwel onmiddellijk viel dat fort hem in handen, terwijl de Maleiers allemaal op de vlucht sloegen. Toen voer de vloot van Edeleer Muntinghe aan één stuk door stroomafwaarts en kwam bij daglicht in Palembang aan. Er waren op dat ogenblik twee oorlogsschepen in Palembang met twee oorlogsschoeners en één korakora. De terugkerende expeditie loste bij aankomst vele geweersalvo's terwijl vanaf de oorlogsschepen als welkomstgroet de kanons werden afgevuurd. Zelfs waren de pangérans door de sultan uitgezonden om Edeleer Muntinghe te verwelkomen. Maar deze liet de boot van Pangéran Ratu wegjagen, die mocht niet in de buurt van Edeleer Muntinghe's vaartuig komen. Alleen Pangéran Dipati de Jongere mocht Edeleer Muntinghe komen begroeten.

13.

13.1. Eenmaal in Palembang aangekomen legde Edeleer Muntinghe in de oude kraton, die leegstond, een bezetting van Hollandse soldaten, honderdzeventig man werd er gelegerd daar in de oude kraton. Een paar dagen later zond Edeleer Muntinghe de Hollandse havenmeester, Valckenaer genaamd, met Pangéran Syarif Muhammad naar Sultan Mahmud Badaruddin, die daarop onverwijld bij hem kwam. Wat Edeleer Muntinghe precies voor klachten had is niet bekend, maar ' $t$ werd

54 wel aan alle mensen in de stad duidelijk dat Edeleer Muntinghe het verzoek had gedaan dat Pangéran Ratu en de pangérans die tot de onmiddellijke omgeving van de sultan behoorden allen naar Batavia zouden worden overgebracht.

In die tijd kwam het tot een breuk tussen de Sultan van Palembang en Edeleer Muntinghe. Dagelijks bleef deze er maar op aandringen dat die Pangéran Ratu en alle pangérans die tot de naaste omgeving van de sultan behoorden zonder mankeren zouden worden uitgeleverd. De sultan antwoordde dan in deze zin: "Hen uitleveren doe ik niet, maar verzetten zal ik me evenmin." De inwoners van de stad Palembang nu raakten in opschudding en de sultan was dag en nacht op zijn hoede, terwijl hij het geschut op de wallen in orde liet brengen en ammunitie binnen de kraton liet brengen. De oorlogsschepen naderden tot vlak vóór de kraton, het ene boven- en het andere benedenstrooms van de kraton, terwijl de oorlogsschoeners en de korakora's gezamenlijk de uitmonding van de Ogan afsloten en daar de wacht hielden. Palembang 
was in beroering. De haji's dromden allen samen in de moskee en de inwoners van de stad zowel als de mensen uit het binnenland trokken in groten getale de kraton van de sultan binnen.

Omdat een boodschapper van Edeleer Muntinghe tegen de sultan had gezegd dat indien Pangéran Ratu die dag niet zou worden uitgeleverd, de kraton van de sultan door de oorlogsschepen met de kanons beschoten en in één uur met de grond gelijkgemaakt zou worden, dáárom waren in de kraton alle strijdmiddelen in staat van paraatheid gebracht. Op het bovenstrooms gelegen bolwerk was een schoonzoon van de sultan, namelijk Pangéran Kramadiraja, de militaire commandant, 55 op het benedenstrooms gelegen bolwerk trad Pangéran Kramajaya, ook een schoonzoon van de sultan, als zodanig op, op het bolwerk aan landzijde en wel op het stroomafwaarts gelegen bastion ervan was Pangéran Citra met het commando belast en bij de hoofdpoort van de kraton voerden vier ambtenaren het bevel.

Allen hier vermeld stonden met hun krijgsvolk gereed, wachtend op de bevelen van de sultan. De hajis hadden bevel gekregen die dag buiten de kraton in de audiëntiezaal bijeen te komen en gezamenlijk, heel uitbundig en luid reciterend, voerden zij hun rituele oefeningen uit. Vervolgens drong het geluid van al die stemmen tot in het oude fort door, waar de Hollanders 't hoorden.

13.2. Toen kwam er een officier met een Javaans soldaat en die gingen naar de audiëntiezaal om te onderzoeken wat het geschreeuw van al die mensen te betekenen had. Zodra de officier met die ene soldaat in de audiëntiezaal was verschenen, ontstond er een opschudding onder de haji's en zetten zij zich gezamenlijk met getrokken sabel in beweging. De officier en die ene soldaat vluchtten daarop de oude kraton in. Ze werden niettemin door de haji's nagezet, die met z'n allen de oude kraton binnendrongen, maar deze werden toen door de hoofdmacht der soldaten beschoten. Daarop keerden de haji's terug. Degenen die bij deze aanval voorop waren gegaan, waren Kemas Said, Haji Zain en Haji Lanang; zij allen werden door de Hollandse troepen in de oude kraton gedood.

Vanaf de muren van de grote kraton werd er toen met verscheidene stukken zwaar en licht geschut op de soldaten in de oude kraton ge56 schoten. De batterijen van de boven- en benedenstrooms langs de rivier gelegen bastions losten tot driemaal toe een salvo op de oorlogsschepen, omdat ze er het dichtst bij waren. De oorlogsschepen beantwoordden het vuur door allebei met hun kanons op de kraton van de sultan te 
schieten; vanuit de oude kraton werd de kraton van de sultan bovendien met geweervuur bestookt, terwijl de oorlogsvaartigen die aan de uitmonding van de Ogan lagen eveneens de kraton van de sultan onder vuur namen.

Het was een uiterst levendige strijd, waarbij de Palembangers op de wallen van de sultanskraton telkens een luid krijgsgeschreeuw aanhieven, omdat de kogels van het scheepsgeschut niets uitrichtten en als ze de kratonmuren raakten slechts ongeveer één span diep in het steen van de muur drongen. De Palembangers die het meest door die kogels getroffen werden, dat waren degenen die op de wallen het geschut bedienden. De oorlogsschepen hadden het niet op de mensen in de stad gemunt; het enige doelwit van het scheepsgeschut was de kraton van de sultan.

13.3. De eerste vijandelijkheden waren uitgebroken om drie uur 's middags en om zes uur's avonds werd de strijd gestaakt. De volgende ochtend vroeg om half zes werden de vijandelijkheden tussen de oorlogsschepen en de kraton van de sultan hervat. Omstreeks tien uur ging een groep Hollandse militairen aan wal. De kratonpoort werd daarop stevig gesloten. Toen die groep militairen daar buiten de kratonpoort voltallig was, trachtte men de poort met bijlen open te hakken, opdat de soldaten

57 de kraton konden binnendringen. Men slaagde erin een kleine opening in de poort te hakken. Toen stak iemand van de binnenkant van de muur met een speer, waardoor de trommelslager werd getroffen en dood neerviel. De soldaten weken een beetje achteruit en werden toen van bovenaf de kratonpoort door de Palembangers met zwaar en licht geschut en met donderbussen en geweren bestookt. Daarop trokken de soldaten af.

13.4. Diezelfde dag kwam er een afgezant van Edeleer Muntinghe. Het was Raja Akil, de Siakker, die naar Pangéran Dipati de Oudere was gestuurd met de boodschap dat Edeleer Muntinghe om een wapenstilstand van vier dagen verzocht. Dit verzoek werd door Pangéran Dipati de Oudere aan de sultan overgebracht en vervolgens door de sultan ingewilligd. Toen men hoorde dat de Hollanders om een wapenstilstand gevraagd hadden, kwamen er steeds meer inwoners van de stad gewapend de kraton binnen.

Nadat de termijn van vier dagen was verstreken, werd de strijd in de vroege ochtend hervat. Midden op de dag deinsden de oorlogsschepen en de kleinere oorlogsvaartuigen af en voeren gezamenlijk weg, zodat 
er geen Hollanders meer in Palembang waren. De Palembangse ambtenaren die als handlanger bij Edeleer Muntinghe in dienst waren getreden werden door de Sultan ter dood gebracht; ze werden op de marktsteiger onthoofd. Demang Wiralaksana liet hij ter dood brengen in het dorp Belidah, ook Kemas Abang en Kemas Kusin, de schrijver van Edeleer Muntinghe, werden allebei in het dorp Belidah ter dood gebracht en 58 heel wat mensen werden er in die tijd door de sultan verbannen. Pangéran Syarif Muhammad en de kapitein-demang van de Chinezen waren met de wegtrekkende Hollanders meegegaan. Er waren destijds verscheidene Chinezen die met wangkangs uit Palembang wegvluchtten; zelfs waren er in die tijd Palembangers die met de Hollanders meevluchtten.

14.

14.1. Wat nu de Sultan te Palembang betreft, nadat de Hollanders tot de laatste man vertrokken waren, bracht hij de twee kratons weer in staat van verdediging. Verscheidene grote en kleine kanonnen werden op de wallen van die twee kratons in stelling gebracht. Langs de oever van de rivier, vanaf de kratonsteiger tot aan het riviertje de Tengkuruk, werden verdedigingswerken aangelegd, terwijl ook daar verscheidene kanonnen werden opgesteld. De hele bevolking van het binnenland werd opgetrommeld om ook versterkingen aan te leggen; benedenstrooms van de stad, aan de uitmonding van de Plaju, bouwde men een fort dat Tambakbaya werd genaamd, stroomopwaarts van Tambakbaya weer een fort, Martapura geheten, verder nog een paar andere vestingwerken tussen Tambakbaya en Martapura in en aan de rechteroever van de rivier als men stroomopwaarts vaart, namelijk op de punt van het eiland Kembara, nog een fort. De commandant ervan was Pangéran Suradilaga, die daar de beschikking had over een aantal pangérans en ambtenaren. In Tambakbaya voerde Pangéran Kramadiraja, de schoonzoon van de sultan, het bevel, bijgestaan door een aantal edelen en ambtenaren. En in het fort Martapura hadden Pangéran Ratu en de

59 beide Pangéran Dipati hun post. In de rivier werd een eiland aangelegd door een brik en een penjajab te beladen met stenen en deze daar te laten zinken. Men voer vervolgens naar dat eiland heen en weer en liet er telkens een mand stenen vallen. Zo ontstond er een eiland, dat met enkele stukken zwaar en licht geschut tot een fort werd gemaakt en Pulau Manguntama genaamd werd. Pangéran Wirasentika was daar commandant en had er een aantal edelen en ambtenaren ter beschikking. 
Verder werden er zogenaamde versperringen aangebracht: een paalwerk van zeer grote bomen dwars over de rivier van de linker- tot de rechteroever, die samen met nog andere grote boomstammen de rivier afsloten. Ook de uitmonding der zijriviertjes werd met paalwerk afgesloten en in de doorgang langs het eiland Kembara werden versperringen aangebracht, terwijl enige penjajabs en van geschutbepantsering voorziene vaartuigen in die doorgang de wacht hielden, evenals in de uitmonding van de Plaju. Voorts beschikte men over tal van branders, want elke Chinees in Palembang leverde een vlot en stelde dat als brander, beladen met hout, ter beschikking. Toen in Palembang alles in staat van verdediging was gebracht, werd ook aan de rivier de Komering een wachtpost uitgezet en een fort gebouwd, omdat de verbinding met de Lampongs daar langs liep en in de Lampongs de Hollanders zaten. In dat fort bij het dorp Kurungun Nyawa had Pangéran Wiradiwangsa het commando, terwijl een aantal edelen en ambtenaren daar samen met hem de wacht hielden. Daar nu is het meermalen tot botsingen gekomen met de Hollanders uit de Lampongs.

60 14.2. In datzelfde jaar nog verscheen de vloot van Generaal Schoutbij-nacht, bestaande uit een aantal oorlogsschepen en vissersvaartuigen van Chinezen. Die vloot kwam met Edeleer Muntinghe aan boord en bracht tevens de zoon van Sultan Ahmad Najamuddin die in Cianjur zat, namelijk Pangéran Jayaningrat, mee. Ook Pangéran Jayakrama en de patih van Sultan Ahmad Najamuddin kwamen met die vloot mee. Wanneer men te zijner tijd de stad Palembang in handen zou krijgen, zou - zo was overeengekomen - Pangéran Jayaningrat sultan in Palembang worden. Zo voer de vloot van de zee-generaal, Generaal Schout-bij-nacht geheten, met al die oorlogsschepen en kleinere oorlogsvaartuigen de rivier binnen. De bewoners van Sungsang waren op dat ogenblik allemaal al naar Palembang vertrokken. Na een tijdje stroomopwaarts gevaren te hebben werd de vloot onderweg door sluipschutters beschoten, dat wil zeggen vanuit geschutstellingen in het bos. Benedenstrooms van de vestingwerken bij het riviertje de Kundur aangekomen hield de vloot ter plaatse in zijn geheel stil; de vloot was vanuit de vestingwerken te zien, maar werd niet onder vuur genomen.

Edeleer Muntinghe en de generaal zonden nu een afgezant naar de Sultan in Palembang. Die afgezant was een zekere Si Gangsa, een Palembanger, die de slaaf was van Pangéran Wirakrama, de patih van de sultan die zich in Cianjur bevond. Si Gangsa kwam met een vissers-

61 bootje naar het fort Tambakbaya, waar hij een paar keer een brief van 
Edeleer Muntinghe afgaf, die dan telkens door de sultan beantwoord werd. Wat er in die brieven besproken werd, weten we niet. Degeen die de sultan als afgezant naar Edeleer Muntinghe daar aan boord afvaardigde, heette Si Kodak. De gevoerde vredesonderhandelingen hadden echter geen succes.

14.3. Op een dag naderde de vloot de vestingwerken en vervolgens werd het die dag een grote strijd. De oorlogsschepen en de kleinere oorlogsvaartuigen vuurden allemaal om het hardst op de vestingwerken en van die vestingwerken schoten de mannen op hun beurt om het hardst op de schepen. Als regen vielen de kogels aan beide zijden, wat klonk als het geraas van de storm en wanneer ze in het water vielen leek het wel een school vissen. Alle forten schudden op hun grondvesten vanwege het gedreun van het geschut, vooral van het geschut van de oorlogsschepen, dat net als een duizendklapper razend snel werd afgevuurd. De kruitdamp vervulde de wijde watervlakte en het stralend-heldere licht werd er door verduisterd, zodat de schepen niet meer te zien waren en alleen nog maar de lichtflitsen der vuurmonden zichtbaar waren vanuit de vestingwerken. Als om strijd vuurde het krijgsvolk de kanonnen af, zonder zich te bekommeren om de dood.

Nadat het gevecht vier uur geduurd had, werd de strijd gestaakt. Alle schepen deinsden af, voeren vervolgens aan één stuk door de rivier af

62 naar Sungsang en zeilden toen gezamenlijk naar buiten. Toen alle vaartuigen van de Hollanders weg waren, keerden de ambtenaren naar Palembang terug en maakten hun opwachting bij de sultan. Toen kregen ze allemaal een stel kleren ten geschenke, tot aan de districts- en dorpshoofden toe, een ieder naar hem toekwam.

14.4. Nu werden de vestingwerken steeds meer versterkt; alle hulpbronnen van Palembang en van het achterland werden daarbij aangewend. De forten raakten steeds drukker bevolkt, evenals de stad, doordat de mensen uit het binnenland daar allemaal samenstroomden. Rijst was er in die tijd in overvloed, maar zout was schaars, omdat de handelaars van Java niet kwamen; alleen de heel kleine bootjes uit Lingga brachten zout mee. Maar de Palembangers waren al bedreven in het winnen van zout. Ook kruit en kanonskogels wisten ze te maken. Voorts kwamen er in groten getale afgezanten van de Maleise vorsten naar de Sultan in Palembang toe, zoals uit Lingga, Riau en Sambas, die allemaal hielpen met kruit en kogels.

$\mathrm{Na}$ verloop van enige tijd nam de Sultan van Palembang de naam 
en titel aan van Suhunan Mahmud Badaruddin en werd Pangéran Ratu verheven tot Sultan Ahmad Najamuddin. Dit geschiedde in de audiëntiezaal in tegenwoordigheid van de ambtenaren, de aanzienlijken,

63 de geestelijkheid, de vooraanstaande Arabieren en de districtshoofden uit het binnenland, die op dat tijdstip allen bijeen waren en deelnamen aan een uitgebreid feestmaal.

Enige tijd nadat deze gebeurtenis had plaatsgevonden, arriveerde weer Pangéran Ratu van Jambi om te helpen in de strijd tegen de Hollanders; dit werd door de Suhunan van Palembang aanvaard. Er werd toen nòg een eiland aangelegd, links van het eiland Manguntama, waar Pangéran Wirasentika gestationeerd was. Het werd voorzien van een aantal stukken zwaar en licht geschut, bemand met volledig bewapend krijgsvolk en het kreeg de naam "Eiland van Pangéran Ratu van Jambi". Zo stonden de zaken te Palembang in die tijd. Zonder ophouden liet de suhunan de vestingwerken en het geschut in orde brengen en kruit en kogels aanmaken, terwijl hij tevens allerlei vermakelijkheden liet houden in de stad, zoals het vorstelijk gebruik in vroeger tijden eiste.

15.

15.1. De geschiedenis verhaalt nu weer van Sultan Ahmad Najamuddin, die zich in Batavia bevond. Nadat hij drie jaar in Cianjur had gewoond, werd Sultan Ahmad Najamuddin, ten tijde dat de Hollandse vloot zich uit de strijd om Palembang had teruggetrokken, door Gouverneur-Generaal Van der Capellen op zeker ogenblik met al zijn ambtenaren en al zijn volk naar Buitenzorg opgeroepen. Sultan Ahmad Najamuddin had toen een ontmoeting met Gouverneur-Generaal Van der Capellen in Buitenzorg.

Op dat tijdstip werd Sultan Ahmad Najamuddin door Generaal

64 Van der Capellen benoemd tot Suhunan Husin Dia'uddin en zijn oudste zoon, Prabu Anom geheten, tot Sultan Ahmad Najamuddin. Wat het rijk van Palembang betreft, dit werd aan Suhunan Husin Dia'uddin teruggegeven, waarmee de oude toestand werd hersteld. Wanneer hij in Palembang zou zijn aangekomen, zou hij aan de overkant van de rivier een fort van bamboe voor de Compagnie laten bouwen en dan zou Suhunan Husin Dia'uddin weer net als vroeger zijn intrek nemen in de kraton; en dat alles werd contractueel vastgelegd.

Het had oorspronkelijk in de bedoeling gelegen dat Pangéran Jayaningrat, Suhunan Husin Dia'uddins zoon die had deelgenomen aan de militaire actie tegen Palembang, als sultan zou worden aangesteld. 
Suhunan Husin Dia'uddin had daartegen echter beleefd bezwaar gemaakt, omdat het van oudsher de regel was dat in Palembang steeds de oudste zoon regerend vorst werd, en om die reden was Prabu Anom toen tot sultan aangesteld. Daarop had de Gouverneur-Generaal gezegd: "Als het zó gesteld is, laat dan, wanneer $U$ in Palembang zult zijn aangekomen, geen ander rechtstreeks onder Sultan Prabu Anom dienen dan alleen Pangéran Jayaningrat, die dan alle staatszaken zal behartigen onder Sultan Prabu Anom."

Tijdens de installatie van Suhunan Husin Dia'uddin en zijn zoon Sultan Ahmad Najamuddin was het heel druk in Buitenzorg. Alle heren en hooggeplaatste personen waren vóór de Gouverneur-Generaal in vergadering bijeen, er werden saluutschoten gelost en er was een erewacht, en de Gouverneur-Generaal overhandigde aan Suhunan Husin Dia'uddin alsook aan al diens kinderen verscheidene geschenken. $\mathrm{Na}$ 65 afloop van die plechtigheid kregen Suhunan Husin Dia'uddin en Sultan Ahmad Najamuddin opdracht naar Palembang terug te keren en samen met Generaal De Kock Palembang te beoorlogen. Daarover wordt hier nu niet verder uitgeweid.

15.2. Generaal De Kock nu vertrok uit Batavia met een vloot, welke uit verscheidene oorlogsschepen en andere oorlogsvaartuigen bestond; hij had de opdracht van Gouverneur-Generaal Van der Capellen om samen met Suhunan Husin Dia'uddin en Sultan Ahmad Najamuddin een militaire actie uit te voeren tegen Palembang. Suhunan Husin Dia'uddin bevond zich met zijn zoon aan boord van een grote brik en hun waren een paar heren toegevoegd om voor hen te zorgen. Toen ging de vloot van Generaal De Kock onder zeil. Na verloop van enige tijd bereikte men de kust van Palembang, vervolgens voer men de Sungsang binnen en zeilde men door tot vóór de verdedigingswerken, maar er werd uit de forten geen schot gelost. Daar ging de vloot ten anker, namelijk bij het riviertje de Kundur, zodat het vaarwater vol vaartuigen van de expeditie lag. De inwoners van Sungsang hadden in die tijd geen gelegenheid gehad stroomopwaarts naar de vestingwerken te varen en hadden zich vervolgens bij Suhunan Husin Dia'uddin aangesloten. Het waren de mensen van Sungsang die vertelden waar er overal in het bos kanonnen stonden, dat wil zeggen verdekt opgestelde batterijen, en die werden toen allemaal door de Hollanders opgeruimd.

15.3. Palembang kwam in opschudding, toen men de Hollandse vloot 
zag aankomen. De ambtenaren en de pangérans vertrokken stroomafwaarts naar de vestingwerken, een ieder naar de batterij waarbij hij

66 was ingedeeld. Ook de Arabieren en Chinezen begaven zich allen naar de forten, een ieder met zijn wapens, en de inwoners die een brander klaar hadden, brachten die naar de forten.

Aan de uitmonding van de Plaju trad Pangéran Kramajaya, evenals Pangéran Kramadiraja een schoonzoon van de suhunan, op als commandant van het fort Tambakbaya, omdat Pangéran Kramadiraja ziek en vreselijk vermagerd was. Daarom was hij vervangen door Pangéran Kramajaya als hoofd van de ambtenaren in Tambakbaya. In het fort op het eiland Kembara was Pangéran Kramadilaga de aanvoerder van alle ambtenaren die daar dienst deden. Op het nieuw aangelegde eiland Manguntama fungeerde Pangéran Wirasentika als commandant van alle daar geplaatste ambtenaren. En op het eiland dat pas was aangelegd om te dienen als post voor Pangéran Ratu van Jambi, dáár was Pangéran Ratu van Jambi de commandant. Er waren verder nog een aantal penjajabs, met een geschutpantser uitgeruste vaartuigen en Buginese boten, die uit Lingga te hulp gekomen waren; de Buginese commandant heette Cik Nauk. Die vaartuigen bevonden zich zowel rechts als links van dat eiland daar midden in de rivier. Enkele mobiele batterijen, dat waren vlotten met kanonnen erop, vormden een aaneengesloten verdedigingslinie tussen het eiland midden in de rivier en het eiland van Pangéran Ratu van Jambi. Wat het fort Martapura betreft, daar waren de sultan, de beide Pangéran Dipati en Pangéran Bupati gestationeerd. Er waren daar veel aanzienlijken en Arabieren, trouwens in alle forten

67 waren Arabieren, die man voor man gewapend waren. Al die forten wachtten, allemaal in staat van paraatheid, de komst van de Hollandse vloot af, die naderbij kwam om slag te leveren. 't Was een hele drukte in die forten en men was er dag en nacht waakzaam, terwijl de ambtenaren aten en dronken en zich vermaakten.

15.4. In die tijd werden er geen mensen meer als gezanten gezonden om de brieven van Generaal De Kock en van de suhunan over te brengen. Vanaf de schepen op de rivier liet men een brief met de stroom meedrijven, voorzien van een witte wimpel. Die brief was in een fles gestopt die stevig was afgesloten en deze werd dan vanuit het fort opgepikt en aan de Sunan in Palembang afgegeven. De antwoordbrief van de Sunan te Palembang aan de generaal liet men evenzo met de stroom meedrijven in een fles met een witte wimpel eraan als kenteken. Verscheidene keren heeft men die paar dagen elkaar zo over en weer 
vanaf de schepen en uit Palembang brieven gezonden. Wat daarin allemaal besproken is, weet de kleine man niet.

15.5. Op zekere dag kapten de Hollanders een pad door het bos. Dit geschiedde onder leiding van Kirangga Wirasentika, een ambtenaar van de Sunan uit Batavia. De aanleg van dat pad diende om de Hollandse soldaten in staat te stellen lopend de Plajurivier te bereiken teneinde daar met bootjes de rivier op te gaan en zodoende de achterkant van het fort Tambakbaya te bereiken. Nog voordat de soldaten de gelegenheid hadden met $\mathbf{z}$ 'n allen aan boord van de sloepen te gaan, werden ze ontdekt door de vele Palembangse vaartuigen die daar in de Plaju68 rivier op de uitkijk lagen. Vervolgens kwam het tot een treffen tussen de Hollandse soldaten in het bos en de Palembangse vaartuigen op de Plajurivier; ' $t$ was een zeer felle strijd, die gepaard ging met luid krijgsgeschreeuw. Toen het gevecht nog maar net aan de gang was, gingen de Palembangers gezamenlijk aan wal om een stormaanval uit te voeren. Daarop trokken de Hollanders terug. Tegen de avond werd alles wat door de Palembangers in het bos was buitgemaakt eerbiedig aan de Sunan in Palembang aangeboden. Het was toen zó gesteld dat als de avond was gevallen, de Hollanders kanonvuur afgaven en intussen met sloepen de forten naderden; vanuit de forten bestookte men 's avonds evenzo de schepen met kanonnen. Zó was het gedrag van de forten en de schepen vóór de grote strijd.

15.6. Nadat de grote vloot al enige dagen in zijn geheel op de ankerplaats had gelegen, naderde op een woensdagmiddag om vijf uur die grote vloot de forten. Op woensdag de negentiende Ramadan van het jaar 1236 om zes uur begonnen de vijandelijkheden. Om zes uur ontbrandde er een grote strijd tussen de gezamenlijke forten en de oorlogsschepen en andere oorlogsvaartuigen, die allen om 't hardst de forten en de eilanden in de rivier beschoten en daarbij zonder ophouden granaten afvuurden. En vanuit de forten bestookte men om 't hardst de oorlogsschepen en de andere oorlogsvaartuigen, terwijl men een luid krijgsgeschreeuw aanhief; 't was zó'n verschrikkelijk lawaai, dat horen en zien je verging. Over en weer vielen de kanonskogels neer als regen, 69 wat klonk als het geraas van de storm en wanneer ze in het water vielen, leek het wel een school vissen. De forten schudden op hun grondvesten vanwege het gedreun van het geschut, wat vergezeld ging van krijgsgeschreeuw en het geluid van de muziek die in die forten werd gemaakt. Vooral het scheepsgeschut vuurde in een razend tempo. 
Bij elke treffer wankelden de forten alsof ze door het schudden uit de grond gerukt zouden worden. Verscheidene bomen in het bos werden ontworteld en stortten neer, getroffen door de kogels van al die oorlogsschepen en andere oorlogsvaartuigen. De kruitdamp vervulde de rivier en het bos; het stralend-heldere licht verkeerde in een schemerdonker, waarin de schepen niet meer te zien waren en alleen nog maar de lichtflitsen der vuurmonden zichtbaar waren vanuit de forten. Van hun kant bestookten de verdedigers van de forten de schepen om ' $t$ hardst met kanonvuur zonder zich te bekommeren om de dood, terwijl er van weerskanten uit aller kelen een oorverdovend krijgsgeschreeuw weerklonk.

15.7. Omstreeks twee uur werd de strijd gestaakt. De vloot deinsde af en alle oorlogsschepen en andere oorlogsvaartuigen voeren stroomafwaarts terug naar hun vroegere ankerplaats. Van de Hollandse vaartuigen bleven toen twee met koper beslagen landingsboten achter. Eén werd er buitgemaakt door het eiland Manguntama en vervolgens in brand gestoken, één werd er op het eiland Kembara buitgemaakt, maar niet in brand gestoken. Het grote koperen kanon van die landingsboot werd op het eiland Kembara aan land getrokken, het andere, dat van ijzer was, werd eveneens in het fort van het eiland Kembara aan wal gebracht.

70 Het landingsvaartuig dat door het fort van het eiland Kembara was buitgemaakt, werd naar Palembang overgebracht en aan de Sunan aangeboden. Het grote koperen kanon van de landingsboot die op het eiland van Pangéran Wirasentika in brand was gestoken, viel in het water en het ijzeren kanon op het achterschip werd er afgesloopt en op het eiland Manguntama aan wal getrokken. Van het schip Nassau waren op dat tijdstip de voormast en de boegspriet afgebroken door een voltreffer van een kanon van het fort Tambakbaya, dat Si Goyang heette en heel groot was. Van elk terugtrekkend schip was het ijzeren anker achtergebleven en dat werd door de mensen van de forten weggehaald.

15.8. Vier dagen na die dag, in de nacht van zaterdag op zondag, naderde om vier uur de Hollandse vloot opnieuw met verscheidene oorlogsschepen en andere oorlogsvaartuigen de forten. Om zes uur begon de strijd, nog heviger dan tevoren bestookten de schepen de forten. Zo ontstond er een groot gevecht, waarbij men vanaf de schepen en vanuit de forten om 't hardst de kanonnen afvuurde onder luid krijgsgeschreeuw. Die nacht bevond de sultan zich in Palembang en waren ook de edelen en de ambtenaren in groten getale in Palembang, omdat zij 
allen vermoedden dat de Hollanders niet zouden gaan vechten aangezien het de volgende ochtend zondag was. $\mathrm{Nu}$ er echter toch werd gevochten, begaven de sultan en de pangérans zich naar de forten en keerden de ambtenaren man voor man terug naar het fort waarbij ze ingedeeld waren.

71 De strijd nam nu in hevigheid toe en breidde zich uit, terwijl er vanaf de schepen steeds sneller gevuurd werd. De granaten vielen zonder ophouden op de forten neer en kwamen zowel binnen als buiten de forten tot ontploffing. Om ongeveer zeven uur werd het fort van het eiland Kembara door de Hollanders veroverd; de vlag op het fort van het eiland Kembara werd toen verwisseld voor de Hollandse vlag. Pangéran Ratu van Jambi stak zijn eigen fort in brand, omdat hij zag dat het fort van het eiland Kembara al door de Compagnie was veroverd en bezet. Wat het fort aan de uitmonding van de Plaju en het fort Martapura betreft, deze leverden nog strijd. Twee landingssloepen voeren nu het nauw van het eiland Kembara in en begaven zich stroomopwaarts naar het uiteinde van die doorgang om zodoende aan de achterzijde van de forten te komen. Toen die twee sloepen stroomopwaarts van de forten te voorschijn kwamen, hielden de forten op met het beschieten van de schepen. De sultan en de edelen en ambtenaren keerden toen met z'n allen over land terug naar Palembang en om één uur waren alle forten door de Hollanders veroverd. De soldaten gingen aan wal en staken al die forten in brand. Op dat punt gekomen staakten Generaal De Kock en Suhunan Husin Dia'uddin de strijd.

15.9. Wat nu de Suhunan te Palembang betreft, deze had alles voor de strijd gereed in de beide kratons, die als verdedigingswerken veel sterker waren dan alle andere forten. $\mathrm{Na}$ ongeveer drie dagen, toen de gewone burgers tot de laatste man gevlucht waren, ging de Suhunan

72 van Palembang echter over tot het voeren van vredesbesprekingen met Generaal De Kock. Daarop voeren de schepen allemaal verder stroomopwaarts naar Palembang. De sultan, de zoon van de Suhunan uit Batavia, ging zijn opwachting maken bij de Suhunan te Palembang. Daarop verhuisde de Suhunan van Palembang met al zijn volk van de kraton naar de woning van Pangéran Dipati de Oudere. Nadat de Suhunan van Palembang drie dagen in het huis van Pangéran Dipati de Oudere had doorgebracht, ging hij tezamen met al zijn kinderen aan boord van een oorlogsschip. Een paar dagen later vertrok hij naar Batavia. Na aankomst te Batavia ging hij bij Cilincing aan wal. Na een verblijf aldaar van enkele dagen ging hij weer aan boord van een 
schip, dat hem naar het eiland Mengarai vervoerde, waar hij in een fort werd ondergebracht terwijl al zijn bezittingen hem werden afgenomen. Nadat hij daar een paar maanden had doorgebracht, werd hij met al zijn kinderen op transport gesteld naar Ternate. Zo kwam Suhunan Mahmud Badaruddin met zijn hele gevolg in Ternate te wonen; ze werden er volledig door de Hollanders verzorgd en van voeding en kleding voorzien.

16.

16.1. Nu gaat het verhaal weer verder over Suhunan Husin Dia'uddin en zijn zoon Sultan Ahmad Najamuddin. Na de verovering van Palembang had de suhunan niet meteen zijn intrek genomen in de kraton. Want de Hollanders hadden verzocht een verblijfplaats voor hen te maken aan de overkant van de rivier, alleen maar een fort van bamboe; wanneer de Hollanders eenmaal naar de overkant verhuisd waren, zou de suhunan de kraton betrekken.

Het rijk Palembang kwam weer onder het gezag van Suhunan Husin 73 Dia'uddin, terwijl de apanagegebieden stuk voor stuk weer in beheer kwamen bij de leden van het ambtenarencorps, net als vroeger. Slechts de heffing van in- en uitvoerrechten bleef voorbehouden aan de Compagnie, verder niets; alle staatszaken, zowel de grote als de kleine, kwamen weer onder de competentie van de sultan. Pangéran Adiwijaya, de schoonzoon van de sultan, kreeg de titel Pangéran Perdana Menteri; hij behartigde de staatszaken onder de bevelen van de sultan. Suhunan Husin Dia'uddin bleef voorlopig nog in Suakbata wonen, zolang de aanleg van een verblijfplaats voor de Hollanders aan de overkant zou duren; het terrein was reeds opengelegd en een aantal huizen in de wijk Kelénténg afgebroken. Pangéran Dipati de Oudere werd door de suhunan Pangéran Bupati Panembahan genaamd, aan Pangéran Jayaningrat, een zoon van de sunan, werd de naam Pangéran Dipati Jayaningrat en aan de zoon van de sunan die Pangéran Jayakrama heette, werd de naam Pangéran Aryakesuma verleend.

16.2. Terwijl de zaken zo stonden in Palembang, kwam er een commissaris Palembang binnen om te onderzoeken, waar de bezittingen van Suhunan Mahmud Badaruddin, die in Ternate verbleef, zich wel mochten bevinden. Enige pangérans werden overgebracht naar Batavia, terwijl Pangéran Bupati Panembahan zeven maanden lang op een oorlogsschip gevangen werd gehouden. Zijn huis en hof werden door de commissaris 
overhoop gehaald. Toen men niets gevonden had, ging de Panembahan weer naar huis en keerden de pangérans die naar Batavia waren gegestuurd, met z'n allen naar Palembang terug.

16.3. Niet lang daarna maakte Pangéran Perdana Menteri zich schuldig 74 aan het ernstige vergrijp van iemand te willen vermoorden. Nog voordat dit voornemen ten uitvoer was gelegd, vertelde Pangéran Dipati Jayaningrat het aan de commissaris. Pangéran Perdana Menteri Adiwijaya werd toen door de commissaris uit zijn ambt ontslagen en al zijn apanagegebieden werden hem door de sultan ontnomen. Toen werd Pangéran Kramajaya, de schoonzoon van de suhunan die in Ternate was, door de commissaris ontboden en door deze tot Pangéran Perdana Menteri gemaakt om de zaken te behartigen onder de bevelen van de sultan. Sindsdien stond Pangéran Dipati Jayaningrat niet meer op goede voet met de suhunan. Hij verliet Suakbata en keerde naar zijn eigen woonplaats terug. Vervolgens vertrok hij samen met de commissaris naar Batavia; hij is later ook samen met de commissaris weer in Palembang teruggekomen.

16.4. Enige tijd later droeg Sultan Ahmad Najamuddin in overleg met de sunan in Suakbata alle districten van de Negen Rivieren over aan de commissaris. Hij had om een vaste bezoldiging gevraagd, maar toch bleven er nog enkele gebieden dienstplichtig aan de sultan. Alle apanagegebieden werden aan de edelen en ambtenaren onttrokken; ter compensatie kregen ze een vaste bezoldiging. Er waren geen apanagehouders meer in Palembang, er gold uitsluitend een stelsel van vaste bezoldigingen.

16.5. Nadat de sultan in Palembang was onderworpen aan het systeem van een vaste bezoldiging, stelde de commissaris een raad in. Voorzitter van de raad was de sultan. Elke maandag en elke donderdag verscheen 75 de sultan in de kraton met enkele ambtenaren, voorzien van de rijkssieraden. Wanneer de sultan ziek was, werd de raadszitting geschorst. Toen de sultan al een poosje voorzitter was van de grote raad in de kraton, begon zijn broer Pangéran Dipati Jayaningrat veelvuldig tegen de sultan te intrigeren. De edelen en de ambtenaren waren toen niet meer verantwoordelijk aan de suhunan of de sultan, omdat zij geen apanagegebieden meer hadden, nu er vanwege de Compagnie een stelsel van vaste bezoldigingen was ingevoerd. $\mathrm{Na}$ enige tijd vertrok de commissaris en keerde naar Batavia terug. De heer Reijnst bleef als 
resident van Palembang achter en trad samen met de Sultan van Palembang op als voorzitter van de grote raad.

17.

17.1. Niet lang daarna geschiedde het door de wil van God - geprezen zij Zijn verheven Naam - dat de sultan op zeker tijdstip krijgsvolk bijeenbracht en een aanval deed op de kraton en wel op maandag 29 Rabicul-awal 1240, 's ochtends vroeg om vier uur. Vrijwel op hetzelfde ogenblik trok de sultan zich met al zijn volk terug om stand te houden in Suakbata, waar Suhunan Husin Dia'uddin woonde. De krijgslieden van de sultan die in de nacht van de aanval buiten de muren van de kraton sneuvelden waren: Pangéran Citra Putang, ten tweede Radén Gubir, ten derde Khatib Jabaruddin en ten vierde een zekere Si Luncuk.

76 In de nacht waarin de sultan die aanval deed, bevond Pangéran Dipati de Jongere zich met Pangéran Dipati Jayaningrat in de kraton, terwijl Pangéran Bupati Panembahan met zijn gezin was uitgeweken naar Kertapati.

Bij daglicht scheepte Suhunan Husin Dia'uddin zich in en de volgende avond vertrok hij naar Batavia, met de brik van Masagus Caguk, die door Resident Reijnst voor hem was ingehuurd. Want er was op dat moment geen oorlogsschip te Palembang. Zo vertrok Suhunan Husin Dia'uddin naar Batavia met al zijn volk.

17.2. De sultan die de aanval had ondernomen, had echter geweigerd mee te gaan; hij was met zijn volk het binnenland in gevlucht, naar de bovenloop van de Musi, en had de bevolking in Muara Beliti op de been gebracht. Pangéran Dipati de Jongere, de broer van de suhunan, kreeg toen van de resident de opdracht met een groep gewapende ambtenaren het binnenland in te gaan. Daarbij werd de toezegging gedaan dat indien de sultan gepakt werd, Pangéran Dipati de Jongere sultan zou worden in Palembang; de vaartuigen van de suhunan en van de sultan stonden Pangéran Dipati ter beschikking en hij zou een uitkering krijgen van duizend gulden, terwijl ook Pangéran Dipati Jayaningrat duizend gulden zou ontvangen. Toen trok Pangéran Dipati de Jongere met een groep volledig bewapende edelen en ambtenaren het binnenland in.

Het duurde niet lang of men bereikte de benedenstrooms van het

77 dorp Muara Beliti gelegen plek waar de sultan verblijf hield. Toen de sultan weigerde over vrede te onderhandelen, ging Pangéran Dipati de wal op en liet enkele schoten lossen vanuit het bos dat aan de overkant 
van de rivier tegenover het dorp lag. Nadat er een paar keer geschoten was, kreeg de sultan de schrik te pakken en vluchtte met al zijn volk verder het binnenland in; daar legde hij versterkingen aan, één aan de bovenloop van de Ogan en één aan de bovenloop van de Lematang, terwijl hij de mensen van Pasemah en van alle marga's met hun volledige bewapening op de been bracht. Pangéran Dipati de Jongere werd echter ziek; vervolgens aanvaardde de hele Palembangse vloot de terugtocht. Nadat Pangéran Dipati de Jongere was hersteld, vertrok de vloot van Pangéran Dipati met edelen en ambtenaren en verscheidene volledig bewapende vaartuigen weer uit Palembang naar het binnenland. Intussen was ook Kirangga Wirasentika naar het binnenland onderweg, met een andere vloot en langs een andere rivier. Pangéran Dipati de Jongere was nog niet erg ver stroomopwaarts gevorderd met zijn vloot, toen hij weer ziek werd. Hij keerde toen om, maar onderweg stierf hij.

Rangga Wirasentika nu had stilgehouden in het dorp Limbun en zich daar verschanst. De sultan gaf aan Pangéran Jayadilaga bevel tot de aanval over te gaan; laatstgenoemde was een masagus, wiens titel kemas daar in het binnenland door de sultan was verhoogd. Het leger van

78 Pangéran Jayadilaga dus had toen een ontmoeting met de strijdmacht van Kirangga Wirasentika en vervolgens voerden zij aan wal een felle strijd met elkaar. Pangéran Jayadilaga werd door een kogel aan het hoofd getroffen, viel neer en stierf. Ook van zijn metgezellen sneuvelden er heel wat. Daarop sloeg al het volk van de sultan op de vlucht.

Toen de sultan in het grote fort ter ore kwam dat Pangéran Jayadilaga was gesneuveld, dat zijn hoofd was afgeslagen door Rangga Wirasentika en dat deze het hoofd uit het binnenland had meegebracht voor Resident Reynst, toen had de sultan geen vertrouwen meer in de bevolking van het binnenland noch in de Palembangers; alleen de mensen van Pasemah, die vertrouwde de sultan nog. Het Pasemahse hoofd heette Pangéran Bajau. Toen begaf de sultan zich met het volk van Pasemah op weg, van plan de wijk te nemen naar de Ogan, naar zijn fort aan de bovenloop van de Ogan. Toen hij halverwege was, werd de sultan door het volk van Pasemah overvallen, want de pangéran was door Rangga Wirasentika opgestookt. Pangéran Bajau werd door de sultan doodgestoken. Al het volk van de sultan vluchtte toen in het wilde weg naar alle kanten uiteen.

17.3. De sultan bleef achter met Pangéran Puspadiprana, die door de 79 Palembangers Pangéran Cingot genoemd werd; dàt was degene die de sultan had aangezet om de kraton aan te vallen. Toen het volk tot 
de laatste man weggevlucht was, keerden de sultan en Pangéran Cingot en Masagus Abduljamil vervolgens langs de Ogan naar Palembang terug om zich aan de Compagnie over te geven. In die tijd was de commissaris reeds in Palembang. Terwijl de sultan zich nog stroomopwaarts van de stad bevond, gaf de commissaris de temenggung van politie opdracht de sultan te gaan afhalen met een vaartuig met gele wimpel. Na zijn aankomst in Palembang begaf de sultan zich aan boord van een oorlogsschip. Door de Compagnie werd voor zijn ochtenden zijn middagmaal gezorgd. Het was de taak van Temenggung Astramenggala om 's ochtends en 's middags het eten voor de sultan aan boord te brengen, zoals het volgens de traditie van de Palembangse vorsten betaamt. Nadat Sultan Ahmad Najamuddin op deze wijze ongeveer zeven maanden aan boord van het oorlogsschip te Palembang had doorgebracht, vertrok hij met datzelfde oorlogsschip uit Palembang om te worden overgebracht naar Banda. 


\section{VERTALING}

TR 1

1.

1 De eerste vorst van het Palembangse Rijk was:

Vorst no 1. In het jaar 966. Keding Suroh, was tweeentwintig jaar vorst . . 22 jaar

”, 2 . „ „ „ 968. Opgevolgd door zijn broer Keding Ilir, die één jaar regeerde; maar deze droeg ook de naam Keding Suroh 1 ,

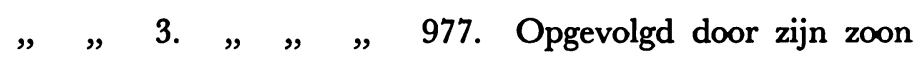
Emas Dipati . . . . 12 ,

» $\quad 4 . \quad, \quad » \quad$, 989. Opgevolgd door zijn broer Pangéran Medang Suka . 35 ,

„ $\quad 5 . \quad, \quad, \quad, 1024$. Opgevolgd door zijn jongere broer Pangéran Madi Alit . . . . . . . . 1 ,

„ $\quad 6 . \quad, \quad, \quad, 1025$. Opgevolgd door zijn jongere broer Pangéran Siding Pura . . . . . . . 7 ,

„ $7 ., ~, ~ „ 1032$. Opgevolgd door zijn neef Pangéran Siding Kenayan 12 ,

„ 8 . „, , 1044. Opgevolgd door zijn neef Pangéran Siding Pesarian 1 ,

„ $9 . \quad, \quad, \quad$ 1045. Opgevolgd door zijn zoon Pangéran Siding Rajak, wiens graf in Saka Tiga is 8 ,

„ $, 10 ., \quad, \quad$ 1053. Opgevolgd door zijn broer Suhunan Abdurrahman, Cindé Walang . . . . 45 , 
Vorst no 11. In het jaar 1098. Opgevolgd door zijn zoon Sultan Muhammad Mansur . . . . . . . . 12 ,

$$
\begin{aligned}
& \text { » }, 12 . \quad, \quad, \quad \text { 1118. Opgevolgd door zijn broer } \\
& \text { Sultan Agung Kamaruddin, } \\
& \text { wiens graf in Palembang } \\
& \text { Lama is . . . . . . . } 10 \text {, } \\
& 2 », 13 ., \%, \ldots . . . \text { Opgevolgd door de zoon } \\
& \text { van zijn broer Sultan } \\
& \text { Mahmud Badaruddin, in } \\
& \text { Kawa Tekurap . . . . ... , } \\
& » \quad, 14 . \quad, \quad, \quad, \ldots . . \text { Opgevolgd door zijn zoon } \\
& \text { Suhunan Ahmad Najam- } \\
& \text { uddin } \\
& \text { „ }, 15 ., \quad, \quad, 1120 \text {. Opgevolgd door zijn zoon } \\
& \text { Sultan Muhammad Baha'- } \\
& \text { uddin, Lemabang . . . } 27 \text {, } \\
& \text { ” }, 16 ., \quad, 1207 \text {. Opgevolgd door zijn zoon } \\
& \text { Suhunan Mahmud Badar- } \\
& \text { uddin, Ternate, ongeveer } \\
& 10 \text { jaar . . . . . . } 10 \text {, }
\end{aligned}
$$

Hij werd opgevolgd door zijn broer Suhunan Husin Dia'uddin, die 7 jaar regeerde in de grote kraton, dankzij de Edele Engelse Heer. Daarna kwam Suhunan Mahmud Badaruddin weer terug en regeerde dankzij de Hollanders ongeveer 6 jaar. Maar God weet het 't beste.

Van het jaar 1227 tot het jaar 1237 was Palembang bezet door de Hollanders en die toestand duurt voort tot op de dag van vandaag.

2.

3 2.1. De regeringsperiode van Suhunan Mahmud Badaruddin wordt opgegeven als volgt: in het jaar 1207 werd hij koning, bekleed met de heerschappij over Palembang en hij bleef aan de regering tot het jaar 1227. Het was in díe tijd dat de Engelsen in Palembang kwamen. Hun politiek scheen erop gericht tweedracht te zaaien tussen mensen die in vrede met elkaar leefden; maar dit ging in het geheim, God alleen weet er het rechte van. 
Toen de Engelsen in Palembang kwamen, waren ze van plan Palembang door wapengeweld in handen te krijgen; maar eigenlijk was het de Engelsen daarbij alleen maar te doen om Suhunan Mahmud Badaruddin. Ter bekorting van het verhaal worde hier volstaan met de mededeling dat Suhunan Mahmud Badaruddin in ballingschap ging door zich met al zijn volk naar de bovenlanden van Muara Rawas te begeven.

Nadat Suhunan Mahmud Badaruddin uit Palembang was verdwenen, zetten de Engelsen Suhunan Husin Dia'uddin op de troon om over Palembang te regeren. Volgens de herinnering van sommigen onder de oudere mensen zou destijds, toen de Engelsen hem koning maakten, Suhunan Husin Dia'uddin dit niet hebben gewild, omdat het gezag van Suhunan Mahmud Badaruddin, die immers geenszins was overwonnen in de strijd, in feite nog steeds bestond.

2.2. Daarna trokken de Engelsen onmiddellijk met een strijdmacht het binnenland in om Suhunan Mahmud Badaruddin in het boven-Rawasgebied te achtervolgen. Nadat zij in de Rawas waren aangekomen, vochten de Engelsen met Suhunan Mahmud Badaruddin; 't ging er heet toe. Toen werd ingevolge de voorbeschikking Gods de aanvoerder van de Engelse soldaten, Mister Salmond genaamd, door een kogel getroffen, waardoor zijn weerstand voorgoed gebroken scheen. Hij moest de strijd opgeven, aanvaardde de terugtocht naar Palembang en keerde vervolgens regelrecht naar Batavia terug. Niettemin was Suhunan Dia'uddin toen door de Engelsen aangesteld als vorst in Palembang met de grote kraton als residentie en werd er tevens de Engelse vlag gehesen. Hoe het Mister Salmond, de Engelsman, na zijn terugkeer in Batavia is vergaan, vermeldt de historie niet. Er wordt alleen verteld dat hij meteen is doorgereisd naar Bengalen en alle kostbaarheden van Palembang die hij uit de Palembangse schatkamer had gehaald toen Suhunan Mahmud

4 Badaruddin naar de Rawas was gevlucht, heeft meegenomen.

2.3. Verder wordt nog verteld dat Batavia door de Engelsen in ruil voor Malakka aan de Hollandse Compagnie was afgestaan. Sindsdien is Batavia voorgoed in handen van de Hollanders gebleven. Op de een of andere wijze kwam door het wijs beleid van God de Allerhoogste, waaraan Zijn dienaren onderworpen zijn, Suhunan Mahmud Badaruddin in vriendschappelijke relatie te staan tot de Gouverneur-Generaal in Batavia; hoe dat precies in zijn werk is gegaan weet God alleen.

2.4. Toen Suhunan Mahmud Badaruddin zo ongeveer twee jaar in 
Muara Rawas was, kwam er een afgezant van de Gouverneur-Generaal uit Batavia, die bij de Hollanders als gemachtigde optrad en de titel pétor voerde; deze arriveerde in Palembang en vestigde zich aan de overkant van de rivier de Aur. Toen de pétor enige tijd in Palembang gevestigd was, trad hij in overleg met Suhunan Husin Dia'uddin met als doel dat tussen de beide suhunans een hereniging zou tot stand komen; Suhunan Mahmud Badaruddin zou dan in de oude kraton worden ondergebracht.

Nadat het overleg met Suhunan Husin was beëindigd, gaven de pétor en Suhunan Husin opdracht dat enkele oudere hofdignitarissen naar Muara Rawas zouden gaan om Suhunan Mahmud Badaruddin af te halen. Eerbiedig verscheen dat gezantschap voor Zijne Hoogheid de Suhunan om hem te verzoeken naar Palembang terug te keren, zoals door de pétor en tevens door Zijne Majesteit Suhunan Dia'uddin werd verlangd. De suhunan gaf die gezanten daarop de groeten mee voor de pétor met het verzoek Pangéran Paharuddin naar de Rawas te zenden. Daarna keerden de gezanten weer naar Palembang terug, meldden zich bij de pétor en deelden hem al hetgeen de suhunan hun had opgedragen mee. Vervolgens gaf de pétor Pangéran Paharuddin opdracht naar Muara Rawas te gaan. Met een klein gezelschap ging Pangéran Paharuddin toen op weg het binnenland in, de rijkssieraden met zich voerende. In Muara Rawas aangekomen had Pangéran Paharuddin een ontmoeting met Zijne Hoogheid Suhunan Mahmud Badaruddin; wat er allemaal tussen hen beiden is besproken weet niemand. Maar hoe dan ook, Zijne Hoogheid de Suhunan keerde naar Palembang terug en bracht de pétor een bezoek.

Nadat dit was geschied, werd aan Zijne Hoogheid de Suhunan door 5 de pétor de oude kraton als verblijf toegewezen; en Suhunan Husin bleef in de grote kraton. Er bestond geen enkele samenwerking tussen hen; integendeel, alle zaken werden door Suhunan Mahmud Badaruddin met de pétor geregeld. Van de onderdanen waren de meesten in die tijd op de hand van Suhunan Mahmud Badaruddin en bleven zijn bevelen volgen. En Suhunan Mahmud Badaruddin onderhield destijds nauwe en vriendschappelijke betrekkingen met de Gouverneur-Generaal in Batavia.

3.

3.1. Toen brak het tijdstip aan waarop de suhunan Pangéran Ratu zou uithuwelijken. In overleg met de pétor werd bepaald dat voor het 
houden van de huwelijksplechtigheden gebruik gemaakt zou worden van de troonzaal in de grote kraton, omdat het geen pas gaf de bruiloft van de oudste nakomeling van het vorstenhuis te vieren in de oude kraton, die daarvoor niet behoorlijk was ingericht. Alleen had Suhunan Husin daar niets meer in te zeggen; door de pétor onder druk gezet bleef Suhunan Husin niets anders over dan te verhuizen naar de oude kraton. Suhunan Mahmud Badaruddin nam zijn intrek in de grote kraton en troonde als regerend vorst in het hoofdverblijf van de kraton, terwijl de koninklijke standaard weer stond opgericht als voorheen en de Engelse vlag was neergehaald. Zo was Palembang in die dagen in een moeilijk parket geraakt.

3.2. Niet lang daarna kwam er een Engels leger, dat afkomstig was uit Benkoelen. De pétor rustte toen een groot leger uit en vertrok naar het binnenland, het Engelse leger tegemoet. Wat er zich, nadat tussen de Hollanders en de Engelsen een ontmoeting had plaatsgevonden, tussen beide partijen precies heeft afgespeeld weet niemand. Maar hoe dan ook, een feit is dat de Engelsen weer naar Benkoelen teruggingen en dat de pétor terugkeerde naar Palembang. Op dat moment was Palembang in rep en roer; en tussen de grote kraton en de oude kraton heerste naar het scheen grote vijandschap.

3.3. In die tijd kwam Edeleer Muntinghe uit Batavia met vele soldaten en oorlogsschepen in groten getale. In de oude kraton was men in die tijd zeer op zijn hoede. Nadat Edeleer Muntinghe had ontdekt hoe de verhoudingen tussen de beide suhunans lagen, liet hij soldaten de wacht betrekken aan de poort van de oude kraton. Niemand mocht eruit, 6 behalve Pangéran Dipati de Oudere: die moest de kraton verlaten en werd naar zijn woonstede teruggestuurd.

In de oude kraton raakte men toen in paniek. In die situatie probeerden de zoons, de gemalin en de bijvrouwen van de suhunan en alle andere vrouwen op alle mogelijke manieren aan de achterzijde de kraton uit te komen, vluchtten vervolgens de grote kraton binnen en meldden zich bij Suhunan Mahmud Badaruddin. Toen Suhunan Husin had bemerkt dat de hele kraton was leeggelopen, ging ook hij over naar de grote kraton, zijn zoons en zijn gemalin achterna. De beide suhunans ontmoetten elkaar; het was alsof ze tot overeenstemming zouden komen. Daarop zond Zijne Hoogheid Suhunan Mahmud Badaruddin iemand naar Edeleer Muntinghe met de boodschap dat Suhunan Husin naar hem toe was gekomen en bij hem in de grote kraton verblijf hield. 
Edeleer Muntinghe gaf toen bevel dat alle hofdignitarissen die zich in de oude kraton bevonden aan boord van de schepen zouden worden geroepen, geen enkele uitgezonderd.

3.4. Vervolgens liet Edeleer Muntinghe Pangéran Jayaningrat roepen. Nadat deze gekomen was, gaf Edeleer Muntinghe hem opdracht Suhunan Husin aan te zeggen dat hij persoonlijk naar Batavia moest gaan teneinde te vragen om een beslissing wie van de twee broers officieel als vorst zou worden aangesteld; hij kon dan tegelijk de benoemingsakte van de Engelsen ten name van Suhunan Husin laten zien, waarbij hij als vorst was aangesteld. Daarop keerde Pangéran Jayaningrat terug van zijn bezoek aan Edeleer Muntinghe en maakte zijn opwachting bij Suhunan Husin. Nadat hij al hetgeen Edeleer Muntinghe gezegd had eerbiedig aan Suhunan Husin had medegedeeld, bleek deze daarmee zeer ingenomen; want die akte van de Engelsen leek van grote invloed te kunnen zijn ter versterking van zijn positie, aangezien de Engelsen de meerderen waren van de Hollanders.

Die nacht moest Suhunan Husin van Suhunan Mahmud Badaruddin in Lawang Buratan logeren, in het grote buitenverblijf bij al zijn zoons en bijvrouwen, terwijl Pangéran Jayaningrat zou overnachten in het buitenhuis aan de rivier. De volgende ochtend begaf de suhunan zich met al zijn mannelijke en vrouwelijke familieleden naar de oever van de rivier en vervolgens scheepten ze zich in aan boord van een oorlogsschip. Toen voer men af en zeilde voort tot men in Batavia aankwam. Hoe het verder ging weet God alleen. Tenslotte werd de suhunan geïnterneerd in Cianjur, terwijl het Gouvernement alle daaraan verbonden 7 kosten voor altijd op zich nam.

3.5. Laat ons nu verder vertellen over Edeleer Muntinghe, die inmiddels Suhunan Mahmud Badaruddin had aangesteld om over Palembang te regeren. Edeleer Muntinghe nu droeg de suhunan op iemand naar de Engelsen in Bengalen te zenden om de kostbaarheden te gaan halen die vroeger door Mister Salmond waren meegenomen. Op bevel van de suhunan ging Pangéran Umar naar Bengalen met een brief, ondertekend door Edeleer Muntinghe. $\mathrm{Na}$ het bezoek van Pangéran Umar aan Bengalen werden al het geld en alle kostbaarheden volledig en zonder gebreke teruggegeven. $\mathrm{Na}$ zijn terugkomst in Palembang kreeg Pangéran Umar de titel van Pangéran Prabumenggala. En tegelijkertijd werd de benaming ubi menggala voor cassave verboden en deze $u b i$ kayu genoemd. 
3.6. Intussen had Suhunan Mahmud Badaruddin de binnenlanddistricten overgedragen aan Edeleer Muntinghe. Voor de suhunan bleven slechts behouden: de gehele streek van Pegagan en verder de gebieden van Panang Karubelah, Penukal, Sungai Keruh, Lingkis, Dana Luar, Perwatin Lima en Belidah. Alle andere gebieden waren aan Edeleer Muntinghe afgestaan, met de bepaling dat hij voor de helft zou delen in alle opbrengsten van het land.

3.7. Enige tijd na de overdracht vertrok Edeleer Muntinghe naar het binnenland met een leger dat uit soldaten en Palembangers bestond. Deze laatsten stonden onder commando van Raja Akil en Pangéran Syarif Muhammad, aan wie enige edelen en ambtenaren waren toegevoegd die van de suhunan de opdracht hadden gekregen Edeleer Muntinghe op zijn tocht naar het binnenland te vergezellen. De tocht begon met het stroomop bevaren van de rivier de Musi. Het was de bedoeling een tournee te maken door alle districten, maar nog vóór dat kon doorgaan ontdekte Edeleer Muntinghe, toen hij een inspectie hield in het dorp Muara Beliti, dat er net Engelsen waren gearriveerd, die van plan waren verder naar Palembang door te reizen. Want de Engelsen waren met Husin Dia'uddin een contract aangegaan, waarbij zij hem inzake Palembang de vrije hand lieten onder beding dat de opbrengst van het land voor de helft aan de Engelsen zou worden afgestaan. Vervolgens wees Edeleer Muntinghe erop dat Suhunan Husin reeds uit eigen vrije wil naar Batavia was vertrokken. Wat er verder 8 ook tussen Edeleer Muntinghe en de Engelsen mag zijn besproken, het resultaat was in ieder geval dat de Engelsen over land naar Benkoelen terugkeerden.

3.8. Nadat de kwestie met de Engelsen was afgedaan, vervolgde Edeleer Muntinghe zijn tournee langs alle dorpen, totdat hij tenslotte aankwam in Semangus. De mensen van Semangus waren recalcitrant, ze wilden zich niet laten registreren. Daarom beval Edeleer Muntinghe de soldaten te schieten; de pangéran van Semangus werd door een kogel getroffen en stierf. Daarop voer Edeleer Muntinghe verder stroomopwaarts. Tijdens de hele verdere reis werd het vaartuig van Edeleer Muntinghe vanuit het bos langs de rivieroever beschoten.

Edeleer Muntinghe zond nu een brief aan Zijne Hoogheid de Suhunan te Palembang, waarin hij mededeling deed van de zojuist vermelde gebeurtenissen. De bode die de brief moest overbrengen zakte de rivier af naar Palembang. $\mathrm{Na}$ aankomst te Palembang meldde hij zich bij 
Zijne Hoogheid de Suhunan en bood deze de brief die hij bij zich had eerbiedig aan. Nadat Zijne Hoogheid de Suhunan de brief gelezen had, beval hij Ngabéhi Balmi naar het binnenland te gaan om Edeleer Muntinghe een bezoek te brengen.

Maar toen de ngabéhi op zijn tocht naar het binnenland bij Rantau Menitang was aangekomen, kreeg hij al te horen dat de Maleiers zich hadden geconcentreerd in Muara Rawas en er volledig bewapende versterkingen hadden aangelegd om zich tegen Edeleer Muntinghe te verzetten. Daardoor moest Muntinghe wel het vermoeden krijgen dat Zijne Hoogheid de Suhunan jegens hem vuil spel speelde en hem bedroog daar in het binnenland. Toen Ngabéhi Balmi tenslotte bij Muntinghe was aangekomen, werd hij door deze meteen gearresteerd en gevangen gezet. Daarop keerden allen die met de ngabéhi meegegaan waren naar Palembang terug om de suhunan op de hoogte te stellen van het feit dat Ngabéhi Balmi door Edeleer Muntinghe gevangen was genomen.

Enige tijd daarna kwam Edeleer Muntinghe aan in Muara Rawas. Vanuit het fort van Muara Rawas opende men het vuur. Edeleer Muntinghe liet daarop de vaartuigen van de expeditie aanleggen; alle soldaten gingen aan wal en bestookten het fort onafgebroken met enkele stukken zwaar geschut, met granaten en met licht geschut en geweervuur. Hevig woedde toen de strijd en in groten getale sneuvelde het volk van Rawas tijdens de gevechten, die van de ochtend tot laat in de middag duurden. Toen brak de weerstand van het fort van Muara 9 Rawas en trok de bezetting van het fort zich terug. Het fort werd door de soldaten ingenomen en geheel leeggeplunderd. Daarna vertrok Edeleer Muntinghe onmiddellijk naar Palembang.

3.9. Toen hij de stad al dicht genaderd was, bracht men Zijne Hoogheid de Suhunan daarvan op de hoogte. Terstond droeg Zijne Hoogheid de Suhunan zijn zoon Pangéran Ratu op samen met een paar oudere hofdignitarissen de Edeleer te gaan afhalen, waarop zij allen stroomopwaarts vertrokken, Edeleer Muntinghe tegemoet. Toen ze bij het vaartuig van Edeleer Muntinghe waren aangekomen, werd de boot van Pangéran Ratu om welke reden dan ook door de Edeleer weggejaagd; hij stond niet toe dat de boot van Pangéran Ratu naderbij kwam. De andere boten kwamen allemaal langszij en werden door Edeleer Muntinghe vriendelijk ontvangen; alleen de boot van Pangéran Ratu stuurde hij weg. Toen keerde Pangéran Ratu weer naar Palembang terug, waar hij vroeg in de ochtend aankwam. Vervolgens wendde hij zich tot zijn 
vader, Zijne Majesteit Suhunan Mahmud Badaruddin, en stelde hem op de hoogte van het feit dat hij door Edeleer Muntinghe niet was ontvangen. Zijne Hoogheid de Suhunan zweeg en sprak geen woord.

4.

4.1. De volgende dag arriveerde Edeleer Muntinghe in Palembang. Edeleer Muntinghe zond de Hollandse havenmeester toen met Pangéran Syarif Muhammad naar Zijne Hoogheid de Suhunan om te vragen om uitlevering van Pangéran Ratu en van de pangérans die aan deze ondergeschikt waren, met de bedoeling dat ze zouden worden overgebracht naar Batavia. Nadat de afgezanten voor Zijne Hoogheid de Suhunan waren verschenen en hem het verzoek van Edeleer Muntinghe hadden overgebracht, antwoordde Zijne Hoogheid de Suhunan: "Ik verzet me niet, maar ik geef ook geen toestemming". Daarop keerden de afgezanten van Muntinghe terug. Nadat hem het bescheid van Zijne Hoogheid de Suhunan was meegedeeld, stuurde hij hen weer terug om de onmiddellijke uitlevering van Pangéran Ratu te verzoeken. Zijne Hoogheid de Suhunan gaf daarop een dergelijk antwoord als hierboven vermeld.

4.2. Tussen Muntinghe en Zijne Hoogheid de Suhunan scheen het nu tot een breuk te zullen komen. Edeleer Muntinghe gaf order dat de oorlogsschepen tot vóór de fortificaties van de kraton zouden naderen. Nadat die order was uitgevoerd, raakte de stad Palembang in opschudding. Zijne Hoogheid de Suhunan verzamelde toen alle hajis binnen de kratonmuren en gaf bevel alle oorlogstuig in staat van paraatheid te brengen, terwijl op de vier hoeken van het bolwerk kanonnen in stelling 10 werden gebracht. Op het poortgebouw werden wachten uitgezet, alle bewapend met donderbussen, geweren, lansen en zwaarden. Ook werd al het mogelijke gedaan ter aanmoediging van het gewone krijgsvolk en van de aanvoerders en voorvechters, die allemaal weer onder commando van ambtenaren stonden. En op het bolwerk werden commandanten gestationeerd met een bepaald contingent dienstdoende manschappen, verdeeld over elk der hoeken van de kratonmuur, dat wil zeggen over elk van de bastions.

4.3. Toen het gehele oorlogspotentieel binnen de kratonmuren in staat van paraatheid was gebracht, gelastte Zijne Hoogheid de Suhunan 
Pangéran Dipati de Oudere en Pangéran Dipati de Jongere naar Muntinghe te gaan om hem mee te delen dat er een dienaar van de suhunan om het leven was gekomen, nadat hij door soldaten vanuit de oude kraton onder vuur was genomen. Wat de oude kraton betreft: zolang het een verwarde toestand was in Palembang, was er in die kraton een garnizoen gelegerd van tweehonderdvijftig man, door Muntinghe aan Zijne Majesteit de Suhunan toegewezen.

De beide pangérans die door de suhunan waren uitgezonden kwamen dus bij Edeleer Muntinghe en brachten hem de zojuist vermelde boodschap van Zijne Hoogheid de Suhunan over. Muntinghe werd toen vreselijk kwaad en zijn gezicht werd vuurrood, terwijl hij op barse toon uitriep: "Wat wil de suhunan eigenlijk? De Hollandse troepen zijn paraat! Als die Pangéran Ratu niet onmiddellijk wordt uitgeleverd, dan zullen vandaag nog, om drie uur, de oorlogsschepen het vuur openen op de kraton". De beide pangérans Dipati werden door Muntinghe vastgehouden en kregen geen toestemming om terug te keren. De twee pangérans verzochten evenwel met klem naar huis te mogen gaan, zeggende: "Ook al staat Edeleer Muntinghe ons niet toe naar huis te gaan, we gaan toch. Zoals het gebruik ten aanzien van hen die als gezanten optreden het voorschrijft: of ze nu goed of slecht nieuws brengen, men moet ze in elk geval weer naar huis terugsturen. Het geldt onder vorsten voor onbehoorlijk om gezanten vast te houden". Toen Edeleer Muntinghe deze woorden van de twee pangérans had gehoord, voelde hij zich zeer beschaamd, daar hij de indruk had gevestigd niet op de hoogte te zijn van de regels die voor vorsten gelden. Daarom stuurde hij de beide pangérans vervolgens naar huis terug. Zo keerden de pangérans terug, ieder naar zijn eigen woonplaats, zonder eerst nog hun opwachting te maken bij Zijne Hoogheid de Suhunan.

4.4. Wat Zijne Majesteit de Suhunan betreft, deze had de vesting 11 binnen de wallen geheel in staat van verdediging gebracht en volledig bewapend. De mannen op de wallen waren zó ingedeeld, dat iedereen er zijn vaste post had. Op het stroomopwaarts gelegen gedeelte van het bolwerk was een schoonzoon van de suhunan, namelijk Pangéran Kramadiraja, gedetacheerd, op het stroomafwaarts gelegen bolwerk een andere schoonzoon van de suhunan, namelijk Pangéran Kramajaya, en op het eveneens benedenstrooms, maar meer landinwaarts gelegen bastion Pangéran Citra Saléh. Op elk van de drie hoeken van het bolwerk had één der bovengenoemde commandanten zijn post betrokken met een aantal ambtenaren, officieren en manschappen. Lawang Buratan was 
zowel aan de stroomopwaarts gelegen als aan de stroomafwaarts gelegen zijde afgesloten, terwijl binnen door enkele zwaargewapende officieren en edellieden de wacht werd gehouden. Bovenal werd de hoofdpoort bewaakt, en wel door verscheidene ambtenaren, officieren en manschappen, allemaal gewapend en uitgerust met kleine kanonnen, donderbussen en geweren.

4.5. Alle haji's, die klaar stonden om de heilige oorlog te beginnen, waren buiten de kraton, dat wil zeggen in de buitenhof, geconcentreerd en volledig tot de heilige strijd toegerust, terwijl ze zonder ophouden godsdienstige teksten reciteerden, gebeden opzeiden en de beginwoorden van de geloofsbelijdenis uitspraken. Dit veroorzaakte een geweldig dreunend geluid, dat door alle mensen werd gehoord; bij de dapperen deed het de strijdlust aanwakkeren, maar de lafaards vervulde het met ontzetting.

Vanwege het geweldige tumult kwam een Hollands officier met een soldaat toelopen om te zien wat er in de grote kraton aan de hand was. Nadat zij door de hoofdpoort naar binnen waren gegaan, kregen de haji's hen in de gaten. Gezamenlijk zetten ze zich in beweging, trokken hun wapens uit de schede en kwamen vervolgens op de officier af, van plan hem te doden. De officier en de soldaat zetten 't op een lopen en renden de oude kraton binnen, nog steeds achtervolgd door de haji's. Deze werden toen door het Hollandse garnizoen vanuit de kraton onder vuur genomen. Het aantal van degenen die aan de heilige strijd deelnamen bedroeg zeventig man. Omdat ze door tweehonderd man soldaten onder vuur werden genomen, trokken ze terug. Haji Zén, Haji Lanang en Kemas Said bin Kemas Haji Ahmad waren bij de aanval aan de spits gegaan.

4.6. Op dat moment schoot Pangéran Citra Saléh met een kanon vanaf 12 het landinwaarts gelegen bastion. Een groot aantal garnizoenssoldaten werd gedood of gewond. Daarna openden zowel het stroomopwaarts als het stroomafwaarts gelegen bastion op hun beurt het vuur op de oorlogsschepen. De oorlogsschepen antwoordden daarop met een beschieting van de kraton. Zo beschoten de kraton en de oorlogsschepen elkaar voortdurend over en weer, onafgebroken en zonder ophouden. De lucht werd verduisterd door de kruitdamp, de aarde bewoog, het water van de rivier raakte in beroering. De stad Palembang daverde van het rumoer, zwaar dreunend alsof de hemel zou instorten; en het kanongebulder klonk als het geluid van een inslaande bliksem, die de aarde 
opensplijt. Men kon geen hand meer voor ogen zien vanwege de kruitdamp; slechts de lichtflitsen uit de vuurmonden kon men zien oplichten tegen de lucht. Zo ging het toe in die geweldige strijd. Men hoorde niets meer dan alleen het kanongebulder en het geschreeuw van het krijgsvolk op de rivier en aan de wal. In die ogenblikken waren de lafaards vervuld van angst, maar de dapperen dachten geen moment aan de dood.

4.7. Toen de avond viel, staakten beide partijen de strijd, de oorlogsschepen zowel als de kraton. De lijken van allen die als geloofsgetuige waren gevallen, liet de suhunan binnen de wallen begraven, terwijl de begrafeniskosten van de gesneuvelden telkens volledig door de suhunan werden vergoed. De lijken van de Hollanders die gesneuveld waren in de oude kraton werden door de Hollanders weggehaald, aan boord van de schepen gebracht en daar toen rechtop gezet, alsof het levende mensen waren.

Nadat aldus was geschied, gaf de suhunan die avond bevel aan de sultan, dat wil zeggen aan Pangéran Ratu, om in gezelschap van een paar edellieden en hoffunctionarissen de kratonmuren te inspecteren, die door de kogels van de oorlogsschepen getroffen waren. Alle muren werden geïnspecteerd. Geconstateerd werd dat zelfs de allergrootste kogels niet meer dan één span diep in de muur waren gedrongen. Vervolgens werd Zijne Majesteit de Suhunan van het resultaat van de inspectie, namelijk dat de kogels slechts één span diep waren binnengedrongen, op de hoogte gesteld. Daarop werd order gegeven dat wanneer de strijd de volgende ochtend vroeg weer zou beginnen, er slechts met grote tussenpozen geschoten mocht worden.

4.8. Toen de dag was aangebroken, werd er vanaf de oorlogsschepen een keer of vier geschoten. De vier schoten van de schepen werden

13 beantwoord met één schot vanuit het bolwerk. De oorlogsschepen echter gaven vervolgens een onafgebroken geschutvuur af, dat dreunde als een zware storm. De kogels die over de wallen heen landinwaarts vlogen, sloegen buiten de stad in de durian- en kemangbomen in; een groot aantal ervan werd geveld en van vele bomen braken de takken af. De lucht werd verduisterd door de kruitdamp uit de vuurmonden en alles beefde en trilde als bij een zware aardbeving vanwege de kogels, die in menigte vanaf de schepen op de kraton afkwamen. Velen waren er die in tranen uitbarstten van angst; velen ook die in lachen uitbarstten van overmoed. Men kon niets meer zien, behalve de lichtflitsen uit de vuurmonden, waarvan het schijnsel telkens zichtbaar werd. 
4.9. Vervolgens werd er door de kanonnen vanuit de kraton niet meer teruggeschoten. Toen staakten ook de oorlogsschepen het vuren, want men vermoedde dat de bezetting van de kraton op de vlucht was geslagen. Daarop beval Edeleer Muntinghe de soldaten zich aan boord van de sloepen te begeven en bij de kratonmuur aan wal te gaan. De soldaten gingen toen in de sloepen, roeiden naar de oever en kropen als mieren de wal op. Nadat ze bij de kratonpoort waren aangekomen, liep hun trommelslager op de poort toe. Van binnenuit maakte een krijgsman nu een gat in de kratonpoort, met een grote boor. Toen de poort doorboord was, stiet die voorvechter aan de binnenkant van de muur zijn lans door dat gat; de trommelslager werd getroffen en stierf. In paniek vluchtte de hele groep soldaten toen van de kratonpoort weg, waarop ze vanaf de trans van het poortgebouw werden beschoten met zware en lichte kanonnen en met donderbussen. Er vielen vele doden onder de soldaten. De legergroep vluchtte nu de sloepen in; de lijken van alle gesneuvelden nam men mee en bracht men aan boord van de schepen. Toen werden ze weer onder vuur genomen vanuit de stroomafen stroomopwaarts gelegen bastions, onafgebroken en zonder ophouden.

Op dat moment waren alle bewoners van het hoofdverblijf van de kraton al via Lawang Buratan naar buiten gevlucht en de weg naar Suakbata opgegaan. Zodra Zijne Hoogheid de Suhunan dat gemerkt had, ging hij hen persoonlijk achterna. Op de weg haalde hij hen in; vervolgens bracht hij hen weer in de kraton terug en sprak: "De kraton is behouden, wij hebben gezegevierd in deze strijd". Toen werd het avond en hield het schieten vanaf het bolwerk op.

14 4.10. Toen de avond was gevallen, verschenen Raja Akil en Temenggung Sura, die door Edeleer Muntinghe waren uitgezonden om Pangéran Dipati de Oudere op te zoeken teneinde om vrede te vragen. Voor het geval men geen vrede wilde sluiten, verzocht Edeleer Muntinghe om een wapenstilstand van vier dagen. $\mathrm{Na}$ aankomst vervoegden die afgezanten zich bij Pangéran Dipati de Oudere en brachten hem bovengenoemd verzoek van Edeleer Muntinghe over. Pangéran Dipati wendde zich vervolgens op zijn beurt tot Zijne Hoogheid de Suhunan en legde hem dat verzoek van Edeleer Muntinghe voor. De suhunan sprak: "Vrede sluiten wil ik niet, maar in een wapenstilstand van vier dagen stem ik toe". Daarop ging Pangéran Dipati naar de eerdergenoemde gezanten van Edeleer Muntinghe terug en bracht hun de beslissing van $\mathrm{Zijne}$ Hoogheid de Suhunan over, namelijk dat hij geen vrede wenste, maar een wapenstilstand van vier dagen wel wilde toestaan. Toen keerden de 
gezanten terug. Nadat zij de beschikkingen van de suhunan volledig aan Edeleer Muntinghe hadden overgebracht, liet deze het oorlogsschip Nassau verhalen tot benedenstrooms van de kraton; en alle kleinere boten en sloepen werden aaneengesloten in linie gelegd.

4.11. Binnen de kratonmuren bleef men paraat en werd al het zware en het lichte geschut weer in stelling gebracht; en van alle kanonnen buiten de wallen werden de zundgaten met een drilboor opengeboord. De edellieden die buiten de kratonmuren woonden, kregen allen bevel binnen de kraton te komen; wie niet wilde zou beschoten worden vanaf het bolwerk. Zo verzamelden allen zich binnen de kraton. Alle edelen en hoffunctionarissen liet de suhunan de eed afleggen dat ze niet zouden deserteren. Aan Radén Kijing werd opdracht gegeven vlotten te vervaardigen om in brand gestoken te worden, vier à vijf stuks. En verscheidene grote merantistammen lagen klaar om als drijfhout door de stroom van de rivier te worden meegevoerd.

4.12. Nadat de termijn van vier dagen was afgelopen, brandde 's ochtends vroeg omstreeks vijf uur het scheepsgeschut op de kratonwal los. Nadat er een stuk of drie salvo's waren gelost, werd het vuur vanuit de kraton beantwoord met één ononderbroken kanonnade, zó snel werden de zware en de lichte kanonnen afgevuurd. Het oorlogsschip Nassau werd daardoor een zeef gelijk: één en al gat. Het oorlogsschip Nassau was een geweldig groot schip: stel dat het dwars op de stroom zou komen te liggen, dan zou het de volle breedte van de Palembangrivier in beslag nemen. Doordat het zo'n groot schip was, hield het 't toch nog uit. De uitrustingstukken die verguld waren en alle waardevolle goederen waren door de Hollanders echter reeds naar de andere, kleinere schepen overgebracht.

Toen de strijd ongeveer twee uur geduurd had, stond de stad Palembang vol kruitdamp; men zag niets meer, alleen de lichtflitsen uit de kanonnen waren te zien, waarvan het schijnsel tot aan de hemel doordrong. Men voelde de aarde dan telkens schokken en de kraton schudde als getroffen door een zware aardbeving. De lafaards raakten daardoor hevig beangst. Sommigen bevuilden hun kleren onwillekurig met urine of ontlasting; andere deden 't in hun broek onder het lopen, bij kleine beetjes spoot hun ontlasting en hun urine naar buiten. Zo waren de lafaards binnen de kraton eraan toe. Vele mensen lachten bij het zien daarvan.

Later — het was omstreeks negen uur en de strijd duurde nog voort - 
kwamen er brandende vlotten en merantistammen op de schepen en de sloepen af. Op dàt moment zonk het schip Nassau, doordat het door een overstelpend aantal kogels van de kratonwal was getroffen. Het anker van dat schip werd op de plek waar het vroegere zoutpakhuis heeft gestaan op de wal getrokken.

Daarna trokken de Hollanders terug. De brandende vlotten nu liepen bij de wijk Kebumén aan de grond. Het vuur verslond de huizen langs de rivieroever; tot in de wijk van Radén Kijing ging alles in vlammen op. Voorts werd het hele etablissement van Edeleer Muntinghe totaal platgebrand, zodat er niets intact bleef, maar alles in de as werd gelegd. Daarbij kwamen de Hollanders die daar met de een of andere ziekte in het ziekenhuis lagen tot de laatste man in de vlammen om. Onmiddellijk daarna vertrok Edeleer Muntinghe met zijn hele troepenmacht en zeilde naar Batavia terug.

4.13. Na de aftocht van de verslagen Hollanders beval Zijne Hoogheid de Suhunan zijn zoon Pangéran Ratu binnen de kratonmuren een aantal optrekjes en tijdelijke verblijven in gereedheid te brengen, die stuk voor stuk als onderkomen moesten dienen voor het gewone krijgsvolk, voor de officieren, voor de hoffunctionarissen uit de adelstand en voor de ambtenaren die niet tot de adel behoorden met al hun bloedverwanten, familieleden en kinderen, en voor alle hooggeplaatsten. Toen al die provisorische verblijven voltooid waren, gaf $\mathrm{Zijne}$ Hoogheid de Suhunan 16 bevel veertig buffels en honderden eenden en kippen te slachten. De dag werd bepaald, waarop door boodschappers van Zijne Hoogheid de Suhunan het gehele volk zou worden opgeroepen voor het feest van het "mengangkat perkuta". Toen kwam men bijeen voor het houden van de volksspelen die van oudsher in zwang waren; zeven dagen en zeven nachten lang weerklonken de gamelans, terwijl al die vermakelijkheden aan de gang waren: een schouwspel zonder weerga. Oorverdovend klonk het gejuich van al het volk. Daar waren de opvoeringen door de mensen uit de bovenlanddistricten, elke streek had zijn eigen spel: maskervertoningen, dansopvoeringen, de sambi, boogschieten, tweegevechten met rottans. Om nog maar te zwijgen van de spelen van Palembang zelf: wajangvertoningen, maskerdansen, ronggèngdansen, de gebejuk, het poppentoneel en het Siamees poppenspel. 't Was toen een onvoorstelbare drukte in de stad Palembang en overal klonk muziek. Menige vrouw vergat haar man en menig man vergat ook zijn vrouw; evenzo dachten kinderen niet aan hun moeder en ouders niet aan hun kinderen. Vanwege de massa mensen die daar bijeen waren wist men niet meer wat 
stroomop- en wat stroomafwaarts, wat water en wat land was. In die zeven dagen en zeven nachten onthaalde Zijne Hoogheid de Suhunan alle civiele en militaire autoriteiten van buiten en van binnen de kraton alsmede het gewone krijgsvolk met hun aanvoerders en voorvechters op eten en drinken, waarbij een ieder volgens zijn rang een plaats kreeg aangewezen. Nadat het programma van die feestmaaltijden afgewerkt was, gaf de suhunan opdracht de gehele voorraad van de schatkamer aan kleingeld, kledingstukken van allerlei soort en rijksdaalders naar buiten te brengen om terstond aan de begunstigden te worden uitgedeeld, aan een ieder van hen naarmate hem toekwam. Daarmee was de zaak afgedaan. Welvarend was de stad Palembang in die tijd en vermaard tot in de verste bovenlanddistricten.

5.

5.1. Toen de feesten achter de rug waren, gaf Zijne Hoogheid de Suhunan bevel versterkingen aan te leggen aan de uitmonding van de Plaju. Elk fort zou onder het commando van een eigen commandant worden gesteld.

No 1. Een fort dat Tambakbaya werd genoemd, gelegen aan de uitmonding van de Plaju, aan de rechteroever als men uit de stad komt. Commandant ervan was Pangéran Kramajaya, die met de opperste leiding was belast. Onder hem stonden enige hoffunctionarissen met 17 officieren en manschappen, volledig bewapend en uitgerust met een aantal kleine kanonnen. Het kanon Seri Palembang geheten was de voornaamste onder de kanonnen.

No 2. Een fort op de punt van Pulau Kembara, Tamèngratu genaamd. Commandant ervan was Pangéran Suradilaga, aan wie hoffunctionarissen waren toegevoegd met officieren en manschappen en die de beschikking had over enkele stukken zwaar en licht geschut en ander wapentuig. No 3. Een fort in Rawa-Rawa Sekampung, Martapura genaamd. Commandant ervan was Pangéran Ratu, onder wiens bevelen een aantal hoffunctionarissen stond met officieren en manschappen, allen bewapend, terwijl men er voorts de beschikking had over verscheidene stukken zwaar en licht geschut, donderbussen en alle verdere krijgsbenodigdheden in voldoende hoeveelheden.

No 4. Een fort middenin de rivier, waaraan de naam Pulau Manguntama was gegeven. Het commando daarover berustte bij Pangéran Kramadiraja tezamen met Pangéran Wirasentika, die een aantal hof- 
functionarissen en officieren tot hun beschikking hadden met volledig bewapend krijgsvolk.

Wat de overige kleinere forten betreft, die hadden een bezetting bestaande uit lieden uit de adelstand; dat waren versterkingen die geen vermaardheid hebben gekregen. De oude en de jonge Pangéran Dipati benevens de oudere edellieden hadden zich met z'n allen bij Pangéran Ratu gevoegd, in het reeds genoemde fort Martapura.

In Palembang zelf legde men versterkingen aan van de kratontrap tot aan de Tengkurukrivier, volledig bewapend met enige tientallen stukken zwaar en licht geschut, met donderbussen, geweren en lontgeweren. De bezetting van die versterkingen werd gevormd door de lagere hofdienaren, aan wie horigen, piekeniers en de oudsten van de senioren onder de ambtenaren waren toegevoegd. Hiermede waren de voorzorgsmaatregelen volledig. Toen alle voorzieningen waren getroffen, was dat gehele verdedigingsstelsel gereed, als een kudde wachtend op zijn tegenstander. Zó wordt vermeld door de schrijver van dit geschiedverhaal. De zuivere waarheid kent God alleen.

5.2. Nu wordt verhaald over de Hollanders, die na hun aftocht waren teruggekeerd naar Batavia. Edeleer Muntinghe had toen verslag uitgebracht aan de Gouverneur-Generaal betreffende het verloop van de strijd om Palembang. Daarop had de Gouverneur-Generaal een rapport 18 verzonden naar Holland, bestemd voor Zijne Majesteit Koning Willem I.

Toen na ongeveer een jaar het antwoord daarop in Batavia was ontvangen, gaf de Gouverneur-Generaal vervolgens op zijn beurt bevel aan Generaal Schout-bij-nacht een tocht naar Palembang te ondernemen met Edeleer Muntinghe, Pangéran Jayaningrat, de zoon van Suhunan Dia'uddin, Pangéran Jayakrama en Pangéran Wirakrama Gubir, de patih van Suhunan Dia'uddin. Aan de expeditie namen deel: vier grote oorlogsschepen, vier oorlogsbrikken en een aantal grote landingsboten, alle van een complete oorlogsuitrusting voorzien, en duizend soldaten.

5.3. Die vloot nu voer de Palembangrivier op. Het dorp Sungsang was geheel verlaten, alle inwoners ervan hadden zich samengetrokken op Palembang. Het dorp Sungsang werd door de Hollanders totaal platgebrand, zodat er niets meer van overbleef. Toen de Hollandse vloot de Kundurrivier had bereikt, gingen alle schepen daar voor anker. Op dat tijdstip waren in elk fort de kanonnen reeds in stelling gebracht en geladen.

De volgende morgen, nog voordat er gezanten gezonden waren, klonk 
er plotseling kanongebulder uit het oerwoud, uit de richting van het fort Tambakbaya. De slotenmaker van de generaal van het grootste oorlogsschip werd getroffen en stierf. Toen ontstond er opschudding aan boord. In groten getale gingen de soldaten in de grote landingsboten en stevenden op het fort af, terwijl ze de dienaar van Pangéran Wirakrama Gubir met zich meevoerden als afgezant van de generaal naar Zijne Hoogheid de Suhunan. Bij het fort ging hij aan wal; vervolgens liep hij verder naar Palembang, maakte zijn opwachting bij Zijne Hoogheid de Suhunan en bood deze een brief aan. Zijne Hoogheid de Suhunan gelastte toen de ambtenaar voor godsdienstzaken de brief in ontvangst te nemen. Nadat de suhunan die brief geopend had, las hij deze. Toen hij hem uitgelezen had, glimlachte Zijne Hoogheid de Suhunan een beetje. Daarop droeg Zijne Hoogheid de Suhunan de ambtenaar voor godsdienstzaken op de brief te beantwoorden. Toen het antwoord klaar was, werd het aan die Si Gangsa overhandigd. Deze groette beleefd, keerde naar het fort terug en vervolgens weer naar het schip. Daar overhandigde hij de brief aan Generaal Schout-bij-nacht. Nadat de generaal die brief had gelezen, gaf hij commando dat alle schepen het fort dicht zouden naderen, elk met de steven derwaarts gewend.

5.4. Toen begon de strijd. Luid dreunden de kanonnen, het lichtere 19 geschut en de granaten. Door de kruitdamp van het geschut werd alles in duisternis gehuld. Onafgebroken vuurden beide partijen de kanonnen af, zodat het fort schudde en het water in de rivier onstuimig golfde. Vanwege het grote aantal brikken en landingsboten was de Kundurrivier vol schepen. Boven- en benedenstrooms, land en water waren niet meer van elkaar te onderscheiden. Het enige wat nog te zien was, waren de lichtflitsen uit de vuurmonden.

Door de wil Gods geschiedde het, dat men in het uur van de strijd in elk fort zonder ophouden bezig was met het reciteren van heilbeden en van de aanhef van de geloofsbelijdenis en met het opzeggen van gebeden; dat gaf een dreunend geluid als van een gezang. Met name het fort Tambakbaya muntte uit in het doen van vrome werken. In het fort Tambakbaya bevond zich het kanon Seri Palembang, waarvan de kogels werden belezen door het uitspreken, veertig maal, van de yasin. Door de macht van God de Allerhoogste vielen die kogels, telkens wanneer ze werden afgeschoten, met absolute trefzekerheid op de schepen, als vielen ze doelbewust daarop aan. Door het kanon Seri Palembang kwam het, dat vele oorlogsschepen schade opliepen en vele soldaten 
werden gedood. Evenzo was de uitwerking van het kanonvuur uit het fort Martapura: een paar brikken liepen schade op aan hun uitrusting en enkele landingsboten zonken. Elk fort weerde zich die dag trouwens zeer krachtig en hield de oorlogsschepen onafgebroken onder vuur. Wat Pangéran Jayaningrat en Pangéran Wirakrama Gubir betreft, die hadden hun doel nog niet bereikt, want al hun plannen waren tot dusver in duigen gevallen.

5.5. Door Gods wil brak de weerstand der Hollanders en alle oorlogsschepen, brikken en landingsboten deinsden af. Toen barstte al het volk in de forten los in een luid gejuich, dat weerklonk als de donder aan het firmament. Daarenboven klonken de trommen en de klarinetten om 't hardst, met een ontzagwekkend geluid. De schepen waren intussen al ver weg en uit het gezicht verdwenen.

Vervolgens werden de commandanten van alle forten door Pangéran Ratu verzameld. Ook Pangéran Ratu van Jambi riep zijn volk bijeen en de Buginezen die aan de strijd hadden deelgenomen, verzamelden zich eveneens. Toen allen verzameld waren, nam Pangéran Ratu de leiding bij de regeling van de terugreis naar Palembang en de indeling van de afzonderlijke boten. Onderweg juichte men uit volle borst, ter-

20 wijl de vreugdetrom werd geroerd, de gamelan werd bespeeld en de klarinet werd geblazen. Zeer indrukwekkend klonk het.

Toen het geluid tot Palembang doordrong en de suhunan het hoorde, gaf $\mathrm{Zijne}$ Majesteit bevel de aankomenden te verwelkomen, waartoe de oudste hoffunctionarissen zich moesten opstellen op de kratonsteiger, met allerlei slaginstrumenten, met troms en met de gamelan. Zijne Hoogheid de Suhunan hield zich gereed om het gezelschap op te wachten in de uit twee gedeelten bestaande ontvangzaal, waar ook de rijkssieraden waren opgesteld. Nadat allen waren aangekomen, maakten zij hun opwachting bij Zijne Hoogheid de Suhunan, groetten eerbiedig en gingen ordelijk in rijen zitten. Pangéran Ratu deed toen het relaas van de strijd en vertelde dat de forten behouden waren gebleven en dat de Hollanders gevlucht en de monding van de Sungsang uit gevaren waren. Daarop hief Zijne Hoogheid de Suhunan beide handen omhoog en sprak: "Lof zij God", waarop allen antwoordden: "Amen". Vervolgens gaf de suhunan order dat allen die aan de strijd hadden deelgenomen zich maandagochtend moesten verzamelen in de raadszaal van de audiëntiehal, allen, groot en klein, jong en oud, hofdignitarissen en edellieden. Toen stond Pangéran Ratu op en bracht dat bevel van de suhunan aan de aanwezigen over. Allen gaven hun instemming daar- 
mede te kennen, terwijl ze als teken van onderdanigheid de handen op het hoofd legden. Daarna vertrok de suhunan en ging het paleis binnen; meer wordt er niet verteld. Iedereen ging toen naar huis.

5.6. Toen de afgesproken dag was aangebroken, kwamen allen bijeen en maakten hun opwachting in de ontvangzaal die uit twee compartimenten bestond; die beide compartimenten waren tot de laatste plaats bezet. Daarna kwam Zijne Hoogheid de Suhunan uit de binnenzaal van de kraton naar buiten en nam plaats op de rijkstroon. Allen wierpen zich ter aarde en bewezen Zijne Hoogheid de Suhunan hulde. Toen stond Pangéran Dipati de Oudere op en deed mededeling van het besluit van Zijne Hoogheid de Suhunan, hetwelk nu meteen aan alle aanwezigen werd bekendgemaakt, te weten dat aan Pangéran Ratu de titel was verleend van Sultan Ahmad Najamuddin, zoon van Zijne Hoogheid Suhunan Mahmud Badaruddin. Daarop dreunden allen in koor: "Amen", terwijl ze als teken van onderdanigheid hun beide handen

21 op het hoofd legden. Vervolgens werden er verscheidene gerechten binnengebracht en in de vergaderzaal opgediend. Iedereen kreeg zijn plaats aangewezen en werd bediend volgens zijn rang en waardigheid: de hofdignitarissen met de hofdignitarissen, de edelen met de edelen en evenzo de officieren en de manschappen, een ieder met zijn soortgenoten, totdat alles in orde was en alle mensen die aanwezig waren in voldoende mate voorzien waren. Toen iedereen voorzien was, begonnen op een teken van $\mathrm{Zijne}$ Hoogheid de Suhunan allen te eten. Nadat de maaltijd was afgelopen, werden er weer dranken geserveerd. Toen men klaar was met eten en drinken, werd tegelijkertijd Pangéran Adimenggala bevorderd tot de rang Pangéran Bupati.

6.

6.1. Op een dag kwamen er mensen van Sungsang hun opwachting maken bij Sultan Ahmad Najamuddin; zij deelden mee dat een Hollands oorlogsschip in de monding van de Sungsang de wacht hield en schepen en brikken verbood de Palembangrivier binnen te varen, dat werd niet toegestaan. Nadat de sultan die klacht van de Sungsangers had aangehoord, gaf Zijne Hoogheid daarvan terstond kennis aan Zijne Majesteit de Suhunan. Toen Zijne Majesteit de Suhunan die mededeling van zijn zoon hoorde, gaf hij de onderscheidene hoffunctionarissen bevel al het oorlogsmaterieel in gereedheid te brengen en alle forten te versterken. Dwars over de rivier bij Muara Plaju bracht men een versperring 
van boomstammen aan en er werd zelfs een zware ketting gespannen van de rivieroever ter hoogte van Muara Plaju helemaal naar de overkant tot aan het eiland Kembara, opdat het zowel voor schepen en brikken als zelfs voor sloepen en landingsvaartuigen onmogelijk zou zijn door te varen en zo de forten binnen te komen. Toen dat alles klaar was, gaf Zijne Majesteit nog opdracht kruit en kogels aan te maken. Dat de Palembangers bedreven waren in het vervaardigen van kruit hadden ze te danken aan een Hollander, die aan Edeleer Muntinghe om een middel van bestaan had gevraagd en toen met de aanmaak van kruit was begonnen; na verloop van tijd is hij tot de Islam overgegaan. Daardoor is het gekomen dat de Palembangers wisten hoe ze kruit, geweren en kogels moesten maken. Later is hij er vandoor gegaan en naar Batavia teruggekeerd, God weet wat er van hem geworden is.

Toen er vervolgens voor de stad Palembang een tijdperk van welvaart was aangebroken, regeerde Zijne Majesteit de Suhunan enige jaren achtereen als onafhankelijk heerser, geheel handelend naar eigen goed-

22 vinden. Volgens de herinnering van sommigen onder de oudste mensen heeft het vier jaar geduurd, anderen zeggen dat het vijf jaar en weer anderen dat het drie jaar geduurd heeft dat de stad Palembang in een toestand van rust en welvaart verkeerde.

6.2. De geschiedenis verhaalt nu weer verder over de Hollanders, die verslagen waren. De Hollanders pleegden overleg met Suhunan Husin Dia'uddin, die naar Cianjur was verbannen, en daardoor ontstond er een verhouding van vriendschap tussen hem en de Gouverneur-Generaal en Edeleer Muntinghe. Geregeld kwam Edeleer Muntinghe Suhunan Husin in Cianjur opzoeken. Op een dag sprak Edeleer Muntinghe tot Suhunan Husin, zeggende: "Zou U tezamen met Suhunan Mahmud Badaruddin vorst willen zijn in Palembang?". Suhunan Husin antwoordde: "Ja, mits dat in een sfeer van werkelijk overleg zou geschieden". Daarop zei Edeleer Muntinghe: "Ik zal er wel voor zorgen dat Suhunan Mahmud Badaruddin het met $U$ eens wordt. De opbrengst van de produkten van Palembang zijn echter voor de helft voor $U$ en voor de helft voor Suhunan Mahmud Badaruddin. Maar met z'n beiden krijgt $\mathrm{U}$ toch slechts de helft van de opbrengst van het land, de andere helft moet $U$ aan het Gouvernement afstaan. Het Gouvernement bepaalt zich ertoe een beroep op Uw gastvrijheid te doen voor de bouw van een loge in de wijk Kelénténg, aan de overkant van de Palembangrivier". Dat verzoek van Edeleer Muntinghe werd ingewilligd.

Daarna werd Suhunan Husin door de Gouverneur-Generaal naar 
Batavia opgeroepen. Nadat Suhunan Husin en de Gouverneur-Generaal elkaar hadden begroet, zei de Generaal: "Ik geloof dat indien U vorst van Palembang wilt worden, $U$ beter alléén vorst kunt zijn. Wat heeft het voor zin met z'n tweeën vorst te zijn? Straks zult $U$ het samen misschien niet eens kunnen worden". Suhunan Husin antwoordde: "Dat is inderdaad het beste". Toen zei de Generaal: "Staat U er voor in dat we Palembang in onze macht zullen krijgen?". De suhunan antwoordde: "Ja, U zult de stad in handen krijgen". Daarop zei de Generaal: "Als dat zo is, dan kunnen we nu een contract opmaken, waarin mijn wensen zijn neergelegd. Wanneer Palembang ons in handen is gevallen, zullen uitsluitend de volgende bepalingen van kracht zijn:

No 1. U zult vorst zijn, en wel alléén.

23 No 2. De opbrengsten van Palembang komen voor de helft aan het Gouvernement.

No 3. Het Gouvernement heeft de volledige zeggenschap over de zaken van het tolkantoor, dat wil zeggen van het douanekantoor; $\mathrm{U}$ hebt daarin geen medezeggenschap.

No 4. Wanneer er vreemde handelaren in Palembang komen zullen zij, zodra ze een jaar in Palembang gevestigd zijn, uitsluitend aan Uw gezag onderworpen zijn.

No 5. Wat de rechtsinstellingen des lands betreft, deze blijven onveranderd van kracht overeenkomstig de bepalingen die van oudsher gelden.

No 6. U zult woongelegenheid voor de Hollanders beschikbaar moeten stellen, aan de andere kant van de rivier dan waar de kraton is gelegen, in dezelfde wijk als waar vroeger Edeleer Muntinghe zijn verblijf had."

Met alles wat in deze zes artikelen was vervat ging de suhunan akkoord. De hier vermelde overeenkomst werd vervolgens aldus vastgesteld. Nadat dit was geschied, gelastte de Generaal Edeleer Muntinghe dat contract te doen verlijden ten overstaan van de gezamenlijke rechters te Batavia.

Tevens gaf de Generaal bevel tien grote oorlogsschepen uit te rusten en één oorlogsschip voor Suhunan Husin Dia'uddin met zijn gevolg; voorts tien grote landingsvaartuigen en een aantal schoeners en brikken, alle voor de oorlog uitgerust. Nadat alle voorzieningen waren getroffen, werd de dag van vertrek uit Batavia bepaald. De soldaten meegerekend telde de Hollandse troepenmacht in totaal vijfduizend man. 
6.3. Zo vertrok men uit Batavia met een grote vloot. Na een reis van verscheidene dagen arriveerde men in de monding van de Sungsang. De suhunan zond een bode uit om aan het hoofd van de Sungsangers en aan de commandant van het patrouillevaartuig, dat wil zeggen van de kruisprauw van Palembang, te laten weten dat Suhunan Dia'uddin 't was, die aan de kant van de Hollandse Compagnie het bevel voerde. De mensen van Sungsang en de bemanning van de patrouilleboot kwamen daarop met z'n allen bij de suhunan aan boord van het oorlogsschip hun opwachting maken. Vervolgens werd door de suhunan geïnformeerd naar alle geheimen in de stad Palembang. Alles werd door de mensen van Sungsang verteld: dat de toestand in de forten zus en zo was en dat de bezetting ervan uit die en gene bestond. Daarna beloonde

24 de suhunan de mensen die de geheimen verteld hadden door hun tal van geschenken te geven. Toen dat was geschied, schreef $\mathrm{Zijne}$ Hoogheid de Suhunan een paar brieven aan Pangéran Dipati de Oudere en droeg de Sungsangers op deze te bezorgen. Daarna voeren alle oorlogsschepen van de vloot de rivier op naar Palembang.

6.4. Hiermee zijn we eigenlijk met ons verhaal op de gebeurtenissen vooruitgelopen; daarom wordt hieronder nu eerst de voorgeschiedenis verteld.

Toen de Generaal dat contract had opgemaakt, vroeg de suhunan drie maanden uitstel. Intussen stuurde de suhunan zijn echtgenote, Nyimas Taipah genaamd, naar Palembang terug, onder voorwendsel dat ze door de suhunan was verstoten en daarom naar Palembang moest terugkeren. Men liet haar naar het oorlogsschip vervoeren dat de riviermonding bij Sungsang bewaakte. Nadat ze aan boord van het oorlogsschip was gekomen, werd ze tot in de monding van de Sungsang gebracht en vervolgens overgedragen aan een patrouilleboot, die haar verder naar Palembang bracht. Welke geheime contacten Nyimas Taipah na aankomst in Palembang met Pangéran Dipati de Oudere en de edelen die op de hand van Suhunan Dia'uddin waren heeft gehad weet niemand, maar het resultaat was dat er uit Palembang een brief kwam, gericht tot de Suhunan te Cianjur, welke aan Suhunan Husin Dia'uddin belangrijke geheime inlichtingen verschafte. Zo kwam het dat de suhunan er toe overging dat contract met de Generaal aan te gaan om Palembang te veroveren en dat de suhunan naar Palembang vertrok, zoals hierboven reeds is beschreven.

6.5. Nadat de vloot het riviertje de Kundur had bereikt, gingen alle 
schepen, brikken en landingsvaartuigen midden op de Kundurrivier ten anker, zodat het vaarwater van de Kundurrivier vol schepen lag. De opperbevelhebber van de vloot heette Generaal De Kock, die samen met Edeleer Muntinghe het commando voerde. In de forten van Muara Plaju was alles voor de strijd gereed, in elk van die forten was iedereen paraat en in afwachting, terwijl men niet afliet zegenbeden en de beginwoorden van de geloofsbelijdenis uit te spreken, dag en nacht.

Van nu af aan zond Generaal De Kock geen mensen meer als afge-

25 zanten naar Palembang, maar hij maakte gebruik van een klein vlot dat hij had laten maken, met een glazen stopfles waarin een brief aan Zijne Hoogheid Suhunan Mahmud Badaruddin. Toen het vloed werd, liet men dat vlot afdrijven naar het fort Martapura, waar Sultan Ahmad Najamuddin en Pangéran Dipati de Oudere zich bevonden. Nadat het vlot bij het fort was aangekomen, pikten de mensen van het fort de fles met die brief op en boden deze aan Sultan Ahmad Najamuddin aan. Toen hij naar het adres had gekeken, "aan Zijne Hoogheid Suhunan Mahmud Badaruddin", durfde de sultan de brief niet te openen. Vervolgens liet hij de brief naar Palembang brengen en aan Zijne Majesteit zijn vader, Suhunan Mahmud Badaruddin, overhandigen. Nadat de Suhunan in Palembang de brief had ontvangen en gelezen, liet hij hem beantwoorden, God weet wat er in stond. Toen de brief af was, werd deze naar het fort Martapura gebracht en vervolgens, nadat men de brief in dezelfde stopfles had gedaan die tevoren verstuurd was, op het vlot gelegd. Toen het eb werd, liet men het weer terugdrijven naar het oorlogsschip. Na aankomst werd de brief in de fles door de bemanning van het schip opgepikt en aan Generaal De Kock en Edeleer Muntinghe gegeven.

6.6. Toen kwamen er sloepen van de oorlogsschepen op het fort af, terwijl ze onophoudelijk hun granaten afvuurden. Toen het vuur vanuit het fort Tambakbaya en de andere forten werd beantwoord, vluchtten de sloepen weg. Dat was het begin van de vijandelijkheden.

Daarna kapten de Hollanders een tracé door het bos van Muara Plaju om een doorsteek te maken naar de achterkant van het fort Tambakbaya. Toen Pangéran Kramajaya, de commandant van het fort Tambakbaya, dat te weten was gekomen, liet hij midden op de Plajurivier de wacht houden met een aantal van geschutbepantsering voorziene vaartuigen, die op de Plajurivier gingen liggen wachten, bewapend met zware en lichtere kanonnen en donderbussen. En toen de Hollandse soldaten aan de oever van de Plajurivier waren aangekomen en zij net 
op het punt stonden hun bootjes van de wallekant af te water te laten, opende de bemanning van de met een geschutpantser uitgeruste vaartuigen vanaf de Plajurivier het vuur op het bos, waar de hoofdmacht 26 van die soldaten zich bevond. Op dat ogenblik begon men elkaar over en weer te beschieten, vanaf het water en vanuit het bos. Onder luid krijgsgeschreeuw van de hele Palembangse strijdmacht werd er uit die met een geschutpantser versterkte prauwen geschoten en de kanonnen van het fort Tambakbaya weerklonken, terwijl hun kogels zonder ophouden het bos in vlogen waar de Hollandse soldaten zich bevonden. Tenslotte klommen de Palembangse krijgers de wal op en bestormden de verblijfplaats van de soldaten. $\mathrm{Na}$ het eerste samentreffen vielen de Palembangse strijders woedend op het leger soldaten aan, terwijl hun krijgsgeschreeuw als donderslagen hoog opklonk in de lucht; zeer fel was hun aanval. De soldaten doorstonden die aanval niet, vluchtten hun sloepen in en zetten in allerijl koers naar de oorlogsschepen.

Toen de Palembangers zagen dat de soldaten zich hadden teruggetrokken, hieven zij een donderend gejuich aan. In grote hoeveelheden werden er schoenen, kleren en geweren buitgemaakt, die daar in het bos waren achtergebleven. Bovendien zeer veel voedsel en vruchten die in Palembang voorkomen, zoals beléwah, semangka, jeruk kuwik-kuwik en andere. De Palembangers vroegen zich met verbazing af waar dat Palembangse fruit vandaan was gekomen, terwijl ze toch zo streng de wacht hadden gehouden. Ook werden er gesneuvelde soldaten gevonden, die werden dan onthoofd. Dat alles werd door de bemanning van de met een geschutpantser uitgeruste boten afgeleverd aan het fort Tambakbaya, waarna het naar Palembang werd vervoerd en aan $Z$ ijne Hoogheid Suhunan Mahmud Badaruddin aangeboden. De suhunan verschoot van kleur onder het luisteren naar het relaas van de mensen van het fort Tambakbaya, maar hij gaf geen enkele opdracht.

6.7. Toen de strijd een paar dagen aan de gang was, verplaatsten alle oorlogsschepen zich tot dichtbij de forten Martapura en Manguntama en het fort in Rawa-Rawa Sekampung, maar ze bleven uit de buurt van het fort Tambakbaya. In de verhalen van de oudere mensen heet het dat de andere forten hun kanonskogels slechts een lading van citrusvruchten gaven om de oorlogsschepen daarmee als het ware te wassen. Zo heet het in de verhalen van de oudere mensen van Palembang. Het

27 fort Tambakbaya was het enige dat kogels van ijzer gebruikte. Daardoor kwam het niet zover, dat die tientallen oorlogsschepen de verdedigers verliezen toebrachten. Er was echter één oorlogsschip dat van alle 
schepen het grootste was; het heette Kerambang en had enorm grote kanons. Dat schip lag recht tegenover het fort Tambakbaya en schoot zijn kogels op dat fort Tambakbaya af; het leek wel alsof het uit de grond zou worden gerukt, terwijl daarbij een geluid weerklonk als van een inslaande bliksem, die de aarde doet splijten. Zo ging het er toe.

Het werd een grote strijd op die dag. Het krijgsgeschreeuw en de schoten van de zware en lichte kanonnen en van de geweren weerklonken alsof de dag des oordeels was aangebroken. Toen alle oorlogsschepen naderbij gekomen waren, nam Sultan Ahmad Najamuddin persoonlijk de leiding en het toezicht over het schieten op zich en eerst tóen werd er door elk fort met ijzeren kogels geschoten.

6.8. Toen dat het geval was, deinsden al die schepen af. Twee grote landingsvaartuigen met hun uitrusting werden buitgemaakt, één door het fort Manguntama van Pangéran Wirasentika en één bij het fort op het eiland Kembara, onder Pangéran Suradilaga. De beide landingsvaartuigen waren met koper beslagen en uitgerust met een koperen kanon, dat drie vadem lang was, en op de achterplecht een kanon van ijzer. De ene landingsboot was precies gelijk aan de andere. Het kanon van het ene landingsvaartuig werd bij het fort van Pulau Kembara op de wal getrokken; het werd Seri Betawi genoemd. Het kanon van de landingsboot die was veroverd door Pangéran Suradilaga zou bij het fort Tambakbaya aan land worden gebracht; het viel toen in het water en men kreeg het niet meer te pakken. Er waren aan boord van die beide landingsvaartuigen geweldig veel kogels; ook andere dingen werden in enorme hoeveelheden buitgemaakt. Bij deze gevechten is het gebeurd, dat van het grote schip Rambang de voormast naar beneden kwam en de boegspriet afbrak.

6.9. De tweede nacht, dat was de nacht van zaterdag op zondag, naderden de landingsvaartuigen en de oorlogsschepen gezamenlijk de forten. Om drie uur 's nachts verscheen de vloot vóór de vestingwerken en om half zes in de ochtend werden de vijandelijkheden geopend. Op die zaterdagavond waren alle mensen echter naar Palembang teruggegaan; alleen degenen die de wacht hadden, waren achtergebleven. Men was im-

28 mers overeengekomen dat er 's zondags, zowel overdag als 's nachts, niet gevochten zou worden. In de vroege ochtend nu weerklonk het geschut met een hevig geweld als van de donder. Tambakbaya was het enige fort dat de aanval beantwoordde. Daarop keerden al het krijgsvolk en ook de sultan weer naar de versterkingen terug. De schepen waren 
echter reeds allemaal vlakbij de forten, terwijl de kanons aan één stuk door werden afgevuurd; het leek wel alsof het stormde en onweerde. Alle schepen schoten in een hecht onderling verband op de forten. De kogels die de forten misten, kwamen op de bomen in het bos terecht, die in groten getale omvielen. Daarbij weerklonk het krijgsgeschreeuw van de soldaten op de schepen als de donder. Verbijsterd van schrik waren de lafaards, vol doodsverachting de dapperen. Wat de toestand in de forten betreft, daar waren allen druk bezig zegenbeden en de beginwoorden van de geloofsbelijdenis op te zeggen, onafgebroken en zonder ophouden. Maar hoe men ook bidt of smeekt of strijdt, wanneer eenmaal het wilsbesluit van God de Allerhoogste is gevallen, kan niemand de uitvoering daarvan tegenhouden. Zo was nu het ogenblik aangebroken waarop er een eind zou komen aan de heerschappij van een islamitisch vorst in de stad Palembang om plaats te maken voor de heerschappij van de ongelovigen.

6.10. Die dag gaf het fort van Pulau Kembara de strijd op en vluchtte de hele bezetting ervan naar Palembang. De Hollanders trokken daarop het fort binnen, haalden de vlag neer en hesen hun eigen vlag.

Toen Pangéran Ratu van Jambi had gezien dat het fort van het eiland Kembara door de Hollanders was veroverd, stak hij zijn eigen fort in brand; vervolgens voer hij stroomopwaarts naar Palembang.

De bezetting van het fort Tambakbaya, dat nog krachtig weerstand bood, vuurde onafgebroken het kanon Seri Palembang af onder het opzeggen van de yasin, van zegenbeden en van de beginwoorden van de geloofsbelijdenis. Van een groot aantal oorlogsschepen brak de mast in stukken en vele soldaten vonden de dood. Gesteld dat er maar een stuk of twee, drie oorlogsschepen waren geweest, dan zouden ze, ook al waren ze nog zo groot, zonder twijfel zijn vernietigd, aangezien ze het tegen de kogels uit het fort Tambakbaya niet hadden kunnen uithouden. Wel sneuvelden er zo'n vier- à vijfhonderd soldaten, maar het aantal oorlogsschepen was tè groot.

Toen Pangéran Wirasentika had gezien dat Pangéran Ratu van Jambi gevlucht was en dat diens fort in brand stond, liet hij zijn fort 29 in de steek en trok hij in bij het fort Martapura, samen met de Buginezen. Toen de zaken zo stonden, bracht Pangéran Dipati de Oudere de sultan naar Palembang terug. Ook alle kleinere forten waren inmiddels tot de laatste toe door de Hollanders in brand gestoken.

6.11. Toen de sultan naar Palembang was gevlucht, was het alleen nog 
maar het fort Tambakbaya dat zich steeds feller werend de Hollanders met angst vervulde. Door landingsboten kon het niet benaderd worden, omdat er zeer hevig werd geschoten. Daarom werd er toen door vijfhonderd soldaten een doorsteek gemaakt naar de achterkant van het fort Tambakbaya, waarna zij met z'n allen tegelijk hun geweren afvuurden, wat klonk als de stormwind. Daardoor raakte het fort Tambakbaya in opschudding. Toen Pangéran Kramajaya zag dat het er zó gesteld was dat een geweldig aantal soldaten op het punt stond het fort te gaan bestormen, trof hij voorbereidingen om zich met al zijn krijgsvolk dood te vechten. Haastig sloeg hij zijn armen om zijn vader, Pangéran Natadiraja, en Haji Kramanandita heen en liet hen niet meer los. Terwijl hij hen beiden bij de hand hield, leidde hij hen weg en bracht hij hen in veiligheid naar een plek, stroomafwaarts gelegen van de plaats waar de soldaten vandaan kwamen. Toen de soldaten de mensen van het fort zagen weglopen, drongen zij terstond het fort binnen en roofden alles wat er maar achtergelaten was; tevens brandden zij het fort Tambakbaya tot op de grond af. Daarmee was er aan de gevechten van die dag een eind gekomen.

6.12. Terwijl alle andere oorlogsschepen buiten het paalwerk voor anker lagen, voer het oorlogsschip aan boord waarvan Suhunan Husin Dia'uddin zich bevond, aan de zijkant langs het paalwerk het afgesloten deel van de rivier binnen. Toen het daar vier dagen lang voor anker had gelegen, kwam 's avonds Pangéran Dipati de Oudere Suhunan Husin aan boord opzoeken. Nadat zij elkaar ontmoet hadden, liet de suhunan Pangéran Dipati de Oudere diezelfde avond nog bij Generaal De Kock brengen. Nadat hij bij deze was aangediend, vertelde Pangéran Dipati de Oudere dat Suhunan Mahmud Badaruddin verzocht de strijd te staken en vrede te sluiten. Voor zichzelf deed Pangéran Dipati de Oudere het verzoek dat zijn huis en hof gespaard en niet vernietigd 30 zouden worden. Toen zei Generaal De Kock: "Ik vind het goed om vrede te sluiten, maar onder één voorwaarde. Indien deze zaak hiermee inderdaad afgelopen is en de forten geen strijd meer leveren, dan zal men in Palembang in vrede en welvaart kunnen leven. Maar als men blijft doorvechten, zullen wij in Palembang ongetwijfeld verder toeslaan en dan kan er van vrede en welvaart geen sprake zijn. Van de bezittingen zullen de soldaten stellig hun deel roven en de hele stad wordt zonder twijfel tot de grond toe afgebrand. Maar bovenal bedenke men dat het de Hollandse Compagnie niet ontbreekt aan soldaten en aan geldmiddelen voor de oorlogvoering; zelfs een expeditie die tienmaal zo 
groot is als deze hier, kan de Compagnie gemakkelijk op de been brengen!" Daarop gaf Pangéran Dipati de verzekering dat er binnen de muren van Palembang beslist niet gevochten zou worden. Toen het gesprek was afgelopen, groette Pangéran Dipati en keerde naar Palembang terug. Vervolgens maakte hij zijn opwachting bij Zijne Hoogheid de Suhunan en deelde hem mee al wat Generaal De Kock gezegd had. De suhunan nu was ten einde raad; want hij bedacht dat hij zo goed als alleen stond en dat hem derhalve niet anders restte dan al hetgeen door Pangéran Dipati de Oudere besproken was te aanvaarden.

6.13. Toen de vredesbesprekingen definitief waren afgesloten, voeren de oorlogsschepen Palembang binnen en ankerden op de rivier ter hoogte van de kratontrap. Zijne Hoogheid de Suhunan verhuisde naar de woonstede van Pangéran Dipati de Oudere. De oorlogsschepen hadden zich ordelijk in linie gelegd midden op de Palembangrivier, van de uitmonding van de Ogan tot aan het riviertje de Bayas. Het was toen het hijrah-jaar 1236.

De voornaamste officieren en tweeduizend soldaten gingen vervolgens aan wal en trokken regelrecht de kraton binnen. Daarna beval Suhunan Mahmud Badaruddin zijn zoon Pangéran Prabukesuma en Pangéran Kramajaya de kraton aan de Hollanders over te dragen met alles wat zich in de schatkamer bevond, de rijksschatten en de boedels die ten behoeve van de wezen daar werden bewaard. Daarop werd alles wat overgedragen werd, door de Hollandse commandant in ontvangst genomen. Na die opdracht te hebben uitgevoerd, keerden Pangéran Prabukesuma en Pangéran Perdana Menteri Kramajaya naar de suhunan terug en deelden hem mee dat de overdracht aan de Hollanders was voltooid.

De volgende dag gingen ook Edeleer Muntinghe en Suhunan Husin

31 Dia'uddin aan wal en trokken de kraton binnen; zij namen hun intrek naast de plek waar de Hollanders zich voorlopig gevestigd hadden in afwachting van de honorering van de toezegging dat er voor hen een verblijfplaats zou worden ingericht aan de overkant van de rivier, in de wijk Kelénténg. Toen Suhunan Husin enige dagen binnen de kratonmuren met de Hollanders had samengewoond, hield hij het er niet meer uit, omdat de Hollanders er andere leefgewoonten op nahouden; daarom verhuisde hij toen naar Suakbata.

6.14. Nu wordt verhaald dat Suhunan Mahmud Badaruddin zich in- 
scheepte aan boord van een oorlogsschip met al zijn familieleden die hem volgen wilden. Nadat het oorlogsschip drie dagen op de aanlegplaats van Pangéran Dipati de Oudere voor anker had gelegen, vertrok het naar Batavia.

Toen de suhunan vertrokken was, ging ook Generaal De Kock aan wal en hield met Suhunan Husin en Prabu Anom zijn intocht in de kraton. Verscheidene hooggeplaatste Hollanders, de hofdignitarissen, de inheemse bevolking van de stad zomede de Arabieren en de Chinezen verzamelden zich binnen de kraton, zodat het stampvol werd in de kraton. Vervolgens beval de generaal de Hollanders van hoge rang op het podium te komen staan. Terstond bracht men Generaal De Kock, Edeleer Muntinghe en Suhunan Husin Dia'uddin de contractbrief, keurig op een presenteerblad en gewikkeld in geel satijn. Nadat de brief was geopend, las een Hollander, die van de bovengenoemde generaal daartoe de opdracht had gekregen en die meneer De Sturler heette, de akte voor.

De eerste bepaling van de akte luidde, dat Suhunan Mahmud Badaruddin uit de heerschappij was ontzet en dat tevens Sultan Ahmad Najamuddin zomede de andere zoons van de suhunan geen bevoegdheden meer hadden. Van nu af aan zouden Suhunan Husin Dia'uddin en diens nakomelingen als vorst heersen op de troon in het rijk Palembang tot in het gebied van de Palembangse bovenlanden toe, onder het voorbehoud evenwel dat het tolkantoor, dat is het douanekantoor, zou worden overgenomen door de Compagnie; wanneer handelaars een vol jaar in Palembang verblijf hadden gehouden, zouden ze echter onder

32 de jurisdictie van de suhunan vallen. En wat de rechtsinstellingen van Palembang aangaat, deze zouden ongewijzigd van kracht blijven zoals ze van oudsher gegolden hadden.

Nadat de akte geheel was voorgelezen, werd hij door meneer De Sturler aan de suhunan overhandigd. Toen weerklonken er saluutschoten van het scheepsgeschut, die beantwoord werden vanaf het bolwerk. Overal werd er toen op tal van muziekinstrumenten gespeeld. Tweeduizend militairen hadden zich in rijen opgesteld vanaf de kratontrap tot aan de uit twee vertrekken bestaande ontvangstruimte en brachten met z'n allen het saluut ter ere van de troonsbestijging van de suhunan.

$\mathrm{Na}$ afloop van die plechtigheden gaf de generaal bevel de grote en de kleinere kanonnen aan boord van de oorlogsschepen te brengen; alleen het kanon dat deel uitmaakte van de Palembangse rijkssieraden bleef op verzoek van de suhunan achter. Toen keerden de generaal en Edeleer Muntinghe met de hele vloot naar Batavia terug. 
7.1. Toen dat alles voorbij was, verleende de suhunan te Suakbata aan al degenen die rechtstreeks onder hem stonden ieder afzonderlijk een nieuwe naam:

No 1. Zijn zoon Prabu Anom kreeg de naam Sultan Ahmad Najamuddin.

No 2. Zijn zoon Pangéran Jayaningrat kreeg de naam Pangéran Dipati.

No 3. Pangéran Jayakrama kreeg de naam Pangéran Aryakesuma.

No 4. Pangéran Dipati de Oudere werd benoemd tot Pangéran Bupati Panembahan.

No 5. Pangéran Wirakrama kreeg de naam Pangéran Purbanegara.

No 6. Radén Said werd benoemd tot Pangéran Martakesuma.

No 7. Radén Badaruddin werd benoemd tot Pangéran Natawijaya.

No 8. Aluddin werd benoemd tot Pangéran Natawiguna.

No 9. Pangéran Sumadilaga werd benoemd tot Pangéran Natakrama.

No 10. Radén Tokid werd benoemd tot Pangéran Natawijana.

No 11. Masagus Keling werd benoemd tot Pangéran Temenggung Mentaun.

No 12. Ngabéhi Carik werd benoemd tot Temenggung Yudawijana.

No 13. Demang Wirasentika werd benoemd tot Kiai Rangga Wirasentika.

No 14. Pangéran Adiwijaya werd benoemd tot Pangéran Perdana Menteri en zou de leiding hebben van de staatszaken.

No 15. Radén Zakiuddin werd benoemd tot Pangéran Natanandita.

No 16. Radén Ajid werd benoemd tot Pangéran Kramanandita.

33 No 17. Nayu Hanipa werd benoemd tot Nayu Reksapura.

No 18. Saripah Zainah werd benoemd tot Ratu Saripah.

No 19. Radén Mahpi werd benoemd tot Pangéran Sutanandita.

No 20. Radén Muksin werd benoemd tot Pangéran Sutakrama.

No 21. Radén Cingot werd benoemd tot Pangéran Puspadiprana.

No 22. Masagus Putang werd benoemd tot Pangéran Citra.

Toen dat was geschied, bouwde Pangéran Bupati Panembahan een huis in Suakbata, dichtbij de suhunan.

7.2. In die tijd werd er beraadslaagd over de bouw van een fort voor de Hollanders aan de overkant van de rivier. Alle binnenlanddistricten kregen de opdracht bamboe te leveren en het terrein van Kirangga Usman in Kelénténg werd opengelegd. $\mathrm{Na}$ verloop van enige tijd kwam 
de bamboe aan, aangevoerd uit het binnenland in naar schatting voldoende hoeveelheden voor de bouw van het fort voor de Hollanders. $\mathrm{Na}$ aankomst van de bamboe wendde Pangéran Dipati Jayaningrat zich tot de suhunan en deelde hem mede dat de bamboe was aangekomen. Hij stelde echter voor de bamboe niet voor de bouw van het fort te gebruiken, omdat bamboe gauw vergaat; het fort kon beter van hout gemaakt worden, dat is duurzamer. De suhunan stemde met dat idee van Pangéran Dipati in en gaf toen weer bevel die districten om balken van petalinghout te vragen teneinde daarvan het Hollandse fort te bouwen, opdat het lang intact zou blijven.

$\mathrm{Na}$ verloop van enige tijd kwamen de mensen uit het binnenland weer met balken, bij duizenden werden de petalingbalken in Palembang aangevoerd. Terstond werd hiervan door Pangéran Dipati mededeling gedaan aan de suhunan. De suhunan gaf daarop bevel dat de handwerkslieden zich zouden verzamelen om aan de bouw van het fort aan de overkant te gaan werken.

Toen kwam Pangéran Dipati weer met een voorstel: "We moesten dat fort maar niet van hout maken, want dat vergaat toch ook in korte tijd; alleen wij zouden dan verlies lijden, niet de Compagnie. Het is veel beter dat we het fort van steen maken in plaats van van hout. Als we dat doen, lijden we slechts éénmaal schade; ook al zijn de kosten hoog, we behoeven ze maar éénmaal op te brengen. Maar dit is slechts een opmerking van Uw nederige dienaar, wat U beveelt zal geschieden". De suhunan vond dat het zeer juist was wat Pangéran Dipati wilde. Bovendien bedacht hij dat eertijds in Batavia deze Pangéran Dipati op de nominatie had gestaan om tot sultan aangesteld te worden; maar de suhunan had niettemin Prabu Anom voorgedragen. Terwijl zulke gedachten hem door het hoofd speelden, gaf de suhunan vervolgens toe aan het verzoek van Pangéran Dipati om het fort van steen te maken.

34 Intussen besefte de suhunan niet dat Pangéran Dipati vervuld was van wrok omdat die ander sultan was geworden en dat hij daarom voortdurend op middelen zon om de regering van de suhunan ten val te brengen.

7.3. Vervolgens beval de suhunan dat stenen fort te maken, maar geldmiddelen waren er niet. Toen sprak Pangéran Dipati: "Wij kunnen wel honderdduizend aan de Generaal te leen vragen". Daarop sprak de suhunan: "Dan moet jij maar naar Batavia gaan". Deze antwoordde: "Wie zal mij vergezellen?". Toen sprak de suhunan: "Pangéran Purbanegara zal je vergezellen". 
Daarna werd Pangéran Dipati Jayaningrat als gezant naar Batavia uitgezonden, tezamen met Pangéran Purbanegara. Zo vertrokken zij beiden met een brief van de suhunan voor de Generaal. Na aankomst te Batavia zochten zij Pangéran Dipati Abdurrahman, Pangéran Natadiraja, Pangéran Kramajaya, Pangéran Wirasentika en de dipati van Belidah op, die daar op de bezittingen van Suhunan Mahmud Badaruddin pasten. Suhunan Mahmud Badaruddin was op dat tijdstip al door de Hollanders naar Ternate overgebracht. Zijn kinderen die in Batavia verblijf hielden, waren: Nayu Purbaya Cik Jaro, Pangéran Sutakrama Akil, Pangéran Sutawijaya Usman, Pangéran Sutadiraja Bakar en Pangéran Puteradinata Ali. Zij allen hadden het erover dat ze naar Palembang terug wilden.

Pangéran Dipati Jayaningrat maakte vervolgens samen met Pangéran Purbanegara zijn opwachting bij de Generaal en overhandigde de brief die hij van Suhunan Husin Dia'uddin had meegekregen. Deze werd door de Generaal in ontvangst genomen en vervolgens gelezen. Er stond in vermeld dat de suhunan de somma van honderddduizend zou willen lenen om daarmee de bouw van een fort voor de Compagnie in Palembang te financieren. Nadat hij de brief gelezen had, antwoordde de Generaal: "Dat fort voor de Compagnie moet de suhunan nu maar eerst van bamboe maken. Later, wanneer de suhunan geldmiddelen heeft verkregen uit de opbrengsten van het land, maakt hij maar een fort van steen of van ijzer, net wat hij wil". Verder zei de Generaal nog tegen Pangéran Dipati Jayaningrat: "Misschien wil men dat bedrag van honderdduizend wel gebruiken om de kraton van Palembang aan te vallen en in bezit te nemen". Pangéran Dipati antwoordde: "Misschien wel". Dáárdoor is het gekomen dat het verbond en de beloften inzake Palembang werden geschonden. Pangéran Dipati nam nu afscheid en keerde terug naar zijn logeeradres. $\mathrm{Na}$ een verblijf van enige dagen in Batavia werd Pangéran Purba ziek; de avond van dezelfde dag kon 35 hij niet meer zien. Vervolgens keerde hij terug naar Palembang. Ook Pangéran Wirasentika werd ziek. Hij overleed te Batavia, de doodkist met zijn stoffelijk overschot werd mee teruggebracht naar Palembang.

7.4. Daarna zond de Generaal een commissaris naar Palembang. Pangéran Dipati ging met de commissaris mee en sloot zich nauw bij de commissaris aan. Na aankomst te Palembang wilde Pangéran Dipati niet meer zijn opwachting komen maken bij de suhunan, maar hij bleef integendeel steeds in de onmiddellijke omgeving van de commissaris.

Toen de commissaris al een tijdlang op de hand van Pangéran Dipati 
Jayaningrat was, diende Pangéran Dipati een aanklacht in, namelijk dat Pangéran Adiwijaya, de eerste minister, van plan was een bijvrouw van Suhunan Husin Dia'uddin om het leven te brengen, omdat zij zich, naar men zei, zou hebben misdragen. Vervolgens werd de zaak door de commissaris onderzocht. Daarbij bleek duidelijk dat de aanklacht van Pangéran Dipati juist was. Daarom nam de commissaris genoemde bijvrouw van de suhunan onder zijn hoede en werd Pangéran Adiwijaya, de eerste minister, uit zijn ambt als eerste minister ontzet. Hij werd vervangen door Pangéran Kramajaya, die in zijn plaats tot eerste minister werd benoemd. Het werd toen stil in Suakbata; men bracht er geen zaken meer voor, dat deed men voortaan bij Pangéran Kramajaya, die als eerste minister aan de Tengkurukrivier zetelde. Pangéran Bupati Panembahan woonde ook niet meer in Suakbata, hij was verhuisd naar zijn eigen dorp in de buurt van Sekanak.

$\mathrm{Nu}$ de zaken zó stonden, voelde Suhunan Husin Dia'uddin dat hij de dupe was geworden van de plannen die zijn eigen zoon had gesmeed. Alles wat bij contract met de Hollandse Compagnie was overeengekomen, was daardoor op losse schroeven komen te staan en zonder enige betekenis geworden; 't zou uiteindelijk zelfs nooit meer in orde komen.

7.5. Nu haastte zich de suhunan de commissaris op te zoeken om hem alle binnenlandgebieden af te staan. Daarvan wilde de suhunan behouden om als bron van inkomsten te dienen voor zijn familieleden: no 1 de vijf dorpsgemeenschappen van de Belidah; 2 Pegagan Ilir; 3 Panang Karubelah; 4 Dana Luar; 5 Pemulutan; 6 Teloko; 7 Penukal; 8 het stroomgebied van de Keruh. Alle andere gebieden werden door de suhunan aan de commissaris overgedragen. De commissaris aanvaardde de overdracht, maar ging niet akkoord met het voorstel betreffende de acht genoemde gebieden. In plaats daarvan werden ter compensatie maandelijkse toelagen toegekend aan elk lid van de adelstand, aan elke zoon en aan elk der overige familieleden van de suhunan; tot zelfs de de suhunan kreeg een toelage voor levensonderhoud.

36 7.6. Toen alle hier genoemde voorzieningen waren getroffen, stelde de commissaris een raad in, dat is een college voor het onderzoek en de berechting van zaken van de ingezetenen tot in de verste binnenlanden en in elk dorp. De hoofden ervan kregen de titel van dipati en hun ondergeschikten die van kria en penggawa. Voorts kreeg elke afdeling zijn eigen gesalarieerde politie. De dorpshoofden en hun ondergeschikten 
kregen slechts een percentage van de opbrengsten van het dorp of het district, alsmede van de belastingen.

De leden van de raad te Palembang, die allen gesalarieerd werden, waren: no 1 Pangéran Perdana Menteri Kramajaya; 2 Kemas Temenggung Kertanegara; 3 Kemas Rangga Hasan; 4 Kirangga Tamin; 5 Kirangga Ahmad; 6 Kirangga Jalil. Zij allen kregen een salaris van tweehonderd gulden per maand, behalve Pangéran Perdana Menteri, die als enige een salaris van vijfhonderd gulden had. Elke raadszitting werd bijgewoond door Suhunan Husin Dia'uddin, die als voorzitter optrad, zomede door Pangéran Penghulu Agama, wiens salaris honderdvijftig gulden bedroeg. De zittingsdagen van de raad werden bepaald op donderdag en maandag; en wanneer de suhunan op de zittingsdag niet verscheen, dan ging de raadsvergadering niet door.

7.7. Nadat hij de zaken in Palembang definitief zo had geregeld, keerde de commissaris naar Batavia terug. Als plaatsvervanger van de vorst te Palembang werd aangesteld Resident Reijnst, die het bestuur zou voeren over de stad Palembang en het binnenland. Zijne Hoogheid Suhunan Husin ontving een maandgeld bij wijze van pensioen. De resident makkte vervolgens een verordening op het wegonderhoud in de wijken van Palembang aan weerszijden van de rivier, een verordening op de uitoefening van de politie en een verordening op het verrichten van wachtdiensten in de wijken. Voor al die regelingen had de commissaris opdracht gegeven; ze werden uitgevoerd door de resident en zouden voor altijd van kracht blijven.

8.

8.1. Toen Suhunan Husin Dia'uddin enige tijd te Suakbata had geresideerd, was het punt bereikt waarop er voor Palembang een ander tijdperk zou aanbreken. Dat kwam door Sultan Ahmad Najamuddin Prabu Anom, die nadat de suhunan enige tijd aan de regering was geweest ingevolge het reeds vermelde contract vorst zou worden. Terwijl de sultan in die tussentijd nog sultan was, liet hij zich plotseling door zijn patih, Pangéran Puspadiprana Cingot, overhalen om een komplot te smeden tegen de Hollandse Compagnie. Verscheidene mensen hadden 37 reeds gehoor gegeven aan diens inblazingen om ontrouw te plegen jegens de Hollandse Compagnie, terwijl de suhunan in Suakbata volstrekt onkundig was van die geheime zaken.

Op zekere dag riep de sultan met allerlei mooie praatjes de amb- 
tenaren die zitting hadden in de raad en verder allerlei lieden uit de adelstand bij zich en beval hen naar Suakbata te gaan, omdat ze zouden zijn opgeroepen door de suhunan. Daarop gingen de ambtenaren en de edellieden met z'n allen naar Suakbata om hun opwachting te maken bij de suhunan. In Suakbata aangekomen gingen ze in dichte drommen op het voorerf zitten om op de suhunan te wachten. Toen de suhunan dit merkte, was hij sprakeloos vanwege de handelwijze van de sultan. Daarna arriveerde de sultan in Suakbata, hield al die mensen vast en zei hun dat ze niet naar huis mochten, maar op de suhunan moesten wachten. Hijzelf zou naar Sekanak teruggaan om de mensen die daar waren te mobiliseren, zodat zij allen paraat zouden zijn voor de heilige strijd.

Nadat de sultan in zijn boot was gestapt, keek hij achterom en toen zag hij Pangéran Perdana Menteri weglopen, naar het scheen van plan naar huis te gaan. Haastig keerde de sultan om, ging aan wal en liep op Pangéran Perdana Menteri toe, terwijl hij een lang kapmes omklemd hield. Naderbijgekomen hief de sultan dat kapmes omhoog om er Pangéran Perdana Menteri een houw mee te geven. Snel pakte Pangéran Bupati Panembahan toen van achteren de hand van de sultan beet. De sultan op zijn beurt greep Pangéran Perdana Menteri vast en liet hem niet los. Bupati Panembahan griste de sultan het kapmes uit de hand; er ontstond een worsteling, waarbij Pangéran Perdana Menteri uit de greep van de sultan loskwam. Toen stieten en staken de anderen die de sultan vergezelden Pangéran Perdana Menteri van achteren met de kris, waardoor diens jasje op verscheidene plaatsen gehavend werd. Maar Pangéran Perdana Menteri was onder de hoede van God de Allerhoogste en bleef geheel ongedeerd; alleen zijn kleren waren overal gescheurd. Zonder dat hij 't merkte nam men hem zijn kris af. Daarna kwam de suhunan persoonlijk Pangéran Perdana Menteri halen, bracht hem naar de uit twee vertrekken bestaande ontvangzaal en stopte hem vervolgens in het geitenhok. Pangéran Bupati Panembahan sloeg zijn armen om de sultan heen en deze ging vervolgens naar Sekanak terug; het was toen al avond geworden. De Panembahan echter bracht terstond zijn gezin naar Kertapati.

Intussen was Pangéran Dipati Jayaningrat naar de kraton gegaan om de resident in te lichten. Nog dezelfde avond werd Pangéran Dipati

38 Abdurrahman door de resident in de kraton ontboden; ook de temenggung van politie en Hasanuddin gingen beiden met hun hele gezin de kraton in. De sultan was inmiddels gereed voor de strijd; verscheidene gewapende lieden hadden zich verzameld en wachtten met z'n allen 
het gunstige tijdstip af om de kraton te bestormen. De boden die door de resident waren uitgezonden om te onderzoeken wat er aan de hand was, liet de sultan zonder uitzondering gevangen nemen; en in Suakbata ging 't net zo.

Wat nu Pangéran Perdana Menteri betreft, het lag in de bedoeling dat hij met geitenhok en al verbrand zou worden; maar zijn tijd was nog niet gekomen. Het nieuws werd bekend aan de Tengkurukrivier. Kedukan verzamelde zich aan de Tengkurukrivier, ongeveer veertig man. Zijne Hoogheid de vader van Pangéran Perdana Menteri, Pangéran Natadiraja, en ook Pangéran Haji Kramanandita gingen nu vlug naar Suakbata met de bedoeling een aanslag te plegen op de suhunan. $\mathrm{Na}$ aankomst te Suakbata kregen ze te horen dat Pangéran Perdana Menteri in het geitenhok zat; meteen gingen ze hem met geweld halen. De grote menigte, allemaal volk van Kedukan, stond buiten gereed, met de wapens uit de schede getrokken.

Toen Pangéran Haji Kramanandita Pangéran Perdana Menteri uit dat geitenhok bevrijdde, durfde niemand hem iets te doen, omdat men bang was voor de zeer vele mensen die buiten de poort met getrokken wapens gereedstonden. Zo kwam hij eruit en werd hij naar huis teruggebracht. Nadat hij zich verkleed had, werd hij samen met zijn zoons en zijn vrouwelijke familieleden naar de kraton gebracht. Toen de resident Pangéran Perdana Menteri ontmoette, was hij zeer verheugd. Vervolgens zond de resident Kirangga Tamin met een brief naar de sultan. Nadat hij bij de sultan was aangekomen en de brief had afgegeven, werd Kirangga Tamin daar vastgehouden, hij mocht niet naar huis terug.

8.2. Toen het vier uur was, zette het leger van de sultan zich in beweging; er waren verscheidene edelen en hajis bij, allen volledig bewapend en met de wapens uit de schede getrokken, terwijl ze tevens het godsdienstig reciteren beoefenden en de lofzangen op de Profeet en de aanhef van de geloofsbelijdenis opdreunden. Dat gaf een oorverdovend geluid. Het was die nacht erg donker, men kon geen hand voor ogen zien; en het motregende. Die nacht - het was de negenentwintigste Rabicul-awal van het jaar 1240 - kwam het leger voor de kraton aan. Toen schoot Panglima Batuapi met een donderbus, mikkend op de

39 poort van de kraton. Onmiddellijk werd er door het garnizoen vanaf de kratonpoort teruggeschoten, vierhonderd man sterk schoten ze met z'n allen tegelijk en zonder ophouden. Ook weerklonk het geschut op de wallen, en eveneens het scheepsgeschut, dat losbarstte op de rivier. 
Pangéran Putang, aan 't hoofd van de aanvallers, verdween tezamen met Haji Jabaruddin in een grote greppel en kwam achter de soldaten weer te voorschijn; toen stormden zij op de vijand in. Toen die stormaanval voorbij was, was 't inmiddels dag geworden. Het leger van de sultan trok toen terug, waarbij ieder voor zich een goed heenkomen zocht. Van het krijgsvolk van de sultan waren gesneuveld: Pangéran Putang, Radén Gusi, Khatib Jabaruddin en Si Luncuk, de lijfdienaar van de sultan. De sultan vluchtte naar Suakbata; 't was toen al klaarlichte dag. Toen de aanval voorbij was, kon men er niet meer achter komen waar hij naar toe was gegaan.

8.3. De resident nu stuurde de ambtenaren die lid van de raad waren er op uit om de suhunan te gaan ondervragen. $\mathrm{Na}$ aankomst in Suakbata maakten de ambtenaren gezamenlijk hun opwachting bij Suhunan Husin Dia'uddin. De suhunan sprak op vriendelijke toon tot de ambtenaren: "Gij moet weten, dat ik van de daden van de sultan volstrekt niet op de hoogte was". Daarna deed Demang Umar aangifte van het feit dat hij de vorige avond op het voorerf zijn kris was kwijtgeraakt. De suhunan gaf er hem een andere - kostbare - kris voor in de plaats. Ook Pangéran Perdana Menteri had zijn kris verloren en kreeg er eveneens een kostbare kris voor in de plaats. Toen dat was gebeurd, namen de ambtenaren-raadsleden afscheid en gingen naar de kraton terug. Nadat ze door de resident geroepen waren, gingen ze gezamenlijk naar de resident toe.

Daarna ontbood de resident Pangéran Dipati Abdurrahman en gelastte hem een brief naar de suhunan te brengen. Pangéran Dipati ging op weg. In Suakbata aangekomen bood Pangéran Dipati de brief van de resident eerbiedig aan. Deze werd door de suhunan aangenomen en vervolgens gelezen. De brief luidde, dat de suhunan naar Batavia moest gaan en voor de Generaal moest verschijnen om vergiffenis te vragen voor de misdaden van de sultan; een vaartuig was nu meteen beschikbaar. De suhunan ontbood toen Pangéran Bupati Panembahan. Nadat deze was verschenen, beval de suhunan hem naar de resident te gaan en hem te zeggen dat de suhunan vandaag nog de raad van de resident zou opvolgen en met genoegen naar Batavia zou gaan.

Nadat de Panembahan bij de resident was aangekomen en die boodschap had overgebracht, liet de resident een brik uitrusten; en de 40 Panembahan ging terug naar de suhunan. Daarop maakte de suhunan zich gereed voor de reis. Diezelfde avond nog ging de suhunan aan boord van de brik. Degenen die met de suhunan meegingen, waren: 
Pangéran Adiwijaya met zijn broer Pangéran Wirakrama en de zoon van de suhunan, Radén Bakar. De andere zoons gingen niet mee, maar de vrouwelijke familieleden gingen allemaal mee. Pangéran Dipati Abdurrahman werd door de resident aangewezen om hen uitgeleide te doen tot Muntok en Kirangga Tamin kreeg bevel van de resident hen te begeleiden tot aan Batavia. Toen alles geregeld was, voer de brik die avond de rivier af. Diezelfde avond nog werden huis en hof van de suhunan te Suakbata volledig platgebrand, zodat er niets van overbleef.

De sultan nu was verdwenen, in Palembang was geen spoor van hem te vinden; hoe men ook zocht, men kreeg zelfs geen inlichtingen over hem.

8.4. Na een tocht van enkele dagen kwam de suhunan in Muntok aan. De resident van Muntok liet ruime hoeveelheden leeftocht aan de suhunan bezorgen. Pangéran Dipati Abdurrahman ging in Muntok van boord en de brik zeilde verder naar Batavia. $\mathrm{Na}$ een reis van enige tijd werd Batavia bereikt. De suhunan ging in Batavia aan wal en begaf zich naar de plaats die als verblijfplaats voor de suhunan was ingericht. Gedurende zijn verblijf aldaar kreeg hij elke maand een ruime toelage om in zijn levensonderhoud te voorzien. En Kirangga Tamin ging terug naar Palembang. Wat Pangéran Dipati Abdurrahman betreft, aan hem werd na zijn terugkeer te Palembang door de resident een uitkering toegekend van duizend gulden. Kirangga Tamin kreeg een beloning van vijfhonderd gulden. $Z_{o}$ is het gegaan.

8.5. Wij komen nu weer terug op de geschiedenis van Sultan Ahmad Najamuddin. Deze was met zijn volgelingen uit Palembang het oerwoud in gevlucht en tenslotte in Muara Beliti aangekomen. Vele districts- en dorpshoofden sloten zich bij hem aan. Daarop legde de sultan in Muara Beliti versterkingen aan.

Nadat de berichten hierover de resident in Palembang hadden bereikt, droeg de resident Pangéran Dipati Abdurrahman op de sultan in Muara Beliti te gaan opzoeken. Daarop vertrok Pangéran Dipati naar het binnenland met een oorlogsvloot van verscheidene van geschutbepantsering voorziene vaartuigen, volledig voor de oorlog uitgerust en bewapend. Nadat men een tijdlang onderweg was geweest en door verscheidene streken was gekomen, arriveerde men tenslotte in Muara Beliti. Toen stuurde Pangéran Dipati zijn patih erop uit om de sultan uit te nodigen

41 aan boord te komen teneinde naar Palembang terug te keren, en om hem te zeggen "dat de vergrijpen van de sultan door de resident ver- 
geven waren" en nog allerlei vriendelijke woorden meer. Maar de sultan wilde niet.

Daarna ging Pangéran Dipati Abdurrahman tegenover het fort van de sultan aan wal. Toen hij dit dicht genaderd was, liet Pangéran Dipati het fort aan één stuk door beschieten met de lichte en de zwaardere kanonnen en met geweren. Daarop trok de sultan zich vandaar terug, ging naar Muara Énim, naar het dorp Limbun, en legde er een versterking aan. Aan de bovenloop van de Ogan had de sultan al een fort. Masagus Dengkak kreeg in die tijd van de sultan de naam Pangéran Jayadilaga en Pangéran Puspa Cingot werd benoemd tot Pangéran Jayadiraja.

Pangéran Dipati Abdurrahman werd na afloop van de vijandelijkheden ziek en voer naar Palembang terug. $\mathrm{Na}$ het vertrek van Pangéran Dipati Abdurrahman naar Muara Beliti had de resident Pangéran Kramajaya de Komering op gestuurd met een gewapende macht, terwijl Kirangga Wirasentika met een gewapende macht de Lematang op was gedirigeerd en Pangéran Dipati Jayaningrat met een gewapende macht de Ogan op.

Nadat Pangéran Dipati Abdurrahman van zijn ziekte hersteld was, werd hij er door de resident opnieuw op uitgestuurd, de Ogan op. Toen hij een eindweegs was gevorderd, kwam hij Pangéran Dipati Jayaningrat tegen, die ziek terugging. Pangéran Dipati Abdurrahman vervolgde zijn reis stroomopwaarts. $\mathrm{Na}$ enige tijd onderweg te zijn geweest werd hij weer ernstig ziek; toen keerde hij om. Bij het dorp Pegayut aangekomen overleed hij aan boord, waarna men rechtstreeks naar Palembang voer. $\mathrm{Na}$ aankomst in Palembang werd hij begraven. De resident liet de eerbewijzen brengen door een afdeling van honderd soldaten, die de begrafenisstoet tot aan het graf begeleidde.

8.6. Hervatten wij ons verhaal met te vertellen over Kirangga Wirasentika. Toen deze aan de bovenloop van de Enim aankwam, merkte hij dat de sultan daar een fort had. Kirangga Wirasentika bouwde toen ook een fort, tegenover het fort van de sultan. Daarna verscheen Pangéran Jayadilaga in opdracht van de sultan met een leger om het fort van Kirangga Wirasentika aan te vallen. De troepen van de sultan vochten toen met de troepen van Kirangga Wirasentika. Door de wil van God werd Pangéran Jayadilaga door een kogel aan het hoofd getroffen en 42 stierf. Ook Radén Utama werd door een kogel getroffen en stierf eveneens. Daarna trok de sultan terug met de bedoeling uit te wijken naar zijn fort aan de bovenloop van de Ogan. 
In dat fort waren veel mensen uit Pasemah, die op de hand van de sultan waren. Hun aanvoerder heette Pangéran Bajau; maar die Pangéran Bajau had zich door Kirangga Wirasentika laten bepraten. Toen de sultan ongeveer halverwege was, werd hem gemeld dat de mensen uit Pasemah die de bezetting vormden van het fort aan de bovenloop van de Ogan, waren overgelopen naar Kirangga Wirasentika. Onmiddellijk daarop kwam Pangéran Bajau er aan om met de sultan een tweegevecht aan te gaan. Toen ze vlak bij elkaar waren, velde de sultan zijn lans en stak Pangéran Bajau ermee recht in de borst, waarop hij stierf. De mensen die de sultan vergezelden, raakten daarna in paniek; allen, mannen zowel als vrouwen, renden weg, lieten de één na de ander de sultan in de steek en sloten zich aan bij Kirangga Wirasentika. Alleen Pangéran Jayadiraja en Masagus Abduljamil bleven de sultan trouw.

8.7. Toen de sultan zag dat hem slechts die twee volgelingen waren overgebleven, vertrok hij vanaf de rivier de Awal stroomafwaarts. Toen hij bij een dorp aankwam, was Temenggung Mahidin, het divisiehoofd van Ogan Ulu, daar toevallig aanwezig. De sultan ging met Pangéran Jayadiraja Cingot en Masagus Abduljamil aan boord van Temenggung Mahidins boot om zich over te gaan geven aan de resident. Toen voer Temenggung Mahidin de rivier af naar Palembang. Na een tocht van enkele dagen bereikte men het dorp Pegayut; de boot van Temenggung Mahidin legde in Pegayut aan. Daarop stuurde hij zijn mensen vooruit met een brief voor de resident.

Toen deze in Palembang aankwamen, was er een commissaris in Palembang, terwijl een oorlogsschip Palembang bewaakte. De boden van de temenggung bezorgden de brief bij de resident en deze liet die brief naar de commissaris brengen. Toen de commissaris de brief las, bleek deze de mededeling te behelzen dat Temenggung Mahidin de sultan had meegebracht om zich aan de resident over te geven. Onverwijld zond de commissaris toen de temenggung van politie met Temenggung Aminuddin erop uit om de sultan af te halen met de staatsiesloep. Nadat zij bij Temenggung Mahidin aangekomen waren, stapte de sultan met zijn twee metgezellen in die boot over. In Palembang aangekomen voer de boot langszij het oorlogsschip en de sultan, Pangéran Jayadiraja 43 en Masagus Jamil gingen aan boord.

8.8. Later kwam er een bode van Kirangga Wirasentika met Kemas Usman, iemand uit het dorp Karangberahi die de sultan was gevolgd, en de poyang van de bevolking van het Ogangebied. Het hoofd van 
Pangéran Jayadilaga, die door een kogel getroffen was, werd naar de commissaris gebracht. De commissaris gelastte dat het hoofd begraven zou worden en de twee mensen gingen de gevangenis in.

De commissaris liet al die zaken toen behandelen in een binnen de kraton te houden raadszitting. Op de dag waarop de zitting zou worden geopend, werden die lieden de kraton binnengebracht. De raadsleden onderzochten de zaken van het begin tot het eind. $\mathrm{Na}$ afloop van het onderzoek gingen alle mensen naar buiten. Nadat men in raadkamer tot vaststelling van het vonnis was gekomen, werden alle mensen weer tot de raadsvergadering toegelaten. Het vonnis werd uitgesproken: vier mensen werden ter dood veroordeeld. Die dag werden Pangéran Jayadiraja Cingot, Masagus Jamil, Kemas Usman en de poyang van de bevolking van het Ogangebied met z'n vieren vóór de kraton ter dood gebracht. Daarmee was die zaak afgehandeld.

Later arriveerde Kirangga Wirasentika in Palembang met Radén Sanusi en de vrouwen die met de sultan meegegaan waren en die men eerst nog in het binnenland had achtergelaten; zij allen werden ter beschikking van de commissaris gesteld. Al degenen die door de kirangga waren meegebracht, werden naar Ambon verbannen, naar dezelfde plaats als de mensen die aan de opstand van de sultan hadden deelgenomen en die reeds eerder naar Ambon verbannen waren. Wat de vrouw van Pangéran Jayadiraja Cingot en Nyimas Irang betreft, beiden werden verbannen naar het dorp Tanjunglaga in de Palembangse Benedenlanden.

8.9. Zeven maanden lang verbleef de sultan aan boord van het oorlogsschip.Daarna werd hij door het oorlogsschip naar Banda gebracht en daar voorgoed geïnterneerd. Ten tijde dat de sultan naar Banda werd verbannen, was Suhunan Dia'uddin reeds in Batavia overleden, evenals de kinderen van de suhunan, Pangéran Wirakrama en Nayu Kamariah. $\mathrm{Na}$ het overlijden van de suhunan werden al zijn familieleden door de Generaal naar Palembang teruggestuurd.

Wat de toelagen van de sultan en Suhunan Dia'uddin betreft, met het bedrag daarvan werden de inkomens van respectievelijk Pangéran Aryakesuma en Pangéran Bupati Panembahan Hamim verhoogd. De toelage van Pangéran Dipati Jayaningrat werd door de commissaris 44 verlaagd van duizend gulden, wat 't oorspronkelijk geweest was, tot vierhonderdvijftig gulden. Wat daarvan de reden was, weet God alleen. 


\section{TEKSTVERGELIJKING TR 1 - UBL 5/MP 2}

Bij de beschrijving van de handschriften in hoofdstuk II is reeds gewezen op de overeenkomst tussen de tekst van TR 1 en een in een tweetal afschriften, UBL 5 en MP 2, bewaard gebleven kroniek, die waarschijnlijk omstreeks $1850 /$ '51 is geschreven. De verschillen tussen de in UBL 5 en MP 2 overgeleverde lezingen van deze kroniek moeten - een enkele omissie daargelaten - deels worden toegeschreven aan een onnauwkeurige transcriptie en zijn overigens veelal het gevolg van het gebruik van synoniemen of van het op bepaalde plaatsen in één van beide teksten ontbreken van de voorvoegsels ber-, ke-, se-, van de achtervoegsels -kan, -lah, -pun, -nya of van woorden als maka, dan, akan, telah, sudah, pula, yang, oléh, itu, di, ke, pada. In de meeste gevallen kan dan ook zonder veel moeite worden vastgesteld welke van de twee lezingen de juiste is of althans de voorkeur verdient, zodat het mogelijk lijkt aan de hand van de beschikbare afschriften het model of prototype van de kroniek te reconstrueren, dat aan de beide afschriften ten grondslag ligt en deze dus bij een vergelijking met TR 1 zou kunnen vertegenwoordigen. De verschillen tussen dit model en de veel jongere tekst van TR 1 zijn van geheel andere aard en tevens dus van veel wezenlijker betekenis dan die tussen UBL 5 en MP 2 onderling. Ze zullen in het hierna volgend overzicht worden behandeld, althans voor zover ze betrekking hebben op de weergave van de historische feiten of vanuit het gezichtspunt van literaire vormgeving van enig belang lijken. De tekst van TR 1 wordt daarin aangeduid als A, het prototype van UBL 5/MP 2 als B. De vetgedrukte cijfers hebben betrekking op de door mij aangebrachte - indeling van TR 1 in hoofdstukken en paragrafen.

1. De voornaamste verschillen van de vorstenlijst volgens $B$ ten opzichte van de vorstenlijst volgens A zijn:

- de namen van sommige vorsten worden anders gespeld;

- de vorsten no 1 en no 2 zijn één en dezelfde persoon; tussen zijn eerste en zijn tweede regeringsperiode regeert vorst no 3 ; 
- de regeringsperioden van de vorsten no 13 en no 14 zijn wel vermeld;

- de regeringsperiode van vorst no 16 beloopt 9 jaar;

- jaartallen komen voor wat B betreft alleen in de versie volgens MP 2 voor; ze kloppen nog veel minder met de opgegeven regeringsperioden dan die van $\mathrm{A}$.

De slotpassage van paragraaf 1 over de invloed van Engelsen en Hollanders op de bezetting van de troon ontbreekt bij B.

De reeds bij de beschrijving van UBL 5 in hoofdstuk II genoemde vorstenlijst dd. 16 maart 1871 , die later aan UBL 5 moet zijn toegevoegd, stemt met de lijst volgens $B$ overeen, met dien verstande dat de jaartallen zijn aangepast aan de regeringsperioden en er bovendien jaartallen volgens de christelijke jaartelling aan zijn toegevoegd. Deze laatste kloppen echter niet met de opgegeven hijrah-jaren. Dit heeft Van Rijn van Alkemade er niet van weerhouden de hier vermelde jaartallen volgens de christelijke tijdrekening over te nemen in zijn artikel over Palembang (Van Rijn van Alkemade, 1883).

Bij de beschrijving van het materiaal in hoofdstuk II zijn we in UBL 2 nòg zo'n Palembangse vorstenlijst tegengekomen, terwijl in enkele andere teksten hetzij een afzonderlijke lijst van de regeringsperioden zonder vermelding van jaartallen (UBL $1 \mathrm{a} / 1 \mathrm{~b}$ ), dan wel een in het verhaal verwerkte opgave van regeringsperioden, met of zonder jaartallen, werd aangetroffen (KI 2, KI 4, UBL 3). Vergelijken wij de verschillende bronnen met elkaar, dan blijkt de overlevering ten aanzien van de duur van de regeringsperioden veel vaster te zijn dan ten aanzien van de daarop niet altijd juist afgestemde jaartallen, die vaak sterk uiteenlopen.

Ook uit andere Palembangse teksten, zoals KI 5, de geschiedenis van Banka volgens KI 12/13/UBL 12, UBL 7 en enkele brieven van UBL 10, kunnen aanwijzingen worden verkregen voor de datering van de regeringsperioden. Weer andere bronnen zijn te vinden in de door Brandes behandelde Palembangse piagems (Brandes, 1891-1900) en in tussen de vorst van Palembang en de Compagnie gesloten contracten (Corpus diplomaticum Neerlando-indicum, 1596-1799). Behalve Van Rijn van Alkemade hebben ook verscheidene andere westerse auteurs aan uiteenlopende bronnen ontleende chronologische gegevens met betrekking tot het Palembangse vorstenhuis gepubliceerd. Deze zijn te vinden in: De Kock, 1846 b; Horsfield, 1848; De Sturler, 1855; Mohnike, 1874; Midden-Sumatra, 1881-82; Stokvis, 1888; De Clercq, 1895. Een vergelijkend onderzoek van alle beschikbare gegevens zou ons te ver buiten het kader 
van ons onderwerp voeren. Mijn voorlopige indruk is dat de data van $\mathrm{KI} 4$ het meest met de gegevens en aanwijzingen van elders in overeenstemming zijn.

Omdat de opgaven van A en B, naar wij hebben gezien, zowel onbetrouwbaar als onvolledig zijn, laat ik hier tenslotte een vergelijkend overzicht volgen van de vorstenlijst van UBL 2, de aan UBL 5 voorgevoegde lijst van 16 maart 1871 (in beide lijsten zijn de regeringsperioden steeds even lang als die van $A$ en $B$ ) èn de relevante data uit KI 4. Achter het hijrah-jaar volgens de handschriften heb ik telkens het daarmee corresponderende jaartal volgens de christelijke tijdrekening vermeld.

\begin{tabular}{|c|c|c|c|c|c|c|}
\hline \multirow{3}{*}{$\begin{array}{l}\text { Vorst van Palembang } \\
\text { Kiai Geding Sura (-Muda) }\end{array}$} & \multicolumn{6}{|c|}{ Jaar van troonsbestijging volgens } \\
\hline & \multicolumn{2}{|c|}{ UBL 2} & \multicolumn{2}{|c|}{ UBL 5} & \multicolumn{2}{|c|}{ KI 4} \\
\hline & 954 & 1547 & 967 & $1560 / 59$ & 981 & $1573 / 74$ \\
\hline Kemas Dipati & 977 & $1569 / 70$ & 989 & 1581 & 998 & $1590 / 89$ \\
\hline Kiai Geding Sura (-Muda) & 一 & - & 1001 & $1593 / 92$ & - & - \\
\hline Pangéran Mading Suka & 989 & 1581 & 1002 & $1594 / 93$ & 1003 & $1595 / 94$ \\
\hline Pangéran Madé Alit & 1024 & 1615 & 1037 & $1628 / 27$ & 1038 & $1629 / 28$ \\
\hline Pangéran Siding Pura & 1025 & 1616 & 1038 & $1629 / 28$ & 1039 & $1630 / 29$ \\
\hline Pangéran Siding Kenayan & 1032 & $1623 / 22$ & 1045 & $1635 / 36$ & 1049 & $1639 / 40$ \\
\hline $\begin{array}{l}\text { Pangéran Siding Pesarian } \\
\text { (Sultan Jamaluddin) }\end{array}$ & 1044 & $1634 / 35$ & 1057 & 1647 & 1061 & $1651 / 50$ \\
\hline $\begin{array}{l}\text { Pangéran Siding Rajak } \\
\text { (-Saka Tiga) }\end{array}$ & 1045 & $1635 / 36$ & 1058 & 1648 & 1062 & $1652 / 51$ \\
\hline $\begin{array}{l}\text { Suhunan Abdulrahman } \\
\text { (-Cindé Belang of Candi Walang) }\end{array}$ & 1053 & $1643 / 44$ & 1066 & $1656 / 55$ & 1069 & $1659 / 58$ \\
\hline $\begin{array}{l}\text { Sultan Muhammad Mansur } \\
\text { (-Kebon Gedé) }\end{array}$ & 1098 & $1687 / 86$ & 1111 & $1699 / 1700$ & 1114 & $1702 / 03$ \\
\hline $\begin{array}{l}\text { Sultan Agung (-Kamaruddin; } \\
\text { Palembang Lama) }\end{array}$ & 1110 & $1698 / 99$ & 1123 & $1711 / 12$ & 1126 & 1714 \\
\hline $\begin{array}{l}\text { Sultan Mahmud Badaruddin } \\
\text { (-Lemabang) }\end{array}$ & 1120 & $1708 / 09$ & 1133 & $1721 / 20$ & 1136 & 1724 \\
\hline Suhunan Ahmad Najamuddin & 1155 & $1742 / 43$ & 1168 & $1755 / 54$ & 1171 & 1757 \\
\hline Sultan Muhammad Baha'uddin & 1180 & $1766 / 67$ & 1193 & 1779 & 1190 & 1776 \\
\hline $\begin{array}{l}\text { Sultan Mahmud Badaruddin } \\
\text { (-Ternati) }\end{array}$ & $\begin{array}{l}1207 \\
(1270 !)\end{array}$ & $\begin{array}{l}1793 / 92 \\
(1854 / 53 !)\end{array}$ & 1220 & $1805 / 06$ & 1218 & 1804 \\
\hline $\begin{array}{l}\text { Sultan Ahmad Najamuddin } \\
\text { (later: Suhunan Husin Dia'uddin) }\end{array}$ & - & - & 1229 & $1814 / 13$ & - & - \\
\hline
\end{tabular}


2.1 - 3.5. De teksten lopen zozeer uiteen, dat volledige weergave van de corresponderende passage uit B gewenst is. Deze luidt als volgt.

"Maka datang Inggeris pada tahun itu mengalahkan Palémbang, pada tahun 1227. Maka Baginda itu berpindah di Muara Rawas, tengah dua tahun lamanya. Maka di Palémbang saudaranya Pangéran Dipati menjadi raja di Palémbang bernama Sultan Ahmad Najamuddin; dan puteranya yang tua bernama Radén Ahmad berjuluk Prabu Anom.

Syahdan Seri Paduka Sultan Mahmud Badaruddin tengah dua tahun di Muara Rawas itu, dapat bicara damai dengan Inggeris. Maka kembali pula milir ke Palémbang bertakhta di kota besar; dan Seri Paduka Sultan Ahmad Najamuddin turun di kota lama. Adapun Pangéran Ratu dan Pangéran Adimenggala pergi ke Betawi.

Dan empatpuluh hari lamanya Seri Paduka Sultan Mahmud Badaruddin itu bertakhta di kota besar, maka datanglah pula Inggeris, anak Raja Menggala, membawa soldadu masuk Palémbang, menurunkan Sultan Mahmud Badaruddin dari kota besar dipindahkannya di kota lama. Maka adindanya Sultan Ahmad Najamuddin itu dinaikkan Inggeris di kota besar, merintah negeri Palémbang tujuh tahun lamanya diatas takhta kerajaan.

Syahdan pada masa itu di Betawi telah berganti Holanda, hingga sampai di Palémbang berganti Holanda, tiada lagi Inggeris. Maka tiada berapa lamanya, maka datang pula orang besar Holanda bernama Idelir Ménténg, dengan satu kapal perang masuk Palémbang, menurunkan Sultan Ahmad Najamuddin dari kota besar menaikkan Sultan Mahmud Badaruddin diatas kota besar. Maka Sultan Ahmad Najamuddin tiada mau turun di kota lama, sekadar berpindah diluar selapis kota besar itu juga sebelah ilir, yaitu dekat Lawang Boratan, memberitahu Inggeris di Bengkulu.

Maka datang orang besar Inggeris dari Bengkulu dengan Raja Bangsawan dan Radén Karim dan Radén Arip serta membawa tigaratus soldadu. Tetapi soldadunya tinggal di Muara Beliti, belum ada perahu membawanya milir. Maka Kapitan Mita Saman saja yang dahulu milir ke Palémbang dengan Raja Bangsawan, Radén Karim dan Radén Arip, soldadunya cuma 3 orang. Maka sampai di Palémbang, bertemulah dengan Sultan Ahmad Najamuddin di muara Lawang Boratan, kota besar itu juga yang di hilir. Setelah habis bicara, maka pada malam itu Inggeris itu didudukkan di rumah dalam kota lama itu. Setelah pagipagi hari, maka datanglah suruhan Idelir Ménténg bernama Kapitan Bandarwik mendapatkan orang besar Inggeris yang bernama Mita Saman itu. Maka Inggeris itupun pergilah ke seberang semuanya men- 
dapatkan Idelir Ménténg. Setelah Mita Saman itu sudah nyeberang, maka datanglah baris Holanda dengan racyat Sultan Mahmud Badaruddin, dari sebelah kota besar datang di Lawang Boratan, merubuhkan bendéra Inggeris di Lawang Boratan itu. Terlalu gempar Palémbang pada hari itu, sama kumpul di Lawang Boratan. Dan pada malam itu juga Lawang Boratan itu ditutup Holanda pintunya itu; tiada lagi boléh periai menteri masuk kedalam Boratan itu, kalau mau keluar boléh. Maka dijagai oléh soldadu diluar Boratan itu kira-kira ada empat lusin.

Syahdan orang besar Inggerispun diantar Holanda berlayar dari laut, pulangnya di Bengkulu semuanya. Maka Boratan itupun ditutuplah serta diberinya kokot besi, malam dikuncinya dari luar. Maka didalam Boratan itu banyak lagi teman Sultan Ahmad Najamuddin itu, menteri periai. Kira-kira sebulan lamanya ditutup Boratan itu, maka dikeluarkan Idelir Ménténg Pangéran Bupati Panembahan daridalam Boratan, dipulangkan di kampungnya serta dijagai soldadu satu lusin, menunggu di balai bandung Panembahan. Adalah kira-kira tiga bulan lamanya Lawang Boratan itu tertutup, maka dikunci pula oléh Sultan Ahmad Najamuddin itu dari dalamnya. Maka disuruh Idelir Ménténg buka. Tiada dibuka, lalu disuruhnya pengalasan menatah pintu Boratan itu akan membuka kancing pintu itu.

Maka gemparlah Palémbang pada masa itu. Dan sebelah Sultan Tua di kota besarpun sama jaga di luar di dalam, istiméwa pula sebelah Sultan Muda didalam Boratan itu semuanya periai sama siaga. Adapun segala anak-isteri Sultan Muda yang dalam Boratan itu sama kuatir, lalu lari ke sebelah kota besar itu semuanya mendapatkan Sultan Tua. Maka tahu Sultan Muda segala isterinya sudah nyebelah, maka lalu diikut oléh Sultan Muda pula. Maka bertemulah sultan keduanya itu di kota besar. Maka Sultan Tuapun suruhanlah kepada Idelir Ménténg mengatakan Sultan Muda sudah nyebelah padanya di kota besar. Maka kutika itu juga berhenti pengalasan menatah Lawang Boratan itu. Maka segala periai dan menteri semua yang ada didalam Boratan, tempat Sultan Muda itu, ada diambil Idelir Ménténg, semuanya diturunkan di kapal dan ada yang di kici.

Syahdan maka Sultan Muda pada malam itu disuruh Sultan Tua diam di taman laut. Maka apabila pagi-pagi hari, maka Sultan Mudapun pulang pada tempatnya di Lawang Boratan. Maka puteranya bernama Pangéran Jayaningrat dipanggil Idelir Ménténg, disuruhnya kepada Sultan Muda, katanya: "Baik Sultan Muda membuat surat, dari Sultan Muda sendiri punya kehendak akan pergi di Betawi, bukan kehendak Holanda." Maka Sultan Mudapun memberi surat serta tanda- 
tangan. Sudah, maka lalulah turun di kapal semuanya laki-laki perempuan, berlabuh di muara Sungai Aur. Maka sekalian orang-orang negeri siapa yang suka bertemu, semuanya dapat. Setelah habis bicara, maka mintarlah kapal dan kici itu, lalu berlayar ke Betawi. Setelah datang ke Betawi, didudukkan Holanda didalam negeri Sianjur. Maka adalah yang tua, Sultan Mahmud Badaruddinpun, tetaplah diatas takhta kerajaan negeri Palémbang, bersahabat dengan Idelir Ménténg.

Maka disuarakan didalam negeri Inggeris itu sudah dibawa ke Betawi, maka Idelir Ménténgpun minta perahu dan orang kepada Sultan hendak mudik Musi meriksa pucukan Palémbang. Maka mudiklah Idelir Ménténg membawa soldadu dan racyatnya. Sampai di Muara Beliti, mendapatkan Inggeris yang tinggal di Muara Beliti itu, diberitahu orang besar Inggeris yang di Palémbang sudah diantar pulang di Bengkulu, berlayar dari laut. Maka soldadu Inggeris itupun pulanglah ke Bengkulu. Maka Idelir Ménténgpun milirlah ke Palémbang."

\section{Commentaar:}

2.1. Het jaartal 1207 voor de troonsbestijging van Mahmud Badaruddin II is onjuist; dit moet zijn 1218. B noemt hier geen jaartal. A spreekt van suhunan Mahmud Badaruddin en suhunan Ahmad Najamuddin, B noemt hen sultan, wat in deze fase van de geschiedenis juister is. De titel suhunan gold in Palembang voor de ex-sultan. Zo neemt Sultan Ahmad Najamuddin eerst de naam Suhunan Husin Dia'uddin aan, wanneer hij zich als regerend vorst terugtrekt ten behoeve van zijn zoon Prabu Anom, die dan Sultan Ahmad Najamuddin wordt genoemd. De bezwaren van Husin tegen aanvaarding der regering zolang zijn broer Mahmud nog niet verslagen is, blijven in B onvermeld. De lezing van A vindt steun in de desbetreffende passage in UBL 7.

2.2. Hier ontspoort A ernstig. De expeditie naar Muara Rawas van 1812 stond onder commando van Captain Meares; Mister Salmond verschijnt eerst in 1816 op het toneel als commandant van een Engelse expeditie vanuit Benkoelen tegen het inmiddels herstelde Hollandse gezag in Palembang. Meares raakte in de Rawas gewond en trok vervolgens naar Palembang terug. Hij heeft Batavia echter niet bereikt; onderweg, enige dagen na aankomst te Muntok, overleed hij. Wie er nu naar Bengalen moet zijn gereisd met de schatten van Palembang is niet duidelijk. 
B gaat geheel voorbij aan het gewapend conflict met de Engelsen en vermeldt slechts de uiteindelijke verzoening, waarna Mahmud Badaruddin op de troon wordt hersteld (door Major Robison, juni 1813) en de kroonprins met Pangéran Adimenggala op transport wordt gesteld naar Batavia.

2.3. Malakka werd bij het Londens Tractaat van 1814 niet van de teruggave der voormalige Nederlandse bezittingen uitgesloten en daarom - hoewel niet eerder dan 1818 - weer door de Hollanders bezet. Van een ruil van Malakka tegen Batavia is nimmer sprake geweest. Heeft de bezetting van Singapore door Raffles in februari 1819 de auteur misschien door het hoofd gespeeld? Over deze gebiedsruil vinden we niets bij B, dat slechts het feit van de bestuurswisseling in Batavia en Palembang vermeldt.

Ook van de vriendschap tussen de Gouverneur-Generaal te Batavia en "Suhunan" Mahmud Badaruddin wordt door B geen gewag gemaakt. Deze hele paragraaf is chronologisch beschouwd trouwens weinig op zijn plaats (Londens Tractaat: 13 augustus 1814, overdracht van Batavia: augustus 1816).

B zegt dat Badaruddin, door Robison weer op de troon geholpen, pas veertig dagen aan het bewind was, toen "de zoon van de koning van Bengalen" in Palembang kwam om hem opnieuw af te zetten en zijn jongere broer op de troon te herstellen (ook UBL 7 duidt deze zoon van de toenmalige Gouverneur-Generaal van "Brits"-Indië te Calcutta (Bengalen), Gilbert Elliot, Lord Minto, aan als "anak Raja Menggala"; slechts in KI 2, KI 3 en KI 4 wordt hij bij zijn naam genoemd: "Kapitan Alijat" resp. "Kaptén Aliat"). Deze mededeling van B klopt aardig met de feiten: de overeenkomst van Robison met Badaruddin te Muara Rawas dateert van 29 juni 1813; laatstgenoemde is 13 juli in Palembang terug en de expeditie die Najamuddin in zijn rechten herstelt, arriveert een maand later (13 augustus 1813) in Palembang.

2.4. Deze hele episode ontbreekt bij B. De auteur van A is ook hier weer danig in de war. Immers, Badaruddin was op 13 juli 1813 in de hoofdplaats terug, terwijl hier beweerd wordt dat hij eerst circa twee jaar na zijn vlucht, dus omstreeks mei 1814, uit het binnenland terugkeert. En dat nog wel op verzoek van de Hollandse pétor, terwijl de eerste Hollandse resident na het Engelse tussenbestuur pas in december 1816 in Palembang aankomt! Hoewel de bijzonderheden historisch moeilijk verklaarbaar blijven, ligt het nog het meest voor de hand te 
veronderstellen dat met de nieuw aangekomen pétor de Engelse Major Robison wordt bedoeld.

De figuur van Pangéran Paharuddin ben ik in de andere teksten niet tegengekomen; volgens de beschikbare genealogieën was hij een halfbroer van Badaruddin en Najamuddin.

De hernieuwde mededeling, dat Badaruddin vriendschappelijke betrekkingen onderhield met de Gouverneur-Generaal in Batavia, ware wellicht weer in de Hollandse tijd te plaatsen: reeds in het voorjaar van 1816, kort na de aankomst van Commissarissen-Generaal, vaardigde de oude sultan een gezantschap naar Batavia af, dat door het nieuwe opperbestuur niet onvriendelijk werd ontvangen.

3.1. De bruiloft van de kroonprins komt in B niet ter sprake, evenmin als het neerhalen van de Engelse vlag. De pétor kan in dit gedeelte niemand anders zijn dan Muntinghe.

In B wordt hij bij name genoemd als degeen die ervoor zorgt dat Najamuddin plaats moet maken voor Badaruddin.

3.2. De Engelse inval vanuit Benkoelen onder Gaptain Salmond, die Palembang bereikte in de nacht van 3 op 4 juli 1818, toen Muntinghe al een maand in Palembang was, is bij A volslagen uit het historisch verband gerukt. Met de pétor die de Engelse hoofdmacht in het achterland van Palembang opzoekt en naar Benkoelen doet terugkeren, moet wederom Muntinghe bedoeld zijn, al wordt zijn aankomst te Palembang eerst in de volgende paragraaf gemeld.

De lezing die B geeft van de Engelse inval en van Muntinghe's reactie daarop is niet alleen veel uitvoeriger maar tevens meer in overeenstemming met de feiten. Een analoog verhaal doet UBL 7. B is overigens de enige tekst waarin de naam wordt genoemd van de officier die door Muntinghe naar de Engelsen in de oude kraton wordt gestuurd met de boodschap dat ze Palembang moeten verlaten en naar Benkoelen zullen moeten terugkeren: "Kapitan Bandarwik", de kapitein-ingenieur C. van der Wijck van de genie, dezelfde die een jaar later tijdens de vijandelijkheden van juni 1819 het commando voert over de landingstroepen die trachten de kratonpoort open te hakken.

3.3. De beschrijving van de conflictsituatie tussen de oude en de jonge sultan en van de door Muntinghe getroffen maatregelen komt bij B in grote lijn op hetzelfde neer, maar is gedetailleerder. De lezing van B komt hier, zoals op vele andere plaatsen, dichter bij de lezing van UBL 7. 
3.4. De voorstelling van zaken in $B$, volgens welke Muntinghe de jonge sultan een verklaring laat tekenen dat hij uit eigen vrije wil naar Batavia vertrekt, is misschien waarschijnlijker, maar wel minder interessant dan de lezing van $\mathrm{A}$, die getuigt van een eigen visie zowel op het tactisch vernuft van Muntinghe als op de krachtsverhouding tussen Engelsen en Hollanders.

3.5. Deze passage ontbreekt in $B$, evenals de eerdere mededeling (par. 2.2) over de beroving van de Palembangse schatkist door Salmond. Ook elders heb ik vergeefs gezocht naar enig bericht over deze door de Engelsen geroofde en nu op last van Muntinghe door Pangéran Prabumenggala, een zoon van de oude sultan, uit Bengalen teruggehaalde rijksschatten. Zou dit verhaal misschien iets te maken kunnen hebben met Major Robison, die zich bij het Engelse opperbestuur (Bengalen) moest verantwoorden wegens zijn financiële arrangementen met de oude sultan in 1813 ?

In plaats van dit weinig authentiek aandoende verhaal vermeldt $B$ hier, evenals UBL 7, de eerste tocht van Muntinghe naar Muara Beliti, waaraan A geheel voorbijgaat. B spreekt daarbij van een ontmoeting tussen Muntinghe en de Engelsen, waarna deze naar Benkoelen terugkeren, terwijl volgens de Hollandse berichten de Engelsen al vertrokken waren voordat Muntinghe ter plaatse aankwam.

3.6. A en B zijn vrijwel eensluidend. In de opsomming der van de overdracht uitgesloten gebieden staat bij B voor Pegagan: Pegagan Ilir, voor Panangkarwilah: Panang Krublah, wat correcter is, en voor Belidah, dat in UBL 5 helemaal is weggevallen: Blidah dan Iliran (volgens MP 2).

3.7-3.8. In deze twee paragrafen wordt de tweede expeditie van Muntinghe naar de bovenlanden (30 november 1818 - 20 mei 1819) behandeld.

In 3.7 gaat het om Muntinghe's optreden naar aanleiding van de tweede Engelse inval vanuit Benkoelen. B schiet bij de beschrijving daarvan ernstig te kort door het contact tussen Engelsen en Hollanders niet eens te noemen, terwijl we bij A zelfs de bij de onderhandelingen te Muara Beliti door partijen naar voren gebrachte argumenten vermeld vinden.

Ook de beschrijving in 3.8 van de oppositie die Muntinghe op zijn verdere tocht van bevolkingszijde ondervindt, is vollediger en vooral 
beter geredigeerd dan de corresponderende passage in B, waarvan de stijl bepaald gebrekkig is. B verzuimt hier een verklaring te geven voor Muntinghe's op zichzelf toch wel vreemde houding tegenover Ngabéhi Balmi, de gezant uit Palembang. De auteur is kennelijk niet op de hoogte van het feit dat Muntinghe de oude sultan als aanstichter van de opstand in het binnenland beschouwt, wanneer hij schrijft: "Entah bagaimana, maka Ngabéhi Balmi, suruhan Sultan itu, ditangkap Ménténg, lalu diblok."

3.9. Als proeve van de lapidaire stijl van B laat ik hier de volledige corresponderende tekst volgen: "Maka Pangéran Ratu dititahkan Sultan memapak Idelir Ménténg. Maka tiada diberinya dekat perahu pangéran dan perahu yang lain-lain boléh dekat. Maka Pangéran Ratupun kembalilah, disembahkannya kepada Sultan."

4.1. In plaats van "Setelah keésokan harinya" heeft B: "Maka didalam dua tiga hari". Overigens lopen de beide teksten parallel, met dien verstande dat B het antwoord van de sultan nog eens herhaalt, terwijl A de tweede keer volstaat met naar het eerste antwoord te verwijzen.

In geen van beide teksten wordt de naam van de Hollandse havenmeester vermeld. UBL 7 noemt hem Parkenan, een verbastering van Valckenaer.

4.2. $B$ is qua strekking gelijk aan $A$, maar veel korter.

4.3. Enige details verschillen:

- B noemt een bezetting van 270 in plaats van 250 man (UBL 7: 170, syacir: 175, UBL 9: 4 officieren en 100 manschappen, Nederlandse bronnen: 8 officieren en 202 manschappen).

- Als tijdstip waarop het ultimatum van Muntinghe afloopt, noemt B 2 uur tegenover A 3 uur; even verder noemt B nog een termijn van drie uren.

- In plaats van "ditetapkan" heeft B, waarschijnlijk juister, "dititipkan".

Belangrijker is dat het intelligente en doeltreffende beroep op de onschendbaarheid van gezanten, waarmee de beide Pangéran Dipati hun aanhouding door Muntinghe met succes aanvechten, bij B ten enenmale ontbreekt. Volgens B brengen ze in dit verband slechts naar voren, dat de "negeri akan rusuh". 
4.4. Vrijwel gelijkluidend. Over de bewaking van de hoofdpoort wijdt $B$ iets verder uit: "Dan di lawang loténg itupun diatasnya diberi léla dan meriam, diatur pada jendélanya itu. Adapun di lawang loténg itu empat menteri jadi kepalanya, semuanya lengkap dengan alat senjatanya serta berapa temannya orang baik-baik."

4.5. In $B$ is uitdrukkelijk sprake van één officier en één soldaat. Het aantal haji's (A: 70) en soldaten (A: 200) dat aan de gevechten deelneemt wordt daarentegen niet vermeld.

$\mathrm{Na}$ "Maka ia semuanya berangkat mengunus senjata" is het verslag van de gevechten in B wat verder uitgewerkt dan in A. Bovendien is de laatste zin van deze paragraaf, waaruit bij A een stuk moet zijn weggevallen, bij B volledig, luidende: "Hanya yang laju mengamuk Haji Jén dan Haji Lanang dan Kemas Said bin Kemas Haji Ahmad."

4.6. B tekent aan - conform UBL 7 - dat de schepen eerst na drie salvo's vanaf de bastions het vuur beantwoorden ("buluwarti ... membedil kapal perang itu tiga kali, baharu dibalas oléh kapal ...”), voorts - wederom conform UBL 7 - dat het toen drie uur was (Muntinghe rapporteert: "omstreeks vier uur") en tenslotte dat aan de beschieting van de vesting wordt deelgenomen door twee oorlogsschepen (namelijk de korvetten "Ajax" en "Eendragt") en door één schoener en twee korakora's, gelegen waar de Ogan in de Musi vloeit. De hevigheid van het vuurgevecht wordt in B met gebruikmaking van andere beelden tot uitdrukking gebracht dan in A.

4.7. De opmerking over het afvoeren van de Hollandse gesneuvelden ontbreekt in B. Aan de hier korter dan bij A geformuleerde constatering van de geringe schade, door het scheepsgeschut aan de vestingmuur toegebracht, voegt B de mededeling toe dat een aantal durian- en andere bomen door verdwaalde kogels zijn getroffen, helemaal tot op (de begraafplaats) Cindi Balang. Deze bijzonderheid is door A verwerkt in de beschrijving van de kanonnades van de volgende dag (par. 4.8).

De opdracht van de sultan om het de volgende ochtend maar kalmpjes aan te doen, in A zonder beweegreden weergegeven, wordt in B dubbel gemotiveerd: "kerana kita kurang lagi obat peluru, lagi kota kita tiada suatu apa-apa."

4.8. Dat de vesting het vijandelijke vuur slechts spaarzamelijk beantwoordt komt in B niet nader tot uiting; in plaats daarvan wordt mee- 
gedeeld dat de schepen 's ochtends om vijf uur het vuur openen (UBL 7: half zes). Voor de traditionele schildering van de strijd gebruikt B weer andere en ditmaal bovendien meer beelden dan $\mathbf{A}$.

4.9. B vermeldt dat de schepen omstreeks negen uur (UBL 7: omstreeks tien uur) het vuren staken, wederom een tijdsaanduiding die in A ontbreekt. Als reden wordt genoemd het vermoeden aan Hollandse zijde dat de verdedigers van de kraton op de vlucht zijn geslagen. Bij de landing van de Hollanders wordt aangetekend dat ze bij de Tengkuruk, een zijriviertje van de Musi, aan wal gaan. In plaats van het onwaarschijnlijke verhaal, dat er van binnenuit in de poort een gat wordt geboord, geeft $B$ in overeenstemming met de Hollandse berichten en met UBL 7 de lezing dat de Hollanders trachten de poort met bijlslagen te forceren. De hulubalang/pahlawan die de trommelslager neersteekt is bij B een hofdienaar ("pinakawan dalam"), Si Bali geheten. Terwijl de trommelslager volgens $A$ (èn volgens UBL 7) sneuvelt, heet het in B: "... lalu terjatuh lepas tukang tamburnya itu ...". Wanneer de sultan de kraton verlaat om zijn gevluchte familieleden (bij B uitdrukkelijk beperkt tot zijn vrouwen en dochters) weer naar de grote kraton terug te halen, zegt B om alle misverstand uit te sluiten, voor het geval men mocht denken dat de sultan had willen vluchten: "Bukan Sultan keluar itu undur, sekadar menjumputi perempuan isi dalam itu saja."

4.10. De eerste zin, die in de gegeven context slecht past en eerder aan het eind van de paragraaf schijnt thuis te horen, ontbreekt bij B. A verwart de korvet "Ajax" met de hulk "Nassau", welke laatste deelnam aan de expeditie tegen Palembang van 1821.

B noemt - aan het eind van de paragraaf - niet de naam van het schip, maar duidt het aan als het stroomopwaarts gelegen schip: "Maka kapal perang yang sebelah ulupun milirlah di ilir tangga dalam itu."

Naast Raja Akil en Temenggung Sura (door B voluit Suradiprana Hasan genoemd) vermeldt $B$ een Pangéran Penghulu als lid van het gezantschap. Niettemin is 't volgens B alleen Raja Akil die bij Pangéran Dipati de Oudere binnengaat en daar het woord doet (UBL 7 noemt Raja Akil als enige gezant). De auteur legt hem de volgende lapidaire uitspraak in de mond, waarmee Raja Akil het verzoek van Muntinghe inleidt: "Apa guna perang? Dari kota Sultan rusak dan racyat Sultan mati, boléh dia bayar!" 
4.11. B verklaart het bevel tot het doorboren van de zundgaten der kanonnen met de mededeling dat deze door de Hollanders waren vernageld: “. . k kerana meriam diluar kota itu semuanya dipaku Holanda pesumbonnya." $\mathrm{Er}$ is enig verschil in woordkeus: voor ". . . hendak dibedil dari buluwarti." heeft B wat pregnanter: ". . akan dikitarkan léla dariatas kota."; voor "wilut" leest men bij B: "berhati dua". Van de laatste twee zinnen vindt men bij B het pendant eerst in het stuk dat correspondeert met de volgende paragraaf. Naast Radén Kijing worden daar als "kepalanya menganyutkan rakit api itu" Radén Kak en Kilurah Lanang genoemd.

4.12. De lezing van $B$ wijkt op verscheidene punten af:

- de tijdsaanduiding "pagi-pagi kira pukul lima" ontbreekt. Niet het scheepsgeschut, maar de kraton opent bij $B$ het vuurgevecht.

- Over het lekschieten en tot zinken brengen van de "Ajax" (in A nog steeds "Nassau" genoemd) en over het overbrengen van de lading zwijgt B.

- De uitbeelding van het strijdgewoel verschilt. De passage waarin op allerminst traditionele wijze het gedrag van de lafaards wordt geschetst, ontbreekt.

- B merkt op dat het circa 11 uur is, wanneer de schepen wegtrekken; de penjajabs van Raja Akil en allerlei handelsvaartuigen gaan met de vloot mee. Ook vele Chinezen trekken met hun wangkangs weg uit vrees dat ze door de sultan ter dood gebracht zullen worden (wegens collaboratie met de Hollanders misschien?).

Er zijn echter ook "verstandige" Chinezen, die thuisblijven: "Dan Cina yang lama yang ada akal semuanya tiada turut lari."

4.13. Deze paragraaf, waarin de viering van de overwinning in Palembang wordt beschreven, ontbreekt in zijn geheel bij $B$.

5.1. Volgens $B$ is de schoonzoon van de sultan, Pangéran Kramadiraja, commandant van het fort Tambakbaya. Bijgevolg wordt hij niet genoemd als commandant van Manguntama naast Pangéran Wirasentika, terwijl Kramajaya bij B in het geheel niet voorkomt. De lezing van B klopt met de opgave van UBL 7.

Eveneens in overeenstemming met UBL 7 duidt B de ligging van het fort Taméngratu, waarvan hij de naam echter niet noemt, ten onrechte aan als "di buntut Pulau Kembara" in plaats van als "di kepala Pulau 
Kembara". De versterkingen waren namelijk gelegen in de oosthoek van het eiland, dat zich ongeveer oost-west in de Musi uitstrekt, m.a.w. op de stroomopwaarts gelegen "kepala" en niet op de "buntut" van het eiland benedenstrooms.

B voegt aan de opsomming van de verdedigingswerken nog toe de aanleg van paalwerken en andere versperringen ter afsluiting van de rivier en eindigt: "Maka orang bekerja di bénténg itu, laut darat terlalu ramainya, sehari-hari tiada sunyi." $B$ is overigens qua stijl van berichtgeving wat beknopter dan A. Er wordt geen melding gemaakt van het machtige kanon "Seri Palémbang" in Tambakbaya en de laatste alinea van A ontbreekt bij B in zijn geheel.

5.2. Dat Muntinghe de Gouverneur-Generaal in Batavia en deze op zijn beurt Koning Willem $I$ in Holland verslag uitbrengt vinden we in B niet vermeld. De auteur van A geeft hiermee te kennen dat hij van de hiërarchische verhoudingen en de staatsrechtelijke organisatie bij de Hollanders op de hoogte is en zelfs de naam van hun koning kent. De datering is daarbij echter een zwak punt: reeds op 30 juli 1819, nog geen maand na Muntinghe's terugkeer te Batavia, besloot de Gouverneur-Generaal tot het uitzenden van de oorlogsvloot onder Schout-bijnacht Wolterbeek, die drie weken later, 22 augustus, naar Palembang vertrok.

Volgens B maken ook Pangéran Jayakrama (een halfbroer van de sultan) en Radén Badaruddin, die een broer van de sultan genoemd wordt, de expeditie mee. UBL 7 noemt Pangéran Jayakrama ook, maar Radén Badaruddin niet. Mede omdat de door A Jayakrama Gubir genoemde patih van de jonge sultan zowel bij B en UBL 7 als in de volgende paragraaf van A zelf Wirakrama (Gubir) heet, heb ik de tekst van A aangevuld tot: “... dan Pangéran Jayakrama < dan Pangéran Wirakrama $>$ Gubir ...". Radén Badaruddin komt in geen der overgeleverde genealogieën als broer van de sultan voor; wel wordt een Radén Badaruddin vermeld als achterneef van de sultan. Wirakrama Gubir heb ik niet kunnen traceren, wel een zekere Pangéran Purba Gubir, die een oom was van de sultan.

De sterkte van de vloot en het aantal soldaten worden door B niet opgegeven. Opmerkelijk is dat de door A genoemde cijfers vrij aardig kloppen met de Hollandse berichten.

5.3. Terwijl A wil dat Sungsang in brand gestoken is door de Hollanders, laat B in het midden door wie dat is gedaan. Overigens verschilt B 
niet wezenlijk van $A$, al is hij wel minder uitvoerig en naar mijn smaak in literair opzicht zwakker.

Ter vergelijking volge hier de beschrijving door B van het diplomatieke verkeer tussen de Hollanders en Palembangers, dat bij $A$ begint met de nadering van een "langbut besar ... membawa pinakawan Pangéran Wirakrama Gubir ..." en vervolgens de rest van de paragraaf vult. B luidt dan: “. . membawa Si Gangsa, pinakawan Pangéran Wirakrama Gubir. Si Gangsa itulah utusan membawa surat disembahkan kepada Seri Paduka Sultan. Maka dibalasi surat, Si Gangsa itu disuruh pulang kepada Holanda. Entah apa-apa bicaranya, telah berapa hari lamanya maka segala angkatan itu dan kapal semuanya mudik ke bénténg."

5.4. De beschrijving van het oorlogsgeweld, welke bij A slechts de eerste alinea van deze paragraaf in beslag neemt, is bij B wat conventioneler en uitvoeriger en lijkt daardoor meer op de beschrijving in UBL 7.

De tweede alinea, waarin de auteur van A met de ogen van de moslim de wil Gods en de kracht van het geloof en van de vrome werken ziet als de beslissende factoren in de strijd, ontbreekt bij B geheel.

Het is opmerkelijk dat A hier opnieuw moeite heeft met de naam van Pangéran Wirakrama Gubir, die hij in de laatste zin van deze paragraaf Wirajaya Gubir noemt.

5.5. B vermeldt conform UBL 7 dat de Hollandse vloot zich terugtrekt, nadat er vier uur lang gevochten is. B gaat echter voorbij aan de zegetocht van de Palembangse krijgers uit de verschillende vestingwerken terug naar Palembang en aan hun feestelijke ontvangst aldaar, door A zo uitvoerig en levendig beschreven. In plaats daarvan weidt B uit over de militaire hulp die de kroonprins van Jambi en de Buginezen onder Encik Nauk na het vertrek van de Hollanders aan komen bieden. Voor de Jambiërs wordt "di sebelah kiri Pulau Manguntama" een tweede eiland aangelegd, dat sedert als "Pulau Pangéran Ratu Jambi" bekend staat, terwijl de Buginezen in het fort Manguntama zelf worden ondergebracht.

5.6. Volgens $B$ (en UBL 7) wordt bij deze gelegenheid niet alleen de kroonprins tot sultan verheven, maar tegelijk Sultan Mahmud Badaruddin tot suhunan. De gebeurtenissen worden minder gedetailleerd weergegeven en de compositie staat op een lager niveau, ook al doordat de inleiding tot de bijeenkomst (par. 5.5) ontbreekt en dientengevolge 
het verband met de overwinning op de vijand hier niet duidelijk wordt. Het karakter van de plechtigheid als publieke huldiging van de overwinnaars komt in B volstrekt niet tot uitdrukking, waar we zonder enige motivering lezen, dat "pada masa itu berhimpunlah segala periai dan menteri dan $\mathrm{ra}^{c}$ yat negeri dan segala pasirah perwatin huluan semuanya sama berhimpun di pemarakan jaba sekalian orang alim-alim dan sekalian Arab-Arab."

6.1. Terwijl $\mathrm{A}$ het nemen van verdere militaire maatregelen ter verdediging van Palembang tegen een eventuele nieuwe Hollandse aanval in verband brengt met de blokkade van de Sungsang door de Hollanders, worden deze feiten door B zonder samenhang en in omgekeerde volgorde opgesomd. De compositie is gebrekkig. De anekdote dat een Hollander de Palembangers heeft geleerd munitie aan te maken, ontbreekt bij $\mathbf{B}$.

B gaat evenwel dieper in op de gevolgen van de Hollandse blokkade voor de bevoorrading van Palembang. Men fabriceert munitie (waarvoor de grondstoffen zwavel en salpeter uit het binnenland worden aangevoerd) en wint zout, maar men krijgt ook hulp van buiten: zendingen munitie van de vorsten van Lingga en Sambas, die clandestien ("maling-malingan") binnenkomen, en zoutleveranties door handelaars uit die streken. Doordat de export stilstaat, is de rijst goedkoper dan voorheen en is er in het algemeen aan voedingsmiddelen geen gebrek. Alleen textiel en thee zijn schaars geworden, al is de invoer van deze artikelen door Chinezen uit Lingga niet geheel stopgezet en ook de handel met Singapore niet onmogelijk geworden.

Ook over de militaire voorbereidingen is B wat uitvoeriger. Zo wordt gezegd dat elke Chinees die een vlot bezit, verplicht wordt tot de levering van een "brander". Dat lezen we ook bij UBL 7. Beslist uniek echter is de mededeling van B in dit kader, dat de suhunan een soort beroepsleger vormt, waarvan de soldaten soldij genieten.

De vredestijd, die volgens A drie, vier of vijf jaar zou hebben geduurd, duurt bij B drie jaar (in werkelijkheid ruim anderhalf jaar).

6.2. Deze passage, waarin de voorbereidingen in Batavia voor de expeditie van 1821 worden beschreven, komt in B niet voor. B volstaat er mee de aankomst van de expeditie te vermelden. Hij noemt in tegenstelling tot A geen sterktecijfers van vloot en strijdkrachten. Wanneer $B$ meedeelt dat de jonge sultan en diens oudste zoon Prabu Anom zich op de vloot van De Kock bevinden, tekent hij aan dat eerstgenoemde 
"sudah dijeneng Generaal di Betawi Suhunan Husin Dia'uddin" en dat Prabu Anom "sudah dijenengkan Sultan Ahmad Najamuddin".

Hiermee voert B (evenals UBL 7) voor de jonge sultan eerst nu de naam in die A van meetaf heeft gebruikt (vgl. de toekenning van de titel suhunan aan Badaruddin bij B in de passage die correspondeert met par. 5.6).

6.3. Over het verstrekken van militaire inlichtingen door de bewoners van Sungsang aan Suhunan Husin Dia'uddin is B kort; over beloningen daarvoor en over brieven van de suhunan aan de mensen van Sungsang zwijgt B volkomen: "Adapun orang Sungsang semuanya tiada lagi mudik ke Palémbang, sekaliannya pinawayah sudah turut Suhunan Husin Dia'uddin yang dari Betawi itu. Maka dari itu sebab maka bedil maling di mana-mana hutan semuanya diambil oléh Holanda, sebab orang Sungsang yang memberitahunya."

6.4. Deze flash-back treft men in B niet aan, begrijpelijk omdat ook de informatie van paragraaf 6.2 ontbreekt.

6.5. A noemt hier en ook verder Muntinghe, die de expeditie van 1821 niet heeft meegemaakt, ten onrechte als expeditiecommandant naast De Kock; B doet dit niet.

Het postverkeer tussen De Kock en Badaruddin wordt door B veel minder gedetailleerd beschreven: “... tiada lagi utusan, Holanda melepaskan surat, dianyutkan di rakit kecil, ditaruhnya didalam gudu" (A: setoplés, UBL 7: botol), "diambil orang bénténg, disembahkan ke Palémbang kepada Suhunan. Maka dibalas surat itu demikian pula dianyutkan di kapal. Entah apa-apa bicaranya di situ, orang kecil tiada boléh tahu."

6.6. B loopt in hoofdzaak parallel met A. Afgezien van het verschil in woordkeus, waardoor ook hier het eigen karakter van elk van beide teksten gehandhaafd blijft, vallen qua inhoud slechts kleine verschillen te constateren: slechts één soldaat wordt in het bos aangetroffen en onthoofd, de reactie van de suhunan op hetgeen hem wordt meegedeeld blijft onvermeld, de verbazing van de Palembangers over het feit dat de Hollanders ondanks de scherpe bewaking van de vruchtbomen kans hebben gezien zich grote hoeveelheden vruchten toe te eigenen, wordt iets pregnanter uitgedrukt: "Sepanjang jalan dalam hutan babatan Holanda itu banyak kulit buah jeruk kuwik dan kulit buah semangka 
dan beléwah. Nyatalah buah itu buah-buahan dari Palémbang; wallahu aclam dunia punya hal, kerana akal manusia yang cerdik itu tiada terkira-kira oléh kita orang yang bodoh yang jaga di bénténg terlalu keras itu, boléh buah-buahan Palémbang ada di tangan musuh."

6.7. Hier lopen de lezingen van A en B enigszins uiteen. De overlevering dat de forten, behalve Tambakbaya, met jeruk in plaats van met echte kogels schieten totdat de vloot tot vlakbij genaderd is en Sultan Ahmad Najamuddin blijkbaar het sein heeft gegeven om met scherp te schieten, is door B niet opgetekend. Het oorlogsschip, dat bij A "Kerambang" en later (par. 6.8) "Rambang" heet, wordt door B terecht "Nassau" genoemd: “. . maka angkatan itupun mendekatlah ke bénténg, kepalanya kapal Nasu namanya yang dikata orang Palémbang kapal hitam itu, terlalu besar-besar meriamnya ...". B geeft enkele tijdsaanduidingen: de vloot komt om vier uur in de ochtend naderbij, de strijd begint om zes uur en duurt vervolgens tot twee uur 's middags. De conventionele schildering van het krijgsgeweld is bij $B$, evenals in UBL 7, veel verder uitgewerkt.

6.8. De beide teksten stemmen in hoge mate met elkaar overeen.

6.9. Met betrekking tot de wapenstilstand op zondag drukt B zich wat voorzichtiger uit dan $\mathrm{A}$ door niet te spreken van een afspraak tussen partijen om elke zondag de strijd te staken, maar van een vermoeden dat de Hollanders dèze zondag niet zouden vechten: “... sebab pada sangkanya hari Minggu bésok pagi tiadakan Holanda perang". Overigens is B gelijk aan A, met dien verstande dat de hevigheid van het gevecht weer op een geheel eigen wijze tot uitdrukking wordt gebracht.

6.10. B tekent aan dat het ongeveer zeven uur is, wanneer het fort op het eiland Kembara door de Hollanders wordt veroverd. De vlag die er wordt neergehaald heet bij B rood te zijn. De in A vermelde bijzonderheden betreffende de schade aan de oorlogsschepen en het verlies aan manschappen bij de Hollanders ontbreken bij B. De Buginezen trekken volgens $B$ niet terug naar het fort Martapura, maar naar Palembang. In plaats van de simpele mededeling aan het slot van deze paragraaf dat de oude Pangéran Dipati de sultan terugbrengt naar Palembang, zegt B dat de beide Pangéran Dipati de sultan aansporen om naar Palembang terug te keren, omdat hij daar in de kraton een betere kans zou hebben om stand te houden, tezamen met zijn vader de suhunan. Ik citeer dit gedeelte: "Setelah langbut dua itu keluar dari 
sirah Pulau Kembara itu, maka Pangéran Dipati keduanya itu menyilakan Sultan pulang ke Palémbang. Sebab tiada terhémat lagi musuh sudah datang dari belakang bénténg, baik melawan di kota Palémbang bersama-sama Seri Paduka Suhunan didalam kota Palémbang. Setelah putus bicara, maka lalu berjalan darat pulang semuanya ke Palémbang."

6.11. In B wordt (evenals in UBL 7) vermeld dat twee sloepen, waarvan reeds tweemaal eerder sprake is geweest, stroomopwaarts door Straat Kembara naar Tambakbaya varen om vervolgens achter het fort landingstroepen aan wal te zetten. Dit betekent volgens beide lezingen de genadeslag voor het Palembangse verzet en is dus een feit van beslissende betekenis.

In A wordt van die twee sloepen niet gerept, wel van de landing, maar de beslissende betekenis daarvan komt minder duidelijk naar voren.

Over de uittocht van de Palembangers uit het fort Tambakbaya, die volgens B omstreeks twee uur begint, is B enerzijds iets uitvoeriger dan A, anderzijds missen we daar de bijzonderheid dat Kramajaya, de commandant van het fort, zijn vader en zijn broer in veiligheid brengt, wanneer hij het hopeloze van de situatie inziet.

6.12. $B$ is iets compacter. Enige bijzonderheden:

- het schip waarmee Suhunan Husin Dia'uddin reist, wordt evenals in UBL 7 "perahu kici" genoemd (in A "kapal perang");

- Suhunan Husin wordt tot tweemaal aangeduid als "suhunan yang dari laut itu", ter onderscheiding van zijn oudere broer, die hier, eveneens bij herhaling, "suhunan di kota" wordt genoemd;

- hier ontbreken de zelfverzekerde opmerking van De Kock over het militaire overwicht van de Hollanders en de daarop volgende verzekering van Pangéran Dipati de Oudere, dat Palembang geen strijd zal leveren.

6.13. De verovering van de laatste Palembangse vestingwerken door de Hollanders wordt door B gedateerd op zondag 23 Ramadan (24 juni), één uur, een historisch juiste informatie, die behalve in $A$ ook in UBL 7 ontbreekt. Volgens B worden in opdracht van Suhunan Husin Dia'uddin de Hollanders door Pangéran Wirakrama Gubir de kraton binnengeleid. Deze patih van Suhunan Husin (zie par. 5.2) speelt ook bij de overdracht van de rijksschatten een bemiddelende rol tussen de Hollandse commandant en de gevolmachtigden van Suhunan Mahmud Badaruddin. Van deze goederen, hier aangeduid als "apa-apa isi kota didalam 
gedung dan segala peti-peti harta yatim yang belum diwaris itu", wordt nog gezegd dat ze op de steiger worden neergezet ("didudukkan di tangga batu itu sekaliannya"), blijkbaar om door de Hollandse schepen te worden ingeladen.

Het laatste gedeelte van deze paragraaf, dat over de inkwartiering van de Hollandse troepen in de kraton handelt, is bij B wat meer uitgewerkt: "Maka kota besar itu ditunggulah oléh Holanda. Dan dari Suhunan Husin Dia'uddin yang dari Betawi itu: apabila sudah kota bambu di seberang, maka sekalian Holanda itu berpindahlah ke seberang semuanya, maka Suhunan Muda itu masuk bertakhta didalam kota besar itu. Sekarang sementara belum sudah kota bambu di seberang dibuatkan oléh Sultan, melainkan Holanda duduklah dahulu semuanya didalam kota besar. Dari hal Suhunan Muda boléh sama-sama duduk didalam kota itu belah dua, sebelahnya Holanda dan sebelahnya Suhunan. Antaranya itu boléh pintu itu dipaku, kerana tiadakan lama. Syahdan maka diputusi oléh segala periai dan menteri sekaliannya itu tiada patut Suhunan bertunggal duduk dalam kota bersama dengan Holanda: barangkali ada perempunan membuat perkara apa-apa, banyak kurang patutnya; kerana kita membuatkan Holanda kota bambu itu tiadakan lama. Maka Suhunan Mudapun naik duduk di Suakbata."

6.14. De details van de voorlezing van het contract verschillen iets. Hier is niet de contractbrief in geel satijn gewikkeld, maar de troon met geel satijn bekleed: "Ditengah balai bandung sirap itu dibuat Generaal singgasana, tinggi ada tengah dua depa, diulas dengan teluki kuning”. Deze bijzonderheid vinden we ook van Hollandse zijde opgetekend. De opstelling van het gezelschap is anders en wederom in overeenstemming met de Hollandse berichten: "Maka adalah yang diatasnya Generaal dan Suhunan Muda dan Sultan; dan yang lain semuanya sama berdiri di bawah." De Sturler, die hier "Holanda kepercayaan Generaal itu" wordt genoemd, leest het contract voor "dengan nyaring suaranya".

In plaats van "turun menurun" heeft B het gebruikelijke "turun temurun", in plaats van "dengan beberapa bunyi-bunyian, semuanya dipalu oranglah" lezen we hier "dengan mainan panjidur" (volgens UBL 5, "jidur" volgens MP 2).

De beschrijving van de Hollandse erewacht is gedetailleerder: “. . soldadu pada masa itu dari tepi laut beratur kiri kanan jalan sampai kedalam kota serta membelit balai bandung sirap itu dengan berapa orang besar-besar pada hadir di situ." 
7.1. De "benoeming" van Pangéran Prabu Anom tot Sultan Ahmad Najamuddin vinden we op deze plaats bij B niet nogmaals vermeld, omdat deze volgens B immers reeds eerder te Batavia zou hebben plaatsgevonden (zie par. 6.3). Overigens is de lijst van "benoemingen" of "bevorderingen" (B heeft telkens het Javaanse "munggah" waar A het eveneens aan het Javaans ontleende "berjeneng" of "dijenengkan" gebruikt), zelfs wat de volgorde betreft, precies gelijk. Het betreft hier een voor de Palembangse adel belangrijke zaak en het is daarom begrijpelijk dat de traditie ten deze met grote zorgvuldigheid is bewaard.

Volgens Hollandse bron zijn de benoemingen, vermeld onder de nrs 2, 4 en 14, door De Kock verleend, terwijl "de benoeming der rijksgrooten van mindere aangelegenheid werd overgelaten aan den Soesoehoenang" (Meis, 1841/42, p. 231).

7.2. De lezing van $B$ dekt die van A vrijwel geheel. Er zijn geringe verschillen in woordkeus, zoals "bambu" voor "buluh", "kayu balok persegi" voor "kayu balok petaling", het gebruik van het Javaanse "matur", wanneer Jayaningrat de vorst toespreekt, het eveneens Javaanse "mambu hati", waar A spreekt van "sudah menaruh dendamnya" (N.B. de betekenis van mambu hati is hier blijkbaar het tegengestelde van de betekenis van mambu ati volgens het Javaans-Nederlands handwoordenboek van Pigeaud). De voorkeur van Suhunan Husin Dia'uddin voor zijn zoon Prabu Anom als troonopvolger boven zijn zoon Jayaningrat wordt in B gemotiveerd: "kerana yang tua". Daarop aansluitend zegt B: "Maka kata Generaal Betawi: "Jika demikian, bésok sampai di Palémbang Pangéran Jayaningrat juga dibawah Sultan, jangan yang lain kalau perkara negeri!" " Een andere bijzonderheid van B is dat hij Jayaningrat zijn pleidooi voor het bouwen met steen in plaats van met hout laat besluiten met de mededeling dat een zekere rangga zich bereid heeft verklaard stenen te leveren: "Kirangga Jalil cakap membuat batunya di Keramasan."

\subsection{Slechts enkele verschillen:}

- B zegt dat de Palembangers nog niet naar Palembang zijn teruggekeerd, omdat ze daartoe nog geen toestemming uit Palembang hebben gekregen: "belum diberi oléh Sultan di Palémbang".

- B geeft ons een nadere kijk op de intriges binnen de sultansfamilie met de woorden: "Maka rusaklah bicara Palémbang" (vgl. A: "Syahadan jadi rusaklah wa'at dan janji dari perkara Palémbang") "pada masa itu, kerana Pangéran Dipati Jayaningrat itu di Betawi 
mupakat pula dengan Pangéran Dipati Abdulrahman, kerana Pangéran Dipati Abdulrahman itu tiada rapat" (volgens MP 2, volgens UBL 5: "mupakat") "lagi dengan Sultan dan Suhunan di Palémbang."

- Voor de syntactisch moeilijke passage bij A betreffende de oogziekte van Pangéran Purbanegara, luidende: “... maka Pangéran Purba jatuh sakit pada malam itu. Sakit juga tiada dapat melihat lagi ..." heeft B: "... maka Pangéran Purbanegarapun kena penyakit. Pada malam itu juga menjadi tiada melihat lagi ...", een lezing die doet vermoeden dat het tweede "sakit" van A in de tekst niet thuishoort, zodat A dan zou worden gelezen: “... maka Pangéran Purba jatuh sakit. Pada malam itu juga tiada dapat melihat lagi ...”.

7.4. De commissaris heet "Benuk" (waarmee Van Sevenhoven bedoeld moet zijn) en doet op de reis van Batavia naar Palembang Billiton aan. Voor "merapatkan/menghampirkan dirinya kepada commissaris" lezen we bij B: "meléngkétlah dengan kumisaris". De "perempuan selir Suhunan" wordt aangeduid als "perempuan pingitan Suhunan" (haremvrouw, opgesloten, gereserveerd voor de suhunan). Het resultaat van het onderzoek in de vrouwenkwestie wordt door B iets uitvoeriger vermeld: "Maka diperiksa kumisaris, nyata itu perempuan sudah dibawa di dusun Buri. Sudah diambil oléh Pangéran Dipati, dibawanya kepada kumisaris." Aan het slot vermeldt $B$ nog de benoeming van Pangéran Puspadiprana Cingot tot patih van de sultan. Daarentegen ontbreekt de laatste alinea van A bij B.

7.5. In plaats van "Perwatin Lima Belidah" heeft B correcter: "Perwatin Lima dan Belidah". Tot tweemaal toe doet B het voorkomen alsof de suhunan zelf om salariëring heeft gevraagd: "minta gajih saja".

7.6. De eerste alinea ontbreekt bij B. Het salaris van de raadsleden bedraagt volgens $\mathrm{B}$ niet tweehonderd, maar honderdvijftig gulden. Pangéran Penghulu Agama wordt bij zijn volledige naam genoemd: Pangéran Penghulu Nataagama.

7.7. B is vrijwel letterlijk gelijk aan A. Resident Reijnst heet bij B Renees (UBL 5) of Resjest (MP 2).

8.1. Het begin is bij B eenvoudiger gesteld: "Sebermula tiada disebutkan lamanya di sini dengan takdir Allah tacala sudah sampai bilangan- 
nya kerajaan Palémbang akan bersalin. Maka tiba-tiba Sultanpun turut kata patihnya Pangéran Puspadiprana Cingat akan membuat jahat kepada Kompagnie. Berapa orang yang dicucuk bicara oléh Pangéran Puspadiprana Gingat; dan Suhunan di Suakbata itu tiada sekali-kali tahu hal bicara itu."

Het gevecht tussen de sultan en Pangéran Perdana Menteri is ook door B opgetekend, zij het zonder het intermezzo van de opsluiting van laatstgenoemde in het geitenhok en zijn bevrijding daaruit door zijn broer Pangéran Haji Kramanandita. Wegens het opvallende verschil in woordkeus tussen A en B laat ik het verslag dat B van dit gevecht geeft hier in zijn geheel volgen.

"Haripun hampir malamlah. Setelah Sultanpun turun ke perahu serta menoléh ke belakang, dilihatnya Pangéran Perdana Menteri berjalan, mau pulang rupanya. Maka Sultanpun kembalilah pula kepada Pangéran Perdana Menteri itu serta menyikep parang panjang. Setelah datang, maka segeralah Sultan itu menganjungkan parang panjang itu akan" (MP 2: "hendak") "mengapak Pangéran Perdana Menteri. Maka segeralah disambar oléh Pangéran Bupati Panembahan dari belakang. Lalu bergelut Sultan dengan Panembahan merebut Pangéran Perdana Menteri itu, tiada juga dilepaskan Sultan. Haripun sirep malam, maka segeralah datang Suhunan mengambil Pangéran Perdana Menteri itu, dibawanya masuk ke balai bandung; dan Panembahanpun memegang Sultan. Maka Sultanpun pulanglah ke Sekanak pada kampungnya berlengkap. Maka haripun malamlah, maka Panembahanpun pulanglah menjauhkan perempuan di Kertapati."

Het slot van deze paragraaf betreffende de aanhouding door de sultan van de afgezant van de resident, Kirangga Tamin, vinden we bij B nagenoeg gelijkluidend terug.

8.2. De verschillen manifesteren zich alweer voornamelijk in de woordkeus: "hujan ricik-ricik" voor "hujan rintik-rintik", "baris empat lapis" voor "baris ... empatratus banyaknya", "carem", dat bij A in paragraaf 6.9 voorkomt, voor "sama sekali". Pangéran Putang wordt voluit Pangéran Citra Putang genoemd (vgl. 7.1) en Radén Gusi conform UBL 7 Radén Gubir.

8.3. Terwijl volgens $A$ de suhunan zegt van de daden van de sultan niet op de hoogte te zijn, verklaart hij volgens B zich volstrekt niet bij de beweging van de sultan te hebben aangesloten: “... aku tiada mengikut suatu apa-apa ini perkara Sultan". 
Inzake de krissen van Demang Umar en Pangéran Perdana Menteri geeft B enige toelichting: de krissen zijn hun blijkbaar ontrukt, want van de kris van laatstgenoemde wordt gezegd: "tiadalah ketahuan siapa mengambilnya" en van Demang Umar lezen we: "tangannya luka oléh keris sendiri". Dat de raadsleden er door de resident op uitgestuurd zijn om uit te vissen of de suhunan in de opstand van zijn zoon de hand heeft gehad, blijkt bij B niet. B tekent aan dat het ongeveer acht uur is, wanneer Pangéran Dipati Abdulrahman met de brief van de resident in Suakbata aankomt.

Het verzoek van de resident aan de suhunan luidt bij $B$ om mèt de sultan naar Batavia te gaan: "pergi ke Betawi membawa Sultan itu mintakan ampun". Pangéran Bupati Panembahan gaat volgens B niet alleen, maar samen met Pangéran Dipati Abdulrahman naar de resident om het antwoord van de suhunan over te brengen. De brik waarmee de suhunan c.s. naar Batavia zal reizen, wordt door B omschreven als: "perahu kici Masagus Jaguk" (MP 2: Cukuk!), "diséwakan oléh resident sebab itu kutika tiada ada kapal Kompagnie di Palémbang, hanya perahu kotak yang jaga di Palémbang". Iets dergelijks vinden we ook bij UBL 7, waar de naam van de eigenaar van de brik Caguk luidt.

Bij B blijkt duidelijk dat met Radén Bakar de zoon van de suhunan wordt bedoeld en niet van Pangéran Wirakrama: “... dan Radén Bakar, putera Suhunan itu juga". Er doen zich ook hier enkele gevallen van verschil in woordkeus voor: "mutung" in plaats van "dibakar", "hilang" in plaats van "gaiblah". De zin "Telah berapa dicari Sultan itu, tiada bertemu, khabarpun tiada." aan het eind van de paragraaf lijkt een meer volledige tekst te zijn tegenover het lapidaire "dicari orang, khabarpun tiada." van A.

8.4. In hoofdzaak eender, maar beknopter. Met name maakt $B$ geen gewag van de aankomst van de suhunan te Batavia. Terwijl A vermeldt dat Kirangga Tamin als beloning voor zijn diensten vijfhonderd gulden ontvangt, lezen we bij B dat Pangéran Dipati Jayaningrat een salaris krijgt van duizend gulden, een in de gegeven context irrelevante mededeling.

8.5. Volgens B is Pangéran Dipati Abdulrahman wanneer hij het binnenland intrekt voorzien van de kentekenen der vorstelijke waardigheid, zoals de witte zonnetent en witte roeiriemen: "... serta diserahkannya semuanya perahu dan alat Suhunan, pengayuh putih dan ébék putih".

De onderscheiding waarmee Pangéran Dipati de Jongere hier blijk- 
baar wordt bejegend, past in het kader van de opmerking in UBL 7 (p. 76) dat hij sultan van Palembang zal worden, als hij erin slaagt de opstandige sultan te pakken te krijgen: "Dan janji: jikalau Sultan itu dapat, maka Pangéran Dipati Mudalah yang jadi sultan di Palémbang". Overigens is B in de tweede alinea enigszins gebrekkig van stijl in vergelijking met A: "Telah sampai dekat Muara Beliti, maka Sultan itupun kumpul berapa orangnya dengan alat senjatanya bertahan di Muara Beliti, tiada mau turut bicara Pangéran Dipati Abdulrahman itu". De tweede expeditie van Pangéran Dipati Abdulrahman is volgens B nog beter uitgerust dan de eerste: "Maka mudik pula dengan alat senjata dan berapa periai dan menteri yang turut lebih banyak dari selamanya". B noemt tenslotte plaats en tijd van de begrafenis van deze onderweg overleden pangéran: "Maka dibawa ke Palémbang, pagi-pagi dipendam" (A: dikuburkan) "di Lemabang dengan alatnya soldadu Holanda semuanya". Ik teken hierbij aan dat Lemabang de voornaamste begraafplaats was van de vorstelijke familie, zodat de bijzetting van Pangéran Dipati Abdulrahman daar ter plaatse zijn bijzondere positie nader accentueert.

8.6. B duidt Radén Utama nader aan als de zoon van Pangéran Batangari. Uit het verhaal bij B blijkt dat de Pasemahers als dragers voor de sultan dienst doen: "Maka Pasemah banyak racyat Pangéran Bajau itu turut Sultan membawakan barang-barang Sultan. Belum sampai di bénténg di ulu Ogan itu, maka Pasemah banyak itu habis lari melarikan barang-barang Sultan itu, kerana Pangéran Pasemah itu sudah kena cucuk rasan daripada Kirangga Wirasentika. Dan Pangéran Bajau itu mati ditombak oléh Sultan sendiri, sebab hendak mengamuk Sultan." Het verschil in stijl tussen A en B is hier weer evident.

8.7. Temenggung Aminuddin (tweede alinea) heet bij B Temenggung Hasanuddin. De staatsiesloep, "perahu alat kerajaan", wordt hier, evenals in UBL 7, aangeduid als "perahu tunggul kuning", de sloep met de gele (vorstelijke) wimpel (vgl. par. 6.14). A is breedvoeriger en meer literair. Ter illustratie volgt hier de lezing die B geeft van de passage "Antara berapa hari lamanya milir itu ..." tot "Setelah itu maka sigeralah commissaris menyuruhkan ...", luidende: "Telah sampai di Pegayut, maka Temenggung Mahidin itupun suruhan ke Palémbang mengatakan Sultan sudah menyerahkan diri. Dan pada masa itu kumisarispun sudah ada di Palémbang dengan kapal perang jaga Palémbang." 
8.8. De berechting van de opstandelingen wordt door B slechts summier weergegeven. Ter vergelijking de eerste zin van deze paragraaf bij B: "Syahdan pada suatu kutika diambil Pangéran Cingat itu dengan Masagus Abduljamil itu, diraadkan didalam kota, dihukumkan mati keduanya itu." Het bevel van de commissaris om het hoofd van Pangéran Jayadilaga te begraven blijft onvermeld. Radén Sanusi heet hier voluit Radén Hasanusi.

8.9. Bij Pangéran Wirakrama tekent $B$ ter verduidelijking aan: "yaitu saudara Pangéran Adiwijaya". Overigens lopen de beide teksten parallel. 


\section{VERTALING}

\section{UBL 9}

1.

41, 1.1. De geschiedenis verhaalt nu verder, dat General Mister Raffles r. 13 regeerde over heel Java en dat zijn bewind heilzaam was, niet alleen voor de mensen van het land zelf maar ook voor alle mensen van elders: Chinezen, Indiërs, Maleiers, Baliërs, Ambonnezen, Ternatanen, Buginezen, Makassaren. Zijn optreden jegens de kleine man was vriendelijk en innemend en elke dag werd er feestgevierd.

$\mathrm{Na}$ verloop van enige tijd beraadslaagde hij met hoge regeringsfunc42 tionarissen over het zenden van een commissie van onderzoek naar Palembang, want naar men zei was de Hollandse loge in Palembang door Sultan Mahmud Badaruddin met de grond gelijkgemaakt en was er van de hele blanke bezetting niemand overgebleven behalve één blanke, die er door de sultan toe gebracht was tot de Islam over te gaan. "Zoiets kunnen we toch niet over onze kant laten gaan! Als 't er op aankomt, moeten we beseffen, dat we blanken zijn!"

1.2. General Mister Raffles zond toen drie personen, ten eerste Mister Hare en voorts Mister Phillips en Mister Wardenaar, naar Palembang. $\mathrm{Na}$ een korte zeereis kwamen zij in de monding van de Sungsang aan. De wachtpost aan de monding meldde het nieuws in de stad. Daarop zond Sultan Mahmud Badaruddin vier ambtenaren uit om Mister Hare, Mister Phillips en Mister Wardenaar af te halen. De ambtenaren namen de drie mannen terstond mee naar de stad. Zodra die drie ter plaatse waren aangekomen, werden ze door de havenmeester bij de sultan gebracht.

Nadat ze een brief van General Mister Raffles hadden afgegeven, vroeg de sultan: "Hoe gaat het met de generaal? Maakt de grote heer het op dit ogenblik goed?" Die drie heren antwoordden: "Onze heer maakt het goed op het ogenblik. Maakt mijnheer de sultan het goed?" Deze antwoordde: "Ja." Toen haalde de sultan de brief uit de envelop en overhandigde deze aan een ambtenaar, die de brief van het begin tot het einde voorlas. Die dag werden de gasten onthaald in de kraton.

43 Vervolgens gaf de sultan een ambtenaar bevel Mister Hare, Mister 
Phillips en Mister Wardenaar naar het huis van Demang Saléh te brengen, dat hun als verblijfplaats was toegewezen en waar hun tevens twee beambten ter beschikking stonden om voor hun maaltijden te zorgen.

$\mathrm{Na}$ enige tijd vroegen zij toestemming om naar Batavia terug te gaan; ze wilden met spoed vertrekken, want de afspraak met General Mister Raffles was dat ze na twee weken naar Batavia zouden terugkeren en nu was het al bijna drie weken geworden. Daarop droeg de sultan een vier- of vijftal ambtenaren op Mister Hare en zijn beide metgezellen uitgeleide te doen naar Sungsang. Aldus geschiedde.

\section{2.}

2.1. Twee maanden later kwam er bericht uit Banka dat er ontelbaar veel vaartuigen, en wel allerlei grote schepen, vrachtboten, sloepen en jachten, bij het eiland Nangka voor anker lagen, die allen de Engelse vlag voerden en uit het oosten gekomen waren. $\mathrm{Na}$ twaalf dagen kwam er een klein vaartuig, dat in de monding van de Sungsang ten anker ging. De posthouder van Sungsang ging erheen om dat schip te visiteren. Nadat de kapitein van het schip drie dagen achtereen de toestemming daartoe had geweigerd, meldden de mensen van Sungsang de zaak in Palembang. De sultan zond toen verschillende ambtenaren, ten eerste een temenggung en voorts een rangga, een demang en een ngabéhi, erheen om aan de monding poolshoogte te gaan nemen. Ze kwamen niet te weten welke nationaliteit dat schip had en ook over de herkomst ervan hadden ze nog geen nieuws gekregen om aan Zijne Majesteit mede te delen; want er was niemand die de kans kreeg die schepen te gaan bekijken.

Tenslotte was er toch een ambtenaar - hij kwam uit Banka - die op zich nam te onderzoeken wat dat voor schepen waren. Vervolgens 44 gaven de ambtenaren uit Palembang hem te eten, "want", zo zeiden ze, "wij zijn niet in staat om erheen te gaan". Die ambtenaar begaf zich toen naar de twaalf grote schepen en naar de brikken, vrachtboten, schoeners, sloepen en lichters, waarvan het aantal niet was vast te stellen maar die zo talrijk waren, dat ze de hele rede in beslag namen. Diezelfde dag voeren één groot schip en één brik de monding van de Sungsang binnen, vol met soldaten: blanken, Ambonnezen en Baliërs. Eerst toen wist men dat al die schepen deel uitmaakten van een Engelse vloot uit Batavia, uitgezonden door General Mister Raffles, de heerser van Batavia. De militaire bevelhebber op die vloot was General Gillespie, 
terwijl verder Major Meares en verscheidene andere officieren zich aan boord van die schepen bevonden.

2.2. Toen, zo vermeldt de geschiedenis verder, sloegen alle ambtenaren die de wacht hadden aan de monding tot de laatste man in wanorde op de vlucht en zocht ieder voor zich in 't wilde weg een goed heenkomen; sommigen voeren aan één stuk door stroomopwaarts, anderen schoten een zijrivier in en weer anderen volgden de weg overland. De grote schepen voeren toen dadelijk de rivier op, evenals alle kleinere vaartuigen. Nadat de vloot twee dagen stroomopwaarts was gevaren, kreeg men in het fort Borang de schepen in zicht; de broer van Zijne Majesteit Sultan Mahmud Badaruddin, Pangéran Adipati genaamd, was op dat tijdstip commandant van het fort.

Daarna kwam er een afgezant van de sultan, die Pangéran Marta heette en vergezeld was van vier ambtenaren: een temenggung, een rangga, een demang en een ngabéhi. Deze had een brief bij zich, waarin de sultan uiting gaf aan zijn vredelievende gevoelens, en bracht boven-

45 dien geschenken ter afwending van onheil mee. Toen de gezant tegenover hem stond, sprak General Gillespie: "Door bemiddeling van U en die vier ambtenaren wens ik geen brief te ontvangen en het heeft ook geen zin tot mij te spreken, aangezien ik geen opdracht heb met $U$ te spreken over wat ik hier kom doen. Ter plaatse waar de vorsten zetelen die zo stijfkoppig zijn, dáár zal ik spreken. Ik wil nu eerst wel eens zien wie de hardste kop heeft, de sultan of ik!" Pangéran Marta en de temenggung namen daarop afscheid en keerden terug naar de sultan om van hun bevindingen verslag uit te brengen.

Tegen de avond ging Pangéran Adipati terug naar de stad. Toen hij vóór de ontvangzaal aankwam, was daar een grote menigte op de been, bestaande uit de gezamenlijke edelen en ambtenaren, haji's, vele andere mensen en Arabieren, terwijl elders op het kratonterrein Chinezen bijeen waren en bergbewoners bij duizenden; niemand kon meer een voet verzetten. Toen nu de sultan Pangéran Adipati in het oog kreeg, barstte hij in tranen uit en omhelsden en kusten de twee broers elkaar. Vervolgens sprak de sultan tot de edelen en ambtenaren: "Wat is Uw aller voorstel met betrekking tot deze stad? Immers, deze stad is niet van mij alleen, maar van jullie allemaal. Uit het diepst van mijn hart vraag ik $U$ alleen, dat $U$ de eendracht bewaart, al bent $U$ nog zozeer van verschillende landaard." Daarop richtte de hele menigte zich eerbiedig tot de vorst met de woorden: "Vergiffenis heer, duizendmaal vergiffenis! Wij hopen dat onze woorden genade mogen vinden onder 
het stof van Uw doorluchtige voeten. Welke bevelen Uwe Hoogheid ons ook geve, wij leggen deze zoveel als in ons vermogen is gehoorzaam en onderdanig op onze schedel. Maar we moeten wel een voorbehoud 46 maken." Op het horen van die woorden zei de sultan: "Wat is dat voorbehoud? Immers, aan geldmiddelen ontbreekt het mij niet!" Daarop spraken al die ambtenaren eerbiedig: "Vergiffenis, heer! Het is ons heus niet om geld te doen." De sultan nu was zeer bedroefd, toen hij die woorden van de menigte hoorde.

De volgende dag wendden de edelen en ambtenaren die de bezetting van het fort hadden gevormd en tot de laatste man waren gevlucht, zich onmiddellijk tot de sultan met de mededeling dat het fort door Engelse soldaten was bezet en dat deze de kanonnen hadden vernageld en de munitie in het water gegooid. Sommige edelen waren meteen hun gezin in veiligheid gaan brengen zonder eerst nog terug te gaan naar de stad. Later kwamen er een Arabier en twee ambtenaren bij Sultan Mahmud Badaruddin met het bericht dat alle schepen, brikken, vrachtboten en sloepen aan één stuk door stroomopwaarts voeren.

Toen verliet Sultan Mahmud Badaruddin met zijn gezin de kraton; dit geschiedde onder een gunstig gesternte, in de nacht van de drieëntwintigste Ramadan van het hijrah-jaar 1226. De sultan voer de Musi en vervolgens de Belidah op, terwijl Pangéran Adipati met zijn gezin de Ogan opvoer.

General Gillespie op zijn beurt trok onmiddellijk daarop met al zijn wapentuig de kraton binnen en de soldaten sloegen meteen aan het plunderen. General Gillespie vestigde zich met de officieren binnen de stenen wallen en de soldaten werden deels binnen deels buiten de wallen

47 ondergebracht, zodat elk huis in het stroomopwaarts gelegen deel van de stad stampvol blanke, Ambonnese en Balinese soldaten zat.

2.3. Toen besloot General Gillespie in overleg met de chef-staf om Pangéran Adipati en de edelen die gevlucht waren te laten terughalen. General Gillespie gelastte ten eerste Pangéran Citrakesuma en ten tweede Radén Muhammad, die met General Gillespie was meegekomen uit Batavia, Pangéran Adipati te gaan halen. Ook de edelen en de gewone mensen die de stad hadden verlaten, werden door de generaal naar de stad teruggeroepen, "want $\mathrm{Zijne}$ Excellentie de Generaal had alle zonden uit het verleden vergeven". Toen voer de pangéran de Oganrivier op, waar hij Pangéran Adipati en de edelen aantrof; terstond werden zij door de pangéran meegenomen naar de stad, de kraton binnengeleid en bij Zijne Excellentie de Generaal gebracht. 
Toen hij voor de generaal genaderd was, bewees Pangéran Adipati hem hulde en eer. De generaal gaf hem een hand. Vervolgens nam hij naast General Gillespie plaats op een stoel in de uit twee gedeelten bestaande ontvangzaal, waar ook het hele korps officieren aanwezig was. 't Was stampvol in de ontvangzaal. Toen vroeg General Gillespie: "Uw broer, Sultan Mahmud Badaruddin, waar is die nu naar toe gevlucht?" De pangéran antwoordde: "Ik weet het niet. Naar men zegt, is hij de Musi opgevaren. Tot nu toe heb ik nog geen stellige berichten ontvangen, wáár Sultan Mahmud zich voorlopig gevestigd heeft." Daarop zei de generaal: "Roept $U$ alle mensen die gevlucht zijn maar terug. $\mathrm{Ze}$ be-

48 hoeven voor mij niet bang te zijn. Ik wil er van nu af aan op toezien dat deze stad welvarend wordt. Wanneer de welvaart hier in Palembang zal zijn weergekeerd, zal men mijn naam prijzen. 't Is het beste dat $U$ hen met spoed terugroept. Ik wil namelijk naar Batavia terug, want ik heb General Raffles beloofd dat ik na één maand naar Batavia zou terugkeren. Een zekere Major Meares blijft achter met een groot aantal officieren en ongeveer vierhonderd voldaten, twee grote schepen en twee brikken, zeven landingssloepen en een stuk of tien kleine vrachtschepen."

Nadat de generaal dit gezegd had, beval hij Pangéran Dipati naar zijn eigen kraton terug te keren. Daar werd hij onder bewaking van soldaten en twee kapiteins gesteld. In die kraton nu wilde een pangéran binnengaan om Pangéran Adipati een bezoek te brengen. Hij gelastte de soldaten naar buiten te gaan, maar deze wilden niet. Vervolgens staken de soldaten naar hem met de bajonet op het geweer, twee of drie soldaten beukten op hem los, zodat de pangéran bezweek en tenslotte als martelaar voor het geloof stierf. Zo is dat gegaan.

Tien dagen later besloot General Gillespie in overleg met de edelen en de Arabieren Zijne Hoogheid Pangéran Adipati te verheffen tot regerend sultan over het Palembangse rijk. Hij werd bekleed met de naam en titel Sultan Ahmad Najamuddin, heerser op de troon van het rijk Palembang uit naam van de Koning van Engeland en onder de bevelen van het gouvernement van General Mister Raffles, die regeerde 49 over het ganse gebied van Java. Nadat de sultan op de troon van Palembang was geïnstalleerd, verliet General Gillespie de stad en zeilde terug naar Batavia.

3.

3.1. Als regerend vorst op de troon besloot de sultan in overleg met 
Major Meares om één pangéran te benoemen tot pepatih en voorts een penghulu, een kerta, een tanda en een kapitein der Chinezen aan te stellen. Vervolgens werden zij allen geïnstalleerd; bovendien werden er allerlei ambtenaren aangesteld, ten eerste een temenggung en voorts een rangga, een demang, een ngabéhi en een pengalasan; al die functionarissen waren elke dag in de audiëntiezaal aanwezig om hun opwachting te maken bij de sultan.

Op een dag vroeg Major Meares aan Zijne Majesteit de Sultan vergunning om met een honderd man sepoy-soldaten de Musi op te varen teneinde Sultan Mahmud Badaruddin te gaan halen. De sultan stelde hem een geleide ter beschikking en wees als zodanig verschillende pangérans en ambtenaren alsmede pangérans van Komering aan, zodat er boven de tien vaartuigen van Major Meares een vloot van zeventig boten met edelen en ambtenaren was gevormd, die allemaal volledig bewapend waren.

Toen zei Major Meares tegen Sultan Ahmad Najamuddin: "Als Sultan Mahmud Badaruddin zich verzet en ik met mijn soldaten vervolgens in de strijd gewikkeld raak, wat zullen de Palembangers dan doen?" Daarop sprak de sultan tot de pangérans en de ambtenaren gezamenlijk: "Elk bevel van Major Meares moeten jullie opvolgen! Verzet je niet tegen Major Meares! Als jullie je plicht verzaakt, ligt de 50 schuld niet bij mij. Dat is mijn opdracht aan jullie allen, vergeet die niet! En verder: naar men zegt is er in het dorp Buaya Langu een sterk fort van Pangéran Wiradinata met als ambtenaren drie rangga's en twee demangs, met vier pangérans en met als edelen een groot aantal masagus en verschillende radéns. Jullie echter moet je steeds solidair tonen met al wat de blanken ondernemen!" Zo luidde de opdracht van de sultan.

De pangérans en de ambtenaren betuigden één voor één hun gehoorzaamheid aan het vorstelijk bevel. Vervolgens werden er allerlei gerechten opgediend voor het feestmaal ter gelegenheid van de aanstaande tocht van Major Meares naar het binnenland, waarbij deze aan één tafel aanzat met de sultan. Toen de maaltijd was afgelopen, gaf Major Meares de sultan de hand en begaf zich rechtstreeks naar de pencalangs om zich in te schepen; Zijne Majesteit de Sultan deed hem uitgeleide tot op de steiger. Zodra Major Meares aan boord was, vertrok de vloot, terwijl er éénentwintig kanonschoten werden gelost en de geweersalvo's weerklonken als slagwerk. Niets anders was er meer te horen dan het gedreun der kanonschoten, dat klonk als de donder aan het firmament. Zó ging het toe bij het vertrek van de majoor naar het binnenland. Daarna ging de sultan terug naar het paleis. 
3.2. Na verloop van vijf of zes dagen kwam er een afgezant van Pangéran Citrakesuma en Pangéran Sumanegara met een brief, bestemd voor Zijne Majesteit; deze was juist bezig de edelen, de ambtenaren en de dorpshoofden uit de buitendistricten in audiëntie te ontvangen, zodat het stampvol was op de grote verzamelplaats. De sultan opende de brief. Nauwelijks had hij er zijn blik over laten gaan, of hij wist wat er in stond. Onmiddellijk daarna sprak Zijne Majesteit de Sultan tot de edelen, de ambtenaren en de dorpshoofden: "Zó staat in deze brief

51 geschreven: "De mensen in het binnenland zijn deels nog bezig het fort van het dorp Buaya Langu in staat van verdediging te brengen." Maar ik heb het gevoel dat ze de strijd tegen de blanken, de Engelsen, niet zullen volhouden." Daarop zeiden de edelen en ambtenaren eerbiedig: "Vergiffenis, heer! Duizendmaal vergiffenis! Wij hopen dat het ons vergeven worde, maar dat men geen stand zal houden en alleen maar op de vlucht zal slaan, dat komt omdat Zijne Majesteit Uw oudere broer zich niet in het fort bevindt en daar slechts edelen en ambtenaren aanwezig zijn; wij zouden niet goed weten wat die mensen anders moeten doen dan op de vlucht slaan."

Twee of drie dagen later meldden de mensen van de wachtpost dat ze zeer vele pencalangs hadden gezien. Men deelde eerbiedig aan $\mathrm{Zijne}$ Majesteit de Sultan mede: "Er zijn vaartuigen, die zijn uitgestuurd door Major Meares. Wij hebben een pencalang gezien die uit het binnenland kwam en grote haast maakte." Slechts een ogenblik later arriveerde de dienaar van Pangéran Citrakesuma met een brief voor Zijne Majesteit, waarin gemeld werd dat de strijdmacht van Major Meares in de komende drie dagen de strijd zou aanbinden tegen het fort daar. De sultan zei tegen degene die de brief bracht: "Wat denk jij ervan, zal het fort 't uithouden of niet?" Toen sprak deze: "Vergiffenis, heer! Heil en zegen zij $U$, o heer! De mensen daar in het binnenland houden het niet vol, omdat Zijne Majesteit Uw oudere broer niet in het fort is en slechts edelen en ambtenaren het fort bewaken, terwijl Zijne Majesteit Uw oudere broer in het dorp Sekayu verblijft. Naar mijn berekening zal 't met het fort van Buaya Langu nu wel gedaan zijn."

Omstreeks twaalf uur kwam er weer een brief van Pangéran Citra-

52 kesuma, waarin stond: "Morgenochtend openen wij de vijandelijkheden tegen het fort. Naar men zegt staat het fort onder commando van Pangéran Wiradinata en zijn er zes ambtenaren. Als mijn schatting juist is, zal het fort binnen een paar uur veroverd zijn. Dat is 't wat ik $U$ wilde zeggen. Overigens is het slechts de zegen van Uwe Majesteit, waarop wij allen hopen bij de uitvoering van de taak die $U$ ons hebt 
opgedragen. Al zou het ons het leven kosten, dat hebben wij er graag voor over."

3.3. Twee dagen daarna kwamen de mensen van de wachtpost melden dat er een groot aantal vaartuigen de rivier kwam afzakken. Vlug zond de sultan ambtenaren uit om naar de boten die daar aan kwamen varen te gaan kijken. Zodra ze elkaar ontmoetten, vroegen de ambtenaren: "Hoe is het U tot dusver gegaan, heren?" De bemanning van de boten antwoordde: "Goed. Wij hebben de strijd gewonnen en het fort van Buaya Langu is platgebrand. Maar onze commandant, Major Meares, is ernstig getroffen door een schot in de buik; men is algemeen van mening dat hij in levensgevaar verkeert. Daarom zijn wij hierheen gekomen. Als dit niet gebeurd was, waren we gewoon doorgevaren."

Op het horen van dat nieuws gingen de ambtenaren vlug terug om de sultan daarvan op de hoogte te brengen. Zodra hij het nieuws had vernomen, begaf de sultan zich op weg; ter plaatse aangekomen ging hij meteen aan boord om naar Major Meares te gaan kijken. Toen deze de sultan zag, wist hij niets anders meer te vertellen dan dat hij graag meteen, "vandaag nog", naar Muntok vervoerd zou willen worden. Daarop gaf de sultan aan ambtenaren de opdracht Major Meares dadelijk en zonder oponthoud daarheen te brengen. De sultan was nu zeer

53 bedroefd; zes of zeven dagen lang verkeerde hij in een neerslachtige stemming. We laten die zaak hier verder rusten.

4.

4.1. Wij komen nu weer te spreken over Sultan Mahmud Badaruddin. Deze had zich terdege verschanst in Muara Rawas en tevens de bevolking van de districten Musi, Beliti, Batu Kuning, Kikim en Rawas verzameld. De hoofden van die districten hadden tijdens een plechtigheid, waarbij een buffel werd geslacht en gezamenlijk met de sultan de maaltijd werd gebruikt, de eed van trouw afgelegd en een verbond gesloten voor het leven en tot in de dood. Bij die gelegenheid verleende de sultan vervolgens een onderscheiding aan een viertal Maleise legeraanvoerders. De eerste kreeg de titel panglima perang besar, de tweede de titel panglima di dalam raja, de derde de titel panglima besar raja, de vierde de titel panglima muda. De vier legeraanvoerders kregen van de vorst ieder een nieuw stel kleren, een hoofddoek, een buikgordel van fijne gebloemde stof en twaalf el lang, en een zwaard ten geschenke; daarna betuigden zij hem hun onwankelbare trouw. 
Daarna bouwde men drie forten, omheind met een palissade van in de grond geslagen boomstammen: één op de landtong van Muara Rawas, een tweede aan de overkant van de Musi en het derde op de landtong van Rawas Mata. Die drie forten waren zeer sterk en elk bastion werd bewaakt door een gewapend ambtenaar met zijn gezin. Te oordelen naar de berichten van degenen die ze gezien hadden waren die forten ongenaakbaar voor hen die ook een donkere huidskleur hebben, ja zelfs van de blanken zijn er velen gesneuveld in al de tijd dat de strijd over en weer heeft geduurd; want die forten hadden een strategisch sterke ligging en de bezetting ervan was standvastig en trouw. Bovendien werd 54 gemeld dat er Maleiers waren gekomen met een onafzienbare vloot Maleise riviervrachtboten, zes tot zeven man per boot. Volgens hetgeen de berichtgevers gezien hadden, waren er niet minder dan dertigduizend Maleiers en mensen van Rawas beschikbaar in die forten. Overdag schreeuwden de mensen die hanengevechten hielden, wat klonk als het dreunen van de donder en 's avonds weerklonk het geschreeuw van de dobbelaars en het gefluit van de wachtposten. Te oordelen naar wat men daar gezien had zou een poging er binnen te dringen geen kans van slagen hebben, tenzij er binnen die forten overlopers zouden zijn. Maar overlopers trof men er niet aan, want er was voor iedereen genoeg goedkoop voedsel, er werd geld voor levensonderhoud verstrekt en men kreeg dagelijks een gratis maaltijd. Vrouwen waren er talrijk; als er iemand was die wilde trouwen, dan werd hij ogenblikkelijk door de sultan in het huwelijk verbonden. Zo was de toestand daar in Muara Rawas.

4.2. Toen hij dit alles gehoord had, besloot de sultan in overleg met de pangérans en de ambtenaren een gezantschap naar het binnenland te zenden om na te gaan wat Sultan Mahmud Badaruddin uitvoerde en een brief mee te nemen. Aan het hoofd van die missie stonden twee personen: Pangéran Citrakesuma en als tweede Pangéran Sumanegara; hun ambtenaar was Demang Surayuda. Ze gingen met een vloot van twintig vaartuigen. "Bij een dorp moeten jullie stilhouden en wanneer de vloot gepasseerd is, vaar je weer door. Ongeveer twee dagen vóór je de verblijfplaats van Sultan Mahmud Badaruddin bereikt, behoeven 55 jullie pas te overleggen, wie van jullie 't beste de brief kan gaan brengen." Nadat hij zo gesproken had, beval de sultan: "Maakt vlug de boten in orde! Over één of twee dagen moeten jullie allemaal vertrekken, met medeneming van je oorlogsuitrusting. Laat niemand nalatig zijn in de uitvoering van zijn taak, welke deze ook zij. Omdat er zich naar men zegt reeds een groot aantal Maleiers heeft verzameld, 
juist daarom moeten jullie eendrachtig zijn. Zo zij het!" Daarop verwijderde de sultan zich en ging het paleis binnen.

$\mathrm{Na}$ een paar dagen waren Pangéran Citrakesuma en Pangéran Sumanegara reisvaardig en lagen de boten van de edelen en de ambtenaren alle aan de steiger; het wachten was alleen maar op het huldebetoon dat men de sultan nog moest gaan brengen. Toen de pangérans en de ambtenaren allemaal in de ontvangzaal aanwezig waren, kwam de sul$\tan$ naar buiten en liep naar de ontvangzaal. Vervolgens werd er een feestmaal opgediend voor de pangérans en ambtenaren, de pangérans van de bovenlanden en de verschillende dorps- en districtshoofden. Toen de maaltijd afgelopen was, gaf de sultan de pangérans en ambtenaren de opdracht: "Wanneer jullie in het binnenland zijn, moet je geregeld, telkens na één of twee dagen, een afgezant van jullie naar Palembang laten komen!" Daarop bewezen de pangérans en de ambtenaren de sultan één voor één hulde en eer. Na dat huldebetoon begaven de pangérans en de ambtenaren zich onmiddellijk aan boord van de vaartuigen en vertrokken onder het driemaal opzeggen van zegenbeden. Dadelijk daarna werden er van elke boot saluutschoten gelost en werd er een luid gejuich aangeheven. De mensen bleven de vertrekkenden nakijken, maar de sultan ging het paleis binnen.

4.3. Nu wordt er verder verteld over de pangérans die op weg waren 56 naar het binnenland. Toen na ongeveer twaalf dagen het dorp Kasemaran was bereikt, legden alle boten daar aan. Slechts de beide pangérans, namelijk Pangéran Citrakesuma en Pangéran Sumanegara, en de demang-modin voeren verder stroomopwaarts. Pangéran Citrakesuma bleef in het dorp Kemang achter en Pangéran Sumanegara ging regelrecht door naar Zijne Majesteit Sultan Mahmud Badaruddin om de brief aan te bieden.

Sultan Mahmud Badaruddin nam de brief in ontvangst. Zodra hij de envelop had geopend, weende Zijne Majesteit de Sultan en zonder nog verder te kunnen lezen deed hij de brief meteen weer in de envelop. Toen vroeg de sultan aan Pangéran Sumanegara: "Hoe gaat het met jullie in de stad en hoe maken mijn jongere broers en zusters en mijn ouders het op 't ogenblik?" Daarop antwoordde de pangéran eerbiedig: "Vergiffenis, heer! Heil en zegen zij U, o heer! De kinderen van Uwe Majesteit die in de stad verblijven, is tot nu toe nog geen enkel onheil overkomen; alleen Zijne Hoogheid Uw oom Pangéran Dita is overleden. Dat is wat ik U had willen zeggen." Vervolgens vroeg Pangéran Sumanegara verlof om naar boord terug te gaan. Toen sprak Zijne Hoog- 
verheven Majesteit: "Wanneer was je van plan weer terug te gaan? Je zult krijgen wat Dipati bedoelt, maar niet zoveel als er in de brief bedoeld wordt. Heb wat geduld! Binnen enkele dagen zal ik iemand naar je toesturen." De pangéran bewees de vorst eerbiedig hulde en keerde daarna meteen terug naar de vaartuigen die in het dorp Kemang lagen te wachten. Het waren drie vaartuigen, namelijk de boot van Pangéran Citrakesuma, die van Pangéran Sumanegara en die van de demang57 modin, die in het dorp Kemang bleven liggen in afwachting van hetgeen Zijne Hoogverheven Majesteit in Muara Rawas zou beschikken.

4.4. Nadat ze er vijf dagen hadden vertoefd, kwamen als afgezanten van Zijne Majesteit Sultan Mahmud Badaruddin een pangéran en een ambtenaar bij de twee pangérans informeren naar wat ze precies kwamen doen. De beide pangérans antwoordden: "Wij tweeën hier zijn erop uitgestuurd met de opdracht een brief te gaan brengen; wij weten niet wat er in die brief staat. Wat ons beiden hier betreft, wij zoeken niets anders dan een goede verstandhouding tussen beide partijen. In Palembang is onze heer, maar hier in het binnenland eveneens. Volgens het vorstelijk bevel moeten wij het oog gericht houden op de goede verstandhouding tussen hen beiden. Maar onze heer in Palembang stelt daarbij geen voorwaarden. Immers waar draait het op uit als een vorst arm is? Het komt er tenslotte op neer dat hij de mindere is van zijn volk! Dat is het wat wij met de goede verstandhouding tussen de beide heren van ons bedoelen."

De ambtenaar uit Rawas zei toen: "Vertelt U eens, wat de sultan van Zijne Majesteit zijn oudere broer hier in het binnenland verlangt!" De pangérans zwoeren, zeggende: "Wij beiden zijn naar het binnenland gekomen met de opdracht uit Palembang om Zijne Majesteit te zeggen dat er in verband met de bouw van een fort aan de overkant van de rivier door Batavia om driehonderdduizend rijksdaalders wordt gevraagd. En voor het geval dit bedrag niet wordt opgebracht ..., wel dat is naar onze mening de reden, waarom ons is opgedragen met deze brief hier onze opwachting te komen maken. Maar jullie die geregeld in de nabijheid van Zijne Hoogverheven Majesteit verkeert, begrijpt dit

58 natuurlijk zoveel te beter." Daarop gaf de ambtenaar de beide pangérans ten antwoord: "Wij, die in de onmiddellijke omgeving van Zijne Majesteit verkeren, gevoelen niets dan medelijden wanneer we Zijne Hoogverheven Majesteit met zijn kleine kinderen hier zo zien in deze wildernis. Dat is de reden, waarom wij het niet over ons kunnen verkrijgen hem in de steek te laten. Daar komt nog bij, dat toen Zijne 
Hoogverheven Majesteit nog in de kraton verbleef, hij zowel de edelen als de ambtenaren, ja zelfs de kleine man steeds met gunstbewijzen heeft overladen. Om die redenen kunnen wij Zijne Hoogverheven Majesteit niet in de steek laten; daarom ook is de stad Palembang nimmer uit onze gedachten." Toen zeiden de beide pangérans: "Wat kunnen jullie beiden met het oog op onze opdracht hier voor ons doen, opdat wij spoedig naar Palembang terug kunnen?" De ambtenaar antwoordde: "Ik ben wel bereid er mijn best voor te doen dat U krijgt zoveel als mogelijk is. Maar als het, zoals $U$ zegt, om driehonderdduizend gaat, kan ik er niet voor instaan, want zóveel heb ik nog nooit bij elkaar gezien, noch ooit horen noemen. Wat Zijne Hoogverheven Majesteit heeft kunnen meenemen is op z'n allerhoogst vijftigduizend. Hiervan is al die tijd dat die zaak nu al aan de gang is dagelijks driehonderd voor levensonderhoud uitgegeven. Enfin, U weet maar al te goed wat het kost volk te onderhouden!" Daarop zeiden de pangérans: "Dan mogen we daar wat er aan voeding verstrekt is wel van aftrekken, als de zaken zo staan." De ambtenaar hernam: "Ik zal in elk geval mijn best voor U doen." Waarop de pangérans antwoordden: "Goed!" Toen namen de pangéran en de ambtenaar afscheid om naar Muara Rawas terug te gaan, terwijl de beide pangérans in het dorp Kemang bleven wachten.

4.5. Zodra de pangéran en de ambtenaar die indertijd door de vorst 59 waren uitgezonden weer terug waren, maakten ze hun opwachting bij Zijne Majesteit en deelden hem al hun wederwaardigheden met Pangéran Citrakesuma en Pangéran Sumanegara mee. De verheven vorst sprak daarop tot de ambtenaar: "Wat vind jij ervan, moeten we op dat verzoek van hen ingaan?" Daarop zei de ambtenaar: "Vergiffenis, duizendmaal vergiffenis! Ik hoop dat mijn woorden tot Uwe Majesteit mij vergeven worden! Als dat verzoek niet wordt ingewilligd, komen er wellicht moeilijkheden van; want de lieden die hierheen zijn gekomen beschikken over vele volledig bewapende vaartuigen en bovendien zijn al hun vaartuigen stuk voor stuk van geschutbepantsering voorzien. Naar mijn mening is het beter dat Uwe Majesteit hun zoveel geeft als U gepast voorkomt." Toen hernam Zijne Hoogverheven Majesteit: "Goed! Kunnen we zoiets als vijftigduizend rijksdaalders geven?" Daarop zei de ambtenaar: "Vergiffenis, duizendmaal vergiffenis! De vrijgevigheid van Uwe Majesteit zou wel zeer groot zijn, als U dat zou doen!" De hoogverhevene zei toen: "Hoeveel vind jij dan dat er gegeven moet worden?" De ambtenaar wierp zich aan de voeten van de vorst en sprak: "Vergiffenis, heer! Als mijn voorstel wordt goedgekeurd, dan 
wordt hun zo'n vijfentwintigduizend rijksdaalders geschonken. Als we eens in de vier of vijf dagen iets als tienduizend geven, dan komen we in ongeveer een maand wel aan het volle bedrag van vijfentwintigduizend. De beide pangérans stuurt $U$ dan met dat geld naar Palembang terug. In de brief aan Uw jongere broer moet Uwe Majesteit schrijven dat $U$ voorlopig zoveel kunt zenden en dat hij later over een drie of vier maanden weer een gezantschap moet sturen, want dat $U$ nog meer wilt bijeenbrengen. 't Moet immers op vele plaatsen worden ingezameld, 60 niet op één plaats; en zodra de door Uwe Majesteit ondernomen werkzaamheden aan het fort zijn voltooid, zal men in groten getale hierheen komen." Toen zei Zijne Hoogverheven Majesteit: "Ga naar die twee mannen toe, vertel hun onze plannen zoals jij die zojuist hebt geopperd en zeg hun dat jij met geld zult komen, als ze willen. Je moet geen andere mensen meenemen; dat kleine kind van je kun je meenemen, laat dat niet achter! Ga met overleg te werk en laten wij onze standvastigheid bewaren!' De ambtenaar betoonde de vorst daarop zijn eerbiedige hulde en begaf zich vervolgens op weg naar de beide pangérans, die in het dorp Kemang wachtten.

4.6. Zodra de ambtenaar bij de twee pangérans aankwam, spraken deze hem terstond aan met de woorden: "Hoe staan de zaken met betrekking tot ons verzoek om rijksdaalders mee te krijgen?" De ambtenaar antwoordde: "Ik heb het geld nog niet gekregen. Zijne Hoogverheven Majesteit zegt dat $U$ geen driehonderdduizend kunt krijgen, zoals $U$ aanvankelijk gevraagd hebt. Waar zou een dergelijk bedrag te vinden zijn?! Hoogstens tien- tot vijftienduizend kunt $U$ misschien krijgen." Daarop zeiden de beide pangérans: "Wat ook Uw voorstel zal zijn, wij hopen dat wij beiden hier spoedig kunnen vertrekken." De ambtenaar antwoordde: "Ik zal er mijn uiterste best voor doen. Ik streef immers naar niets anders dan naar een goede verstandhouding tussen beide doorluchtige hoogheden. Want van mijn verste voorouders die nog koppensnellers waren af tot op mijzelf is het altijd zó geweest, dat geen ander dan een afstammeling van het vorstengeslacht over ons mocht regeren. Dat is de reden, waarom ik Zijne Hoogverheven Majesteit blijf volgen en het niet over me kan verkrijgen hem met zijn volk

61 van onaanzienlijke lieden in de wildernis alleen te laten. Als $U$ beiden medelijden en genegenheid voelt voor Zijne Hoogverheven Majesteit, in welke zin zult U Zijne Doorluchtige Hoogheid in Palembang dan adviseren en wiens naam zal met het oog daarop genoemd worden? Maar $U$ beiden weet zoveel te beter hoe in deze te handelen en het is 
beslist niet zo, dat ik $U$ de les lees of verwijten maak over wat $U$ komt doen, volstrekt niet! Dit is wat ik U wilde zeggen." Toen spraken de beide pangérans: "O meneer de rangga! Wij tweeën gaan in al wat $\mathrm{U}$ gezegd hebt met $U$ mee en spreken dat niet tegen. Want deze onderneming moet met spoed worden volbracht; $U$ weet, dat is nu eenmaal zo met wat blanken, zoals de Engelsen, ondernemen." De ambtenaar antwoordde: "Als 't werkelijk is zoals $U$ zegt, zal ik die taak uitvoeren. Naar mijn mening zal $U w$ verzoek onder de zegenrijke invloed van de voorspraak van de profeet wel worden ingewilligd." Daarop nam de ambtenaar afscheid van de beide pangérans.

4.7. Zonder onderweg nog ergens aan te gaan wendde hij zich dadelijk tot Zijne Hoogheid om deze zijn wederwaardigheden mede te delen bij het overbrengen aan Pangéran Citrakesuma en Pangéran Sumanegara van al die dingen die de vorst hun te zeggen had. Toen zei Zijne Hoogheid: "Je mag net zoveel bijeenbrengen als je wenst te geven; ga het maar bij Hamzah en Si Acu halen, die ik al zestienduizend heb laten klaarleggen, voor zover ' $t$ in guldens is tegen een koers van twee guldens voor één rijksdaalder, tot een totaal van zestienduizend. Zeg hun dat we over zeven dagen weer zullen geven zoveel als we kunnen krijgen en dat we verder nog moeten inzamelen, omdat het geld van vele plaat-

62 sen moet komen. Zo is het." Daarop sprak de ambtenaar: "Ik vraag verlof om iemand naar de verblijfplaats van de beide pangérans te sturen met een brief, waarin hun wordt verzocht het geld in ontvangst te komen nemen. Als mijn voorstel wordt goedgekeurd, zal mijn zoon Muhammad erheen gaan om de beide pangérans te laten weten dat ze naar Muara Rawas moeten komen om daar het geld in ontvangst te nemen." Zijne Hoogverheven Majesteit zei: "Stuur Muhammad maar!" Toen ging de ambtenaar heen.

4.8. Op een middag arriveerde Pangéran Sumanegara en legde aan in Muara Rawas. Muhammad bracht zijn vader op de hoogte van het feit dat Pangéran Sumanegara was aangekomen. Zijn vader wendde zich terstond tot Zijne Hoogverheven Majesteit met de mededeling dat Pangéran Sumanegara was gekomen om geld te ontvangen. Toen zei de doorluchtige vorst: "Ga het geld maar halen bij Hamzah! Geef hun eerst zestienduizend en laat ze later, over een dag of vier vijf, nog meer komen halen, want het geld moet nog verder bijeengebracht worden." Daarop ging die ambtenaar met vrouw en kind op weg om dat bedrag van zestienduizend te gaan brengen. 
Zodra hij bij Pangéran Sumanegara was aangekomen, telde hij het geld uit. Toen hij klaar was met uittellen, namen de pangéran en de demang-modin het geld tot het volle bedrag van zestienduizend in ontvangst. Daarna ging de ambtenaar terug, terwijl de pangéran die het geld ontvangen had naar het dorp Kemang terugreisde. De ambtenaar deelde de vorst mede dat de beide pangérans de gift in eerbiedige dankbaarheid jegens de vorst hadden aanvaard en dat ze de volgende gift in de komende paar dagen hoopten te ontvangen. "Want", zo zeiden ze, "wij willen spoedig, in deze maand nog, terugkeren, opdat wij beiden de vastenmaand in Palembang kunnen doorbrengen. Kom, wees ons terwille, wij hopen op $U$, dat $U$ het verzoek van ons tweeën aan de hoogverheven vorst wilt overbrengen!"

63 4.9. Nadat al deze gebeurtenissen hadden plaatsgevonden, richtte $\mathrm{Zijne}$ Hoogverheven Majesteit zich tot de pangérans, tot alle ambtenaren, de districts- en dorpshoofden, tot de gezamenlijke legeraanvoerders en tot de grote massa van het gewone volk met de vraag: "Hoe staat het op dit ogenblik met Uw werk?" Daarop spraken allen tot de hoogverheven vorst: "Vergiffenis heer, duizendmaal vergiffenis vragen wij $U$ ! Van de door Uwe Hoogheid opgedragen werkzaamheden aan de vestingwerken is er nog maar een weinig te doen overgebleven; naar onze berekening zullen al die werkzaamheden tegen het midden van deze maand Ramadan afgelopen zijn. Wanneer er straks iemand serieus kwaad wil jegens $U$, dan kunnen wij het tegen hem opnemen; zelfs een vijand die met vierduizend man sterk komt, zouden wij partij geven!" Toen sprak Zijne Hoogverheven Majesteit tot al die lieden: "Blijft eendrachtig en verzaakt in geen enkel opzicht Uw plicht!"

4.10. Na verloop van zes dagen gaf $\mathrm{Zijne}$ Hoogverheven Majesteit bevel de twee pangérans de som van vierduizend rijksdaalders te gaan brengen. Wederom ging de ambtenaar met zijn zoon op weg, met een bedrag van vierduizend rijksdaalders bij zich. Zodra ze bij die beide pangérans waren aangekomen, nam de demang-modin het geld uit handen van die ambtenaar, dezelfde als van de vorige keer, in ontvangst. Daarop zeiden de beide pangérans: "O meneer de rangga! Wanneer maakt $U$ het bedrag vol tot het totaal dat $\mathrm{U}$ ons hebt toegezegd? Er ontbreekt nog een weinig aan." De ambtenaar antwoordde: "U beiden bent wel zeer lankmoedig jegens $U w$ oude dienaar hier. Wat dat ontbrekende 64 geld betreft, als er voor mij geen ernstig beletsel optreedt, kom ik over 
drie of vier dagen bij $U$ met geld om het bedrag vol te maken dat ik $U$ vroeger heb beloofd. Maakt $U$ zich niet ongerust; deze oude dienaar is immers volstrekt niet als een dienaar die pas komt kijken en de wijde wereld nog niet heeft gezien! Maar dat weet $U$ veel te goed!" Toen zeiden de pangérans: "Gode zij dank! Op U, meneer de rangga, hebben wij al onze hoop gevestigd!" De ambtenaar nam afscheid en wendde zich vervolgens terstond tot $\mathrm{Zijne}$ Hoogverheven Majesteit met de mededeling dat het geld door de beide pangérans in ontvangst was genomen. Toen sprak de vorst: "Wat hadden ze te zeggen?" "Niets bijzonders. Ik heb hun beloofd dat ik over zeven dagen vijfduizend kom brengen, waarmee het bedrag van vijfentwintigduizend rijksdaalders dus zal zijn volgemaakt."

4.11. Zeven dagen later beval Zijne Hoogverheven Majesteit: "Ga het geld brengen dat je beloofd hebt; je kunt het bij Hamzah halen. En zeg tot beide pangérans dat ze over drie maanden moeten terugkomen, maar niet met een hele vloot. Immers, zou ik me niet schamen, als men zou zien en als verder ook in andere streken verteld zou worden dat "hoe heet hij ook al weer" naar zeggen in het bos alle gevoel van schaamte heeft verloren, omdat hij daar nooit fatsoenlijke mensen ontmoet en dag in dag uit slechts wevervogels en apen te zien krijgt. Dat is mijn boodschap, breng die over! Want hij daar is geen vreemde, maar een familielid van mij; mijn schande is ook zijn schande." Daarop bracht de ambtenaar de vorst zijn eerbiedige hulde en ging dadelijk de nog ontbrekende geldsom van vijfduizend wegbrengen.

Toen de ambtenaar met zijn zoon in het dorp Kemang aankwam, zeiden de beide pangérans: "Gode zij dank! U komt, meneer de rangga, 65 precies op de dag dat wij klaar staan om te vertrekken. Als U vandaag nog niet gekomen zou zijn, dan zouden we iemand naar $U$ toe gestuurd hebben. Maar nu U er bent, kunnen we morgen naar Palembang vertrekken." De ambtenaar en zijn zoon antwoordden: "Misschien wil Zijne Hoogverheven Majesteit een brief meegeven voor Zijne Hoogheid in Palembang." Daarop zeiden beide pangérans: "Als dat het geval is, vraagt $U$ de vorst er vandaag dan nog om, zodat wij morgen kunnen vertrekken. Verder moet $U$ Zijne Majesteit zeggen dat wij beiden vergiffenis, duizendmaal vergiffenis vragen; dat wij de goedgunstigheid van Zijne Hoogverheven Majesteit om die vijfentwintigduizend te schenken in eerbiedige aanvaarding op onze schedel leggen en dat het voor ons gevoel is alsof we een berg goud gekregen hebben. Wat ons overigens verdriet is, dat wij op dit ogenblik niets bij ons hebben om $U$ te belonen. 
Maar later zullen wij $U$ als we het mogen beleven voor Uw moeite om steeds heen en weer te gaan wel belonen."

Nadat de demang-modin vervolgens het geld in ontvangst had genomen, nam de ambtenaar afscheid met de woorden: "Morgen kom ik terug. Misschien wil Zijne Hoogverheven Majesteit een brief meegeven of wil hij Uzelf spreken." Toen zeiden de pangérans: "Ga vlug terug en wend $U$ rechtstreeks tot de vorst met de mededeling dat als het verzoek van ons beiden wordt ingewilligd, wij morgenochtend zullen vertrekken. Kom in elk geval vandaag nog met bericht en breng voorts onze gevoelens van hoogachting over aan onze ooms en onze groeten aan al onze jongere broers!"

66 4.12. Zo kwam de ambtenaar bij de hoogverheven vorst zijn opwachting maken en bracht verslag uit van zijn ontmoeting met de beide pangérans. Toen sprak Zijne Hoogverheven Majesteit: "Wat zou jij willen dat ik deed?" De ambtenaar zei: "Heer! Mijn verzoek is, dat Uwe Hoogheid een brief zende aan Uw jongere broer, waarin wordt verklaard dat de som gelds die de beide pangérans bij zich hebben vijfentwintigduizend bedraagt; Uwe Hoogheid lichte Uw jongere broer in, opdat deze op de hoogte zij. Het hart van de mens kan men niet doorgronden, dat kan God alleen." Daarop sprak Zijne Hoogverheven Majesteit: "Goed. Ik zal nu meteen een brief opstellen." Daarna vroeg de ambtenaar nog: "Wilt $U$ in Uw brief vermelden dat mijn Heer, de Grote Koning, Zijn gevoelens van liefde en genegenheid erbij insluit, want dat $\mathrm{Hij}$ dag en nacht onafgebroken aan $\mathrm{Zijn}$ geliefden denkt en hen geen ogenblik vergeet? Dat is mijn eerbiedig verzoek aan Uwe Hoogheid." "Als jij dat zo zegt, zal ik de brief opstellen overeenkomstig jouw bedoelingen. Ik zal de brief nu schrijven, dan kun je hem morgenochtend bij hen bezorgen."

Vervolgens keerde de ambtenaar terug naar het fort, waar alle ambtenaren gezamenlijk hun verblijf hadden en waar de legeraanvoerders van de Maleiers uit Minangkabau druk bezig waren met het houden van hanengevechten en met dobbelen. Toen de nacht voorbij was, kwam de volgende morgen een hofdienares in opdracht van Zijne Hoogverheven Majesteit de kiai samen met de dienaar van deze kiai roepen. Die ambtenaar kwam toen vlug naar buiten om zich bij de vorst te melden. Toen hij daar aankwam, bracht hij Zijne Doorluchtige Hoogheid terstond zijn eerbiedige hulde. Deze sprak: "Ga heen en geef deze

67 brief aan Mas Utih en Mausub!" De ambtenaar haastte zich op weg en begaf zich regelrecht naar de pangérans in het dorp Kemang. 
4.13. Dadelijk na aankomst overhandigde hij de brief. De beide pangérans namen de brief eerbiedig aan en zeiden: "Meneer de rangga! Wij hier gaan naar Palembang terug. Wat $U$ betreft, $U$ doet er goed aan al die Maleiers niet al te zeer te vertrouwen, want ze zijn onze gelijken niet." De ambtenaar antwoordde: "Er zal wel niets anders op zitten, de meesten van ons gaan nu eenmaal niet naar Palembang terug. Wat bent $U$ hier nu eigenlijk wezen doen? Denkt $U$ daar eens over na! Toen de hoogverheven vorst de kraton en de stad verliet, dacht de grote massa van het volk op z'n minst dat hij goud, diamanten en bovendien ik weet niet hoeveel geld bij zich had. Ik heb al dat volk toen verzameld; er waren niet zulke grote aantallen Minangkabauers of lieden uit Kerinci, uit Rejang of uit het bovenland van de Mata bij, ' $t$ was al met al een allegaartje. Intussen is elke bevolkingsgroep onder leiding van een ambtenaar gesteld, die bij de uitvoering van onverschillig welke taak in elk van de forten de leiding heeft en zorgt voor het ochtendmaal en voor de verstrekking van honing. Maar van 's avonds tot de volgende ochtend houdt men zich met niets anders bezig dan met allerlei dobbelspelen en overdag weerklinkt het onophoudelijk geschreeuw tijdens de hanengevechten in de forten aan weerszijden van de rivier. Onze hoop is daarom uitsluitend gevestigd op de gebeden die $U$ in de naam van wijlen de sultan, wiens graf in Lemabang is, zult opzenden voor ons allen, die bezig zijn met de verzorging van hem die in deze rampzalige omstandigheden is komen te verkeren; àls er nog heil te verwachten is voor de toekomst!"

5.

5.1. Toen aanvaardden de beide pangérans de terugreis naar Palembang, terwijl de ambtenaar in tegenovergestelde richting naar $Z_{i j n e}$ Hoogverheven Majesteit terugging om hem mee te delen dat beide 68 pangérans diezelfde dag nog waren vertrokken. Zijne Doorluchtige Hoogheid sprak daarop tot alle edelen en ambtenaren, tot de gezamenlijke districts- en dorpshoofden en tot alle opperbevelhebbers: "Gij allen! Wijdt $U$ toch met hart en ziel aan Uw werk, wat het ook zij, en bereidt $\mathrm{U}$ eensgezind voor op de toekomst! Zonder enige twijfel zullen die lieden uit Palembang weer geld komen vragen, want de afspraak is dat ze over drie maanden terug zouden komen. Maar wij hebben helemaal geen haast om ook maar één rijksdaalder te geven. Zo lang ons werk nog niet af was, moesten we wel geven om ongestoord onze gang te kunnen gaan. Zodra ons werk helemaal klaar is, kunnen we weerstand bieden wan- 
neer de mensen uit Palembang komen en dan kunnen we voet bij stuk houden, omdat er vroeger al vijfentwintigduizend rijksdaalders is gegeven. Die lui uit Palembang komen vast en zeker; de afspraak luidt dat ze over drie maanden hier zullen zijn om geld in ontvangst te nemen. Als ze hier aankomen met vertoon van geweld, dan moeten jullie hen uit alle macht bestrijden. Want wij voeren Gods wet uit, maar zij zijn medeplichtigen van de blanken; als wij als geloofsgetuigen sterven, dan wacht ons het hiernamaals; als zij sterven, dan sterven ze als opstandigen tegen de goddelijke wet. Doet daarom allen Uw plicht in deze zaak met inzet van al Uw krachten!" Daarop zeiden al die edelen, ambtenaren en hoofden: "Vergiffenis Sire, Heer der wereld! Onze gezindheid is zódanig, dat wij in geen enkel opzicht in gebreke zullen blijven; want wij zijn verplicht ons werk te doen."

5.2. Niet lang daarna meldden Maleiers uit het grensgebied met Jambi dat Zijne Hoogheid de Sultan van Jambi in antocht was uit Jambi en zich in het dorp Surulangun bevond. Zodra Zijne Hoogverheven Majes-

69 teit dat nieuws hoorde, gaf hij het dorpshoofd van Rawas opdracht Zijne Hoogheid de Sultan van Jambi met het nodige ceremonieel tegemoet te gaan. Enige dagen later kwam de sultan aan en werd onmiddellijk bij Zijne Hoogverheven Majesteit gebracht.

Zodra die twee elkaar ontmoetten, drukten zij elkaar de hand en vervolgens omhelsden en kusten zij elkaar, terwijl ze beiden weenden. Daarna sprak Zijne Hoogverheven Majesteit: "O Oom! Dit is nu eenmaal de wil van de Grote Opperheer!" Zijne Hoogheid de Sultan van Jambi antwoordde: "O mijn zoon! Dit is nu eenmaal Uw lot; daar kunt $U$ toch niets meer aan veranderen. Maar ik behoor niet tot een vreemd ras. Er zijn Arabieren zelfs die bij U horen, die even blank van huid zijn als de Engelsen. Zo gaat het dus met Gods dienaren! Wat is mijn zoon daar in Palembang ditmaal weer van plan jegens mijn zoon hier?" Toen sprak Zijne Hoogverheven Majesteit: "U weet 't Oom, wie niet in de stenen kraton wil blijven, die vergaat het zó. $U$ zit nu trouwens in hetzelfde parket, waarmee ik maar zeggen wil: laten we er maar niet langer over spreken."

6.

6.1. $\mathrm{Nu}$ volgt het verhaal over de komst van de lieden uit de stad Palembang. Een haji had gemeld dat hij buiten het terrein van de vestingwerken toen hij op het punt stond stroomopwaarts te vertrekken 
een edele en een ambtenaar had aangteroffen, namelijk Radén Muksim en de demang-modin, die op weg waren om bij Zijne Hoogverheven Majesteit geld in ontvangst te komen nemen; over vier of vijf dagen zouden ze hier kunnen zijn. Dat nieuws werd dadelijk door een ambtenaar ter kennis van Zijne Doorluchtige Hoogheid gebracht. Deze vroeg toen: "Wat komen ze doen?" De ambtenaar zei eerbiedig: "Ze komen

70 geld in ontvangst nemen, als $U$ zo goed bent dat te geven." Toen sprak Zijne Hoogheid: "Wanneer ze aankomen, moet je geen notitie van die lui nemen. Wel moeten jullie erop letten van wat voor aard hun gedragingen zijn en weest alsjeblieft zeer op je hoede! Als ze met een hele vloot komen, dan is er blijkbaar iets mis. Wat willen jullie dat we nog doen? Onze vestingwerken zijn gereed!' Daarop spraken alle edelen en ambtenaren eerbiedig: "Alwat Uwe Hoogheid ons opdraagt zullen wij ten uitvoer brengen. Zolang wij nog leven, behoeft $U$ zich over de uitvoering van die opdrachten geen zorgen te maken!"

Een paar dagen later arriveerden de afgezanten van Palembang met twee vaartuigen, het ene was van Radén Muksim en het andere van de demang-modin; hun opdracht was geld te vragen als aanvulling op het bedrag dat vroeger ontvangen was en tevens kwamen ze een brief brengen van de sultan. Toen dit aan de vorst werd meegedeeld, sprak Zijne Doorluchtige Majesteit tot de gezamenlijke edelen en ambtenaren: "Gij allen, hoort mijn woorden! Van degenen die daar zijn aangekomen moet jullie volstrekt geen enkele notitie nemen. Wel moet je er van tijd tot tijd op letten, wat zij jegens ons in hun schild voeren."

6.2. Toen er een maandlang niets gebeurd was, gaven de radén en de demang aan bergbewoners de opdracht: "Weest zo goed een ambtenaar de volgende boodschap over te brengen, luidende: "Wat moeten wij hier beginnen? Als $\mathrm{U}$ medelijden met ons hebt, wil dan aan Zijne Majesteit vragen of wij in audiëntie mogen worden ontvangen dan wel de brief mogen aanbieden die we hebben meegebracht." " Die ambtenaar nu ging vervolgens meteen zijn opwachting maken bij Zijne Hoogverheven Majesteit om dat verzoek over te brengen. Deze vroeg: "Wat denk jij

71 ervan?" Daarop sprak die ambtenaar: "Sire! Naar mijn mening is 't het beste dat Uwe Hoogheid iemand uitzendt om poolshoogte te nemen; dan kunt $U$ precies te weten komen of de bedoelingen van $U w$ jongere broer in Palembang kwaad of goed zijn." Toen zei de vorst: "Wie komt er verder nog in aanmerking om door ons te worden uitgezonden? Want jij gaat in elk geval!" De ambtenaar zei beleefd: "Als ik met deze missie word belast, zou ik om iemand van Uw familie willen vragen. Want 
een dienaar van Uwe Hoogheid is volgens mij niet genoeg in tel, maar als 't een familielid van $U$ is, zullen de Palembangers zich schamen. Intussen aanvaard ik volledig wat $U$ mij beveelt." Daarop zei Zijne Hoogverheven Majesteit: "Wie zou jij het meest geschikt vinden?" De ambtenaar antwoordde: "Om Pangéran Wiradiwangsa zou ik U willen verzoeken." Toen zei de vorst: "Vraag jij hem maar om met je mee te gaan!"

6.3. Zo gebeurde het, dat de pangéran en de ambtenaar Radén Muksim en de demang-modin gingen opzoeken. De pangéran vroeg hoe ' $t$ in Palembang ging. De radén en de demang antwoordden: "Op dit ogenblik niet zo best." "En wat Uw taak hier betreft, wat is nu eigenlijk precies de bedoeling?" Daarop antwoordden de radén en de demang: "Wij beiden hier hebben van de Sultan van Palembang de opdracht gekregen een brief aan Zijne Hoogverheven Majesteit te gaan brengen, met de bedoeling dat we geld ontvangen als aanvulling op wat er door Pangéran Sumanegara en Pangéran Citrakesuma is ontvangen. $U$ moet weten dat wij beiden hier met $U w$ verlof een verzoek wilden richten tot Zijne Majesteit namelijk om hem, aangenomen dat $U$ dit aan Zijne Majesteit wilt overbrengen, te vragen om het geld dat $\mathrm{Zijne}$ Majesteit

72 na drie maanden zou geven. Met die opdracht zijn wij beiden hierheen gekomen. Intussen vragen wij verschoning voor al wat we doen." De pangéran en de ambtenaar uit het binnenland antwoordden: " $U$ moet een poosje wachten, radén, een dag of vijf. Als $U$ binnen die tijd geen bericht hebt ontvangen, zie dan maar wat U doet!"

Toen die termijn verstreken was, overlegden de radén en de demang: "Zouden we dat geld nog krijgen of niet?" De demang zei: "Ik heb 't idee dat we dat geld niet krijgen." De radén zei: "Hoe zou het komen dat we 't niet krijgen? Zitten we hiervoor naar schatting nu al zo'n veertig dagen lang te wachten, zonder dat iemand zich om ons bekommert of ons iets vraagt! Mijns inziens kunnen we beter teruggaan. Waar wachten we al die tijd op? Als we nou nog wat zouden bereiken, dan was het nog tot dáár aan toe!" De radén vervolgde: "Wat vind jij ervan, demang? Kom, laten we teruggaan! Misschien worden we door de sultan wel naar Muara Rawas opgeroepen en als we dan door hem worden vastgehouden, hoe kunnen we ons dan verzetten? Nu de zaken zo staan, is het ' $t$ beste dat we vanavond nog vertrekken. Ik voel met niet op mijn gemak, misschien zal ons iets kwaads overkomen."

Toen aanvaardden de radén en de demang-modin de terugreis, in een neerslachtige stemming omdat ze al een hele tijd uit Palembang weg 
waren en niettemin nog steeds geen cent hadden gekregen, terwijl de brief zelfs niet was beantwoord door die lui. "Als we nu nog goede tijding hadden meegekregen, zouden we nog wel een vriendelijk gezicht van $\mathrm{Zijne}$ Majesteit krijgen. O demang! Laten we onderweg nergens meer aangaan, opdat onze onderneming spoedig ten einde zal zijn! Wie weet, misschien is Zijne Majesteit de Sultan wel zó vertoornd, dat hij oorlogsvaartuigen uitstuurt."

6.4. Na drie dagen kwamen de radén en de demang in de stad aan; 73 dadelijk zochten ze hun oudere broers Pangéran Sumanegara en Pangéran Citrakesuma op en brachten verslag uit van hun wederwaardigheden tijdens hun missie naar het binnenland. "Laat staan dat we geld hebben gekregen, we hebben zelfs geen goede tijding meegekregen en de brief is door die lui daar niet eens beantwoord. Als niet de zegenrijke invloed van Zijne Hoogverheven Majesteit zich had laten gelden, dan zou men ons niet eens naar het binnenland hebben laten komen. Naar onze mening en naar ons inzicht zou men vroeger, al was er honderdduizend gevraagd, 't zeker gegeven hebben, want het aantal mensen was toen nog niet groot en hun vestingwerken waren toen nog niet sterk. Dat was de reden, waarom ze drie maanden uitstel vroegen. $\mathrm{Na}$ drie maanden waren hun vestingwerken voltooid, hadden de mensen uit de afgelegen streken zich allemaal verzameld, waren in groten getale de Maleiers uit Minangkabau gekomen en was zelfs de Sultan van Jambi verschenen, vergezeld van verscheidene prinsen en edellieden. Daardoor is het met ons tweeën zo gelopen. Zelfs met een groot leger hoeft men het niet meer te proberen hen te benaderen, want ze zijn volledig paraat en ze beschikken over een grote hoeveelheid geldmiddelen; naar men zegt worden er elke dag in onbeperkte mate geld voor levensonderhoud en gratis kledingstukken verstrekt."

Zodra de beide pangérans die mededelingen van de radén en de demang hoorden, werden ze vuurrood in het gezicht en onmiddellijk brachten zij de radén en de demang bij Zijne Hoogverheven Majesteit om deze over de uitvoering van hun opdracht in te lichten en hem de berichten die ze meebrachten over te brengen.

7.

7.1. Toen hij dat nieuws hoorde, ontstak ook Zijne Majesteit in toorn, begaf zich naar de ontvangzaal van de kraton en beval: "Roep Pangéran

74 Citrakesuma en Pangéran Sumanegara!" Zodra die beide pangérans gekomen waren, sprak Zijne Majesteit aldus tot de aanwezigen: "Wat 
vinden jullie van die zaak? Blijft niet werkeloos toezien, maar gaat allen aan het werk om bewapende vaartuigen uit te rusten, vijftig stuks! Gaan jullie maar met z'n allen! Laat geen der ambtenaren achterblijven; ik zal wel de wacht houden in de stad samen met de blanken en de sepoys!"

$\mathrm{Na}$ enkele dagen lagen al die vaartuigen bewapend en wel bij de aanlegplaats van de kraton op stroom, alleen nog maar wachtend op de bevelen van Zijne Majesteit. Toen de beide pangérans, de gezamenlijke ambtenaren, zoals de rangga's, de demangs en de ngabéhi's, de pangérans van Komering, de hoofden van de dorpsgemeenschappen en het dorpshoofd van Sungsang met hun volk in de audiëntiezaal aanwezig waren, beval Zijne Hoogheid: "Maandag om zeven uur moeten jullie met z'n allen vertrekken!' De edelen en ambtenaren brachten de vorst toen hun eerbiedige groet en aanvaardden gehoorzaam dat bevel. Daarop verwijderde $\mathrm{Zijne}$ Majesteit zich en ging het paleis binnen.

Maandag om zeven uur waren alle edelen en ambtenaren reisvaardig en bevond een ieder zich aan boord van zijn boot. Toen kwam Zijne Hoogverheven Majesteit naar buiten om de vloot in ogenschouw te nemen. Aan de pangérans en ambtenaren gaf $Z_{i j n e}$ Majesteit vervolgens bevel van alle vaartuigen saluutschoten te laten lossen. Dadelijk daarop vertrok men onder luid gejuich. Als donderslagen aan het firmament weerklonken de schoten en de juichkreten; en de wereld werd verduisterd door de kruitdamp.

7.2. Keren wij thans terug tot Zijne Majesteit Sultan Mahmud, die maar steeds zat te wachten op de komst van de mensen uit Palembang. "Wat zouden ze van plan zijn? Als ze erop uit zijn om ons te vernietigen, 75 dan zullen wij van onze kant maar afwachten of ze een overval zullen doen op onze vestingwerken hier. Als 't Palembangers zijn die zullen komen, geloof ik dat ze niet tegen ons fort opgewassen zullen zijn; als 't blanken zijn, dan zal daar nu eindelijk eens blijken of ze vrouwen of mannen zijn. Naar men zegt zijn hun vaartuigen al in groten getale onderweg, vijftig boten met een aparte eetruimte." Toen zeiden de ambtenaren, de edelen en alle krijgsoversten eerbiedig: "Wij, Uw dienaren, wachten op de bevelen van Uwe Hoogheid." Daarop klonk het vorstelijk bevel: "Gij allen, maakt de boten gereed en vaart 's nachts op die vloot af, terwijl deze voor anker ligt!"

Allen namen toen afscheid en vertrokken met zeven vaartuigen stroomafwaarts. Bij het dorp Kasemaran aangekomen hielden ze stil. In de nacht zond men een kleine boot op verkenning uit; tot voorbij het 
dorp Ulak Tebru werd door de mensen uit het binnenland het terrein verkend. Zonder dat er tussen de lieden uit Palembang en die van het binnenland iets was voorgevallen, begonnen de Palembangers, zodra het daglicht was aangebroken, vanaf drie boten zonder ophouden te schieten; er werd slechts voor de schijn teruggeschoten. Toen de avond was gevallen, gingen de mensen uit het binnenland bij het dorp Kemang aan wal en legden zich in hinderlaag om te spionneren. Om acht uur kwamen de vaartuigen van de Palembangers bij het dorp Kemang aan en meteen ging de vloot ten anker. Ze werden toen door de mensen uit het binnenland beschoten, maar deze werden verslagen. De mensen uit Palembang staken vervolgens het dorp in brand en de dorpelingen vluchtten tot de laatste man het bos in. In de nacht gingen de lieden uit het binnenland naar de bovenloop van de rivier terug. Toen ze ter plaatse aankwamen, waren de forten aan weerszijden van de rivier in staat van paraatheid.

$76 \mathrm{Er}$ werd luid geschreeuwd en onophoudelijk weerklonk het geluid van trommen, gongs en klarinetten; dag en nacht waren er aan één stuk door dansvoorstellingen van de Maleiers uit Kerinci en werden er allerlei dobbelspelen beoefend.

$\mathrm{Nu}$ gaat het verhaal weer over de troepen uit Palembang, die bezig waren rondom het dorp Kemang versterkingen aan te leggen. Elke tot bolwerk versterkte heuveltop werd bezet door een demang, een ngabéhi en een pangéran van Komering. Er werd streng de wacht gehouden en bovendien deden vijftien man van de nieuw aangekomen troepen de ronde met een aflossing van eenmaal per uur. Pangéran Citrakesuma en Pangéran Sumanegara waren het er met de pangérans en de ambtenaren over eens geworden dat ze naar Muara Rawas zouden gaan om de vesting van Sultan Mahmud Badaruddin te overvallen. Toen het plan tot die onderneming bekend was geworden, lieten de ambtenaren die als commandanten en legeraanvoerders der Maleiers optraden aan weerszijden van de rivier de Musi mangaten maken. In één gat lagen twee man op de loer met lontgeweren; degenen die zich zo ingegraven hadden, waren niet te zien. Van die aard nu was de manier van doen van de Maleiers uit Minangkabau.

7.3. Keren we nu weer terug tot de mensen uit Palembang, die klaar stonden om de vesting Muara Rawas te gaan aanvallen: Pangéran Citrakesuma, Pangéran Sumanegara en de pangérans van Komering. Onder onophoudelijk gejuich vertrok de vloot stroomopwaarts. $\mathrm{Na}$ enige tijd kwamen de vestingwerken aan de uitmonding van de Rawas, de versterkingen langs de Musi en de vesting Muara Rawas in zicht, 
waar iedereen waakzaam was, de oorlogstrom werd geroerd en een onafgebroken krijgsgeschreeuw weerklonk; zó was het daar gesteld. Toen men op de vloot van de Palembangers die drie vestingen te zien $77 \mathrm{kreeg}$, ontstaken de pangérans en de ambtenaren in woede. Terwijl ze naderbij voeren, kwam er een Maleier uit een mangat te voorschijn en schoot op Pangéran Citrakesuma. Omdat ze toen niet verder stroomopwaarts konden, zetten ze vervolgens gezamenlijk koers naar de overkant van de rivier, maar toen ze aan de overkant kwamen, werden ze beschoten door de lieden die in de mangaten zaten. Zonder een schot gelost te hebben, deinsden de mensen uit Palembang toen af, keerden onmiddelijk naar Kemang terug en beraadslaagden er met de edelen, de ambtenaren en de pangérans van Komering over om over land ten aanval te trekken: "Laat de mensen takken halen van een vadem lang om een verplaatsbare verschansing te maken! In de komende vier tot vijf dagen zullen we proberen de forten van de achterzijde aan te vallen. Zo geschiede!" Later kwamen de mensen van Muara Rawas het plan van de Palembangers echter te weten en toen legden de lieden uit het binnenland een verschansing aan aan de landzijde van de weg waar men langs moest als men van de verblijfplaats van de Palembangers vandaan kwam. Die versterkte post werd bezet door tien man, bewapend met vijf gewone en vier lontgeweren.

Toen men een dag binnen die verschansing had gezeten, gingen drie krijgsoversten naar buiten om vruchten te zoeken. Onderweg troffen ze een menigte aan van driehonderd man, die een aanval op die schans langs de weg zou doen en onder aanvoering stond van Demang Singayuda, een pangéran van Komering. Zodra men de drie mannen in het oog kreeg, zette men hen na, waarop die drie mannen naar hun schans vluchtten. Ze werden door de Palembangers tot vlak bij hun schans achtervolgd. Toen de lieden binnen de verschansing zagen dat hun

78 makkers door de Palembangers achtervolgd werden, kwamen zij onder luid geschreeuw naar buiten. Op het horen daarvan keerden de Palembangers om, in de mening dat de Maleiers op z'n minst twee- of driehonderd man sterk waren, en sloegen onmiddellijk in het wilde weg op de vlucht. Men zette hen na en kreeg één man te pakken; die werd vervolgens vastgebonden en het hoofd afgehakt. Toen men dit aan $\mathrm{Zijne}$ Hoogverheven Majesteit aanbood, werd er twintig rijksdaalders voor betaald. Er was namelijk aan de Maleiers toegezegd dat als ze iemand met afgeslagen hoofd afleverden, er twintig rijksdaalders voor betaald zou worden en dat als ze iemand levend afleverden, er eveneens twintig rijksdaalders zou worden betaald. Als Palembangers zichzelf kwamen 
overgeven, werd hun een compleet stel kleren en tien rijksdaalders zakgeld geschonken. Wanneer Maleiers zich benedenstrooms van de vestingwerken in hinderlaag gingen leggen, werd hun geld voor levensonderhoud verstrekt. Maakten ze een geweer of een donderbus buit, dan werden deze van hen gekocht, terwijl andere dingen zonder meer de buit werden van degenen die in hinderlaag gegaan waren. Zo waren de zaken geregeld in de vesting Muara Rawas en tevens werd er zeer streng de wacht gehouden.

Wat de gang van zaken bij de edelen in Kemang betreft, dagelijks werkte men er dag en nacht onafgebroken aan de versterkingen, uit vrees voor de patrouilles van de Maleiers, die elke nacht kwamen kijken; als men overdag voetklemmen uitzette, haalden de Maleiers ze 's nachts weer weg, zonder dat de wachtposten het zagen. "Wat kunnen we in deze zaak anders doen dan ons versterken?! Of we nu zes of zeven dagen danwel maanden wachten, we spelen 't niet klaar en verder stroomopwaarts ten aanval trekken, daar zien wij ook geen kans toe, hoezeer het ook het bevel van Zijne Majesteit de Sultan is om verder stroomopwaarts te gaan. Hopelijk komt er een afgezant uit Palembang met de opdracht dat wij allen moeten terugkeren of komen er blanken

79 met een tweehonderd man soldaten, want dan kunnen wìj wel teruggaan! En wat nu Zijne Majesteit de Oude Sultan betreft, staat die tegenover ons als onze heer of als vijand?" Vervolgens zeiden beide pangérans: "Zover is het dus gekomen! Zolang we nog twee heren willen dienen, kunnen we niet met succes de zaak van één van hen behartigen. Het is 't beste dat we nu we het leven nog hebben naar de stad teruggaan. Alles wat wij hier geregeld hebben mag gerust vermeld worden. Voor het ogenblik moeten wij er met z'n allen het beste van zien te maken. Laten de lieden die de voorposten bewaken en degenen die de ronde doen, niet verslappen, want het zijn bandieten daar in Muara Rawas, de Maleiers van Kerinci en Pegagan!

Om drie uur 's nachts kwamen er Pegaganse dieven, die aan de stroomopwaarts gelegen zijde de voorposten van de vesting van de bewoners van het dorp Kemang binnendrongen en er lichte kanonnen en donderbussen weghaalden. Degenen die op wacht in slaap gevallen waren, werden door hen beschoten en raakten gewond, terwijl één man bijna gedood werd. De dieven uit Pegagan gingen toen weer weg met medeneming van een kanon, dat ongeveer twee en een halve pikol woog. Het werd door een ambtenaar aangeboden aan Zijne Majesteit. Deze gaf de ambtenaar de opdracht: "Geef hun rijksdaalders, honderd rijksdaalders en volop kleren! Geef niet minder, opdat al hun makkers zien 
hoezeer ik dat op prijs stel." De lieden uit Palembang waagden zich niet meer naar buiten om een aanval op de vijandelijke stellingen te ondernemen of om bosvruchten te zoeken of naar het fort aan de overkant van de rivier te gaan. De mensen van Muara Rawas waren de vestingwerken in Kemang binnengedrongen, in één nacht hadden ze vier of vijf forten bezet. Elke dag en elke nacht werd er gevochten, zodat de bezetting van de vesting Kemang uit angst voor de Maleiers niet meer naar buiten kon, behalve om heen en weer naar de boten te gaan.

7.4. Toen diezelfde oorlog zo ongeveer drie maanden geduurd had 80 het was intussen wel mogelijk voor Palembangers om elkaar te ontmoeten, als er maar geen Maleiers bij waren -, toén gaf Sultan Mahmud Badaruddin aan een edelman de opdracht om de Palembangse pangtrans en de Palembangse ambtenaren te gaan opzoeken. "Als je hen ontmoet, zeg hun dan dat ik mijn verwanten en mijn vrienden daar vurig liefheb en zonder ophouden naar hen verlang. Zeg hun verder dat ik van kleinsaf nog nooit van hen gescheiden ben geweest, al was het maar één enkele dag. Dit is nu eenmaal het lot dat mij is toebedeeld, namelijk dat in 't hele bos waar ik nu met mijn kroost verblijf er geen enkel familielid is dat mij liefheeft. Ja zelfs zijn mijn verwanten gekomen met de bedoeling om mij het leven te ontnemen, terwijl ik dacht dat ze kwamen om het goede na te streven. Daardoor ben ik ertoe gekomen deze menigte Maleiers en Jambiërs bijeen te brengen om als mijn familie te fungeren, omdat ik onder mijn eigen volk geen echte familieleden heb."

De edelman die erheen zou gaan anvaardde eerbiedig het vorstelijk bevel en begaf zich onmiddellijk op weg naar de vestingwerken langs de rivieroever tegenover Kemang. 's Avonds had hij een ontmoeting met de pangérans en de ambtenaren, die terstond van alle kanten tegen hem begonnen te praten. Daarop bracht de edelman de boodschap van Zijne Hoogverheven Majesteit over. Nadat hij de woorden van Zijne Hoogheid had overgebracht, barstten de pangérans en ambtenaren op het horen van de inhoud van die boodschap allen in tranen uit, omdat ze terugdachten aan de tijd van vroeger. Toen beraadslaagden die edelen en ambtenaren er met elkaar over om hun opwachting te gaan maken bij Zijne Majesteit teneinde hem hun kris aan te bieden en hem om 81 vergiffenis, duizendmaal om vergiffenis te vragen; daarbij werd tevens afgesproken dat men 's avonds voor Zijne Majesteit zou verschijnen, als het stil was, opdat Pangéran Citrakesuma en Pangéran Sumanegara het niet te weten zouden komen. 
7.5. Toen ' $t$ avond was, gingen de edelen en ambtenaren bij Zijne Majesteit in Muara Rawas hun opwachting maken, ten eerste de pangérans Natawikrama en Sutawikrama en voorts hun ambtenaren Demang Singayuda en Kemas Rakria. Die vier mannen waren het die voor de vorst verschenen, meer hadden er niet weg kunnen komen om hun opwachting te gaan maken, omdat ze bang waren dat de beide pangérans er achter zouden komen. Hun kris hadden de twee pangérans en de twee ambtenaren alleen maar meegenomen om die aan de vorst aan te bieden. Zijne Hoogverheven Majesteit sprak toen tot beide pangérans: "Breng jullie mijn gevoelens van genegenheid over aan allen die mij nog liefhebben en mijn groeten aan al degenen die ik nog niet vergeten ben, ook al hebben ze mij in een zodanige toestand gebracht als waarin ik nu verkeer. Dat zij geen moment aan mij denken, dat is nu eenmaal mijn lot, daar is niets aan te doen. Voor zover ze mij nog liefhebben, ben ik hun daar zeer dankbaar voor."

Om ongeveer één uur namen de beide pangérans afscheid om naar de boten in het dorp Kemang terug te keren. Zodra ze bij de boten arriveerden, kwamen alle ambtenaren en edelen die achtergebleven waren, informeren naar de toestand van de vestingwerken en de welstand van $\mathrm{Zijne} \mathrm{Majesteit} \mathrm{de} \mathrm{Sultan.} \mathrm{Toen} \mathrm{vertelden} \mathrm{de} \mathrm{beide} \mathrm{pangérans}$ dat de vestingwerken van Muara Rawas bij de zwarte mensen hun weerga niet vonden en zelfs door de blanken niet licht zouden worden geëvenaard; en zulks niet vanwege de bezetting ervan, maar vanwege het feit dat de forten omgeven waren door een palissade van in de grond geheide palen, terwijl andere forten slechts aarden wallen hadden. Vervolgens brachten de beide pangérans de oprechte en welgemeende 82 groeten van Zijne Majesteit de Sultan "aan Onze familieleden" over. Wat dat bezoek aan de sultan betreft, alleen Pangéran Citrakesuma en Pangéran Sumanegara waren onkundig van wat de edelen en de ambtenaren hadden gedaan; overigens was 't $z o$, dat de mensen in de forten aan weerszijden van de rivier geregeld met elkaar gingen dobbelen, elke avond zochten ze elkaar op.

8.

8.1. Na ongeveer drie maanden kwam Sékh Abdulrahman Mesri uit Palembang in Muara Rawas aan. Een halve maand later arriveerden er blanken - 't waren Engelsen: de één heette Captain D'Aguilar en de ander Bruggemeyer - en die legden aan in het dorp Kemang, van plan, zo werd verteld, hun opwachting te maken bij de sultan. Toen 
gaf de vorst zijn zoons Pangéran Bupati en Pangéran Prabu de opdracht om met een gevolg, bestaande uit een temenggung, een rangga, een demang en een ngabéhi de blanken af te halen en naar Muara Rawas te brengen.

De prinsen met hun gevolg vertrokken stroomafwaarts met tien vaartuigen. Toen ze in het dorp Kemang aankwamen, drukten de twee pangérans, elkaars broers, de beide blanken de hand. De blanken informeerden: "Maakt de sultan het goed?" Daarop antwoordden de beide broers, de pangérans: "Onze vader maakt het goed op dit ogenblik en hij zendt $\mathrm{U}$ vele groeten. $\mathrm{Wij}$ en de temenggung, de rangga, de demang en de ngabéhi hier zijn er door onze vader op uitgestuurd om $U$ beiden uit te nodigen met ons mee te gaan met al $U_{w}$ boten; er mag niets van Uw bagage achterblijven, onze vader heeft ons gezegd alles mee te nemen." De beide kapiteins antwoordden: "Goed! Wij willen de sultan

83 't liefst dadelijk ontmoeten." Toen zeiden de beide broers, de pangérans: "Hoe laat kunnen we vertrekken?" De beide kapiteins antwoordden daarop: "Wacht nog even! We zijn nog niet klaar met een brief, die we naar de grote heer in Palembang willen sturen om hem mee te delen dat wij $\mathrm{U}$ beiden hebben ontmoet, die door Sultan Mahmud Badaruddin zijt uitgezonden om ons uit het dorp Kemang te halen en naar Muara Rawas te brengen."

Omstreeks elf uur waren de boten voor vertrek gereed en onmiddellijk voer men af naar Muara Rawas. $\mathrm{Na}$ een half uur kwamen de vestingwerken in zicht. De sultan kwam hen tegemoet. Zodra de beide boten elkaar genaderd waren, begaf de sultan zich aan boord van de boot van de kapiteins. Vervolgens stapten de beide kapiteins vlug over in de boot van de sultan, terwijl ze elkaar bij de hand hielden. Door de bezetting van het fort werden saluutschoten gelost, er werd op de trom geslagen en onder donderend geschreeuw voerde men Maleise zwaarddansen uit. Nadat ze elkaar over en weer vragen gesteld hadden, nam de sultan de kapiteins bij de hand; vervolgens stapten ze aan wal en gingen het grote huis binnen dat ingericht was met slaapbanken.

8.2. Een maand later werd gemeld dat Zijne Excellentie de Grote Heer van Palembang op weg was naar Muara Rawas. Enkele dagen na die melding kwam de grote heer in het dorp Kemang aan. Hij was van plan verder stroomopwaarts te varen en alle pangérans en ambtenaren van daar mee te nemen; die moesten van Major Robison aan Zijne Majesteit de Sultan vergiffenis gaan vragen voor het feit dat zij tegen Zijne Majesteit waren opgestaan. Intussen gaf de sultan van zijn kant pangé- 
rans en ambtenaren de opdracht om vlug Major Robison in het dorp Kemang te gaan afhalen, terwijl Zijne Hoogheid de Sultan zelf met 84 de kleine kinderen in Muara Rawas zou blijven wachten. Major Robison voer dus verder stroomopwaarts. Toen de vaartuigen van beide kanten elkaar ontmoetten, gaf Zijne Hoogheid de Sultan Major Robison de hand en stapte aan boord. Major Robison bracht de sultan zijn saluut en de sultan dankte hem; dadelijk daarna voeren ze door in de richting van de vesting Muara Rawas.

Zodra ze bij de vesting aankwamen, weerklonken er saluutschoten als donderslagen. Er wordt vermeld, dat de sultan en Major Robison samen hand in hand de vesting binnengingen. De pangérans en ambtenaren die uit het dorp Kemang waren meegekomen liepen achter hen aan en zo raakten de edelen en ambtenaren van Palembang vermengd met de ambtenaren en edelen van Muara Rawas. Major Robison nam met de sepoy-soldaten zijn intrek in een huis, terwijl de mensen van het binnenland daar binnen de wacht hielden; en elke dag, zowel overdag als 's nachts, gingen de ambtenaren en edelen op pad om te onderzoeken of er misschien iets aan de hand was.

8.3. Na drie dagen wilde Major Robison naar Palembang terug. Zijne Hoogheid Pangéran Ratu en een kemas en een rangga zouden Major Robison naar Palembang begeleiden en de bagage meenemen. Dezelfde dag nog vertrok Major Robison naar Palembang, samen met Zijne Hoogheid Pangéran Ratu, Kemas Kecik en een ambtenaar van de kemas, Rangga Kumbang.

Tien dagen later kwam Pangéran Ratu, de broer van de sultan, zijn oudere broer de oude sultan uitnodigen om mee te gaan naar Palem-

85 bang; 't was daarbij de opdracht van Major Robison om alsjeblieft haast te maken, want hij wilde naar Batavia terugkeren en wachtte alleen nog maar op de aankomst van Zijne Majesteit de Sultan te Palembang; diezelfde dag nog zou Major Robison vertrekken.

Een paar dagen later vertrok Zijne Majesteit de Sultan uit Muara Rawas met alle vaartuigen en al het volk. $\mathrm{Na}$ een tocht van vier dagen arriveerde Zijne Majesteit de Sultan in Karang Anyar en legde daar aan. Toen gaf Zijne Majesteit de Sultan aan Captain D'Aguilar opdracht Major Robison te gaan melden "dat Wij hier zijn aangekomen", waarop Captain D'Aguilar Bruggemeyer er op uitzond.

8.4. De sultan beval een ambtenaar met de blanke mee te gaan om Major Robison uit te nodigen in de kraton te komen. Vervolgens ging 
Zijne Majesteit de Sultan hand in hand met Major Robison aan boord van een vaartuig om Zijne Majesteit Sultan Mahmud Badaruddin, die uit Muara Rawas in aantocht was, te gaan verwelkomen. Toen de pencalang van Major Robison langszij de pencalang van Zijne Majesteit de Sultan gekomen was, stapte de sultan over in de boot van Major Robison, waarna ze gezamenlijk plaatsnamen op drie zetels: de oude sultan nam plaats aan het hoofd van de tafel, de jonge sultan ging links van zijn oudere broer zitten en Major Robison nam plaats aan de rechterhand van Sultan Mahmud Badaruddin.

$\mathrm{Na}$ een poosje arriveerde men aan de kratonsteiger. Major Robison nam toen de oude sultan aan zijn rechterhand en de jonge sultan aan zijn linker en zo ging Major Robison tussen de beide sultans in aan wal. Terwijl aan de linkerkant ................., liepen ze het poortgebouw in, klommen regelrecht de stenen trap op en gingen vervolgens de troonzaal van de kraton binnen.

86 Na een uur maakte Major Robison aanstalten om samen met de jonge sultan naar buiten te gaan. Major Robison nam de sultan bij de hand en bracht hem naar de oude kraton. Nadat ze in de oude kraton aangekomen waren, keerde Major Robison terug en nam aan de overkant van de rivier zijn intrek in het huis van de kapitein der Chinezen, dat stroomopwaarts lag. Intussen was het zó, dat Zijne Majesteit Sultan Mahmud Badaruddin nu definitief op de troon was gekomen en $\mathrm{Zijne}$ Majesteit de Jonge Sultan zijn vaste domicilie had gekregen in de oude kraton.

8.5. Negen dagen later verscheen Major Robison voor de sultan met de mededeling dat hij naar Batavia wilde zeilen om zijn opwachting te maken bij de Gouverneur-Generaal samen met de zoons van de sultan, Pangéran Ratu en Pangéran Adimenggala, met Pangéran Kramadiraja, de schoonzoon van de sultan, met zijn jongere broers, de pangérans Suryakesuma en Natawikrama, met Pangéran Sutadiwangsa en Pangéran Puterakrama en voorts met hun ambtenaren: Kemas Temenggung Kerta, Demang Darpateruna, Ngabéhi Darpacita, Kemas Demang Ahmad, Ngabéhi Pinding, Ngabéhi Ahmad en Ngabéhi Keling; dat waren degenen die met Major Robison zouden meegaan om de Gouverneur-Generaal hun eerbiedige dank te betuigen. Aan alle hiergenoemde pangérans en ambtenaren werden door Zijne Majesteit de Sultan geschenken uitgereikt.

Niet lang daarna vertrok Major Robison. Zijne Majesteit de Sultan met zijn broer deden Major Robison uitgeleide tot aan Lemabang. Ma- 
jor Robison voer vervolgens verder stroomafwaarts, terwijl de pangérans en allen die hem zouden wegbrengen met Major Robison mee verder de rivier afvoeren. Zijne Majesteit Sultan Mahmud Badaruddin bracht vervolgens meteen een bedevaartsbezoek aan de graven van wijlen $Z i j n e$

87 Majesteit de Sultan en Zijne Majesteit de Suhunan in Lemabang. Na dat bedevaartsbezoek keerde de sultan terug naar het paleis in de nieuwe kraton; en de jonge sultan ging terug naar de oude kraton.

Wij vervolgen ons verhaal nu weer met de vermelding, dat Major Robison, Zijne Hoogheid Pangéran Ratu, Pangéran Suryakesuma, Pangéran Adimenggala, Pangéran Nata, Pangéran Wangsa en Pangéran Putera, Kemas Temenggung Kerta en de andere ambtenaren met z'n allen van de Generaal een groot stenen huis ter beschikking kregen met een militaire bewaking en volledig van voedsel en zelfs van kaarsen voor avondverlichting werden voorzien. Zodanig was de verzorging van de pangérans door de Generaal. Maar Pangéran Adimenggala en Pangéran Surya waren de enige twee pangérans die tot de Generaal werden toegelaten.

8.6. Na enige dagen kwam General Gillespie ter ore dat Sultan Mahmud Badaruddin door Major Robison in de regering over Palembang was hersteld en dat de jonge sultan door Major Robison als vorst was afgezet en de oude kraton als verblijfplaats toegewezen had gekregen. Zeer ontstemd ging General Gillespie toen naar General Mister Raffles toe, smeet zijn hoed op tafel en zei tegen General Mister Raffles: "Wie heeft Major Robison gemachtigd om Sultan Mahmud Badaruddin uit de bergen te halen en weer tot koning van Palembang te maken? Ik wil naar Palembang om Sultan Mahmud Badaruddin te ontmoeten; en wat de jonge sultan betreft die mijn vriend is, dat hij op zo'n manier

88 behandeld wordt dat neem ik niet." Daarop zond General Mister Raffles de zoon van de onderkoning van Bengalen met een aantal officieren en met soldaten naar de stad om de jonge sultan weer op de troon van Palembang te brengen; en Sultan Mahmud Badaruddin trad af als vorst en verhuisde naar de oude kraton.

Drie en een half jaar lang bleef de jonge sultan vorst van Palembang. Maar in de tijd dat de jonge sultan aan het bewind was, droeg hij de titel suhunan. Hij was nog niet zo lang op de troon, toen Edeleer Muntinghe op bevel van Batavia Sultan Mahmud Badaruddin in zijn waardigheid als vorst van Palembang herstelde. Zo was het de tactiek van de blanken om steeds maar verwarring te stichten en bedrog te plegen. 
9.

9.1. Toen Edeleer Muntinghe twee maanden in Palembang was, arriveerde er een blanke, een Engelsman, uit Benkoelen met soldaten; zestig man kwamen er in Palembang aan, terwijl er tweehonderd sepoy-soldaten uit het binnenland in aantocht waren, die nog met vlotten onderweg waren en dus nog niet waren aangekomen. Ze werden in de oude kraton ondergebracht. 's Avonds kwam daar in opdracht van Edeleer Muntinghe een officier met honderd soldaten, die de Engelsen die in de oude kraton waren kwam halen; Zijne Hoogheid de Jonge Sultan verbleef toen in Buratan. De Engelsen werden onmiddellijk, diezelfde dag nog, op last van Edeleer Muntinghe naar Batavia gebracht.

Edeleer Muntinghe nu was van plan naar het binnenland te gaan om de Engelse soldaten op te zoeken, die met vlotten de rivier kwamen afzakken. Daarom vroeg Edeleer Muntinghe Zijne Majesteit Sultan

89 Mahmud Badaruddin om drie pencalang-prauwen met een bemanning bestaande uit lieden die met vuurwapens konden omgaan, tien man per boot, de schipper niet meegerekend; het waren ambtenaren en de pangérans, met uitzondering van Pangéran Adipati, Pangéran Adimenggala, Pangéran Putera en de sultan zelf. Toen voer Edeleer Muntinghe de Musi op en bereikte in tien dagen Muara Beliti. Een maand later keerde Edeleer Muntinghe weer naar Palembang terug. Vervolgens nam Sultan Mahmud Badaruddin de titel aan van Suhunan Mahmud Badaruddin.

De jonge sultan werd met zijn gezin op transport gesteld naar Batavia en geïnterneerd in het dorp Cianjur, terwijl zijn ambtenaren en de edelen deels in het dorp Sumedang werden ondergebracht. Zijne Majesteit de Sultan kreeg een toelage voor levensonderhoud en de ambtenaren en edelen eveneens: sommigen kregen een volledige toelage, anderen twintig gulden en weer anderen vijftien gulden per maand.

9.2. Later is Edeleer Muntinghe een politiek gaan volgen van ongepaste intriges tegen Suhunan Mahmud Badaruddin; tegen geen enkele daad van Edeleer Muntinghe is de suhunan ooit in verweer gekomen.

Edeleer Muntinghe, die nogmaals naar het bovenstroomgebied van de Beliti wilde, had gevraagd om volledig bewapende vaartuigen en voor elke boot om een ambtenaar, die als schipper moest optreden. Vervolgens voer Edeleer Muntinghe het binnenland in tot Muara Beliti. Na verloop van enige tijd kwam Edeleer Muntinghe weer in Palembang terug, met een nors gezicht, omdat hij in Muara Rawas strijd had 
moeten leveren tegen Said Hamzah en Demang Arsad en de Maleiers uit Minangkabau. Hij had het vermoeden gekregen dat de suhunan 90 daarin de hand had gehad, terwijl de suhunan volstrekt niet op de hoogte was van wat zich daar had afgespeeld.

Welnu, de suhunan had Pangéran Ratu en Pangéran Adipati er op uitgestuurd om Edeleer Muntinghe ter verwelkoming tegemoet te varen. Toen Pangéran Ratu bij de boot van Edeleer Muntinghe was aangekomen, werd hij echter niet aan boord van het vaartuig van Edeleer Muntinghe toegelaten. Het was Pangéran Adipati die aan boord werd genodigd, terwijl Pangéran Ratu ter hoogte van de kratonsteiger op stroom bleef liggen.

Nadat Pangéran Adipati van boord was gegaan, keerde hij samen met de prins, Pangéran Ratu, terug naar de overkant van de rivier; hij wendde zich vervolgens dadelijk tot diens vader de suhunan om het relaas dat Edeleer Muntinghe van zijn lotgevallen had gedaan, aan hem over te brengen, luidende: "Wat de tocht naar het binnenland betreft, we hebben daar in de bovenlanden veel smerige streken ondervonden van de Maleiers en van de bevolking van het Musigebied. De Pangéran van Semangus, wiens kwade gezindheid duidelijk bleek, hebben wij doodgeschoten. Toen we op de terugweg in Muara Rawas aankwamen, raakten we in gevecht met Said Hamzah en Demang Arsad, die zich in de vesting Muara Rawas verschanst hadden; hun Maleise makkers sloegen tot de laatste man op de vlucht. Zo is het ons daar vergaan. Ik acht het niet waarschijnlijk dat wat daar gebeurd is het werk van onaanzienlijke lieden is geweest. Ik houd er rekening mee dat naderhand alle mensen op deze wereld naar ons zullen kijken. $U$, meneer de pangéran, moogt dat wel goed bedenken en orders geven dat men evenzeer als men schuldenaars hun schulden moet laten betalen ook moordenaars ter dood moet brengen. Dat zal niet lang meer duren, ik ben er al bijna aan toe, de eerste tekenen zijn er al." Nadat Pangéran Adipati dat hele relaas aan de suhunan had overgebracht, sprak Zijne Hoogverheven Majesteit: "Als het zó is, dat wij bij hem onder verdenking staan, dan is er niets aan te doen! Maar wij weten er hoegenaamd niets van."

91 9.3. $\mathrm{Nu}$ handelde Edeleer Muntinghe geheel naar eigen willekeur. Van de handelsvaartuigen hief hij tol, hij stichtte een tolkantoor en stelde een kapitein der Chinezen aan; hij deed wat hij maar wilde in de stad Palembang, zonder overleg te plegen met de suhunan. Ook liet Edeleer Muntinghe Pangéran Muhammad het kanon Seri Padah genaamd, een erfstuk van Palembang, weghalen van vóór het poortgebouw, 
zonder ook maar de minste plichtpleging jegens Zijne Majesteit of jegens de edelen die aan de buitenkant van het poortgebouw woonden. Zijne Majesteit de Suhunan raakte ontstemd, toen hij zag dat Edeleer Muntinghe zó optrad.

Binnen een paar maanden nadat Zijne Majesteit ter ore was gekomen dat Edeleer Muntinghe besloten had geheel eigenmachtig op te treden, was de suhunan van zijn kant paraat. Omdat de ambtenaren en edelen wanneer ze iets verkeerds zouden zien, wel geen gelegenheid zouden hebben Zijne Majesteit in te lichten, had deze al van tevoren aan alle ambtenaren en edelen bevel gegeven zich eveneens gereed te houden voor de strijd. Immers, als er maar in 't minst zou worden afgeweken van hetgeen van oudsher had gegolden, dan was dat wel een teken dat voor Palembang het tijdperk van het bondgenootschap van de vroegere vorsten met de Hollandse Compagnie voorbij was.

10.

10.1. Edeleer Muntinghe nu legerde vier officieren met honderd man soldaten in de oude kraton en van de drie schepen liet hij er één op de rivier recht tegenover de kraton ten anker gaan. Op dat ogenblik voelde Zijne Majesteit de Suhunan: "Edeleer Muntinghe heeft niet meer het welzijn van Palembang op het oog. Het is 't beste dat wij paraat zijn, ons uit alle macht verzetten en zoveel als in ons vermogen ligt de weg van Gods gebod volgen om uiteindelijk als geloofsgetuige te sterven." Zijne Hoogverheven Majesteit riep toen alle ambtenaren, edelen, pangé-

92 rans, vreemdelingen, haji's en het gewone volk van de stad Palembang, zomede de dorpshoofden uit het binnenland bijeen. Toen men op de audiëntieplaats aanwezig was, beval Zijne Majesteit de hajis: "Wijdt $\mathrm{U}$ met hart en ziel aan het verrichten van vrome werken hier op de audiëntieplaats en voert Uw godsdienstige oefeningen uit!' De haji's aanvaardden eerbiedig het bevel van Zijne Majesteit de Suhunan en een ieder van hen kreeg wat geld van de vorst. Daarop voerden de haji's uit wat hun was opgedragen; ze deden dat met grote ernst en toewijding, de haji's evenals de edelen en ambtenaren.

Toen kwam er een Hollander uit de oude kraton vandaan om naar de haji's te kijken die daar met hun godsdienstige oefeningen bezig waren. Ze riepen hem toe weg te gaan, die reciterende haji's, met name een khatib die de naam had zeer fel te zijn; die zette hem achterna, waarop hij naar de oude kraton terugrende. Terwijl de soldaten in de oude kraton zich gereed hielden voor de strijd, overlegden de haji's om 
ten heiligen strijde te trekken en een aanval te doen op de oude kraton. Onmiddellijk daarop gingen ze op weg, met veertig man. Vier of vijf haji's drongen regelrecht de oude kraton binnen, terwijl de meesten naar de kraton terugkeerden om hun opwachting te maken bij Zijne Majesteit de Suhunan en sommigen naar huis gingen en niet meer terugkwamen om voor de vorst te verschijnen.

Daarna braken de vijandelijkheden uit tussen de suhunan en Edeleer Muntinghe. De schepen beschoten de kraton en de kraton beschoot de schepen. Toen er een afdeling soldaten vóór de kratonpoort verscheen, werd de poort terstond gesloten; de soldaten gingen daarop weer naar de oude kraton terug. Het was in die tijd erg onrustig in de stad Palembang. Na twee dagen van strijd waren vele Hollanders gesneuveld, terwijl er onder de mensen in de kraton van de suhunan één dode was gevallen. Op de derde dag van de strijd gingen de officieren en soldaten terug aan boord van de schepen, met vele doden en gewonden. Zijne

93 Majesteit de Suhunan verliet de kraton met zijn kinderen, maar drie uur later keerde hij in de kraton terug. Diezelfde dag nog trokken de drie schepen zich van voor de kraton terug en voeren toen dadelijk stroomafwaarts. Edeleer Muntinghe was op zijn beurt uit het fort aan de overkant van de rivier gevlucht, had zich ingescheept en was vervolgens ook de rivier afgevaren. In Sungsang aangekomen zeilde men zonder aan de monding nog aan te leggen meteen door naar Batavia.

11.

11.1. Na verloop van drie maanden kwam er weer bericht dat Edeleer Muntinghe een aanval zou doen op Palembang met zeven grote schepen, vier brikken en tien landingsvaartuigen. Toen dat nieuws de suhunan bereikte, was het fort aan de uitmonding van de Plaju, Tambakbaya geheten, reeds in staat van verdediging gebracht; daar hadden postgevat leden van het vorstenhuis met temenggungs, rangga's, demangs en ngabéhi's, voorts de haji's en de pangérans uit de bovenlanden met hun volk van duizenden mensen. Ten tweede was er, meer stroomopwaarts gelegen, het fort waar Pangéran Citra met de edelen en dorpshoofden van Ogan, Pegagan en Martapura met al hun volk, de prinsen, de Arabieren en het volk van Palembang gelegerd waren. Ten derde was er het fort in de rivier, van de pangéran-patih, Pangéran Wirasentika genaamd, die vergezeld was van allerlei ambtenaren. Verder nog een fort, eveneens in de rivier gelegen, waar Pangéran Ratu van Jambi met zijn volk de wacht hield; en de vestingwerken van het eiland Kembara, 
die bezet waren door de broer van de suhunan, Pangéran Suryadilaga geheten, tezamen met temenggungs en rangga's, de kapitein der Chinezen, dorpshoofden van Kikim, demangs en jenangs. Zo was de toestand en dagelijks werd er onafgebroken gewerkt, dag en nacht zonder ophouden; bovendien was men ook binnen de stad aan het werk, zowel op de wallen als in de grond van de vesting en er lagen vlotten van twee tot drie verdiepingen gereed om in brand gestoken te worden.

94 Drie maanden later kwam de wachtpost van de Sungsangmonding melden dat er veel vaartuigen waren: grote schepen en brikken, sloepen, vrachtboten en penjajabs, ongeveer een stuk of veertig, grote en kleine tezamen. In die tijd ging Zijne Majesteit de Sultan dagelijks de vestingwerken inspecteren; als ze niet sterk genoeg waren, beval hij ze te versterken; waar wapentekorten waren, liet hij deze aanvullen. Het fort Tambakbaya had honderdachtenzestig vuurmonden en het aantal kleine kanonnetjes op de wallen was ontelbaar groot. Daarbinnen bewaakten edelen, pangérans en ambtenaren, zoals temenggungs, rangga's, demangs, ngabéhi's, districts- en dorpshoofden uit de bovenlanden, het adathoofd van Sungsang ........... de achterzijde van het fort, terwijl pangérans, temenggungs, rangga's, demangs en ngabéhi's ook de wacht hielden bij de kanonnen, één ambtenaar bij één stuk zwaar en één stuk licht geschut, met verder nog veertig man gewoon krijgsvolk tot hun beschikking, kinderen en verdere familieleden niet meegerekend. Stampvol was het binnen het fort en in de overige forten was het net zo. Verder waren er nog sluipschuttersposten langs de wegen. Zo stonden de zaken.

11.2. Wij vervolgen nu ons verhaal over de vloot uit Batavia van Edeleer Muntinghe, bestaande uit vier grote schepen, zes brikken, vijf landingsboten, zeventien penjajabs. Al die vaartuigen voeren stroomopwaarts. Toen de vloot de uitmonding van de Opang had bereikt, ging een pangéran erheen om poolshoogte te nemen. Toen er met een draaibas werd geschoten, schrokken de schepelingen en vluchtte de pangéran stroomopwaarts; de vloot voer vervolgens verder de rivier op.

$\mathrm{Na}$ drie dagen en drie nachten kreeg men in de vestingwerken al die vaartuigen in zicht, waarmee de rivier bezaaid was. De edelen en ambtenaren stonden klaar als lieden die zich aan een schotel rijst willen

95 zetten om zich te goed te doen, terwijl er slechts een man of twee, drie van kunnen eten. Voortdurend daverde het geschut, dag en nacht zonder ophouden en kruitdamp verduisterde de lucht, zodat men geen hand voor ogen kon zien.

Toen de strijd twee dagen geduurd had, werd er een landingsvaartuig 
veroverd met als buit een roodkoperen kanon, kruit en kogels en het anker van een sloep. Toen deinsden alle grote schepen, brikken, landingsboten en penjababs zonder uitzondering af en voeren allemaal stroomafwaarts tot aan de monding van de rivier. Edeleer Muntinghe zeilde meteen door naar Batavia; één oorlogsschip had van Edeleer Muntinghe de opdracht gekregen de riviermond te bewaken. Als er in die tijd handelaars uit de zeestraat in de monding van de Sungsang aankwamen om in Palembang handel te gaan drijven, kwam de scheepssloep de boten van degenen die de monding wilden binnenvaren achterna. Alle handelsvaartiugen sloegen dan op de vlucht; sommigen werden gepakt, anderen wisten te ontkomen en soms ook werden de opvarenden gevangen genomen en dadelijk opgehangen.

11.3. Anderhalf jaar later kwam er bericht dat mensen uit de buurt van de monding van de Sungsang een vloot hadden gezien op de rede vóór de riviermond. Het nieuws werd aan $\mathrm{Zijne} \mathrm{Majesteit} \mathrm{gemeld.} \mathrm{Zijne}$ Hoogheid zond toen Zijn jongere broer Pangéran Panembahan er met sepoy-soldaten op uit om een onderzoek te gaan instellen aan de monding van de Sungsang. Toen hij bij de monding arriveerde, voer de vloot juist de Sungsangmond binnen.

$\mathrm{Na}$ verloop van 


\section{VERTALING}

\section{MP 4b: SYAcIR PERANG MÉNTÉNG}

1 Allereerst moet worden vermeld de schanddaad van Pangéran Muhammad: net als Raja Akil had gedaan, bij de heidenen sloot hij zich aan!

2 De oorzaak van alles, naar men zegt, waren de Hollanders met hun handlangers de Ambonnezen, Edeleer Muntinghe, een Hollander van naam, en Kolonel Bakker, die 't militair commando voerde.

3 Nadat daartoe in rade was besloten, gingen soldaten met hun officieren aan wal. In de oude kraton namen zij hun intrek honderd vijfenzeventig man sterk.

4 Toen men vanaf de kratonmuren zag hoe 't Hollandse leger daar compleet stond aangetreden, wendde men zich eerbiedig tot de troon, waarna Zijne Majesteit naar buiten kwam.

5 Men sprak: "Heer, wat moeten wij doen?

$\mathrm{Nu}$ Muntinghe de rivier is overgestoken en zijn leger heeft opgesteld, een overmacht van talloos velen, verkeren wij allen in grote nood!

6 Zodra $U$ het bevel daartoe geeft, vallen wij de Compagniestroepen aan. Met Gods gunst, geprezen zij Zijn Naam, zal Muntinghe's krijgsmacht volledig vergaan!"

7 Daarop sprak Zijne Hoogverheven Majesteit:

"Roept het volk bijeen en laat het zich gereedmaken!

Met de hulp van de Heer, de Almachtige, zijn wij Muntinghe's vloot de baas!"

8 De haji's verzamelden zich nu, jong en oud, en buigend verschenen zij voor de vorst; zij brachten Hem hun afscheidsgroet alvorens de Hollanders te lijf te gaan. 
9 Alle haji's verklaarden zich tot strijden bereid en in staat en wierpen zich voor de vorst in het stof, volledig bewapend en paraat; en sommigen brachten hulde aan de vorst, gehurkt en met de armen

10 't Was op een zaterdag, [gekruist voor de borst. de achttiende Sya ${ }^{c}$ ban, dat 's middags om vier uur de haji's op het kratonplein aan 't reciteren gingen.

11 De haji's reciteerden op het kratonplein, dichtopeengedrongen als namen ze aan een feestmaal deel; volkomen in trance geraakt voerden zij in rijen tegenover elkaar hun rituele oefeningen uit.

12 Ze sloegen zich bij de woorden "Er is geen God dan Allah" links op de en zo in het hart, op de plaats waar dit sanubari heet; [borst, een officier kwam toen poolshoogte nemen en bleef staan, maar toen de haji's op hem afkwamen, zette hij het op een lopen.

13 Met Haji Zain aan 't hoofd zetten de woedende haji's hem na: zó begonnen de vijandelijkheden die tot de aanval op de oude kraton leidden.

14 De haji's achtervolgden hem zo snel ze konden en stortten zich op de gelederen van de vijand; met hun sabels hieuwen ze links en rechts, zodat de Hollandse soldaten en masse op de vlucht sloegen.

15 De haji's, schreeuwend: "God is groot!", vielen wild op de vijand aan, buiten zichzelf van woede; met de hulp van de Heer, de Almachtige Koning, werden Muntinghe's soldaten totaal uiteengeslagen.

16 Toen verschenen de krijgslieden van Palembang en kwamen de haji's te hulp in de strijd; er sneuvelden wel vier tot vijf officieren, maar de haji's stootten tot in de oude kraton door.

17 De haji's achtervolgden de vijand overal, houwend met hun sabels naar alle kanten; de Hollandse soldaten vluchtten tot de laatste man, alleen de commandant wist stand te houden. 
18 De haji's schreeuwden, terwijl ze 't schouwspel gadesloegen:

"O ongelovige, kom maar op!

De hemel gaat schuil in het lemmet van Uw zwaard en zie, dáár staan de hemelnimfen met haar sléndangs klaar!"

19 Daar hielden de haji's toen lange tijd stand, omringd door schurkachtige Hollandse soldaten; onbeschrijfelijk zwaar gewond viel een haji in zwijm en bezweek.

20 Toen naderde de commandant, blakend van strijdlust, en beschoot de haji's zonder ophouden; de kogels kwamen recht op hun doel af en daar vond een haji de dood.

21 Zo vielen er enkele haji's als martelaar voor de heilige zaak om in de hemelse heerlijkheid te worden opgenomen; een grote schare nimfen zonder tal kwam de bejaarde haji's welkom heten.

22 Terwijl hun bloed vloeide, welriekend als de muskusplant, naderde het heerleger der hemelnimfen; in uitbundige vreugde dansend bij handgeklap namen zij de lichamen van de voortreffelijke haji's mee.

23 Toen kwam Pangéran Prabukesuma er aan, het gelaat glanzend als de volle maan en in zijn houding Grootvorst Boma gelijk: wanneer zou hij ooit zijn weerga vinden!

24 Pangéran Prabu kwam te hulp in de strijd en door zijn kogel van het zuiverste goud, een toverkogel, feilloos op zijn doel gericht, werd een Fransman dodelijk getroffen.

25 Alle Palembangers juichten, 't was een oorverdovend lawaai; en de voorvechters als dolle olifanten beschoten de Fransen vanaf de wallen.

26 De pangéran vuurde onbeschrijfelijk hevig, de schoten weerklonken tot hoog in de lucht; de mannen van de kolonel waren er ellendig aan toe: ze zagen er uit als apen! 
27 De zoon van Zijne Majesteit de Koning, rondom door Fransen en Hollanders ingesloten, hield nochtans stand - zijn borst was hem tot vesting en week geen stap achteruit.

28 De Hollanders en de Fransen waren met elkaar verenigd, Ambonnezen en Javanen vormden hun hulptroepen; verder was er ook nog Raja Akil, die zich met Muntinghe had verbonden.

29 De kroonprins, 's konings oudste zoon, die in de strijd voor niemand onderdeed, vuurde lachend zijn kanon af en twee van Muntinghe's officieren vielen dood neer.

30 De pangéran besteeg het bolwerk en gaf een onafgebroken geweervuur af, terwijl zijn houding aan Vorst Masapati deed denken: onder de Hollanders en de Fransen vielen vele doden.

31 In groten getale sloegen de Hollanders op de vlucht, naar alle kanten opgejaagd door onze strijders; terwijl Raja Akil, die schurk van een Siakker, zich in een vlotwoning schuilhield.

32 Deze was een wel zeer verachtelijk vorst, die in het land der Maleiërs een waardeloze figuur was geweest, op Billiton zijn toverkunsten had bedreven en nu in Compagniesdienst een fortuinzoeker was geworden.

33 Als volgeling van de Compagnie, die heidenen en vijanden van het was hij een wijndrinker en een koeketer geworden; geen wonder dat hij op een schildpad leek, hij die bijna zelfs varkensvlees ging eten.

34 Voortdurend rebellerend tegen God verdiende hij slechts in de hel terecht te komen; het pad van de Islam verkoos hij niet te gaan, en daarom werd hij door Gods toorn getroffen.

35 Keren wij terug tot de strijd te land, waar men streed met kris en sabel; daar dreunde het krijgsgeschreeuw als de golven in een westerstorm en dreigde het leger van Zijne Majesteit nu het onderspit te zullen 
36 De Palembangers sloegen op de vlucht, overal vervolgd door de vijand;

ze waren geheel in verwarring geraakt

en wisten niet meer wat ze deden.

37 Toen verscheen er een Hollands officier aan het hoofd van een troep grimmige soldaten;

met kapmessen begonnen ze op de deuren van het poortgebouw te terwijl de officier hen met luide stem toeschreeuwde.

[hakken,

38 Terwijl ze uit alle macht met bijlen op de poort losbeukten

- de slagen volgden elkaar zonder onderbreking op -, verscheen daar Rangga Satyagati ten tonele;

hij stak met zijn lans en de tamboer was op slag dood.

39 Toen traden 's konings raadslieden naar voren en makkten tegen de Hollanders front; ze staken met krissen en zwaaiden hun knotsen en weken geen stap achteruit.

40 Vanaf het bolwerk vuurden de kanonnen een dichte regen van kogels af; getroffen aan het hoofd of in de maagholte vonden vele Hollanders de dood.

41 Toen deed Kemas Said een uitval, blakend van strijdlust; nadat hij van het leger van duizend tien man had gedood, stortte Kemas bij de kratonpoort neer.

42 Een officier kwam naderbij en beschoot Kemas onafgebroken; de kogels troffen hem in de lever en ter plaatse vond Kemas de dood.

43 Met het geweer over de schouder deinsden de Hollanders af onder een regen van flitsende kogels die de hemel verduisterde, en nergens vonden zij dekking.

44 Op het bolwerk vuurde men beurtelings de zware en de lichte kanonnen af; van Muntinghe's soldaten sneuvelden er velen, maar tegen de middag werd de strijd gestaakt. 
$45 \mathrm{Nu}$ wordt weer verteld hoe de vijand aftrok en de mannen naar boord werden teruggestuurd; op weg naar de schepen sleepten ze de geweren achter zich aan, en sommigen waren ernstig aan het hoofd gewond.

46 De dokter kwam om hun wonden te helen, waaruit het bloed onophoudelijk vloeide; toen Muntinghe het zag, ontzonk hem de moed en werd hij door schaamte overmand.

47 Muntinghe sprak toen in grote haast: "Laat ons iemand uitsturen die om wapenstilstand gaat vragen, zodat de troepen eerst na drie dagen weer tot de aanval overgaan; want vele soldaten zijn gewond en uitgeput."

48 De officieren stemden in met de woorden van Muntinghe, de opperbevelhebber; Pangéran Nataagama werd met de missie belast, hem werd gezegd zich te haasten en niet te dralen.

49 De pangéran ging zo snel hij maar kon en pagaaide aan één stuk door, op weg naar Zijne Hoogheid Pangéran Bupati. Daar aangekomen sprak hij met vaste stem:

50 "Ik ben door Muntinghe naar $U$ toe gestuurd om $U$ te vragen of $U$ naar $U w$ oudere broer de vorst wilt gaan en hem om een wapenstilstand van een dag of drie wilt vragen; U hoeft dus volstrekt niet bang te zijn!"

51 De blik afgewend gaf Pangéran Bupati daar in de vergadering het gepaste antwoord op, flauwtjes glimlachend en met opgetrokken wenkbrauwen, hij was voor de duivel niet bang!

52 "Het verzoek van de Hollanders om een wapenstilstand zal mijn oudere broer worden overgebracht. of hij 't zal inwilligen of niet, dat weet ik niet, blijft $U$ in elk geval hier eerst maar wachten, oom!"

53 Pangéran Bupati vertrok en wandelde voort, gevolgd door een groep metgezellen; correct in de houding liepen ze mee aan weerszijden van hem, zijn getrouwen. 
54 Aangekomen bij het vorstelijk paleis trof hij de Koning op de troon in de audiëntiehal; eerbiedig groette hij, de vingers van beide handen tegen elkaar gedrukt en zei dat Muntinghe drie dagen wapenstilstand vroeg.

55 Toen Zijne Majesteit dit hoorde, werd Zijn gelaat vuurrood; vervolgens sprak hij zonder zich te bedenken: "Geef ze maar een wapenstilstand, die vervloekte ongelovigen!

56 Geef maar een rustperiode van een dag of wat, opdat wij ons intussen gereedmaken voor de strijd; de troepen mogen zich niet verspreiden, wij blijven in de kraton paraat!"

57 Aan Zijn eerste minister, de grootvizier, beval Zijne Majesteit, de heer der wereld: "Beschiet nog vóór het eerste ochtendgloren de schepen, opdat ze tot zinken worden gebracht!"

58 Daarop vertrok de voortreffelijke Pangéran Bupati, ging terug naar Pangéran Nataagama en zei: "Muntinghe's voorstel is door mijn oudere broer aanvaard. Keer dus maar terug, oom, en talm niet langer!"

59 De pangéran keerde terug en stak de rivier over, 't was nog klaarlichte dag; toen hij bij Muntinghe, die woeste Hollander, aankwam, was deze bijzonder verheugd.

60 De pangéran sprak, met de vingertoppen tegen elkaar, terwijl hij de boodschap van de koning mededeelde: "Zijne Majesteit geeft $U$ drie dagen rust, 't zou het beste zijn als $U$ zich intussen gereed maakt."

61 Muntinghe antwoordde, toen hij dit hoorde: "Heb dank, mijnheer de pangéran! Later zal ik, dat ben ik van plan, U naar behoren belonen."

62 En tot de officieren sprak Muntinghe, terwijl hij hun beval alle wapentuig in orde te brengen: "Laat de grote schepen en de brikken zich in linie leggen, dan schieten wij de kratonpoort in puin!" 
63 Op dinsdag de éénentwintigste, 's ochtends om zeven uur, zette Zijne Majesteit een hevig bombardement in, waardoor Muntinghe's vloot zware schade opliep.

64 Muntinghe schrok en krabde zich in wanhoop op 't hoofd, terwijl de schoten dreunden alsof de wereld verging; daardoor werd de strijdlust van Kolonel Bakker opgewekt en hij vuurde het geschut af met donderend geweld.

65 Donker rookten de vuurmonden der schepen, het heldere licht werd donker als de nacht; daar kwam mijnheer Willem in een bootje langszij om te zeggen dat de kraton vol mensen was.

66 Muntinghe liep aan het dek heen en weer en hield zijn kijker precies op de kraton gericht; toen hij het poortgebouw zag, blinkend als de maan, zonk hem de moed in de schoenen.

67 Omdat het boven de kraton zo helder licht was, zag hij Haji Bustam daar duidelijk staan; toen smeet hij, door onmacht overmand, zijn hoed neer en sprak geen woord.

68 Alle schepen vuurden toen tegelijk, het kanongebulder was oorverdovend; de kogels vlogen op de kratonwal af en troffen het geschut, dat vernield werd en beschadigd.

69 De aanval werd beantwoord door Pangéran Kramayuda, in houding de vogel Garuda gelijk; hij greep het zwaard "Glans der Majesteit" om de Hollanders de kop af te slaan.

70 Hem stond terzijde Demang Wiratenaya, in houding Grootvorst Salya gelijk; zijn gelaat leek op de bloem van de kemboja, schrander was hij en vindingrijk.

71 De officieren werden woedend toen ze hen zagen, hun bleke gezichten werden rood; in 't wilde weg schoten zij, zonder te mikken, alwie getroffen werd baadde in het bloed. 
72 De officieren schoten, aan het hoofd van hun troepen, de kogels vlogen onvoorstelbaar snel; vele Palembangers stonden klaar of traden naar voren, wie getroffen werd was er ellendig aan toe.

73 Daar was de schoonzoon van Zijne Majesteit, Kramadiraja, een voortreffelijk pangéran; boven op de kratonmuur stond hij de bewegingen van de Hollanders gade te slaan.

74 Muntinghe, die Hollander die knollen eet, verloochent de godsdienst van de Profeet; hij drinkt brandewijn en eet varkensvlees: geen wonder, dat hij op een schildpad lijkt!

75 De pangéran las gebeden om heil, opdat met de zegen van alle heiligen en de voorspraak van de Profeet, de Heer van het geschapene, Muntinghe's leger vernietigd zou worden.

76 De tweede schoonzoon van de edele vorst was Kramajaya, een heldhaftig pangéran; vergezeld door krijgers, hem trouw en toegewijd, bond hij met de commandant de strijd aan.

77 De commandant vuurde onafgebroken en beschoot de pangéran daar op het bolwerk; de pangéran schoot terug, nauwkeurig richtend: de commandant werd getroffen en stierf.

78 Toen juichte het volk van Zijne Hoogheid de Pangéran, zodat 't een oorverdovend lawaai was daar op de kratonmuur; maar de Hollanders die 't zagen waren verbijsterd en verslagen: dit was een teken dat 't slecht ging met Muntinghe's strijd.

79 Toen de Hollandse bevelhebber zag dat 't met zijn troepen was gedaan, was hij volkomen teneergeslagen, want er was nu niets meer aan te doen.

80 Terwijl Kolonel Bakker er zo aan toe was, kwamen in brand gestoken vlotten aandrijven; toen ontwijken onmogelijk bleek, kapten de schepen de ankertrossen. 
81 De Franse kolonel was al evenzeer van streek en rukte zich de hoed van het hoofd; Raja Akil ging als een bezetene te keer en maakte van zijn opiumpijp zijn afgod.

82 Hoezeer verschilde hij van Raja Mansur! Hij die in de Maleise landen zoveel praatjes had gehad en had beweerd 't tegen de vorst op te zullen nemen, was nu de slaaf van de Hollanders geworden!

$83 \mathrm{Nu}$ wordt verteld over de Hollanders die op de vlucht aan 't riviertje de Aur waren achtergebleven: als waren ze geesten of feeën verscholen ze zich achter de wanden van hun huizen.

84 Door alle krijgsoversten werden ze bestookt met geschutvuur vanaf de wallen: een oorverdovend krijgsgeschreeuw barstte los en onuitsprekelijk snel vlogen de kogels.

85 De kogels vlogen tenslotte alle kanten op, zodat de Hollanders in grote groepen op de vlucht sloegen; ze gedroegen zich net als opgejaagd wild, dat door de helpers van de jager verdient te worden afgemaakt.

86 Temenggungs en haji's kwamen toegesneld, in hun bewegingen de god Sahperi gelijk; de Hollanders die achtergebleven waren, lieten ze boeien, terwijl anderen door het geweervuur werden gedood of wisten te

87 Laat ons nu weer vertellen van de Edeleer: op zijn tafel stond van alles opgediend, terwijl de commandanten zaten te kwijlen op hun stoel, 't hoofd op de borst gezakt.

88 Kolonel Bakker nam het woord en zei:

"Onze strijd is veel te zwaar; de Sultan Ratu is een geweldig strijder, uiteindelijk worden wij weggekapt als struikgewas."

89 Daarop antwoordde Muntinghe, het Hollandse opperhoofd: "Onze strijd verloopt wel heel anders dan we gewend zijn; de Palembangers zijn als de garuda: naar men zegt zijn ze hier, maar je ziet ze niet." 
90 Toen sprak een onstuimig officier:

"Morgen vallen wij aan!

Neemt bijl en kapmes mee

en breekt dan de deuren van het poortgebouw open!"

$91 \mathrm{Om}$ zes uur in de morgen

- 't was zondag, de gunstige tijd -

bond Zijne Majesteit, de bekwame koning, de strijd aan met de Hollanders in de stad.

92 Onder vijf geopende parasols zag men Palembang's vorstenzonen;

hun gevolg leek uit goden en geesten te bestaan:

alwie ' $t$ aanschouwde beefde van ontzag.

93 Onverschrokken vuurden de mensen van Komering hun kanonnen af, in liggende houding;

doordringend floten de kogels

en bijna kapseisde Muntinghe's schip.

94 De kampanje was getroffen en helde naar één kant over;

de konstabel zag het schip splijten en dacht:

"deze oorlog is lang niet mis;

als 't zo doorgaat, delven we vast het onderspit."

95 De aanval werd met hevig granaatvuur beantwoord, op advies van Pangéran Muhammad gebeurde dat; toen het dak van het poortgebouw aan flarden was geschoten, voelde men zich er niet veilig meer.

96 Op het bolwerk antwoordde het geschut met goedgerichte salvo's;

overweldigend klonk het kanongebulder en menig Hollander vond de dood.

97 Die salvo's werden door Kolonel Bakkers schip met een donderend kanonvuur beantwoord; de kogels vlogen af op een gevaarlijk doel: zo sneuvelde Sayyid Zain, doordat zijn munitie ontbrandde.

98 Toen juichten de Hollanders, het volk van Muntinghe, en sprongen en dansten op en neer; ze richtten het geschut op het poortgebouw en schoten de stenen en dakpannen aan stukken. 
99 Op zijn beurt schoot nu Temenggung Astrawijaya, zijn kanon spuwde vuur; door de gunst van de Heer, de Almachtige, werden Muntinghe's troepen ontkracht.

100 Door de magische kracht van de temenggung en zijn bovennatuurlijke verduisterde het heldere licht van de dag; en op het dek van de schepen zaten wezenloos voor zich uit te staren de soldaten, zonder enige dekking.

101 De temenggung las de formulieren der onthouding en Muntinghe's schip draaide als een tol in het rond; het dreef meer af dan 't vooruit kwam, zodat de matrozen volkomen in de war raakten.

102 De kolonel schoot zonder ophouden en wie getroffen werd vond een wisse dood; daardoor laaide de hartstocht op in Pangéran Bupati om de kolonel te bevechten op leven en dood.

103 Menig soldaat werd dodelijk getroffen door de schoten van een pangéran op het bolwerk; 't was Citrawijaya, een strijder vol magische kracht, die richtte onder Muntinghe's troepen een ware slachting aan.

$104 \mathrm{Al}$ schietend trokken nu de soldaten terug, dekking zoekend in de hutten; als geesten en feeën gedroegen ze zich, sommigen stonden zelfs in de latrines.

105 Tot zijn grote vreugde zag $\mathrm{Zijne}$ Majesteit hoe de vijand aanhoudend werd bestookt; hij liet de trommen en de bekkens slaan ten teken dat Muntinghe te schande was gemaakt.

106 De pangéran vuurde meermalen achtereen op vorstelijk bevel; en terwijl de trommen opnieuw werden geroerd, vluchtten de soldaten in ' $t$ wilde weg heen.

107 Vanaf het bolwerk bleef men hen beschieten, aan 't kanongebulder kwam geen eind; de Hollanders en de Fransen telden vele doden, toen de dag ten einde liep. 
108 Tegen de avond werd de strijd gestaakt en verzamelden allen zich weer;

de manschappen en hun dappere aanvoerders

verschenen voor de vorst, wiens gelaat helder glansde.

109 Zijne Majesteit zat op zijn gemak en sprak tot zijn uitmuntende raadslieden:

"Wat staat ons nu te doen in de strijd tegen die woeste Hollanders!"

110 De sultan sprak op ongedwongen toon, terwijl hij uitgelezen spijzen rond liet gaan; er was eten en drinken in overvloed en in een feestelijke stemming zaten de mannen aan.

111 Khatib Muhammad Saléh verklaarde zich nu tot de strijd bereid en in badend in het zweet bewees hij zijn vorst hulde en eer; [staat, hij trok zijn zwaard en keek speurend om zich heen: op Kolonel Bakker had hij het gemunt!

112 Toen betuigde Pangéran Puspawijaya zijn strijdlust, zijn gelaat geleek op een hibiscusbloem; terwijl hij de verheven vorst hulde bracht, sprak hij: "Pangéran Muhammad neem ik voor mijn rekening!"

$113 \mathrm{Nu}$ weer was 't de beurt van Pangéran Wirasentika, een man blakend van strijdlust;

hij sprak, nederig knielend voor Zijne Majesteit:

"Ik ga die vervloekte heidenen te lijf!"

114 Vervolgens trad Pangéran Wiradiwangsa naar voren, elegant en indrukwekkend was zijn houding;

zijns gelijke ware met moeite te vinden in die tijd, hij was alleszins bekwaam voor een vorst van den bloede te verschijnen!

115 Ook Pangéran Puspadiraja liet zich niet onbetuigd, een man van bijna vorstelijke waardigheid;

elegant in zijn bewegingen was hij bij al wat hij deed en innemend was zijn gelaat.

116 Haji Abdulrahim knipte met zijn vingers en sprak, de beide handen omhoog geheven:

"Weest Gij maar niet bevreesd, o Heer, ik zal die Muntinghe op zijn gezicht geven!" 
117 Tenslotte was het Haji Mas Su'ud die zich aanbood voor de strijd, terwijl hij zich voor de voeten van de sultan in het stof wierp:

"Als Uwe Hoogheid het mij gebiedt,

draai ik de majoor de oren van het hoofd!"

118 Vriendelijk glimlachend sprak nu Zijne Majesteit, stralend en met een blos op zijn gezicht:

"Over onze vijanden, die vervloekte ongelovigen, moeten jullie maar geen gekheid maken!

119 In de heilige oorlog te land worden alle zonden jegens God uitgewist: wie van het heilige vuur is bezield behoudt slechts zijn aansprakelijkheid jegens mensen.

120 In de heilige oorlog ter zee wordt zonder hindernis of hapering de ziel door de doodsengel weggehaald en vervolgens door de nimfen des doods ten hemel gevoerd.

121 Dit is het loon van de strijders op de weg Gods: dat al hun zonden hun door God vergeven worden en dat zij zonder ooit vermoeid te raken het water zullen smaken van de Paradijsrivier.

122 En wat betreft de vrouwen die ze achterlaten: als zij vroom en nederig leven, worden ze de eersten onder de hemelnimfen, zwevend in de hemel af en aan."

123 Toen het daglicht was aangebroken, kwamen de woeste krijgers naar buiten: met geweerschoten en sabelhouwen werden Hollanders en Ambonnezen toen afgemaakt.

124 Toen hun opperbevelhebber zag hoeveel Hollanders en Ambonnezen er wel gesneuveld waren, raakte hij buiten zichzelf van woede en ging als een tijger te keer.

125 Het scheepsgeschut vuurde onafgebroken beurtelings van één der beide oorlogsschepen; stroomopwaarts voeren de schepen naderbij en niemand meer vreesde de dood. 
$126 \mathrm{Nu}$ stond Rangga Darpacita op en bracht de vorst zijn eerbiedige hulde; zijn houding was onuitsprekelijk imponerend, toen hij 't geschut op de wallen tot ontbranding bracht.

127 In een oogwenk brandde het kanon los met een zware slag als van de donder; allen die ' $t$ hoorden beefden van schrik, sommigen schreeuwden en dansten in ' $t$ rond.

128 Het schot trof de ra van één der oorlogsschepen en heel veel opvarenden werden gedood; nu 't met de Hollanders en Ambonnezen duidelijk was gedaan, juichten om 't hardst de krijgslui van Palembang.

129 Het vuur werd beantwoord door een oude majoor, die de officier was van de Ambonnezen en Javanen; de kogels kwamen laag in het moerasbos terecht, en twee veldheren van Zijne Majesteit vielen als geloofgetuigen.

130 Toen schoot Temenggung Citradita met een kanon vanaf de vestingwal, in houding de vorst der demonen gelijk: de vlotwoningen der Chinezen kregen de volle laag!

$131 \mathrm{Nu}$ weer schoot kapitein Jonker, met regelmatige tussenpozen dreunde het geschut: van de Palembangers stortten er sommigen dood neer, anderen zochten dekking achter de wallen en hielden zich stil.

132 Dit vuur werd beantwoord door Pangéran Citrawijaya, een man van vorstelijken bloede; lans en zwaard hield hij gereed, niets kon hem overkomen of deren.

133 De kogels vlogen om 't hardst op hun doel af, terwijl zijn vuurwapen donkere rookwolken uitstootte; de schoten weerklonken als het geraas van de storm en vele vijanden stortten ontzield neer.

134 De pangéran schoot met toverkogels; glanzend in korte krullen hing zijn haar, dat geurde als de pinangbloesem; en de gongs en de bekkens dreunden zwaar. 
135 Toen Muntinghe dit alles zag, werd hij razend, zijn bleke gezicht werd van woede rood; heel zijn troepenmacht liet hij aantreden, toen er branders verschenen in overvloed.

136 Terwijl verscheidene vlotten, reeds in brand gestoken,

- de takken en wortels hoog opgetast -

op het schip van Kolonel Bakker afkwamen, juichte het volk en voerden de voorvechters krijgsdansen uit.

137 Toen het vuur naderde met lekkende vlammen, als de heuvel Serila zo hoog, werd Muntinghe uitzinnig van woede en schudden de officieren verbijsterd het hoofd.

138 De schepen deinsden af en sloepen schoten toe om de branders met vaarbomen te keren; sommige bleven overdwars steken, andere gingen voorbij en tenslotte dreven de branders als boomstammen op de stroom verder.

139 Muntinghe schreeuwde met brallende stem, terwijl de schepen onder tromgeroffel stroomafwaarts voeren; voortdurend bestookt, onder een regen van kogels raakten ze zwaar beschadigd, Muntinghe's schepen.

140 Muntinghe, buiten zichzelf van woede, liet het geschut vuren aan één stuk door; de commandanten beval hij waakzaam te zijn als een hond die zijn tanden in een kluif heeft gezet.

141 Terwijl Muntinghe zijn woede niet kon bedwingen, kwam de admiraal rustig met een plan; het bevel van de vlootvoogd luidde: "Stuur een boodschap aan de suhunan!"

142 Een brief werd overgebracht en aangeboden aan de suhunan met het verzoek hem in ontvangst te nemen; de inhoud van de brief stond de vorst niet aan, hij wilde helemaal geen vrede sluiten.

143 "Wij zoeken de vrede", zo heette het, "uit de tijd, dat Uw Grootvader bevriend was met de Koning van Holland en men elkaar geregeld gezantschappen zond, die dan een keur van geschenken meebrachten." 
144 Vlot kwam het antwoord op de brief:

„Wij staan onder Gods bevelen .

Indien het Gode behaagt, zo gelasten wij U naar Muntok te gaan!"

145 Dit antwoord maakte de admiraal razend en op donderdag, 't was de Asyuramaand, om één uur, het als gunstig bepaalde tijdstip, veranderden de schepen en brikken hun koers.

146 De bezetting van de forten was op volle sterkte, de pangérans en hun helpers waren voor de heilige strijd gereed; toen de vloot naderbij kwam, werd hij onder vuur genomen: van de brikken en schepen bleef geen spaander heel!

147 De kogels drongen door tot midden op ' $t$ veld van Kramadiraja, een man van zwierige allure; de Hollanders leken wel dronken of dol, terwijl hun lichaam werd vermorzeld.

148 In Tambakbaya woedde een geweldige strijd, men wist er van geen wijken noch van overgave; de bezetting van het fort was tot de heilige strijd bereid, vertrouwend op de hulp van Gods Almacht.

149 Dat fort was zeer solide gebouwd, de pangérans en hun helpers voelden zich er helemaal op hun gemak, terwijl de admiraal het beschoot uit alle macht, in de mening dat 't zo sterk niet was en wel bezwijken zou.

150 Daar was de oude Pangéran Puspadiraja, die nimmer tekortschoot in de strijd; begeerten of lusten koesterde hij niet, lachend stond hij op de wallen.

151 De pangéran vuurde ontelbare schoten af, die weerklonken hoog in de lucht; duidelijk openbaarden zich de dapperen daar, maar de lafaards waren er ellendig aan toe.

152 Hevig woedde het krijgsgeweld en de aanvoerders juichten luid; keer op keer vuurden zij hun kanonnen af en werden het admiraalsleger zware verliezen toegebracht. 
153 Overal dreven lijken als dorre takken in 't rond, meegevoerd op de stroom als bedwelmde vissen; rood als kesumbasap vloeide het bloed en tal van gewonden kropen op de tast rond.

154 Traag vloeide het water van de rivier, als drakebloed zo rood;

hoe zou de admiraal tevreden kunnen zijn, wanneer hij aan de vele doden onder zijn troepen dacht!

$155 \mathrm{Bij}$ duizenden vielen de knappe soldaten, net als in de oorlog van Generaal Raffles was gebeurd; heel wat verliezen werden door de schrijver geteld, 't leek wel alsof de mannen waren weggeslingerd door de duivel zelf!

156 De admiraal schoot, nauwkeurig mikkend, zonder ophouden en aan één stuk door; hij beval de officieren dichterbij te komen, terwijl Muntinghe dit alles met bezorgdheid gadesloeg.

157 Toen verrees Pangéran Puspakrama, vriendelijk glimlachend en met de allure van de veldheer; in hoofddoek en gordel had hij een granaatappelbloem gestoken, er was in het fort geen tweede als hij!

$158 \mathrm{Hij}$ droeg een groene jas met glinsterend goud doorweven, tussen de borstknopen waren diamanten ingezet; hij bood een aanblik van betoverende schoonheid, zoals hij daar stond, bestraald door 't schitterend zonnelicht.

159 Uitgerust met talisman en amulet bewoog hij zich als de edele Arjuna; terwijl hij zijn zwaard trok met 't gulden gevest, was hij onkwetsbaar voor de aansuizende granaten.

160 De pangéran verrees met een glimlach zo zoet als de gemberdrank of als een overrijpe granaatappel op het fort van Pangéran Anom.

161 Toen de admiraal hem zag, werd hij vreselijk kwaad en steeg hem het bloed naar het hoofd; hij schoot zonder te richten in 't wilde weg, terwijl hij al 't krijgsvolk aantreden liet. 
$162 \mathrm{Al}$ zeilende vuurden de schepen, terwijl men dacht dat het fort uiteenspatten zou; maar door de hulp van de Heer, de Almachtige Koning, was 't juist Muntinghe's krijgsmacht die uiteengeslagen werd!

163 De schepen gaven een onbeschrijfelijk kanonvuur af en wendden de steven naar het eiland Kembara; terwijl de schepen en brikken naderbij kwamen, blaakte men in het fort van strijdlust.

164 Daar verhief zich Pangéran Sutadiwangsa, zich gedragend als een hemeling;

hij schoot onafgebroken aan één stuk door, totdat de krijgsmacht van de admiraal vernietigd was.

165 De pangéran schoot als een geest en hield de kolonel scherp in het oog; toen de admiraal hem zag, was hij zeer verontrust, als was Indra uit de hemel neergedaald.

166 Sumawijaya, een jeugdig pangéran, streed schouder aan schouder met zijn oudere broer; hij hief het vaandel, met bladgoud beschreven, dat nog uit Grootvaders tijd een erfstuk was.

167 Toen het vaandel werd geheven, vol praal en pracht, waren alle mensen met stomheid geslagen; door de Hollanders die 't zagen werd 't als een vredesteken opgevat, maar toen hun sloepen naderden, werden ze hevig beschoten.

168 Terwijl op de sloepen terstond de zeilen werden gehesen, werden ze op een onbeschrijfelijke manier door schrootvuur getroffen; toen sloegen ze een inham in om beschutting te zoeken en zo vluchtten ze weg, al die penjajabs en sloepen.

169 De pangéran schoot als een bezetene, het was een lawaai alsof de wereld verging;

Kolonel Bakker was diep terneergeslagen door de zware verliezen die zijn leger leed.

170 De admiraal werd woedend toen hij 't zag en gaf bevel aan heel zijn troepenmacht van land- en zeestrijdkrachten het fort op 't eiland Kembara met de grond gelijk te maken. 
171 De vijand werd beschoten door Rangga Darpacita, in zijn bewegingen de grootvorst van Danta gelijk; het kanongebulder was oorverdovend en heel Muntinghe's vloot kwam in zicht.

172 Toen loste Temenggung Astrawijaya een salvo, hij, de hoogverheven grootvizier; zijn gelaat was zuiver en glansde, gelijk een kembojabloem.

$173 \mathrm{Nu}$ weer verscheen Rangga Satyagati, zijn baard was wit als de melatibloem; door de hulp van de Heer der Heerlijkheid bleven verwonding en dood hem bespaard.

174 De schepen schoten al laverend en vuurden de kanons af aan stuurboord en aan bakboord; ze bewogen zich als geesten en feeën, allen die 't zagen huiverden van schrik.

175 Het vuur werd beantwoord door Pangéran Suradilaga, in zijn bewegingen een slang of een draak gelijk; zijn kogels vonden een open plek in de verdediging en troffen een schip, dat met koper bepantserd was.

176 De pangéran schoot als een geweldenaar, terwijl hij tegenover tienduizenden tegenstanders stond; met de hulp van de Heer, de Enige, werden Muntinghe's troepen in de pan gehakt.

177 De schepen vuurden alle tegelijk, en bewogen zich als waren het veldheren of legeraanvoerders; Pangéran Sutakesuma beantwoordde het vuur: van de officieren van de admiraal kwamen er vijf om het leven.

178 Die pangéran was een kundig veldheer, kort en gedrongen van lichaamsbouw; als hij parfum en poeder gebruikte, geurde hij als welriekend hout.

179 De admiraal schoot nauwkeurig richtend, de steven naar het eiland Batu gewend; de bezetting van het fort was met stomheid geslagen en van de krijgers van de pangéran werd er één gedood. 
180 Wirasentika, een pangéran van naam, de zoon van Pangéran Wirakesuma, in houding de grootvorst Boma gelijk, hield stand op het eiland Manguntama.

181 Ook daar werd hevig gevochten, de kogels vlogen over de rivier heen en weer; stuitend op de weerstand van grimmige krijgers gingen de troepen van de admiraal hun ondergang tegemoet.

182 Onafgebroken vuurden de schepen in de richting van Pangéran Bupati's fort; de pangéran schoot terug, nauwkeurig mikkend: de commandant werd getroffen en stierf.

183 Het kanonvuur uit Martapura was als een regen van gloeiende kolen; de Hollanders verkeerden in een benarde toestand en Muntinghe trok een gezicht als een aap.

184 De admiraal, die vervloekte ongelovige, laadde het geschut met granaten; terwijl hij dacht dat 't fort bezwijken zou, vielen de kogels neer zonder doel te treffen.

185 De onverschrokken Pangéran Bupati trok zijn zwaard van Khorasans staal: niet alleen dat de Hollanders christenen waren, ze waren bovendien nog soldaten van de Compagnie!

186 Van alle forten brandden de kanonnen los, zodat de heldere hemel verduisterd werd; de vloed kwam op en liep zó hoog, dat het admiraalsschip er bijna in onderging.

187 Toen vuurde Demang Darpayuda, in houding god Narada gelijkend;

hij stond pal, met zijn borst als een vesting, van plan de Hollanders de hals af te snijden.

188 Daar verscheen Pangéran Natadiwangsa, zich gedragend als een hemelbewoner; hij was er op uit zich verdienstelijk te maken, want in zijn hart had hij nog geen vrede gevonden. 
190 Temenggungs en haji's stonden als in gepeins verzonken stil, wachtend op de hulp van de Verhevene en Barmhartige; ze spraken de Naam Gods uit met een toebereid hart, opdat het geloof niet ten onder zou gaan.

191 Hun gebed werd verhoord door de Heer van al het zijnde en met de zegen van heer Kutub-al-sulwan, die zijn leerlingen helpt hun vijand in handen te krijgen, werd de admiraal bijna krijgsgevangen gemaakt.

192 Toen vuurde Sayyid Abdulrahman een salvo af en de admiraal viel in zwijm; door de hulp van de Heer, de Barmhartige Koning, werd Muntinghe's gezicht als van een spook.

193 Die heer schoot in een zeer hoog tempo, terwijl de kleuren van zijn hoofddoek schitterden in de zon; 't was een zeer vreemd schouwspel, zó gretig schoot hij, zoals een knaap drinkt die dorst naar melk.

$194 \mathrm{Hij}$ schoot naar hartelust en vuurrood werd zijn gezicht; aan broers en zusters dacht hij niet, op Muntinghe, die ellendeling, legde hij aan.

195 Sayyid Husin, de commandant van de paleiswacht, vuurde zijn kanon af aan één stuk door;

hij schoot zonder op te houden en menig Hollander stortte dood terneer.

196 Naar alle kanten schoot deze heer, in zijn bewegingen leek hij een danser; allen die hem zagen rilden van angst, een tweede als hij was in 't land moeilijk te vinden.

197 Sayyid Akil bin Muhammad, schoot heel nauwkeurig en precies; hij droeg talismans in zijn hoofddoek en alwie hem zag beefde van schrik.

198 Sayyid Ahmad bin Ali voegde zich bij hem in de strijd, elegant in zijn bewegingen en vastberaden; onbuigzaam was zijn wilskracht, hard als steen, en trouw vervulde hij zijn dagelijkse godsdienstplichten. 
$189 \mathrm{Hij}$ werd door een groot verdriet gekweld, denkend aan zijn vrouw die pas overleden was; bij de gedachte aan een hernieuwde ontmoeting na de dood kende zijn vreugde geen grenzen meer.

$199 \mathrm{Hij}$ schoot openlijk en duidelijk zichtbaar, zijn houding was als van een tijger; zo vuurde hij het kanon "Luister van de Sultan" af, richtend op de vloot van die duivelse Hollanders.

200 Zo schoot men uit alle macht met de kanonnen zonder op te houden; vele doden telde het leger van de Compagnie, de admiraal zag het met onbehagen.

201 Toen weken de schepen en brikken achteruit onder een niet aflatende kogelregen; volkomen vernietigd werd het leger van de admiraal, terwijl de vloot de Kundurrivier opvluchtte.

202 Daar lagen de schepen lange tijd stil, wachtend tot de eb in vloed zou verkeren; er werd geschoten uit alle macht tot 't al bijna donker was geworden.

203 Toen het daglicht weer was aangebroken, stonden ze op, de krijgers van de kundige vorst; ze schoten naar alle kanten, waarop de vloot van de admiraal een goed heenkomen zocht.

204 Onafgebroken vuurden de strijders beurtelings hun kanonnen en draaibassen af; 't was door de hulp van God, de Heer der Ere, dat de aanvoerder van de Siakkers dodelijk getroffen werd.

205 Toen trok de vijand in zijn geheel terug met zijn twee brikken en vijf grote schepen; door onze wakkere krijgers verjaagd vluchtte de vloot naar Salahnama

206 De Chinezen namen de wijk, 't geluk liet hen in de steek, zelfs in hun bedehuis vonden ze geen toevlucht meer; ontelbaar veel Hollanders waren op de vlucht, sommigen bleken gewond, anderen zwaar verminkt te zijn. 
207 Ook de vissers sloegen op de vlucht, met hun hele vloot, terwijl ze door honger en dorst gekweld werden; naar het eiland Lingga werd koers gezet, bedrógen waren ze door Muntinghe, die Hollander!

208 Muntinghe had hun een beloning beloofd, te ontvangen bij aankomst te Palembang; hij zou betalen tien gulden de man, maar, eenmaal in Palembang, beval hij hun te vechten!

209 Duidelijk kon je daar Raja Akil zien, die zich gedroeg als een bosgeest en werkelijk heel erg in de zorgen zat, want wie zijn lusten volgt wordt geplaagd door de duivel!

210 De Palembangers hieven een krijgsgeschreeuw aan, dat daverde daar op de vestingwallen; als dolle olifanten stonden de voorvechters klaar om die leugenachtige heidenen weg te jagen.

211 De pangérans en hun edele helpers traden naar voren om te verdrijven de bevelvoerende admiraal;

Muntinghe was 't met wie men de strijd aan zou binden en Pangéran Dipati die daartoe de opdracht kreeg.

212 Waarlijk vreemd en onbegrijpelijk is de aard van de Siakker!

Dat Raja Akil, die toch wijs en verstandig was, Muntinghe trouw bleef in lief en in leed!

$213 \mathrm{Hij}$ wierp zichzelf in de hel en schepte in de Islam geen vreugde meer; zijn broers en zusters liet hij in de steek om Muntinghe te volgen op het onheilspad.

214 Verdwenen was het geloof uit zijn hart, bij het leger van Satan had hij zich ingelijfd; hij negeerde de geboden der wet, maar in de hel, daar hoorde hij thuis.

215 De suhunan sprak tot de sultan: „Breng de kanonnen over naar het bos! $\mathrm{Nu}$ die Muntinghe zich gedraagt als de duivel, moet men zich verschuilen en zich niet laten zien! 
216 Laat alle manschappen stroomafwaarts gaan naar de forten om zich daar te melden en geef de dienstdoende pangérans met hun helpers bevel de naderende schepen onder vuur te nemen!"

217 Vervolgens werd er op de bekkens geslagen en als eerste vertrok toen Pangéran Bupati; allen ontroerden, toen ze hem weg zagen varen als een pauw die zijn veren tentoonspreidt.

218 Met de gunst van de Enige God vertrokken de mannen bij tienduizenden stroomafwaarts; hun geschreeuw klonk tot hoog in de lucht ten teken dat Muntinghe verslagen zou worden.

219 Twintig dagen daarna ankerde in de riviermond een vloot; opgewonden liep de bevolking heen en weer, maar een gepantserde pencalang voer er heen.

220 't Was Puspadilaga, een pangéran en veldheer wiens weerga in Kadipan niet gevonden werd; edelen en beambten bevonden zich bij hem en als god Brama bewoog hij zich.

221 De mensen van Sungsang stroomden toen Palembang binnen met hun vrouwen en met al hun kinderen; ze boden er hun diensten aan de suhunan aan om met Muntinghe, die opschepper, de strijd aan te gaan.

$222 \mathrm{Al}$ hun huizen waren afgebrand en hun dorp was door struikgewas overwoekerd; Kolonel Bakker vreesde, toen hij dit zag, dat ze 't hem betaald zouden zetten.

223 Daar gingen de schepen, de zeilen gehesen, en zeilden als gold het een spelevaart; vóór de wind liepen zij met een koers als deze, wie 't schouwspel zag, keek er begerig naar.

224 Toen bij 't eiland Bayak de schepen bleven liggen, wachtten de onzen ze al op in het bos; en door hun goedgerichte schoten werden vele Hollandse soldaten gedood. 
225 De schepen waren tenslotte verzeild geraakt in Straat Jaran en wierpen daar het anker uit; maar van de wal af werden ze onder vuur genomen, de schoten dreunden als bij westenwind de golven.

226 Muntinghe was volslagen machteloos en ging als een demon te keer; een zekere Si Gangsa zond hij uit met een officiële brief.

227 Daar ging Si Gangsa met drie makkers, hij roeide zo snel hij kon; op het eiland Borang ontmoette hij Puspadiraja, die uitmuntende pangéran.

228 Daar kwam hij toen te weten dat Pangéran Wirakrama aan boord was van zijn brik met een masagus en vijf makkers.

229 De inhoud van de brief, het verzoek om vrede, werd tenslotte aan de wijze vorst overgebracht; de suhunan raakte ontstemd, toen hij het hoorde: Muntinghe zon weer op list en bedrog!

230 De brief werd beantwoord als volgt: "Wat strookt met Gods gebod is goed! Als $U$ vrede wilt, moeten de schepen gaan; zo niet, val dan maar aan!"

231 Zijne Majesteit sprak en gaf het bevel om alles in orde te brengen: de wapens, de forten, de grachten, dat allemaal, maar bovenal toch het poortgebouw en de kraton.

232 "Laat men aan het bolwerk werken en de levering van palen verhaasten! Laat het paalwerk in de rivier vlug herstellen en de vervaardiging van branders versnellen!"

233 Op dit bevel van de heer der wereld werkte men dag en nacht; palissaden werden verhoogd en grachten uitgediept om de duistere heidenen te keren. 
234 De leiding van 't werk had Pangéran Bupati, die de stad rondging, terwijl men op de bekkens sloeg en steeds maar weer uitriep:

"Werkt toch met hart en ziel!"

235 Zeer nadrukkelijk gaf de pangéran 't bevel: "Alle huisgezinnen leveren stenen!

Breng ze naar 't eiland en gooi ze daar neer!

Dat is de order van Zijne Hoogheid de Koning."

236 Het fort van Pangéran Bupati

was Martapura genaamd;

als men 't nauwlettend bekeek, bleek het zeker waardig

door een bovennatuurlijk begaafd vorst te zijn gemaakt.

237 Het fort van Pangéran Dipati de Jongere

lag dicht bij dat van zijn oudere broer;

't was volledig voorzien van alle middelen

om de Hollandse ongelovigen te weerstaan.

238 Ook in Tambakbaya was een vesting gebouwd, het fort van Pangéran Kramadiraja;

en Pangéran Puspadiraja was in zijn gevolg, schoon van gelaat en gestalte.

239 Op het eiland Kembara deed als wachtpost dienst het fort van Pangéran Kramadilaga; dag en nacht smachtte hij naar de strijd en dacht hij niet meer aan iets anders.

240 Van hoog tot laag was men aan het werk geweest, tussen eiland en vastewal was zelfs een fort van de Chinezen; de planken en alle palen ervoor waren door Demang Jayateruna vervaardigd.

$241 \mathrm{Nu}$ wordt er nog verhaald dat mensen van Sungsang de tijding brachten: Muntinghe staat met al zijn troepen gereed om Zijne Majesteit aan te vallen!

242 Aan de suhunan deelden ze eerbiedig mee:

"Muntinghe is gekomen met een leger, zijn vloot is bij Malang Semirang voor anker gegaan en zeer talrijk zijn zijn troepen! 
$243 \mathrm{Er}$ zijn zes grote schepen en twee brikken met een menigte soldaten: mensen van Ambon en van Java, Buginezen en Baliërs, lui van Buton en Sumbawa, goedlachse klanten zijn het aan boord!"

244 Toen de suhunan dit stellige nieuws had gehoord, sprak hij tot Pangéran Bupati:

"Hou jij die Muntinghe maar goed in het oog; als hij wil vechten, wij wachten hem op!"

245 Bij bekkenslag werd omgeroepen overal in de stad:

"Mensen, komt allen hierheen!

Wij allen bereiden ons voor op de strijd, wij houden stand, vlucht niet!"

246 Van hoog tot laag stroomde het volk toen samen, een bontgekleurde menigte, dicht opeengepakt; men zag er Indiërs en ook Chinezen hun opwachting maken bij hun wijze vorst.

247 Wie de Hollanders was gevolgd moest daarvoor boeten, die zonde was immers heel zwaar; volgens de wet van de Heer der mensen moest zo iemand op het marktplein worden onthoofd.

248 Zo ook de mensen van Muntok die met Muntinghe, die schandelijke heiden, waren meegegaan en niet kennend het verschil tussen goed en kwaad in Palembang als gekken waren te keer gegaan.

249 Die Muntinghe, die Hollandse lafaard, was beslist niet als Major Court;

Lingga en Riau hadden zijn zijde gekozen en alle Chinezen boden hem hun diensten aan.

250 Daar ging niet lang daarna de vloot op de rivier ten anker; men wilde naar het vaderland terug en zeer gedrukt was de stemming.

251 Stroomafwaarts laverend zette de vloot koers in de richting van de monding; een deel van de troepen was gevlucht, wie weet waarheen ze gingen. 
252 In Sungsang aangekomen wierp men het peillood uit en drie schepen moesten op de uitkijk blijven liggen; de bemanning, die door dorst werd gekweld, zocht naar drinkwater in poelen en riviertjes.

253 Toen zeilde de vloot in snelle vaart regelrecht naar de stad Muntok; de manschappen aten brood en kaas en droegen alleen nog maar broek of jas.

254 Muntinghe was nu een gebroken man en ging aan wal met gebogen hoofd; hij ging zitten en wreef zich over de borst, verlangend om naar Holland terug te gaan.

255 De krijgsmacht van Muntinghe zeilde terstond al zwervend naar Java terug; diep terneergeslagen en van zorgen vervuld kwam Muntinghe tenslotte in Jakatra aan.

256 Ten einde is nu het gedicht, dat ik geschreven heb

- ik die traag van begrip en allerminst helder van inzicht ben in de tijd dat Palembang in oorlog was en de admiraal een aanval deed op de stad.

257 Het maken van 't gedicht heeft weinig tijd in beslag genomen: van de tweede tot de vijfde dag van de maand in het jaar twaalfhonderd vijfendertig, gerekend van de hijrah van de Grote Profeet.

258 De admiraal viel, zoals men vertelt, de stad van alle kanten aan; zo begon voor de forten toen de strijd tot de admiraal vluchtte, te schande gemaakt.

259 Het gedicht is ten einde, o heer!

't Dichten was inspannend, 't ging bepaald niet vanzelf; de letterkundigen vraag ik excuus voor de vele vergissingen, uit onkunde begaan!

260 De juiste maat der dingen ken ik niet: op Uw clementie is al mijn hoop nu gericht; omdat ik het dichten pas heb geleerd, hoop ik op aller vergiffenis. 


\section{SLOTBESCHOUWINGEN}

Er hebben in de Maleis-Indonesische archipel vroeger verscheidene grote en kleine min of meer onafhankelijke vorstendommen bestaan waarvan de geschiedenis evenals die van Palembang op een meer of minder uitgebreide wijze in het Maleis is opgetekend en voor het nageslacht bewaard gebleven. Voor een eerste verkenning van deze Maleise geschiedbronnen zijn de gedrukte catalogi waarin het handschriftenbezit in openbare verzamelingen is beschreven, het aangewezen hulpmiddel. Ze zijn niet altijd volledig betrouwbaar en, zoals bij de inventarisatie van de Palembangse handschriften is gebleken, bovendien niet altijd up to date bijgewerkt of aangevuld, zodat men steeds op het bestaan van ongecatalogiseerd materiaal bedacht moet zijn. Naast deze handschriftencatalogi kunnen de hoofdstukken over historische teksten in de Maleise literatuurgeschiedenissen van Hooykaas en Winstedt, ${ }^{1}$ de vooral op Maleisië georiënteerde bibliografie van Bottoms ${ }^{2}$ en verder ook overzichten van de Maleise historische literatuur betreffende één bepaald gebied, zoals dat van Djajadiningrat betreffende $\mathrm{Aceh}^{3}$ en, naar ik hoop, mijn inventarisatie en beschrijving van de Palembangse bronnen, voor zo'n eerste verkenning nuttige informatie verschaffen.

De Maleise historische literatuur zelf is nog slechts ten dele in druk verschenen. Van een aantal geschriften bestaat een met inachtneming van wetenschappelijke normen ingerichte en verantwoorde tekstuitgave, zoals bijvoorbeeld van de kronieken van Kutai, ${ }^{4}$ Banjarmasin, ${ }^{5}$ Brunai, ${ }^{6}$ Aceh, ${ }^{7}$ Pasai, ${ }^{8}$ Patani ${ }^{9}$ en Johor, ${ }^{10}$ en van de rijmkronieken betreffende episoden uit de geschiedenis van Batavia ${ }^{11}$ en Makassar. ${ }^{12}$ Van sommige verhalen is de tekst gepubliceerd zonder dat daarbij naar een wetenschappelijke behandeling werd gestreefd. Ik denk hierbij aan de verschillende tekstedities van de Sejarah Melayu, aan uitgaven van de Pérakse kroniek Misa Melayu, ${ }^{13}$ aan de publikatie van de kronieken van Kedah, Johor, de Riau-Lingga archipel en van rijkjes in WestBorneo, ${ }^{14}$ aan de publikatie van een vorstenlijst van Aceh, ${ }^{15}$ aan de Balai Pustaka-uitgave van een geschiedenis van het Benkoelense vorstenhuis. ${ }^{16}$ Van andere kronieken beschikken we slechts over een 
vertaling of een vrije al dan niet verkorte weergave in een westerse taal. Deze zijn met name te vinden in de negentiende-eeuwse afleveringen van de Nederlandse en Engelse tijdschriften op het gebied van de "Indische taal-, land- en volkenkunde" en zijn vaak te danken aan de taalkundige werkzaamheid van koloniale bestuursambtenaren, die uit de aard van hun beroep een levendige belangstelling hadden voor de geschiedenis van de door hen bestuurde gebieden. Ik noem in dit verband de bijdragen betreffende Midden-Sumatra ${ }^{17}$ en de Sumatraanse rijken Aceh, ${ }^{18} \mathrm{Jambi}^{18}$ en Minangkabau, ${ }^{20}$ de Borneose vorstendommen Sambas ${ }^{21}$ en Brunai, ${ }^{22}$ en het eiland Banka ${ }^{23}$ en voorts betreffende gebieden buiten de eigenlijke Maleise wereld, zoals de Preanger ${ }^{24}$ en de Minahassa. ${ }^{25}$

Is er op het gebied van de catalogisering en de publikatie van het handschriftelijk materiaal dus nog veel te doen, het onderzoek van de historische teksten zelf, zowel filologisch en literair als historisch en cultureel-anthropologisch, is nog maar nauwelijks op gang gekomen. Een dergelijk onderzoek zou eigenlijk volgens de methode van de "comprehensive approach" vanuit verschillende disciplines, in het bijzonder de filologie, de literatuurwetenschap, de geschiedwetenschap en de anthropologie, tegelijk moeten worden aangepakt. Een voorbeeld van zo'n multidisciplinair onderzoek vinden we in de door Teeuw en Wyatt gemeenschappelijk verzorgde uitgave van de Hikayat Patani. Andere in dit opzicht belangwekkende studies op het gebied van de Maleise historiografie zijn de dissertatie van Ras over de Hikayat Banjar en het opstel van De Josselin de Jong over de Sejarah Melayu. ${ }^{26}$ In de hier vermelde publikaties is een karakteristiek van de behandelde tekst en daarmee tevens een eerste aanzet gegeven tot een typologie van de Maleise historiografie. Op die manier wordt het inzicht in de verhouding van de verschillende teksten onderling uitgebreid en verbeterd, zodat het uiteindelijk mogelijk zal zijn de teksten in een algemeen Maleis historiografisch kader te plaatsen.

In dit slothoofdstuk zal ik proberen tot een zekere karakteristiek van elk der vier in dit boek gepubliceerde teksten te komen. Van de elementen waaruit de karakteristiek van de tot ver in het "legendarische" verleden teruggrijpende geschiedverhalen van Sejarah Melayu, Hikayat Banjar en Hikayat Patani is opgebouwd, vinden wij in de Palembangse kronieken, die zich met negentiende-eeuwse geschiedenis bezighouden, niets terug. Dat maakt een vergelijking van die vier Paleembangse teksten met de bovengenoemde kronieken van andere Maleise staten 
weinig zinvol. Zo'n vergelijking zou wel passen in een tekstuitgave van KI 1-3, KI 4 of UBL 3, waarin verscheidene gegevens en motieven uit de Maleise en de Javaanse historische traditie zijn verwerkt of zelfs zoals in KI 1 het geval is - een hele passage uit het eerste gedeelte van de Sejarah Melayu is opgenomen. Bij de beschrijving van deze handschriften in hoofdstuk II heb ik reeds op enkele parallelen met de Maleise en Javaanse overlevering uit andere bron gewezen. $\mathrm{Er}$ is, zoals in KI 1 expliciet wordt vermeld, voor wat het Sejarah Melayu-verhaal betreft weliswaar van rechtstreekse ontlening sprake, maar daarmee wordt tegelijkertijd de Maleise historische traditie tot grondslag van de Palembangse geschiedenis verklaard. Ook de Palembangse geschiedenis wortelt daardoor in de gemeenschappelijke Maleise oermythe van Puteri Tunjung Buih ${ }^{27}$ en steunt op het oorspronkelijke contract tussen vorst en volk, tussen de van elders gekomen Sri Tribuana (Sang Suparba) en de vertegenwoordiger van de autochtone bevolking Demang Lébar Daun. ${ }^{28}$ Daarnaast wordt in deze teksten en bijvoorbeeld ook in de met het Arya Dilah-verhaal uitgebreide genealogieën van KI 8 en UBL 2 aan de Javaanse invloed op de loop der Palembangse geschiedenis een beslissende rol toegekend. Een voorname plaats wordt in deze Palembangse teksten verder ingenomen door anekdotische verklaringen van geografische namen en van de namen van tot de rijksinsignia behorende magisch krachtige wapens, door gegevens over hofgebruiken en over de structuur van de adel, door allerlei adatvoorschriften tenslotte, allemaal zaken die ook wel in andere Maleise kronieken een rol spelen.

Een andere karaktertrek van de Maleise historiografie die in KI 1-3, KI 4 en UBL 3 duidelijk aan de dag treedt, is het feit dat de geschiedenis primair dynastieke geschiedenis is en dat het grondpatroon van zo'n Maleise kroniek wordt gevormd door de dynastieke genealogie. ${ }^{29}$ En zo zullen er bij nader onderzoek waarschijnlijk nog wel meer voor de typologie van de Maleise historiografie interessante karaktertrekken in de Palembangse geschiedschrijving over de oudere tijd te onderkennen zijn.

Voor een karakteristiek van de teksten waarmee wij ons in dit boek in het bijzonder hebben beziggehouden en die uitsluitend op de latere geschiedenis van Palembang betrekking hebben, leveren de bovengenoemde criteria dus geen aanknopingspunt op, evenmin als bijvoorbeeld de islamisering, een uiteraard ingrijpend gebeuren, dat in de kronieken van sommige Maleise staten, zoals bijvoorbeeld in de Hikayat Patani ${ }^{\mathbf{3 0}}$ en in de Hikayat Marong Mahawangsa ${ }^{31}$ uitdrukkelijk wordt gememoreerd. De Palembangse teksten UBL 7, TR 1, UBL 9 en MP 4a/4b zullen daarom aan andere criteria getoetst moeten worden. In de nu 
volgende karakteristiek zal met name worden gelet op zaken als historische betrouwbaarheid, objectiviteit en volledigheid, politiek en godsdienstig besef en engagement, stilistische en literaire vormgeving en compositie.

\section{$U B L 7$}

Deze kroniek begint met een inleiding van twee pagina's. Daarin deelt de auteur, die zijn identiteit op geen enkele manier openbaart, mede dat hij de gegevens voor zijn tekst zowel aan schriftelijke als mondelinge overlevering ontleend heeft. Hij bestempelt deze tekst uitdrukkelijk als hofkroniek, als geschiedenis van het Palembangse sultanaat, ook wanneer hij de verschillende oorzaken bespreekt die in het verleden van het sultanaat tot troonopvolging hebben geleid.

$\mathrm{Na}$ deze inleiding wordt in elf bladzijden uitvoerig stilgestaan bij de laatste jaren van de successieoorlogen na de dood van Sultan Muhammad Mansur (ca 1720-1723). De daarop aansluitende regeringsperioden van de sultans Mahmud Badaruddin I (ca 1724-1757), Ahmad Najamuddin I (ca 1757-1776) en Muhammad Baha'uddin (ca 1777-1804) worden vervolgens afgedaan met niet meer dan respectievelijk twee en een halve, anderhalve en vier pagina's, zodat het overgrote deel van de kroniek (achtenvijftig van de negenenzeventig pagina's) gereserveerd blijft voor het tijdvak 1804-1825. Daarin zijn de Engels-Nederlandse rivaliteit in de archipel, de daarmee samenhangende strijd om de macht tussen Sultan Mahmud Badaruddin II en zijn jongere broer Ahmad Najamuddin II en voorts de Nederlandse militaire acties tegen Palembang de voornaamste factoren waardoor de loop van de Palembangse geschiedenis wordt bepaald. Een geschiedenis die tenslotte uitloopt op de volledige liquidatie van de Palembangse souvereiniteit en de verbanning van de laatste telg uit het regerende vorstengeslacht naar Banda.

Wat de periode ca 1720-1804 betreft, die overigens buiten het bestek van ons onderwerp valt, is het belangwekkend dat de eerste vier jaren van dit tijdvak in verhouding tot de rest hier wel bijzonder breed worden uitgemeten. Trouwens, ook in UBL 3 nemen deze en de onmiddellijk daaraan voorafgaande jaren een voorname plaats in, terwijl we in de onvoltooid gebleven kroniek KI 5 een uiterst gedetailleerde beschrijving van het eerste gedeelte van de onrustige tijd na Sultan Mansurs dood (ca 1714-1720) aantreffen. De strijd om de troon tussen de zoons van deze sultan vormt een kritieke episode in de geschiedenis van het Palembangse vorstenhuis en is daarom een zaak van groot politiek gewicht. 
Dat de kroniekschrijver, voor wie geschiedschrijving immers dynastieke geschiedschrijving betekent, aan deze episode veel meer aandacht besteedt dan aan de rustige tijden daarna onder de elkaar regelmatig opvolgende vorsten, is dus wel verklaarbaar.

Veruit het uitvoerigst wordt overigens het meer recente verleden door de kroniekschrijver behandeld. Dat is begrijpelijk. Hij en zijn informanten staan er 't dichtst bij of hebben die tijd zelfs geheel of gedeeltelijk persoonlijk meegemaakt. Het is bovendien een bij uitstek bewogen tijd, waarin het voortbestaan van de dynastie zelf voortdurend op het spel staat.

Ten aanzien van het gedeelte van de kroniek dat deze periode behandelt (pp. 22 v.v.) valt het volgende op te merken.

De weergave der gebeurtenissen wordt gekenmerkt door een grote mate van evenwichtigheid, onpartijdigheid en nauwkeurigheid. De auteur, die zelf in zijn inleiding zegt zijn gegevens terdege geordend te hebben, is er inderdaad in geslaagd een chronologisch goed geordend en veelal logisch samenhangend geschiedverhaal op te stellen, al is de stof niet overal even intensief behandeld. Zo zijn de berichten over de laatste jaren van het Engelse "tussenbestuur" schaarser dan over de tijd daarvoor en daarna. Dit houdt ongetwijfeld verband met de geringe activiteit die dit bestuur, dat zijn hoofdzetel niet in Palembang maar in Muntok op Banka had gevestigd, in afwachting van de opdracht tot teruggave der koloniën aan de Hollanders toen nog aan de dag legde. Deze samenhang vormt op zichzelf weer een illustratie van het feit dat de invloed van buitenlandse machten op de binnenlandse aangelegenheden van Palembang ook door de Palembangse geschiedschrijver van beslissende betekenis wordt geacht; een feit dat eveneens gedemonstreerd wondt door de ruime aandacht die aan de strijd tegen de Hollanders wordt besteed.

De verteltrant is over het algemeen zeer gelijkmatig maar daardoor ook vlak. De figuren die in de geschiedenis een rol spelen worden zelden sprekende ten tonele gevoerd en dialogen blijven tot slechts enkele gevallen beperkt. Het relaas der gebeurtenissen wordt nergens onderbroken en verlevendigd door anekdoten of bijzondere voorvallen, die op de loop der geschiedenis misschien weinig invloed uitoefenen, maar die aan de feiten wel meer kleur en diepte geven en daardoor toch ook weer waardevolle achtergrondinformatie kunnen verschaffen. Wel worden wij tweemaal (p. 61 en pp. 68-69) onthaald op een literaire uitbeelding van het oorlogsgeweld in de strijd om Palembang, achtereenvolgens in 1819 en 1821, maar de daarbij gebruikte beelden en vergelijkingen zijn 
weinig origineel; zij behoren veeleer tot het vaste, conventionele arsenaal van in de Maleise literatuur gebezigde stilistische hulpmiddelen.

Wij zouden de kroniekschrijver echter te kort doen, als we het bij deze algemene typering zouden laten. De schrijver moge dan weinig blijk geven van een creatieve fantasie, hij is wel degelijk in staat tot een logisch juiste analyse van de feiten en hier en daar ook tot een goede weergave van de motieven en overwegingen die aan die feiten ten grondslag liggen.

Enkele passages waarin die positieve kwaliteiten in het bijzonder tot hun recht komen zijn bijvoorbeeld:

1) de beschrijving van de voorbereidingen die de Engelsen hebben getroffen voor hun aanval op Batavia, de dialoog tussen hen en de Palembangse gezanten over de houding die Palembang in het BritsHollandse conflict het beste zou passen (p. 24) en vooral de daarna volgende passage, waarin een helder inzicht wordt gegeven in de tactische overwegingen aan Palembangse kant om de uitslag van de strijd om Batavia af te wachten alvorens tot actie tegen de Hollandse vestiging ter plaatse over te gaan (pp. 25-26);

2) het sobere relaas van de overval op de Hollandse loge in Palembang in aansluiting op het ooggetuigeverslag van de val van Batavia (pp.27-28) en tenslotte de onthullende mededelingen van de Engelse spionnen van Arabischen bloede zowel omtrent het tijdstip waarop de overval in feite was gepleegd als over het lot dat de bezetting van de loge uiteindelijk had getroffen, nadat kort tevoren het gezantschap van de sultan de officiële Palembangse lezing van het gebeurde had verkondigd (p. 30);

3) het subtiele en niet minder logische onderscheid dat gemaakt wordt tussen de eerste en de tweede verklaring van de oude sultan, door hem afgegeven met het oog op de eventuele installatie door Gillespie van zijn jongere broer als sultan in zijn plaats (p. 35);

4) de levendige beschrijving van hetgeen zich de dag na aankomst van Salmond uit Benkoelen in Palembang afspeelde tussen de aanhangers van de door de Engelsen gesteunde jonge sultan enerzijds en de volgelingen van de oude sultan, geholpen door de soldaten van het Hollandse garnizoen, anderzijds, met als inzet de tussen de beide kratons in gehesen Engelse vlag (pp. 48-49).

Uit niets blijkt dat de auteur zijn kroniek heeft geschreven in opdracht van de nazaten van het Palembangse vorstenhuis - ook dit geschiedverhaal is pas teboekgesteld, nadat het sultanaat zijn politieke zelf- 
standigheid volledig heeft verloren ${ }^{32}$ - dan wel in opdracht van een vertegenwoordiger van het Nederlandse bestuur. Zo dit niettemin het geval mocht zijn geweest, dan heeft hij zijn onafhankelijkheid als auteur uitstekend weten te bewaren. Hij kiest in geen enkel conflict partij, ook niet in dat van de oude sultan Mahmud Badaruddin II met zijn jongere broer Ahmad Najamuddin II; zelfs naar welke zijde zijn sympathie uitgaat, worden we niet gewaar. De neutraliteit van de auteur is een goede waarborg voor een objectieve berichtgeving en verhoogt de historische betrouwbaarheid van de kroniek. Geen spoor is hier te vinden van een geschiedbeschouwing volgens welke de beschrijving van het verleden vooral dient om het gezag van de dynastie de gewenst geachte sanctie te verlenen, zodat alles wat daartoe niet dienstig lijkt angstvallig uit de beschrijving wordt geweerd en slechts overblijft de geruststellende wetenschap dat, zoals Edel het met betrekking tot de Javaanse historiografie uitdrukt, "het verleden zich heeft gedragen, zoals het zich volgens het levensinzicht van den schrijver behoorde te gedragen". ${ }^{33}$

De objectiviteit van de berichtgeving gaat hand in hand met de nauwkeurigheid ervan. De auteur blijkt meestal goed op de hoogte, zowel van hetgeen er aan Palembangse kant gebeurt als van wat er van Britse en Hollandse zijde wordt ondernomen. De door hem vermelde feiten en ook de daarbij soms gegeven datering stemmen over het algemeen overeen met wat terzake uit Europese bronnen bekend is. Ook aan de chronologie, vaak het zwakke punt in de Maleise geschiedschrijving ${ }^{34}$ wordt door de schrijver steeds consequent de hand gehouden. Of en in hoeverre het schriftelijk en mondeling bronnenmateriaal dat hem ter beschikking stond, hem onderling tegenstrijdige gegevens opleverde, waarin hij zelf een keuze moest doen, valt slechts te gissen. Uit het resultaat blijkt in elk geval dat zijn kritisch vermogen hem in de meeste gevallen de goede weg heeft gewezen en dat hij uiteindelijk zoal niet een waar verhaal dan toch een aannemelijk verhaal heeft weten te vertellen.

Dat zijn inlichtingen niet beperkt zijn gebleven tot de gebeurtenissen in eigen stad en land blijkt uit de berichten uit Batavia, zoals bijvoorbeeld op pp. 63-64. Berichtgevers waren er trouwens genoeg; de kroniek zelf maakt melding van het bestaan van handelscontacten overzee en van het verblijf van Palembangers in Batavia. Veel overvloediger is uiteraard de informatie van dicht bij huis. Deze levert soms ook wel nieuwe gegevens op, die men in de westerse bronnen tevergeefs zal zoeken en die soms nader onderzoek verdienen. Dit nieuws omvat zowel zaken die de verhouding met Engelsen en Hollanders raken, zoals de 
bemiddelingspoging van de latere Pangéran Kramadiraja in het conflict van de oude sultan met de Engelsen in 1813 (p. 39), het verzoek om wapenstilstand van Muntinghe in 1819 (p. 57) en het briefverkeer per fles over de rivier tussen de sultan en De Kock in 1821 (p. 67), als ook gegevens van meer lokale betekenis, zoals de namen van de commandanten van de verschillende verdedigingswerken in en rondom Palembang in 1819 en 1821 (pp. 58-59 en 66) of - op diverse plaatsen van adellijke en ambtelijke personen die in de geschiedenis een rol hebben gespeeld.

Vanzelfsprekend is het mogelijk dat de schrijver in bepaalde gevallen, waar hij omtrent de werkelijke achtergrond der feiten in het duister tast, die feiten met andere dan de werkelijke oorzaken en beweegredenen in verband brengt en daaraan vervolgens een eigen interpretatie geeft. Dat gebeurt uiteraard vooral, wanneer het gaat om het politieke beleid van Engelsen en Hollanders. Voor zover de schrijver daarbij niet alleen zijn eigen mening geeft, maar tegelijkertijd de officiële Palembangse visie vertolkt, illustreren deze gevallen het in de gegeven conflictsituatie voor de hand liggende optreden van misverstanden tussen de vertegenwoordigers van twee partijen, die in zo vele opzichten van elkaar verschilden. Waartoe een dergelijk misverstand, zij het niet als enige noch zelfs als hoofdoorzaak kan leiden, ziet men aan de moord op de bezetting van de Hollandse factorij in 1811, waaraan Raffles volgens een weliswaar eenzijdige maar niet volstrekt onmogelijke "Palembangse" interpretatie van zijn brieven aan de sultan en door de levering van geweren en munitie aan Palembang tevoren impliciet zijn goedkeuring zou hebben gehecht. Een goed voorbeeld van zo'n Palembangse interpretatie vinden we in het aanbod van de sultan om zijn eigen kraton van de Engelsen te kopen tegen de prijs van 400.000 rijksdaalders (p. 40) en de voorstelling van zaken als zou Pangéran Ratu door Robison worden meegenomen naar Batavia om het Engelse opperbestuur te bedanken voor het feit, dat zijn vader weer in genade was aangenomen (p. 41), terwijl volgens de Engelse tekst van het verdrag dat Robison op 29 juni 1813 in Muara Rawas met de sultan heeft gesloten de betaling van dit bedrag door de sultan moet dienen ter vergoeding van de onkosten van de militaire expeditie tegen Palembang onder Gillespie in 1812 en het vertrek van Pangéran Ratu naar Batavia zijn terbeschikkingstelling aan het gouvernement ten doel heeft, omdat hij als verdachte wordt beschouwd in de zaak van de moord op de Hollanders in 1811. Toch bewijst dit voorbeeld tegelijkertijd, hoe dicht de auteur de werkelijkheid heeft benaderd. Want ten eerste zijn aan de totstandkoming van het 
verdrag langdurige onderhandelingen tussen de sultan en Robison voorafgegaan, waarbij de sultan - ook volgens berichten uit Engelse bron ${ }^{35}-$ betaling aanbood voor zijn eventueel herstel op de troon en dus indirect voor zijn terugkeer in de grote kraton, terwijl Robison hem slechts een ambteloos bestaan onder Britse bescherming wilde verzekeren; en ten tweede zou behalve Pangéran Ratu nog een andere zoon van de sultan samen met twee hoge ambtenaren naar Batavia worden gezonden, feitelijk als gijzelaars maar volgens de letter van het verdrag "to do homage to the Java Government", zodat vereenzelviging van de verschillende motiveringen die aan de opzending van de beide pangérans werden gegeven, wel zeer voor de hand ligt.

Samenvattend zou ik UBL 7 willen karakteriseren als een historisch betrouwbare beschrijving van een aantal belangrijke episoden uit de Palembangse geschiedenis, waarbij het accent ligt op het tijdvak 18181825.De beschrijving heeft alleen betrekking op de min of meer officiële gebeurtenissen en gaat geheel voorbij aan bijzonderheden van meer persoonlijke aard. Het verhaal is chronologisch en logisch goed opgebouwd; het heeft een formele inleiding, maar eindigt enigszins abrupt, is althans niet met een colofon afgesloten. De stijl is koel-beschrijvend, sober en weinig levendig, geheel in overeenstemming met het kroniekachtig karakter van het verhaal.

\section{$T R 1$}

Over deze kroniek is behalve in hoofdstuk II ook in het vergelijkend overzicht van de kronieken UBL 5/MP 2 en TR 1, dat achter de vertaling van de tekst is opgenomen, reeds het een en ander gezegd. Daarom beperk ik mij hier tot een enkele opmerking over de indeling, de stijl en de historische betrouwbaarheid van deze kroniek in vergelijking tot UBL 7.

TR 1 opent zonder enige inleiding, toelichting of verantwoording met de incomplete en chronologisch waarschijnlijk incorrecte lijst van $\mathrm{Pa}$ lembangse vorsten en laat vervolgens het kroniekverhaal zelf beginnen op het moment van de verovering van Palembang door de Engelsen in 1812.

Dan volgt een summiere en historisch vaak onbetrouwbare beschrijving van de tijd van het Engelse tussenbestuur. Ook de eerste maanden na het herstel van het Nederlandse bestuur worden nog uiterst beknopt en bovendien veelal onjuist beschreven. Feiten en personen worden hier soms zo ernstig verward of verwisseld en de chronologische volgorde 
blijkt wel eens zozeer verstoord, dat men de indruk krijgt dat de auteur voor deze hele periode uitsluitend op een aantal losse onsamenhangende gegevens aangewezen is geweest.

Met de beschrijving van de tocht van Muntinghe naar het binnenland, waarbij overigens abusievelijk de beide, met een tussenpoos van enkele maanden gemaakte reizen als één reis worden beschouwd en behandeld, komt er meer orde in het verhaal en treedt ook de parallellie met UBL 7 aan de dag.

Tegelijkertijd wordt de beschrijving uitvoeriger, op verscheidene plaatsen zelfs uitvoeriger dan die van UBL 7. Dit geldt met name voor het laatste jaar van het behandelde tijdvak, waarin de opstand van Sultan Prabu Anom tegen het Nederlandse gezag het belangrijkste nieuws oplevert.

Dit betekent dat TR 1 hier en daar waardevolle informatie verschaft die in UBL 7 ontbreekt. Deze heeft in de eerste plaats betrekking op feiten en gebeurtenissen van overwegend lokaal belang, zoals bijvoorbeeld het verslag van de overwinningsfeesten die in Palembang werden gehouden na de aftocht van Muntinghe in juni 1819 (p. 16) en na de nederlaag van Wolterbeek eind oktober 1819 (p. 20), de flash-back betreffende de geheime missie van Husin Dia'uddins echtgenote naar Palembang in 1821 (p. 24), de mededelingen over het optreden van Pangéran Jayaningrat na de verovering van Palembang in 1821 en over zijn rancuneuze houding tegenover zijn vader, Suhunan Husin Dia'uddin (pp. 33 en 35), het relaas van de gebeurtenissen die zich rondom de opstand van Sultan Prabu Anom tegen het Nederlandse gezag in 1824 hebben afgespeeld (pp. 36-40) en tenslotte het korte verslag van de berechting van de medeplichtigen aan die opstand (p. 43). Deze en dergelijke inlichtingen zijn waardevol, omdat zij bijdragen tot een beter inzicht in de hofgebruiken en de interne verhoudingen aan het Palembangse hof van die tijd, maar ook in de soms subtiele afweging van vaak sterk persoonlijk gerichte belangen die aan de politieke besluitvorming ten grondslag ligt.

Daarnaast vinden we soms bijzonderheden vermeld die op de houding van Palembang ten opzichte van de Hollanders van invloed kunnen zijn geweest of nader licht werpen op de verhouding tussen beide.

Ik noem hier:

1) het protest van de sultan over het feit dat de Hollandse soldaten vóór het uitbreken van de vijandelijkheden in juni 1819 één van zijn horigen zouden hebben doodgeschoten (p. 10), een incident dat de sultan ernstig genoeg acht om een gezantschap naar Muntinghe 
te zenden. Misschien is hier wel sprake van hetzelfde voorval dat de sultan later, in zijn brief aan Wolterbeek van 15 oktober 1818 (ARA 1) waarin hij zich beklaagt over het onbetamelijke gedrag van de Hollanders, memoreert met de woorden: “. . s sampai serdadu membedil orang Palémbang, lalu mati diatas kita punya jambatan";

2) de vredesonderhandelingen tussen De Kock en Pangéran Dipati de Oudere (de latere Pangéran Bupati Panembahan) na de nederlaag van Palembang in 1821 (pp. 29-30);

3) de plechtige installatie in 1821 van Husin Dia'uddin op de troon in de plaats van zijn afgezette broer Mahmud Badaruddin (pp. 31-32);

4) het bezoek van Pangéran Jayaningrat aan Batavia als gezant van de Suhunan om bij de Gouverneur-Generaal een geldlening aan te vragen in verband met de bouw van een stenen loge voor de Hollanders na de verovering van Palembang in 1821 (p. 34).

In enkele andere gevallen bestaat de extra informatie van TR 1 slechts uit een nadere uitwerking van in het kort ook in UBL 7 vermelde gegevens of een aanvulling daarvan met geografische- en persoonsnamen. Deze gevallen doen zich voor, wanneer (p. 15) melding wordt gemaakt van het door de Hollandse berichten bevestigde feit dat er tengevolge van het afdrijven van de "branders" die bij de vijandelijkheden van juni 1819 op de Hollandse vloot waren losgelaten, langs de rivieroever en met name ook in het Hollandse hospitaal brand is uitgebroken, of wanneer er bij de bestuursoverdracht zowel van 1818 als van 1821 wordt aangetekend dat de sultan een aantal met name genoemde apanagegebieden voor zichzelf wil behouden (pp. 7 en 35), en ook wanneer er na de troonsbestijging van Suhunan Husin Dia'uddin in plaats van vier, zoals in UBL 7, tweeëntwintig naamsveranderingen worden opgegeven (pp. 32-33). Soms ook wijkt de lezing van TR 1 af van de lezing van UBL 7 en UBL 5/MP 2 of voegt daaraan een detail toe waaruit een zekere bekendheid van de auteur met verhoudingen en gebruiken aan Nederlandse zijde blijkt. Ik doel hier op passages als op p. 13, waar gezegd wordt dat de Hollanders in plaats van bijlen een grote boor gebruiken om de kratonpoort te forceren; pp. 17-18, waar Koning Willem I als chef van de Gouverneur-Generaal ten tonele wordt gevoerd; p. 23, waar sprake is van het verlijden van de in 1821 door de Gouverneur-Generaal met Husin Dia'uddin gesloten overeenkomst ten overstaan van een rechtscollege, waarmee wellicht de bekrachtiging van die overeenkomst door de Raad van Indië bedoeld wordt.

Bij de beoordeling van de historische betrouwbaarheid van de bericht- 
geving in TR 1 blijft voorzichtigheid geboden, al blijven anachronismen en andere ernstige vergissingen na de eerste bladzijden tot een enkel geval beperkt, zoals bijvoorbeeld op p. 14 v.v., waar de auteur de korvet "Ajax" verwart met de hulk "Nassau", die niet in 1819 maar eerst in 1821 op het toneel verschijnt (de "Nassau" wordt in TR 1, p. 27, "Kerambang" en even later "Rambang" genoemd). Datering treffen we slechts tweemaal aan, namelijk met betrekking tot de expeditie onder Generaal De Kock en de opstand van Sultan Prabu Anom. Beide dateringen zijn correct.

De auteur presenteert zich tenslotte nog als een goed moslim, die zijn godsdienstige overtuiging ook in zijn geschiedschrijving laat meespreken: er wordt vóór de strijd veelvuldig gebeden (pp. 19, 28 en 38), het kanon Seri Palémbang wordt belezen met de woorden van de yasin, de zesendertigste soera van de Koran (pp. 19 en 28), en de gebeurtenissen vinden plaats overeenkomstig Gods Wil (pp. 28 en 37).

Het meest karakteristieke aspect van TR 1 zijn echter de stilistische kwaliteiten van de tekst. De auteur beschikt over een goed waarnemingsen voorstellingsvermogen; hij kan goed vertellen, formuleert over het algemeen helder en heeft daarbij oog voor het logisch verband der dingen. Deze positieve hoedanigheden treden in verscheidene passages duidelijk aan de dag. Als voorbeelden noem ik:

1. De passage betreffende de Hollandse landingsmanoeuvre en het verdere verloop van de strijd in juni 1819 (pp. 13-15).

2. De onmiddellijk daarop volgende beschrijving van de overwinningsfeesten (p. 16).

3. De suggestieve uitbeelding van het postverkeer tussen Wolterbeek en de sultan in 1819 (p. 18).

4. De boeiende beschrijving van de terugkeer van de zegevierende Palembangse troepen uit de forten naar de kraton en hun feestelijke ontvangst aldaar (pp. 19-21).

5. Het met dialoog verlevendigde relaas van de onderhandelingen te Batavia over het eventuele herstel op de troon van de sultan in ballingschap (pp. 22-23).

6. De nauwkeurige en zeer directe weergave van de manier waarop Generaal De Kock en de sultan in 1821 met elkaar corresponderen (p. 25).

7. Het levendige verslag van de eerste gevechten bij de Plaju (pp. 25-26).

8. Het boeiende verhaal van de opstand van Sultan Prabu Anom in 1824 (pp. 36-40). 
$U B L 9$

Deze tekst is ons overgeleverd als een voortzetting van de Hikayat Marsekalek, een met wijsgerige en godsdienstige uitspraken doorspekte verhandeling over het optreden van Maarschalk Daendels op Java. Hoewel de tekst naar de vorm zonder enige onderbreking, inleiding of verantwoording bij de Maarschalkgeschiedenis aansluit, is er wat de inhoud betreft van aansluiting geen sprake en vormt ons tekstgedeelte een op zichzelf staand relaas van de gebeurtenissen in Palembang tijdens de jaren 1811-1813 en 1818-1819, dat met het daaraan voorafgaande niets te maken heeft.

Dit Palembangse deel van het handschrift nu begint met het verhaal, dat Raffles een commissie naar Palembang stuurt om uit te vissen wat er na de val van Batavia met de Hollandse loge in Palembang gebeurd is (november 1811) en is verder voor het overgrote deel gewijd aan de jaren 1812-1813 (pp. 42-88). Over het tijdvak 1814-1817 wordt niet meer gezegd dan dat "de jonge sultan" in die tijd aan het bewind is. De rest van de tekst (pp. 88-95) handelt over de jaren 1818-1819 om tenslotte te eindigen met de vermelding van de aankomst van de Hollandse vloot onder De Kock voor de monding van de Palembangrivier (17 mei 1821).

Deze tekst neemt ten opzichte van de andere Palembangse teksten, zoals UBL 7 en TR 1, een onafhankelijke positie in en vertoont een volstrekt eigen karakter. Om te beginnen worden de gebeurtenissen, voor zover ze ook in die andere teksten zijn beschreven, hier op een zo heel andere manier verteld, dat van ontlening of van het gebruik van gemeenschappelijke bronnen geen sprake kan zijn geweest. Maar bovendien nemen de desbetreffende passages niet meer dan een derde deel van de tekst in beslag en zijn dus sterk in de minderheid bij de passages over feiten die in de andere teksten niet worden beschreven maar die klaarblijkelijk de hoofdschotel van deze tekst uitmaken, een hoofdschotel die voornamelijk uit ingrediënten van eigen, Palembangse bodem bestaat, op kundige wijze is toebereid en met smaak wordt opgediend.

Dit brengt ons vanzelf op het eigen karakter van de tekst. De Palembang-tekst uit UBL 9 vertoont namelijk veel meer het karakter van een ooggetuigeverslag dan van een na raadpleging van de beschikbare bronnen doelbewust geredigeerd en evenwichtig opgebouwd kroniekverhaal, zoals de teksten van UBL 7 en TR 1 te zien geven. Dit karakter komt zowel formeel als inhoudelijk tot uiting.

Van de formele aspecten is het veelvuldig voorkomen van dialogen 
in de tekst wel het meest opvallende verschijnsel. Daarnaast is ook de manier waarop de chronologie in de geschiedenis wordt aangegeven eerder kenmerkend voor de verslaggever dan voor de kroniekschrijver. De schrijver bedient zich namelijk van aanduidingen als "niet lang daarna", "na verloop van enige tijd" of exacter: "twee maanden later", "na tien dagen", "na een uur", en, behoudens de overigens volkomen onjuiste datering van Mahmud Badaruddins vlucht uit Palembang na de aanval van Gillespie (p. 46), nooit van formele data of jaartallen.

Naar de inhoud blijkt het karakter van het authentieke ooggetuigeverslag in positieve zin uit de gedetailleerdheid waarmee en de directe, levendige wijze waarop de auteur de gebeurtenissen in zijn naaste omgeving weergeeft. Anderzijds openbaart dit karakter zich ook in negatieve zin, doordat de auteur van zaken die zich aan zijn persoonlijke waarneming onttrekken minder goed op de hoogte blijkt te zijn en daarover dan ook maar weinig weet te vertellen. Dit laatste geldt in het bijzonder voor hetgeen van Engelse en Hollandse zijde wordt ondernomen. Zo vindt men, om maar een paar voorbeelden te noemen, niets vermeld over de overeenkomsten van de Engelsen met de jonge respectievelijk de oude sultan, gesloten in de jaren 1812 en 1813, en zoekt men tevergeefs naar de naam van de commandant van de Hollandse expeditie van 1819, de schout-bij-nacht Wolterbeek. Treden de vreemdelingen echter uitdrukkelijk binnen de gezichtskring van de schrijver, zoals bijvoorbeeld de in geen der andere teksten vermelde Engelse kapitein en zijn Hollandse adjudant die de oude sultan in het binnenland namens het Britse gouvernement een bezoek komen brengen (mei 1813), dan worden ze prompt door onze verslaggever bij name genoemd (pp. 82 en 85).

Dit alles wil niet zeggen dat de belangrijke rol, die de vreemde machten in het drama van de Palembangse geschiedenis hebben gespeeld en die als een rode draad door het kroniekverhaal van UBL 7 en TR 1 heenloopt, door de auteur van UBL 9 zou worden miskend, maar wel zijn deze buitenlandse invloeden hier volledig naar het tweede plan verschoven ten gunste van meer specifiek binnenlandse belangen, die de auteur in de eerste plaats schijnen te interesseren.

Zijn belangstelling gaat daarbij vooral uit naar de oude sultan, die zich na de verovering van Palembang door de Engelsen in het binnenland heeft teruggetrokken en wiens beklagenswaardig lot als balling, ver van de bewoonde en beschaafde wereld, ons met sympathie wordt geschilderd. Anderzijds worden wij ook geregeld op de hoogte gehouden van wat er in de stad Palembang gebeurt, waar de jonge sultan, die 
bij onze auteur wat minder goed uit de verf komt dan zijn oudere broer, intussen door Gillespie op de troon is gezet.

Tegen de achtergrond van de oude controverse tussen de beide broers, waaraan wij overigens steeds slechts op een indirecte en impliciete wijze worden herinnerd, wordt er dan na de mislukte expeditie-Meares in het binnenland een heel subtiel diplomatiek steekspel opgevoerd tussen gezanten van de nu meestal als "sultan in Palembang" aangeduide jonge sultan, die geld komen vragen voor de bouw van een nieuwe loge in Palembang, en vertegenwoordigers van de oude of "binnenlandsultan", die tot taak hebben op het gevraagde bedrag af te dingen en de betaling ervan zolang mogelijk uit te stellen om de oude sultan intussen gelegenheid te geven zijn militaire positie te versterken. Geleidelijk gaat dit diplomatieke verkeer tussen partijen over in iets dat op een koude oorlog gaat lijken en wanneer de oude sultan zijn althans schijnbaar toeschietelijke houding van voorheen definitief heeft laten varen en zijn jongere broer een flinke gewapende macht naar het binnenland heeft gestuurd, komt het conflict tot uitbarsting. Aan deze strijd komt tenslotte een einde, doordat de Palembangers uit het kamp van de jonge sultan zich verzoenen met hun stadgenoten uit het andere kamp en zich aan de oude sultan onderwerpen, die vervolgens door de Engelsen naar Palembang wordt teruggehaald en volledig gerehabiliteerd.

De auteur gunt ons met de beschrijving van deze episode, welke meer dan de helft van de tekst in beslag neemt, een ruime blik achter de schermen. Hij laat ons niet alleen de min of meer officiële gesprekken tussen de vertegenwoordigers van partijen beluisteren, maar doet ons ook getuige zijn van het tussentijdse overleg van de oude sultan met zijn dienaren en raadslieden, de overpeinzingen van de gezanten uit Palembang wanneer ze onder elkaar zijn en de uiteindelijke, in een conspiratoire en tegelijk emotionele sfeer voorbereide onderwerping van de "lieden uit Palembang" aan de oude sultan. Zo kunnen wij de ontwikkeling der gebeurtenissen op de voet volgen en komen we intussen heel wat te weten over zaken als de omgang van een vorst met zijn onderdanen, de politieke achtergronden van de verhouding tussen de beide sultans, de kijk van de Palembangers op de militair superieure blanken en op Indonesiërs uit andere streken, zoals de mensen uit Kerinci of Rejang en vooral de Maleiers uit Minangkabau, die de oude sultan als hulptroepen heeft aangeworven.

Vergeleken bij de unieke bijdrage van UBL 9 tot de kennis van wat er zich in de jaren 1812-1813 in het binnenland van Palembang heeft 
afgespeeld, gebeurtenissen waarover trouwens ook van Europese zijde vrijwel niets wordt meegedeeld, kunnen we over de rest van het overigens onvoltooid gebleven verhaal, waarin Muntinghe de hoofdrol speelt, kort zijn. Aan feitenmateriaal levert dit deel van de tekst met zijn uiterst summiere behandeling van de periode 1818-1819 niet veel nieuws op, veel minder ook dan de eerste tien bladzijden van de tekst, die aan de tijd van Gillespie en Meares zijn gewijd en al evenzeer buiten het hoofdthema van het verhaal vallen. Worden we in dat eerste gedeelte nog vergast op een enkele dialoog, die de levendigheid van de vertelling verhoogt, of op een boeiende beschrijving als van de tocht van Meares naar het binnenland, wat vergeleken bij de weergave in UBL 7 een subliem stuk is, in het laatste deel van de tekst is van dergelijke literaire hoogtepunten nauwelijks nog sprake. Het lijkt wel alsof de stijl hier geleden heeft onder een tekort aan feitelijke informatie bij de auteur en zijn wellicht minder rechtstreekse betrokkenheid bij die latere gebeurtenissen. Hoe dit zij, na het met zoveel verve geschreven middenstuk maakt het relaas van deze laatste bladzijden een nogal matte indruk. Zelfs de in TR 1 zo geestdriftig beschreven militaire successen van Palembang tegenover de Hollanders in 1819, die ook de auteur van UBL 9, een goed Palembanger en zeker geen vriend van de Hollanders, ${ }^{36}$ niet onverschillig zullen zijn gebleven, hebben hem niet kunnen inspireren tot een verslag op het niveau van zijn eerdere werk.

De tekst bevat overigens naast het zojuist in voetnoot 36 geciteerde commentaar van de schrijver op de wisselende begunstiging door de blanken van de oude en de jonge sultan niet veel van dit soort kritische opmerkingen over het gedrag van de blanken. Er zijn nog slechts enkele van dergelijke uitspraken te noemen van de oude sultan, die als moslim en als politicus de strijd tegen de blanken en naar analogie ook de strijd tegen zijn jongere broer, die immers hun "medeplichtige" is, graag met de heilige strijd voor het geloof vereenzelvigt ${ }^{37}$ zoals ook de dichter van de syacir doet.

Men moet echter vermijden uit zulke uitspraken nu meteen tot een anti-westerse gezindheid van de auteur te concluderen. Veeleer treft bij lezing van de tekst een meer genuanceerde visie op de blanken; de verschillen in houding en optreden tussen mannen als Gillespie, Meares, Robison en Muntinghe blijven niet onopgemerkt en geven aanleiding tot een individueel oordeel over ieder van hen. Dat zo'n oordeel meestal niet zo duidelijk wordt uitgesproken, is in een Maleis geschrift geen bijzonderheid. Zelfs in het in deze tekst centrale conflict tussen de oude en de jonge sultan spreekt de auteur zich niet duidelijk voor één der 
beide partijen uit, al meen ik af en toe een zekere voorliefde en een groter respect voor de oude sultan, doorgaans angeduid als "(Duli/ Seri/Paduka) Yang Mahamulia", in de tekst te horen doorklinken.

\section{$M P 4 a /-4 b$}

De Syacir Perang Ménténg is een poëtische weergave van een korte maar belangrijke episode uit de Palembangse geschiedenis (begin junieind december 1819), die ook behandeld wordt in de prozateksten van UBL 7, TR 1 en UBL $9{ }^{38}$ Het gedicht is korte tijd na afloop van deze periode geschreven. De dichter is onbekend.

Alvorens op de inhoud en de stilistische aspecten van dit gedicht in te gaan, wil ik op een formele bijzonderheid ervan wijzen, waardoor het zich van andere syacirs onderscheidt. De Syacir Perang Ménténg is opgebouwd uit tweehonderdzestig vierregelige strofen met het kenmerkende rijmschema van de Maleise syacir: $a-a-a-a$. Bij nader onderzoek van dit rijmschema blijken er op die tweehonderdzestig strofen zeventig verschillende eindrijmen te onderscheiden te zijn, die met een frequentie van één tot zesentwintig maal voorkomen, te weten:

1 maal eindrijm op: -ba, -ban, -bang, -bu, -bur, -but, -dak, -dan, -dang, -dur, -guh, -han, -ju, -kap, -kut, -léh/-lih, -lér/-lir, -li, -mai, -maut, -ngan, -ngin, -num, -pat, -puh/-poh, -ring, -sar, -tang, -tar, -téng/-ting, -tung;

2 maal eindrijm op: -bar, -bi, -dung, -ja, -kur, -lan, -lis, -man, -nang, $-n i$, -pan, -ran;

3 maal eindrijm op: -tan, -rat, -lu, -kan;

4 maal,$\quad$, : -lang, -mat, -na, -rah, -wa;

5 maal „ „: -wan, -nya, -lam, -la, -ga;

6 maal $, \quad,:-y a,-k a,-t u$;

7 maal $, \quad,:-k a r,-l a h,-s a$;

9 maal $, \quad,:-r a$;

12 maal,$\quad$ : $-d a,-m a$;

13 maal,$\quad$ : -rang, -ta;

24 maal $, \quad,:-t i$;

26 maal $, \quad,:-r i$. 
Afwijkingen van dit strikte rijmschema blijven tot een betrekkelijk klein aantal gevallen beperkt, namelijk tot slechts vijftien van de tweehonderdzestig strofen. ${ }^{39}$

Uit dit overzicht blijkt dat in deze syacir bij op consonant eindigende woorden ook identiteit van de voorlaatste consonant tot het rijmschema behoort (-GVG). De meeste syacirs volstaan in zulke gevallen met identiteit van vocaal plus slotmedeklinker (-VG), zoals bijvoorbeeld de Syacir Hémop, de Syacir Perang Mengkasar, de Syacir Kén Tambuhan ${ }^{40}$ en ook de meest oorspronkelijke uitingen van deze dichtkunst: de syacirs van de Sumatraanse mysticus uit de tweede helft van de zestiende eeuw Hamzah Fansuri. ${ }^{41}$

Evenmin als andere syacir-dichters is de auteur van deze syacir geheel ontkomen aan de verleiding om stereotiepe versregels of gedeelten daarvan meer dan eens te gebruiken; dit geldt voor vergelijkingen ("pahlawan seperti gajah yang meta" en dergelijke), staande uitdrukkingen als "mérah padam warnanya muka", "bahana gemuruh gegak gempita", en vooral voor de in beschrijvingen van gevechtsscènes gebruikelijke uitdrukkingen als "orang membedil bersungguh hati", "memasang meriam berulang-ulang". Maar hij doet dit met mate, zodat er genoeg afwisseling blijft bestaan en eentonigheid wordt vermeden. Van de 1040 versregels waaruit de $s y a^{c} i r$ is opgebouwd, komen er slechts enkele tientallen - al dan niet met geringe variaties - tweemaal en slechts twee driemaal voor; en om nòg een statistisch gegeven betreffende één van de bovengenoemde vaste $s y a^{c} i r$-elementen te vermelden: in de drieënzeventig versregels die een vergelijking behelzen, treffen wij er slechts vier tweemaal en één driemaal aan. Daarnaast komen we ook in deze syacir sommige uitdrukkingen en woorden meer dan eens tegen die - onder meer vanwege hun bruikbaarheid als rijmwoord - tot de geliefde bouwstenen van een syacir behoren; maar ook hierbij ligt de frequentie van zulke herhalingen niet bijzonder hoog. Als voorbeelden mogen gelden:

"habis(lah) lari, habis bubar, habis mati, habis terang" e.d., "bukan (lagi) (alang) kepalang", "hancur luluh, hancur dan lebur" e.d., "sangat sengsara", "susahlah hati", "sekalian rata".

De Syacir Perang Ménténg is een rijmkroniek, evenals de Syacir Hémop en de Syacir Perang Mengkasar. Met de Syacir Hémop vertoont het Palembangse gedicht geen duidelijke aanknopingspunten, wel met de Syacir Perang Mengkasar. Bij een nauwkeurige vergelijking van deze twee rijmkronieken blijkt er op een aantal plaatsen zelfs van een zo 
treffende overeenkomst sprake te zijn, dat de veronderstelling zich aan ons opdringt dat de Palembangse auteur de zo'n honderdvijftig jaar tevoren geschreven syacir uit Makassar kende en er - hetzij bewust hetzij onbewust - door is beïnvloed.

In de eerste plaats zijn er drie strofen die in deze beide gedichten tot op zekere hoogte gelijkluidend zijn. Het is niet aan te nemen dat deze parallellen toevallig zijn. Ter vergelijking worden ze hieronder naast elkaar afgedrukt:

Syacir Perang Mengkasar

str. 30

Demikian asal mula pertama

Welanda dan Bugis bersama-sama Kornilis Sipalman Welanda ternama Raja Palaka jadi panglima.

str. 119

Buton la ${ }^{c}$ nat mengyangkan ${ }^{42}$ ubi lupalah ia akan agama Nabi sungguhpun ia tiada makan babi pakaiannya sudah menurut serani.

str. 68

Enci' Amin itu orang yang bijak tubuhnya sedang sederhana pandak memakai minyak dengan kelembak baunya harum amat semerbak.
Syacir Perang Ménténg

str. 2

Inilah konon mula pertama

Holanda dan Ambon bersama-sama

Idelir Ménténg Holanda nama

Kornél Bakar jadi panglima.

str. 74

Ménténg Holanda memakan ${ }^{42}$ ubi lupalah kepada agama Nabi minum arak dengan babi patutlah rupanya bagai labi-labi.

str. 178

Pangéran itu hulubalang yang bijak tubuhnja sedang sederhana pandak jika memakai ukup dan bedak baunya harum amat semerbak.

Verder valt in dit opzicht te denken aan het in beide syacirs voorkomen van de meestal met "bercakap(lah)" e.d. ingeleide verklaringen van onverschrokkenheid en vechtlust waarmee de Makassaarse en Palembangse krijgers zich aanmelden voor de strijd. Men vergelijke de strofen 111-117 van de Syacir Perang Ménténg met de strofen 46-66 van de Syacir Perang Mengkasar.

In de derde plaats kan worden vastgesteld dat beide dichters de verschillende voorvechters die zij ten tonele voeren graag vergelijken met helden en goden uit de wajangverhalen, althans uit de Hindoe- 
javaanse epische literatuur (zie Skinner, 1963 pp. 25-26). De Palembangse hofcultuur herleidt zijn oorsprong tot Majapait en is in zijn ontwikkeling in sterke mate door de Javaanse cultuur beïnvloed. Dat de wajang in het Palembangse cultuurpatroon was geïntegreerd, mogen we dus wel aannemen. Het zowel in KI 4 als in UBL 3 opgetekende verhaal over de dalang uit Java, die in Palembang aan het hof van Arya Damar wajangvoorstellingen geeft, is in dit verband illustratief.

Een vierde parallel tussen de twee gedichten vindt men in de korte beeldende beschrijvingen van uiterlijk, kleding en opschik van de individuele deelnemers aan de strijd en van hun houding en gedrag in de concrete gevechtssituatie. Voor zover zij, vanuit het standpunt van de dichter gezien, in die strijd aan de goede kant staan, worden ze steeds in voor betrokkenen gunstige zin uitgebeeld.

In de Syacir Perang Ménténg worden zo enkele tientallen leden van Palembang's wereldlijke en geestelijke elite: familieleden van de sultan en leden van de lagere adelstand, ambtenaren, haji's en Arabische sayyids met onderscheiding genoemd en beschreven.

In de Syacir Perang Mengkasar, welke uitdrukkelijk is opgedragen aan de sultan van Goa, in wiens dienst de dichter als hofschrijver werkzaam was, komen dergelijke beschrijvingen ook voor en bovendien nog formele lofprijzingen aan het adres van deze sultan en van diens broer, de sultan van Tallo'.

Het laatste punt van overeenkomst tussen de beide syacirs is het sterke religieuze engagement dat de moslimse dichters ten toon spreiden. Weliswaar wordt de Palembangse sya ${ }^{c}$ ir niet ingeleid door een doxologie zoals de Syacir Perang Mengkasar, ${ }^{43}$ maar overigens wordt ook hier aan godsdienst en mystiek een essentiële rol in het leven toegekend en blijkt op tal van plaatsen dat de visie van de Palembangse dichter op het conflict waaraan zijn gedicht is gewijd evenzeer als die van zijn Makassaarse collega door zijn godsdienstige overtuiging is bepaald. ${ }^{44}$

Ook hij ziet de oorlog tegen de Hollanders en hun Indonesische vazallen of hulptroepen als de door de Islam voorgeschreven strijd tegen de ongelovigen èn - een nadere opmerkelijke overeenkomst - ook bij de Palembanger richt de kritiek zich niet alleen tegen de blanken, waarvan de regeringscommissaris Muntinghe en de kapitein-luitenant-ter-zee Bakker als exponenten gelden, maar zijn het vooral hun handlangers onder de eigen ras- en geloofsgenoten van de auteur, met name Raja Akil en Pangéran Muhammad, die als verraders en collaborateurs zijn afschuw en verachting opwekken. Zoals een nadere beschouwing van deze kritiek ons leert, schieten de Hollanders naar de mening van de 
dichter met name tekort in koelbloedigheid en zelfbeheersing, deugden die bij de Indonesiër in hoog aanzien staan, zoals blijkt uit zijn bewondering voor de vorst die onder alle omstandigheden zijn emoties verbergt achter een fijnzinnige glimlach, en uit zijn voorkeur voor de stille kracht die achter de charme en de elegance van zijn helden schuilgaat boven de zwaarwichtige indrukwekkendheid van een grimmig uiterlijk en een zich in uitbarstingen van woede en razernij ontladende martialiteit. Bij de minachting van de auteur voor een huurling als Raja Akil ligt het accent behalve op diens lafhartigheid vooral op het feit dat hij door zijn diensten te verlenen aan de blanken en bovendien hun voor de islamiet verfoeilijke levensgewoonten over te nemen zowel de goede zaak van de zelfstandige identiteit van zijn eigen ras als het ware geloof verloochent.

Wat deze persoonsbeschrijvingen in het algemeen aangaat, of ze nu betrekking hebben op Palembangers dan wel op de vijanden, ze vertonen inhoudelijk onvoldoende variatie om van een duidelijke karakterisering van individueel herkenbare personen te kunnen spreken. Men krijgt eerder de indruk van een zekere typering van elk der beide groepen afzonderlijk in een wat onscherpe groepsfoto, waarop de individuele trekken van de geportretteerden in de regel slechts vaag te onderscheiden zijn. Maar ook deze regel kent zijn uitzonderingen, zoals bijvoorbeeld in de ontroerende passage van strofen 188-189, waar van Pangéran Natadiwangsa wordt gereleveerd, dat hij kortgeleden zijn vrouw heeft verloren. Meestal valt bij deze beschrijvingen de nadruk op het uiterlijk, dat vaak zeer beeldend wordt beschreven, zoals bijvoorbeeld dat van Pangéran Puspakrama in de strofen 157-160.

Is de dichter ook bij de beschrijving van gebeurtenissen en van de menselijke reacties daarop naar onze maatstaven misschien niet altijd even helder en scherp, toch weet hij herhaaldelijk op kundige wijze gebruik te maken van de tot bondigheid dwingende structuur van de syacir en zo met weinig woorden veel te zeggen, zoals over de missie van Pangéran Nataagama in de strofen 47-61. Ditzelfde geldt des te meer voor de kernachtige en vaak treffende vergelijkingen waarmee de dichter zijn verhaal illustreert. Ik denk hier aan de vergelijking van de vluchtende Hollanders met opgejaagd wild of bijeengedreven slachtvee (strofe 85) en aan de vergelijking van de waakzaamheid waartoe Muntinghe zijn officieren aanspoort met die van een hond met een kluif in zijn bek (strofe 140), aan het beeld van de lijken die op de rivier drijven als dorre takken of als met $t u b a$ bedwelmde vissen (strofe 153) en aan de vergelijking van een wegvarend zeilschip met een pauw die zijn veren spreidt (strofe 217). 
Richten wij onze aandacht tenslotte op de feitelijke inhoud van deze Palembangse rijmkroniek, dan blijkt het moeilijk om in de beschreven gebeurtenissen de juiste chronologische volgorde te ontdekken. De enkele data die de dichter vermeldt worden zowel door de Hollandse als door de Palembangse berichten bevestigd, maar geven niettemin voor de chronologie weinig houvast. Met name de caesuur tussen de beschrijving van de vijandelijkheden van juni en die van oktober (de expeditieWolterbeek) is niet scherp aangegeven. Op grond van de aanhef "Alkissah suatu cerita" van strofe 241 zou men geneigd zijn te veronderstellen dat de beschrijving van de tweede actie daar begint, maar de tijdsaanduiding in strofe 145 wijst duidelijk uit dat de beschrijving van die tweede actie dan al aan de gang is, zodat de passage van 241 v.v. eerder als een recapitulatie van het voorafgaande moet worden opgevat. Ook de interpretatie van de omschrijving "pukul enam paginya hari, hari Ahad sa cat musytari" in strofe 91 schept problemen. In verband met de tevoren in strofe 63 genoemde datum dinsdag 15 juni zou chronologisch de interpretatie zondag 20 juni passen, maar aangezien de vloot toen al was vertrokken, is zondag 13 juni hier misschien beter op zijn plaats. Is dit laatste het geval, dan heeft de dichter in strofe 91 nog eens teruggegrepen naar een eerder stadium van de strijd. Ook elders in dit gedicht dient men steeds op zo'n speelse, misschien wel dichterlijke verontachtzaming van de chronologie bedacht te zijn. Het is alsof alle gevechtshandelingen die tezamen het hoofdthema van de rijmkroniek vormen, zijn opgenomen in één maalstroom van gebeurtenissen, waarin volgorde en oorzakelijk verband van geen wezenlijke betekenis meer zijn, zodat de beschrijving meer een revolverend dan een logisch-evoluerend karakter krijgt. Het lijkt me dan ook niet in overeenstemming met de bedoeling van de dichter om te trachten aan zijn weergave van de historische gebeurtenissen exacte kennis omtrent het feitelijke verloop van de geschiedenis te ontlenen of deze weergave op minutieuze wijze aan de uit andere bron bekende historische feiten te toetsen. Waarmee niet gezegd wil zijn dat de dichter, wie de realiteit van wat hij beschrijft nog vers in het geheugen moet hebben gelegen, terzake niet op de hoogte zou zijn geweest. Het tegendeel blijkt het geval te zijn. Ook de auteur van de rijmkroniek beantwoordt voor wat de door hem beschreven periode betreft in grove trekken aan het verhaal dat UBL 7 ervan doet en van de daar aangetroffen elementen vinden we er hier verscheidene terug. Om er enkele te noemen: de aanval van de door mystische oefeningen in geestesvervoering geraakte hajis, de poging van de Hollanders om de kratonpoort open te hakken en de dood van hun 
tamboer, het verzoek van Muntinghe om wapenstilstand, de vruchteloze kanonnade van het scheepsgeschut op het poortgebouw, de bijzonderheden over het Palembangse verdedigingsstelsel en over het gebruik van branders, de aanleg van een eiland in de rivier om als "waterbatterij" te kunnen dienen.

De conclusie lijkt gerechtvaardigd dat de rijmkroniek over het algemeen historisch-betrouwbare informatie behelst, maar dat de dichter, wie het er in de eerste plaats om te doen was de door Palembang met zoveel success gevoerde strijd tegen de Hollanders uit te beelden en daarbij de heldendaden van elk der met name genoemde deelnemers aan de strijd duidelijk te doen uitkomen, het chronologisch verband tussen de verschillende stadia van die strijd en tussen de individuele wapenfeiten als een zaak van ondergeschikt belang heeft verwaarloosd. 


\section{NOTEN}

\section{NOTEN BIJ HOOFDSTUK I}

1 Van Sevenhoven, 1823, p. 80.

2 Juynboll, 1899, p. 20; Van Ronkel-BG, pp. 353 en 356.

3 Het is begrijpelijk, dat deze "Palembangse moord" en vooral de mate van Raffles' medeverantwoordelijkheid daarvoor - de sultan heeft later tegenover het Nederlandse opperbestuur getracht zich achter de brieven van Raffles te verschuilen - in de Nederlandse en Engelse geschiedschrijving uitvoerig is behandeld, het laatst, tevens het best gedocumenteerd en het meest objectief, door Bastin in zijn artikel "Palembang in 1811 and 1812", verschenen in de Bijdragen tot de Taal-, Land- en Volkenkunde van 1953, honderd jaar nadat Baud de kwestie onder dezelfde titel in de eerste jaargang van dat tijdschrift had aangesneden.

4 Indiase soldaten in het Britse koloniale leger (Perzisch/Urdu: sipähi = soldaat).

\section{NOTEN BIJ HOOFDSTUK II}

$1 \mathrm{Ph}$. S. van Ronkel, Catalogus der Maleische handschriften in het Museum van het Bataviaasch Genootschap van Kunsten en Wetenschappen. VBG 57. Batavia-'sHage 1909. Afgekort als: Van Ronkel-BG.

2 Ph. S. van Ronkel, Catalogus der Maleische handschriften van het Koninklijk Instituut voor de Taal-, Land- en Volkenkunde van Nederlandsch-Indië. In: BKI 60 (1908), pp. 181-248. Afgekort als: Van Ronkel-KI.

$3 \mathrm{H}$. H. Juynboll, Catalogus van de Maleische en Sundaneesche handschriften der Leidsche Universiteits-Bibliotheek. Leiden 1899. Afgekort als: Juynboll, 1899.

$4 \mathrm{Ph}$. S. van Ronkel, Supplement-catalogus der Maleische en Minangkabausche handschriften in de Leidsche Universiteits-Bibliotheek. Leiden 1921. Afgekort als: Van Ronkel-UBL.

5 H. C. Klinkert, Verzamelingen van Maleische brieven, voorhanden in de Rijksbibliotheek te Leiden. Gecatalogiseerd door _- In TNI, nieuwe serie jrg. 11, dl 2 (1882), pp. 81-103; 161-206 enz. Afgekort als: Klinkert, 1882.

6 Deze collectie is op pp. 353-363 geïnentariseerd in: J. de Hullu, De archieven der admiraliteitscolleges. 's-Gravenhage 1924. Afgekort als: De Hullu, 1924.

7 Luitenant-kolonel Albert Hendrik Wendelin baron de Kock was waarnemend resident van Palembang in de jaren 1842-1847.

8 De verwijzing in de eerste alinea van KI 1 vindt men in het citaat dat ik in noot 10 laat volgen. De verwijzing in de laatste alinea van KI 1 luidt als volgt: "Maka habislah cerita pasal yang pertama di negeri Palémbang. Maka disambut cerita pasal yang kedua, suratnya sudah ada kepada Seri Paduka Resident". De verwijzing op p. 1 van KI 3 tenslotte luidt: "Maka adalah 
perihalnya ceritanya di kerajaan seperti sudah ada tersebut di pasal 14 cerita dahulu". Met "pasal 14" wordt de passage op pp. 12-14 van KI 1 bedoeld, waarin de regeringsperiode van de als veertiende vorst van Palembang genoemde Sultan Muhammad Baha'uddin wordt beschreven.

9 Het begin van KI 2 luidt als volgt: "Inilah suatu cerita daripada aturan rajaraja didalam negeri Palémbang. Maka adalah kepada tahun 1842 pada masa satu orang besar dan anak dari orang yang bangsawan dan yang mulia, yaitu Paduka Tuan Luitenant-Kolonel De Kock yang memakai bintang tanda hormat dari Seri Maharaja Nederland, ialah kommendant atas sekalian orang militair. Dan yang menjadi Resident memerintah negeri Palémbang dengan segala daérah tacluknya, ialah yang bangsawan serta arif bijaksana melakukan perintah Gouvernement dengan kasih sayang atas racyatnya, istiméwa pada sekalian sahabatnya. Maka dipohonkan kiranya barang dilanjutkan usianya serta kekal memerintah di negeri Palémbang, karena memberi kebajikan atas sekaliannya. Syahadan maka adalah Paduka Tuan Resident itu suka mendengarkan dan mengetahui daripada aturan raja-raja yang dahulukala serta dia punya aturan dan kelakuan satu satunya. Maka barang yang saya dapat khabar dan cerita daripada orang tua-tua dan setengah daripada kisahnya didalam surat-surat lama maka saya kumpulkan dan tuliskan didalam satu hikayat ini mudah-mudahan berkenan kiranya pada Paduka Tuan yang mulia itu".

10 Het begin van KI 1 luidt als volgt: "Bahwa adalah Seri Paduka Tuan Resident yang memerintah negeri Palémbang yang amat arif lagi bijaksana atas sekalian perkara dan setiawan dan bangsawan lagi adil dengan tolong peliharanya atas hamba racyatnya. Maka adalah Seri Paduka itu suka cari dan mengetahui cerita Palémbang yang terkeatas daripada cerita yang telah didapatnya. Maka saya cari daripada kisah dan hikayatnya maka saya perbuat satu hikayat supaya mudah-mudahan dapat lebih keterangan daripada surat yang asal. Maka inilah jadi cerita yang pertama negeri Palémbang, akan tetapi tiada boléh dapat kepada témpoh mana dan sudah berapa lamanya, sekadar diaturkan kisahnya jua".

11 De in KI 1 gevolgde lezing van de ciri vertoont ten opzichte van de tekst in de Sejarah Melayu voornamelijk verschillen die aan een foutieve transliteratie moeten worden toegeschreven. De ciri van KI 1 luidt in de spelling van het handschrift: "Hoe soewaijta Padoeka Srie Machradja sariemo srie sapta soeriena boemie ijoedjaija Pala Nakaramo Nitkaling Karta makoeta Ran moeka Trie Boewana parie Sang Sakaraijta biena Nangka Darmo Rana Soran Gito Sengosano Ran Wikramo wadat Ratta pala waijka Saij Daij daij wa Daij die Paraboe kala moelie malikie Daramo Radja Paramaijsoerie".

Nadere bijzonderheden over de ciri zijn te vinden in de artikelen van W. E. Maxwell in JRAS 13 (1881), pp. 80-101 en in JSBRAS 10 (1883), pp. 287289, getiteld "An account of the Malay "Chiri", a Sanskrit formula" respectievelijk "The Chiri".

$\mathrm{Ph}$. S. van Ronkel behandelt het onderwerp veertig jaar later opnieuw in een tweetal artikelen in BKI, respectievelijk getiteld "De raadselachtige toespraak van den Hindoe-bard in de Maleische Kronieken" (BKI 77 (1921), pp. 175-181) en "Nogmaals de toespraak van den Hindoe-bard" (BKI 78 (1922), pp. 463-465).

12 Deze datering is ontleend aan de tekstwoorden: "... adalah pada itungan Nabi Mohammad sudah 289 tahun lamanya dari waktu diperbuat surat ini":

A.D. $1842=$ H. 1258 ; H. $1258-289=$ H. 969 .

13 TNI jrg. 6 (1844), dl 4, pp. 99-107.

14 TNI jrg. 8 (1846), dl 3, pp. 341-355. 
15 TNI jrg. 8 (1846), dl 3, pp. 356-376.

$16 \mathrm{P}$. J. Veth geeft in een noot bij het tweede gedeelte van zijn in de jaargangen 1850-1852 van TNI onder de titel "Verslag aangaande het eiland Banka" verschenen Nederlandse vertaling van Thomas Horsfield's "Report on the island of Banka" (The Journal of the Indian Archipelago and Eastern Asia Vol. II (1848), pp. 299-336, 373-427, 705-725, 779-824) een uitvoerige samenvatting van "Schetsen van Palembang" (jrg. 1850, dl 1, pp. 358-363), wat hij "een zeer belangrijk artikel" noemt, hetwelk hem "door een schier onbegrijpelijk toeval" tot dusver "was ontgaan" (p. 358). Uit de tekst van deze samenvatting blijkt niet dat Veth bekend was met het feit, dat A. H. W. de Kock de auteur is van de "Schetsen van Palembang" en dat de bijdragen VI en VII van deze reeks rechtstreeks op Maleise handschriften teruggaan.

17 Zie De Graaf, 1963, p. 98.

18 Zie Van Ronkel-KI, p. 217.

19 TNI jrg. 8, dl 4 (1846), pp. 33-56: "Legenden van Djambi". Onder het stuk staat als datering "Palembang, Augustus 1843". Het manuscript van deze publikatie bevindt zich in de verzameling westerse handschriften van het Koninklijk Instituut voor Taal-, Land- en Volkenkunde onder nr H 271 (zie De Graaf, 1963, p. 98, waar de relatie met het Maleise handschrift overigens niet wordt vermeld). Bij deze "legenden" sluit aan de eerder gepubliceerde bijdrage van De Kock, TNI jrg. 6, dl 4 (1844), pp. 107-112, getiteld: "Val van de Djambische Vorstenheerschappij".

20 Van Ronkel-KI, pp. 211-212.

21 UBL cod.or. 2013, Juynboll, 1899, pp. 244-245.

22 Cod.or. 12189 (= Oph. 68). Zie Van Ronkel-UBL, p. 44.

23 Feestbundel KBG, 1929, dl II, pp. 316-352.

24 Zie De Graaf, 1963, p. 99. Deze verhandeling over Palembang draagt de wijdlopige titel: "Historische en ethnografische beschrijving van Palembang, getrokken uit de bescheiden betreffende onze staatkundige- en handelsbetrekkingen van 1655-1804, in 's Rijks Koloniaal Archief, voorafgegaan door een onuitgegeven inlandsche Kronijk van de Palembangsche vorsten. Met aanhangsel, bevattende: Compendium van Wetten, Oendang-Oendang, verzameld door J. F. R. S. van den Bossche, eene geslachtslijst van de vorsten, benevens eene kaart en plans van Palembang". De Sturler heeft het manuscript ter publikatie aangeboden aan het Koninklijk Instituut voor Taal-, Land- en Volkenkunde, dat het evenwel om velerlei redenen niet heeft uitgegeven. De kwestie is behandeld in de bestuursvergaderingen van het Instituut van 19-9-1874, 26-2-1875, 6-11-1875 en 8-1-1876 (BKI, derde volgreeks; dl 10: pp. XVIII, XXXI-XXXIV en dl 11: pp. XXXI, XLII-XLIII).

25 Zie p. 33.

26 Waarschijnlijk papier van de fabrikant Dirk Blauw. Zie Voorn, 1960, pp. 136-137. Hoofd- en contramerk zijn afgebeeld onder nrs 141 resp. 140 en gedateerd 1794 resp. 1790.

27 In feite correspondeert H. 1126 met A.D. 1714.

28 Zie De Graaf, 1963, p. 97. De Graaf dateert het handschrift zonder aan te geven op welke gronden "Palembang, begin 19de eeuw".

29 In de notulen van de bestuursvergaderingen van het Bataviaasch Genootschap, dl VIII (1870), p. 66 is sprake van "zes van den Resident van Palembang ontvangen stamregisters der vorstenhuizen van Palembang en Djambi met bijbehorende nota en kaart", die vervolgens door het bestuur worden bestemd om in het tijdschrift van het Genootschap te worden opgenomen (Not. B.G. dl IX (1871), p. 1). Eerst jaren later worden de stukken ter voorbereiding van de voorgenomen publikatie aan de heer Van Schouwenburg en vervolgens 
aan de heer Netscher ter hand gesteld (Not. B.G. dl XVII (1879), pp. 100101 ) en door deze ter verdere bewerking overgedragen aan "de heer A. A. Hoos, laatstelijk assistent-resident van Palembang" (Not. B.G. dl XVII (1879), p. 109), die tenslotte bij brief van 26 mei 1880 "eenige werken uit de bibliotheek" van het Genootschap te leen vraagt teneinde aan de opdracht tot bewerking van de geslachtslijsten te kunnen voldoen (Not. B.G. dl XVIII (1880), p. 94). Omtrent het verdere verloop van de zaak blijven we in het onzekere verkeren. In de notulen wordt er niet meer van gerept en de publikatie in TBG heeft nimmer plaatsgevonden. Zodat wij niet meer dan veronderstellen kunnen, dat de bovenbedoelde "zes stamregisters der vorstenhuizen van Palembang en Djambi" identiek zijn met KI 8 en KI 9 of daarmee de oorsprong gemeen hebben.

30 Dit zijn de initialen van de Noordhollandse papierfabrikant Van der Ley. Het watermerk komt als nummer 124 voor in Churchill, 1935. Churchill geeft van dit watermerk geen datering.

31 Kemas is de in Palembangse teksten gebruikelijke samentrekking van de titels $k i$ (als afkorting van kiai) en mas.

32 Zie Babad tanah Djawi, 1941, pp. 19-23 ; Pararaton, 1897, pp. 194-197.

33 Onder dit nummer is bijeengebracht: "Materiaal voor de geschiedenis van Palembang en Djambi, memories van overgave e.a. nagelaten papieren van J. W. J. Wellan, secretaris van het Zuid-Sumatra-Instituut". De Graaf, 1963, p. 100.

34 Zie Churchill, p. 13.

35 Afbeeldingen van het hier aangetroffen watermerk zijn opgenomen in Voorn onder $\mathrm{nr} 102$ en in Churchill onder nr 158. Voorn dateert het: 1846. Zie ook noot 29.

36 Als $\mathrm{nr} 860$ opgenomen en afgebeeld in Heawood, 1950.

37 BKI dl 45 (1895), pp. 113-163.

38 De Clercq was van 3 september 1888 tot 4 mei 1890 resident van Riouw en Onderhoorigheden te Tanjung Pinang.

$39 \mathrm{Zie}$ de notulen van de bestuursvergadering van het Instituut dd. 27 januari 1894 (BKI dl 44, p. XXXV). Dat De Clercq KI 13 en niet KI 12 of het als UBL 12 in de inventarisatie opgenomen exemplaar van de tekst tot zijn beschikking heeft gehad, blijkt uit het - zoals De Clercq terecht opmerkt foutieve - jaartal 1258 op p. 150 van zijn "Bijdrage" in BKI. Dit jaartal komt namelijk alleen in KI 13 voor (p. 96, regel 14); de beide andere handschriften hebben de juiste datering 1208. Verwisseling van de Arabische tekens voor 5 en 0 ligt voor de hand. In dit geval doet zich daarbij nog de bijzonderheid voor, dat het jaartal 1258 in KI 13, dat zoals wij zagen in Arabisch schrift is geschreven, met de in het westen algemeen gebruikte zogeheten Arabische cijfers is weergegeven. Haji Idris moet bij het overschrijven het nul-teken van zijn model voor een 5 hebben aangezien en aldus weergegeven; waarom hij hier niet de in het schriftbeeld passende en elders ook door hem gebezigde authentieke Arabische cijfers heeft gebruikt, blijft intussen onopgehelderd.

40 Van de bovenrand van het papier is een stukje afgescheurd. Het hierdoor verloren gegane tekstgedeelte kan worden gereconstrueerd aan de hand van een nader te noemen transcriptie van het handschrift. Het blijkt uit slechts drie woorden te bestaan.

41 Vgl. handschrift H 379 van het Koninklijk Instituut voor Taal-, Land- en Volkenkunde; De Graaf, 1963, p. 19.

42 W. L. de Sturler, 1855. De lijst van de Palembangse vorsten is afgedrukt op pp. $79-80$. 
43 Midden-Sumatra, 1881-92. De gedeeltelijke transcriptie van UBL 1 b is als tabel II opgenomen tussen pp. 204 en 205 van het in 1882 verschenen deel III, 1e ged., 1e afd., getiteld "Volksbeschrijving van Midden-Sumatra" door A. L. van Hasselt.

44 Van Rijn van Alkemade begon zijn loopbaan bij het Binnenlands Bestuur in Nederlands-Indië op 30 april 1879 als "aspirant kontroleur, toegevoegd aan de Assistent-resident voor de policie te Palembang". In 1882 wordt hij overgeplaatst naar Sumatra's Oostkust en eind oktober 1895 naar Aceh. In oktober 1900 keert hij als resident naar Palembang terug; hij blijft er als zodanig in functie tot zijn pensionering in 1906.

45 In de bestuursvergadering van het Bataviaasch Genootschap van 6 november 1883 (Not. B.G. dl XXI, p. 122) wordt "ter tafel gebracht" een "fragment eener vertaling van een Maleisch handschrift, de legendarische geschiedenis van Palembang bevattende, bewerkt door 's Genootschaps gewoon lid den heer J. A. van Rijn van Alkemade, Kontr. der 2de kl. b/h B.B. te Siak". Het is niet onmogelijk dat hier sprake is van een vertaling van UBL 3, welk handschrift in dat geval reeds in 1883 in bezit van Van Rijn van Alkemade moet zijn geweest. Dat dit laatste inderdaad het geval is, blijkt uit zijn nog nader te noemen artikel van 1883, waarin hij een gedeelte uit UBL 5 heeft opgenomen. Merkwaardigerwijs wordt door het bestuur van het Genootschap besloten "den schrijver mede te delen, dat aangezien een dergelijke geschiedenis reeds voorkomt in de "Schetsen van Palembang", opgenomen in het tijdschrift van Ned. Indië, Jaargang VIII, Deel III", (zie noot 16) "het niet wenschelijk wordt geacht op nieuw een verhaal van denzelfden aard uit te geven; dat toch al komen de legenden in beide niet geheel met elkander overeen, zij zich evenwel aansluiten bij de overleveringen, die ook omtrent de stichting van andere Maleische staten in den Archipel bestaan en reeds vroeger zijn bekend gemaakt; dat ondertusschen voor 's Genootschaps verzameling handschriften zeer veel prijs zou gesteld worden op het bezit van het Maleische geschrift en toezending daarvan derhalve hoogst gewenscht zou wezen". Over Van Rijn van Alkemade's reactie op deze mededeling vernemen wij uit de notulen verder niets. Het Maleise handschrift schijnt hij niet aan het Genootschap te hebben afgestaan; in Van Ronkel-BG komt het althans niet voor.

46 Vele verschillen zijn het rechtstreekse gevolg van een onjuiste transliteratie door verwisseling van op elkaar gelijkende Arabische lettertekens. Hierdoor ontstaan fouten als Seriai voor Soerabaja, bekas voor lekas, Lematang voor Lemabang, noetera voor poetera, maar ook onderling verschillende lezingen die niet onmiddellijk als juist of onjuist te onderkennen zijn, zoals bijvoorbeeld bij eigennamen: Djentoek/Tjentoek, Mendana/Mendapah, Berasan/Boeasan, Loetjoe/Soetjoe.

47 In de lijst van Hollandse papierfabrikanten bij Churchill opgenomen op p. 14. Voor wat het hoofdmerk betreft zie noot 34 .

$48 \mathrm{Ik}$ heb dit watermerk in geen der mij bekende handboeken kunnen traceren. Over het uitgebreide geslacht van Duitse papierfabrikanten en typografen Keferstein zie: K. Th. Weiss, Handbuch der Wasserzeichenkunde. Leipzig 1962.

49 De Regeringsalmanak vermeldt Gramberg voor het eerst in 1864 als kommiesboekhouder te Palembang. Met ingang van 10 juli 1864 wordt hij er tot eerste kommies, tevens agent der Bataviase wees- en boedelkamer, benoemd. Gerekend van 21 december 1866 vinden wij hem in dezelfde rang bij het Departement van Onderwijs, Eredienst en Nijverheid te Batavia. Deze ambtenaar, die intussen tot buitengewoon lid van het Bataviaasch Genootschap was benoemd, heeft tal van publikaties, voornamelijk reisbeschrijvingen en historische schetsen, op zijn naam staan. Hiervan worde voor wat de geschiedenis 
van Palembang betreft met name genoemd zijn in 1878 onder de titel "Palembang. Historisch-romantische schets uit de geschiedenis van Sumatra" verschenen weergave van de overval van de Palembangers op de Hollandse factorij in 1811.

50 Zie Not. B.G. dl IV (1866), pp. 24-26.

51 Ter illustratie geef ik deze passage uit UBL 7 hieronder weer. De lezing van UBL 4 en die van MP 3 heb ik, voor zover daarvan verschillend, tussen haken toegevoegd. "... bahwa aku himpunkan didalam surat ini akan" ("akan" ontbreekt in UBL 4) "setengah daripada cerita" (UBL 4: "cerita" = "nama raja-raja", MP 3: "cerita" = "segala nama raja-raja") "didalam negeri Palémbang", (volgt bij UBL 4 èn MP 3 een in dit verband te verwaarlozen uitweiding, die in UBL 7 ontbreekt) "sekira-kira aku dapat didalam surat orang yang dahulu-dahulu kala dan" ("dan" = "dan dengan") "aku dengar daripada perkhabaran orang" ("orang" = "daripada orang") "yang tua-tua pada masa itu; dan aku aturkan didalam surat ini" ("didalam surat ini" = "turunan meréka-itu") "dengan aturannya."

52 Zie hiervóór op p. 49.

53 A. L. V. L. van der Linden, De Europeaan in de Maleische literatuur. Proefschrift Utrecht. Meppel 1937.

54 J. P. Moquette overleed op 26 februari 1927. Zie: Hoesein Djajadiningrat, Jean Pierre Moquette (5 Juli 1856 - 26 Februari 1927), TBG dl 67 (1927), pp. 1-35. Over Rinkes, die wellicht van de gunstige positie waarin hij als hoofd van het Kantoor voor de Volkslectuur (Balai Pustaka) te Batavia verkeerde, gebruik heeft gemaakt om deze transcriptie te laten maken, schreef G. W. J. Drewes in BKI dl 117 (1961), pp. 417-435 een levensbericht onder de titel "D. A. Rinkes. A note on his life and work".

55 H. T. F. K. E. W. A. C. von de Wall, de bestuursambtenaar-taalgeleerde over wie de Encyclopaedie van Nederlandsch-Indië een uitgebreid artikel geeft, was van 1838 tot 1846 civiel gezaghebber te Nieuw-Brussel (= Sukadana) in West-Borneo en vervolgens tot 1852 van Kutai en de Oostkust van Borneo. Van 1853 tot 1855 was hij met een bijzondere opdracht (commissie) weer aan de westkust terug. Mede in aanmerking genomen dat tengku een in West-Borneo en met name in Sukadana zeer gebruikelijke titel is (ook Raja Akil wordt in de tekst steeds Tengku Akil genoemd), veronderstel ik dat de auteur een man van West-Borneo en waarschijnlijk een ingezetene van Sukadana is geweest.

56 Bij deze datering is, naar het handschrift te oordelen door Snouck Hurgronje, in margine aangetekend: "24 Juni 1893", de datum die ook op het titelblad voorkomt en bovendien op een zaterdag valt. De datering 11 Zulhijah 1310, die correspondeert met maandag 26 juni 1893, zal dus wel op een vergissing berusten.

57 Raja Akil was de kleinzoon van de tegen het eind van de $18 \mathrm{e}$ eeuw door zijn schoonbroer verdreven sultan van Siak, Raja Yahya. Met een eigen legertje en een eigen vloot leidde hij een zwervend leven, aanvankelijk in dienst van de Engelsen (in 1815 werd hij door de toenmalige resident van Palembang, Major Court, tot hoofd van Billiton benoemd) en later van de Hollanders. In 1827 werd hij als beloning voor zijn hulp bij de uitvoering van een Hollandse strafexpeditie tegen Matan (West-Borneo) tot sultan van Sukadana aangesteld. Zie verder de artikelen Akil (Radja-) en Soekadana in de Encyclopaedie van Nederlandsch-Indië.

58 Hierop wordt reeds door Roolvink gewezen in zijn artikel "The variant versions of the Malay Annals", verschenen in BKI, dl 123 (1967), pp. 301324, en later opnieuw afgedrukt als inleiding tot C. C. Brown's Sejarah 
Melayu-vertaling van 1970, pp. XV-XXXV. De S.M.-versie van UBL 8 vindt men er genoemd en als "hikayat Raja Akil" gekarakteriseerd op p. 309 resp. p. XXIII.

59 C. C. Berg, Javaansche geschiedschrijving. In: Stapel, 1938, Dl II, pp. 7-148.

$60 \mathrm{Zie}$ noot 35.

61 Door Ph. S. van Ronkel in zijn aan de Hikayat Marsekalek gewijd artikel "Daendels in de Maleische Litteratuur" niet geheel correct weergegeven met de woorden: ". . . die zijn werk verrichtte in het jaar 1247 der Hidjrah, d.i. $1830 / 31$, en het op een Zaterdag te negen ure voleindigde" (Van Ronkel, 1918 , p. 860).

62 Die andere handschriften zijn afschriften van de Hikajat Marsekalek die eveneens door een met name genoemde kopiïst vervaardigd zijn. Het zijn de Leidse codices cod.or. 1724 (1), beschreven in Juynboll, 1899, p. 243, en cod.or. 6057, beschreven in Van Ronkel-UBL, pp. 44-45. Eerstgenoemd handschrift, waarin de auteur voluit "Syaikh Abdullah ibn Muhammad Abubakar Raja Bandarkhan bin Syaikh Ibrahim al-Mesri" heet en waarvan de tekst nog vrij veel overeenkomst met de Maarschalkgeschiedenis van UBL 9 vertoont, is gedateerd: woensdag, 4 Rabicul-awal 1243 (= 26 september 1827). Het tweede is een op 26 of 28 Rabicul-akhir (beide data worden genoemd) 1303 (= 2 of 4 februari 1886) vervaardigde kopie van een afschrift dd. 26 Rabiculakhir 1299 (= 18 maart 1882) van een oorspronkelijk in H. 1234 (= A.D. 1818/'19) geschreven tekst. De versie van cod.or. 6057 wijkt zeer sterk af van de lezing van UBL 9, al vinden wij er voor een deel ook dezelfde elementen in terug waar het Maarschalkverhaal uit is opgebouwd. Voor nadere gegevens omtrent de auteur, de kopiïsten en de inhoud van de drie versies van de tekst verwijs ik naar het eerdergenoemde artikel van Van Ronkel van 1918, dat aan het Palembangse deel van UBL 9 overigens vrijwel stilzwijgend voorbijgaat.

63 Van Ronkel wijst op de mogelijkheid van een nog eerdere datering op grond van een opmerking in de tekst volgens cod.or. 1724 (1) dat de daar beschreven gebeurtenissen eerst vijf jaar geleden zouden zijn voorgevallen (o.c., p. 873, noot 1$)$.

$64 \mathrm{Zie}$ noot 5 .

65 Volgens UBL 7 heeft Muhammad Baha'uddin de regering aanvaard op de dag van het overlijden van zijn vader en voorganger Ahmad Najamuddin: 20 Zulkacédah 1190 (= 31 december 1776). KI 4 dateert precies twee weken eerder: 6 Zulkacédah 1190. Het overlijden van Muhammad Baha'uddin en het optreden van zijn zoon Mahmud Badaruddin als regerend vorst wordt in UBL 7 overeenkomstig de hierna te noemen brief $\mathrm{nr} 8$ gesteld op 21 Zulhijah 1218 ( = 2 april 1804) te 4 uur. KI 4 dateert één dag later en geeft als tijdstip op: 3 uur.

66 De naam van de fabrikant wordt vermeld in Churchill, p. 51 met als datering de periode 1780-1801. Het hoofdmerk komt overeen met Churchill, nr 323 en met de watermerken op pl. 352 by Heawood. Het contramerk S. Lay (zonder $\mathrm{C}$ eronder) is door Heawood opgenomen onder $\mathrm{nr}$ 1857, maar dan in combinatie met de Franse lelie als hoofdmerk, en is gedateerd 1789.

67 Zie Heawood, nr 2408 voor het hoofdmerk en nr 2412 a voor het contramerk. Het papier zou afkomstig zijn uit Marseille en wordt door Heawoord gedateerd 1764.

68 Het hoofdmerk vindt men bij Heawood onder nr 1860, gedateerd 1779 (?); het contramerk bij Voorn onder nrs 148 en 166.

$69 \mathrm{Zie}$ voor het hoofdmerk Voorn, $\mathrm{nr} 100$; voor het contramerk weer Voorn, nrs 148 en 166. 
70 De naam van de fabrikant wordt door Churchill genoemd op p. 51 met als datering 1798. Het hoofdmerk is conform Heawood, nrs 1849, 1855 en 1856 (periode 1785-1788).

71 Zie Voorn, p. 126.

72 De brief is - als gevolg van een begrijpelijke schrijffout - abusievelijk gedateerd 6 juni 1821: "Tersurat kepada enam hari bulan Juni malam Sabtu tahun 1821".

73 Zie Heawood, nr 55. Als datering geeft hij 1860.

74 Van der Linden, 1937, transcribeert abusievelijk 1246 en komt daardoor tot de onjuiste datering 31 juli 1830 (p. 181).

75 Ch. M. G. A. M. Ecoma Verstege was van 3 mei 1878 tot 29 juni 1884 resident van Banka en Onderhoorigheden te Muntok.

76 Zie p. 47.

77 Atja, 1967.

78 Van der Linden, 1937, p. 160.

79 Zie Not. B.G. dl XV (1877), pp. 17-18, 38-39 en 47.

80 Zie Van Ronkel-BG, p. 347.

81 Zie Not. B.G. dl IV (1866), pp. 24-26.

82 Over de herkomst van dit papier heb ik geen gegevens gevonden.

$83 \mathrm{Het}$ is dr. P. Voorhoeve geweest die mij op het bestaan van dit typoscript, dat in geen enkele handschriftencatalogus genoemd werd, heeft geattendeerd. Het blijkt aan de hand van de door Voorhoeve verstrekte gegevens tezamen met een hierna te noemen getype S.M.-versie als boek te zijn gecatalogiseerd; het fiche is onder de titel "Sedjarah Melaju" in de kaartcatalogus van de beherende instelling opgenomen met als signatuur Sed. 902.556/IJz.kast 112.3.

84 De bladen van deze typoscripten zijn vervat in een omslag van bruin kaftpapier en worden door een wit linnen lint bijeengehouden, dat via met een perforator vervaardigde gaten door het papier gaat.

85 Door Roolvink in zijn artikel "The answer of Pasai" (JMBRAS Vol. 38, Pt 2, 1965) de "Palembang versie" gedoopt. Zie ook zijn reeds in noot 57 genoemd artikel, p. 309.

$86 \mathrm{Zie}$ de uitvoerige biografie "Louis Constant Westenenk (3 Februari 1872 2 Mei 1930)" door H. T. Damsté in Westenenk, 1932, pp. 133-256.

87 L. C. Westenenk, 1923, pp. 212-226.

88 Dat de tekst van Westenenk in Arabisch schrift was geschreven, zou kunnen blijken uit zijn conjectuur "(of dahoeloenja)" na de woorden "di hoeloenja" onderaan op p. 214.

89 Dergelijke rekensommetjes worden ook wel in Arabische handschriften aangetroffen. De toenmalige conservator van de oosterse handschriften van de universiteitsbibliotheek te Leiden, drs. P. Sj. van Koningsveld, attendeerde mij in 1974 op zo'n aantekening in margine op het laatste blad van cod.or. 321 III. Dit handschrift is gedateerd H. 644; in die aantekening, gemaakt in H. 879, heeft iemand uitgerekend hoe oud zijn handschrift toen was: $879-644=235$ jaar. Ook in het Arabische handschrift cod.or. 12328 wordt een dergelijke notitie aangetroffen, die gediend schijnt te hebben om een schatting omtrent de ouderdom van het handschrift te controleren. Een derde geval waarop mijn aandacht werd gevestigd, doet zich voor in het Maleise handschrift cod.or. 6576. Onder de colofon van dit handschrift heeft iemand een aftreksom gemaakt, "waaruit moet blijken, dat het boek in 1904 132 jaar oud was" (Teeuw in zijn "Aantekeningen voor de supplement-catalogi Maleis", welke op de afdeling Oosterse handschriften van de Leidse universiteitsbibliotheek worden bewaard).

90 Opgenomen in de lijst van Britse papierfabrikanten bij Heawood, p. 49. 
91 Opgenomen in de lijst van Britse papierfabrikanten bij Churchill, p. 48 met als dateringen: 1837 en 1846-'54.

92 In de lijst bij Churchill vermeld op p. 50 met als datering 1801.

93 Heawood, nr 2774 (pl. 356) met als datering 1837.

$94 \mathrm{Bij}$ Heawood eveneens onder $\mathrm{nr} 2774$ (pl. 356).

95 Vgl. de afbeeldingen nrs 201-221 (pl. 30-36) bij Heawood.

\section{NOTEN BIJ HOOFDSTUK III:}

\section{NOTEN BIJ KI 4}

1 Gespeld: dh-l-h-j.

2 In deze tekst steeds: $\mathbf{g}$-l-s-p-i.

3 Steeds: p-l-m-b-ng.

4 Steeds: kh-s-i-n.

5 Steeds: a-l-i-a-t.

6 Steeds: s-c-b-a-n.

7 Gespeld: s-i-a-n-j-u-r.

8 Gespeld: b-a-r-u-n p-n-d-a-r k-p-i-l-n.

9 Gespeld: d-k-u-k.

10 Gespeld: s-w-a-l.

11 Gespeld: r-s-i-d-i-n-t r-i-n-i-s.

12 Gespeld: j-m-b-l-h.

13 Steeds gespeld: t-r-n-a-t-i-h.

\section{NOTEN BIJ UBL 7}

1 De tekst luidt: "satu", terwijl gelet op de toenmalige tinprijs "seratus" bedoeld moet zijn. Vgl. ook p. 14, onderaan, waar dezelfde prijs wordt genoemd per pikul $(1$ pikul $=100$ kati $)$.

2 De tekst luidt: "keduanya Palémbang". Ik heb "keduanya" geëlimineerd, omdat nergens vermeld wordt dat het gezantschap uit twee personen bestaat, en vervolgens "kembali di" toegevoegd.

3 De tekst luidt: "pésta ia".

4 Gespeld: a-1-i-m-d-a-n-a.

5 In het handschrift wordt "antara" op de volgende regel herhaald.

6 De tekst luidt: "anak".

7 Tussen "Isnin" en "pagi-pagi" staat in het handschrift: "hari"; door mij als overtollig element uit de tekst geëlimineerd.

8 In het handschrift wordt "dan" op de volgende regel herhaald.

9 Gespeld: $z-a-l-k-c-i-d-h$.

10 Als noot 8.

11 Gespeld: dh-a-l-h-j-h.

12 In het handschrift worden de woorden "di Palémbang" op dezelfde regel herhaald.

13 In het handschrift wordt "segala" onmiddellijk gevolgd door "sekalian". Ik heb dit als een verschrijving beschouwd en daarom "sekalian" weggelaten. 
14 In het handschrift wordt "itu" op dezelfde regel herhaald.

15 Gespeld: b-i-l-m.

16 Gespeld: g-a-l-s-p-i-h, verder ook: g-a-l-s-p-i.

17 Gespeld: b-l-n-d-h.

18 Gespeld: b-l-h-r-u-b-i.

19 Gespeld: d-i-d-u-d-u-d-u-k-k-n.

20 "Di dusun" gespeld: d-u-d-u-s-n.

21 De tekst luidt: "itu itupun".

22 In het handschrift wordt "lamanya" op dezelfde regel herhaald.

23 Gespeld: m-i-n-u-n.

24 In het handschrift wordt het laatste woord van de vorige bladzijde hier herhaald.

25 In het handschrift wordt "itu" op de volgende regel herhaald.

26 De tekst luidt: "dua duaribu" (herhaling van "dua" op de volgende regel).

27 De tekst luidt: "Surya semuanya", door mij opgevat als een verschrijving van "Suryakesuma". Ook de conjectuur "keduanya" zou een aanvaardbare tekst opleveren.

28 Hier en op alle volgende plaatsen in de tekst gespeld: k-b-u-r-n-u-r.

29 Gespeld: a-u-r-ng-n. Terwille van het zinsverband heb ik "jangan" ingevoegd, maar het is ook mogelijk, dat "jangan" moet worden gelezen in de plaats van "orangnya".

30 In het handschrift wordt "maka" op de volgende regel herhaald.

31 Hier bij uitzondering gespeld: s-r-d-a-d-u.

32 Gespeld: s-i-n-j-u-r.

33 In het handschrift wordt "pulang" op dezelfde regel herhaald.

34 Gespeld: p-r-k-n-n.

35 In het handschrift wordt "kedalam" op de volgende regel herhaald.

36 Als noot 25.

37 Hier gespeld: p-ng-u-r-a-s.

38 Als noot 24.

39 Gespeld: k-o-d-a-k.

$40 \mathrm{Vgl}$. de beknopte weergave van deze passage bij Van der Linden, 1937, p. 159.

41 Gespeld: d-k-k.

42 In het handschrift wordt "baya" op dezelfde regel herhaald.

43 Hier en ook elders (pp. 77, 78) wordt de naam van deze rangga gespeld: w-i-r-a-s-n-t-i-k-ny. De spelling "Wirasentiknja" treffen we verder aan in het in Latijns schrift geschreven UBL 5 en bij Van Doren, 1853 ("Ranga" (of "Karanga") "Wiera Santicknja") ; niet echter in MP 2, dat overigens vrijwel gelijkluidend is met UBL 5 .

44 De tekst luidt: "sembilan", door mij aangevuld tot "sembilanbelas", omdat de gevechten volgens de Hollandse berichten op woensdag 20 juni (= $19 \mathrm{Ra}$ madan) begonnen. 9 Ramadan (=10 juni) viel op zondag.

45 Als noot 40.

46 De tekst luidt: $y$-ng-d of l-ng-d, door mij opgevat als een verschrijving van k-p-d = kepada.

47 Als noot 30 .

48 Gespeld: $t-r-a-n-a-t-i$.

49 Hier gespeld: r-i-n-s, op p. 78: r-i-n-i-s.

50 Steeds gespeld: $r-s-d-n-t$.

51 Gespeld: p-u-t-ng.

52 Gespeld: g-u-b-i-r.

53 In het handschrift wordt "oléh" op de volgende regel herhaald.

54 Als noot 21. 


\section{NOTEN BIJ TR 1}

1 De getypte tekst luidt "panah", met potlood gewijzigd in "pélor".

2 Een typisch corrupte plaats. Patah is door mij geïnterpreteerd als een uitdrukking ter karakterisering van de fysieke toestand van "Mr. Salmond", wiens weerstand door de bekomen schotwond definitief is gebroken. Misschien moet rupanya hierbij dan worden opgevat als "zijn gestalte, zijn lichamelijke gesteldheid". Omdat we uit andere teksten weten dat hij in zijn buik werd geraakt, is het verleidelijk rupanya als het resultaat van een verkeerde transcriptie van perutnya te beschouwen, maar dan is patah wel vreemd. Ook kan worden gedacht aan verwisseling van rupanya en lukanya, in welk verband patah alweer eigenaardig aandoet. Aangezien de getypte tekst oorspronkelijk panah had voor pélor, kan het ook zijn dat patah sloeg op panah (hoewel dit een weinig zinvolle mededeling zou opleveren), in welk geval het door de wijziging van panah in pélor onvertaalbaar zou zijn geworden.

3 De tekst luidt "Tetapi", door mij opgevat als een foutieve transcriptie van tidak.

4 De tekst luidt "boeroetan". In overeenstemming met de in UBL 5/MP 2 (in Latijns schrift) gevolgde schrijfwijze "Borattan" en de spelling b-u-r-a-t-n van UBL 7 heb ik de tekst hier en op pp. 11 en 13 gewijzigd in "Buratan".

5 De getypte tekst luidt "Sindjoer", met potlood gewijzigd in "Tjiandjoer". Verder (p. 22 v.v.) evenzo.

6 De tekst luidt "Panangkarwilah", door mij, gelet op de spelling van deze geografische naam op p. 35 alsook in de andere Palembangse teksten en in de Lijst van aardrijkskundige namen, 1923, weergegeven als "Panang Karubelah".

7 Misschien wordt hiermee de streek van Danau Luar bedoeld, maar de Palembangse teksten spellen consequent: Dana Luar.

8 Deze emendatie is ontleend aan de tekst van UBL 5/MP 2. Ook UBL 7, p. 55, heeft iets dergelijks: "Yang laju mengamuk itu Kemas Said dan Haji Zain dan Haji Lanang".

9 Het in het typoscript op deze plaats volgende tekstgedeelte, luidende: "Dan kapal perang Nasu itu maka kapal terlalu besarnya. Sekira-kiranya ia melintang, memenuhi laut Palémbang.", past m.i. hier niet. Ik vermoed dat het een volle bladzijde verderop in het typoscript, dus bovenaan op p. 15, thuishoort, waar 't wel in de context past, en heb het daarom op die plaats (na "lobang-lobang") ingelast.

10 De tekst luidt "Maka kapal Nasoe perang itoe". Het woord "Nasoe" is met potlood geschreven, op de plaats die de typist open had gelaten tussen "kapal" en "perang".

11 Zie noot 9.

12 Gespeld: perhamaän.

13 De getypte tekst luidt "perkoeat", met potlood gewijzigd in "perkoeta".

14 De getypte tekst luidt "sigra-sigra", met potlood gewijzigd in "sikira-kira".

15 Gespeld: setanggar.

16 De tekst luidt "hoetan raicat" (sic!).

17 De getypte tekst luidt "bergantjanglah", met potlood gewijzigd in "berkoentjanglah".

18 De tekst luidt "Wiradjaja Goebir", door mij naar analogie van mijn toevoeging "<dan Pangéran Wirakrama Gubir>" bovenaan op p. 18 van het typoscript gewijzigd in "Wirakrama Gubir". 
19 Gespeld: meneramlah. Mogelijk is hier geen spelfout gemaakt, maar een bestaande vorm naast menderamlah weergegeven, zoals menengar naast mendengar.

20 De getypte tekst luidt "perisijan", met potlood gewijzigd in "perisen" (vgl. Jav. isèn).

21 Ook deze emendatie is ontleend aan UBL 5/MP 2, waar het corresponderende tekstgedeelte luidt: "Keduanya langbut itu lapis tembaga, meriamnya besar, di luan satu dan di burinya satu. Yang di luan itu meriam tembaga besar, panjang hampir tiga depa dan di burinya itu meriam besi". UBL 7 spreekt eveneens van een koperen en een ijzeren kanon. Ik heb daarom aangenomen dat hier in TR 1 geen sprake is van een ijzeren achtersteven, wat trouwens voor mijn gevoel een scheepbouwkundig monstrum zou opleveren.

22 Het laatste woord van de vorige bladzijde is hier herhaald.

23 Hier, evenals in UBL 5, gespeld: tjeroetjoep; in de volgende zin: tjeroetjoeb.

24 De tekst luidt "kapal", wat in het zinsverband niet past. Mede gelet op de vaak zeer onregelmatige spelling van kepala en kapal in de in Arabisch schrift geschreven Palembangse teksten en voorts in aanmerking genomen dat in deze tekst tussen "kapal" en het daarop volgende "jang" door de typist één extra spatie open is gelaten, acht ik het waarschijnlijk dat voor "kapal" het hier wel passende "kepala" moet worden gelezen.

25 De tekst luidt "isinja-isinja".

26 Hier en op p. 37 op z'n Javaans gespeld: $\operatorname{seseg(lah),~op~pp.~} 19$ en 20 echter: sesek(lah).

27 De tekst luidt "tiada", door mij opgevat als een foutieve transcriptie van jika.

28 De tekst luidt "Soltan", terwijl "Soehoenan" bedoeld moet zijn.

29 Uit de oorspronkelijke tekst “... maka Pangéran Purba jatuh sakit pada malam itu. Sakit juga tiada dapat melihat lagi ;..." heb ik naar analogie van de lezing van UBL 5/MP 2 het tweede "sakit" geëlimineerd (zie de toelichting bij par. 7.3 in de Tekstvergelijking TR 1 - UBL 5/MP 2).

30 De tekst luidt "di deketin". Hoewel het achtervoegsel -in in populaire (Jakartaas-) Maleise schrijftaal voorkomt in de betekenis van het Maleis-Indonesische achtervoegsel $-i$, heb ik op grond van bezwaren van semantische aard en voorts overwegende dat het achtervoegsel -in verder in deze tekst niet voorkomt, evenmin als in één der andere Palembangse teksten, gemeend in deze vorm eerder een foutieve transcriptie van di dekatnya te moeten zien.

31 De oorspronkelijke getypte tekst luidt "hal jang demikian itoe", maar is met de schrijfmachine ditmaal - gewijzigd in "hal demikian itoe jang". De oorspronkelijke lezing verdient m.i. de voorkeur.

32 De getypte tekst luidt "Penangkroe-belah", met potlood gewijzigd in "Penangkroe-bila". Zie verder noot 6 .

33 Zie noot 7.

34 Als noot 22.

35 De tekst luidt "Adapoen".

36 Gespeld: memerang (vgl. Jav. merang).

37 De getypte tekst luidt hier en even verder "kadoewakan", met potlood gewijzigd in "kadoedoekan" resp. "kadoekan". Ik heb het op beide plaatsen als "Kedukan" gelezen en als een geografische naam opgevat. Eén van de zestien wijken van Palembang aan de rechter- (ulu-) oever van de Musi, nl. ulukampung nr 5, heette Kedukan (zie Van Rijn van Alkemade, 1883, p. 52). Een andere mogelijkheid lijkt het aan de linkeroever en dus aan dezelfde kant als de Tengkurukrivier verder landinwaarts gelegen Kedukan Bukit. Of moeten we toch denken aan de hier dan wel in een bijzondere betekenis gebruikte vorm ke-duduk-an? 
38 De tekst luidt "Goesi", door mij conform de andere Palembangse teksten gewijzigd in "Gubir".

39 De tekst luidt "sampailah di pada Resident". De getypte tekst is in de rechterbenedenhoek van p. 39 weggevallen, doordat het carbonpapier tijdens het typen ter plaatse omgevouwen is geweest. Dit tekstgedeelte is later met potlood aangevuld, op deze plaats met de woorden "pada Resident". Op die manier kan allicht een foutje als "di pada" zijn ontstaan.

40 Als noot 22.

\section{NOTEN BIJ UBL 9}

1 Gespeld: r-b-p-l-s, verder ook: r-b-p-a-l-(i-)s en op p. 87: r-p-l-i-s.

2 Steeds gespeld: l-i-h-i-r.

3 Gespeld: p-l-i-m, verder ook: p-i-l-m.

4 Steeds gespeld: kh-f.

5 De tekst luidt "mentanyakan".

6 Gespeld: j-r-u-l-i-s.

7 De tekst luidt "bunyinya".

8 De tekst luidt "kecil".

9 Gespeld: $\mathrm{g}-\mathrm{a}-\mathrm{-}-\mathrm{i}-\mathrm{p}-\mathrm{i}$, verder afwisselend ook: $\mathrm{g}$-a-l-p-i en $\mathrm{g}$-l-i-p-i.

10 Gespeld: k-p-a-l; in de volgende zin echter: k-a-p-l. Niettemin lees ik op alle drie de plaatsen "kepala" en niet "kapal", omdat "besar kapal" mij vreemd Maleis lijkt en omdat "kepala" m.i. beter in het zinsverband past dan "kapal". De spelling is in dit opzicht overigens zeer onvast ; op pp. 92-93 bijv. is "kapal" gespeld: k-p-a-l, maar elders treffen we weer de meer gebruikelijke spelling k-a-p-l of k-p-l aan.

11 De tekst luidt onmiskenbaar: h-n-d-k.

12 Gespeld: r-u-s-a, verder steeds: r-u-s $(-\mathrm{u})$.

13 De tekst luidt "demikiankah".

14 In het handschrift is het angka dua na "setiap" tweemaal geschreven.

15 De tekst luidt "tangan".

16 Gespeld: b-u-a-l-i-h l-ng-u, verder steeds correct: b-u-i l-(a-)ng-u.

17 De tekst luidt m-l-i-h-t, "melihat". Op grond van de mededeling, dat er tegen de middag weer een brief komt van Pangéran Citrakesuma (p. 51, onderaan), heb ik aangenomen dat deze hier niet "komt kijken" (het lijkt bovendien onwaarschijnlijk dat de auteur hem verder zou aanduiden als "de brenger van de brief"), maar dat hier een ondergeschikte van de pangéran wordt bedoeld. Gedacht zou kunnen worden aan een verschrijving - onder invloed van het twee zinnen eerder gebruikte melihat - van miji, Jav. dienaar, in de toenmalige Palembangse samenleving iemand die behoort tot de klasse van dienstplichtigen aan leden van de vorstelijke familie of de adelstand, of aan een dan wel zeer ernstige verschrijving van het onderaan p. 50 gebruikte suruhan.

18 Tussen "pagi" en "patik" staat in het handschrift: "waktu / lohor datang pula surat", door mij als een geval van dittografie opgevat ten opzichte van het begin van de zin en daarom geëlimineerd.

19 De tekst luidt: "Apa khabar baik". Het stereotiepe antwoord op de vraag "Apa khabar?" is "Khabar baik!". Handhaaft men de lezing van het handschrift, dan zijn er drie interpretaties mogelijk: "Apa? Khabar baik!", "Apa khabar? Baik!" en "Apa khabar baik?!" (als rhetorische vraag). De eerste twee passen m.i. niet goed in het Maleise taalgebruik. De derde interpretatie, misschien nog de beste van de drie want er is inderdaad sprake van een com- 
binatie van goed en slecht nieuws, veronderstelt dat geantwoord wordt op de vraag "Apa khabarnya ...., (ada) baik?", hetgeen hier niet het geval is. Op grond hiervan heb ik "apa" uit de tekst geëlimineerd.

20 Gespeld: s-ng-k-n-g-a-r-a, verder steeds correct: s-u-m-n-g-a-r-a.

21 Gespeld: m-ny-a-t-r.

22 De tekst luidt "pangéran", maar het zinsverband eist "menteri".

23 In het handschrift wordt "kepada" op de volgende regel herhaald.

24 De tekst luidt: ".... zuriat yang lain ....". Dit "lain" na "yang" heb ik beschouwd als een verschrijving onder invloed van de reeks "yang lain" vóor "daripada zuriat".

25 De tekst luidt "antarlah", terwijl het tegenovergestelde, ambillah, bedoeld moet zijn.

26 Gespeld: s-u-r-a.

27 Gespeld: b-u-l-n.

28 Gespeld: d-i-b-a-t-r-k-n.

29 Gespeld: m-s-a-u-t-c-h.

30 Gespeld: m-u-s-b.

31 De tekst luidt "beberapa".

32 Gespeld: m-a-t-'-h.

33 In het handschrift is het angka dua na "bertalu" tweemaal geschreven.

34 In het handschrift worden de woorden "dan menteri-menteri" bij de overgang naar de volgende regel herhaald.

35 Gespeld: s-u-r-l-ng-u-n.

36 Tussen "itu" en "kepada" staat in het handschrift "maka". Omdat dit in het zinsverband niet past, heb ik het weggelaten.

37 Gespeld: $\mathrm{m}-\mathrm{k}-\mathrm{s}-\mathrm{m}$.

38 In het handschrift wordt het laatste woord van de vorige bladzijde, "menerima", hier herhaald.

39 Tussen "itupun" en "selalu" staan in het handschrift de woorden "khabar itu". Vanwege het zinsverband heb ik deze weggelaten en verder na het volgende "khabar" de woorden "itu. Maka titah" ingevoegd.

40 De tekst luidt: a-d-a-c-a-l-i-m-a-d-a-h, door mij gelezen als "ada alim atas". Vgl. de zin "Didalam itu apa juga alim atas kami kedua." bovenaan p. 72.

41 De tekst luidt "Suranegara", terwijl "Sumanegara" moet zijn bedoeld.

42 De tekst luidt "Paduka punya".

43 Gespeld: m-m-n-a-s-a-k-n.

44 Gespeld: m-ny-u-b-u-h.

45 Gespeld: $p-a-i-k^{2}$.

46 De tekst luidt "sorak", gespeld s-u-r-k, terwijl "korok", gespeld k-u-r-k, moet zijn bedoeld.

47 Vóór $m-1-a-y-u$ staat in het handschrift $m-u$. Een verschrijving in anticipatie op "Melayu"?

48 In het handschrift wordt "dan" op dezelfde regel herhaald.

49 De tekst luidt "mesuarat akan".

50 Alleen hier voluit "Kesumanegara".

51 Gespeld: d-g-l-r; verder, op p. 85, tweemaal: d-i-g-l-r. Van der Linden, 1937, p. 158, leest "orang poetih Inggeris kapitan gelarnja (een Engelsch kapitein)"!

52 Gespeld: b-a-r-i-k-m-i-l ; verder, op p. 85: b-a-r-k-m-l.

53 Gespeld: $m-i-j-r-b-a-s-n$, verder meestal: $m-i-j-r-b-s-n$. In mijn tekst heb ik in afwijking van deze spelling de gebruikelijke schrijfwijze méjer gevolgd.

54 Gespeld: m-n-d-a-r-k, vgl. Jav. duraka.

55 De tekst luidt "telah", maar dit geeft hier geen zin; vandaar mijn conjectuur "tua(h)". 
56 Hier en in de volgende zin bij uitzondering gespeld: m-ny-u-m-p-u-t-i.

57 De tekst is onduidelijk. Ik lees s-u-m-ng-i-gh, s-u-m-p-i-n-g of s-u-m-ng-i-ng, maar weet niet wat dat zou kunnen betekenen. In de vertaling heb ik deze passage daarom open gelaten.

58 De tekst luidt "tiada apa berapa"; ik heb "apa" als een verschrijving opgevat en daarom geëlimineerd.

59 Hier gespeld: z-i-a-r, even later: dh-i-a-r-a.

60 In het handschrift wordt het laatste woord van de vorige bladzijde, "dan", hier herhaald.

61 De tekst luidt: “.... Sultan Muda negeri naik kerajaan bergelar suhunan."

62 In het handschrift wordt "yang" op dezelfde regel herhaald.

63 Gespeld: d-t-a-r-u-', vgl. Jav. ditaruk.

64 Gespeld: s-i-n-j-r.

65 Gespeld: s-m-a-d-ng.

66 Gespeld: r-a-m-s-u-m.

67 Gespeld: p-s-u-n, door Van der Linden, 1937, p. 155, ten onrechte gelezen als "pitenah".

68 Gespeld: w-l-n-d-h, verder ook: w-(i-)l-n-d-(a-)h.

69 Gespeld: d-i-a-a-j-a-'-ny, door Van der Linden, 1937, p. 158, ten onrechte gelezen als "diadjoek (bootsten hen na)".

70 Gespeld: u-s-a-k-n, door Van der Linden, 1937, p. 158, ten onrechte gelezen als "oesahan (oppasser)".

71 Gespeld: s-i-a-p-l-h, door Van der Linden, 1937, p. 158, ten onrechte gelezen als "sépahlah (in wanorde verspreid lagen)".

72 De tekst luidt "Suryadilaga", maar bij vergelijking met corresponderende passages uit UBL 7, TR 1 en MP 4b blijkt dat Pangéran Suradilaga bedoeld wordt.

73 In het handschrift wordt "pasirah" op de volgende regel herhaald.

74 Gespeld: p-i-n-a-w-a-i-a.

75 Ik lees hier: g-i-r-a-n-. Misschien de titel van een functionaris, evenals de voorafgaande woorden?

76 De tekst luidt "berbayar".

\section{NOTEN BIJ HOOFDSTUK V}

1 Winstedt, 1940 en 1958; Hooykaas, 1937/47.

2 Bottoms, 1959/62/65.

3 Djajadiningrat, 1911.

4 Mees, 1935.

5 Ras, 1968.

6 Sweeney, 1968.

7 Iskandar, 1959.

8 Hill, 1960.

9 Teeuw-Wyatt, 1970.

$10 \mathrm{Kratz}, 1973$.

11 Rusconi, 1935.

12 Skinner, 1963.

13 Winstedt, 1919; Misa Melayu, 1962.

14 Sturrock, 1916, Dzulkifli, 1968 en Siti Hawa Saléh, 1970; Winstedt, 1932 a en -b; Tuhfat al-Nafis,1965; A. F. von de Wall, 1891; Netscher, 1853 en 1855. 
15 Dulaurier, 1839.

16 Tambo Bangkahoeloe, 1933.

17 Malayan Miscellanies II, 1822, 12.

18 Malayan Miscellanies I, 1820, 3; Braddell, 1850.

19 De Kock, 1844 b en 1846 a.

20 Netscher, 1850.

21 De Hollander, 1871.

22 Low, 1880.

23 De Clercq, 1895.

24 Stockhausen, 1863.

25 Wiersma, 1871.

26 De Josselin de Jong, 1964.

27 Zie de uitvoerige beschouwingen van Ras, o.c. hoofdstukken IV-VI.

$28 \mathrm{Vgl}$. de opmerkingen van De Josselin de Jong over de charter-functie van de Sejarah Melayu, o.c. pp. 239-240.

29 Vgl. de opmerkingen over het genealogische karakter van de Hikayat Patani bij Teeuw-Wyatt, 1970, p. 290.

$30 \mathrm{Zie}$ Teeuw-Wyatt, 1970, pp. 71-75 en 221-224.

31 Zie Siti Hawa Saléh, 1970, p. 110 v.v.

32 Zie Teeuw-Wyatt, 1970, p. 294.

33 Edel, 1938, p. 7.

34 Zie R. A. Kern, 1948, p. 30: "Zin voor chronologie is haar" (de Maleise geschiedschrijving, W.) "vreemd, alles buitelt door elkaar, de historische aders of ribben die door hun verhalen heen loopen, kunnen het geheel niet bijeen houden".

35 Court, 1821, pp. 25-32.

36 Op p. 88 verzucht hij: "Demikianlah pusing-memusing tipu-menipu bijaksana orang kulit putih".

37 Zie bijv. pp. 68 en 91 .

38 UBL 7: pp. 54-61; TR 1: pp. 10-21; UBL 9: pp. 91-95.

39 Het zijn de eindrijmen: yar-yar-bar-bar (str. 162), jak-dak-dak-bak (str. 178), dung-bung-dung-dung (str. 43), dung-dung-nung-dung (str. 100), dur-durbur-dur (str. 201), ga-ga-ga-da (str. 21 en 207), kur-fur-dur-bur (str. 190), yam-lam-lam-lam (str. 186), lam-yam-yam-bam (str. 195), mat-mat-nat-mat (str. 75), nat-nat-mat-mat (str. 184), laut-paut-maut-maut (str. 120), kainmain-ngin-ngin (str. 223), nyum-num-num-num (str. 160).

40 Zie de tekstedities, verzorgd door respectievelijk Rusconi (1935), Skinner (1963) en Teeuw (1966).

41 Zie de uitgave van zijn geschriften door Doorenbos (Doorenbos, 1933). Voor de problematiek van oorsprong en ontwikkeling van dit literaire genre verwijs ik naar de studies van Teeuw en Syed Naguib Al-Attas, die ieder op hun eigen wijze de oorsprong van de Maleise syacir herleiden tot Hamzah Fansuri (Teeuw, $1966 \mathrm{~b}$; Al-Attas, 1968). Men raadplege verder in dit verband: Sweeney, 1971.

42 Opvallend is hier het verschil van de tekst van de Palembangse syacir ten opzichte van de lezing van de Syacir Perang Mengkasar in de uitgave van Skinner, door deze opgevat als een verbale vorm met yang (in de betekenis van godheid) als grondwoord en vertaald met "jam worshippers". Een ongebruikelijke, enigszins hoogdravende uitdrukking, die overigens goed in het verband past. Daartegenover bezigt de dichter van de Syacir Perang Ménténg een alledaagse uitdrukking, welke geen enkel verband met de godsdienst impliceert. Het is echter de vraag, of de lezing van Skinner juist is. Het handschrift spelt ter plaatse onmiskenbaar: $m-n g-n y-k-n$ en in $118 \mathrm{a}$ - vollediger -: 
$m-n g-n y-n g-k-n$. Moet men hier wellicht mengenyangkan lezen? Dat zou meer in overeenstemming met de grondtekst zijn en mengenyangkan is op zichzelf zeker geen ongebruikelijk woord. Wel misschien de syntactische verbinding met $u b i$ in de betekenis: "zich verzadigen met knollen". Het verschil in betekenis met de Palembangse lezing zou bij deze laatste interpretatie vrijwel wegvallen. Dat de Palembangse dichter niettemin de gewone uitdrukking memakan ubi gebruikt, zou erop kunnen duiden dat de uitdrukking mengenyangkan ubi later onduidelijk werd gevonden of althans minder goed paste in het Palembangse taalgebruik van de negentiende eeuw.

$43 \mathrm{Zie}$ met betrekking tot deze doxologie, welke de eerste twaalf strofen van het gedicht in beslag neemt, de beschouwingen van Skinner in de inleiding van zijn tekstuitgave, pp. 38-41.

44 Dezelfde visie komt ook naar voren in de aan het begin van de Aceh-oorlog gewijde "Syacir Perang Acéh", waarvan een Nederlandse vertaling door E. Blok is gepubliceerd in TBG 30 (1885), pp. 568-595. Van de Maleise tekst van deze syacir zijn in Singapore een aantal steendrukken verschenen. De Leidse universiteitsbibliotheek bezit drie verschillende edities, respectievelijk van 25 Jumadil-awal 1298 (= 25 april 1881), 6 Safar 1303 (= 14 november 1885) en 1 Zulkacédah 1303 (= 1 augustus 1886). Slechts in de editie van 1885, afkomstig van de persen van Haji Muhammad Siraja ibn al-marhum Haji Muhammad Saléh en Haji Termidi, "achter de moskee van Sultan Ali", is boven de tekst een titel afgedrukt. Deze luidt: "Syacir Negeri Acéh", dus niet, zoals bij Blok, "Syacir Perang Acéh". Misschien heeft Blok, op zijn exemplaar van de tekst geen titel vermeld vindende, deze overigens wel zo toepasselijke titel zelf bedacht. 


\section{VERGELIJKINGSTABEL VOOR DATA VOLGENS DE MOSLIMSE EN DE CHRISTELIJKE TIJDREKENING}

Onderstaande tabel bevat een chronologische opgave van de jaartallen en data die in de gepubliceerde teksten voorkomen. Naast elke datering volgens de moslimse jaartelling is de daarmee corresponderende datering volgens de christelijke jaartelling vermeld. In de derde kolom is aangegeven op welke plaats het jaartal of de datum voorkomt; de paginering is die van het handschrift. Voor de omrekening van de moslime in de christelijke jaartelling is gebruik gemaakt van Wüstenfeld-Mahler, 1961. In de dateringen waarin de dag van de week met name wordt genoemd, blijkt de omrekening van moslimse in christelijke jaartelling vaak een verschil van één of twee dagen op te leveren. Dit verschil kan slechts in enkele gevallen worden verklaard uit het feit dat de dagen volgens de moslimse tijdrekening verspringen met zonsondergang en volgens de christelijke tijdrekening 's nachts om 00.00 uur. De werkelijke dag is tussen haakjes vermeld achter de Nederlandse naam voor de dag die in de tekst genoemd wordt.

\begin{tabular}{|c|c|c|}
\hline Moslimse jaartelling & Christelijke jaartelling & \\
\hline 966 & $1559 / ’ 58$ & TR 1, p. 1 \\
\hline 968 & $1561 / ' 60$ & TR 1, p. 1 \\
\hline 977 & $1569 / ' 70$ & TR 1, p. 1 \\
\hline 989 & 1581 & TR 1, p. 1 \\
\hline 1024 & 1615 & TR 1, p. 1 \\
\hline 1025 & 1616 & TR 1, p. 1 \\
\hline 1032 & $1623 / ' 22$ & TR 1, p. 1 \\
\hline 1044 & $1634 / ’ 35$ & TR 1, p. 1 \\
\hline 1045 & $1635 / ’ 36$ & TR 1, p. 1 \\
\hline 1053 & $1643 / ’ 44$ & TR 1, p. 1 \\
\hline 1098 & $1687 / ' 86$ & TR 1, p. 1 \\
\hline 1118 & $1706 /{ }^{\prime} 07$ & TR 1, p. 1 \\
\hline 1120 & $1708 /{ }^{\prime} 09$ & TR 1, p. 2 \\
\hline $\begin{array}{l}\text { 1136, } 27 \text { Jumadil-akhir, } \\
\text { hari Khamis }\end{array}$ & $\begin{array}{l}\text { 1724, } 23 \text { maart, } \\
\text { donderdag }\end{array}$ & UBL 7, p. 14 \\
\hline $\begin{array}{l}\text { 1140, } 8 \text { Rajab, } \\
\text { hari Jumcat }\end{array}$ & $\begin{array}{l}\text { 1728, } 19 \text { februari } \\
\text { vrijdag (donderdag) }\end{array}$ & UBL 7, p. 15 \\
\hline $\begin{array}{l}\text { 1150, } 4 \text { Jumadil-akhir, } \\
\text { hari Isnin }\end{array}$ & $\begin{array}{l}\text { 1737, } 29 \text { september, } \\
\text { maandag (zondag) }\end{array}$ & UBL 7, p. 15 \\
\hline
\end{tabular}


Moslimse jaartelling

1161, 28 Jumadil-awal, hari Isnin

1171, 3 Muharram, malam Sabtu

1190, 20 Zulkacédah, malam Isnin

1191

1207

1211, 23 Syacban, hari Isnin

1218, 21 Zulhijah, hari Isnin

1218, 22 Zulhijah, hari Isnin

1226, 28 Syacban, hari Selasa

1226, 3 Ramadan, hari Ahad

1226, 23 Ramadan

1227

1227, 11 Rabicul-akhir

1227, 12 Rabicul-akhir, malam Sabtu

1227, 13 Rabicul-akhir, malam Ahad

1227, 18 Rabicul-akhir, hari Jumcat

1227, 19 Rabicul-akhir, hari Sabtu

1227, 2 Jumadil-awal, hari Khamis

1227, 6 Jumadil-awal

1228, 17 Rajab,

hari Khamis

1228, 17 Syacban,

hari Sabtu

1228, 22 Syacban,

hari Khamis

1232, 21 Muharram,

hari Selasa

1233, 30 Rajab, malam Khamis
Christelijke jaartelling

1748, 26 mei, maandag (zondag)

1757, 17 september, vrijdagavond (zaterdag)

1776, 31 december, zondagnacht (dinsdag)

1777

1793/'92

1797, 21 februari,

maandag (dinsdag)

1804, 2 april,

maandag

1804, 3 april,

maandag (dinsdag)

1811, 17 september, dinsdag

1811, 21 september

zondag (zaterdag)

1811, 11 oktober

1812

1812, 24 april

1812, 25 april,

vrijdagnacht en vrijdagavond (zaterdag)

1812, 26 april, zaterdagavond (zondag)

UBL 7, p. 15

UBL 7, p. 16

UBL 7, p. 17

KI 4, p. 28

TR 1, p. 2

UBL 7, p. 18

UBL 7, p. 21

KI 4, p. 26

UBL 7, p. 28

UBL 7, p. 28

UBL 9, p. 46

TR 1, p. 2

UBL 7, p. 32

KI 4, p. 26

en

UBL 7, p. 34

UBL 7, p. 34

1812, 1 mei,

vrijdag

1812, 2 mei,

zaterdag

1812, 14 mei,

donderdag

1812, 18 mei

1813,16 juli,

donderdag (vrijdag)

1813,15 augustus,

zaterdag (zondag)

1813, 20 augustus,

donderdag (vrijdag)

1816, 11 december,

dinsdag (woensdag)

1818,5 juni,

woensdagavond

of -nacht (vrijdag)
UBL 7, p. 35

UBL 7, p. 35

UBL 7, p. 36

UBL 7, p. 36

KI 4, p. 27

KI 4, p. 27

KI 4, p. 27

KI 4, p. 27

KI 4, p. 27 
Moslimse jaartelling

1233, 22 Syacban, hari Jumcat

1233, 1 Ramadan, hari Sabtu

1234, 2 Safar,

hari Isnin

1234, 18 Syacban, harinya Sabtu

1234, 19 Syacban, hari Sabtu

1234, 21 Syacban, hari Selasa

1234, 22 Syacban, hari Selasa

1235, bulan Asyura (2 Muharram?), hari Khamis

1236

1236, 11 Ramadan, hari Isnin

1236, 19 Ramadan, hari Arbac

1236, 24 Ramadan, malam Ahad

1236, 5 Sawal, hari Khamis

1237

1240, 29 Rabicul-awal, malam Isnin

1240, 1 Rabicul-akhir, malam Isnin

1240, 2 Rabicul-akhir, malam Selasa

1240, 4 Rajab, hari Isnin

1241

1260, 10 Jumadil-awal

1269, 14 Safar, hari Jumcat

1277, 2 Rajab, malam Ahad
Christelijke jaartelling

1818, 27 juni, vrijdag (zaterdag)

1818,5 juli, zaterdag (zondag)

1818,1 december, maandag (dinsdag)

1819, 12 juni, zaterdag

1819,13 juni, zaterdag (zondag)

1819, 15 juni, dinsdag

1819, 16 juni, dinsdag (woensdag)

1819 ,

( 21 oktober?), donderdag

1821

1821, 12 juni, maandag (dinsdag)

1821, 20 juni, woensdag

1821, 25 juni, zaterdagnacht (maandag)

1821, 6 juli, donderdag (vrijdag)

$1822 / ' 21$

1824, 21 november, zondagnacht

1824, 23 november, zondagnacht (dinsdag) 1824, 24 november, maandagavond of -nacht (woensdag) 1825, 22 februari, maandag (dinsdag)

$1826 / 25$

1844, 28 mei

KI 4, p. 27

KI 4, p. 27

KI 4, p. 27

Syacir, str. 10

KI 4, p. 27

Syacir, str. 63

KI 4, p. 27

Syacir, str. 145

TR 1, p. 30

KI 4, p. 28

UBL 7, p. 68

KI 4, p. 28

KI 4, p. 28

TR 1, p. 2

TR 1, p. 38

en

UBL 7, p. 75

KI 4, p. 28

KI 4, p. 28

KI 4, p. 28

KI 4, p. 29

KI 4, p. 29

KI 4, p. 29

vrijdag (zaterdag)

1861,14 januari, zaterdagnacht (maandag)

KI 4, p. 29 


\section{WOORDENLIJST BIJ DE MALEISE TEKSTEN GEPUBLICEERD IN HOOFDSTUK III}

Deze woordenlijst omvat naast een beperkt aantal woorden die niet in de Maleise woordenboeken te vinden zijn, een groter aantal woorden waarvan de bijzondere betekenis in de tekst op niet geheel bevredigende wijze door de woordenboeken wordt weergegeven of waarvan het voorkomen als zodanig mij vermeldenswaard leek, en tenslotte de in het Palembangs Maleis vrij frequent voorkomende Javaanse leenwoorden, ook al zijn deze in sommige Maleise woordenboeken opgenomen. Alle onder vermelding van hun vindplaats rechtstreeks uit de Maleise tekst geciteerde woorden zijn cursief gedrukt.

De vindplaats van een woord wordt aangegeven als volgt. De hoofdletters A - E verwijzen naar de teksten, resp. KI 4 (p. 26, r. 16 - p. 29), UBL 7, TR 1, UBL 9 en MP 4b. De nummers achter de hoofdletters A - D verwijzen naar de bladzijde van de tekst volgens de paginering van het handschrift. De nummers + één der kleine letters a-d achter de hoofdletter $E$ verwijzen naar de regel van de syacir waarin het woord voorkomt. Bijv. C 39, E 43b.

adap: pengadapan, B 27, D 49, 55, 74,

92, E $11 \mathrm{a}$, audiëntiehal, ontvangzaal; z.o. balai, marak, paséban.

afdeeling: satu afdeelingnya, C 36 , elk der afdelingen.

$a k u$, ik; gebruikt a) door de vorst: B 2, 35, C 39, D passim; b) door de auteur van $B$ ter aanduiding van zichzelf: B 1 ; z.o. gua, hamba, patik, saya.

alim (1): orang alim-alim, B 21, 62, de moslimse wetgeleerden, de geestelijkheid.

(2), D 71, 72, Jav., vergiffenis, verschoning, verlof.

aman: aman sentosa, B 2, 3, 18, 21 ; sentosa aman, B 4, 17, in een toestand van rust en vrede.

ampilan, B 59, D 59, houten borstwering, schild of pantser in Indon. oorlogsvaartuig ter bescherming van kanonschutter; C 25, 26, v.e. zodanig pantser voorzien vaartuig, = perahu (pakai) ampilan, B 59, C 25, 26, 40, = perahu bera(m)pilan, B 66, E $219 \mathrm{~d}$. amuk: beramuk, B 11, 12, 68, tot de aanval overgaan, een aanval doen (intransitief) ; ook wederkerig: elkaar aanvallen. ancir, C 14, = incar, drilboor.

anggur, E 43b, 96b, 168b, = anggur meriam, schroot; vgl. Eng. grape-shot.

aniaya: buat aniaya padanya, C 8, tegenwerken, ageren tegen, een gemene streek uithalen t.o.v.

apilan, zie ampilan.

arak: mengarak surat, B $8,16,18,20$, een officiële brief in optocht ronddragen, plechtig en met groot ceremonieel ontvangen.

asal: asalnya, A 26, B 3, = dahulunya, A 27, voorheen.

atur, C 21, 33, eerbiedige mededeling, beleefd verzoek of voorstel; mengaturi, C 41 , beleefd uitnodigen; mengaturkan, C 8, 20, 30, 39, diaturkan(nya), C 12, 18, Baginda aturkan, C 21, beleefd mededelen, (een brief) beleefd aanbieden; vgl. Jav. atur.

babat: berbabat jalan, B 67, een pad, een tracé (door het bos) kappen; vgl. tebas.

bahari, C 32, bahri, C 16, overoud, uit vroeger dagen, uit de (goede) oude tijd; vgl. De Clercq, 1876, p. 527.

bahri, zie bahari. 
baik: diperbaiki segala hati, C 10, diperbaiki Suhunan akan hatinya, G 23, met geschenken aangemoedigd, beloond; vgl. Kl. s.v. baik: membaiki orang, membaiki hati.

bakar: membakar léla, E 29c, een kanon tot ontbranding brengen, afvuren; obat terbakar, E 97d, het kruit vat vlam, ontbrandt, komt tot ontploffing.

balai: balai bandung, B 36, C 20,32, 37, D 47, een uit twee afdelingen bestaande ontvangstruimte op het kratonterrein, vgl. Wlk. s.v. bandong; balai seri, E $54 \mathrm{~b}$, = seri balai, het podium in de audiëntiezaal, waar de vorst met zijn gevolg zijn plaats heeft, onderscheiden van het als paséban, pengadapan of pemarakan aangeduide gedeelte, dat bestemd is voor de ambtelijke en niet-ambtelijke onderdanen; vgl. Kl. s.v. balai; z.o. adap, marak, paséban.

bandar, A 27, de (haven)stad (Palembang), D 42 = sahbandar, C 9, havenmeester; vgl. vdW. s.v. bandar.

bangkai, C 12, 13, lijken (van Hollanders); vgl. mayit, mayat, B 12, C 12, E 22d, lijken (van Palembangers).

bangsa Yang, B 30, de adelstand "Yang" op Banka; vgl. KI 12, p. 72 onderaan, waar van deze stand gezegd wordt dat hij op één lijn staat met de "bangsa periai di keturunan raja-raja di Palémbang". De titel "Yang" gold voor de vrouwelijke en de titel "Akub" voor de mannelijke nakomelingen van de door Sultan Mahmud Badaruddin I omstreeks 1725 onderscheiden Wan Awang van Bangka-Kota; z.o. De Clercq, 1895, p. 135.

baris, A-E passim, militairen, krijgsvolk, legergroep, B 64, C 32, erewacht; baris meriam, A 28: rij boordkanons; vgl. Kl. s.v. baris: geschutrij, batterij.

batangari, B 37, 59, 69, 77, = batanghari, (grote) rivier; ook in combinatie met de naam v.e. rivier: Musi (B, C, D), Komering, Plaju, Rawas (B), Awal (C) ; Batangari Sembilan, B passim, (het gebied van) de Negen Rivieren. batanghari, zie batangari.

bebawan, E 128a, gaffel, ra; vgl. Jav. pambaon, Mal. pembawan, pebahu; zie Kl. s.v. bawan, Wlk., Wns. s.v. bahu. belah: (me)nyebelah di / ke(pada), B $13,59,78, \mathrm{C} 6,42$, de wijk nemen, uitwijken, afslaan, overlopen naar, partij kiezen voor.

belongkang: perahu belongkang Melayu, D 54, een Maleise riviervrachtboot of laadprauw; zie Nooteboom, 1932, pp. 33, 39 v.v.

bélot, zie wilut.

bénténg: bénténg berjalan, B 66, D 77, mobiele batterij, verplaatsbare schans; berbénténg dada, E 27c, 187c, terwijl de borst dienst doet als vestingmuur; vgl. Skinner, 1963, 347d, berbénténgkan dada ("he opposed his breast to the enemy's attacks").

bicara: kepala bicara, B 25, 43, 79, raadsman, woordvoerder, initiatiefnemer; kantor bicara, B 31, bestuurskantoor; bicara negeri, B 64, 73, staatszaken; memegang bicara, $\mathrm{B} 73=$ megang perkara, B 74, de staatszaken behartigen.

bikin, membikin(kan), uitsluitend $\mathrm{C}$, = membuat(kan), maken enz.; zie buat,

bilang, D 76, sebilang, D 89, elke; bilang tahu, D 83, meedelen (in citaat v. Engelsen); berbilang, D 62, uittellen; dibilangkan, C 23, verteld; pembilang, D $71,=$ terbilang, in tel, waard; tiada terbilang, D 43, 94, ontelbaar.

boor, C 13, Ned., boor; Mal. spelling: bor. buat: (mem)buat, dibuat, A-E passim, zonder of met object (bijv. bénténg, jalan, garam, obat, kontrak, aturan), (mem)buatkan, dibuatkan, B 59, 63, $64,72,73$, C 31, 33, diperbuatkannya, diperbuat, $\mathrm{C} 25,33,1$ bouwen, vervaardigen, bereiden, aanleggen, tot stand brengen, opstellen; 2 instellen (van ambten of colleges: kaptén Cina, pabéan, raat), aanstellen (van functionarissen: raja, pangéran perdana menteri); 3 verrichten, doen, plegen, ten uitvoer leggen, aanwenden, zich bedienen van, zijn toevlucht nemen tot (bijv. salah, cela, durhaka, fitnah, gila, akal); berbuat peramalan, D 92, goede (vrome) werken doen; terbuat, B 74, ten uitvoer gelegd; bukan buatan, E $209 \mathrm{c}$, in hevige mate, geweldig.

buji, D 95, klein, licht anker; vgl. Wlk. sauh buji s.v. buji.

buluwarti, B 56, C 9-14, 32, E 30a, 40a, 
44a, 77b, 96a, 103b, 107a, bolwerk, vestingmuur, bastion; vgl. Jav., Mal. baluarti.

buntut: buntut Pulau Kembara, B 58, het verst stroomafwaarts gelegen deel v.h. eiland Kembara; vgl. Kl. s.v. boentoet; z.o. kepala.

buri: di burinya, B 70, C 27, aan de achterkant, op het achterdek, op de achterplecht (v.e. schip); vgl. Jav. (ing) buri; z.o. De Clercq, 1876, p. 539.

but, D 43, 44, 46, 94, sloep; vgl. Ned. boot; z.o. langbut.

buta: berbuta-tuli, E 106d, = (mem)buta-tuli, onbesuisd, in 't wilde weg.

buyar, E $162 \mathrm{~b}$, uiteengaan, uiteenvliegen, uiteenspatten; vgl. Jav. buyar; z.o. De Clercq, 1876, p. 539.

cakap: bercakap, E 111a, 112a, 113a, 114a, 115a, mengeluarkan cakap, E 9a, cakap dikeluarkan, E $117 \mathrm{a}$, zich in staat en bereid verklaren om te strijden, zich aandienen voor de strijd, zijn strijdlust tonen.

cakep: menyakep, C 37, omklemd houden, in zijn vuist houden; vgl. Jav. cakep, nyakep.

carem: pada carem, C 28, allen tegelijk, dicht aaneengesloten, in een hecht onderling verband; vgl. Jav. carem, intieme omgang, geslachtsgemeenschap hebben; in UBL 5/MP 2 als synoniem v. "sama sekali".

catur: menyatur, D 57, vertellen; vgl. Jav. catur, nyatur.

cebur: tercebur, E 190d, ten onder, te gronde gegaan; vgl. Wlk. s.v. chebur.

cerai: dicerai, C 24, verstoten; diceraikan, B 30, 31, gescheiden; menceraikan daripada, C 3, tweedracht zaaien onder, tussen; perceraian, C 9, breuk, verwijdering; bercerai-berai, B 9, 78, cerai-berai, D 44, naar alle kanten uiteen.

cerit-berit, C 15, = cérét-bérét, bij kleine beetjes, in stroompjes; vgl. cérét, cirit, diarrhee.

cerocok = kayu besar-besar lalau, B 59, frequentatief bij cocok, ook als cerucup (vgl. masup voor masuk), C 29, E 232c, rasterwerk, versperring van palen, paalwerk, palissade. cerucup, zie cerocok.

commissaris, C 35-43, komisaris, B 8-75, Ned., commissaris.

commissie, C 8, commissiereis, dienstreis; vgl. Ned. commissie $=$ opdracht.

conderong, $\mathrm{C} 5$, frequentatief bij condong, = cenderong, overhellend naar, sympathiserend met.

contract, zie kontrak.

cunia, D 44, laadschouw, lichter.

curi: mencuri berjual, B 20, clandestien verkopen; mencuri-curi membunuh, B 52 , verraderlijk vermoorden, een sluipmoord plegen op; bedil curi, D 94, sluipschutterspost $=$ bedil maling, zie maling; pencuri, D 79, E 19b, 31c, struikrover, schurk, boef, dief(achtig).

dalam, B 40, C $6,20,40$, D 42, 48, 66, $73,74,85$, E $65 \mathrm{~d}$, (het binnenste gedeelte van) de kraton, het eigenlijke sultanspaleis, = tempat pedalaman sultan, B 9; zie Kl. s.v. dalam, Pig. s.v. padaleman.

Dalem: putera Dalem, C 9, Jav., zijn zoon, de zoon van $Z_{\text {ijne }}$ Majesteit.

dapat, A-D passim, komt overwegend intransitief en v.z.v. de agens genoemd wordt in de passieve constructie (met of zonder oléh) voor in de betekenis van: gepakt, bemachtigd, overweldigd, overmeesterd, ingenomen, (in handen) vallen; bijv.: bénténg / Betawi / $\mathrm{Pa}$ lémbang / langbut dapat (oléh), B 25, $27,29,30,33,38,53,60,69-72$, C 9 , 22, 27, D 52, 95; vgl. Kl. s.v. dapat; voorts komen, in volgorde van frequentie, B-D passim voor: mendapatkan, berdapat, mendapat, didapat (nya), kedapatan, pendapatan.

darat: pendarat, E 225b, landvast, meertouw.

datang: datangnya, A 27, C 5, 26, D 43, 70,80 , zijn (hun) (her) komst, het komen van hen; zij komen, zijn gekomen; mendatangkanlah satu pengaduan, C 35, een aanklacht indienen; mendatangkan sembah, D 45, (de vorst) eerbiedig aanspreken, vgl. Wlk. s.v. datang; didatangkanlah akan surat contract itu, C 31, men brengt het contract; sedatang perintah, B 29, zodra het bevel kwam, was ontvangen; 
in $\mathbf{E}$ vaak met opvolgend werkwoord, bijv.: datang menuju, 20c, 42c; datang membantu, 24a, 28b, 198a; datang mendekati, 42a, 125a, 156c; datang menyerang, $256 \mathrm{~d}, 258 \mathrm{~b}$.

dawam: dawam perkejaan itu, D 58, zolang het werk duurt; amal yang dawam, E 198d, de godsdienstplichten, de steeds weerkerende vrome werken. daya: mencari daya, B 4, 13, = (men)cari akal, C 34, zon op middelen; kita perdaya, E 70d, patik perdaya, E $112 \mathrm{~d}$ $=\mathrm{kita} /$ patik perdayakan, een kool stoven, verschalken, bij verrassing overmeesteren; z.o. tipu.

demang, D passim, titel v.e. ambtenaar van middelbare rang; vgl. Jav. demang; zie De Sturler, 1855, p. 74; z.o. Van den Berg, 1902.

dénayu, B 30 , verkorting van radén ayu, vrouw v.e. pangéran of radén, z.a.; zie De Sturler, 1855 , p. 81 ; z.o. Van den Berg, 1902.

dengar: tiada penengar, D 50, = tiada terdengar, niet hoorbaar, niet te horen.

depisi, C 42, = dipisi, district; Ned. divisie.

désa, B 51, 73, 74, C 7, 31, 35, 40, landstreek, gebied, D 54, 89, dorp; vgl. Jav. désa; désa pegangan ..., B 51, apanagegebieden van ...; megang désa, B 74, 75, een gebied in beheer hebben met het recht daarvan inkomsten te trekken, apanagegebieden hebben.

diri: mendirikan, B 14, 36, aanstellen tot, installeren als; berdirinya, B 14, de installatie van; mendirikan bendéra, B 47, C 3, 28, een vlag (met stok en al) oprichten, overeind zetten.

embok: embok dalam, D 66, een gehuwde vrouw aan het hof (bijvrouw v.e. pangéran?), hofdienares; zie Van den Berg, 1902.

éntrés, B 44, rente, interest; vgl. Jav. èntrèsan.

gamelan, C 16, 20, Jav. orkest van vnl. slaginstrumenten.

gandi, C 16, boog, 't boogschieten; vgl. De Clercq, 1876, p. 551: "een slinger om steenen te werpen". gandok, B 55, D 53, 76, 79, vooruitstekend koepelvormig deel v.e. vestingmuur of schans, waarin het geschut staat opgesteld, bastion, batterij, geschutstelling; vgl. 1 Jav. gandok, voorhuis, aangebouwde kamer, uitbouw, bijgebouw; 2 Mal., Jav., Indon. gondok, kropgezwel, bult, uitstulping; 3 Mal. gandik, hoepelvormig voorhoofdversiersel v.e. bruid.

gantung: tempat bergantung, E 206b, = pergantungan, toevluchtsoord, schuilplaats, toeverlaat.

gari, E 83a, 122a, = kari, z.a., achterblijven, E 86c, boeien, in de boeien slaan; menggari, E 50a, iemand opzoeken, een bezoek brengen; vgl. De Clercq, 1876, p. 529.

gawai: pegawai, B 51, 74, werkkracht, dienstplichtig(e); pegawai meriam, B 56, degene die het geschut bedient; vgl. Jav. gawé, werk, dienst; de (heren) dienstplichtigen in de Pal. bovenlanden werden "mata gawai" genoemd, die ter hoofdplaats "orang miji" (Van Sevenhoven, 1823, p. 66); z.o. miji.

gebejuk, $\mathrm{C} 16, \mathrm{Pal}$. toneelopvoering of volksvertoning.

Geburnur-Jénderal, zie Gubernur-Jénderal.

gedung, C 3, 16, 30, het landsmagazijn, de schatkamer (v. Pal.).

gelanggang, D 69, het (afgebakende) terrein, de kring van versterkte posten, de verdedigingslinie.

gembol, E 94a, = kimbul, verhoogde achterste gedeelte v.e. schip, kampanje; vgl. Kl. s.v. gembol.

gembur: bunyi begembur, E 139a, met bulderende, brallende stem; vgl. Indon. gembar-gembor, Jav. nggembor; z.o. Kl. s.v. gemboer, woeden, bulderen (van vuur).

gemuncang: gemungcanglah, $\mathrm{C} 15,=$ berguncanglah, B 61,69, C 12,19 , schudden, schokken, in heftige beweging zijn.

girana(?), D 94, titel, aanduiding v.e. functie of rang?

gua, D passim, ik; gebruikt door Gillespie, Meares en Muntinghe; z.o. aku, hamba, patik, saya.

Gubernemén, zie Gubernement. 
Gubernement, C 7, Gubernemén, C 22, 23, Gupernemén, D 48, het (Ned. Ind.) Gouvernement.

Gubernur-Jénderal (di Betawi), C 4, 5, 17, 18, 22, Geburnur-Jénderal (Holanda), B 45, 63-65, Guburnur-Jénderal, D 86, Jénderal (Betawi), A 28, B 7, 22, 27, 63, C passim, D 87, de Gouverneur-Generaal (van "Ned. Indië" te Batavia); Jénderal Menggala, B 43, 44, de Gouverneur-Generaal (van "Brits-Indië" in Bengalen).

Guburnur-Jénderal, zie Gubernur-Jénderal.

gudang: gudang Holanda, B 20, het Hollandse pakhuis, de Hollandse factorij; z.o. kota, loji, tempat.

gulu, E 87d, Jav., hals; vgl. De Clercq, 1876, p. 551 .

guncang, zie gemuncang.

Gupernemén, zie Gubernement.

gurnat, B 68, 71, C 8, 19, 25, E 95a, 159d, 184b, granaat; vgl. Jav. gernat. gusti, gusti kita, D 57, gusti patik, D 66, gustiku, D 79, Jav., (onze, mijn) heer; vgl. Van den Berg, 1902.

habis, B-E passim, geheel en al, totaal, allen zonder uitzondering, allemaal tot de laatste man; sehabis-habis, D 42, uiteindelijk, als 't erop aankomt; sehabis-habis banyak, D 58, op z'n allerhoogst, allermeest.

hak al-Adam, E 119d, = hak adami, recht v.d. mens, in tegenstelling tot hak Allah, recht v. God; zie Juynboll, 1930, p. 297.

hakékat, D $63,=$ pada hakékatnya, werkelijk.

halontar, C 12, 27, E 127b, bliksemschicht, donder en bliksem; vgl. Mal. halintar.

hamba, D passim, 1 dienaar, bijv. hamba pangéran; 2 ik, vooral gebruikt door een hogergeplaatste tegenover een mindere, maar ook wel andersom; hamba sekalian, D 67, wij; hambanya, B 5, C 4, Zijn (Gods) dienaren, de mensen; z.o. aku, gua, patik, saya.

hambung, B 59, = ambung, draagmand. hampir: menghampirkan dirinya kepada $=$ merapatkan dirinya kepada, C 35, zich aansluiten bij, nauwe contacten onderhouden met.

harab: harabi, E 33a, behorende tot de aan de Islam vijandige, (nog) nietgeïslamiseerde wereld (dar al-harab).

hari: hari ésok, ésok hari, D 65, morgen; pagi ésok, D 65, 66, morgenochtend.

hémat: tiada terhémat, D 78, het is ondoenlijk, het lukt ons niet, wij zien er geen kans toe; vgl. Kl. s.v. himmat.

héwan: binatang héwan, $\mathrm{E} 85 \mathrm{c}$, opgejaagd wild (of bijeengedreven slachtvee?).

Holanda, A, B, E passim, Olanda, C passim, Wilanda, D 42, 91, 92, Hollands, Hollander.

hormat: hormatan, C 41, = penghormatan, eerbetoon; memberi hormat dan khidmat, D 47, 84, hulde en eer bewijzen, het saluut brengen.

hudur: hatinya hudur, E 190c, met een aandachtig, toegewijd, toebereid hart; vgl. Kl. s.v. hoedlóér; Rinkes, 1909, p. 73, noot 3: "hoedhoerlah ia serta hatinja", met tegenwoordigheid, bereidheid des harten.

hulu: peng(h)ulu, C 3, 7, 17, 39, D 76, 77, E 79a, 89a, 122c, 124a, 234a, aanvoerder, D 49, rechter of ambtenaar voor godsdienstzaken.

hulubalang, C 13, 21, E passim, militair commandant, veldheer, krijgsoverste; hulubalang pahlawan, C 10, 11, 16 , 17, hulubalang panglima, E 16a, 177b, 205c, de officieren, de legerleiding; z.o. menteri, pahlawan, panglima, penghulu, punggawa.

hundak: tiada yang akan hundak, D 45, er kon niemand meer bij; vgl. Jav. unḑak, toename?

hutan: hutan raya, C 18, hutan rimba belantara, C 40, oerwoud, wildernis.

isi: perisén, C 26, lading; vgl. Jav. isén. jaba, C 11, Jav., buiten; vgl. De Clercq, 1876 , p. 541 ; z.o. marak.

jadi: dijadikan dengan, B 43, in het huwelijk verbonden met.

jagat: jagat tanah Jawa, D 41, 48, het gebied van Java.

jajah: negeri (Palémbang) dengan segala/sekalian jajahan, B 4, 14, 18, 21, Palembang en onderhorigheden. 
jalan: sejalan-jalan, C 8, langs de hele weg, gedurende de hele reis.

jari: menyembah sepuluh jari, E 54c, memegang jari, E 60a, mengangkat tangan sepuluh jari, E $116 \mathrm{~b}$, beleefd groeten (omschrijvingen v.d. traditionele handhouding bij de sembah); vgl. Teeuw, 1966a, menyembah sepuluh jari, 4.87d, 6.8d, 6.154c, 10.27a.

jenang, D 93, belastinggaarder, rentmeester v.e. apanage, rechtstreeks ondergeschikt aan de apanagehouder; vgl. Wns. s.v. jenang; zie Van Sevenhoven, 1823, p. 70, De Sturler, 1855, p. 71 .

Jénderal, zie Gubernur- Jénderal.

jeneng, C 32, naam; berjeneng, C 32, de naam krijgen, genoemd worden; menjenengkan, B 45, C 32 , = mengangkat nama, B 64, een naam verlenen, benoemen; dijenengkan, B 16 , 43, C 20, 21, 32-33, 41, = diangkat nama, B 45, 62-64, 77, dinamai, B 45, 73, digelar nama, B 73, de naam krijgen van, benoemd worden tot; vgl. Jav. k. jeneng naast $n$. nama.

jengkal: sejengkal, C 12, = satu kilan, B 56, vgl. Jav. kilan, één span (van duim tot middelvinger) .

jeruk: jeruk kuwik-kuwik, C 26, kleine, zoete jeruk; vgl. Jansz, 1932 s.v. koewik, UBL 5, p. 38: "buah jeruk kuwik".

juluk, B 7, ambtstitel; berjuluk, C 1, 36, de naam of titel dragende van ...; vgl. Pig. s.v. (dje) djoeloek.

jumeneng, C 27, 36, Jav., opstaan, de leiding op zich nemen, aan de regering komen.

jumpa: berjumpa kepada, C 22, een ontmoeting hebben met, een bezoek brengen aan.

jumput: menjumput, D 82, (men)jumputi, B 41, 79, C 4, 42, D 42, 69, 82-85, afhalen, (gaan) verwelkomen; vgl. jemput.

jurulés: jurulés Sungsang, D 43, degeen die a.d. riviermonding de registratie voert van in- en uitgaande schepen, de posthouder van Sungsang? Of eenvoudig een verschrijving v. jurutulis?

$k a k a$, E 194c, 213c, = kakak, oudere broer of zuster.

kalah: kalah oléh, B 24, 25, overwonnen, overweldigd, verslagen door.

kalér, E 87b, uitgespreid en onafgedekt, opgediend laten staan (v. spijs en drank); vgl. Jav. dilér.

kali, B 49, Jav., beek, riviertje.

kampung: kampungnya, C 6, zijn woonstede; kampung dan rumahnya, B 73, karang kampungnya, C 29, zijn huis en hof.

kantoor, zie kantor.

kantor: kantor bicara, B 31, bestuurskantoor; kantoor pabéan, C 23, kantoor boom, C 23, 31, douanekantoor, tolkantoor.

kapak: mengapak, B 56, met scheepsbijlen hakken op; dikapak, B 57, gehakt, door te hakken; pengapak kepala, D 60, koppensneller.

kapan, D 48, 56, 63, Jav., wanneer (voegw.), wanneer? (bijw.); vgl. manakala, D 68, 69, 91.

kapitan, zie kaptén.

kaptén, A 26. D 48, 82, 83, kapitan, B 16, kapitein, militair commandant; kaptén Cina, D 49, 86, 91, 93, kapitan-demang, B 58, titel v.h. ambtelijk hoofd v.d. Chinezen; kaptén kapal, D 43, scheepskapitein.

kapur: belum sampai sekapur sirih, D 51, binnen de tijd dat men één sirihpruim gebruikt, slechts een ogenblik later, kort daarna; zie Kl. s.v. kapoer.

kari: berkari, C 18, overblijven; vgl. Jav. kari; z.o. gari.

kasih, mengasih, dikasih(kan), vooral C, $=$ beri enz., geven enz.

kata: tiada terkata lagi, B 10, onbeschrijfelijk, ontelbaar; tidak terkata, E 84d, $126 \mathrm{c}$, onbeschrijfelijk, onuitsprekelijk; tiadalah terkata-kata lagi, C 5, 37, had niets meer te zeggen, was sprakeloos.

kecéwa, E 29b, 150b, in gebreke, ten achter blijven, tekortschieten, de mindere zijn van, onderdoen voor; vgl. Jav. kuciwa.

kedengan, uitsluitend MP 4a: 28d, $74 \mathrm{c}$, $90 \mathrm{c}, 91 \mathrm{~d}, 138 \mathrm{~b}$, = dengan, met, tezamen met, zomede, met behulp van.

keja: perkejaan, = pekerjaan, $\mathbf{C}$ passim, taak, werk, onderneming, viering, feest. kekes: berkekes, C 21, (met object), in 
gereedheid brengen, C 29, (zonder object), voorbereidingen treffen; vgl. pe(r) kakas.

kelam: kafir yang kelam, E 233d, duistere heidenen.

kelar: kelarkan, C 30, op de been brengen; vgl. Ned. klaar (citaat Generaal De Kock); mogelijk valt ook te denken aan Jav. n. kelar (k. kuwawi), bij machte zijn, kunnen verschaffen, kunnen bekostigen.

kelaran, E 78d, getroffen door onheil, er rampzalig, droevig aan toe zijn; vgl. Jav. lara, ziekte.

kemas (1), B 39, 77, D 84, E 41d, 42b, 42d, verkorting van $\mathrm{ki}(\mathrm{ai})$ mas, zoon v.e. masayu of mesayu en een man v.h. gewone volk, mannelijke adellijke titel, lager dan masagus; z.a.; zie Van Sevenhoven, 1823, p. 65, De Sturler, 1855 , p. 81 ; $(2)$ :berkemas, B 8 , in gereedheid brengen, gereed houden, C 40, zich reisvaardig maken, inpakken; berkemas diri, E 56b, 60d, 245c, zich klaar maken (voor de strijd).

kepala: kepala Pulau Kembara, G 17, de punt v.h. eiland Kembara die 't meest stroomopwaarts is gelegen; z.o. buntut.

keponakan, zie misan.

keramas: keramas kapal perang, C 26, de oorlogsschepen een haarwasbeurt geven, schoon spoelen (bij het haarwassen wordt jeruk gebruikt); figuurlijk voor prikkelen, tergen?

keraton, zie kota.

kerta, D 49, = kertanegara, B 7, vrederechter, politierechter; z.o. temenggung; zie De Sturler, 1855, p. 72.

khémah: perkhémahan, C 15, afdak, provisorisch bouwsel, optrekje, kampement.

kici, A-D passim, brik, zeilvaartuig met 2 masten; vgl. Eng. ketch, Ned. kits.

kidemang, $\mathrm{B} 28,29$, = $\mathrm{ki}(\mathrm{ai})$ demang; z.o. demang.

kilan, zie jengkal.

kilat: kilat seribu, B 61, vermoedelijk een soort vuurwerk, een "rèntèngan", die "duizend" lichtflitsen geeft, "duizendklapper"; vgl. Ned. zevenklapper.

kirangga, $\mathrm{C}$ 40-43, = $\mathrm{ki}(\mathrm{ai})$ rangga; z.o. rangga. koci, zie sekoci.

komisaris, zie commissaris.

kontrak (perjanjian), B 5, 7, 14, 18, 21, 64, (surat) contract (perjanjian), C 7, $22-24,31,35,36$, overeenkomst, contract, verdrag, verbond; kontrak perjanjian selama-lamanya, B 5, een "eeuwig" verbond.

kora-kora, B 53, 54, korakora, Indon. oorlogsvaartuig; vgl. de Molukse "corra-corra's" uit de Compagniesberichten; z.o. Nooteboom, 1932, p. 180.

kota, A-E passim, 1 het ommuurde kratoncomplex, de kraton, het sultanspaleis, = kota keraton, kota Sultan, B passim; kota besar, residentie v.d. regerende vorst in tegenstelling tot kota lama, oude, voormalige kraton; kota-negeri, D 67, de kraton en de stad, z.o. negeri; 2 muur, omheining: kota kayu, B 46; de kratonmuren, de wallen: diatas kota, C 11, E 42a, penjurunya kota, C 10; 3 de Hollandse factorij, het Hollandse fort: kota Kompeni, B 14, 20, kota Olanda, C 33; z.o. gudang, loji, tempat.

kotak: sampan kotak(-kotak), C 25, Europese sloep met één of meer laadruimen of laadvakken.

kria, G 36, verkorting van ki(ai) aria of ria (zie Van den Berg, 1902), dorpshoofd; vgl. lurah; zie De Sturler, 1855, p. 77.

kruis, = (perahu) pair, C 23, kruisboot, patrouillevaartuig, snelvarende zeilboot, i.h. bijz. gebruikt bij de bestrijding van zeeroverij, smokkel e.d.

kuala, B-E passim, uitmonding v.e. rivier in zee, i.h. bijz. v.d. Sungsang (naam v.d. benedenloop v.d. Musi of Palembangrivier), ook: kuala negeri, E 219b, $251 \mathrm{~b}$; slechts éénmaal v.e. andere rivier: kuala Opang, D 94 ; z.o. muara.

kuawa, B 12, Jav., in staat tot, bij machte, sterk genoeg om; z.o. Ras, gloss. s.v. kuawa, De Clercq, 1876, p. 528.

kubah, B 2, kubah perkuburan, B 3, grafkoepel.

kumendir: dikumendirkannya, C 18, hij gaf het commando; vgl. Ned. commanderen.

kunang: mengunang, E 134b, glanzend; vgl. Kl. s.v. konang, waar het citaat 
"rambutnya ikal patah mengunang" uit de Hikayat Gholam, letterlijk gelijk aan regel $E$ 134b .

kustabel, E 94b, constabel, kanonnier; vgl. Jav. kestabel.

kuta: mengangkat perkuta, C 16 , een feest of plechtigheid?

kutung, E 206d, afgehakt, afgesneden (vooral v. ledematen), verminkt; vgl. Jav. kuţung.

la ilaha illa llahu dipalukan ke kiri, kepada hati nama sanubari, E 12a-b; over dit soort godsdienstoefeningen in het kader van de moslimse mystiek en de bijzondere betekenis van sanubari zie: Rinkes, 1909, pp. 67-68, 77-78, 113.

laban, E 193d, Ar., melk.

ladén: meladéni perang, C 28 , een aanval beantwoorden.

laju: laju mengamuk, B 55, aanvallend vooruitgaan, bij de aanval de voorhoede vormen, aan de spits gaan; vgl. maju.

laku: perihal ihwalnya kelakuan, B 1, perihal perlakuan, C 17, lotgevallen en gebeurtenissen, de gang van zaken, het verloop; hal kelakuan, C 5, verhouding, situatie; bukan kelakuan, E $259 \mathrm{~b}$, niet vlot verlopend, geen routinewerk, niet van een leien dakje, niet zonder moeite.

lalau, B 59, afsluiten(d), versperren(d) ; z.o. cerocok.

lalu: selalu, B 49, C 12, 13, voortdurend, steeds, B 53, 62, D passim, onmiddellijk, terstond, dadelijk, meteen daarna, rechtstreeks, in één ruk door; vgl. Wlk. s.v. selalu.

lanca, D 43, 44, 46, 48, 94, E 138a, $167 \mathrm{~d}, 168 \mathrm{a}, 168 \mathrm{~d}$, vrachtschip met drie masten; vgl. Port. lancha.

lancang, D 43, snelzeilend oorlogs- of zeeroversvaartuig (met tot 50 roeiers).

langbut, A-D passim, sloep, landingsboot; Eng. longboat; vgl. Encycl. v. N.I.: lamboet, vissers- of vrachtprauw.

lantar: pelantaran, E 100c, dek (v.e. schip).

larén, C 39, Jav., geul, greppel.

laut, B-E passim, 1 rivier (in tegenstelling tot het land, darat), watervlakte v.e. rivier, vooral v.d. Musi of Palembangrivier, laut Palembang, C 14, 30, maar ook van bijv. de zijrivieren Kundur en Plaju, laut Sungai Kundur, C 24, laut Sungai Plaju, C 25, laut Muara Plaju, C 21; gedeelte v.e. rivier, bijv. laut pangkalan Kidemang Saléh, B 28, laut pangkalan dalam, D 74, laut tangga (dalam), C 30, D 90, laut kota, D 91; ook: lautan, B $61 ; 2$ rede, zee, laut Betawi, B 7, 27, laut tanah Jawa, B 26, laut kuala (Sungsang), C 21, D 95.

léna: tiada léna, B 4, zonder te verslappen; tiada boléh lena, B 5, 52, zonder dat men kon slapen, zodat men geen rust kreeg.

lihat: pelihatan, D 73, = penglihatan, D 54, 91 .

likur: selikur, B 21, E 63a; dualikur, C 1; tigalikur, B 18, D 46; tujuhlikur, B 14; delapanlikur, B 15, 28; sembilanlikur, B 75; vgl. Jav. likur.

limpat, E 227d, uitmuntend, wijs; vgl. Jav. limpad.

loji, B 14-29, C 22, D 42, de loge, factorij (v.d. O.I. Compagnie te Pal.); z.o. gudang, kota, tempat.

lotang, E 133b, vuurwapen; vgl. Kl. en Wlk. s.v. lotang.

loténg, C 10, 13, D 85, 91, E 38a, 66c, 98c, 231d, opbouw op de kratonmuur boven de hoofdpoort, poortgebouw; atap loténg, E 95c, het dak v.h. poortgebouw; pintu loténg, C 11, E $37 \mathrm{c}$, $90 \mathrm{~d}$, lawang loténg, $\mathrm{C} 11,=$ pintu kota, de hoofdpoort v.d. kraton; z.o. kota.

luan, E 37b, spits, voorhoede; z.o. De Clercq, 1876 , p. $553,=$ huluan .

luaran, zie menteri.

lungguh: melungguh, E 109a, 149b, ontspannen, op z'n gemak zitten, op zijn plaats (post) zitten (zijn), dienst doen, zijn ambt of functie uitoefenen; vgl. Jav. lungguh.

lurah, B 14, dorpshoofd; lurah Sungsang, D 74; vgl. Jav. lurah; zie De Sturler, 1855, p. 77.

luru: berluruan, C 34, bij elkaar zoeken, opsporen, zorgen voor; vgl. Jav. luru. 
ma'al-kausar, E 121d, water(en) v.h. paradijs, paradijsrivier; vgl. kal(i) kausar. mak, verkorting van mamak, D passim, oom, vader, mijnheer als aanspreektitel; vgl. Jav. mak, mamak; ook: mamanda, D 62, E 52d, 58d.

makan: makan pagi, D 67, het ochtendmaal; makan pagi soré, B 79 , het ochtend- en middagmaal; pemakan, B 51, bron van inkomsten, apanage; perma$k a n, \mathrm{C} 35$, apanage, C 36,40 , onderstand.

Makota: Baginda Seri Makota, E 4d, Duli (Seri) Makota, E 126b, 241d, Makota Negeri, E 50b, betiteling v.d. vorst als drager v.d. kroon; vgl. Wlk. s.v. mahkota.

malam, B 4, 39, D 87, = hari malam, B 54, 68, C 12, malam hari, D 80, 81, 's nachts; semalam-malam, B 12, de hele nacht door.

maling: bedil maling = meriam dari/ dalam hutan, B 60, 65, verdekt opgestelde batterij, sluipschutterspost; vgl. bedil curi s.v. curi.

maclum: bermaclumkan dari hal, C 8, mededeling doen van, rapporteren over.

mamak, zie mak.

mamanda, zie mak.

manakala, zie kapan.

marak: pemarakan, B $8,20,51,55,62$, C $20,37,39$, E 10d, audiëntieplaats, ontvangstruimte; pemarakan jaba, C 11 , verzamelplaats buiten de kratonmuur; vgl. Pig. s.v. marak, Ras, gloss., s.v. arak, parak; z.o. adap, balai, paséban.

marga, B 13, 77, C 36, dorpengemeenschap, streekgemeenschap, district.

masagus, B 76, 77, 79, D 50, E 228d, titel v.d. zoon v.e. pangéran of radén en een vrouw uit de volksklasse, mannelijke adellijke titel, lager dan radén; z.a.; vgl. Jav. mas agus; zie Van Sevenhoven, 1823 , p. 64 , De Sturler, 1855 , p. 81.

mastaib, C 15, 17, 20, mastaib lengkap, C 10, mastaib sedia, C 24, gereed, in orde, paraat, in staat van verdediging; vgl. Ras, gloss. s.v. mustaip, Skinner, 1963, pp. 53-54.

mayat, zie bangkai. mayit, zie bangkai.

mayur, E 117d, 129a; Ned. majoor; vgl. méjir.

méjer, zie méjir.

méjir, B passim, méjer, D passim, E 249b, Eng. major, majoor; vgl. mayur.

mendari, B 11, 33, 37, 66, E 183a, MPa $225 \mathrm{c}$, = dari, vanaf, vandaan.

menggala: ubi menggala, $\mathrm{C} 7,=$ ubi benggala, cassave.

menteri, B-E passim, hoffunctionaris, ambtenaar, beambte; menteri-hulubalang, B 26, C 11, 15, 17, de militaire en de burgerlijke autoriteiten; vgl. punggawa-menteri; menteri yang luaran, C 15, ambtenaren die niet tot de adelstand behoren; vgl. $\mathrm{Kl}$. s.v. loewar; menteri hulubalang luaran dan dalam, C 16, de civiele en militaire gezaghebbers uit de buitendistricten en de hofdignitarissen; menteri yang kesepuhan, C 17, oudste categorie ambtenaren, senioren?; menteri agama, C 18, ambtenaar voor godsdienstzaken; vgl. penghulu; perdana menteri, C 35 , eerste minister.

mesuarat, D 72, overleggen, beraadslagen; mesuarat dengan ... hendak, D $41,47,54,77$, mesuaratkan hendak, D 80 , met ... overeenkomen, afspreken om, in overleg met ... besluiten om, erover beraadslagen om; dengan musyawaratnya pétor, $\mathrm{C} 5$, in overleg met de pétor; tiada dengan mesuarat Paduka Suhunan, D 91, zonder overleg te plegen met de suhunan.

miji, C 10, 17, D 51, herendienstplichtige, horige, dienaar v.d. vorst of v.e. edele; vgl. Jav. miji: voor een bepaalde dienst aangewezen; zie Van Sevenhoven, 1823, p. 66, De Sturler, 1855, p. 81 ; z.o. gawai.

minggat, C 21, weglopen, ervandoor gaan, zijn werk of dienst in de steek laten; vgl. Jav. (m) inggat.

minta, zie pinta.

mintar, B $34,72,76$, D 50, 55, 74, 82, 86, Jav., vertrekken; vgl. De Clercq, 1876, p. 553.

misan: misanannya, C 1, zijn (volle) neef (cousin); vgl. keponakannya, C 1 , zijn neef (oomzegger, nephew); vgl. Jav. $\operatorname{misan}(\mathrm{an})$, ponakan. 
Mista: Mista Saman, B 46, 47, C 3, 7, Mister Salmond; vgl. misti.

misti, D passim, Eng. mister; vgl. Wlk. mistar.

mohon, zie pinta.

muafakat, zie mupakat.

muara, A-D passim, uitmonding v.e. zijrivier in een hoofdrivier, bijv. muara Sungai Aur / Ogan / Plaju / Rawas; z.o. kuala.

mufakat, zie mupakat.

muhun, D 56, Jav., wenen.

muncar, C 12, Jav., stralen, schitteren, opflikkeren, omhoogschieten.

mupakat, A, B, D passim, mufakat, C 6 , 22 , pakat, C 22, overleg plegen, 't eens worden, tot overeenstemming komen, eensgezind (zijn); sepakat, G 22, 35, eensgezind; mupakat / muafakat / pekat kepada, B 4, C 22, C 4, partij kiezen voor, op de hand zijn van, een accoord bereiken met; dipekatkannya, C 4, hij voerde besprekingen, kwam overeen met; mupakatan, B 25, met elkaar overleggen; vgl. Jav. mupakatan.

musyawarat, zie mesuarat.

musytari, zie sacat.

naik, A-E passim, 1 aan wal gaan; meestal met complement: ke darat / dusun / tebing / Mentok; ook: menaik, B 71, C 37; 2 aan boord gaan; meestal met complement: (di / ke / kepada) kapal / perahu; 3 binnengaan, (op)klimmen; soms met complement: gandok, di buluwarti, (ke)bénténg; ook: menaik diatas singgasana, C 31 . De vormen zonder -kan komen ook voor met transitieve betekenis: menaik, D 48, verheffen (= menaikkan, A 27, B 42,45$)$; dinaik, B 69,70 , omhooggehaald, opgetrokken, aan wal gebracht (= dinaikkan, B 7, 69, C 15, 28); vgl. turun.

nakal: menakal, B 52, C 8, = menakalkan, lastig vallen, tegenwerken, molesteren.

nama, B 39, 40, 75, iemand genaamd $\ldots$, een zekere ....

natar, C 15, terrein, (voor)erf; vgl. Jav. natar.

negeri, A-E passim, 1 de stad Palembang als politiek, economisch en cultureel centrum v.h. sultanaat, onderscheiden van het binnenland (désa, (tanah) (h) ulu(an), pucukan), en de onderhorigheden (jajahan), maar ook van het kratongebied (kota, kota keraton); z.o. désa, jajah, pucuk, kota; ook wel ruimer: het rijk Palembang als politieke entiteit of als geografisch begrip: de staat, het land; orang negeri, B 54, D 56, E 36a, de inwoners v.d. stad, onderscheiden van de orang (h)ulu; anak negeri, racyat negeri, C 5, 36, 31 , autochtonen, onderscheiden van Arabieren en Chinezen; 2 elke andere stad of plaats, elk ander gebied, land of eiland; bijv. negeri Betawi, Bogor, Menado, Mentok, Sinjur; negeri Bandan, Belitung, Pulau Pinang, Bengkulu, Olanda (Holanda); negeri yang di luar, B 1 ; negeri yang lain, D $64 ;$ z.o. tanah.

ngabéhi, B 43, D 43, 44, 49, 74, 76, 82, 93, 94, ngambai, C 8, één v.d. lagere bestuursambtenaren, dorpshoofd; vgl. Jav. ngabéhi; zie De Sturler, 1855, p. 77; z.o. Van den Berg, 1902.

ngambai, zie ngabéhi.

ngawin, C 17, piekenier, hofdienaar die bij officiële gelegenheden de staatsiepiek meedraagt; vgl. Jav. (pa) ngawin. niat: keniatan salah, C 36 , snode plannen, een komplot.

nopéng, zie topéng.

nugerah: dinugerahi kurnia, C 23, met geschenken beloond; vgl. Mal. anugerah, Jav. nugraha.

nyang, C 13, 24, = yang.

officier, C 11, Ned., officier.

olah: bukannya olah, E 94c, = bukan olah-olah, lang niet mis, geen sinecure. Olanda, zie Holanda.

padang, B 61, 69, E 65b, licht; vgl. Jav. paḍang; z.o. De Clercq, 1876, p. 546. padudan, E 81d, Jav., opiumpijp; vgl. De Clercq, 1876, p. 547.

pahlawan, B 11, C 13, 17, E 76b, 210c, $211 \mathrm{~b}$, ervaren krijgsman, voorvechter, aanvoerder; z.o. hulubalang, panglima, penghulu, punggawa.

pair, zie kruis.

pakat, zie mupakat. 
paku: meriam sudah dipakunya, D 46, ze hadden de kanonnen vernageld.

palér: gulu terpalér, E 87d, met een rimpel of vouw in de hals, met gebogen hoofd; vgl. Jav. palir, voor, geul.

paling: yang paling tua sekali, B 3; de alleroudste; yang paling besar, C 12, de grootste.

pangéran, A-E passim, hoogste mannelijke adellijke titel; pangéran ratu, B-E passim, kroonprins; zie De Sturler, 1855, pp. 71, 80; z.o. Van den Berg, 1902.

panglima, D 53, 63, 66, 68, 75, 76, E 2d, $48 \mathrm{a}, 157 \mathrm{~b}, 204 \mathrm{~d}, 220 \mathrm{a}$, panglima perang, $\mathrm{D}$ 77, militair bevelhebber, aanvoerder; in $\mathrm{D}$ vooral ter aanduiding van (Minangkabaus-) Maleise legeroversten; panglima hulubalang, E 181c, de gezamenlijke officieren; als bijz. titels worden genoemd: panglima perang besar, panglima di dalam raja, panglima besar raja, panglima muda, D 53, panglima dalam, E 195a; vgl. Kl. s.v. panglima; z.o. hulubalang, pahlawan, penghulu, punggawa.

papag, zie papak.

papak: memapak, D 83, 90, engkau papak, D 75, memapag, C 9, 20, mapag, C 9, ter verwelkoming tegemoetgaan, afhalen.

paséban, D 45, audiëntiezaal, verzamelplaats, waar men zijn opwachting maakt voor de vorst; paséban agung, D 50, de grote ontvangzaal; paséban dalam, $\mathrm{D} 73$, de (binnenste) ontvangzaal v.d. kraton; vgl. Jav. séba; z.o. adap, balai, marak.

pasirah, D 68, 69, pasirah pucukan, B 13 , pasirah ( $h$ )uluan, B 26, 63, adathoofd(en), bestuurshoofd(en) v.e. district of marga i.h. binnenland v. Pal., hoger in rang dan perwatin, z.a.; (pasirah-) pasirah-perwatin, B 62, C 40, D 63, 68,94 , de gezamenlijke (districts- en dorps) hoofden; vgl. Jav. sirah, hoofd. patih, B 38, 60, C 36, D 93, pepatih, C 18, 41, D 49, hooggeplaatst raadsman v.d. vorst, rijksbestuurder; zie Van Sevenhoven, 1823, p. 68; z.o. Van den Berg, 1902.

patik, C 34, D passim, E 6b, 112d, 116d, $117 \mathrm{c}, 117 \mathrm{~d}$, ik; patik sekalian, $\mathrm{D}$ pas- sim, E 5d, wij; gebruikt door onderdanen (edelen, ambtenaren, gewone burgers) tegenover de vorst; z.o. aku, gua, hamba, saya.

pecah: pecah perang bénténg, D 51, pecahkan perang bénténg, D 52, de strijd aanbinden met, de vijandelijkheden openen tegen het fort; picahlah perang(nya), C 3, 8, 19, de weerstand breekt, men moet de strijd opgeven; picahlah bénténg, $\mathrm{C} 28$, het fort bezwijkt, valt; picahlah apa-apa yang diwacat-janjikan, C 35 , de verdragsbepalingen worden met voeten getreden, te niet gedaan; picah-picah, C 37 , overal gescheurd, aan flarden.

pecil, D 56, 62, Jav., kind, 7non.

pekat, zie mupakat.

peluk: berpeluk-bercium, D 45, berpelukcium, D 69, elkaar omhelzen en kussen, elkaar innig omhelzen.

pencalang, perahu pencalang, D 50, 51, 85,89 , grote zeil- tevens roeiboot (40-80 voet lang en 6-12 voet breed), vooral als vervoermiddel in gebruik bij aanzienlijken; zie Nooteboom, 1932, p. 14 v.v.

penengar, zie dengar.

pengalasan, B 57, C 17, D 49, Jav., hofbeambte, bediende of dienaar i.h. alg.

penggawa, C 36, helper v.h. dorpshoofd; zie De Sturler, 1855, p. 77.

penghulu, zie hulu.

pengulu, zie hulu.

penjajab, B 59, 66, E 168d, penjajap, D 94, 95, snelvarend oorlogsvaartuig met twee masten en 20-30 roeiers, ook in Ned. dienst gebruikt als "kruisprauw", (perahu) kruis; z.a.

pepatih, zie patih.

perai: berperai-perai, E 174a, 251a, laveren; vgl. Kl. s.v. perai.

perang: perangan, $\mathrm{C} 3$, peperangan, C 10, strijd.

perdana menteri, zie menteri.

pergat, B 7, fregat.

perihal, zie laku.

periksa: periksaan, C 12, 43, = pemeriksaan, inspectie, onderzoek.

perkejaan, zie keja.

permili, C 15, familieleden; hier onderscheiden van kerabat, bloedverwanten, en zuriat, kinderen; z.o. s.v. zuriat. 
pe(r)salin, B 62, D 53, 73, geschenken van de vorst aan zijn onderdanen; z.o. timbang.

perwatin, D 74, 93, perwatin pucukan, D 50 , perwatin uluan, D 92 , perwatin segala marga huluan, B 13, adathoofd(en), bestuurshoofd(en) v.e. dorp i.h. binnenland v. Pal., lager in rang dan pasirah, z.a.; perwatin pasirah-pasirah, D 55, de gezamenlijke (dorps- en districts) hoofden; vgl. (per)batin.

pétor, B 16, 20, C 4-5, vertegenwoordiger v.h. Ned. bestuur, hoofd v.d. factorij. piara: miara, D 58, onderhouden; vgl. Jav. miara.

picah, zie pecah.

pinakawan, C 18, 39, E 85d, dienaar, helper, knecht; vgl. Jav. panakawan. pinggir: rumah-rumah yang pinggir laut, C 15 , de huizen die a.h.w. de rivieroever vormen, paalwoningen in de rivier langs de oever.

piniwayah, D 94, adathoofd, oudste?; vgl. Jav. piniwayah; eveneens, gespeld p-i-n-w-a-y-h, in KI 5, p. 9, regel 3 ("piniwayah Sungsang"), p. 11, regels 18 en 22 , p. 12 , regel 13 ; voorts, gespeld pinawaya, in MP 2, p. 96 , regel 35.

pinta: minta pulang, C 10, minta pulang kembali, D 43, minta kembali, D 45, 64, 65, minta mudik kembali, D 58, $=$ bermohonlah pulang, C 39, mohon(lah) kembali, D 56, 61, mohonkan hendak kembali, D 81, memohonkan supaya pulang, $\mathrm{C} 4$, verlof vragen om terug, naar huis te gaan, afscheid nemen; berminta, C 6,14 , = minta, verzoeken, vragen om.

poyang, $\mathrm{C} 43$, tovenaar, medicijnman.

pucuk: pucukan, B 13, 51, C 7, 33, D 50, 53, 73, uithoeken v.h. land, de meer afgelegen streken, stroomgebieden, binnenlanddistricten v. Pal.; pucukan (tanah) uluan, C 7, 16, 33; pucukan Batangari Sembilan, B 4, 23, 74; pucukan Musi, Beliti ..., D 53; vgl. Wlk. penghulu pucuk, tribal headman. pukat, E 207a, (perahu) sampan pukat, B 60, vissersvaartuig, ook handels- of vrachtvaartuig; vgl. Kl. s.v. poekat.

punggawa: punggawa menteri, B passim, de militaire en de civiele autoriteiten te Pal., het ambtenarencorps, de gezamenlijke ambtenaren; z.o. hulubalang, menteri, pahlawan, panglima, penghulu.

punya, B-E passim, overwegend, maar zeker niet uitsluitend gebruikt binnen de niet-Indon. sfeer, vooral waar het gaat om onderhandelingen of verdragen met de Engelsen of Hollanders, of wanneer deze vreemdelingen worden geciteerd; bijv. Sultan punya kuasa, B 45 , soldadu punya bahagian, C 30 , Sultan punya perbuatan, C 39 ; gua punya kerja, D 45, aku punya cintakasih, D 80, saya punya pikiran, E $61 \mathrm{c}$.

raat, zie rat.

raba, E 153a, = reba, droge takken; vgl. De Clercq, 1876, p. 535.

radén, B 38, D passim, adellijke titel v.d. zoon v.e. pangéran en een radén ayu of dénayu, z.a.; zie De Sturler, 1855, p. 81 ; z.o. Van den Berg, 1902.

rahasia, C 5, geheime bespreking, memberi/mengasih rahasia, C 23,24 , geheimen vertellen, geheime inlichtingen verschaffen.

raja, A-E passim, vorst; Raja Menggala, A 27, B 42, Raja Benggala, D 88, de Eng. onderkoning in het voorm. BritsIndië; raja-raja, D 93, personen van koninklijken bloede, leden v.h. vorstenhuis; kerajaan, A-D passim, 1 regering, 2 = takhta kerajaan, troon; kerajaan raja, A 28 , tot vorst verheven, met de vorstelijke waardigheid bekleed.

rambang: kerambangan, E 153a, ronddrijven; vgl. Jav. dirambang, krambang.

ramsum, D 89, rantsoen; vgl. ransum, rangsum.

rangga, D passim, E 38c, Jav., ambtenaar van middelbare rang; zie De Sturler, 1855, p. 74 ; 2.o. Van den Berg, 1902.

rantau: di rantau, B 77 , C 40,41 , op reis, onderweg; didalam teluk rantau, D 58, 61, in de wildernis, ver van de bewoonde wereld.

rapport, C 17, Ned., rapport.

rasan: terkena cucuk rasan, B 15, sudah dicucuk rasan, B 78, sudah kena rasan, C 42, bepraat, overgehaald, opge- 
stookt; vgl. Jav. (re) rasan, praten, bespreken; z.o. De Clercq, 1876, p. 533. rat, B 74, 75; raat, C $36-43$, raad, bestuurscollege.

racyat, B-E passim, a) binnen de Pal. samenleving: 1 het volk, de burgerij, onderscheiden van de ambtenaren (menteri) en de adel (periai) ; 2 krijgsvolk, manschappen, onderscheiden van de officieren (hulubalang, panglima) ; b) buiten de Pal. samenleving: 1 het volk, de mensen (= orang); 2 de militairen, soldaten ( $=$ baris, soldadu); ook met nadere bepaling, bijv.: racyat Holanda/ jénderal/ Kompeni/ Ménténg, E passim.

repoh, C 19, gezang; vgl. vdW. s.v. repoh.

resident, B 75, 76, 78, C 36-42, résidént, A 28, Ned., resident.

rial, B 33, 44, munten, geldstukken, geld. risau, D 79, bandiet, avonturier; over de orang risau (vogelvrij verklaarden, desperado's) in Midden-Sumatra, zie Olivier, 1828, pp. 408-409.

rubuh, C 12, instorten, C 13, 28, omvallen; merubuhkan, A 26, afbreken, slopen, B 48, C 28 , neerhalen; dirubuhkan, A 26, D 42, afgebroken, gesloopt, C 5, neergehaald; kita rubuhkan, E 62d, schieten wij in puin; de vormen zonder -kan worden in B ook transitief gebruikt met de betekenis afbreken, slopen: rubuh, merubuh, B 28; dirubuh, B 73.

rundung, E 43c, 100b, duister, betrokken, bewolkt (?).

rungkat, B 69, C 27, ontworteld, met geweld uit de grond gerukt; vgl. Jav. rungkad.

sacat: sacat musytari, D 46, E $91 \mathrm{~b}$, sacatnya zohrah, E 145c, terwijl Jupiter (musytari) c.q. Venus (zohrah) aan de hemel staat, een gelukkig gesternte, het gunstige of als gunstig bepaalde tijdstip (om iets te doen); vgl. Wlk. s.v. mushtari.

sahaja: sahaja tertentu, E 24c, 179a, $198 \mathrm{~b}, 235 \mathrm{a}$, met een vast doel, vastberaden, doelbewust; sahajakan pasti, E 156a, 224c, nauwkeurig mikkend. sahaya, zie saya. sahbandar, zie bandar.

sajak, E 157b, houding, allure, stijl, voorkomen; vgl. Jav. sajak.

sambi, C 16, volksspel uit de Pal. bovenlanden.

sampan, B 67,68, C 14, 21, sloep, roeiboot; z.o. kotak, pukat; bersampan, E $65 \mathrm{c}$, in, met een bootje, roeien(de). sangat: waktu sangatnya, C 38 , het tijdstip, het geschikte ogenblik; vgl. Jav. sangat.

sangkuh, D 48, Jav., bajonet; vgl. Mal. sangkur.

sanubari, zie la ilaha illa llahu.

saputangan, D 53, E $157 \mathrm{c}, 197 \mathrm{c}$, hoofddoek.

sawa, E 129c, moeras, vloedbos(?); vgl. Kl. s.v. sawa.

saya, B-E passim, ik; gebruikt a) i.h. verkeer met Europeanen: B 19, C 10, 22 , D 47, 82-83; b) door een ambtenaar tegenover een pangéran of radén: D 58 (ook saya sekalian of sekalian saya, wij), 72 ; c) door pangérans tegenover een (misschien oudere?) rangga: D 61, 63-65; d) door de dichter v.d. syacir ter aanduiding van zichzelf: E 256a; z.o. aku, gua, hamba, patik.

Sayyid al-kainat, E 75c, Heer v.h. geschapene.

sedia, D 75 , = sediakan, klaarmaken, gereed houden.

segara, E 250b, = laut, rivier; z.a.; vgl. De Clercq, 1876, p. 546.

sekoci, C 15, D 95, sloep, boot; koci, C 14, = sekoci?; vgl. Jav. koci.

sekonyar, zie sikunyir.

sekutu: bersekutuan, C 5, er bestaat een verbond tot samenwerking.

selalu, zie lalu.

selat, B 59, E 225b, doorvaart tussen eiland en rivieroever, D 95, zeestraat (i.c. Straat Banka?).

sembilu: tiada ketahuan sembilu dan duri, $\mathrm{E} 36 \mathrm{c}$, geen bamboespaander meer van een doorn kunnen(de) onderscheiden, geheel in de war, de kluts kwijt, in paniek geraakt (zijn).

seméper: berseméper, B 33, onderweg ergens aangaan, aan wal gaan; vgl. Jav. semeper (k. bij mampir).

senang: kesenangan, B 4, op zijn gemak, 
tevreden gesteld.

sendakap, E 9d, = Jav. siḍakep, met de armen voor de borst gekruist (ten teken $v$. eerbied).

sentosa, zie aman.

seperti: bukan seperti, E 96c, bepaald niet gering, geweldig, ongeëvenaard.

sepuh: kesepuhan, zie menteri.

serah: perserahan, C 7, overdracht, C 30, het overgedragene, hetgeen wordt overgedragen.

serot: diserotnya, D 77 , ze zetten hen achterna; vgl. Jav. diserod, achternagezet.

serta: sertanya, C 17, D 44 ; beserta, C 19 , 40, E 1d, 53c, 76c, 207b, zomede, benevens, met, vergezeld van.

sesak: hati itu sesak, D 52, de lever (als zetel of centrum v.h. leven) is beklemd geraakt, hij verkeert in levensgevaar, is er zeer ernstig aan toe.

siaga: dengan siaganya, B 49, geheel gereed, gevechtsklaar; vgl. Jav. sayaga, siyaga, zich gereed maken, Indon. siapsiaga, gereed.

siap: bersiaplah dengan angkatan besar, C 5, rustte een groot leger uit; bersiapkan (dengan), C 9, 15, 37, in orde brengen, gevechtsklaar maken, paraat houden.

sikap, B 47, 54, E 9c, paraat, gereed, strijdvaardig, D 73, uitrusting, E passim, houding, gestalte; bersikap, B 33, $58,67,71$, zich uitrusten tot de strijd, zich gereed houden, klaar staan met, paraat zijn; dengan (me)nyikap senjata, B 48, met het wapen in de vuist; vgl. Jav. sikep, gewapend met; Indon. (ber) sigap, actief, paraat (zijn).

sikunyir, B 53, 54, = sekonyar, C 23, D 44, schoener.

siluman, E 192d, spook, geestverschijning; tipu siluman, E 229d, bedriegelijke en geheimzinnige praktijken, list en bedrog.

singkir: bersingkirkan dirinya, C 3 , de wijk nemen, zich verwijderen; vgl. P./T., menyingkirkan diri.

sipai, B 46, D 74; soldadu sipai, D 49, 84, 88, 95, Indiase (Bengalese) soldaten in het Brits-Indische leger, sepoys.

sirap, B 46, C 5, 13, D 85, = rumah raja besar, B 46, hoofdverblijf v.d. vorst in de kraton, troonzaal; vgl. Ras, gloss., s.v. sirap.

sirat: tersirat, E 119d, vastgeknoopt, vervat, opgesloten (in een netwerk), intact, van kracht, geldig.

suhunan, B-E passim, susyuhunan, A passim, titel v.d. vorst; vgl. Jav. susuhunan.

sujut: sujutan, B 41, diep ter aarde gebogen (als teken v. onderwerping); vgl. Wlk. s.v. sujud, sujut; -an-vorm met verbale betekenis, vgl. suruhan, utusan.

suka: melakukan kesukaan, C 21, membuat sesukahatinya, D 91, geheel naar eigen believen, naar willekeur handelen, eigenmachtig optreden; suka tertawa, E 150d, 243d, goedlachs, opgewekt (zijn) ; vgl. Skinner, 1963: 135c, 174a, 235a, 277c; Rusconi, 1935: 1984. sungai, A 26, D 44, rivier, meestal gebruikt voor een kleinere rivier dan batangari, z.a., maar soms ook voor de Musi: D 93 ; vooral in combinatie met de naam v.e. rivier: Aur ( $A-C, E)$, Kundur (B, C, E), Tengkuruk (B, C), Plaju, Keruh, Bayas (C), Ogan (D). suruh: suruh(kan), menyuruh(kan) (met of zonder object), disuruh enz., A-E passim, gelasten, zenden enz.; suruhi, D 48, iemand erop uit sturen; suruhan, 1 A-E passim, bode, gezant (schap); 2 C 10, boodschap; 3 B 35, 52, C 6, 7, D 71, E 141d, verbaal gebruikt met de betekenis v. suruh(kan), menyuruh(kan) ; vgl. utusan; pesuruhan, C 16, boodschappers.

susyuhunan, zie suhunan.

takhsis iradat, G 28, wilsbesluit (van God).

taclim: dengan taclimnya, D 67, eerbiedig, beleefd; menaclim atas, D 57, eerbied betonen, onderdanig zijn jegens, de mindere zijn van.

taman, B 18, tuin, aanplanting, lusthof; tempat rumah tamannya, B 46, zijn buitenverblijf, rumah taman besar, C 6, het grote buitenverblijf, taman laut, $\mathrm{C} 6$, het buitenhuis aan de rivier. tamban: tidak tertamban, E 193a, zonder dralen, niet vertraagd, niet langzaam; 
vgl. Jav. tamban, langzaam aan, niet overhaast; z.o. KI 5, p. 19, regel 2: "Apa lagi dinanti? Bedillah! Jangan tamban lagi!"

tambur, E 139b, tukang tambur, B 57, C 13, E 38d, tamboer, trommelslager. tampil: tampil berperang, tampil pula perang itu, B 56, men trekt (weer) ten strijde, de strijd begint (opnieuw), breekt (weer) los; vgl. Wns. s.v. tampil, get going started (work).

tanah: tanah Bangka, B, D passim; tanah Jawa, B, D, E, passim; tanah Melayu, E 32b, 82b; tanah Belitung, E 32c; z.o. negeri.

tanda, D 49, assistent v.d. kerta(negara) of vrederechter, griffier; zie De Sturler, 1855, p. 72 .

tandang: marilah tandang, E 18b, kom maar bij ons op bezoek, kom maar op; ook: kom, aan de slag, probeer ons eens aan te pakken; vgl. Jav. tandang.

tangga, B 4, D 55, 90, trap, steiger; tangga dalam, C 17, 20, 30, 32, D 85, tangga kota, B 58, de kratonsteiger, kratontrap; tangga batu, D 85, stenen trap.

tapuk, C 16, Jav., maskervertoning.

tebas: bertebas pada hutan, C 25, een tracé kappen door het bos; vgl. babat.

teguh: teguh setia, D 53, volkomen betrouwbaar, vgl. lemah setia, D 60 , onbetrouwbaar; bersetia yang teguh, D 53 , betuigden hun onwrikbare trouw; berteguh, B 10, berteguh bénténg, D 53, zich versterken; meneguhi bénténg-bénténg, C 21, de forten versterken; perteguhan bénténg, C 40, versterkingen.

teluk, zie rantau.

temenggung, A-E passim, titel v.e. hoge ambtenaar; zie Van den Berg, 1902 (toemenggoeng); temenggung kertanegara, B 7, vrederechter, politierechter; zie De Sturler, 1855, p. 72; temenggung polisi, B 79, temenggung politie, C 37, 42 ; z.o. kerta.

tempat: tempat Holanda, A 26, tempat Olanda, C 31, 33, de Hollandse factorij; z.o. gudang, kota, loji; ketempatan, C 15, 23, verblijf, onderkomen, woongelegenheid.

témpo(h), B 57, C 14, E 47b, 50c, 52b, 55d, 56a, 60c, wapenstilstand, C 24, D 73, bedenktijd, uitstel, D $64,80,90$, 91, tijd, tijdsgewricht, tijdperk, B 27, ten tijde dat; ditémpokan, G 14, wordt (wapenstilstand) toegestaan, verleend.

tempur: tempur berperang, B 11, oorlog voeren, vechten.

temu: bertemu, B passim, C 34, D 80 , 84, ontmoeten, samenkomen met; ketemu, C 5, 13, 29, 41, D 82, 83, 87, ontmoeten, treffen; bertemuan, C 6 , $22,26,29$, een ontmoeting hebben; bertemu-temuan, D 79, elkaar ontmoeten.

tenung: bertenung, E 100c, afwezig voor zich uit staren, turen (als een ziener); vgl. Kl. s.v. tenoeng.

tetas: menetas jangkar, E 80d, de ankertouwen doorsnijden; vgl. Jav. tatas, natas.

tigas, D 78, met afgeslagen hoofd; vgl. Jav. ditigas (guluné), afgehakt, onthoofd.

timbang: timbang pesalin, B 13, geschenken voor de vorst (die moeten dienen als tegenprestatie voor te verwachten geschenken van de vorst, voor pesalin dus); z.o. pe(r) salin.

tindih: bertindih tulang, E 189c, zwaar drukkend (innig) met de botten tegen elkaar liggen, een intieme ontmoeting hebben na de dood, verenigd zijn in de dood.

tinggal, B 33, 46, 53, C 18, = ketinggalan, ontruimd, verlaten; (désa-désa uluan) yang ditinggalkan Suhunan, C 35, die door de Suhunan werden achtergehouden, behouden; (saya sekalian) tiada tertinggal Duli, D 58, kunnen Z.M. niet in de steek laten; sepeninggal, $\mathrm{C} 15,41$, na het vertrek van.

tipu: setipu-dayanya, C 6, met alle mogelijke middelen, op alle mogelijke manieren; tipu siluman, zie siluman; z.o. daya.

tob: perahu tob, B 28, = perahu top, groot Maleis koopvaardijschip, vrachtboot.

tolak bahala, D 44, geschenken ter afwending van onheil, afweermiddelen tegen rampen.

topéng: nopéng, C 16, Jav., een masker- 
dans of maskerspel opvoeren.

tuan, B-E passim, heer, mijnheer; uitsluitend gebruikt: a) B-E passim, wanneer wordt gesproken over of tot haji's, Arabieren, Engelsen of Hollanders; b) C, D passim, wanneer door Engelsen of Hollanders wordt gesproken over of tot de vorst of tot leden v.d. adel; c) E 259a, wanneer de dichter v.d. syacir zich richt tot zijn lezers.

tunang: petunang, E 24c, 134a, = peluru petunang, een kogel die betoverd is om een doel te raken, toverkogel; vgl. Kl. s.v. toenang, Wns., Wlk. s.v. peluru, tunang.

tunduk: tunduk merakap, E $9 \mathrm{~b}$, = tunduk merakak (vgl. masup = masuk), diep gebogen naderbij kruipen; $t u n d u k$ tengadah, E $8 \mathrm{~b}, 254 \mathrm{~b}$, het hoofd op en neer bewegend, telkens buigend, als teken $v$. onderdanigheid (E 8b), maar ook als teken $\mathrm{v}$. schaamte en verslagenheid (E 254b); vgl. Skinner, 1963, $140 \mathrm{c}, 383 \mathrm{~d}$ ("hardly knowing what to do"), 479b.

tunggal: (empat bersaudara laki-laki) yang tunggal <ibu>, B 21, ... van één moeder; in tegenstelling tot: (saudara ...) yang lain ibu, B 22, ... van een andere moeder; vgl. Jav. tunggal.

tunggu, B 53, D 46, bezetten, bezet houden; yang tunggunya, B 32, bezetting; menunggu, B 25, de wacht houden, C 10, gelegerd zijn, C 42, bezet houdende, C 31, 37, 38, wachten op, afwachten; ditunggu, B 18, 27, 71, C 2, 4, D 46, 93, bezet, geoccupeerd, bewoond, bewaakt; menunggukan, C 17 , opwachten; bertunggu, B 32, 50, de wacht houden, op zijn post zijn, D 76, een bezetting hebben; tempat meriam tungguannya, B 65, de batterij waarbij hij was ingedeeld.

tunggut, E 249d, dienst nemen, in dienst zijn bij, diensten verrichten voor; vgl. Jav. tungguk.

turun, A-D passim, 1 aan boord gaan; meestal met complement: di/ke(pada) kapal/ sampan/ kici/ perahu/ langbut ; in $\mathrm{C}$ komt éénmaal een $m e$-vorm zonder -kan voor met transitieve betekenis: menurun, C 32, aan boord brengen; 2 naar buiten gaan: D 66 ;
3 aftreden, afstand doen: turun dari kerajaan, D 88; menurunkan, A 27, B 42, 45, afzetten; diturunkan, B 42 , 46 , D 87, afgezet; menurunkan, C 25 , te water laten; diturunkannya, B 23, werd door hem verlaagd, verminderd; turun-menurun, $\mathrm{C} 31$, = turun-temurun, van geslacht op geslacht; vgl. naik.

tutul: menutul, C 6, achterna gaan, achterna jagen; zie De Clercq, 1876, p. 540 ; vgl. Jav. nututi, achterna lopen, trachten in te halen.

ujungan, C 16, tweegevecht met rottans, een Jav. volksspel; zie Pigeaud, 1938b. umak: umaknya, B 28, zijn moeder (niet: "zijn grootmoeder", v.d. Linden, 1937, p. 150).

upama: tiada seupama, C 5, niet behoorlijk, C 16, zonder weerga.

usul: usulnya dandan, E $147 \mathrm{~b}$, goed verzorgd van uiterlijk, fraai uitgedost, zwierig van allure.

utang: diutangnya, B 22, bleef hij schuldig.

utus: utusan, 1 B-D passim, bode, gezant; 2 B 5, 7, 16, 18, 22, 45, 46, 60, 67 , verbaal gebruikt $=$ mengutus $($ kan $)$, (een) gezant(en) zenden, iemand als gezant (uit)zenden; vgl. Jav. utusan in verbale betekenis; berutusan, C 18, elkaar gezanten zenden.

wangkang, B 58, Chinees vaartuig. wangsa (-wangsa), D 71, Jav., familielid. waras, B 77, Jav., genezen, hersteld v.e. ziekte; vgl. De Clercq, 1876 , p. 554. wayang, C 16, Jav., poppentoneel; wayang krucil, C 16, id. met vast, eigen repertoire; wayang Siam, C 16, Siamees poppenspel; zie Pigeaud, 1938b. Wilanda, zie Holanda.

wilut, C 14, 36, bélot, D 54, overlopen, deserteren, verraad of ontrouw plegen. wirang, E 258d, Jav., schande; vgl. De Clercq, 1876, p. 530.

Yang, zie bangsa Yang.

zohrah, zie sacat.

zuriat, C 15, kroost, nakomelingschap, D 60, (pregnant:) afstammeling van het vorstengeslacht. 


\section{REGISTER BIJ DE MALEISE TEKSTEN GEPUBLICEERD IN HOOFDSTUK III}

Dit register van de persoonsnamen en de geografische en staatkundige eigennamen die in de in hoofdstuk III gepubliceerde Maleise teksten voorkomen, is ingericht met inachtneming van de volgende regels.

Bij de persoonsnamen is de titel (demang, haji, kemas, masagus, ngabéhi, pangéran, radén, rangga, suhunan, sultan, temenggung, enz., maar ook jénderal, kaptén, méjir, misti, e.d.), die in de Maleise teksten veelal een integrerend onderdeel van de naam uitmaakt, als eerste hoofdwoord gekozen en dus bepalend voor de alfabetische volgorde; van de eigenlijke persoonsnaam wordt vervolgens naar dit hoofdwoord verwezen. Verschillende namen van één persoon zijn, zoveel mogelijk met handhaving van de chronologie der naamsveranderingen, onder één naam als hoofdwoord opgenomen; de overige namen van die persoon zijn bovendien als verwijzing opgenomen. Verschillende personen van dezelfde naam zijn onderscheiden door een volgnummer, waarbij de volgorde zoveel mogelijk chronologisch bepaald is.

De hoofdwoorden en de andere rechtstreeks aan de tekst ontleende eigennamen waarvan de vindplaats wordt vermeld, zijn cursief gedrukt.

De vindplaats van een eigennaam wordt aangegeven als volgt. De hoofdletters A - E verwijzen naar de teksten, resp. KI 4 (p. 26, r. 16 - p. 29), UBL 7, TR 1, UBL 9 en MP 4b. De nummers achter de hoofdletters A-D verwijzen naar de bladzijde van de tekst volgens de paginering van het handschrift. De nummers + één der kleine letters a - $d$ achter de hoofdletter $E$ verwijzen naar de regel van de syacir waarin de naam voorkomt. Bijv. B 43, E 188a.

Dit register moge tevens dienen bij hoofdstuk IV, waarvoor ik geen afzonderlijk register heb samengesteld omdat dit hoofdstuk afgezien van de tekstvergelijking TR 1 - UBL 5 / MP 2 uitsluitend een vertaling behelst van de in hoofdstuk III gepubliceerde Maleise teksten.

Abang, zie Kemas Abang.

Abduljamil, zie Masagus Abduljamil.

Abdulrahim, zie Haji Abdulrahim.

Abdulrahman, zie 1 Sayyid Abdulrahman,

2 Sékh Abdulrahman Mesri.

Abdurrahman, zie 1 Pangéran Natakesuma, 2 Suhunan Abdurrahman.

$A c u$, zie Si Acu.

Adikesuma, zie Pangéran Adikesuma.

Adimenggala, zie 1 Pangéran Adimenggala (1), 2 Pangéran Adimenggala (2). Adipati, zie 1 Pangéran Adimenggala

(1), 2 Pangéran Natakesuma.

Adiwijaya, zie Pangéran Adiwijaya.

Ahmad, zie 1 Kemas Haji Ahmad, 2 Kirangga Ahmad, 3 Ngabéhi Ahmad, 4
Pangéran Ratu (5), 5 Sayyid Ahmad bin Ali.

Ahmad Najamuddin, zie 1 Pangéran Ratu (2), 2 Pangéran Adimenggala (1), 3 Pangéran Ratu (5), 4 Pangéran Prabu Anom.

Ajid, zie Radén Ajid.

Akil, zie 1 Raja Akil, 2 Pangéran Sutakrama Akil, 3 Sayyid Akil bin Muhammad.

Alamuddin, zie Sultan Muhammad Alamuddin.

Aliat, zie Kaptén Aliat.

Alimdana: orang Alimdana, B 11.

Aluddin, zie Radén Aluddin.

Ambon, C 43, Ambon; D 41, E2b, 28b, 
$123 \mathrm{~d}, 124 \mathrm{~b}, 128 \mathrm{c}, 129 \mathrm{~b}, 243 \mathrm{~b}$, = orang Ambon, D 44, Ambonnees, Ambonnezen; soldadu Ambon, D 47.

Aminuddin, zie Temenggung Aminuddin. anak Raja Benggala/Menggala, zie Kaptén Aliat.

Anom, zie Sultan Muhammad Alamuddin. Anum, zie Pangéran Anum.

Anyar, zie Pulau Anyar.

Arab, B 30; Arab-Arab, B 47; anak Arab, D 46; bangsa Arab, D 69; (se)orang Arab(-Arab), B 27, 29, 66, 67, C 31; tuan(-tuan) Arab(-Arab), B 23, 63, D 45, 48, 93, Arabier(en).

Arif, zie Radén Arif.

Arsad, zie Demang Arsad.

Arya, zie Pangéran Adikesuma.

Aryakesuma, zie 1 Pangéran Adikesuma, 2 Pangéran Jayakrama, 3 Pangéran Natakesuma.

Astramenggala, zie Temenggung Astramenggala.

Astrawijaya, zie Temenggung Astrawijaya.

Aur, zie Sungai Aur.

Awal: Batanghari Awal, C 42, zijrivier v.d. Ogan.

Aziz al-Gafur, E 190b, de Verhevene en Barmhartige, God.

Badaruddin, zie 1 Pangéran Jayawikrama, 2 Pangéran Ratu (4), 3 Radén Badaruddin.

Bafakih, zie Said Zain Bafakih.

Baha'uddin, zie Pangéran Ratu (3).

Bajau, zie Pangéran Bajau.

Bakar, zie 1 Kornél Bakar, 2 Radén Bakar, 3 Pangéran Sutadiraja Bakar.

Bakar Rum, zie Said Bakar Rum.

Bali, B 15, D 41, 44, E 243c, = orang Bali, B 15, Balinees, Baliër; soldadu Bali, D 47.

Balmi, zie Ngambai Balmi.

Bandan, B 79, C 43, Banda.

Bangka: tanah Bangka, B 1, 6, 14, 16, 44, D 43, Banka; racyat Bangka, B 32.

Bangkahulu, B 46-48, 50, 51, = (negeri) Bengkulu, A 27, C 5, 8, D 88, Benkoelen.

Bangsawan, zie Raja Bangsawan.

Baron Pandar Kapélan, zie GeburnurJénderal Kapélah.

Batangari Komering, zie Komering.
Batangari Plaju, zie Plaju.

Batangari Rawas, zie Rawas.

Batangari Sembilan, B 1, 4, 14, 23, 51, 74, (het stroomgebied van) de Negen Rivieren: Banyu-Asin, Kikim, Klingi, Komering, Lakitan, Lematang, Lintang, Ogan, Rawas.

Batang(h)ari Musi, zie Musi.

Batanghari Awal, zie Awal.

Batu, zie Pulau Batu.

Batu Ampar, B 26, plek in Palémbang Lama.

Batuapi, zie Panglima Batuapi.

Batu Kuning: pucukan Batu Kuning, D 53, marga in Musi Ulu.

Bayak, zie Pulau Bayak.

Bayas, zie Sungai Bayas.

Belahrubi, B 36, Villarubi; kapitein bij de expeditie onder Gillespie, van Spaanse afkomst; zie De Haan, 1935, p. 657, Thorn, 1815, p. 139 (die de naam "Villneruby" spelt).

Belidah, C 7, D 46, zijrivier v.d. Musi, tevens stroomgebied v.d. rivier: dipati Belidah, C 34; dusun Belidah, B 57; Muara Belidah, B 33, 35; z.o. Perwatin Lima (Belidah).

Beliti, D 89, zijrivier v.d. Klingi; pucukan Beliti, D 53, het stroomgebied v.d. Beliti; Muara Beliti, B 47, 50, 51, 76, C 7, 40-41, D 89, dorp a.d. uitmonding v.d. Beliti i.d. Klingi.

Belitung, B 16, negeri Belitung, B 1, tanah Belitung, E 32c, Billiton; racyat Belitung, B 32.

Benderang, zie Dénayu Benderang.

Benggala, C 3, 7, = Menggala, B 43-44, Bengalen; z.o. Jénderal Menggala.

Bengkulu, zie Bangkahulu.

Berikmil, D 82, 85, luitenant Bruggemeyer, Holl. officier, als tolk in dienst v.d. Engelsen; zie Bengal Civil Colonial Consultations, Nos 75-98 dd. 2-10-1813 (India Office Records P/167/43); z.o. Court, 1821, pp. 25-26.

Betawi, A-D passim, Batavia; z.o. Seri Betawi.

Bilam, zie Tuan Bilam.

Bogor, B 63, 64, Buitenzorg.

Boma, zie Maharaja Boma.

Borang, B 23, 26, 32, = Pulau Borang, E 227c, eiland i.d. Musi bij Pal.; bénténg Borang, B 32-33, D 44. 
Brama, zie Déwa Brama.

Buaya Langu, B 37; dusun Buaya Langu, B 37, D 50, 51, dorp a.d. Musi; bénténg Buaya Langu, B 38, D 51, 52.

Bugis, D 41, E 243c, orang Bugis, B 11, C 19, 29, Buginezen; kepala Bugis, B 66 ; perahu Bugis, B 66 ; soldadu Bugis, B 47.

Bukit Serila, E 137b, berg i.h. Pal. binnenland (Lematang Ulu).

Bupati, zie 1 Pangéran Adikesuma, 2 Pangéran Adimenggala (2).

Bupati Panembahan, zie Pangéran Adikesuma.

Buratan, zie Lawang Buratan.

Buri: dusun Buri, B 28, dorp ten Z. v. Pal.

Burnai: orang Burnai, B 11, lieden van Borneo.

Bustam, zie Haji Bustam.

Butun, E 243c, Butonnezen.

Caguk, zie Masagus Caguk.

Candi, zie Kampung Candi.

Cianjur, C 6, 22, 24, = Sianjur, A 27, $=$ Sinjur, B 50, 60, 63, D 89, plaats op Java, waar Suh. Husin Dia'uddin werd geïnterneerd.

Cik Nauk, B 66, bevelhebber v.e. Buginese vloot uit Lingga.

Cilincing, B 72, plaats op Java, waar Sultan Mahmud Badaruddin (2) enige dagen verblijft op doorreis naar zijn verbanningsoord Ternate.

Cina, D 41, 45, E 130d, 206a, 240b, $246 \mathrm{c}$, orang Cina, B 58-60, 66, C 31 , E 249d, Chinezen; kaptén Cina, D 49, 86, 91,93.

Cindé Walang, C 1, ook: Candi Walang/ Balang of Cindai Belang, wijk v. Pal. (kpg 24 Ilir), waar Suh. Abdurrahman begraven is.

Cingot, zie Radén Cingot.

Citra, zie 1 Masagus Putang, 2 Pangéran Citradiningrat.

Citradiningrat, zie Pangéran Citradiningrat.

Citradita, zie Temenggung Citradita.

Citrakesuma, zie Pangéran Citrakesuma.

Citra Putang, zie Masagus Putang.

Citra Saléh, zie Pangéran Citradiningrat.

Citrawijaya, zie Pangéran Citrawijaya.
Dana Luar, C 7, 35 (= Danau Luar, een meer ten Z. v. Pal.?).

Darpacita, zie 1 Ngabéhi Darpacita, 2 Rangga Darpacita.

Darpateruna, zie Demang Darpateruna.

Darpayuda, zie Demang Darpayuda.

Dégelar, zie Kaptén Dégelar.

Dekok, zie Jénderal Dekok.

Demang Arsad, D 89, 90.

Demang Darpateruna, D 86.

Demang Darpayuda, E 187a.

Demang Jayateruna, E 240d.

Demang Singayuda, D 77, 81, een "pangéran" v. Komering, volgeling v.d. pangérans Natawikrama en Sutawikrama.

Demang Surayuda, D 54, volgeling v.d. pangérans Citrakesuma en Sumanegara.

Demang Umar, C 39.

Demang Wiralaksana, B 57, volgeling v. Muntinghe, als "collaborateur" door de Sultan ter dood gebracht.

Demang Wirasentika, G $32,=$ Kiai Rangga Wirasentika, C $32,=K i$ rangga Wirasentika, B $67,77,78, \mathrm{C}$ 41-43, = Rangga Wirasentika, B 77, 78.

Demang Wiratenaya, E 70a.

Dénayu Benderang, B 13, dochter v. Sultan Anom, gehuwd met de sultan v. Jambi.

Dengkak, zie Masagus Dengkak.

Denta, zie Maharaja Denta.

Déwa Brama, E 220d, de god v.h. vuur in wayangverhalen.

Déwa Narada, E 187b, figuur uit wayangverhalen.

Déwa Sahperi, E 86b, godenfiguur, "Heer der geesten".

Dipati, zie 1 Pangéran Adikesuma, $2 \mathrm{~Pa}$ ngéran Adimenggala (1), 3 Pangéran Dipati (1), 4 Pangéran Jayaningrat, 5 Pangéran Natakesuma.

Dipati Abdurrahman, zie Pangéran Natakesuma.

Dipati Muda, zie Pangéran Natakesuma. Dipati Tua, zie Pangéran Adikesuma.

Dita, zie Pangéran Dita.

Emas Dipati, C 1, ook: Kemas/Mas Dipati, zoon en troonopvolger v. Kiai Geding Sura Muda of Kiai Geding Ilir; broer v. Pang. Medang Suka, 
Pang. Madi Alit en Pang. Siding Pura; vorst v. Pal., eind $16 \mathrm{e}$ eeuw.

Enim, C 41 , zijrivier v.d. Lematang; Muara Enim, C 41, dorp a.d. uitmonding v.d. Enim i.d. Lematang.

Galipi, zie Jénderal Galispi.

Galispi, zie Jénderal Galispi.

Gangsa, zie Si Gangsa.

Geburnur-Jénderal Kapélah, B 63, 65, = Jénderal Kapélah, B 63, = Baron Pandar Kapélan, A 28, GouverneurGeneraal G. A. G. P. baron Van der Capellen.

Goyang, zie Si Goyang.

Gubir, zie 1 Pangéran Wirakrama (3), 2 Radén Gubir.

Gunung Méru, B 28, = Gunung Mahaméru, heuvel bij Pal.; vgl. Westenenk, 1923.

Haji Abdulrahim, E 116a.

Haji Ahmad, zie Kemas Haji Ahmad.

Haji Bustam, E 67b.

Haji Jabaruddin, C 39, = Khatib Jabaruddin, B 75, C 39.

Haji Lanang, B 55, C 11.

Haji Mascud, E 117a.

Haji Zain, B 55, E 13b, = Haji Zén, C 11.

Hamzah, D 61, 62, 64, = Said Hamzah?

Hanafi, zie Kemas Muhammad (Hanafi).

Hanipa, zie Nayu Hanipa.

Hasan, zie Kemas Rangga Hasan.

Hasanuddin, C 38, zoon v. Temenggung Mahidin?

Holanda, A, B, E passim, Olanda, C passim, Wilanda, D 92, de Hollanders; bendéra Holanda, B 71 ; gudang/kota/ loji/tempat Holanda/Olanda/Wilanda, A 26, B 20, 24, 28, 29, 73, C 31, 33, D 42; Raja Holanda, E 143b; syahbandar/sahbandar Holanda/ Olanda, B 53, C 9.

Husin, zie 1 Pangéran Adimenggala (1), 2 Sayyid Husin.

Idelir Ménténg, A 27, B 45-61, C 5-32, D 88-95, E 2c, Idelir, E 87a, Ménténg, E passim, Edeleer (Mr. Herman Warner) Muntinghe; zie De Haan, 1935, pp. 614-617.
Iliran Palémbang, C 43, de Pal. benedenlanden.

Indera, E 165d, de god Indra uit het Hindoeistische pantheon; i.d. wayang "zoon" v. Batara Guru en "vader" v. Arjuna.

Inggelan, zie Maharaja Inggelan.

Inggeris, A 26-27, B 15-51, C 2-8, D 44, 46, 51, 61, 69, 82, 88, Engels, de Engelsen; bendéra Inggeris, $\mathrm{C}$ 3, 5, D 43.

Irang, zie Nyimas Irang.

Islam, C 21, E 213b; agama Islam, B 28, D 42; jalan Islam, E 34c; raja Islam, C 28 .

Jabaruddin, zie Haji Jabaruddin.

Jakatra, E 255d, door metathesis uit Jakarta; vgl. Ned. Jacatra.

Jalil, zie Kirangga Jalil.

Jambi, B 13, 15, D 68; orang Jambi, D 80; Sultan Jambi, B 13, D 68, 69, 73.

Jamil, zie Masagus Abduljamil.

Jawa, A 28, B 25, 26, tanah Jawa, B 25-27, D 41, 49, E 255b, Java; (orang) Jawa, B 28, E 28b, 129b, 243b, Javanen; dagang Jawa, B 62 ; soldadu Jawa, B 28, 55.

Jaya, zie Pangéran Jayawikrama.

Jayadilaga, zie Masagus Dengkak.

Jayadiraja (Cingot), zie Radén Cingot. Jayakrama, zie Pangéran Jayakrama.

Jayaningrat, zie Pangéran Jayaningrat. Jayateruna, zie Demang Jayateruna.

Jayawikrama, zie Pangéran Jayawikrama. Jénderal Dekok, A 28, B 65, 67, 71, 72, C 24, 25, 29-31, Generaal-Majoor Hendrik Merkus de Kock.

Jénderal Galispi, A 26, B 31-36, 42, Jénderal Galipi, D 44-49, 87, MajorGeneral Robert Rollo Gillespie; zie De Haan, 1935, pp. 551-556.

Jénderal Kapélah, zie Geburnur-Jénderal Kapélah.

Jénderal Laut, zie Jénderal Sekaubenah. Jénderal Maskalek, B 22, 23, Maarschalk (Mr. Herman Willem) Daendels.

Jénderal Menggala, B 43, 44, = Raja Benggala, D 88, = Raja Menggala, A 27, B 42, de Gouverneur-Generaal v. "Brits-Indië" te Calcutta (Bengalen). 
Jénderal (Misti) Rabpelis, zie Jénderal Raflis.

Jénderal Misti Raplis, zie Jénderal Raflis.

Jénderal Raflis, B 30-31, 42, = Jénderal (Misti) Rabpelis, D 41-44, 48, = Jénderal Misti Raplis, D 87, = Jénderal Ruplis, E 155b, Luitenant-Gouverneur Sir Thomas Stamford Raffles.

Jénderal Ruplis, zie Jénderal Raflis.

Jénderal Sekaubenah, B 60, = Jénderal Sukubanah, C 18, = Jénderal Laut, B60, Schout-bij-nacht C. J. Wolterbeek.

Jénderal Sukubanah, zie Jénderal Sekaubenah.

Johor: orang Johor, B 11.

Jungkur, zie Kapitan Jungkur.

Kadipan, B 4, 5, 9-12, E 220b, wijk v. Pal. (kpg 13 Ilir).

Kamariah, zie Nayu Kamariah.

Kampung Candi, B 10-12, wijk v. Pal. (= Candi Walang/Balang, zie Cindé Walang?).

Kapélah, zie Geburnur-Jénderal Kapélah. Kapélan, zie Geburnur-Jénderal Kapélah.

Kapitan Jungkur, E 131a, kapitein Jonker; is mij uit Ned. bron niet bekend; wordt hier misschien de kapitein Jhr. C. van der Wijck bedoeld?

Kaptén Aliat, A 27, = anak Raja Benggala, D 88, = anak Raja Menggala, A 27, B 42, Captain Elliot, zoon v. Gilbert Elliot, Lord Minto, G.G. v. "Brits-Indië" te Calcutta (Bengalen); z.o. Jénderal Menggala.

Kaptén Dégelar, D 82, 85, George Thomas D'Aguilar (1783-1839), CaptainLieutenant i.h. Brits-Indische leger; zie Bengal Civil Colonial Consultations, Nos 75-98 dd. 2-10-1813 (India Office Records P/167/43) en voor nadere bijzonderheden: Hodson, 1928, p. 2 ; z.o. Court, 1821, pp. 25-26.

Kaptén Saman, zie Mista Saman.

Karang Anyar, D 85, dorp a.d. Musi.

Karangberahi: kampung Karangberahi, C 43, dorp i.d. omgeving v. Pal., dichtbij Kertapati.

Karim, zie Radén Karim.

Kasemaran: dusun Kasemaran, D 56, 75 , dorp a.d. Musi.
Kawah Terkurap, B 2, Kawa Tekurap, C 2, naam v.d. begraafplaats v. Sultan Mahmud Badaruddin (1) in Lemabang (lett. omgekeerde pot, vgl. Jav. kureb).

Kebumén, C 15, wijk v. Pal. (kpg 16 Ilir). Kebun Gedé, B 3, wijk v. Pal. (kpg 32 Ilir), waar Sultan Muhammad Mansur en Sultan Anom begraven zijn.

Kecik, zie Kemas Kecik.

Kedah, B 31.

Keding Ilir, C 1, juister: Kiai Geding Sura Muda of Kiai Geding Ilir, zoon v. Kiai Hang Sura, jongere broer en troonopvolger v. Keding Suroh, z.a.; vorst v. Pal., eind $16 \mathrm{e}$ eeuw.

Keding Suroh, C 1, juister: Kiai Geding Sura, zoon v. Kiai Hang Sura, oudere broer v. Keding Ilir; vorst v. Pal., 2e helft $16 \mathrm{e}$ eeuw.

Kedukan, C 38, wijk v. Pal. (kpg 5 Ulu of 35 Ilir = Kedukan Bukit).

Kelénténg: kampung Kelénténg, B 73, C 22, 31, 33, wijk v. Pal. (kpg 7 Ulu).

Keling, D 41, Klingalezen, Indiërs afkomstig v.d. kust v. Coromandel (Z.O. India); z.o. 1 Masagus Keling, 2 Ngabéhi Keling.

Kemang: (dusun) Kemang, D 56-84, dorp a.d. Musi.

Kemas Abang, B 57.

Kemas Demang Ahmad, zie Kirangga Ahmad.

Kemas Haji Ahmad, C 11.

Kemas Kecik, D 84.

Kemas Kusin, B 57.

Kemas Muhammad (Hanafi), B 39, 42, $=$ Pangéran Kramadiraja, B 43-44, $54,66, \mathrm{C} 11,17, \mathrm{D} 86, \mathrm{E} 73 \mathrm{~b}, 147 \mathrm{~b}$, $238 \mathrm{~b}$, broer v. één v.d. vrouwen v. Sultan Mahmud Badaruddin (2), na zijn huwelijk met een dochter van Sultan Mahmud Badaruddin (2) bij een bijvrouw Pang. Kramadiraja genaamd.

Kemas Rakria, D 81, volgeling v.d. pangérans Natawikrama en Sutawikrama.

Kemas Rangga Hasan, C 36.

Kemas Said (bin Kemas Haji Ahmad), B 55, C 11, E 41 a.

Kemas Temenggung Kertanegara, C 36, $=$ Kemas Temenggung Kerta, D 86, 87, = Temenggung Kertanegara, B 43. Kemas Usman, C 43. 
Kembara, zie Pulau Kembara.

Kerambang, C 27, Rambang, C 27, naam v.e. Ned. oorlogsschip (= Nassau?).

Kerinci: bangsa Kerinci, D 67; Melayu Kerinci, z.a.

Kerta(negara), zie Kemas Temenggung Kertanegara.

Kertapati, B 76, G 37, dorp i.d. omgeving v. Pal.

Keruh, zie Sungai Keruh.

Khaf, zie Misti Khaf.

Khatib Jabaruddin, zie Haji Jabaruddin.

Khatib Muhammad Saléh, E 111a.

Kiai Rangga Wirasentika, zie Demang Wirasentika.

Kidemang Saléh, B 28, 29, = Demang Saléh, D 43, mogelijk zoon v. Masagus Zainuddin en dan een rechtstreekse afstammeling i.d. 5e graad v. Suh. Abdurrahman.

Kijing, zie Radén Kijing.

Kikim: pucukan Kikim, D 53, het stroomgebied v.d. Kikim, een zijrivier v.d. Musi; perwatin Kikim, D 93.

Kirangga Ahmad, C 36, = Rangga Ahmad, B 43, = Kemas Demang Ahmad, D 86.

Kirangga Jalil, C 36.

Kirangga Tamin, C 36, 38, 40.

Kirangga Usman, C 33.

Kirangga Wirasentika, zie Demang Wirasentika.

Koci, E 246c, mensen v. Cochin-China (Zuid-Vietnam) afkomstig.

Kodak, zie Si Kodak.

Komering, C 41; Batangari Komering, B 59 ; orang Komering, E $93 \mathrm{a}$; pangéran(-pangéran) Komering, D 49, 74, 76, 77.

Kompeni (Holanda/Olanda/Wilanda), A 28, B 5-28, 45, 64, 71, 73, 75, 79, C $4,23,30,31,33-36, \mathrm{D} 91, \mathrm{E} 6 \mathrm{~b}$, 32d, 33a, 185d, 200c, de V.O.C. als vertegenwoordiger v.h. Ned. gezag.

Kornél Bakar, E 2d, 64c, 80a, 88a, 97a, $111 \mathrm{~d}, 136 \mathrm{c}, 169 \mathrm{c}, 222 \mathrm{c}$, kapitein-luitenant-ter-zee (bij de expeditie v. 1821: kapitein-ter-zee) T. Bakker.

Kramadilaga, zie Pangéran Kramadilaga.

Kramadiraja, zie Kemas Muhammad (Hanafi).

Kramajaya, zie Pangéran Kramajaya.

Kramanandita, zie Radén Ajid.
Kramayuda, zie Pangéran Kramayuda.

Kumbang, zie Rangga Kumbang.

Kundur, zie Sungai Kundur.

Kurungan Nyawa: dusun Kurungan Nyawa, B 59, dorp in Komering Ulu. Kusin, zie Kemas Kusin.

$K u t$, zie Méjer Kut.

Kutub al-sulwan, zie Syékh Kutub alsulwan.

Lampung, B 59.

Lanang, zie Haji Lanang.

Lawang Buratan, B 46, 48-49, C 6, = Buratan, B 47, 49-50, D 88, een plek i.d. nabijheid v.d. kraton v. Pal.

Léhér, zie Misti Léhér.

Lemabang, B 2-3, C 2, D 67, 86, wijk v. Pal. (kpg 3 Ilir), waar de sultans Mahmud Badaruddin (1) en Muhammad Baha'uddin begraven zijn; z.o. Kawah Terkurap.

Lematang, B 77, C 41.

Limbun: dusun Limbun, B 77, C 41, dorp bij Muara Énim.

Lingga, B 62, 66, E 207c, 249c.

Lingkis, G 7, zijrivier v.d. Komering, ten Z. v. Pal.

Luncuk, zie Si Luncuk.

Madi Alit, zie Pangéran Madi Alit.

Maharaja Boma, E 23c, 180c, tegenstander v. Kresna en Arjuna in wayangverhalen (Hik. Sang Boma).

Maharaja Denta, E $171 \mathrm{~b}$, de koning v. Ampil Denta, Sunan Makhdum, één v.d. negen heiligen (wali) uit de Jav.moslimse overlevering.

Maharaja Inggelan, D 48, de Koning van Engeland.

Maharaja Salya, E 70b, koning v. Mandraka, "schoonvader" v.d. zonnegod Karna; figuur uit wayangverhalen.

Maharaja Willem Een, zie Seri Maharaja Willem Een.

Mahidin, zie Temenggung Mahidin.

Mahmud Badaruddin, zie 1 Pangéran Jayawikrama, 2 Pangéran Ratu (4).

Mahpi, zie Radén Mahpi.

Makasa, D 41, Makasar.

Malang Semirang, E 242c.

Malik al-Jabbar, zie Tuhan Malik alJabbar.

Malik al-Rahman, zie Tuhan Malik alRahman. 
Manguntama, zie Pulau Manguntama.

Mansur, zie 1 Sultan Muhammad Mansur, 2 Raja Mansur.

Marta, zie Pangéran Marta.

Martakesuma, zie Radén Said.

Martapura, B 58, 66, 71, C 17, 19, 25, 26, 29, E 183a, 236b, fort bij Pal., D 93, dorp in Komering Ulu.

Masagus Abduljamil, B 79, C 42, = Masagus Jamil, C 43, mogelijk zoon v. Masayu Hamidah en dan een rechtstreekse afstammeling i.d. 4e graad v. Sultan Muhammad Mansur.

Masagus Caguk, B 76.

Masagus Dengkak, C 41, = Pangéran Jayadilaga, B 77-78, C 41, 43.

Masagus Jamil, zie Masagus Abduljamil.

Masagus Keling, C 32, = Pangéran Temenggung Mentaun, C 32, voluit: Pang. Temenggung $\mathrm{Me}(\mathrm{n})$ taun $\mathrm{Bu}-$ tong, zoon v. Masayu Hatijah; rechtstreekse afstammeling i.d. 5e graad v. Suh. Abdurrahman.

Masagus Putang, C 33, = Pangéran Citra Putang, B 75, = Pangéran C $i$ tra, C 33, = Pangéran Putang, C 39.

Masapati, zie Ratu Masapati.

Maskalek, zie Jénderal Maskalek.

Mas $\subset$ ud, zie Haji Mascud.

Mas Utih, D 66.

Mausub, D 67.

Medang Suka, zie Pangéran Medang Suka.

Méjer Kut: Tuan Méjer Kut, E 249b, Major M. H. Court, Resident v. Palembang en Banka (1813).

Méjer Mir, zie Méjir Mir.

Méjer Rabsan, zie Méjir Rabsun.

Méjir Mir, B 37-38, Méjer Mir, D 4452, Major R. Meares; zie De Haan, 1935, p. 609.

Méjir Rabsun, B 40-43, = Méjer Rabsan, D 83-87, Major W. Robison; zie De Haan, 1935, pp. 630-632.

Melaka, C 4.

Melayu: tanah Melayu, E 32b, 82b; (orang) Melayu, B 37, 39, 52, 53, C 8, D 41, 53-55, 67, 68, 77-80, 90; panglima Melayu, D 53, 76; raja-raja Melayu, B 62; bermain pedang Melayu, D 83.

Melayu Kerinci: orang Melayu Kerinci, D 79; pencak Melayu Kerinci, D 76.
Melayu Minangkabau, D 73, 76, 89; panglima-panglima Melayu Minangkabau, D 66.

Melayu Padang, B 38.

Melayu ulu Jambi, B 38.

Menado, A 29.

Mengarai, zie Pulau Mengarai.

Menggala, zie Benggala.

Mentaun, zie Masagus Keling.

Ménténg, zie Idelir Ménténg.

Mentok, B 15, 25, 27, 30, 37-39, C 40, E 144d, 248a, 253b, Muntok.

Minangkabau: bangsa Minangkabau, D 67 ; z.o. Melayu Minangkabau.

Mir, zie Méjir Mir.

Mista Saman, B 46-47, C 3, 7, = Kaptén Saman, A 27, Mr./Captain Francis Salmond.

Misti Khaf, D 42-43, Willem Wardenaar, lid v.e. gezantschap v. Raffles naar Pal. (nov. 1811); zie De Haan, 1935, pp. 661-662.

Misti Léhér, D 42-43, Alexander Hare, lid v.e. gezantschap v. Raffles naar Pal. (nov. 1811); zie De Haan, 1935, pp. 562-565.

Misti Pilim, D 42-43, Richard Phillips, leider v.e. gezantschap v. Raffles naar Pal. (nov. 1811); zie Raffles, 1830, p. 110.

Misti Rabpelis, zie Jénderal Raflis.

Misti Raplis, zie Jénderal Raflis.

Muara Belidah, zie Belidah.

Muara Beliti, zie Beliti.

Muara Enim, zie Énim.

Muara Plaju, zie Plaju.

Muara Rawas, zie Rawas.

Muhammad, D 62, zoon v.e. niet bij name genoemde rangga-boodschapper v. Sultan Mahmud Badaruddin (2) in Muara Rawas, ca 1812-1813 (tevens auteur v. D?) ; z.o. 1 Kemas Muhammad (Hanafi), 2 Pangéran Syarif Muhammad, 3 Radén Muhammad.

Muhammad Alamuddin, zie Sultan Muhammad Alamuddin.

Muhammad Baha'uddin, zie Pangéran Ratu (3).

Muhammad Mansur, zie Sultan Muhammad Mansur.

Muhammad Saléh, zie Khatib Muhammad Saléh.

Muksim, zie Radén Muksim. 
Muksin, zie Radén Muksin.

Musi, B 50, D 47, 49, 53, 76, 89; Batang(h)ari Musi, B 36, C 7, D 46, 76; hulu Musi, B 76; orang Musi, D 90; pucukan Musi, D 53.

Najamuddin, zie 1 Pangéran Ratu (2), 2 Pangéran Adimenggala (1), $3 \mathrm{~Pa}$ ngéran Ratu (5), 4 Pangéran Prabu Anom.

Nangka, zie Pulau Nangka.

Narada, zie Déwa Narada.

Nasu: kapal (perang) Nasu, B 70, C 14-15, het oorlogsschip (de hulk) Nassau; z.o. Kerambang.

Nata, zie Pangéran Sumadilaga.

Nataagama, zie Pangéran Nataagama.

Natadiraja, zie Pangéran Natadiraja.

Natadiwangsa, zie Pangéran Natadiwangsa.

Natakesuma, zie Pangéran Natakesuma.

Natakrama, zie Pangéran Sumadilaga.

Natanandita, zie Radén Zakiuddin.

Natawiguna, zie Aluddin.

Natawijana, zie Radén Tokid.

Natawijaya, zie Radén Badaruddin.

Natawikrama, zie Pangéran Sumadilaga.

Nauk, zie Cik Nauk.

Nayu Hanipa, C 33, = Nayu Reksapura, C 33, dochter v. Rd. Sulaiman, rechtstreekse afstammelinge i.d. 4e graad v. Sultan Muhammad Mansur, zuster v. Pang. Puspadiprana Cingot, 2e echtg. v. Rd. Umar.

Nayu Kamariah, C 43, dochter v. Suh. Husin Dia'uddin.

Nayu Purbaya Cik Jaro, C 34, ook genaamd: Dénayu Kramanandita Purbaya Cik Jeru, dochter v. Sultan Mahmud Badaruddin (2), volle zuster v. Sultan Ahmad Najamuddin (3) (gehuwd met Radén Ajid?).

Nay'u Reksapura, zie Nayu Hanipa.

Ngabéhi Ahmad, D 86.

Ngabéhi Darpacita, D 86.

Ngabéhi Keling, D 86.

Ngabéhi Pinding, D 86.

Ngambai Balmi, C 8.

Ngambéhi Carik, G 32, = Temenggung Yudawijana, C 32.

Nyimas Irang, C 43.

Nyimas Taipah, C 24, echtgenote v. Suh. Husin Dia'uddin.
Ogan, B 78, 79, C 41, D 46, 47; muara Ogan, B 54, 56, C 30; orang Ogan, C 43, perwatin Ogan, D 93; ulu Ogan, B 77, 78, C 41, 42; depisi Ogan Ulu, C 42.

Opang: kuala Opang, D 94, de monding v.d. Opang, een zijrivier v.d. Sungsang.

Olanda, zie Holanda.

Padang, zie Melayu Padang.

Paharuddin, zie Pangéran Paharuddin.

Palémbang, A-D passim, E 89c, 92b, 208b, 208d, 248d, 256c; z.o. Seri Palémbang.

Palémbang Lama, B 26, C 1, wijk v. Pal. (kpg 1 Ilir), waar Sultan Agung Kamaruddin is begraven.

Panang Karubelah, C 7, 35, marga in Lematang Ilir.

Panembahan, zie Pangéran Adikesuma.

Pangéran Adikesuma, B 22, = Pangéran Aryakesuma (1), B 22, 23, 32, 45, = Pangéran Arya, B 33, 34, = Pangéran Dipati (Tua), B 45, 49-50, 57, 58, $66,72,73, \mathrm{C} 5,10,14,17,20,24$, 25, 29-32, = Pangéran Bupati Panembahan, B 73, 76, C 32, 33, 35, 37, 39-40, = Pangéran Bupati Panembahan Hamim, C 43, = (Pangéran) Panembahan, B 73, D 95, = Pangéran Bupati (1), E 49c, 182b, 185a, $217 \mathrm{~b}, 234 \mathrm{a}, 236 \mathrm{a}, 244 \mathrm{~b}$, zoon v. Sultan Muhammad Baha'uddin, volle broer v. Sultan Mahmud Badaruddin (2).

Pangéran Adimenggala (1), B 21, = Pangéran Dipati (2), A 26, B 21, 32-36, 43, D 48, 56, = Pangéran Adipati (1), D 44-48, = Sultan Ahmad Najamuddin (2), B 36-37, 41-49, 60, 63, D 48, 49, = Sultan Muda, Sultan (yang di) Palémbang, B, D passim, = Susyuhunan Husin (Dia'uddin), A passim, Sultan Husin Dia'uddin, A 27, Suhunan Husin Dia'uddin, Suhunan Husin, Suhunan Dia'uddin, B $64-65,71-76$, C 2-7, 18, 22-31, 34$36,39,43$, zoon v. Sultan Muhammad Baha'uddin, volle jongere broer $v$. Sultan Mahmud Badaruddin (2).

Pangéran Adimenggala (2), B 41-42, C 21, D 86, 87, 89, = Pangéran Bu- 
pati (2), B 66, C 21, D 82, zoon v. Sultan Mahmud Badaruddin (2), volle broer v. Sultan Ahmad Najamuddin(3).

Pangéran Adipati, zie 1 Pangéran Adimenggala (1), 2 Pangéran Natakesuma.

Pangéran Adiwijaya, B 73, C 32, 35, 40, = Pangéran Perdana Menteri (Adiwijaya), B 73-74, C 32, 35, schoonzoon v. Suh. Husin Dia'uddin.

Pangéran Anum, E 160d, = Pangéran Prabu Anom?

Pangéran Arya, zie Pangéran Adikesuma.

Pangéran Aryakesuma, zie 1 Pangéran Adikesuma, 2 Pangéran Natakesuma, 3 Pangéran Jayakrama.

Pangéran Bajau, B 78, G 42, hoofd v.d. Pasemahers, door Sultan Ahmad $\mathrm{Na}$ jamuddin Prabu Anom gedood.

Pangéran Bupati, zie 1 Pangéran Adikesuma, 2 Pangéran Adimenggala (2).

Pangéran Bupati Panembahan (Hamim), zie Pangéran Adikesuma.

Pangéran Cingot, zie Radén Cingot.

Pangéran Citra, zie 1 Masagus Putang, 2 Pangéran Citradiningrat.

Pangéran Citradiningrat, B 45, = $P a$ ngéran Citra, B 55, D 93, = Pangéran Citra Saléh, C 11, zoon v. Suh. Husin Dia'uddin, volle broer v. Sultan Ahmad Najamuddin Prabu Anom.

Pangéran Citrakesuma, D 47, 50-51, 5461, 71-73, 76-77, 81, 82, = Rd. Citrakesuma Kelit, zoon v. Pang. Wirakesuma, rechtstreekse afstammeling $i$. d. 4e graad v. Suh. Abdurrahman?

Pangéran Citra Putang, zie Masagus Putang.

Pangéran Citra Saléh, zie Pangéran Citradiningrat.

Pangéran Citrawijaya, E 103c, 132a.

Pangéran Dipati, zie 1 Pangéran Dipati (1), 2 Pangéran Adikesuma, 3 Pangéran Adimenggala (1), 4 Pangéran Jayaningrat, 5 Pangéran Natakesuma.

Pangéran Dipati (1), B 3-4, zoon v. Sultan Anom.

Pangéran Dipati Abdurrahman, zie $\mathrm{Pa}$ ngéran Natakesuma.

Pangéran Dipati Muda, zie Pangéran Natakesuma.

Pangéran Dipati Tua, zie Pangéran Adikesuma.
Pangéran Dita, D 56, zoon v. Sultan Ahmad Najamuddin (1), halfbroer v. Sultan Muhammad Baha'uddin, oom v. Sultan Mahmud Badaruddin (2).

Pangéran Haji Kramanandita, zie Radén Ajid.

Pangéran Jayadilaga, zie Masagus Dengkak.

Pangéran Jayadiraja (Cingot), zie Radén Cingot.

Pangéran Jayakrama, B 45, 60, 73, C 18, 32, = Pangéran Aryakesuma (3), B 73, C 32, 43, zoon v. Suh. Husin Dia'uddin, volle broer v. Sultan Ahmad Najamuddin Prabu Anom.

Pangéran Jayaningrat, B 45, 60, 64, 73, C 6, 18, 19, 32, = Pangéran Dipati (Jayaningrat), B 73-76, C 32-35, 37, 41,43 , zoon v. Suh. Husin Dia'uddin, volle broer v. Sultan Ahmad Najamuddin Prabu Anom.

Pangéran Jayawikrama, B 3-19, = Pangéran Jaya, B 4, 9, = Sultan Mahmud Badaruddin (1), B 2, 3, 14-17, 19, C 2, = Sultan Lemabang, B 2, = Marhum yang di Lemabang, D 67 , = Marhum Seri Sultan, D 86, zoon v. Sultan Muhammad Mansur, volle broer v. Sultan Anom, neef en troonopvolger v. Sultan Agung Kamaruddin.

Pangéran Komering, zie Komering.

Pangéran Kramadilaga, B 66, E 239b, $=$ Pang. Suradilaga, commandant v. h. fort op Pulau Kembara?

Pangéran Kramadiraja, zie Kemas Muhammad (Hanafi).

Pangéran Kramajaya, B 55, 66, 74, C 11, $16,25,29,30,34,35,41, \mathrm{E} 76 \mathrm{~b}$, = Pangéran Perdana Menteri (Kramajaya), B 74, C 30, 36-39, zoon v. Pang. Natadiraja (Muhammad Hanafi), rechtstreekse afstammeling i.d. 5e graad v. Sultan Muhammad Mansur, schoonzoon v. Sultan Mahmud Badaruddin (2).

Pangéran Kramanandita, zie Radén Ajid.

Pangéran Kramayuda, E 69a, = Pang. Kramayuda Muksin, kleinzoon i.d. vrouwelijke lijn v. Sultan Mahmud Badaruddin (1)?

Pangéran Madi Alit, C 1, zoon v. Kiai Geding Sura Muda of Kiai Geding Ilir, broer v. Emas Dipati, Pang. Me- 
dang Suka en Pang.Siding Pura; vorst v. Pal. als troonopvolger v. Pang. Medang Suka, 1e helft 17e eeuw; begraven in kpg 20 Ilir, Talang Jawa, Pal.

Pangéran Marta, D 44, 45, afgezant v. Sultan Mahmud Badaruddin (2) naar Gen. Gillespie (= Pang. Martakesuma?).

Pangéran Martakesuma, zie Radén Said. Pangéran Medang Suka, C 1, ook bekend als Pang. Madang Suka of (wschl. juister) Pang. Madi Angsoka, zoon v. Kiai Geding Sura Muda of Kiai Geding Ilir, broer v. Emas Dipati, Pang. Madi Alit en Pang. Siding Pura; vorst v. Pal. als troonopvolger v. Emas $\mathrm{Di}$ pati, eind $16 \mathrm{e} /$ begin $17 \mathrm{e}$ eeuw; begraven in Candi Angsoka, kpg $20 \mathrm{Ilir}$, Talang Jawa, Pal.

Pangéran Muhammad, zie Pangéran Syarif Muhammad.

Pangéran Nata, zie Pangéran Sumadilaga.

Pangéran Nataagama, E 48c, 58b, = Pangéran Penghulu Agama, C 36, voluit: Pang. Penghulu Nataagama Muhammad Akib, zoon v. Pang. Penghulu Nataagama Akil, rechtstreekse afstammeling i.d. 4e graad v. Sultan Muhammad Mansur.

Pangéran Natadiraja, C 29, 34, 38, ook: Pang. Natadiraja (Muhammad Hanafi), zoon v. Pang. Wiramenggala Muhammad Kasim, vader v. Pang. Kramajaya (Perdana Menteri) en Pang. (Haji) Kramanandita Abdulaziz, rechtstreekse afstammeling i.d. $4 e$ graad v. Sultan Muhammad Mansur.

Pangéran Natadiwangsa, B 43, E 188a.

Pangéran Natakesuma, B 22, = Pangéran Suryakesuma, B 22, 45, D 86, 87, = Pangéran Surya, B 32-34, D 87, = Pangéran Aryakesuma (2), B 45, 50, = Pangéran Dipati (Muda), B 50, $53,58,66,76-77$, C 10,17 , E 211d, 237a, = Pangéran Adipati (2), D 89, 90, = Pangéran Dipati Abdurrahman, C 34, 37, 39-41, zoon v. Sultan Muhammad Baha'uddin, volle broer $v$. Sultan Mahmud Badaruddin (2).

Pangéran Natakrama, zie Pangéran Sumadilaga.

Pangéran Natanandita, zie Radén Zaki- uddin.

Pangéran Natawiguna, zie Aluddin.

Pangéran Natawijana, zie Radén Tokid.

Pangéran Natawijaya, zie Radén Badaruddin.

Pangéran Natawikrama, zie Pangéran Sumadilaga.

Pangéran Paharuddin, C 4, voluit: Pang. Penghulu Natakesuma Paharuddin, zoon v. Sultan Muhammad Baha'uddin, halfbroer v. Sultan Mahmud Badaruddin (2) en Suh. Husin Dia'uddin.

Pangéran Panembahan, zie Pangéran Adikesuma.

Pangéran Penghulu Agama, zie Pangéran Nataagama.

Pangéran Perdana Menteri, zie 1 Pangéran Adiwijaya, 2 Pangéran Kramajaya.

Pangéran Prabu, zie Pangéran Prabukesuma.

Pangéran Prabu Anom, B 45, 64, = Prabu Anom, A 27, C 31-33, = Sultan Prabu Anom, B 64, = Sultan Ahmad Najamuddin (bin Susyuhunan Husin Dia'uddin), A 27-29, B 64-65, 72, 74, 79, C 32, 40, = Sultan Ahmad Najamuddin Prabu Anom, C 36, oudste zoon v. Suh. Husin Dia'uddin, in sommige genealogieën nader aangeduid als "Sultan (yang) ngamuk".

Pangéran Prabukesuma, C 30, E 23a, = Pangéran Prabu, D 82, E 24a, zoon v. Sultan Mahmud Badaruddin (2), volle broer v. Sultan Ahmad Najamuddin (3).

Pangéran Prabumenggala, zie Pangéran Umar.

Pangéran Purba(negara), zie Pangéran Wirakrama (1).

Pangéran Puspa Cingot, zie Radén Cingot.

Pangéran Puspadilaga, E 220a.

Pangéran Puspadiprana (Cingot), zie Radén Cingot.

Pangéran Puspadiraja, E 115a, 150a, 227d, 238c, voluit: Pang. Puspadiraja Talabuddin, zoon v. Pang. Wiramenggala Muhammad Kasim, rechtstreekse afstammeling i.d. 4e graad v. Sultan Muhammad Mansur, broer v. Pang. Natadiraja.

Pangéran Puspakrama, E 157a, zoon v. 
Dénayu Marta, kleinzoon v. Sultan Muhammad Baha'uddin.

Pangéran Puspawijaya, E 112a.

Pangéran Putera, zie Pangéran Puterakrama.

Pangéran Puteradinata Ali, C 34, zoon v. Sultan Mahmud Badaruddin (2), haflbroer v. Sultan Ahmad Najamuddin (3), volle broer v. Pang. Sutadiraja Bakar, Pang. Sutawijaya Usman en Pang. Sutakrama Akil.

Pangéran Puterakrama, D 86, = Pangéran Putera, D 87, 89.

Pangéran Ratu (1), B 14-15, oudste zoon v. Sultan Mahmud Badaruddin (1), volle broer v. Pang. Ratu (2), de latere Suh. Ahmad Najamuddin; op instigatie v. Sultan Anom door zijn eigen (Balinese) slaven vermoord; i.d. genealogieën bekend als: Rd. Belani alias Pang. Ratu Kamuk (yang wafat diamuk Bali).

Pangéran Ratu (2), B 15, 16, = Sultan Ahmad Najamuddin (1), B 16-17, = Su(hu)nan Ahmad Najamuddin, B 17, C 2, zoon en troonopvolger v. Sultan Mahmud Badaruddin (1), volle broer v. Pang. Ratu (1).

Pangéran Ratu (3), B 16, 17, = Sultan Muhammad Baha'uddin, A 26, 28, B 17-21, C 2, oudste zoon en troonopvolger v. Pang. Ratu (2), de latere Suh. Ahmad Najamuddin.

Pangéran Ratu (4), B 18, 21, = Susyuhunan (Mahmud) Badaruddin, A passim, = Sultan Mahmud (Badaruddin) (2), B 21-22, 31-38, 41-53, D 42-49, 53-57, 76-89, = Suhunan Mahmud Badaruddin, B 62, 72, 73, C 2-9, 22, 25-26, 29-31, 34, D 89, = Sultan Tua, Sultan Ulu, B, D passim, = (Seri Paduka/Duli) Yang Mahamulia, D passim, = Ratu Agung, D 66 , = Séh Alam, D 68, = Syéh Alam, E 57a, = Syah Alam, E 233a; oudste zoon en troonopvolger v. Sultan Muhammad Baha'uddin, volle oudere broer v. Suh. Husin Dia'uddin.

Pangéran Ratu (5), A 27, B 21, 22, 41 $44,53-54,58,62$, C $5,9-10,12,15$, 17, 19-20, D 84, 86, 87, 90, = Sultan Ahmad Najamuddin (3), A 27-29, B 62, C $21,25,27,31$, = Sultan
Ahmad, A 27, = Sultan Ahmad Najamuddin bin Seri Suhunan Mahmud Badaruddin, C 20, oudste zoon v. Sultan Mahmud Badaruddin (2).

Pangéran Ratu Jambi, B 63, 66, 71, C 19, 28, D 93 ; z.o. Pulau Pangéran Ratu Jambi.

Pangéran Semangus, zie Semangus.

Pangéran Siding Kenayan, C 1, zoon v. Emas Dipati, neef en troonopvolger v. Pang. Siding Pura, gehuwd met de in hoog aanzien staande "wetgeefster" v. Pal., Ratu Sinuhun, die begraven is in kpg 2 Ilir, Sabukingking, Pal.; vorst v. Pal., 1e helft $17 \mathrm{e}$ eeuw.

Pangéran Siding Pesarian, G 1, zoon v. Temenggung Mancanegara en Nyai Geding Pembayun (oudste dochter v. Kiai Geding Sura Muda of Kiai Geding Ilir), neef en troonopvolger v. Pang. Siding Kenayan, broer v. Ratu Sinuhun; vorst v. Pal., midden $17 \mathrm{e}$ eeuw; krijgt van de Sultan v. Surakarta de titel "Sultan Jamaluddin"; begraven in kpg 2 Ilir, Sabukingking, Pal.

Pangéran Siding Pura, G 1, zoon v. Kiai Geding Sura Muda of Kiai Geding Ilir, broer v. Emas Dipati, Pang. Medang Suka en Pang. Madi Alit; vorst v. Pal., troonopvolger v. Pang. Madi Alit, le helft $17 \mathrm{e}$ eeuw; begraven in kpg 1 Ilir, Palémbang Lama.

Pangéran Siding Rajak, C 1, zoon en troonopvolger v. Pang. Siding Pesarian, broer v. Suh. Abdurrahman; vorst v. Pal., midden $17 \mathrm{e}$ eeuw; begraven te Saka Tiga (Ogan Ilir).

Pangéran Sumadilaga, C 32, = Pangéran Natakrama, C 32, = Pangéran Natawikrama, D 81, 86, = Pangéran Nata, D 87, zoon v. Sultan Muhammad Baha'uddin, halfbroer v. Sultan Mahmud Badaruddin (2) en Suh. Husin Dia'uddin.

Pangéran Sumanegara, D 50, 54-56, 59, 61-62, 71-74, 76, 81, 82.

Pangéran Sumawijaya, E 166a.

Pangéran Suradilaga, B 58, C 17, 27, D 93, E 175a, volgens $D$ een broer v. Sultan Mahmud Badaruddin (2); volgens de genealogieën de zoon v.e. halfbroer v. Sultan Muhammad Baha'- 
uddin (Pang. Surawijaya) en dus een neef v. Sultan Mahmud Badaruddin (2) ; z.o. Pangéran Kramadilaga.

Pangéran Surya(kesuma), zie Pangéran Natakesuma.

Pangéran Sutadiraja Bakar, C 34, voluit: Pang. Sutadiraja Abubakar, zoon v. Sultan Mahmud Badaruddin (2), halfbroer v. Sultan Ahmad Najamuddin (3), volle broer v. Pang. Sutawijaya Usman, Pang. Sutakrama Akil en Pang. Puteradinata Ali.

Pangéran Sutadiwangsa, B 43, D 86, E 164a, = Pangéran Wangsa, D 87.

Pangéran Sutakesuma, E 177c, zoon v. Pang. Purbaya, kleinzoon v. Suh. Ahmad Najamuddin en volle neef $v$. Sultan Mahmud Badaruddin (2).

Pangéran Sutakrama, zie Radén Muksin.

Pangéran Sutakrama Akil, C 34, zoon v. Sultan Mahmud Badaruddin (2), halfbroer v. Sultan Ahmad Najamuddin (3), volle broer v. Pang. Sutadiraja Bakar, Pang. Sutawijaya Usman en Pang. Puteradinata Ali.

Pangéran Sutanandita, zie Radén Mahpi. Pangéran Sutawijaya Usman, C 34, zoon v. Sultan Mahmud Badaruddin (2), halfbroer v. Sultan Ahmad Najamuddin (3), volle broer v. Pang. Sutadiraja Bakar, Pang. Sutakrama Akil en Pang. Puteradinata Ali.

Pangéran Sutawikrama, D 81, voluit: Pang. Suta(wi) krama Yasin, zoon v. Pang. Dipakesuma, kleinzoon v. Suh. Ahmad Najamuddin, volle neef $v$. Sultan Mahmud Badaruddin (2).

Pangéran Syarif Muhammad, B 29-31, 53, 58, C 7, 9, = Pangéran Muhammad, B 31, D 91, E 1b, 95b, 112d, zoon v.e. Arabische vader en v.e. Pal. moeder, handlanger v.d. Engelsen.

Pangéran Umar, C 7, = Pangéran Prabumenggala, C 7, zoon v. Sultan Mahmud Badaruddin (2), halfbroer v. Sultan Ahmad Najamuddin (3).

Pangéran Wangsa, zie Pangéran Sutadiwangsa.

Pangéran Wiradinata, B 38, D 50, 52, patih v. Sultan Mahmud Badaruddin (2), commandant v.h. fort Buaya Langu.

Pangéran Wiradiraja, B 41, 45, mogelijk
$=$ Pang. Wiradiraja Yahya, zoon v. Pang. Jayakesuma, een kleinzoon van Sultan Muhammad Mansur.

Pangéran Wiradiwangsa, B 59, D 71, E 114a, boodschapper in dienst $v$. Sultan Mahmud Badaruddin (2) tijdens diens "ballingschap" i.h. binnenland, later commandant v.h. fort Kurungan Nyawa.

Pangéran Wirajaya Gubir, zie Pangéran Wirakrama (3).

Pangéran Wirakesuma, E $180 \mathrm{~b}$, vader v. Pang. Wirasentika; $=$ Pang. Wirakesuma Usman, zoon v. Pang. Wirakesuma, rechtstreekse afstammeling i.d. 4e graad v. Sultan Muhammad Mansur.

Pangéran Wirakrama (1), G 32, = Pangéran Purbanegara, C 32, 34, = Pangéran Purba, C 34, zoon v. Rd. Gedé (ook Panembahan of Muhammad Zainuddin genoemd), neef v. Sultan Muhammad Baha'uddin.

Pangéran Wirakrama (2), C 40, 43, zoon v. Suh. Husin Dia'uddin, broer v. Pang. Adiwijaya; overleden te Batavia. Pangéran Wirakrama (3), B 60, E 228b, = Pangéran Wirakrama Gubir, G 18, = Pangéran Wirajaya Gubir, C 19, patih v. Suh. Husin Dia'uddin.

Pangéran Wirakrama Gubir, zie Pangéran Wirakrama (3).

Pangéran Wirasentika, B 59, 63, 66, 70, C 17, 27, 28, 34, 35, D 93, E 113a, 180 a, zoon v. Pang. Wirakesuma, commandant v.h. fort Pulau Manguntama; overleden te Batavia.

Panglima Batuapi, C 38.

Parkenan, B 53, J. J. V. Valckenaer, tot 1819 douaneambtenaar-kommies bij het bestuurskantoor te Pal., later "kommies en adjunct-ontvanger der inkomende en uitgaande regten" te Muntok en van 1823 tot zijn overlijden in 1825 secretaris v.d. resident van Banka te Muntok; zie Regeringsalmanak 1817-1825.

Pasemah: orang Pasemah, B 77, 78, G 42; racyat Pasemah, B 78; kepala Pasemah, B 78.

Pegagan: désa Pegagan, C 7 ; orang Pegagan, D 79; pencuri Pegagan, D 79; perwatin Pegagan, D 93; Pegagan Ilir, 
C 35 .

Pegayut, C 42, dusun Pegayut, C 41, 42, dorp a.d. Ogan, ten Z. v. Pal.

Pemulutan, C 35, dorp a.d. Ogan, ten Z. v. Pegayut.

Penghulu Agama, zie Pangéran Nataagama.

Penukal, C 7, 35, marga in Musi Ilir.

Perancis, E 24d, 25d, 27b, 28a, 30d, 81a, 107 c, Fransman, Fransen.

Perdana Menteri, zie 1 Pangéran Adiwijaya, 2 Pangéran Kramajaya.

Perwatin Lima (Belidah), C 7, 35.

Pilim, zie Misti Pilim.

Pinang, zie Pulau Pinang.

Pinding, zie Ngabéhi Pinding.

Plaju: Batangari Plaju, B 67, 68,Sungai Plaju, C 25, zijrivier v.d. Musi bij Pal.; muara/Muara Plaju, A 28, B 58, 59, 66, 71, C 16, 21, 24, 25, D 93.

Prabu, zie Pangéran Prabukesuma.

Prabu Anom, zie Pangéran Prabu Anom.

Prabukesuma, zie Pangéran Prabukesuma.

Prabumenggala, zie Pangéran Umar.

Pulau Anyar, B 26, eilandje i.d. Musi tegenover Borang.

Pulau Batu, E 179b.

Pulau Bayak, E 224a.

Pulau Borang, zie Borang.

Pulau Kembara, A 28, B 58, 59, 66, 69-71, C 17, 21, 27-28, D 93, E 163b, 170d, 239a, eilandje i.d. Musi bij Pal.

Pulau Manguntama, B 59, 63, 66, 69, 70, C 17, E 180d, = Manguntama, C 26, 27, kunstmatig eilandje i.d. Musi bij Pal., dat dienst doet als fort (in Ned. bronnen aangeduid als waterbatterij).

Pulau Mengarai, B 72.

Pulau Nangka, D 43, eiland(engroep) in Straat Banka.

Pulau Pangéran Ratu Jambi, B 63, 66, kunstmatig eilandje i.d. Musi bij Pal., dat dienst doet als fort (in Ned. bronnen aangeduid als waterbatterij).

Pulaupanggung: dusun Pulaupanggung, B 36, dorp a.d. bovenloop v.d. Musi (Musi Ulu).

Pulau Pinang, B 22-24.

Pulau Underus, B 7, het eiland Onrust voor de rede v. Batavia.

Purba(negara), zie Pangéran Wirakrama (1).

Purbaya Cik Jaro, zie Nayu Purbaya Cik
Jaro.

Puspa Cingot, zie Radén Cingot.

Puspadilaga, zie Pangéran Puspadilaga.

Puspadiprana (Cingot), zie Radén Cingot.

Puspadiraja, zie Pangéran Puspadiraja. Puspakrama, zie Pangéran Puspakrama. Puspawijaya, zie Pangéran Puspawijaya. Putang, zie Masagus Putang.

Putera, zie Pangéran Puterakrama.

Puteradinata Ali, zie Pangéran Puteradinata Ali.

Puterakrama, zie Pangéran Puterakrama.

Rabb al-akwan, E 191a, de Heer van al 't zijnde, God.

Rabb al-izzati, E 173c, 204c, de Heer der Heerlijkheid, de Heer der Ere, God.

Rabpelis, zie Jénderal Raflis.

Rabsan, zie Méjir Rabsun.

Rabsun, zie Méjir Rabsun.

Radén Ajid, C 32, = Pangéran (Haji) Kramanandita, C 29, 32, 38, voluit: Pang. Haji Kramanandita Abdulaziz, zoon v. Pang. Natadiraja (Muhammad Hanafi), rechtstreekse afstammeling i.d. 5e graad v. Sultan Muhammad Mansur; broer v. Pang. Kramajaya (Perdana Menteri).

Radén Aluddin, G 32, = Pangéran Natawiguna, C 32, zoon v. Sultan Muhammad Baha'uddin, halfbroer v. Sultan Mahmud Badaruddin (2) en Suh. Husin Dia'uddin.

Radén Arif, B 46, 47, een prins v. Benkoelen.

Radén Badaruddin, G 32, = Pangéran Natawijaya, C 32, zoon v. Sultan Muhammad Baha'uddin, halfbroer $\mathbf{v}$. Sultan Mahmud Badaruddin (2) en Suh. Husin Dia'uddin.

Radén Bakar, C 40, zoon v. Suh. Husin Dia'uddin.

Radén Cingot, C 33, = Pangéran Cingot, B 79 , = Pangéran Puspa (diprana) Cingot, C 36, 41, = Pangéran Puspadiprana, B 78, C 33 , = Pangéran Jayadiraja (Cingot), C 41-43, elders ook: Pang. Puspadiprana Céngat, zoon v. Rd. Sulaiman, rechtstreekse afstammeling i.d. 4e graad v. Sultan Muhammad Mansur.

Raden Gubir, B 75, C 39. 
Radén Karim, B 47, een prins v. Benkoelen.

Radén Kijing, G 14, 15.

Radén Mahpi, C 33, = Pangéran Sutanandita, C 33, zoon v. Suh. Husin Dia'uddin.

Radén Muhammad, D 47.

Radén Muksim, D 69-71.

Radén Muksin, C 33, = Pangéran Sutakrama, C 33, zoon v. Suh. Husin Dia'uddin.

Radén Said, C 32, = Pangéran Martakesuma, G 32, zoon v. Suh. Ahmad Najamuddin, halfbroer v. Sultan Muhammad Baha'uddin.

Radén Sanusi, C 43, ook Rd. Hasan Nusi, zoon v. Suh. Husin Dia'uddin.

Radén Tokid, C 32, = Pangéran Natawijana, C 32, zoon v. Sultan Muhammad Baha'uddin, halfbroer v. Sultan Mahmud Badaruddin (2) en Suh. Husin Dia'uddin.

Radén Utama, C 41.

Radén Zakiuddin, C 32, = Pangéran Natanandita, C 32, zoon v. Sultan Muhammad Baha'uddin, halfbroer v. Sultan Mahmud Badaruddin (2) en Suh. Husin Dia'uddin.

Raflis, zie Jénderal Raflis.

Raja Akil, B 48, 57, C 7, 14, E 1c, 28c, 31c, 81c, 209a, 212c, prins v. Siak, helper v.d. Engelsen en later v.d. Hollanders.

Raja Bangsawan, B 46, 47, een prins v. Benkoelen.

Raja Benggala, zie Jénderal Menggala. Raja Mansur, E 82a.

Raja Menggala, zie Jénderal Menggala.

Rajuna, zie Sang Rajuna.

Rakria, zie Kemas Rakria.

Rambang, zie Kerambang.

Rangga Ahmad, zie Kirangga Ahmad.

Rangga Darpacita, E 126a, 171a, = Ngabéhi Darpacita?

Rangga Hasan, zie Kemas Rangga Hasan.

Rangga Kumbang, D 84.

Rangga Satyagati, E 38c, 173a, een hofbeambte v. Balinese afkomst; vgl. UBL 5, p. 21 onderaan: "pinakawan dalam, nama Si Bali".

Rangga Wirasentika, zie Demang Wirasentika.

Rantau Menitang, C 8.
Raplis, zie Jénderal Raflis.

Ratu, zie 1 Pangéran Ratu (1), $2 \mathrm{Pa-}$ ngéran Ratu (2), 3 Pangéran Ratu (3), 4 Pangéran Ratu (4), 5 Pangéran Ratu (5), 6 Pangéran Ratu Jambi.

Ratu Agung, zie Pangéran Ratu (4).

Ratu Jambi, zie Pangéran Ratu Jambi.

Ratu Masapati, E 30c, = Jav. Maswapati of Mangsapati, vorst v. Wirata, schoonvader v. Abimanyu; vgl. GerickeRoorda, 1901, II, p. 501.

Ratu Saripah, zie Saripah Zainah.

Rawa-Rawa Sekampung, B 26, G 17, 26.

Rawas, A 26, B 39, C 3, 4, D 57, 76; Batangari Rawas, B 12; dusun Rawas, D 69; hulu Rawas, B 12; Muara Rawas, B 38-53, C 3, 4, 8, D 53-90; orang Rawas, C 8, D 54; pucukan Rawas, D 53.

Rawas Mata, D 53.

Rejang: bangsa Rejang, D 67, de bevolking v.h. grensgebied v. Pal. met Benkoelen.

Reksapura, zie Nayu Reksapura.

Résidént Rinis, A 28, = Resident/Tuan Rinis, B 75, 76, 78, = Resident Ris, C 36, resident J. G. Reijnst, later wnd. G.G. (1844/'45).

Riau, B 62, E 249c.

Rinis, zie Résidént Rinis.

Ris, zie Résidént Rinis.

Ruplis, zie Jénderal Raflis.

Suhperi, zie Déwa Sahperi.

Said, zie 1 Kemas Said, 2 Radén Said.

Said Bakar Rum, B 29-30, = Said Abubakar, zoon v. Rd. Syarif Hasan, volle broer v. Sayyid Abdulrahman?

Said Hamzah, D 89, 90; z.o. Hamzah.

Said Zain Bafakih, B 27.

Saka Tiga, C 1, dorp a.d. Ogan, waar Pang. Siding Rajak begraven is.

Salahnama, E 205d, eiland i.d. Musi, benedenstrooms v. Pal.

Saléh, zie 1 Khatib Muhammad Saléh, 2 Kidemang Saléh.

Salya, zie Maharaja Salya.

Saman, zie Mista Saman.

Sambas, B 62.

Sang Rajuna, E 159b, de held Arjuna uit de wayangverhalen (middelste v.d. 
5 Pandawa's, “zoon" v. Indra); vgl. Skinner, 1963, 355a.

Sanusi, zie Radén Sanusi.

Saripah Zainah, C 33, = Ratu Saripah, C 33, dochter v. Syarif Ali, afstammelinge i.d. 5e graad v. Sultan Mahmud Badaruddin (1).

Satyagati, zie Rangga Satyagati.

Sayyid Abdulrahman, E 192a, zoon v. Rd. Syarif Hasan, rechtstreekse afstammeling i.d. 4e graad v. Sultan Mahmud Badaruddin (1).

Sayyid Ahmad bin Ali, E 198a.

Sayyid Akil bin Muhammad, E 197a.

Sayyid al-Basyar, E 247c, de Heer der mensen, de Profeet Muhammad.

Sayyid al-ka'inat, E 75c, de Heer v.h. geschapene, God.

Sayyid Husin, E 195a.

Sayyid Zain, E 97d.

Séh Alam, zie Pangéran Ratu (4).

Sekanak, A 28, C 35, 37, zijriviertje v.d. Musi bij Pal., tevens naam v.e. wijk v. Pal. (kpg 26 Ilir).

Sekaubenah, zie Jénderal Sekaubenah.

Sekayu: dusun Sekayu, D 51, dorp a.d. Musi.

Sékh Abdulrahman Mesri, D 82.

Selat Jaran, E 225b, Straat Jaran i.d. Musi, tevens naam v.h. daarbij gelegen dorp, benedenstrooms v. Pal.

Semangus, C 8, zijrivier v.d. Musi; dusun Semangus, B 52 ; orang Semangus, C 8; Pangéran Semangus, C 8, D 90. Sényur Bilam, zie Tuan Bilam.

Seri Betawi, C 27, naam v.e. kanon.

Seri Maharaja Willem Een, C 18, Koning Willem I.

Seri nan Baginda: pedang Seri nan Baginda, E 69c, naam v.e. zwaard.

Seri nan Sultan: bedil meriam Seri nan Sultan, E 199c, naam v.e. kanon.

Seri Padah, D 91, naam v.e. kanon.

Seri Palémbang, C 17, 19, 28, naam v.h. grootste kanon v. fort Tambakbaya.

Setulur, zie Tuan Setulur.

Si Acu, D 61.

Siak, E 31c; orang/racyat Siak, B 48, 57, E 212b, Siakker(s) ; panglima Siak, E 204d.

Siam: wayang Siam, C 16.

Sianjur, zie Cianjur.

Siding Kenayan, zie Pangéran Siding
Kenayan.

Siding Pesarian, zie Pangéran Siding Pesarian.

Siding Pura, zie Pangéran Siding Pura. Siding Rajak, zie Pangéran Siding Rajak.

Si Gangsa, B 60, C 18, E 226c, 227a.

Si Goyang, B 70, naam v.e. kanon.

Si Kodak, B 61.

Si Luncuk, B 75, C 39.

Singayuda, zie Demang Singayuda.

Sinjur, zie Cianjur.

Suakbata, A 28, B 73-75, C 13, 31-33, 35-40, wijk v. Pal. (kpg 23 Ilir).

Suhunan Abdurrahman, C 1, zoon v. Pang. Siding Pesarian, broer en troonopvolger v. Pang. Siding Rajak; vorst v. Pal., $2 \mathrm{e}$ helft $17 \mathrm{e}$ eeuw; begraven te Candi/Cindé Walang/Belang, kpg 24 Ilir, Pal.; daarom ook bekend als Sunan Candi Walang/Cindé Belang.

Suhunan Ahmad Najamuddin, zie Pangéran Ratu (2).

Suhunan Dia'uddin, zie Pangéran Adimenggala (1).

Suhunan Husin (Dia'uddin), zie Pangéran Adimenggala (1).

Suhunan Mahmud Badaruddin, zie Pangéran Ratu (4).

Sukubanah, zie Jénderal Sekaubenah.

Sultan Agung Kamaruddin, C 1, ook Sultan Kamaruddin Seri Teruna genoemd, zoon v. Suh. Abdurrahman, volle jongere broer en troonopvolger v. Sultan Muhammad Mansur; vorst v. Pal., 1e kwart 18e eeuw; begraven in Palémbang Lama.

Sultan Ahmad, zie Pangéran Ratu (5).

Sultan Ahmad Najamuddin, zie $1 \mathrm{~Pa}-$ ngéran Ratu (2), 2 Pangéran Adimenggala (1), 3 Pangéran Ratu (5), 4 Pangéran Prabu Anom.

Sultan Ahmad Najamuddin bin Seri Suhunan Mahmud Badaruddin, zie Pangéran Ratu (5).

Sultan Ahmad Najamuddin bin Susyuhunan Husin Dia'uddin, zie Pangéran Prabu Anom.

Sultan Ahmad Najamuddin Prabu Anom, zie Pangéran Prabu Anom.

Sultan Anom, zie Sultan Muhammad Alamuddin.

Sultan Husin Dia'uddin, zie Pangéran 
Adimenggala (1).

Sultan Jambi, zie Jambi.

Sultan Lemabang, zie Pangéran Jayawikrama.

Sultan Mahmud, zie Pangéran Ratu (4).

Sultan Mahmud Badaruddin, zie $1 \mathrm{~Pa}$ ngéran Jayawikrama, 2 Pangéran Ratu (4).

Sultan Muda, zie Pangéran Adimenggala (1).

Sultan Muhammad Alamuddin, B 3, = Sultan Anom, B 3-15, ook bekend als Pang. Mangkubumi, zoon v. Sultan Muhammad Mansur, volle broer v. Pang. Jayawikrama / Sultan Mahmud Badaruddin (1); begraven in Kebun Gedé.

Sultan Muhammad Baha'uddin, zie Pangéran Ratu (3).

Sultan Muhammad Mansur, C 1, zoon en troonopvolger v. Suh. Abdurrahman, volle oudere broer v. Sultan Agung Kamaruddin ; vorst v. Pal., begin $18 \mathrm{e}$ eeuw; begraven in Kebun Gedé.

Sultan (yang di) Palémbang, zie Pangéran Adimenggala (1).

Sultan Tua, zie Pangéran Ratu (4).

Sultan Ulu, zie Pangéran Ratu (4).

Sumadilaga, zie Pangéran Sumadilaga.

Sumanegara, zie Pangéran Sumanegara.

Sumawijaya, zie Pangéran Sumawijaya.

Sumbawa, E 243c.

Sumedang, B 50, D 89, plaats op Java, waar het gevolg v. Suh. Husin Dia'uddin wordt ondergebracht.

Sunan Ahmad Najamuddin, zie Pangéran Ratu (2).

Sungai Aur, A 26, 27, B 6, 14, C 4, E 83b, zijriviertje v.d. Musi bij Pal., aan welks uitmonding de Holl. factorij was gevestigd, tevens naam v.e. wijk v. Pal. (kpg 9 Ulu).

Sungai Bayas, C 30, zijriviertje v.d. Musi, tevens naam v.e. wijk v. Pal. (kpg 8 Ilir).

Sungai Keruh, C 7, 35, zijrivier v.d. Semangus.

Sungai Kundur, B 60,65 , C 18, 19, 24, E 201d, zijriviertje v.d. Musi, benedenstrooms v. Pal.

Sungai Plaju, zie Plaju.

Sungai Tengkuruk, B 58, C 17, 35, 38, zijriviertje v.d. Musi, tevens naam v.e. wijk v. Pal. (kpg 16 Ilir).

Sungsang, B 25, 36, 62, 65, C 24, D 43, 93, E 252a; dusun Sungsang, C 18; kuala Sungsang, B 27, 28, 30, C 20, $21,23,24, \mathrm{D} 42-44,95$; orang Sungsang, B 60,65, C 21, 23-24, D 43, E 221a, 241b; jurulés Sungsang, D 43; lurah Sungsang, D 74; piniwayah Sungsang, D 94.

Sura, zie Temenggung Sura.

Suradilaga, zie Pangéran Suradilaga.

Suradiraja, zie Temenggung Suradiraja.

Suranandita, zie Temenggung Suranandita.

Surayuda, zie Demang Surayuda.

Surulangun: dusun Surulangun, D 68, dorp a.d. Rawas, dichtbij de grens met Jambi.

Surya(kesuma), zie Pangéran Natakesuma.

Susyuhunan Badaruddin, zie Pangéran Ratu (4).

Susyuhunan Dia'uddin, zie Pangéran Adimenggala (1).

Susyuhunan Husin, zie Pangéran Adimenggala (1).

Susyuhunan Mahmud Badaruddin, zie Pangéran Ratu (4).

Sutadiraja Bakar, zie Pangéran Sutadiraja Bakar.

Sutadiwangsa, zie Pangéran Sutadiwangsa.

Sutakesuma, zie Pangéran Sutakesuma.

Sutakrama, zie 1 Radén Muksin, $2 \mathrm{~Pa}$ ngéran Sutakrama Akil.

Sutanandita, zie Radén Mahpi.

Sutawijaya Usman, zie Pangéran Sutawijaya Usman.

Sutawikrama, zie Pangéran Sutawikrama.

Syah Alam, zie Pangéran Ratu (4).

Syéh Alam, zie Pangéran Ratu (4).

Syékh Kutub al-sulwan, E 191b, Heer "Spil van de vertroosting"; betr. de betekenis v. kutub i.d. mystiek zie Rinkes, 1909, p. 12.

Taipah, zie Nyimas Taipah.

Tambakbaya, B 58, 60, 66, 67, 70, C 16, $18,19,25-29$, D 93, 94, E 148a, 238a, fort a.d. monding v.d. Plaju bij Pal.

Taméngratu, C 17, fort op het eiland Kembara.

Tamin, zie Kirangga Tamin. 
Tanjung Kalian, B 38, kaap bij Muntok (Banka).

Tanjunglaga: dusun Tanjunglaga, C 43, dorp ten N. v. Pal.

Tanjung Saga: dusun Tanjung Saga, B 34, dorp a.d. Ogan ten Z. v. Pal.

Teloko, C 35, dorp a.d. Komering.

Temenggung Aminuddin, C 42.

Temenggung Astramenggala, B 79.

Temenggung Astrawijaya, E 99a, 172a, ook Rd. Rangga Astrawijaya Abdullah genaamd, zoon v. Pang. Penghulu Abusamah, rechtstreekse afstammeling i.d. 5e graad v. Sultan Muhammad Mansur.

Temenggung Citradita, E 130a.

Temenggung Kerta(negara), zie Kemas Temenggung Kertanegara.

Temenggung Mahidin, C $42,=$ Rd. Mahidin, zoon v. Rd. Cik, rechtstreekse afstamming i.d. 5e graad v. Suh. Abdurrahman?

Temenggung Mentaun, zie Masagus Keling.

Temenggung Sura, C 14.

Temenggung Suradiraja, B 29.

Temenggung Suranandita, B 29.

Temenggung Yudawijana, zie Ngambéhi Carik.

Tempiri: dusun Tempiri, B 34, dorp in Musi Ilir.

Tengkuruk, zie Sungai Tengkuruk.

Teranati, zie Ternati.

Ternati, A 29, C 2, 34, D 41, = Teranati, B 72, 73, Ternate.

Timur: orang Timur, B 11, Timorezen.

Tokid, zie Radén Tokid.

Tuan Bilam, B 28, = Sényur Bilam, E 65c, Willem van de Weeteringe Buijs, zoon v.e. Holl. vader en een Pal. moeder, klerk bij de Holl. factorij te Pal., later (tot 1842) als deurwaarder verbonden a.d. rechtbank aldaar; zie Regeringsalmanak 1825-1842; z.o. Gramberg, 1878.

Tuan Rinis, zie Résidént Rinis.

Tuan Setelur, G 31, 32, W. L. de Sturler, tijdens de expeditie v. 1821 2e luitenant v.h. bataillon pionniers v.d. landmacht, tevens "élève voor de inlandsche talen"; zie Meis, 1841/42, p. 231.

Tuhan Malik al-Jabbar, E 15c, 162c, de Almachtige Koning, God.
Tuhan Malik al-Rahman, E 192c, de Barmhartige Koning, God.

Tuhan Yang Esa, E 176c, 218a, de Enige Heer, God.

Tuhan Yang Kaya, E 7c, 99c, de Almachtige Heer, God.

Ulak Tebru: dusun Ulak Tebru, D 75, dorp a.d. Musi ten Z. v. Kasemaran.

Ulu Mata: bangsa Ulu Mata, D 67.

Umar, zie 1 Demang Umar, 2 Pangéran Umar.

Underus, zie Pulau Underus.

Usman, zie 1 Kemas Usman, $2 \mathrm{Ki}$ rangga Usman, 3 Pangéran Sutawijaya Usman.

Utama, zie Radén Utama.

Wangsa, zie Pangéran Sutadiwangsa.

Wilanda, zie Holanda.

Willem Een, zie Seri Maharaja Willem Een.

Wiradinata, zie Pangéran Wiradinata.

Wiradiraja, zie Pangéran Wiradiraja.

Wiradiwangsa, zie Pangéran Wiradiwangsa.

Wirajaya Gubir, zie Pangéran Wirakrama (3).

Wirakesuma, zie Pangéran Wirakesuma.

Wirakrama, zie 1 Pangéran Wirakrama (1), 2 Pangéran Wirakrama (2), 3 Pangéran Wirakrama (3).

Wirakrama Gubir, zie Pangéran Wirakrama (3).

Wiralaksana, zie Demang Wiralaksana.

Wirasentika, zie 1 Demang Wirasentika, 2 Pangéran Wirasentika.

Wiratenaya, zie Demang Wiratenaya.

Yang: bangsa Yang, B 30, bijzondere stand i.d. autochtone samenleving op Banka.

Yang Mahamulia, zie Pangéran Ratu (4).

Yang Mulia Raya, D 69, de Grote Opperheer, God.

Yudawijana, zie Ngambéhi Carik.

Zain, zie 1 Haji Zain, 2 Sayyid Zain.

Zain Bafakih, zie Said Zain Bafakih.

Zakiuddin, zie Radén Zakiuddin.

Zén, zie Haji Zain. 


\section{BIBLIOGRAFIE}

\section{Opgave van geraadpleegde en geciteerde literatuur}

Aanteekeningen en schetsen over Palembang. (Anoniem versch. in TNI 6 (1884), dln 3 en 4.) Zie: De Kock, 1844a.

Abstract of the genealogy of the rajahs of Pulo Percha (Sumatra). Zie: Malayan Miscellanies II, 1822, 12.

Acte van Vreede, Vriend- en Bondgenootschap.... tusschen $H$. W. Muntinghe .... en Mahometh Badaroedin dd. 20 Juni 1818. Hs KI H 173 (De Graaf, 1963, p. 6).

Adat Atjéh. Zie: Drewes/Voorhoeve, 1958.

Adipati Wira Tanoe Datar, Tjarieta. Zie: Stockhausen, 1863.

Ahmad bin Abdullah Haman Al-kadri, Geschiedenis der eerste AlQadris. Zie: Netscher, 1855.

Al-Attas, 1968

Al-Attas, Syed Muhammad Naguib, The origin of the Malay shacir. Kuala Lumpur 1968. Dewan Bahasa dan Pustaka Kementerian Pelajaran Malaysia. Siri pengetahuan bahasa dan sastera DBP. 16. Mohammad Ali, 1965

Ali, R. Mohammad, Historiographical problems. In: Soedjatmoko, 1965, pp. 1-23.

Al-marhum Raja Ali Al-Haji Riau. Zie: Tuhfat al-Nafis, 1965.

Almanak en naamregister van Nederlandsch-Indië. Zie: Almanak van Nederlandsch-Indië.

Almanak van Nederlandsch-Indië: 1817-1837; Almanak en naamregister van Nederlandsch-Indië: 1838-1864; Regerings-almanak voor Nederlandsch-Indië: 1865-1883; Regeeringsalmanak voor NederlandschIndië: 1884-1942. (Aangehaald als: Regeringsalmanak.)

Amin, Entji', Sja cir perang Mengkasar. Zie: Skinner, 1963.

Annals of Achin. Zie: Malayan Miscellanies I, 1820, 3.

Atja, 1967

$\checkmark$ Sjair perang Palembang. Digarap oleh Atja. Djakarta 1967. Departemen Pendidikan dan Kebudajaan Republik Indonesia, Museum Pusat. Seri sardjana karja. 1.

Babad tanah Djawi, 1941

Babad tanah Djawi in proza. Naar de uitg. van J. J. Meinsma in het Nederl. vert. door W. L. Olthof. 's-Gravenhage 1941.

Balbian Verster, J. F. L. de, De expeditie naar Palembang voor honderd jaar. In: Vierde jaarverslag (1920) van de Vereeniging Nederlandsch Historisch Scheepvaart Museum te Amsterdam, pp. 61-75. 
Bastin, J. S., Palembang in 1811 and 1812. In: BKI 109 (1953), pp. 300-320, en 110 (1954), pp. 64-88.

Bastin, J. S., Raffles and British policy in the Indian Archipelago, 18111816. In: JMBRAS, 27 (1954), Pt 1, pp. 84-119.

Bastin, J. S., The native policies of Sir Stamford Raffles in Java and Sumatra. An economic interpretation. Oxford 1957.

Bastin, J. S., Essays on Indonesian and Malayan history. Singapore 1961. Monographs on Southeast-Asian subjects. 2.

Bastin, J. S. Zie ook: Malayan and Indonesian studies, 1964.

Bataviasche Courant, 1818-1825.

Baud, J. C., Palembang in 1811 en 1812. In: BKI 1 (1853), pp. 7-40.

Bengal Civil Colonial Consultations. Nos 75-98, 2 October 1813. India Office Records P/167/43.

Berg, C. C., Javaansche geschiedschrijving. In: Stapel, 1938-40, dl 2, pp. 7-148.

Berg, L. W. C. van den, De Mohammedaansche vorsten in NederlandschIndië. In: BKI 53 (1901), pp. 1-80.

Van den Berg, 1902

Berg, L. W. C. van den, De inlandsche rangen en titels op Java en Madoera. 2e herz. dr. 's-Gravenhage 1902.

Blok, 1885

Sjair perang Atjeh. Naar een te Singapoera (?) gelithographeerden Maleischen tekst in het Hollandsch vert. door E. Blok. In: TBG 30 (1885), pp. 568-595.

Booms, A. S. H., Neerlands krijgsroem in Insulinde. Schitterende daden van moed, beleid, trouw en zelfopoffering in de negentiende eeuw sedert de instelling van de Militaire Willemsorde. 2 dln. 's-Gravenhage 1902.

Bottoms, 1959/62/65

Bottoms, J. C., Malay historical works. A bibliographical note on Malay histories as possible sources for the history of Malaya (repr. from the Journal of the South Seas Society, Vol. XV, Pt 2, December 1959). In: Malaysian historical sources. A series of essays on historical material mainly in Malaysia on Malaysia. Ed. by K. G. Tregonning. Singapore 1962. University of Singapore, History Department (2nd pr.: 1965).

Bottoms, 1965

Bottoms, J. C., Some Malay historical sources. A bibliographical note. In: Soedjatmoko, 1965, pp. 156-193.

Boulger, D. C., The life of Sir Stamford Raffles. London 1899.

Braddell, 1850

Braddell, Th., Translation of the Annals of Acheen. In: The Journal of the Indian Archipelago and Eastern Asia 4 (1850), pp. 598-606.

Brandes, 1891-1900

Brandes, J. L. A., Nog eenige Javaansche piagem's uit het mohammedaansche tijdvak, afkomstig van Mataram, Banten en Palembang. III: Palembang. In: TBG 34 (1891), pp. 605-623; 37 (1894), pp. 121-126; 42 (1900), pp. 131-134 en 491-507. 
Brandes, J. L. A. Zie ook: Pararaton, 1897.

Bruining, G., De heldhaftige bevrediging van Palembang, het aldaar sints 1810 vooraf gebeurde, wederlegging van Raffles en Court en voorloopige korte beschrijving van Palembang, Banca, enz. Rotterdam 1822 .

Bruijn Kops, G. F. de, Iets over de zeevaart van den Indischen Archipel. In: Tijdschrift voor nijverheid en landbouw in Nederlandsch-Indië 1 (1854), pp. 21-69 en 97-135.

Buddingh, S. A. Neêrlands-Oost-Indië. Reizen over Java, Madura, Makassar enz., gedaan gedurende het tijdvak van 1852-1857. 3 dln. Rotterdam 1859-61. Dl 3, pp. 80-114.

Bijdrage tot de kennis der geschiedenis van de residentie Palembang. In: TNI nieuwe serie 6 (1877), dl 1, pp. 81-98 en 161-188.

Bijdrage tot de kennis der oorspronkelijke instellingen van Palembang. In: TNI 15 (1853), dl 2, pp. 454-462.

Bijdragen tot de geschiedenis der onderhandelingen met Engeland betreffende de overzeesche bezittingen, 1820-1824,.... Zie: Elout, 1863.

Bijdragen tot de kennis van het koloniaal beheer, .... Zie: Elout, 1851.

Capellen, G. A. G. Ph. van der, Het journaal van den baron Van der Capellen op zijne reis door de Molukko's. In: TNI 17 (1855), dl 2, pp. 281-315 en 357-396.

Cense, A. A., Enige aantekeningen over Makassaars-Boeginese geschiedschrijving. In: BKI 107 (1951), pp. 42-60.

Cense, A. A., Old Buginese and Macassarese diaries. In: BKI 122 (1966), pp. 416-428.

Chronique du royaume d'Atcheh .... Zie: Dulaurier, 1839.

Raja Chulan bin Raja Hamid. Zie: Misa Melayu, 1962.

Churchill, 1935

Churchill, W. A., Watermarks in paper in Holland, England, France etc. in the XVII and XVIII centuries and their interconnection. Amsterdam 1935.

Chijs, J. A. van der, Inventaris van 's-Lands Archief te Batavia (16021816). Samengest. en uitg. op last van de Ned. Ind. Regeering. Batavia 1882.

Van der Chijs, 1897

Nederlandsch-Indisch Plakkaatboek, 1602-1811. Uitg. door J. A. van der Chijs. 17 dln. Batavia-'s-Hage 1885-1900. Dl 16, 1810-1811: ibid. 1897.

De Clercq, 1876

Clercq, F. S. A. de, Eenige bijzonderheden over het Maleisch van Palembang. In: TBG 23 (1876), pp. 517-554.

De Clercq, 1877

Clercq, F. S. A. de, De hoofdplaats Palembang. In: Tijdschrift van het Aardrijkskundig Genootschap 2 (1877), pp. 174-175.

De Clercq, 1895

Clercq, F. S. A. de, Bijdrage tot de geschiedenis van het eiland Bangka. Naar een Maleisch handschrift. In: BKI 45 (1895), pp. 113-163.

Cohen Stuart, A. B., Nota van den ambtenaar voor de Javaansche taal 
en letterkunde over "adelijke titels". Batavia 1880.

Colenbrander, 1925-26

Colenbrander, H. T., Koloniale geschiedenis. 3 dln. 's-Gravenhage 192526.

Colenbrander, H. T. Zie ook: a: Gedenkstukken der algemeene geschiedenis van Nederland. . . b: Falck, A. R., Gedenkschriften. . . .

Coolhaas, W. Ph., Baud on Raffles. In: JMBRAS 24 (1951), Pt 1, pp. 109-120.

Coolhaas, W. Ph., A critical survey of studies on Dutch colonial history. 's-Gravenhage 1960. Kon. Inst. voor Taal-, Land- en Volkenkunde. Bibliographical series. 4.

Corpus diplomaticum Neerlando-indicum (1596-1799). Uitg. en toegelicht door J. E. Heeres en F. W. Stapel. 6 dln. In: BKI 57 (1907), 87 (1931), 91 (1934), 93 (1935), 96 (1938), 96a (1955).

Court, 1821

Court, M. H., An exposition of the relations of the British Government with the Sultaun and State of Palembang and the designs of the Netherlands' Government upon that country. London 1821.

Damsté, H. T., Louis Constant Westenenk (5 Februari 1872 - 2 Mei 1930). In: Westenenk, 1932.

Descriptive account of Palembang. In: The Asiatic Journal 17 (January 1824), pp. 28-34.

Deventer, M. L. van, Het Nederlandsch gezag over Java en onderhoorigheden sedert 1811. Dl 1: 1811-1820. 's-Gravenhage 1891. (Verder niet versch.)

Djajadiningrat, 1911

Djajadiningrat, $H$., Critisch overzicht van de in Maleische werken vervatte gegevens over de geschiedenis van het soeltanaat van Atjeh. In: BKI 65 (1911), pp. 135-265.

Djajadiningrat, H., Critische beschouwing van de Sedjarah Bantěn. Bijdrage ter kenschetsing van de Javaansche geschiedschrijving. Proefschrift Leiden. Haarlem 1913.

Djajadiningrat, H., Jean Pierre Moquette (5 Juli 1856 - 26 Februari 1927). In: TBG 67 (1927), pp. 1-35.

Doorenbos, 1933

Hamzah Pansoeri, Geschriften. Uitg. en toegelicht door J. Doorenbos. Proefschrift Leiden. Leiden 1933.

Van Doren, 1853

Doren, J. B. J. van, Twee episodes uit de geschiedenis van Palembangs hoofdstad, of de wreedaardigheid van den sultan Machmoed Badaroedin. 's-Gravenhage 1853.

Doren, J. B. J. van, Fragmenten uit de reizen in den Indischen Archipel, enz. 2 dln. Amsterdam 1854-56. Dl 1, pp. 57-104: Mijne bestemming naar Palembang; dl 2, pp. 145-256: Kortstondig verblijf op het eiland Banka.

Drewes, G. W. J., D. A. Rinkes. A note on his life and work. In: BKI 117 (1961), pp. 417-435.

Drewes/Voorhoeve, 1958 
Adat Atjéh. Reproduced in facsimile from a manuscript in the India Office Library. With an introd. and notes by G. W. J. Drewes and P. Voorhoeve. VKI 24 (1958).

Dulaurier, 1839

Chronique du royaume d'Atcheh dans l'île de Sumatra, traduite du malay sur un manuscript appartenant à la Société asiatique de Paris, collationné sur deux exemplaires manuscrits de la Bibliotheca Marsdeniana, de King's College, à Londres; par Ed. Dulaurier. In: Journal asiatique, 3e série, tome 8 (1839), pp. 47-81.

Dutch expedition against Palembang. In: The Asiatic Journal 10 (1820), pp. 199-200, 294-298, 620-621; 11 (1821), pp. 200, 202, 405-406; 12 (1821), pp. 606-607.

Dzulkifli, 1968

Hikayat Merong Mahawangsa. Diusahakan oleh Enche' Dzulkifli bin Mohd Salleh. Kuala Lumpur 1968.

Edel, 1938

Hikajat Hasanoeddin. Uitg. door J. Edel. Proefschrift Utrecht. Meppel 1938.

Egerton, H. E., Sir Stamford Raffles. England in the Far East. London 1900.

Elout, 1851

Bijdragen tot de kennis van het koloniaal beheer, getrokken uit de nagelaten papieren van wijlen den Minister van Staat Elout, oudCommissaris-Generaal over Neerlands Indië. 's-Gravenhage 1851.

Elout, 1863

Bijdragen tot de geschiedenis der onderhandelingen met Engeland betreffende de overzeesche bezittingen, 1820-1824, getrokken uit de nagelaten papieren van wijlen den Minister van Staat Elout. 's-Gravenhage 1863.

Encyclopaedia of Islam

The Encyclopaedia of Islam. New edition. Ed. by H. A. R. Gibb a.o. Leiden-London 1960 -

Encyclopaedie van Nederlandsch-Indië. 2e dr. 8 dln. 's-GravenhageLeiden 1917-39.

Falck, A. R., Ambts-brieven, 1802-1842. 's-Gravenhage 1878.

Falck, A. R., Gedenkschriften van —_, uitg. en met een appendix voorzien door H. T. Colenbrander. 's-Gravenhage 1913. Rijks Geschiedkundige Publicatiën. Kleine Serie. 13.

Feestbundel KBG, 1929

Feestbundel uitg. door het Koninklijk Bataviaasch Genootschap van Kunsten en Wetenschappen bij gelegenheid van zijn 150-jarig bestaan, 1778-1928. 2 dln. Weltevreden 1929.

Francis, E. Herinneringen uit den levensloop van een' Indisch' ambtenaar van 1815 tot 1851 , medegedeeld in brieven. 3 dln. Batavia 1856-60.

Garland, F., Tour in Sumatra. Extract of a letter from 22nd March 1819. In: The Asiatic Journal 9 (1820), pp. 547-552.

Gedenkstukken der algemeene geschiedenis van Nederland van 1795 tot 
1840, uitg. door H. T. Colenbrander. Dl 5-8 (1806-25), 's-Gravenhage 1911-16. Rijks Geschiedkundige Publicatiën 12, 16, 17, 23, 25, 27,30 .

Gericke-Roorda, 1901

Gericke, J. F. C. en T. Roorda, Javaansch-Nederlandsch handwoordenboek, verm. en verb. door A. C. Vreede, met medew. van J. G. H. Gunning. 2 dln. Amsterdam-Leiden 1901.

Gerlach, A. J. A., Fastes militaires des Indes-Orientales Néerlandaises. Zalt-Bommel 1859.

Geschiedenis van Nederlandsch Indië, o.l.v. F. W. Stapel. Zie: Stapel, 1938-40.

De Geschiedenis der Palembangsch Vorsten. Palembang begin 19e eeuw (?). Hs KI H 184 (De Graaf, 1963, p. 97).

Gillespie, R. R., A memoir of Major-General Sir —. London 1816. 1816.

Graaf, H. J. de, Geschiedenis van Indonesië. 's-Gravenhage-Bandung 1949.

De Graaf, 1963

Graaf, H. J. de, Catalogus van de handschriften in westerse talen, toebehorende aan het Koninklijk Instituut voor Taal-, Land- en Volkenkunde. 's-Gravenhage 1963.

Gramberg, 1878

Gramberg, J. S. G., Palembang. Historisch-romantische schets uit de geschiedenis van Sumatra. Batavia-Haarlem 1878.

Grotefend, H., Taschenbuch der Zeitrechnung des deutschen Mittelalters und der Neuzeit. 10 erw. Aufl. Hrsg. von Th. Ulrich. Hannover 1960.

De Haan, 1935

Haan, F. de, Personalia der periode van het Engelsch bestuur over Java, 1811-1816. In: BKI 92 (1935), pp. 477-681.

Habbema, J., Brieven van Raffles aan den Sultan van Palembang. In: Ind. Gids 32 (1910), dl 1, pp. 744-756.

Hahn, E., Raffles of Singapore. A biography. London 1948.

Hall, 1961

Historians of South East Asia. Ed. by D. G. E. Hall. London etc. 1961. Historical writing on the peoples of Asia. 2. School of Oriental and African studies, University of London.

Hallema, A., Palembang en de Compagnie. In: Ind. Gids 57 (1935), pp. 216-239.

Hallema, A., Aanvullingen en verbeteringen bij mijn opstel Palembang en de Compagnie. In: Ind. Gids 58 (1936), pp. 604-606.

Hamzah Pansoeri, Geschriften. Zie: Doorenbos, 1933.

Hartmann, A. Zie: Re pertorium-Hooykaas.

Heawood, 1950

Heawood, E., Watermarks mainly of the 17 th and 18th centuries. Hilversum 1950. Monumenta chartae papyraceae historiam illustrantia. 1.

Helfrich, O. L., Proeve van een Lampongsch-Hollandsche woordenlijst, bepaaldelijk voor het dialect van Kroë. VBG 45 (1891). 
Helfrich, O. L., Bijdragen tot de kennis van het Midden-Maleisch (Běsěmahsch en Sěrawajsch dialect). VBG 53 (1904).

Helfrich, O. L., Nadere aanvullingen en verbeteringen op de "Bijdragen tot de kennis van het Midden-Maleisch (Běsěmahsch en Sěrawajsch dialect)". VBG 61 (1915), 3e en 4e stuk.

Helfrich, O. L., Supplement op de "Nadere aanvullingen en verbeteringen op de Bijdragen tot de kennis van het Midden-Maleisch (Bësĕmahsch en Sërawajsch dialect)"'. VBG 63 (1921), le stuk.

De Hikajat Atjéh. Zie: Iskandar, 1959.

Hikajat Bandjar. Zie: Ras, 1968.

Hikajat Hasanoeddin. Zie: Edel, 1938.

Hikayat Marong Maha Wangsa or Kedah Annals. Zie: Sturrock, 1916.

Hikayat Merong Mahawangsa. Zie: a: Dzulkifli, 1968; b: Siti Hawa Saléh, 1970.

Hikayat Patani. Zie: Teeuw-Wyatt, 1970.

Hikayat Raja-Raja Pasai. Zie: Hill, 1960.

Hill, 1960

Hikayat Raja-Raja Pasai. A rev. romanised version of Raffles MS 67, together with an English transl., both prep. by A. H. Hill. In: JMBRAS 33 (1960), Pt 2 (No 190).

Historians of South East Asia. Zie: Hall, 1961.

Hodson, 1928

Hodson, V.C.P., List of Officers of the Bengal Army, 1758-1834. Pt 2. London 1928.

Hoek, I. H. J., Het herstel van het Nederlandsch gezag over Java en onderhoorigheden (1816-1819). Proefschrift Leiden. 's-Gravenhage 1862.

De Hollander, 1871

Hollander, J. J. de, Geslachtregister der vorsten van Sambas. In: BKI 3e volgreeks dl 6 (1871), pp. 185-203.

Hooyer, G. B., De krijgsgeschiedenis van Nederlandsch-Indië van 1811 tot 1894. 3 dln. Den Haag-Batavia 1895-97.

Hooyer, G. B. Zie ook: Winckel-Hooyer, 1890.

Hooykaas, $1937 / 47$

Hooykaas, C., Over Maleische literatuur. Leiden 1937. 2e dr.: ibid. 1947.

Hooykaas, J. C. Zie: Repertorium-Hooykaas.

Horsfield, 1848

Horsfield, Th., Report on the island of Banka. In: The Journal of the Indian Archipelago and Eastern Asia, 2 (1848), pp. 299-336, 373427, 705-725, 779-824. Ned. vert. door P. J. Veth o.d.t. "Verslag aangaande het eiland Banka" in: TNI 12 (1850), dl 1: pp. 192-226, 358-382; 13 (1851), dl 1: pp. 50-62, 273-292, 388-405; 14 (1852), dl 2: pp. 321-345.

De Hullu, 1924

Hullu, J. de, De archieven der admiraliteitscolleges. 's-Gravenhage 1924. An introduction to Indonesian historiography. Zie: Soedjatmoko, 1965. Iskandar, 1959

De Hikajat Atjéh. Uitg. door Teuku Iskandar. Proefschrift Leiden. 's-Gravenhage 1959. 
Jansz, 1932

Jansz, P., Practisch Javaansch-Nederlandsch woordenboek. Met Latijnsche karakters. 3e verb. en veel verm. uitg., voor den dr. bew. en voortgezet door P. Ant. Jansz. Semarang etc. 1932.

Java Government Gazette, 1812-1813.

De Josselin de Jong, 1964

Josselin de Jong, P. E. de, The character of the Malay Annals. In: Malayan and Indonesian studies, 1964, pp. 235-241.

Juynboll, 1899

Juynboll, H. H., Catalogus van de Maleische en Sundaneesche handschriften der Leidsche Universiteits-Bibliotheek. Leiden 1899.

Juynboll, 1930

Juynboll, Th. W., Handleiding tot de kennis van de Mohammedaansche wet volgens de leer der Sjâficitische school. 4e dr. Leiden 1930.

Kalff, S., Een verdienstelijk hoofdambtenaar. In: Kol. Ts. 8 (1919), dl 2, pp. 1117-1139.

Kalff, S., Een Groninger jurist in Indië. In: Kol. Ts. 13 (1924), pp. 400-420.

Kampen, N. G. van, Geschiedenis der Nederlanders buiten Europa of Verhaal van de togten, ontdekkingen, oorlogen, veroveringen en inrigtingen der Nederlanders in Aziën, Afrika, Amerika en Australië. Van het laatste der zestiende eeuw tot op dezen tijd. $3 \mathrm{dln}$. Haarlem 1831-32.

Kemp, P. H. van der, De sluiting van het Londensch Tractaat van 13 Augustus 1814. In: BKI 47 (1897), pp. 239-339.

Kemp, P. H. van der, Fendall's en Raffles' opvattingen in het algemeen omtrent het Londensch Tractaat van 13 Augustus 1814. In: BKI 47 (1897), pp. 341-497.

Kemp, P. H. van der, De geschiedenis van een Engelschen raid op Hollandsch grondgebied. In: De Gids 62 (1898), dl 1, pp. 253-294.

Kemp, P. H. van der, Palembang en Banka in 1816-1820. In: BKI 51 (1900), pp. 331-764.

Kemp, P. H. van der, Brieven van en aan Mr. H. J. van de Graaf, 18161826. Eene bijdrage tot de kennis der Oost-Indische bestuurstoestanden onder de regeering van G. A. G. P. Baron Van der Capellen. VBG 52 (1901).

Kemp, P. H. van der, De teruggave der Oost-Indische koloniën, 18141816. Naar oorspronkelijke stukken. 's-Gravenhage 1910.

Kemp, P. H. van der, Oost-Indië's herstel in 1816. Naar oorspronkelijke stukken. 's-Gravenhage 1911.

Kemp, P. H. van der, Het Nederlandsch-Indisch bestuur in 1817 tot het vertrek der Engelschen. Naar oorspronkelijke stukken. 's-Gravenhage 1913.

Kemp, P. H. van der, Het Nederlandsch-Indisch bestuur in het midden van 1817. Naar oorspronkelijke stukken. 's-Gravenhage 1915.

Kemp, P. H. van der, Het Nederlandsch-Indisch bestuur van 1817 op 1818 over de Molukken, Sumatra, Banka, Billiton en de Lampongs. Naar oorspronkelijke stukken. 's-Gravenhage 1917. 
Kemp, P. H. van der, Sumatra in 1818. Naar oorspronkelijke stukken. 's-Gravenhage 1920.

R. A. Kern, 1948

Kern, R. A., Proeve van Boegineesche geschiedschrijving. In: BKI 104 (1948), pp. 1-31.

W. Kern, 1942

Kern, W., Aantekeningen op de Sjacir Hémop (Sjacir Kompeni Welanda berperang dengan Tjina). In: TBG 82 (1942-48), pp. 211-257.

Kielstra, E. B., De ondergang van het Palembangsche Rijk. In: De Gids 56 (1892), dl 2, pp. 76-111. Opgenomen in: E. B. Kielstra, Indisch Nederland. Geschiedkundige schetsen. Haarlem 1910 (pp. 196-241).

Klerck de Reus, G. C. Uit het journaal van den generaal-majoor Van Geen. In: De tijdspiegel 1 (1885), pp. 51-60 en 162-193.

Klinkert, 1882

Klinkert, H. G., Verzamelingen van Maleische brieven, voorhanden in de Rijksbibliotheek te Leiden. Gecatalogiseerd door —. In: TNI nieuwe serie 11 (1882), dl 2, pp. 81-103, 161-206 enz. "Brieven van Pelimbang": pp. 86-89.

Klinkert, 1910

Klinkert, H. C., Nieuw Maleisch-Nederlandsch zakwoordenboek. 2e verb. en verm. dr. Leiden-Batavia 1910.

Klinkert, 1930 (afgekort: Kl.)

Klinkert, H. C., Nieuw Maleisch-Nederlandsch woordenboek met Arabisch karakter. 4e dr. Leiden 1930.

Knoerle, J. H., Aanteekeningen, gehouden op eene reize in de binnenlanden van Sumatra, bijzonder met betrekking tot Benkoelen en Palembang (gedateerd: Benkoelen, 20 April 1832). In: De Oosterling 1 (1834), pp. 49-98.

Kock, A. H. W. de, Korte chronologische geschiedenis van Palembang. Palembang dec. 1842. Hs KI H 307 (De Graaf, 1963, p. 98).

Kock, A. H. W. de, Bijdrage tot de geschiedenis van de Residentie Palembang. Palembang dec. 1842. Hs KI H 186 (De Graaf, 1963, p. 98).

Kock, A. H. W. de, Oude geschiedenis van Palembang. Palembang ca 1842-45. Hs KI H 272 (De Graaf, 1963, p. 98).

Kock, A. H. W. de, Geschiedenis van het Rijk van Djambie. Palembang aug. 1843. Hs KI H 271 (De Graaf, 1963, p. 98).

De Kock, $1844 a$

Kock, A. H. W. de, Aanteekeningen en schetsen over Palembang. In: TNI 6 (1844), dln 3 en 4.

De Kock, $1844 b$

Kock, A. H. W. de, Val van de Djambische Vorstenheerschappij. In: TNI 6 (1844), dl 4, pp. 107-112.

De Kock, 1846 a

Kock, A. H. W. de, Legenden van Djambi. In: TNI 8 (1846), dl 4, pp. 33-56 (gedateerd: Palembang, Augustus 1843).

De Kock, $1846 b$ 
Kock, A. H. W. de, Schetsen van Palembang. In: TNI 8 (1846), dl 3, pp. 281-376.

Kock, H. M. de, Vermeestering van Palembang, Junij 1821 (Dagorders en rapporten). Hs KI H 304 (De Graaf, 1963, p. 32).

Köffler, G. C. E., De Militaire Willemsorde, 1815-1940. Samengest. in opdracht van het Ministerie van Algemeene Zaken bij gelegenheid van het 125-jarig jubileum van de Militaire Willemsorde. 's-Gravenhage 1940.

Kortz, J. A., De generaal-majoor Jhr. Carel van der Wijck. In: TNI 16 (1854), dl 1, pp. 114-134. (Overgenomen van Weitzel, 1853; z.a.)

Kratz, 1973

Peringatan sejarah negeri Johor. Eine malaiische Quelle zur Geschichte Johors im 18. Jahrhundert. Texted. und Ubers. von E. U. Kratz. Veröffentlichungen des Ostasiatischen Seminars der Johann-Wolfgang-Goethe-Universität, Frankfurt/Main, Reihe A: Südostasienkunde. Bd 3. Wiesbaden 1973.

Van der Kroef, 1958

Kroef, J. M. van der, On the writing of Indonesian history. In: Pacific Affairs 31 (1958), pp. 352-371.

Krom, N. J., De heiligdommen van Palembang. Meded. KNAW nieuwe reeks dl 1, no 7, afd. Letterk. (1938), pp. 397-423.

De Kroniek van Koetai. Zie: Mees, 1935.

Kronijk van Sambas en van Soekadana. Zie: Netscher, 1853.

Lange, H. M., Het eiland Banka en zijne aangelegenheden. 's-Hertogenbosch 1850 .

Lauts, G., Geschiedenis van de Nederlandsche Regeering in Indie gedurende 1816-1858. 2 dln. Amsterdam 1866. (Dl 1, tevens dl 6 van: Geschiedenis van de vestiging, uitbreiding, bloei en verval van de magt der Nederlanders in Indië; ibid. 1866.)

Legenden van Djambi. (Anoniem versch. in TNI 8 (1846), dl 4, pp. 33-56.) Zie: De Kock, $1846 a$.

Leicher, F. P., Het leven en de lotgevallen van wijlen —. Uitg. door Ths. Leicher. Groningen 1843.

Levyssohn Norman, H. D., De Britsche heerschappij over Java en Onderhoorigheden (1811-1816). Proefschrift Leiden. 's-Gravenhage 1857.

Van der Linden, 1937

Linden, A. L. V. L. van der, De Europeaan in de Maleische literatuur. Proefschrift Utrecht. Meppel 1937.

Low, 1880

Selesilah (Book of the descent) of the rajas of Bruni. By H. Low. In: JSBRAS 5 (1880), pp. 1-35.

Lijst van aardrijkskundige namen, 1923

Lijst van de voornaamste aardrijkskundige namen in den NederlandschIndischen Archipel (volgens Gouvernementsbesluit dd. 4 Mei 1922 no 50). 2e uitg. Weltevreden 1923.

Mackay, D. J., De handhaving van het Europeesch gezag en de hervorming van het regtswezen onder het bestuur van den Gouverneur- 
Generaal Mr. H. W. Daendels over Java en Onderhoorigheden (18081811). Proefschrift Leiden. 's-Gravenhage 1861.

Malayan and Indonesian studies, 1964

Malayan and Indonesian studies. Essays presented to Sir Richard Winstedt on his 85th birthday. Ed. by John Bastin and R. Roolvink. Oxford 1964.

Malayan Miscellanies I, 1820, 3

Annals of Achin. Transl. from an original M. S. In: Malayan Miscellanies, Vol. I, No 3. Bencoolen, Sumatran Mission Press, 1820.

Malayan Miscellanies II, 1822, 12

Abstract of the genealogy of the rajahs of Pulo Percha (Sumatra). From a M.S. in the possession of the Sultan of Indrapura. In: Malayan Miscellanies, Vol. II, No 12, Bencoolen, Sumatran Mission Press, 1822.

Maxwell, W. E., An account of the Malay "Chiri", a Sanskrit formula. In: JRAS 13 (1881), pp. 80-101.

Maxwell, W. E., The "Chiri". In: JSBRAS 10 (1883), pp. 287-289.

Mees, 1935

De Kroniek van Koetai. Tekstuitg. met toelichting, door C. A. Mees. Proefschrift Leiden. Santpoort 1935.

Meinsma, J. J., Geschiedenis van de Nederlandsche Oost-Indische bezittingen. 2 dln in 3 stukken. Delft-'s-Hage 1872-75. Dl 2: 's-Hage 1873.

Meis, $1841 / 42$

Meis, A., Verhaal van den Palembangschen oorlog van 1819-1821. Hs UBL 1841. Gepubl. in: De Militaire Spectator 10 (1842), pp. 111127, 135-151, 157-173, 181-189, 225-236.

Midden-Sumatra, 1881-92

Midden-Sumatra. Reizen en onderzoekingen der Sumatra-expeditie, uitgerust door het Aardrijkskundig Genootschap 1877-1879, beschreven door de leden der expeditie onder toezicht van P. J. Veth. $4 \mathrm{dln}$. Leiden 1881-92. Dl 3: Volksbeschrijving en taal, door A. L. van Hasselt. Ibid. 1881-82.

Misa Melayu, 1962

Raja Chulan bin Raja Hamid, Misa Melayu. Kuala Lumpur, Penerbitan Pustaka Antara, 1962.

Misa Melayu. Zie ook: Winstedt, 1919.

Mohnike, 1874

Mohnike, O. G. J., Banka und Palembang. Nebst Mittheilungen über Sumatra im Allgemeinen. Münster 1874.

Müller, G., Proeve eener geschiedenis van een gedeelte der West-kust van het eiland Borneo. In: De Indische Bij, Leiden 1843, pp. 197-375 (over Raja Akil: pp. 371-374).

Muller, W. C. Zie: Repertorium-Hooykaas.

Mijer, P., Geschiedenis der Nederlandsche Oost-Indische bezittingen onder de Fransche heerschappij. In: TNI 2 (1839), dl 2, pp. 229427. (Afzonderlijk versch.: Batavia 1839.)

Mijer, P., Kronijk van Nederlandsch Indie, loopende van af het jaar 1816 (-1825). In: TNI 3 (1840), dl 2, pp. 265-306, 345-395, 477-541, 
589-636: 1816-20; TNI 4 (1842), dl 1, pp. 1-69, 129-228: 1821-23; TNI 7 (1845), dl 2, pp. 4219-566, dl 3, pp. 43-109, 171-210: 1824-25. (Afzonderlijk versch.: 1817-21: Batavia 1841; 1824-25: ibid. 1842.)

Nederlandsch-Indië in 1817. In: TNI 23 (1861), dl 1, pp. 271-300 en 339-371. ("De eilanden Sumatra, Banka en Billiton": pp. 366-371.)

Nederlandsch-Indisch Plakkaatboek, 1602-1811. Zie:Van der Chijs, 1897.

Netscher, 1850

Verzameling van overleveringen van het rijk van Manangkabou. Uit het oorspr. Maleisch vert. door E. Netscher. In: Indisch Archief 2 (1850), dl 3, pp. 33-68.

Netscher, 1853

Kronijk van Sambas en Soekadana; in het oorspronkelijk Maleisch, voorzien van de vertaling en aanteekeningen door E. Netscher. In: TBG 1 (1853), pp. 1-41.

Netscher, 1855

Ahmad bin Abdullah Haman Al-kadri, Geschiedenis der eerste Al-Qadris (Mal. hs dd. 1 Zulhijah $1268=17$ aug. 1852). Met eene vertaling door E. Netscher. In: TBG 4 (1855), pp. 285-332 ("bijlage" van Willer, 1854).

Nieuwenhuys, R., De tijd van Van der Capellen. In: Tirade 11 (1967), pp. 109-125.

Nooteboom, 1932

Nooteboom, C., De boomstamkano in Indonesië. Proefschrift Leiden. Leiden 1932.

Olivier, $1826 / 27$

Olivier, J., Aanteekeningen gehouden op eene reize in Oost-Indië en gedurende een veeljarig verblijf in onderscheidene Nederlandsche etablissementen aldaar. In: Cybele, Tijdschrift ter bevordering van de land- en volkenkunde, 5 (1826), pp. 81-140. (Ook afzonderlijk versch.: Amsterdam 1827.)

Olivier, J., Land- en zeetogten in Nederland's Indie en eenige Britsche etablissementen, gedaan in de jaren 1817 tot 1826. 3 dln. Amsterdam 1827-30. Dl 2: ibid. 1828.

Olivier, J., Bijzonderheden betreffende Sir Thomas Stamford Raffles, Lt-Gouverneur van Java, Benkoelen enz. In: De Oosterling 1 (1834), pp. 1-8 en 140-157.

Olivier, J., Iets over het eiland Sumatra. In: De Oosterling 1 (1834), pp. 37-48; 2 (1834), pp. 124-139.

Olivier, J., Tafereelen en merkwaardigheden uit Oost-Indië. 2 dln. Amsterdam 1836-38. Dl 2: ibid. 1838.

Palembang. In: De Weegschaal, Leyden 1821, pp. 444-448.

Pararaton, 1897

Pararaton (Ken Arok) of het Boek der Koningen van Tumapĕl en van Majapahit. Uitg. en toegelicht door J. Brandes. VBG 49 (1897). (2e dr.: VBG 62 (1920), bew. door N. J. Krom e.a.)

Pedoman edjaan, 1972

Pedoman edjaan Bahasa Indonesia jang disempurnakan. Djakarta 1972. Departemen Pendidikan dan Kebudajaan Republik Indonesia. 
Peringatan sejarah negeri Johor. Zie: Kratz, 1973.

Pigeaud, 1938a (afgekort: Pig.)

Pigeaud, Th. G. Th., Javaans-Nederlands handwoordenboek. GroningenBatavia 1938.

Pigeaud, $1938 b$

Pigeaud, Th. G. Th., Javaanse volksvertoningen. Bijdrage tot de beschrijving van land en volk. Batavia 1938.

Poerwadarminta-Teeuw, 1952 (afgekort: P./T.)

Poerwadarminta, W. J. S. en A. Teeuw, Indonesisch-Nederlands woordenboek. 2e bijgew. dr. Djakarta-Groningen 1952.

Pompe, A., Geschiedenis der Nederlandsche overzeesche bezittingen. 2e verm. en verb. dr. Schoonhoven 1872 (1e dr. Kampen 1863).

Praetorius, C. F. E., Eenige bijzonderheden omtrent Palembang. In: De Indische Bij 1 (1843), pp. 376-479.

Pijnappel, J., De Maleische handschriften der Leidsche bibliotheek. In: BKI 3e volgreeks 5 (1870), pp. 142-178.

Radermacher, J. C. M., Beschrijving van het eiland Sumatra, in zooverre hetzelve tot nog toe bekend is. VBG 3, 2e dr. (1824), pp. 1-89.

Raffles, Th. S. Embassy from — to several native princes seized by the Dutch authorities of Palembang. In: The Asiatic Journal 7 (1819), p. 91.

Raffles, Th. S. Protest by against the aggressions of the Dutch in the Malayan Archipelago. In: The Asiatic Journal 7 (1819), pp. 206-215.

Raffles, 1830

Raffles, Th. S. Memoir of the life and public services of - By his widow. London 1830.

Ras, 1968

Ras, J. J., Hikajat Bandjar. A study in Malay historiography. Proefschrift Leiden. 's-Gravenhage 1968. Ook versch. als uitg. van: Kon. Inst. voor Taal-, Land- en Volkenkunde, Bibliotheca indonesica, 1.

Ras, 1968-70

Ras, J. J., Lange consonanten in enige Indonesische talen. In: BKI 124 (1968), pp. 521-541 en 126 (1970), pp. 429-447.

Regeeringsalmanak voor Nederlandsch-Indië. Zie: Almanak van Nederlandsch-Indië.

Regels voor het uitgeven van historische bescheiden. Samengest. in opdracht van het bestuur van het Historisch Genootschap. Geheel herz. $4 \mathrm{e}$ dr. Groningen 1966.

Regerings-almanak voor Nederlandsch-Indië. Zie: Almanak van Nederlandsch-Indië.

Reglementaire en andere wettelijke bepalingen betreffende het beheer der justitie op de buitenbezittingen in Nederlandsch-Indië. . . 4e dr. Batavia 1874.

Relations of the Dutch with the native powers. In: The Asiatic Journal 9 (1820), pp. 406-408.

Repertorium-Hooykaas

Repertorium op de koloniale litteratuur of systematische inhoudsopgave 
van hetgeen voorkomt over de koloniën (beoosten de Kaap) in mengelwerken en tijdschriften van 1595 tot 1865 uitg. in Nederland en zijne overzeesche bezittingen. Door J. G. Hooykaas. 2 dln. Amsterdam 1877-80. Met 5 vervolgdelen door A. Hartmann, W. J. P. J. Schalker en W. C. Muller. 's-Gravenhage 1895-1923.

Resink, 1953

Resink, G. J., Zakelijkheid en zekerheid in de Indonesische geschiedschrijving. In: Weerklank op het werk van Jan Romein, Liber amicorum, Amsterdam-Antwerpen 1953, pp. 146-156.

Resink, 1955

Resink, G. J., Veronachtzaamde uitspraken. In: Indonesië 8 (1955), pp. 1-26.

Resink, 1956

Resink, G. J., Uit het stof van een beeldenstorm. In: Indonesië 9 (1956), pp. 433-448.

Reijnst, J. C., Iets over het Inlandsch Bestuur in de binnenlanden van Palembang, aldus bevonden in 1822. In: TNI (1838), pp. 258-267.

Rinkes, 1909

Rinkes, D. A., Abdoerraoef van Singkel. Bijdrage tot de kennis van de mystiek op Sumatra en Java. Proefschrift Leiden. Heerenveen 1909.

Van Ronkel-KI

Ronkel, Ph. S. van, Catalogus der Maleische handschriften van het Koninklijk Instituut voor de Taal-, Land- en Volkenkunde van Nederlandsch-Indië. In: BKI 60 (1908), pp. 181-248.

Van Ronkel-BG

Ronkel, Ph. S. van, Catalogus der Maleische handschriften in het $\mathrm{Mu}-$ seum van het Bataviaasch Genootschap van Kunsten en Wetenschappen. VBG 57. Batavia - 's-Hage 1909.

Van Ronkel, 1918

Ronkel, Ph. S. van, Daendels in de Maleische litteratuur. In: Kol. Ts. 7 (1918), 2e halfjr, pp. 858-875 en 1152-1167.

Ronkel, Ph. S., De raadselachtige toespraak van den Hindoe-bard in de Maleische Kronieken. In: BKI 77 (1921), pp. 175-181.

Ronkel, Ph. S., Nogmaals de toespraak van den Hindoe-bard. In: BKI 78 (1922), pp. 463-465.

Van Ronkel-UBL

Ronkel, Ph. S. van, Supplement-catalogus der Maleische en Minangkabausche handschriften in de Leidsche Universiteits-Bibliotheek. Leiden 1921.

Rooo de la Faille, P., Uit den Palembangschen sultanstijd. In: Feestbundel KBG, 1929, dl 2, pp. 316-352.

Roolvink, R., The answer of Pasai. In: JMBRAS 38 (1965), Pt 2, pp. 129-139.

Roolvink, R., The variant versions of the Malay Annals. In: BKI 123 (1967), pp. 301-324. (Eveneens versch. in: Sejarah Melayu or Malay Annals. An annotated transl. by C. C. Brown. With a new introd. by R. Roolvink. Kuala Lumpur etc. 1970, pp. XV-XXXV.)

Roolvink, R. Zie ook: Malayan and Indonesian studies, 1964. 
Roorda van Eysinga, S., Verschillende reizen en lotgevallen van mitsgaders die van deszelfs zoon P. P. Roorda van Eysinga. Uitg. door laatstgemelden. 4 dln. Amsterdam 1830-32. Dl 3: ibid. 1832.

Rusconi, 1935

Sjacir Kompeni Welanda berperang dengan Tjina. Voorzien van inhoudsopgave en aanteekeningen. Door J. Rusconi. Proefschrift Utrecht. Wageningen 1935.

Van Rijn van Alkemade, 1883

Rijn van Alkemade, J. A. van, De hoofdplaats Palembang. In: Tijdschrift van het Aardrijkskundig Genootschap 1e reeks 7 (1883), pp. 51-69.

Salmond, F., Diary of a journey across the island of Sumatra from Fort Marlborough to Palembang in 1818. In: Malayan Miscellanies Vol. II, No 3, Bencoolen, Sumatran Mission Press, 1822.

Schalker, W. J. P. J. Zie: Repertorium-Hooykaas.

Schetsen van Palembang. (Anoniem versch. in TNI 8 (1846), dl 3, pp. 281-376.) Zie: De Kock, $1846 b$.

Schnitger, F. M., Oudheidkundige vondsten in Palembang. Bijl. G. Leiden 1936.

Schnitger, F. M., Forgotten kingdoms in Sumatra. Leiden 1939.

Schoemaker, J. P., De 2e Palembangsche expeditie. In: TNI 2e nieuwe serie 3 (1899), pp. 570-610. (Ook opgenomen in: Schoemaker, J. P., Verhalen uit de oorlogen in Ned. Oost-Indië. 's-Hertogenbosch 1900.)

Sedjarah Melayu, menurut terbitan Abdullah. Zie: Situmorang-Teeuw, 1952.

Selesilah (Book of the descent) of the rajas of Bruni. Zie: Low, 1880.

Van Sevenhoven, 1823

Sevenhoven, J. J. van, Beschrijving van de hoofdplaats van Palembang. VBG 9 (1823), pp. 39-126.

Shair Ken Tambuhan. Zie: Teeuw, 1966 a.

Silsilah Raja-Raja Berunai. Zie: Sweeney, 1968.

Siti Hawa Saléh, 1970

Hikayat Merong Mahawangsa. Diselenggarakan oléh Siti Hawa Saléh. Kuala Lumpur-Singapore 1970. University of Malaya Press. Seri klasik Melayu. (Proefschrift Kuala Lumpur 1966.)

Situmorang-Teeuw, 1952

Sedjarah Melaju, menurut terbitan Abdullah. Diselenggarakan kembali .... oleh T. D. Situmorang dan A. Teeuw. Djakarta-Amsterdam 1952.

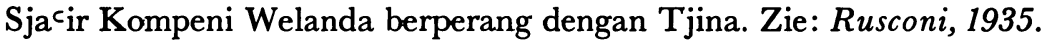

Sjair perang Atjeh. Zie: Blok, 1885.

Sjair perang Palembang. Zie: Atja, 1967.

Skinner, 1963

Amin, Entji', Sjacir perang Mengkasar. (The rhymed chronicle of the Macassar war.) Ed. and transl. by C. Skinner. VKI 40. 's-Gravenhage 1963.

Smail, 1961

Smail, J. R. W., On the possibility of an autonomous history of modern 
Southeast Asia. In: Journal of Southeast Asian history Vol. 2, No 2 (July 1961).

Soedjatmoko, 1960

Soedjatmoko, An approach to Indonesian history: towards an open future. An address before the Seminar on Indonesian history, Gadjah Mada University, Jogjakarta, December 14, 1957. Ithaca, N.Y., 1960. Translation Series. Modern Indonesia Project. Southeast Asia Program. Cornell University.

Soedjatmoko, 1965

An introduction to Indonesian historiography. Ed. by Soedjatmoko a.o. Ithaca, N.Y., 1965. Modern Indonesia Project. Southeast Asia Program. Cornell University.

Spengler, J. A., De Nederlandsche Oost-Indische bezittingen onder het bestuur van den Gouverneur-Generaal G. A. G. P. Baron van der Capellen, 1819-1825. Proefschrift Utrecht. Utrecht 1863.

Stapel, 1938-40.

Geschiedenis van Nederlandsch Indië, o.l.v. F. W. Stapel. 5 dln. Amsterdam 1938-40.

Stapel, 1940

Stapel, F. W., De Bataafsche Republiek en de Fransche tijd. Het Engelsche tusschenbestuur. Het Koninkrijk der Nederlanden. In: Stapel, 1938-40, dl 5.

Stockhausen, 1863

Adipati Wira Tanoe Datar, Tjarieta (Mal. hs KI 215a, Van Ronkel-KI p. 212). Ned. vert. door C. M. F. Stockhausen o.d.t. "Inlandsche verhalen van den regent van Tjiandjoer in 1857", met voorw. van S. Keyzer. In: BKI nieuwe volgreeks 6 (1863), pp. 291-313.

Stokvis, 1888

Stokvis, A. M. H. J., Manuel d'histoire, de généalogie et de chronologie de tous les états du globe, depuis les temps les plus reculés jusqu'à nos jours. 3 tomes. Leide 1888-93. Tome 1, pp. 355-357.

Sturler, J. E. de, Journaal van eene reize door de bovenlanden van Palembang, aangevangen op den 18 Januarij en voleindigd den 2en April 1823. Hs KI H 557a (De Graaf, 1963, p. 58).

Sturler, J. E. de, Aanteekeningen van eene reis in de bovenlanden van het Palembangsche Rijk van den 18den Januarij tot 2 April 1823. Hs KI H 557b (De Graaf, 1963, p. 58).

Sturler, J. E. de, Anonieme klacht over J. C. Reijnst. Palembang 29 nov. 1824. Hs KI H 170 (De Graaf, 1963, p. 33).

Sturler, J. E. de, Het grondgebied van Nederlandsch Oost-Indië in verband met de tractaten met Spanje, Engeland en Portugal. Proefschrift Leiden. Leiden 1881.

Sturler, W. L. de, Proeve eener beschrijving van het gebied van Palembang (Zuid-Oostelijk gedeelte van Sumatra). Groningen 1843.

Sturler, W. L. de, Over Palembang. Voordrachten gehouden in Felix Meritis, afd. Koophandel. Amsterdam 1854.

De Sturler, 1855

Sturler, W. L. de, Bijdrage tot de kennis en rigtige beoordeeling van den 
zedelijken, maatschappelijken en staatkundigen toestand van het Palembangsche gebied. Groningen 1855.

Sturler, W. L. de, Historische en Ethnographische Beschrijving van Palembang. ... Den Haag ca 1870. Hs KI H 371a (De Graaf, 1963, p. 99).

Sturler, W. L. de, Herinneringen en wenken betreffende het belang en het beheer der buitenbezittingen in den Oost-Indischen Archipel in 't algemeen en van Palembang in het bijzonder (gedateerd: 's-Gravenhage, 28 Febr. 1876). In: BKI 4e volgreeks 6 (1882), pp. 301-340.

Sturrock, 1916

Hikayat Marong Maha Wangsa or Kedah Annals. Ed. by A. J. Sturrock. In: JSBRAS 72 (1916), pp. 37-123.

Sweeney, 1968

Silsilah Raja-Raja Berunai. Ed. and annotated by P. L. Amin Sweeney. In: JMBRAS 41 (1968), Pt 2, pp. 1-82 (Errata and short note in: JMBRAS 42 (1969), Pt 2, pp. 222-224).

Sweeney, 1971

Sweeney, P. L. Amin, Some observations on the Malay shacir. In: JMBRAS 44 (1971), Pt 1, pp. 52-70.

Tambo Bangkahoeloe, 1933

Tambo Bangkahoeloe. Balai Poestaka. Serie no 1097. Batavia-Centrum 1933.

Tarling, N., Anglo-Dutch rivalry in the Malay world, 1780-1824. St Lucia, Queensland 1962.

Teeuw, A., A critical survey of studies on Malay and Bahasa Indonesia. With assist. of H. W. Emanuels. 's-Gravenhage 1961. Kon. Inst. voor Taal-, Land- en Volkenkunde. Bibliographical series. 5.

Teeuw, 1966 a

Shair Ken Tambuhan. Diselenggarakan oleh A. Teeuw. Kuala Lumpur 1966. Seri klasik Melayu.

Teeuw, 1966 b

Teeuw, A., The Malay shacir. Problems of origin and tradition. In: BKI 122 (1966), pp. 429-446.

Tecuw-Wyatt, 1970

Hikayat Patani. The story of Patani. By A. Teeuw and D. K. Wyatt. 2 vols. The Hague 1970. Kon. Inst. voor Taal-, Land- en Volkenkunde. Bibliotheca Indonesica. 5.

Teeuw, A. Zie ook: a: Poerwadarminta-Teeuw, 1952; b: SitumorangTeeuw, 1952.

Thorn, 1815

Thorn, W., Memoir of the conquest of Java. With the subsequent operations of the British Forces in the Oriental Archipelago. London 1815.

De togt naar Palembang in 1821. In: De Militaire Spectator 1 (1833), dl 1, pp. 85-86, 91-93, 97-99, 105-107, 113-115.

Tuhfat al-Nafis, 1965

Al-marhum Raja Ali Al-Haji Riau, Tuhfat al-Nafis. Sejarah Melayu dan Bugis. Malaysia Publications Ltd. Singapura 1965. 
Ullmann, L., Een blik in de Residentie Palembang. Muntok 1 mrt 1854. Hs KI H 117 (De Graaf, 1963, p. 35).

Val van de Djambische Vorstenheerschappij. (Anoniem versch. in TNI 6 (1844), dl 4, pp. 107-112.) Zie: De Kock, 1844 b.

Verslag aangaande het eiland Banka. Vert. door P. J. Veth. Zie: Horsfield, 1848.

Verslagen omtrent 's-Rijks oude archieven. 23 (1900), no 267; 38 (1915), dl 1, bijl. XI, no 64; 39 (1916), dl 1, bijl. X; 40 (1917), dl 1, bijl. VIII; 47 (1924), dl 1, bijl. V.

Verzameling van overleveringen van het rijk van Manangkabou. Zie: Netscher, 1850.

Veth, P. J., Borneo's Wester-Afdeeling, geographisch, statistisch, historisch; voorafgegaan door eene algemeene schets des ganschen eilands. 2 dln. Zalt-Bommel 1854-56. Dl 2: pp. 150-155 (over Raja Akil).

Voorhoeve, P., A Malay scriptorium. In: Malayan and Indonesian studies, 1964, pp. 256-266.

Voorhoeve, P., The origin of the Malay sjacir. In: BKI 124 (1968), pp. 277-278.

Voorhoeve, P. Zie ook: Drewes/Voorhoeve, 1958.

Voorn, 1960

Voorn, H., De papiermolens in de provincie Noord-Holland. Haarlem 1960. De geschiedenis der Nederlandse papierindustrie. 1.

Waal, E. de, Nederlandsch Indië in de Staten-Generaal sedert de grondwet van 1814. Eene bijdrage tot de geschiedenis der koloniale politiek in Nederland. 3 dln. 's-Gravenhage 1860-61. Dl 1: ibid. 1860.

Waey, H. W. van, Palembang 1809-1819, Toeboeali 1820-1821. In: TNI nieuwe serie 4 (1875), dl 1, pp. 99-123.

Wakeham, E., The bravest soldier. Sir Rollo Gillespie 1766-1814. A historical military sketch. Edinburgh-London 1937.

Walbeehm Sr., C. W., Lijst van de voornaamste inlandsche ambtsbenamingen, met korte aanduiding der aan de betrekking verbonden werkzaamheden en voorrechten, enz. In: TBG 16 (1867), pp. 479502.

A.F. von de Wall, 1891

Wall, A. F. von de, Beknopte geschiedenis van het vorstenhuis en de rijksinstellingen van Lingga en Rijau. In: Ts. Binn. Best. 6 (1891), pp. 298-324.

H. von de Wall, 1877-80 (afgekort: vdW.)

Wall, $\mathrm{H}$. von de, Maleisch-Nederlandsch woordenboek. Samengest. door $\longrightarrow$, uitg. door H. N. van der Tuuk. 3 dln. Batavia 1877-80. (Aanhangsel bew. door H. N. van der Tuuk en uitg. door Ph. S. van Ronkel, Batavia 1897).

Weiss, K. Th., Handbuch der Wasserzeichenkunde. Leipzig 1962.

Weitzel, 1853

Weitzel, A. W. P., De generaal-majoor Carel Jhr. van der Wijck. In: De Militaire Spectator 2e serie 5 (1853), pp. 70-88. Eveneens versch. in: TBG 1 (1853), pp. 480-509. 
Wellan, J. W. J., Çriwijaya 1250 jaren geleden gesticht. In: Tijdschrift van het Koninklijk Nederlands Aardrijkskundig Genootschap, 2e serie 51 (1934), pp. 348-402.

Wellan, J. W. J., De stad Palembang in 1935 tweehonderd vijfenzeventig jaar geleden, als een phoenix, uit haar asch herrezen. In: Kol. Ts. 24 (1934), pp. 215-232.

Wellan, J. W. J., Materiaal voor de geschiedenis van Palembang en Djambi, memories van overgave enz. Den Haag ca 1935. Hs KI H 590a (De Graaf, 1963, p. 100).

Wellan, J. W. J. en O. L. Helfrich, Zuid-Sumatra. Overzicht van de literatuur der gewesten Bengkoelen, Djambi, de Lampongsche districten en Palembang. 2 dln. 's-Gravenhage 1923-28. Uitg. van het ZuidSumatra-Instituut.

Weslij, L. F., De onderafdeling Rawas (residentie Palembang). In: Ts. Binn. Best. 3 (1889), pp. 275-315, 351-366.

Westenenk, L. C., Opstellen over Minangkabau. II. Pariangan-Padang Pandjang in de Larèh nan Pandjang. Sang Sapoerba's Boekit Si Goentang en de Goenoeng Mahamèroe. In: TBG 57 (1916), pp. 241-262.

Westenenk, Uit het land van Bittertong (Zuid-Soematra). In: Djåwå 1 (1921), no 1, pp. 5-11.

Westenenk, 1923

Westenenk, L. C., Boekit Segoentang en Goenoeng Mahaméroe uit de Sedjarah Melajoe. In: TBG 63 (1923), pp. 212-226.

Westenenk, 1932

Westenenk, L. C., Het rijk van Bittertong. 's-Gravenhage 1932.

Wiersma, 1871

Geschiedenissen van Ratahan en Passan van de vroegste tijden tot op den tegenwoordigen tijd volgens de geheime overleveringen der ouden van dagen. Medegedeeld door _ (Naar een Mal. hs van 1860.) In: BKI 3e volgreeks 6 (1871), pp. 204-227.

Wilkinson, 1932 (afgekort: Wlk.)

Wilkinson, R. J., A Malay-English dictionary (romanised). 2 pts. Mytilene 1932.

Willer, 1854

Willer, J. T., Eerste proeve eener kronijk van Mampawa en Pontianak. In: TBG 3 (1855), pp. 516-562, 6 (1857), pp. 69-74.

Willinck, J. P. M., Reize om de wereld, gedaan in de jaren 1823 en 1824 met Z.M. Korvet Lynx, onder bevel van —. Breda 1835.

Winckel-Hooyer, 1890

Winckel, L. F. A. en G. B. Hooyer, De Militaire Willems-Orde. Het 75-jarig bestaan (1815-1890) herdacht. Leiden 1890.

Winstedt, 1919

Misa Melayu. Ed. with introd. and notes by R. O. Winstedt. Singapore 1919. Malay Literature Series. 15.

Winstedt, 1932 a

Winstedt, R. O., A history of Johore (1673-ca 1800 A.D.). In: JMBRAS 10 (1932), Pt 1, pp. 164 v.v. 
Winstedt, $1932 b$

Winstedt, R. O., A Malay History of Riau and Johore (Malay text (Tuhfat al-Nafis) and summary of contents). In:JMBRAS 10 (1932), Pt 2, pp. 1-320.

Winstedt, 1940

Winstedt, R. O., A history of Malay literature. In: JMBRAS 17 (1940), Pt 3.

Winstedt, 1958

Winstedt, R. O., A history of classical Malay literature. Monographs on Malay subjects. 5. In: JMBRAS 31 (1958), Pt 3. Repr.: Kuala Lumpur 1969.

Winstedt, R. O., Malay chronicles from Sumatra and Malaya. In: Hall, 1961, pp. 24-28.

Winstedt, 1962 (afgekort: Wns.)

Winstedt, R. O., An unabridged Malay-English dictionary, 4th ed. Singapore etc. 1962.

Wüstenfeld-Mahler, 1961

Wüstenfeld, F., Wüstenfeld-Mahler'sche Vergleichungs-Tabellen zur muslimschen und iranischen Zeitrechnung. Mit Tafeln zur Umrechnung orient-christlicher Ären. 3 verb. und erw. Aufl. der "Vergleichungs-Tabellen der mohammedanischen und christlichen Zeitrechnung". Wiesbaden 1961. Deutsche Morgenländische Gesellschaft.

Wurtzburg, C. E., Raffles and the massacre at Palembang. In: JMBRAS 22 (1949), Pt 1, pp. 38-52.

Wurtzburg, C. E., Raffles and the Palembang Massacre. In: JMBRAS 25 (1952), Pt 1, pp. 178-180.

Wurtzburg, C. E., Raffles of the Eastern Isles. London 1954.

Zainu'ddin, A., A short history of Indonesia. Melbourne etc. 1968. Cassell Asian histories.

Zondervan, H., Bangka en zijn bewoners. In: Ind. Gids 16 (1894), dl 2, pp. 1942-1966 en vervolgd in versch. afl. van 17 (1895), dln 1 en 2 (slot in: 17, 2, pp. 1456-1461). 


\section{SUMMARY}

The subject of this book is the history of the Sultanate of Palembang (South Sumatra, Indonesia) during the period 1811-1825, the last years in which Palembang was still politically independent of the central government of the Dutch East Indies. To be more specific, it is an edition of several Malay chronicles covering this period of the history of Palembang. Until now these chronicles have only been accessible in manuscript form.

Western historians have paid a great deal of attention to this epoch, in which Dutch and British colonial policy played an important part. It seemed useful, therefore, to supplement the material available from Western sources with the information provided by the Palembang chronicles, information which to date has been unavailable for historical research. The texts published here will, moreover, provide linguistic and literary material for comparison with other Malay sources and so may serve to further research into the history of Malay literature. This publication was envisaged not only as a contribution to historical research with regard to Palembang (and thereby to a better understanding of Palembang-Malay historiography in the context of Indonesian historiography), but also as a contribution to the study of the Malay language. The lay-out of the book reflects its twofold purpose.

The introductory historical survey is intended to make the lay reader acquainted with the period of Palembang history described in the texts themselves. It does not pretend to be more than a chronological reviewal of the historical facts, drawn principally from secondary sources. For this reason it is not provided with references to the literature consulted, details of which are to be found in the general bibliography at the end of the work.

The presentation of the Malay historical texts which form the actual subject of this study falls into four parts. Chapter II contains an inventory of the material found. In it the texts are described and 
classified according to a number of characteristics of form and content. Classification of the original material facilitated the choice of texts to be published and translated in chapters III and IV. In the final chapter a tentative characterization of the various texts has been made on the basis of a number of criteria.

Further treatment of the material includes a listing of spelling peculiarities, the presentation of an apparatus criticus accompanying the rhymed chronicle Syacir Perang Ménténg and of the summary of an unpublished text (inserted in chapter IV) for comparison with one of the published texts to which it is closely related, the conversion of the dates given in the texts according to the Muslim calendar into the corresponding dates of the Christian era, mainly for the convenience of historians, and finally, the supplying of indexes, in which an attempt has been made to register the lexicographical, genealogical and geographical data gathered from the published texts. 


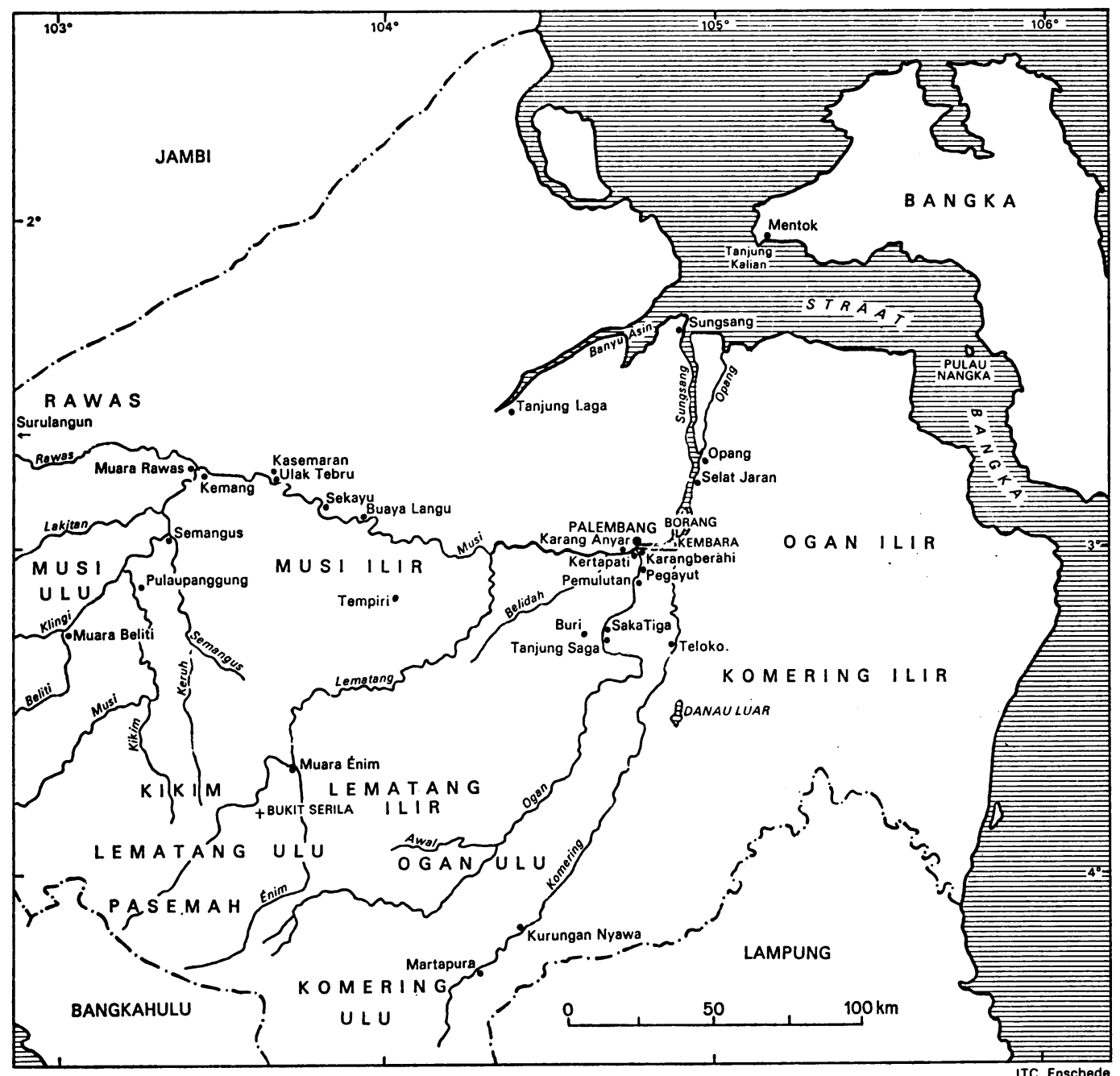


EERDER VERSCHENEN IN DE VERHANDELINGEN:

52. C. R. Boxer, Francisco Vieira de Figueiredo: A Portuguese merchant-adventurer in South East Asia, 1624-1667. 1967. 117 pp., map.

53. Jaap Kunst, Music in New Guinea. Three studies. English translation and correction by J. Scott-Kemball. 1967. VI, 178 pp., ills., 1 fold. map.

54. J. Ensink, On the old-Javanese Cantakaparwa and its tale of Sutasoma. 1967. XII, 66 pp.

55. B. J. Hoff, The Carib language. Phonology, morphonology, morphology, texts and word index. 1968. XV, 440 pp., 1 fold. map.

56. J. Steltenpool, Ekagi-Dutch-English-Indonesian dictionary. 1969. 269 pp.

57. A. Ploeg, Government in Wanggulam. 1969. VI, 216 pp., maps

58. Teodoro A. Llamzon, A subgrouping of nine Philippine languages. Preface by J. C. Anceaux. 1969. VII, 128 pp.

59. B. J. Boland, The struggle of Islam in modern Indonesia. 1971. VIII, 283 pp.

60. H. G. Schulte Nordholt, The political system of the Atoni of Timor. 1971. XV, 511 pp., 1 fold. map, ills.

Bound

61. H. R. van Heekeren, The stone age of Indonesia. Second rev. ed. with a contribution by R. P. Soejono. 1972. XIX, 247 pp., 105 plates.

62. A. C. Niemeijer, The Khilafat movement in India 1919-1924. 1972. VII, $263 \mathrm{pp}$.

63. Boen S. Oemarjati, Chairil Anwar: the poet and his language. 1972. XXV, 159 pp.

64. Johannes King: life at Maripaston. Edited by H.F.de Ziel. 1973. VII, 142 pp., 1 ill., 1 map

65. H. E. Lamur, The Demographic Evolution of Surinam 1920 1970. 1973. VIII + 207 pp., map.

66. L. Onvlee, Cultuur als Antwoord. 1973. XIV + 314 pp.

67. S. Hylkema, Mannen in het Draagnet. 1974. XVI + 480 pp., 21 foto's.

68. J. L. Swellengrebel, In Leydeckers Voetspoor I. 1974. 256 pp., 16 illustrations.

69. H. J. de Graaf en Th. G. Th. Pigeaud, De eerste Moslimse Vorstendommen op Java. 1974. 218 pp.

71. Willem F. L. Buschkens, The Family System of the Paramaribo Creoles. 1974. XVI + 324 pp.

Leden van het Instituut hebben het recht op een reductie van $40 \%$ bij aankoop van éen exemplaar van de Instituutspublicaties, exclusief de voor bestellingen in Nederland geldende B.T.W. en eventuele verzend- en bankkosten.

Deze regeling is slechts van toepassing indien de boeken schriftelijk of telefonisch worden besteld bij het Instituut (Stationsplein 10, Leiden, tel.: 071-48333, toestel 4775). $\mathrm{Na}$ ontvangst van $U w$ bestelling zal $U$ een rekening worden toegezonden. Zodra het daarin vermelde bedrag aan ons is overgemaakt, wordt overgegaan tot verzending van de bestelde publicaties. 